Universidad de Lima

Facultad de Ingeniería y Arquitectura

Carrera de Arquitectura

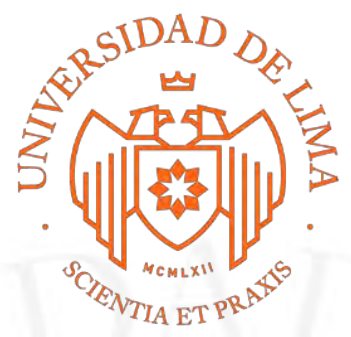

\title{
REVALORIZACIÓN DEL MERCADO SAN JOSÉ DE JESÚS MARÍA COMO ESPACIO PÚBLICO
}

Trabajo de suficiencia profesional para optar el Título Profesional de Arquitecto

\section{Jose Alonso Panduro Castellano}

Código 20122963

Ana Paula Araujo Murga

Código 20120096

Asesor

Daniel Ricardo Rondinel Oviedo

Lima - Perú

Abril de 2020 
REVALORIZACIÓN DEL MERCADO SAN JOSÉ DE JESÚS MARÍA COMO ESPACIO PÚBLICO 


\section{TABLA DE CONTENIDO}

\section{INTRODUCCIÓN .............................................................................................}

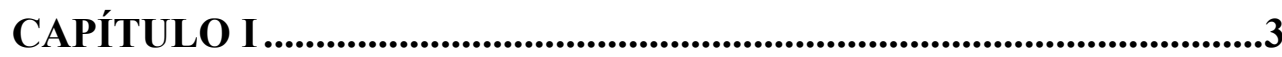

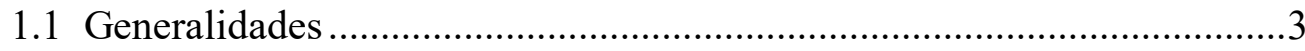

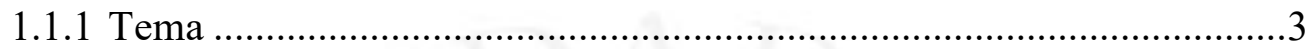

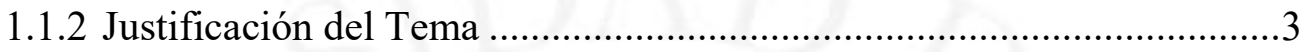

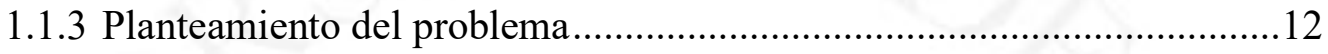

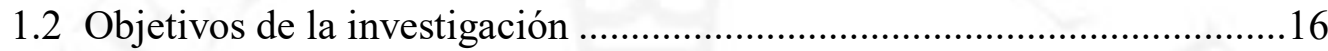

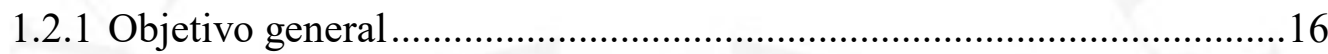

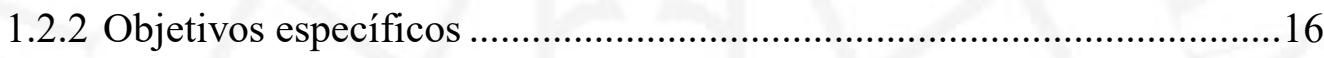

1.3 Supuesto básico de la información .................................................... 17

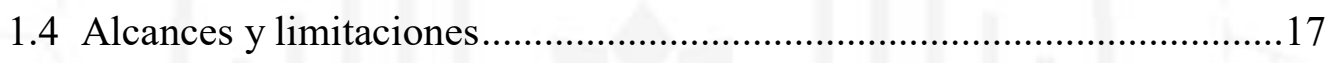

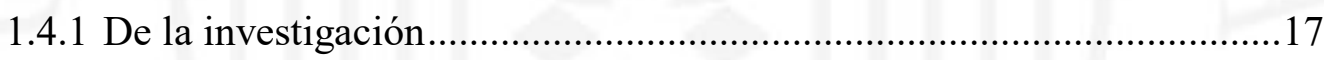

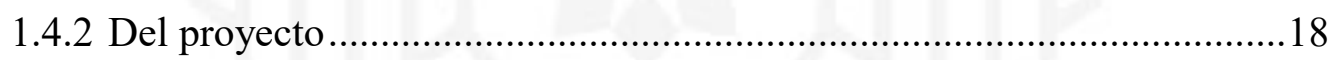

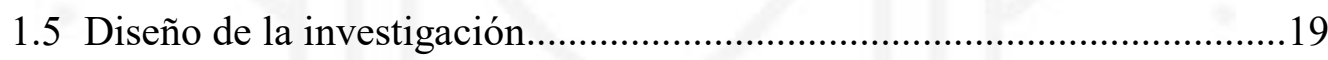

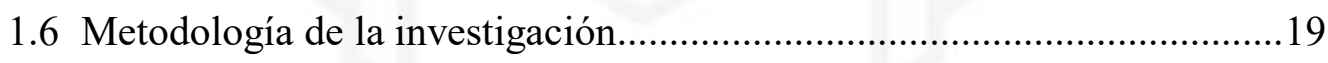

1.6.1 Forma de consulta y recopilación de la información ..............................19

1.6.2 Forma de análisis de la información ...............................................20

1.6.3 Forma de la presentación de la información .......................................20

CAPÍTULO II: MARCO HISTÓRICO - REFERENCIAL ......................21

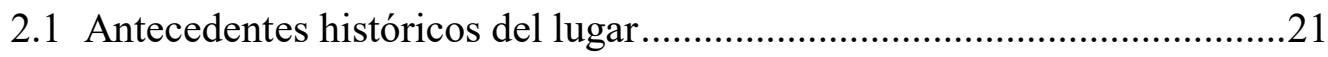

2.1.1 Antecedentes históricos de Jesús María..............................................21

2.1.2 Antecedentes históricos del Mercado San José........................................36

2.2 Antecedentes históricos de los mercados de abastos..............................43 
2.2.1 Antecedentes históricos en el mundo. .43

2.2.2 Orígenes de los mercados tradicionales en Lima ..................................65

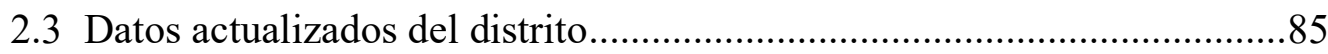

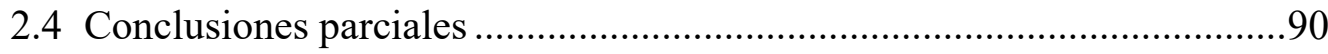

CAPÍTULO III: MARCO TEÓRICO .......................................................95

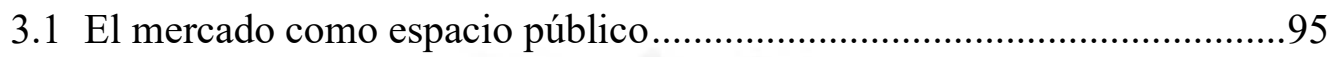

3.1.1 Espacio público y su valor en la sociedad...........................................95

3.1.2 Clasificación del espacio público contemporáneo .................................100

3.1.3 Espacios públicos en las ciudades peruanas .........................................106

3.1.4 Beneficio de los mercados como espacio público ................................109

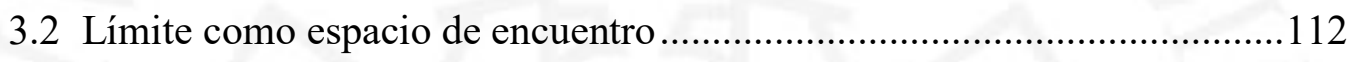

3.2.1 Concepto del límite en la arquitectura ..............................................112

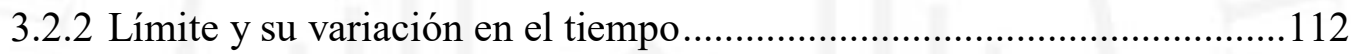

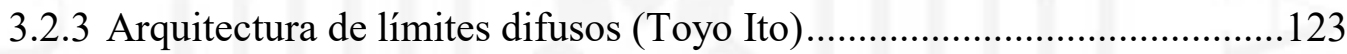

3.3 Límite en los establecimientos comerciales en el Perú ............................130

3.4 Mercados como nuevos exponentes turísticos .......................................138

3.4.1 Nuevas experiencias para la cultura del consumo ................................138

3.4.2 Calidad espacial para desarrollar buenas experiencias .........................138

3.4.3 Turismo cultural y los mercados tradicionales ...................................143

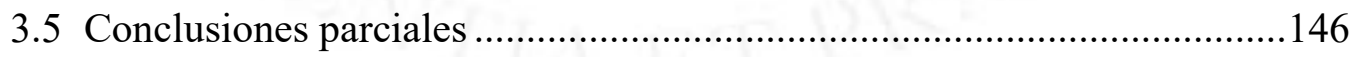

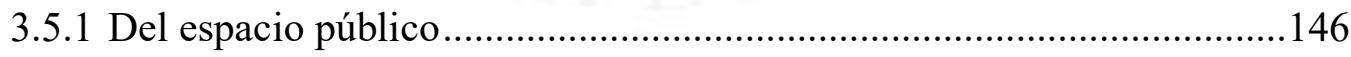

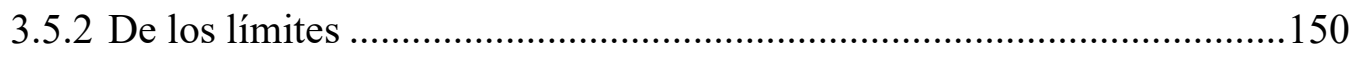

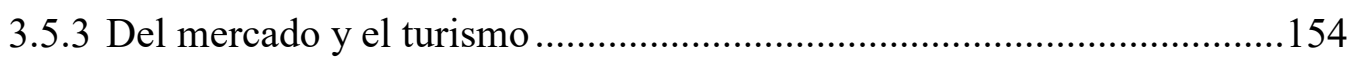

CAPÍTULO IV: MARCO NORMATIVO ................................................157

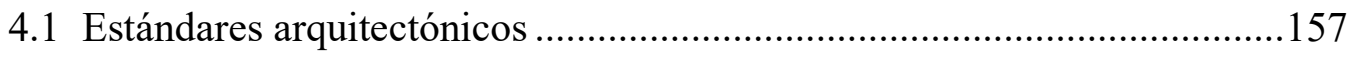




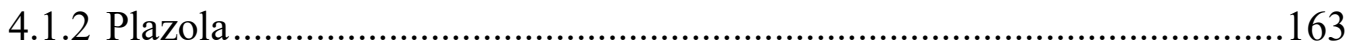

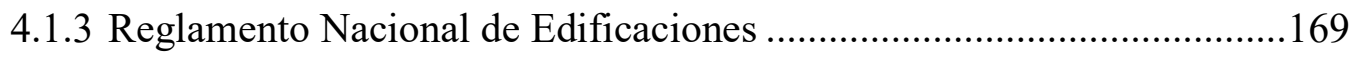

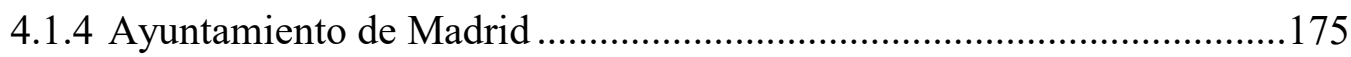

4.1.5 Plan de Modernización de los Mercados Municipales ..........................179

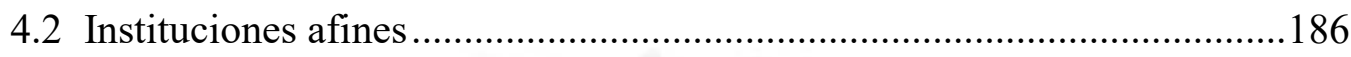

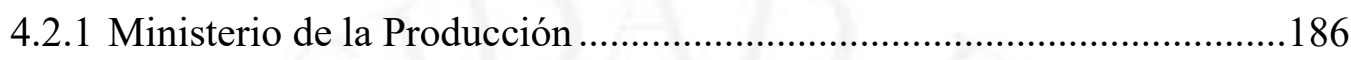

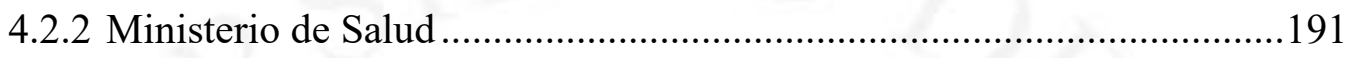

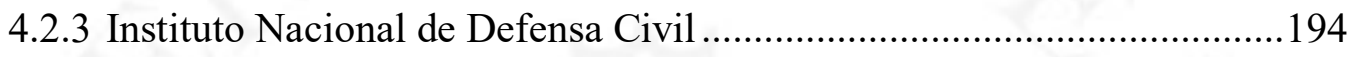

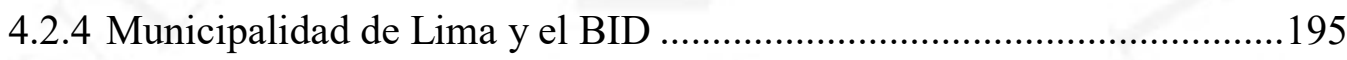

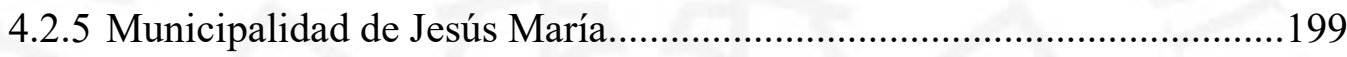

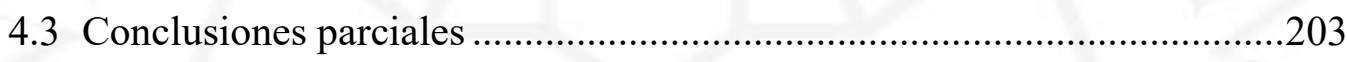

CAPÍTULO V: MARCO OPERATIVO..................................................207

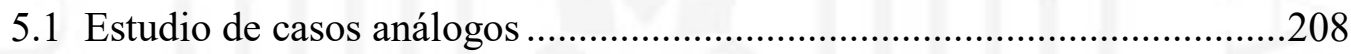

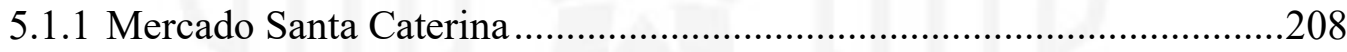

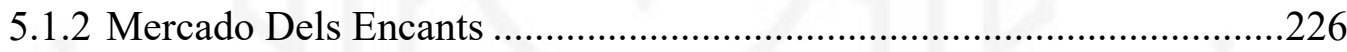

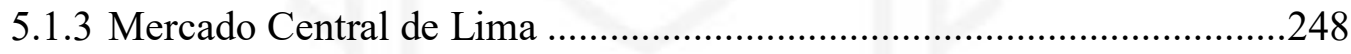

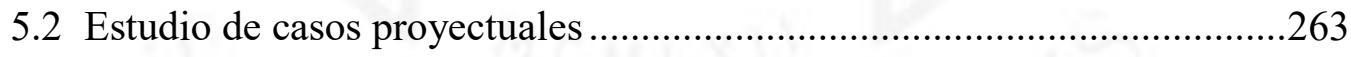

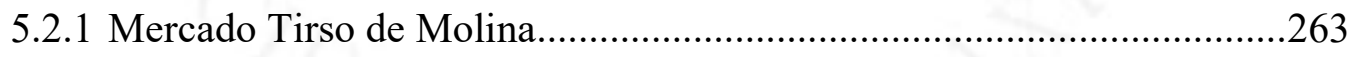

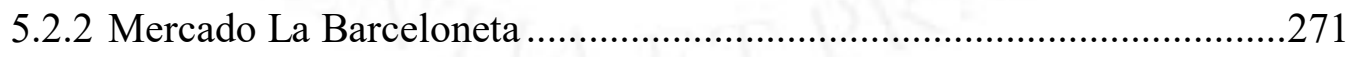

5.2.3 Los pasajes como espacios semi-públicos .......................................280

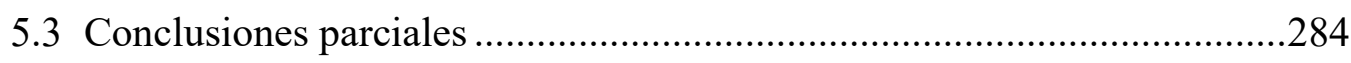

CAPÍTULO VI: MARCO CONTEXTUAL ...........................................289

6.1 Redes de equipamiento y radio de influencia.....................................289

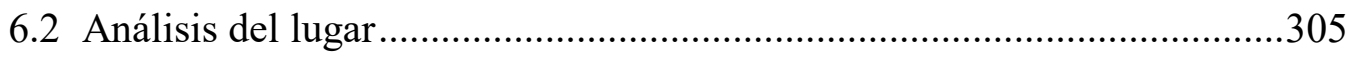




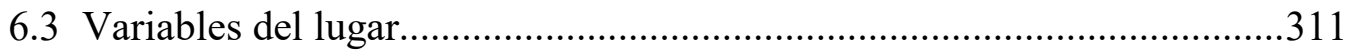

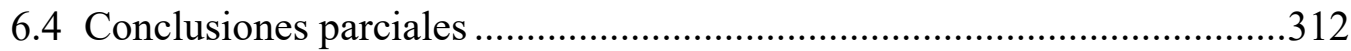

CAPÍTULO VII: CONCLUSIONES FINALES ........................................315

CAPÍTULO VIII: PROYECTO .................................................................3320

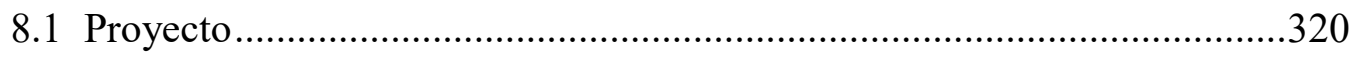

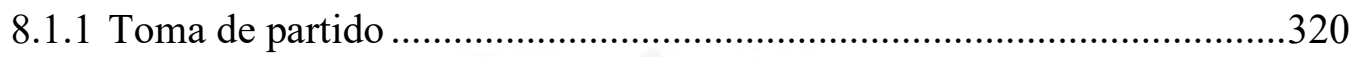

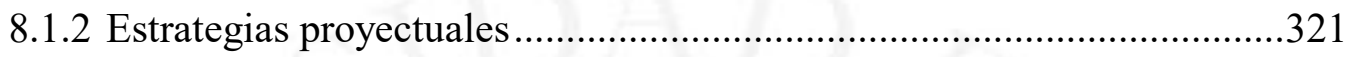

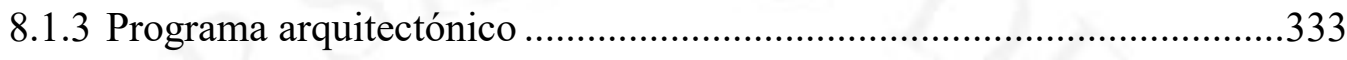

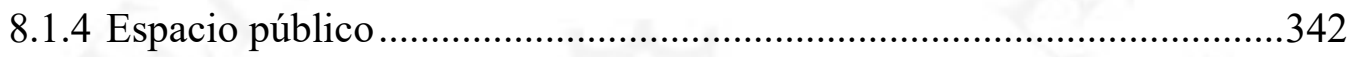

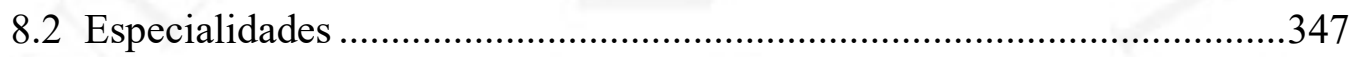

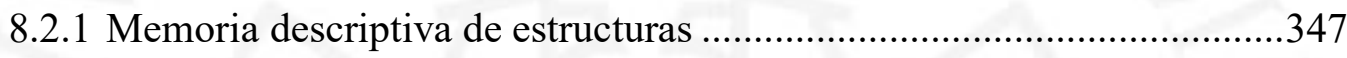

8.2.2 Memoria descriptiva de instalaciones eléctricas ...................................350

8.2.3 Memoria descriptiva de instalaciones sanitarias ....................................351

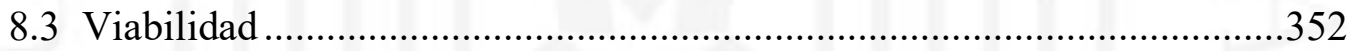

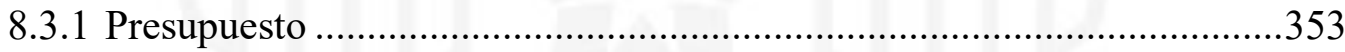

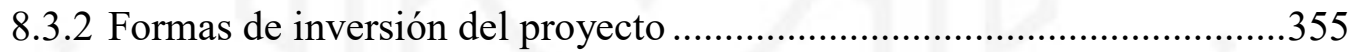

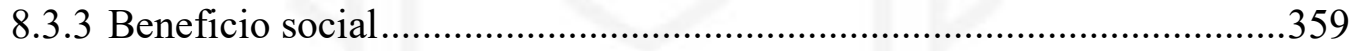

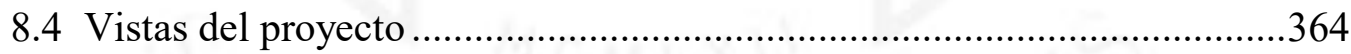

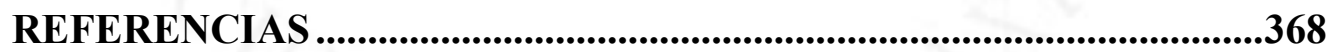

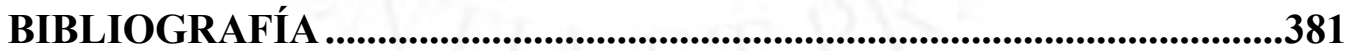




\section{ÍNDICE DE TABLAS}

Tabla 1.1 Demanda de visitantes a los mercados reinventados de Europa ............................... 6

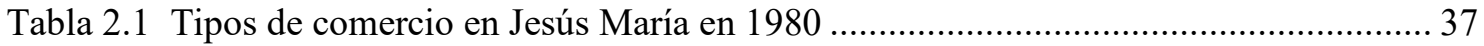

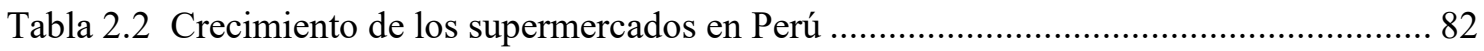

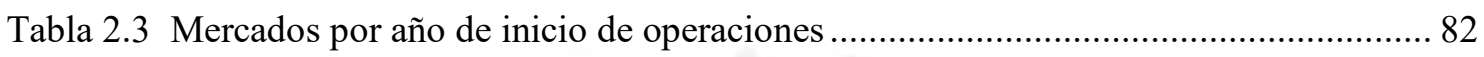

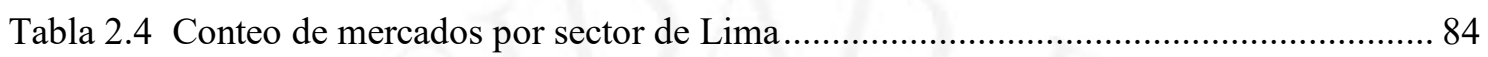

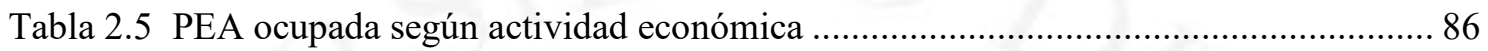

Tabla 3.1 Criterios de una nueva tipología de espacios públicos urbanos .............................. 101

Tabla 3.2 Tipología de espacios públicos de la ciudad contemporánea ................................... 105

Tabla 3.3 Combinación de variables y tiempo de acceso de la nueva clasificación................. 106

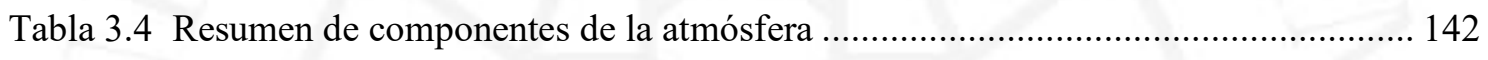

Tabla 3.5 Relación de condiciones y factores de percepción................................................... 143

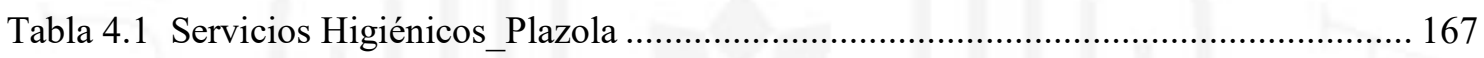

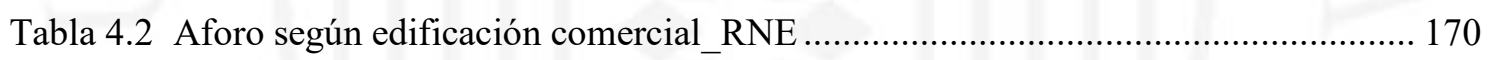

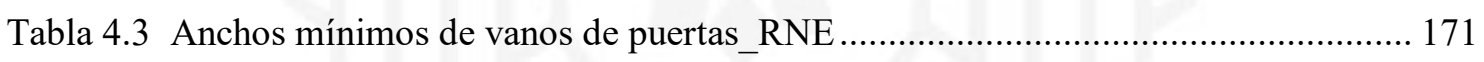

Tabla 4.4 Área mínima de los puestos de venta_RNE.......................................................... 172

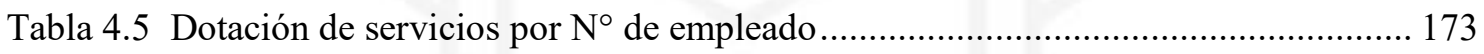

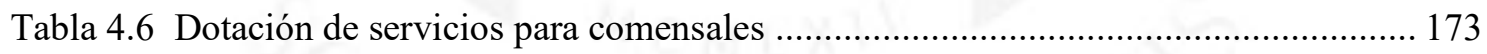

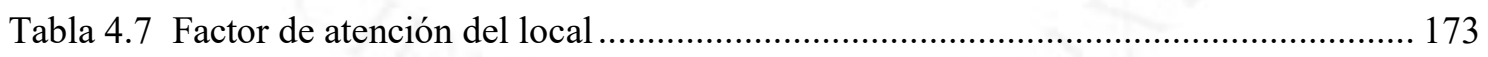

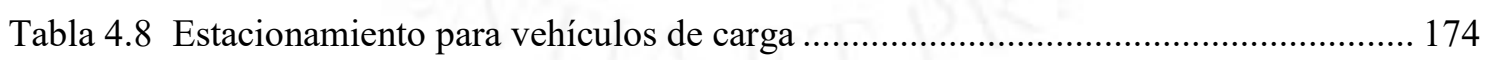

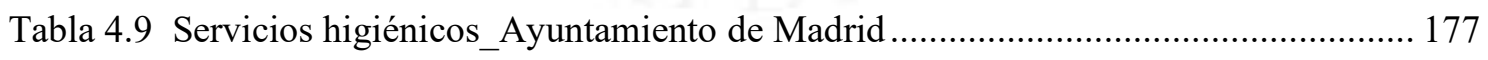

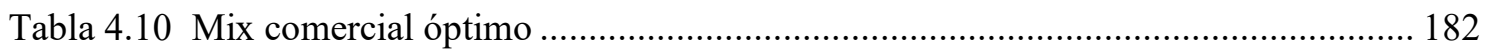

Tabla 4.11 Plan de actuación_Gestión y Política Comercial ................................................... 184

Tabla 4.12 Plan de actuación_Adecuación Física y Funcional .............................................. 185

Tabla 4.13 Áreas mínimas de puestos de venta_Produce ...................................................... 187

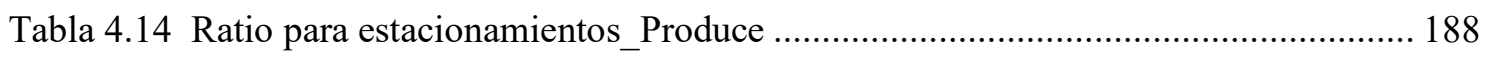


Tabla 4.15 Ratio para cámaras frigoríficas_Produce

Tabla 4.16 Ratio de áreas de residuos

Tabla 4.17 Aforo según edificación comercial_Produce

Tabla 4.18 Anchos mínimos de vanos de puertas_Produce........ 190

Tabla 4.19 Dotación de servicios por número de personas 192

Tabla 4.20 Servicios complementarios al mercado 196

Tabla 4.21 Acciones a realizar del objetivo 202

Tabla 4.22 Cálculo plazas de estacionamiento 205

Tabla 4.23 Cálculo de almacenamiento y acopio de desechos 205

Tabla 4.24 Comparación de estándares arquitectónicos 206

Tabla 6.1 Distritos con mayor índice de des-abastecimiento. 305

Tabla 6.2 Cuadro comparativo de terrenos 308

Tabla 8.1 Programa del Mercado San José 339

Tabla 8.2 Ingresos y egresos del proyecto 353

Tabla 8.3 VAN y TIR del proyecto 356

Tabla 8.4 Flujo de caja del Mercado San José 358

Tabla 8.5 Comparación de precios_Autoservicios vs Mercado. 361

Tabla 8.6 Beneficio por ahorro en gasto de alimentos 361

Tabla 8.7 Beneficio por turismo 362

Tabla 8.8 Beneficio por generación de empleo 362

Tabla 8.9 Ahorro por beneficio social 364 


\section{ÍNDICE DE FIGURAS}

Figura 1.1 Razones para promover la gastronomía. .......................................................... 5

Figura $1.2 \mathrm{~N}^{\circ}$ turistas al año en mercados de Barcelona ........................................................ 7

Figura $1.3 \mathrm{~N}^{\circ}$ de turistas en ediciones de Mistura .............................................................. 7

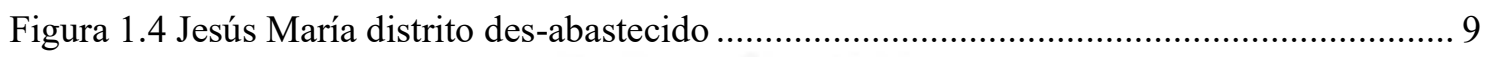

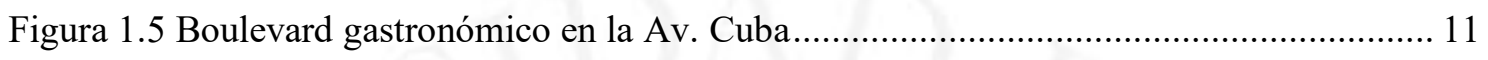

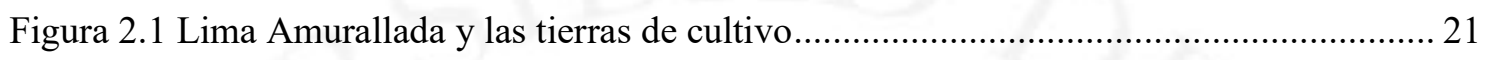

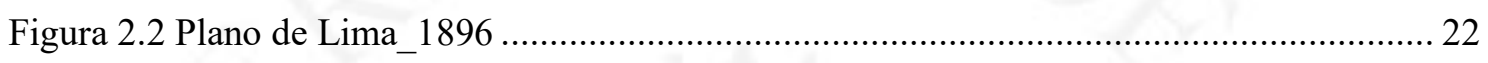

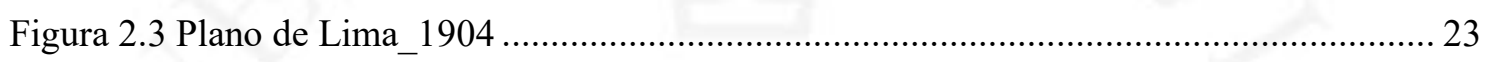

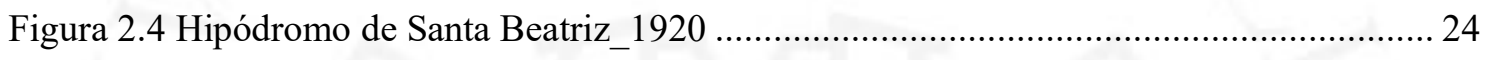

Figura 2.5 Vista aérea del Hipódromo Santa Beatriz_1920 ..................................................... 24

Figura 2.6 Fachada interior del Hipódromo de Santa Beatriz_1924 ....................................... 25

Figura 2.7 Fachada exterior del Hipódromo de Santa Beatriz ................................................. 25

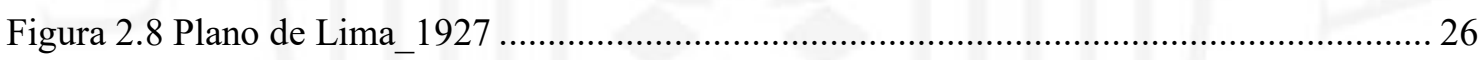

Figura 2.9 Fotografía aérea de la Iglesia y Plaza San Jose_1950 ........................................... 27

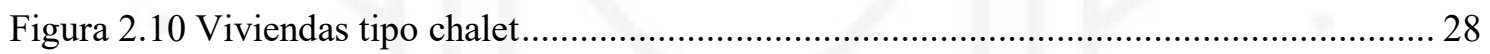

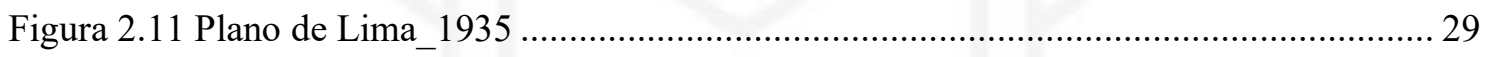

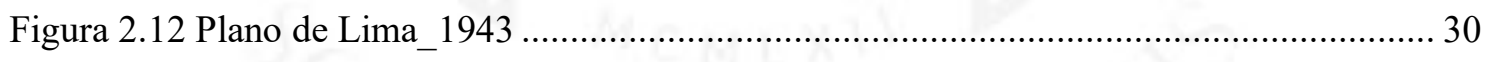

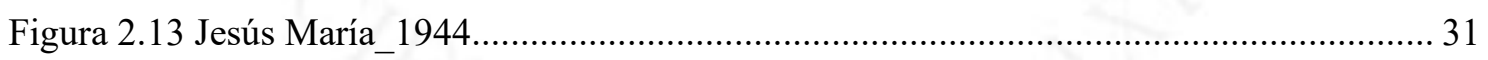

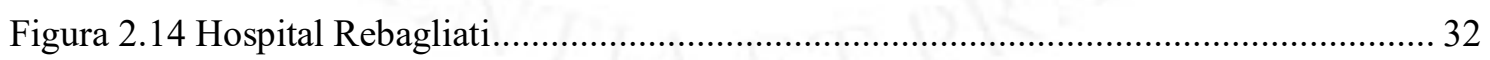

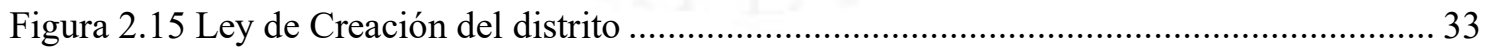

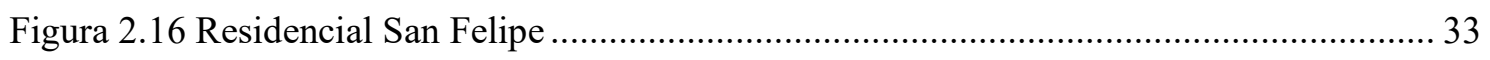

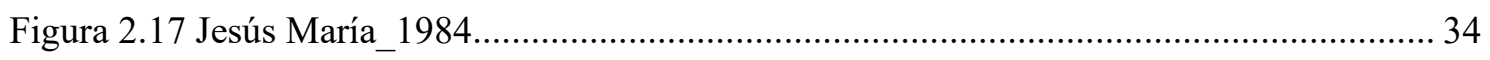

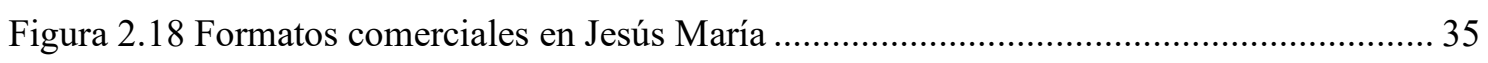

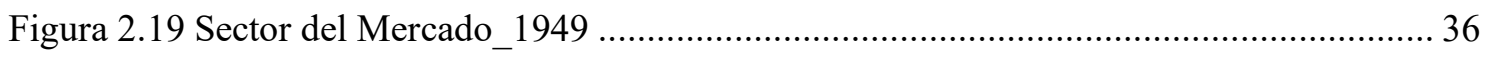

Figura $2.20 \mathrm{~N}^{\circ}$ de puestos por rubro en Jesús María en 1980................................................ 38 
Figura 2.21 Población servida de mercados por distrito 1980 38

Figura 2.22 Comparación del $\mathrm{N}^{\circ}$ de puestos por rubro en 1980 y 2017 ..................................... 39

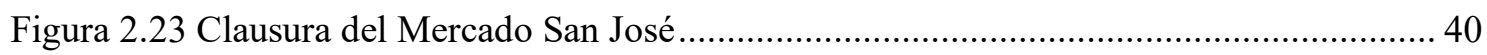

Figura 2.24 Reportaje sobre las cevicherías del Mercado San José .......................................... 41

Figura 2.25 Evolución de la trama urbana alrededor del mercado........................................... 42

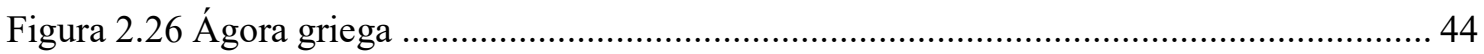

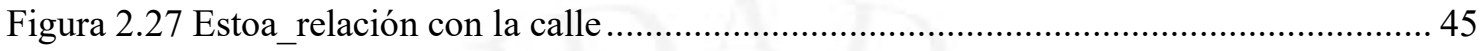

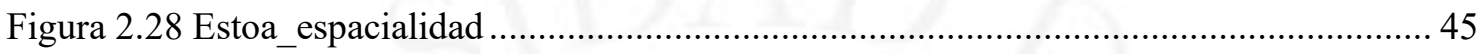

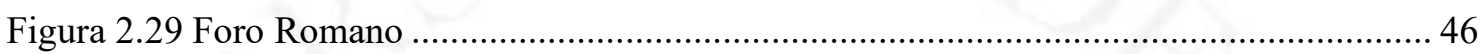

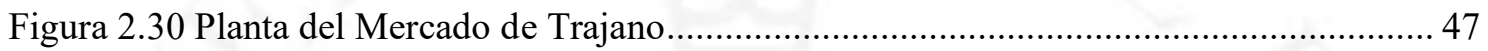

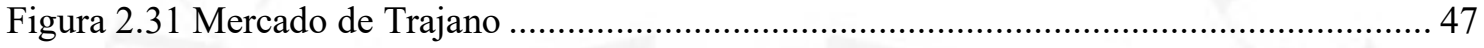

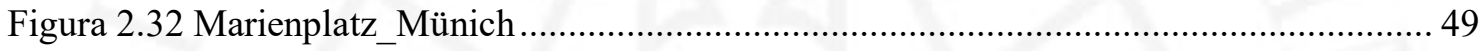

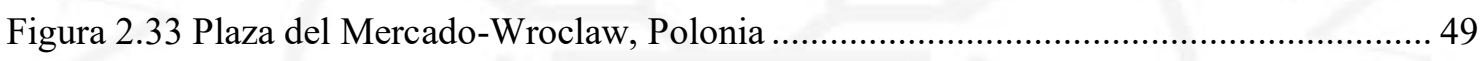

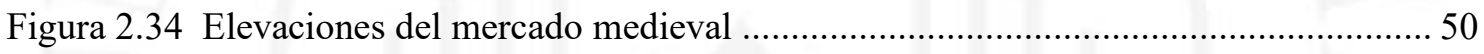

Figura 2.35 Mercado medieval_Shrewsbury, Inglaterra _........................................................ 51

Figura 2.36 Mercado medieval_Hereford, Inglaterra ….......................................................... 51

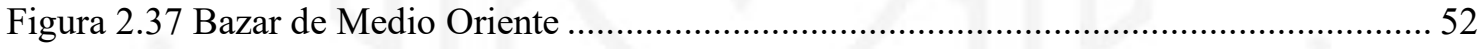

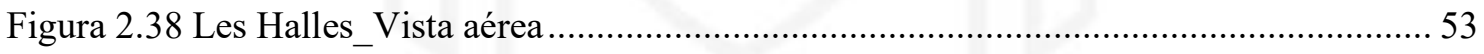

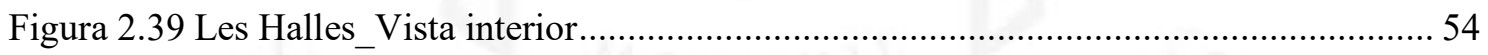

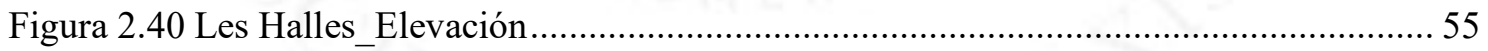

Figura 2.41 Les Halles_Estructura metálica ........................................................................... 55

Figura 2.42 Índice de construcción de mercados en Gran Bretaña de 1751 a 1950 .................... 56

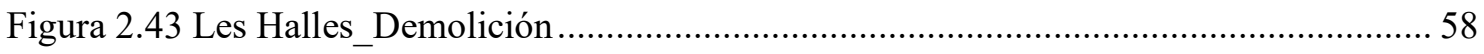

Figura 2.44 Destrucción del Les Halles_1971 ......................................................................... 59

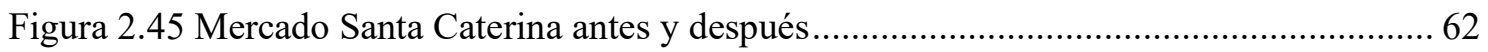

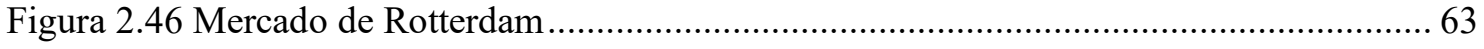

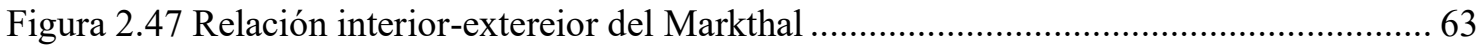


Figura 2.48 Proceso tipológico de los mercados

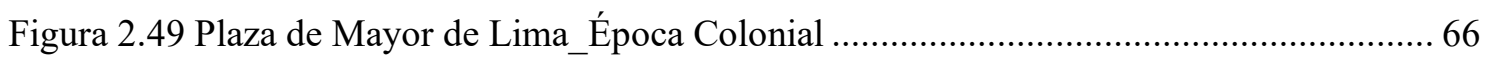

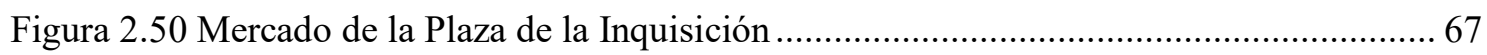

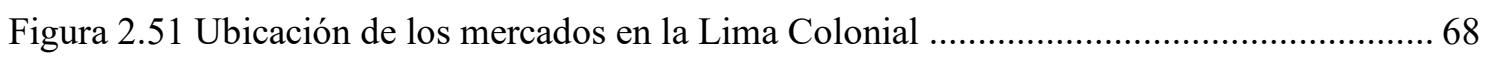

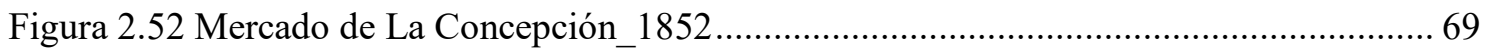

Figura 2.53 Mercado Gran Mariscal Ramón Castilla_ 1905 .................................................... 70

Figura 2.54 Mercado Central de Lima_Actualidad .................................................................... 71

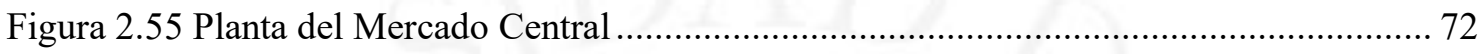

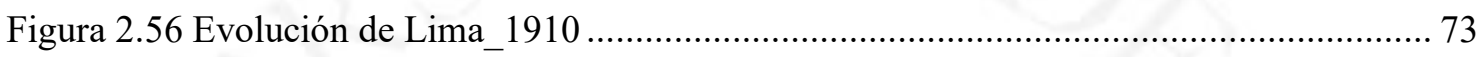

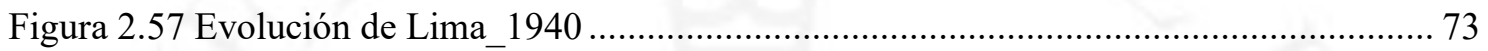

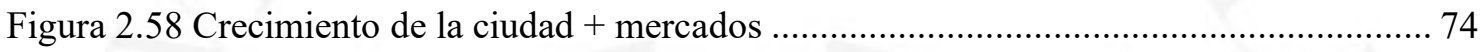

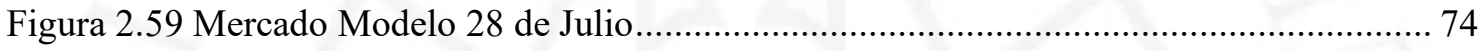

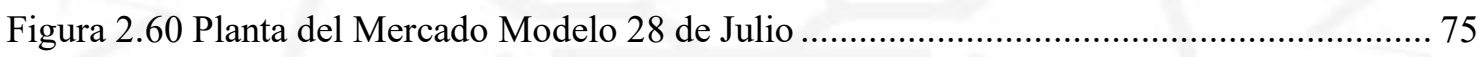

Figura 2.61 Interior del Mercado Modelo 28 de Julio ............................................................ 75

Figura 2.62 Mercado Magdalena y Plaza Túpac Amaru ............................................................ 76

Figura 2.63 Interior del Mercado Magdalena ……................................................................ 76

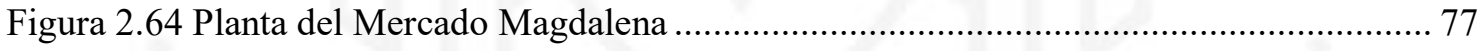

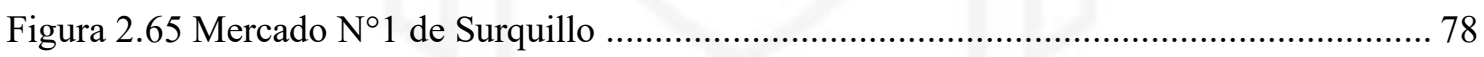

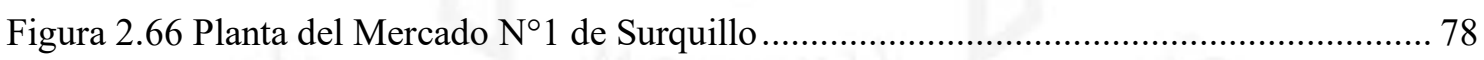

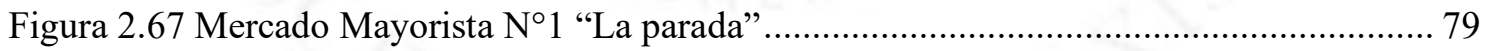

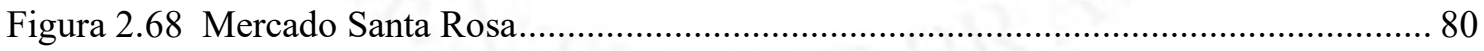

Figura 2.69 Paraboloide similar al del Mercado Santa Rosa .................................................... 80

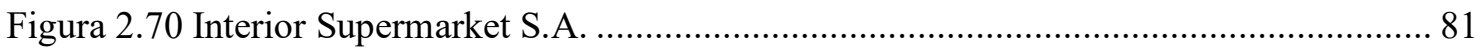

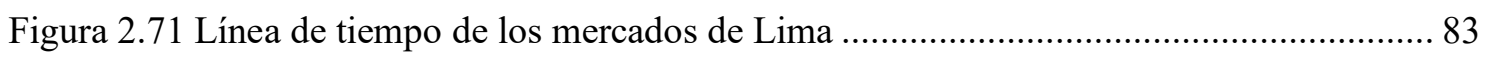

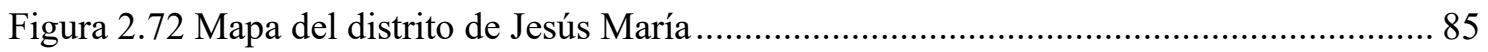

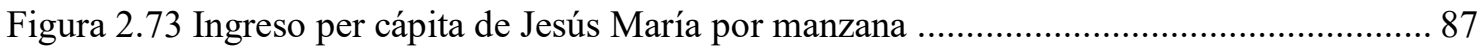

Figura 2.74 Ubicación de las centralidades económicas de Jesús María .................................... 88 
Figura 2.75 Localización de Jesús María

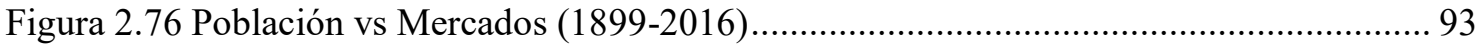

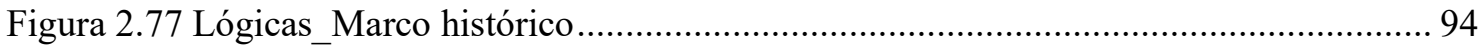

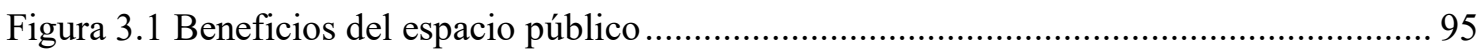

Figura 3.2 Calidad de espacios vs Duración en el espacio ...................................................... 97

Figura 3.3 Principios de clasificación de un buen espacio público ........................................... 98

Figura 3.4 Cualidades para un buen diseño de edificios y espacios al aire libre ........................ 99

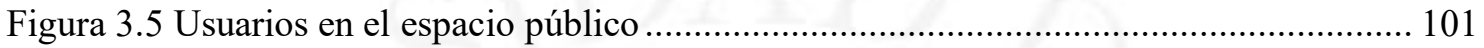

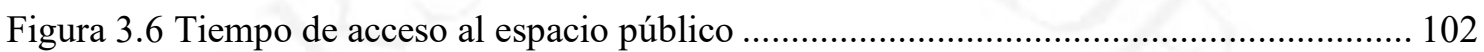

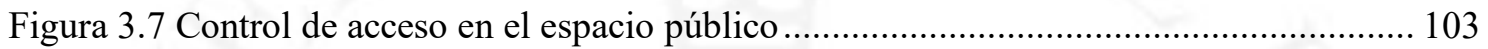

Figura 3.8 Funciones en el espacio público ....................................................................... 104

Figura 3.9 Características visuales de los espacios públicos ................................................ 104

Figura 3.10 Jockey plaza y elementos de espacio público ....................................................... 108

Figura 3.11 Interacción social entre comerciante y cliente …................................................ 110

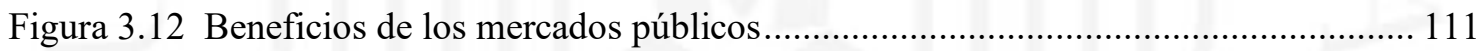

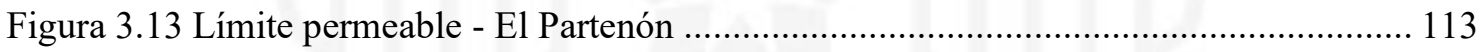

Figura 3.14 Arquitectura gótica (derecha) y barroco (izquierda) ........................................... 114

Figura 3.15 Exterior e interior del Palacio de Cristal del Retiro de Madrid............................ 115

Figura 3.16 Cinco puntos de la arquitectura moderna por Le Corbusier. ................................ 115

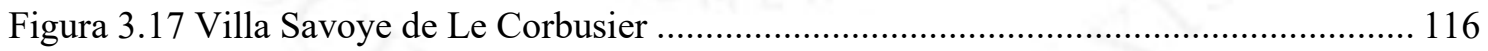

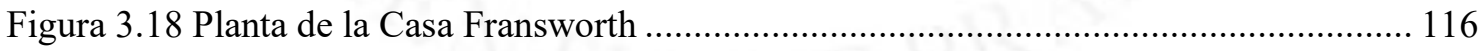

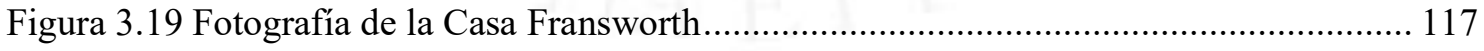

Figura 3.20 Apertura de la chimenea central en la Casa Robie (1910) .................................. 118

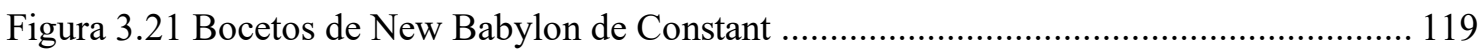

Figura 3.22 Relaciones espaciales al interior de New Babylon.......................................... 119

Figura 3.23 Fachada + estructura_ Tiendra Prada en Tokio .................................................... 121

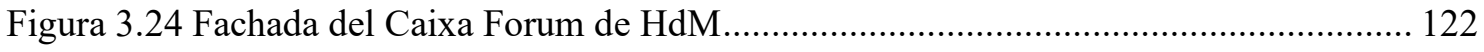


Figura 3.25 Fachada del Dominus Winery de HdM

Figura 3.26 Interior de la biblioteca de la Universidad de Arte de Tama ............................... 124

Figura 3.27 Fachada de la biblioteca de la Universidad de Arte de Tama ............................... 125

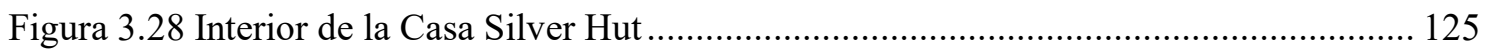

Figura 3.29 Axonometría constructiva de la Casa Silver Hut................................................. 126

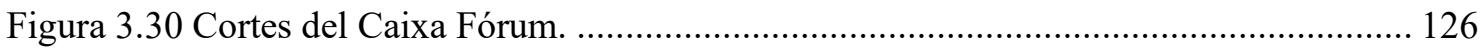

Figura 3.31 Axonometría estructural del Caixa Fórum ......................................................... 127

Figura 3.32 Fachada de la Fundación Cartier de Jean Nouvel ............................................... 129

Figura 3.33 Superposición de capas en la fachada de la Fundación Cartier ............................ 129

Figura 3.34 Fachada edificio comercial_El Dorado (Raúl Morey-1967)............................... 130

Figura 3.35 Límite del edificio comercial_El Dorado (Raúl Morey-1967) ............................. 131

Figura 3.36 Comparación_S Sociedad Mercantil vs Tienda Ferrand y Cia ............................... 132

Figura 3.37 Intercambio comercial y Mercado de Chincheros ............................................. 133

Figura 3.38 Actividad comercial en la Plaza Mayor.............................................................. 133

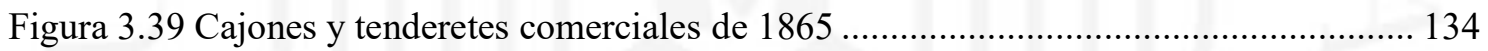

Figura 3.40 Actividad comercial al exterior del Mercado Central de Lima ............................ 135

Figura 3.41 Primera planta_Mercado Central de Lima.......................................................... 135

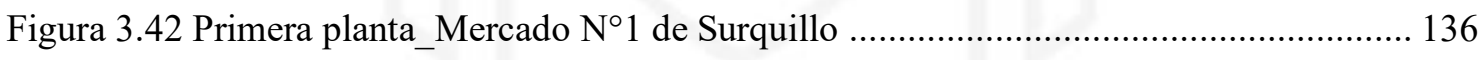

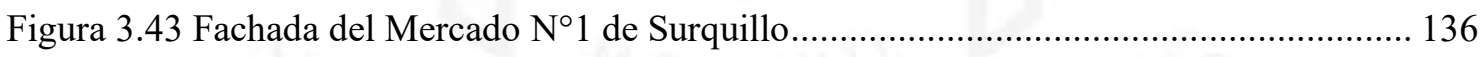

Figura 3.44 Puestos de venta en fachada_Mercado $N^{\circ} 1$ de Surquillo ..................................... 137

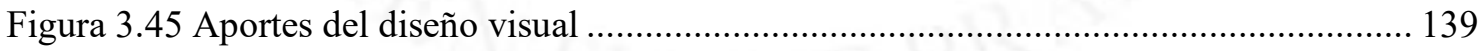

Figura 3.46 Cinco variables que determinan aislamiento en un espacio ................................. 140

Figura 3.47 Proceso perceptivo del ser humano ................................................................. 141

Figura 3.48 Aspectos básicos para la creación de armósferas del lugar .................................. 141

Figura 3.49 Actividades opcionales y necesarias desarrolladas en el espacio público............. 147

Figura 3.50 Lógicas de diseño según teoría de Jan Gehl. .................................................... 148

Figura 3.51 Lógicas de diseño según teoría de Bentley ........................................................ 149 
Figura 3.52 Romper el límite a través del envolvente

Figura 3.53 Lógicas de diseño_ Teoría de límites

Figura 3.54 Criterios de diseño para nuevas experiencias de consumo

Figura 3.55 Beneficios sociales,culturales y urbanos para el diseño del mercado 156

Figura 4.1 Neufert_Productos de forma visible 158

Figura 4.2 Neufert_Puesto de pescados 158

Figura 4.3 Neufert_Puesto de carnes y avícolas 159

Figura 4.4 Neufert_Puesto de verduras y frutas 159

Figura 4.5 Medidas zonas de carga y descarga 160

Figura 4.6 Muelles de carga 161

Figura 4.7 Medidas cuarto de basura 162

Figura 4.8 Diagrama funcional. 163

Figura 4.9 Plazola_ Medidas de puesto en general. 165

Figura 4.10 Plazola_Puesto de frutas y verduras 165

Figura 4.11 Plazola_Puesto de pescado 165

Figura 4.12 Plazola_Puesto de jugos y comida 166

Figura 4.13 Plazola_Circulaciones 167

Figura 4.14 Partes de un mercado según Produce 187

Figura 4.15 Temas de los eje del distrito de Jesús María. 199

Figura 4.16 Boulevard gastronómico de Jesús María 201

Figura 4.17 Zonas de intervención del Plan de Desarrollo 201

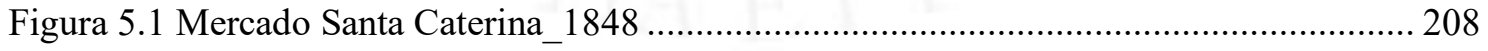

Figura 5.2 Inseguridad en el barrio Sant Pere .................................................................... 209

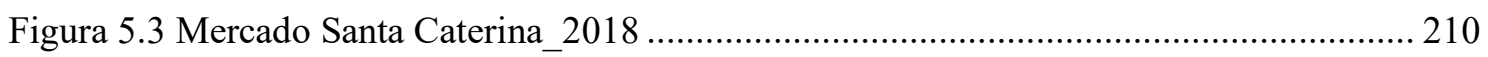

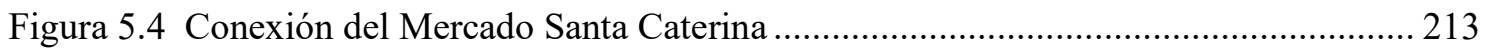

Figura 5.5 Emplazamiento del Mercado Santa Caterina ......................................................... 214

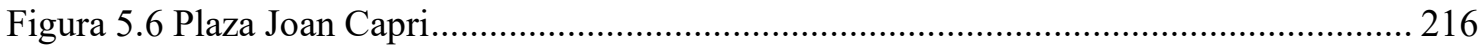




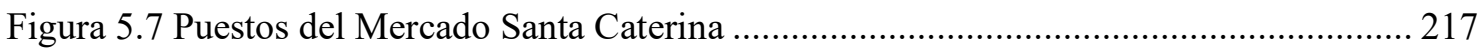

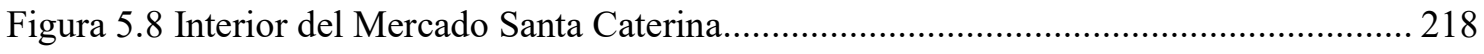

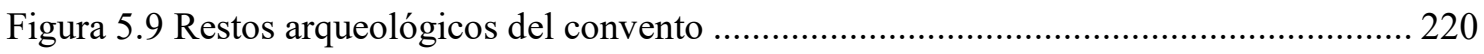

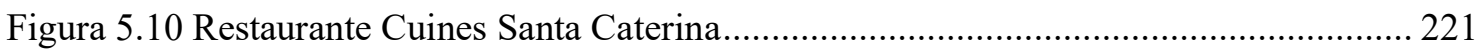

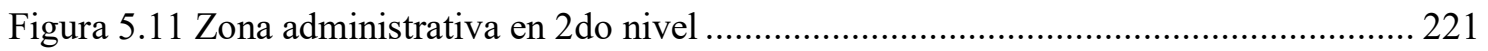

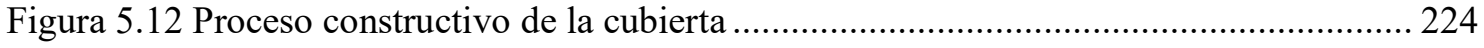

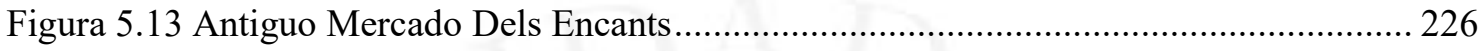

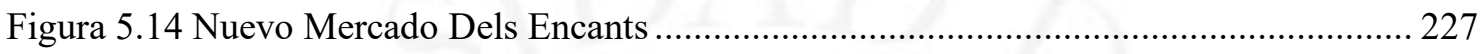

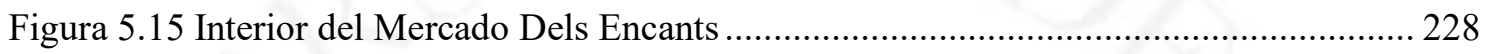

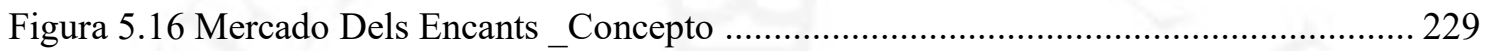

Figura 5.17 Mercado Dels Encants_Circulación .................................................................... 229

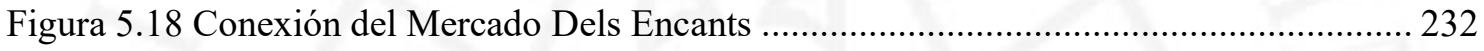

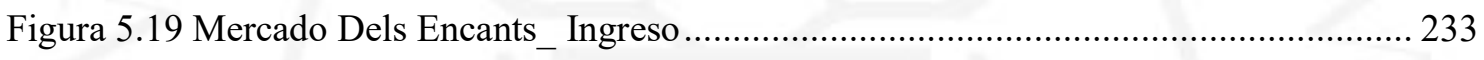

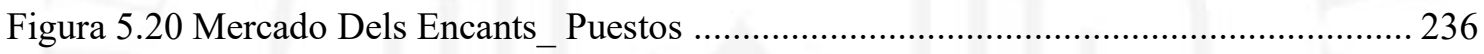

Figura 5.21 Mercado Dels Encants_Fachada de puestos …….................................................. 236

Figura 5.22 Mercado Dels Encants_Street Food ..................................................................... 239

Figura 5.23 Mercado Dels Encants_Puestos Street Food ......................................................... 239

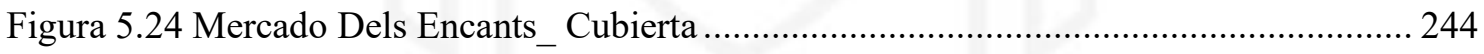

Figura 5.25 Mercado Dels Encants_Recubrimiento …......................................................... 245

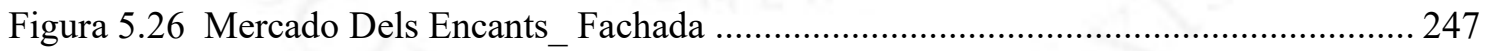

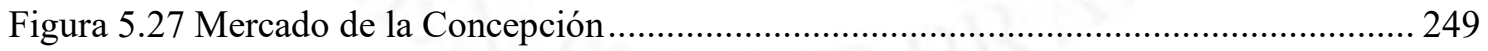

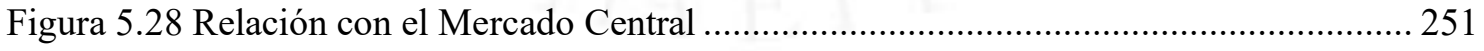

Figura 5.29 Relación con el entorno_ Mercado Central …................................................... 252

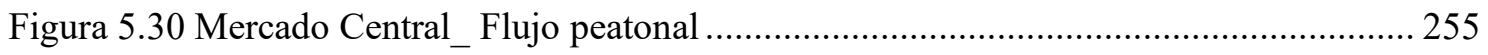

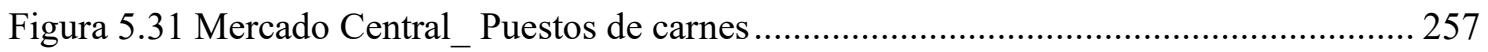

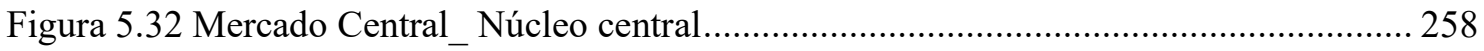

Figura 5.33 Mercado Central_ Organización lineal ................................................................. 258 


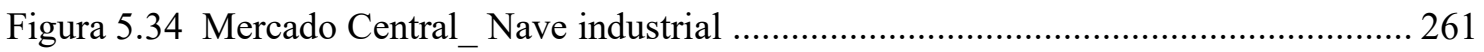

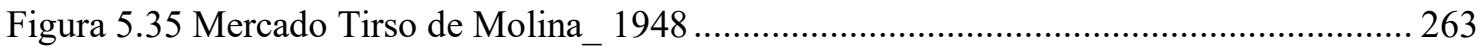

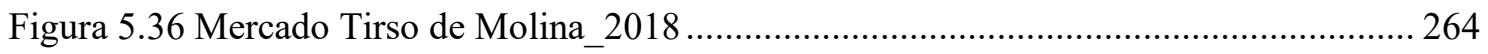

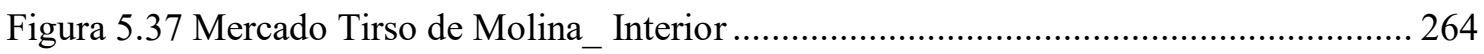

Figura 5.38 Mercado Tirso de Molina_Permeabilidad ............................................................ 265

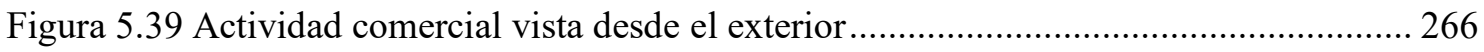

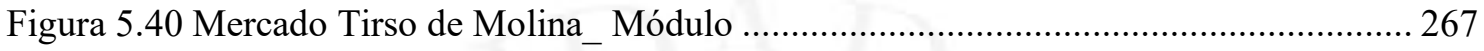

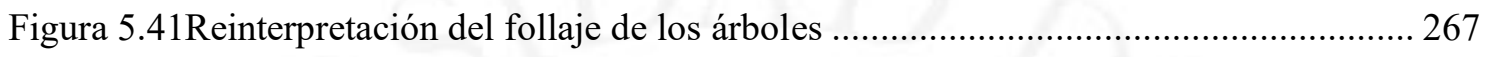

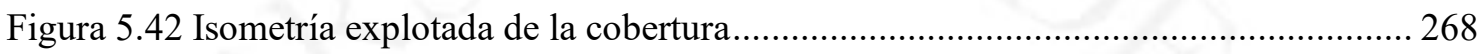

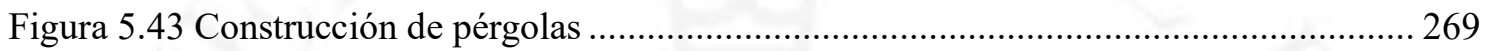

Figura 5.44 Revestimiento metálico de las pérgolas .............................................................. 269

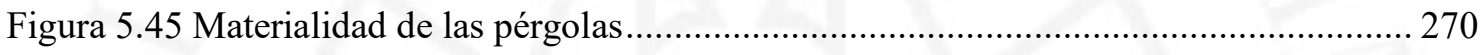

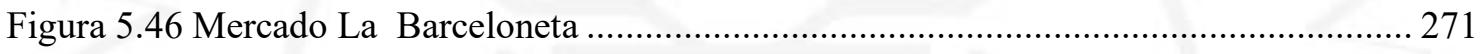

Figura 5.47 Esquema conceptual del Mercado La Barceloneta ............................................. 272

Figura 5.48 Sección longitudinal_ Mercado La Barceloneta.................................................... 272

Figura 5.49 Espacio público del Mercado La Barceloneta ….................................................. 273

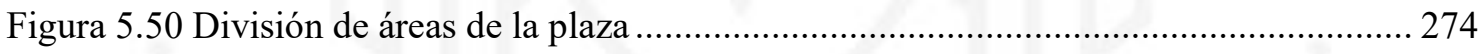

Figura 5.51 Pavimentos del espacio público del Mercado La Barceloneta .............................. 275

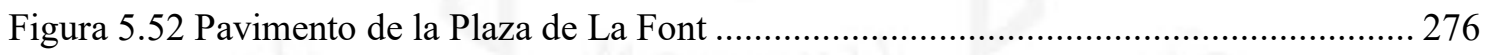

Figura 5.53 Pavimento de la Plaza del Poeta Boscá ................................................................. 276

Figura 5.54 Identificación y ubicación de la vegetación_Plaza del Poeta Boscá ...................... 277

Figura 5.55 Mobiliario urbano del espacio público del Mercado La Barceloneta ................... 278

Figura 5.56 Tipo de mobiliario urbano en el espacio público del Mercado La Barceloneta .... 279

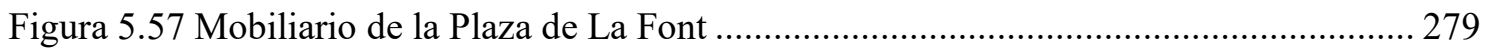

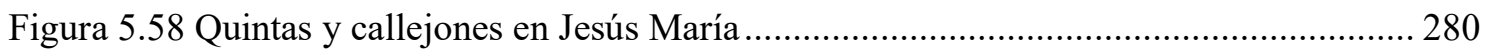

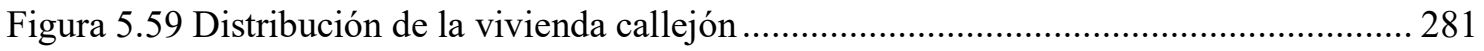

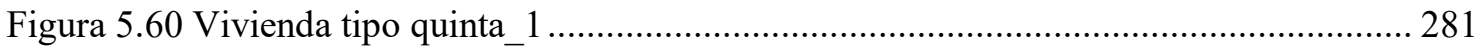




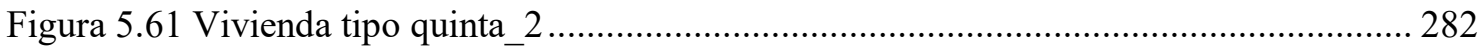

Figura 5.62 Tipos de pasajes en la trama urbana de Jesús María.............................................. 283

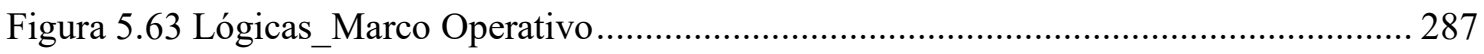

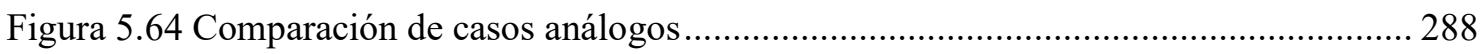

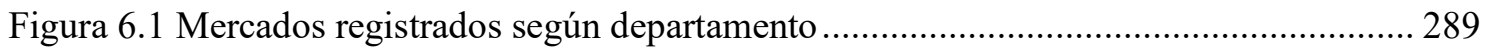

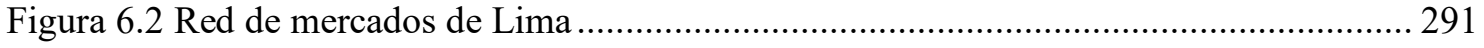

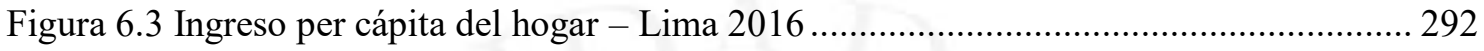

Figura 6.4 Vacío de mercados vs ingreso per cápita ............................................................... 293

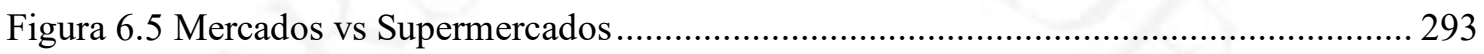

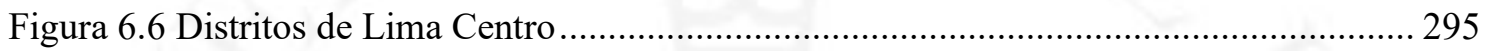

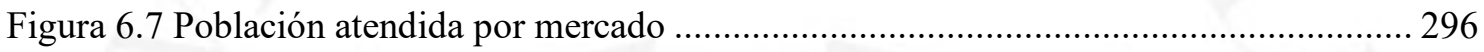

Figura 6.8 Clasificación de abastecimiento de distritos de Lima Centro ................................. 297

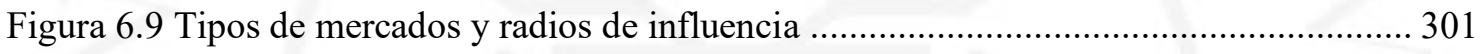

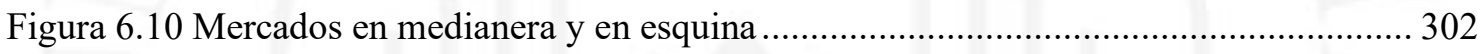

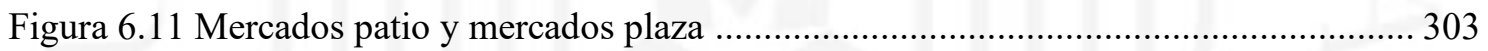

Figura 6.12 Mercados centrales y mercados pool.................................................................... 304

Figura 6.13 Filtro para la selección del mercado .................................................................... 306

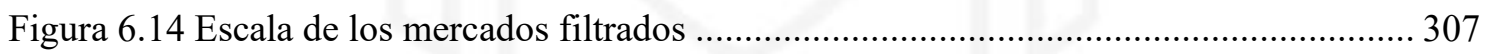

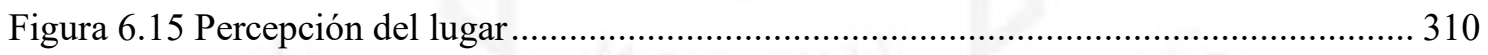

Figura 6.16 Vista semi-aérea del Mercado San José …........................................................ 310

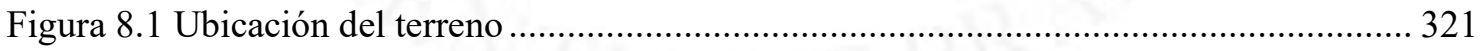

Figura 8.2 Estrategias_Jerarquía frente al contexto urbano …............................................... 322

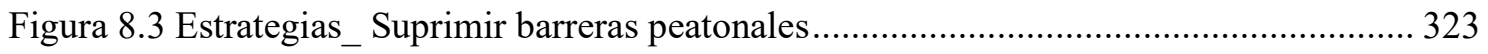

Figura 8.4 Estrategias_Re dimensión de puestos externos ……………………..................... 323

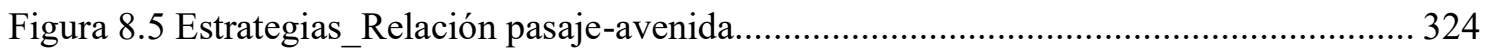

Figura 8.6 Estrategias_Re dirección de flujo peatonal ........................................................ 325

Figura 8.7 Estrategias_Límite como espacio de encuentro e interacción social .......................326 


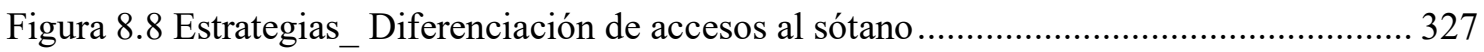

Figura 8.9 Estrategias_Accesibilidad al 2do nivel y graderías ............................................. 327

Figura 8.10 Estrategias_Extensión de techos para conectar zonas ......................................... 328

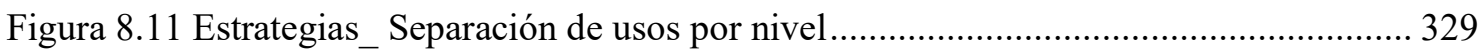

Figura 8.12 Estrategias_Anillo de oficinas y mercado al aire libre. ....................................... 329

Figura 8.13 Estrategias_Marcar configuración lineal en fachada y cobertura …..................... 330

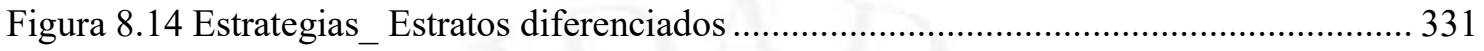

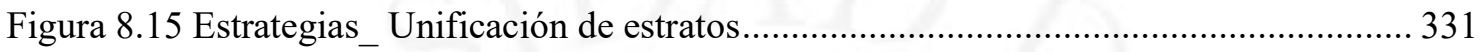

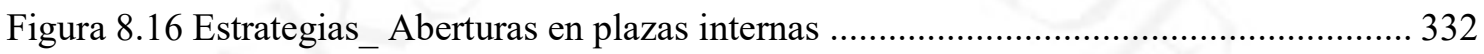

Figura 8.17 Estrategias__Desfases según el asoleamiento y espacialidad................................ 332

Figura 8.18 Precios de Jesús María y Lince ……................................................................... 333

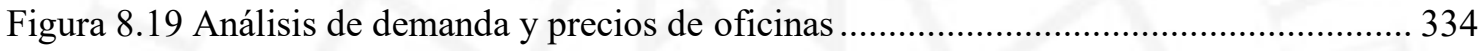

Figura 8.20 Precio en USD / $\mathrm{m} 2$ por mes de alquiler de oficinas .......................................... 335

Figura 8.21 Rentabilidad anual por alquiler de oficinas ….................................................... 335

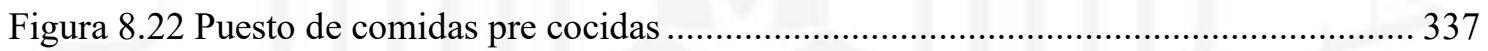

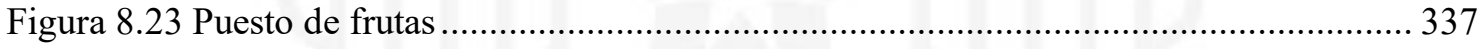

Figura 8.24 Axonometría por niveles del mercado.............................................................. 338

Figura 8.25 Lineamientos de diseño del espacio público .................................................... 342

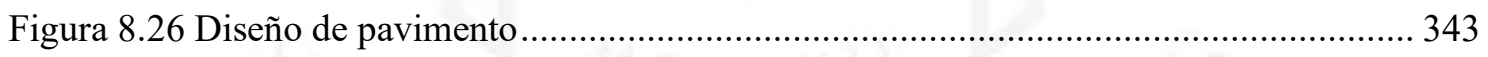

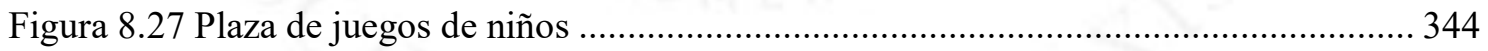

Figura 8.28 Plaza central de actividades municipales.......................................................... 345

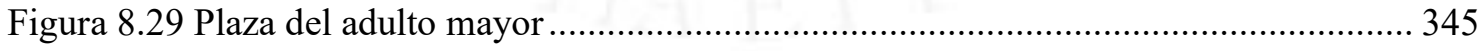

Figura 8.30 Propuesta del pasaje Punta Pacochas ................................................................ 346

Figura 8.31 Axonometría de un pabellón del mercado .......................................................... 348

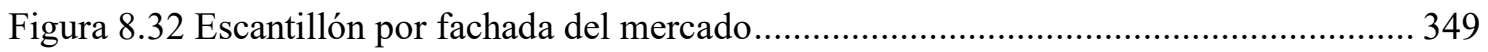

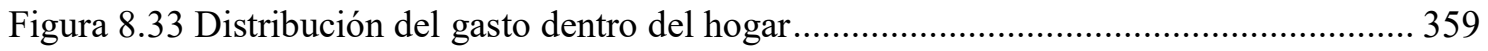

Figura 8.34 Costo promedio mensual por alimentos .............................................................. 360 


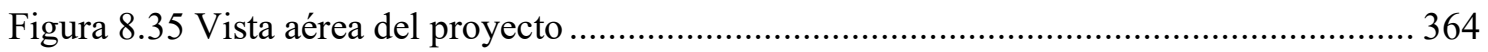

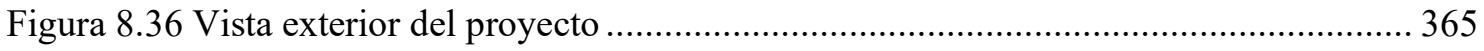

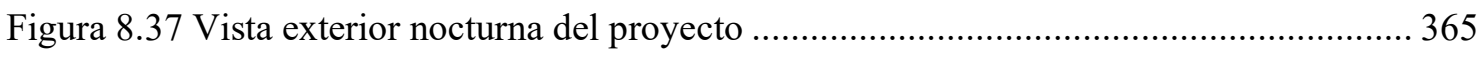

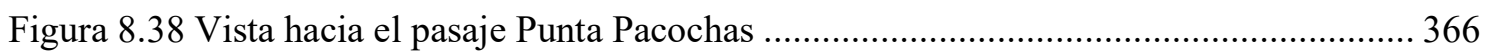

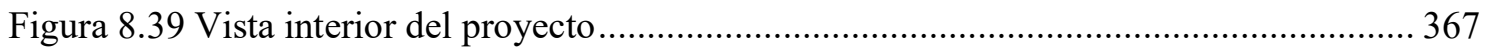




\title{
INTRODUCCIÓN
}

\author{
“Consumir bienes y servicios en nuestra \\ sociedad actual tiene un significado y \\ una función mucho más allá de la superación \\ de las necesidades básicas de abastecimiento; \\ es más bien un acto fundamental en la constitución \\ de una identidad personal y social”
}

- $\quad$ R. Liliana De Simone

La relación entre el comercio y la ciudad ha existido a lo largo de la historia como un vínculo de dependencia entre núcleos urbanos y las redes comerciales existentes. La aglomeración de actividades en torno al comercio da origen a la vida urbana y ella a las ciudades. El acto de compra es una acción indispensable de nuestra existencia a través del cual los estilos, códigos y valores son asimilados por las personas y comprometidos en la relación ser-sociedad. Además, por medio del contacto y el estímulo manifestados al momento de la compra, se nutren necesidades psicológicas del ser humano. El mercado, por lo tanto, no solo es un espacio para el desarrollo del intercambio comercial, sino que también cumple el rol de ser espacio público, como lugar en el que se construyen y fortalecen las relaciones sociales de una ciudad.

Los valores gastronómicos, la biodiversidad de los productos y la promoción turística que muchos países de Europa han desarrollado vieron que los mercados presentaban características positivas convertirse en los nuevos exponentes turísticos y generador de identidad de las ciudades, obteniendo impactos positivos en los residentes, comerciantes, usuarios tradicionales y su entorno. 
Lamentablemente, esta situación no se repite para el caso peruano, evidenciando la falta de un referente de modelo que genere un reconocimiento y una connotación positiva a los mercados del Perú, que fortalezca las interacciones sociales entre los vecinos, comerciantes y turistas. Un mercado que disminuya las brechas sociales y culturales, que funcione tal cual una plaza con espacios ocio y de encuentro que propicie la interacción social y al mismo tiempo que genere ciudadanía.

Por tales motivos, la siguiente investigación trata de entender la repercusión que tienen los mercados a nivel internacional, para luego analizar su situación a nivel local dentro de cada distrito, evaluarlos y categorizarlos; además de cómo la intervención en el Mercado San José de Jesús María podría fortalecer las interacciones sociales y revalorizarlo como espacio público. 


\section{CAPÍTULO I}

\subsection{Generalidades}

\subsubsection{Tema}

El tema de la presente tesis de grado propone desarrollar un proyecto de arquitectura en el Mercado San José del distrito de Jesús María, que revalorice el mercado como espacio público, aumente la oferta comercial y se convierta en un atractivo turístico para la ciudad. La propuesta considera al mercado como lugar de estructuración de las relaciones sociales donde las personas interactúan entre sí, al mismo tiempo en el que realizan las actividades comerciales.

\subsubsection{Justificación del Tema}

Los mercados de abastos tienen un valor como espacios de convivencia e intercambio en el barrio de una ciudad. Son lugares en los que se desarrollan y construyen fuertes lazos de reciprocidad y confianza entre vecinos a través de los años gracias al intercambio comercial. Tal como lo señala el antropólogo Juan Ignacio Robles (2008):

El mercado minorista, cumple una función de estructuración de las relaciones sociales dentro del espacio urbano, relacionándose también con una forma específica de "uso del espacio", de "forma de vida" y, finalmente, definiendo un modelo distintivo de ciudad y de barrio vertebrado alrededor de las relaciones vecinales en un espacio social equilibrado y sostenible. (p. 28)

Los mercados también pueden definirse como vitrinas socioculturales, pues exhiben la cultura de un país. Aglomeran gran diversidad de productos frescos y platos típicos que se disponen de manera visual a los compradores, brindando una variada gama de colores, texturas y aromas. Además, en ellos se reflejan las distinciones culturales de los mismos comerciantes como resultado del fenómeno migratorio.

Los mercados no son sólo eso. Son sitios excepcionales para la observación de contextos socioeconómicos (...), pero sobre todo de las relaciones sociales: un espacio público de encuentro, de negociaciones y transacciones entre personas de diferentes orígenes y credos donde también se comunica, se hace circular y recibe información... por tanto, un potente espacio sociocultural y de significación. (Medina, 2007, p. 183) 
Es así como los mercados se convierten en productos turísticos, atrayendo visitantes que buscan escapar de la homogeneidad, y que van al encuentro de productos novedosos, que logren una sensación única a través de todos sus sentidos (gusto, vista, olfato, tacto y sonido); es decir, un producto de sensaciones. Es precisamente esa búsqueda de lo local, lo que incita a los turistas visitar los mercados, con la finalidad de conocer y aprender la idiosincrasia del lugar como: los hábitos alimenticios, gustos y costumbres, la manera de ofertar, entre otros (García, 2017, p. 169).

Es precisamente la posibilidad de sentir el pulso de una sociedad, de acercarse a sus gentes y a sus productos, lo que ha favorecido, en los últimos años, que especialmente en Europa los mercados se hayan convertido, más que nunca, en un reclamo turístico de primer orden. (Medina, 2007, p. 194)

Por otro lado, la gastronomía peruana, la cual está ampliamente relacionada con el turismo en nuestro país es considerada a nivel nacional como patrimonio cultural y reconocida internacionalmente por el World Travel Adwards (WTA) como mejor destino culinario del mundo en el año 2007 (World Travel Adwards, 2017, párr.1). Esto se comprueba durante el 2008, cuando más de 97 mil de visitantes extranjeros fueron atraídos al Perú por su gastronomía, generando un promedio de \$16 dólares diarios en gastos alimenticios. No obstante, esta cifra aumento a \$21 dólares diarios durante el año 2011 y a \$35 dólares diarios en el año 2016 (PROMPERÚ, 2017, p 22).

En la encuesta "Razones para promover la gastronomía" realizada por Apega (2013), el 54\% de los peruanos asegura que la gastronomía contribuye al desarrollo del turismo y exportaciones, el $48 \%$ cree que la gastronomía permite valorar nuestra biodiversidad de productos alimenticios y un 44\% considera que la gastronomía mejora la imagen del país (Apega, 2013, p. 24). (Ver Figura 1.1). 


\section{RAZONES PARA PROMOVER LA GASTRONOMIAA}

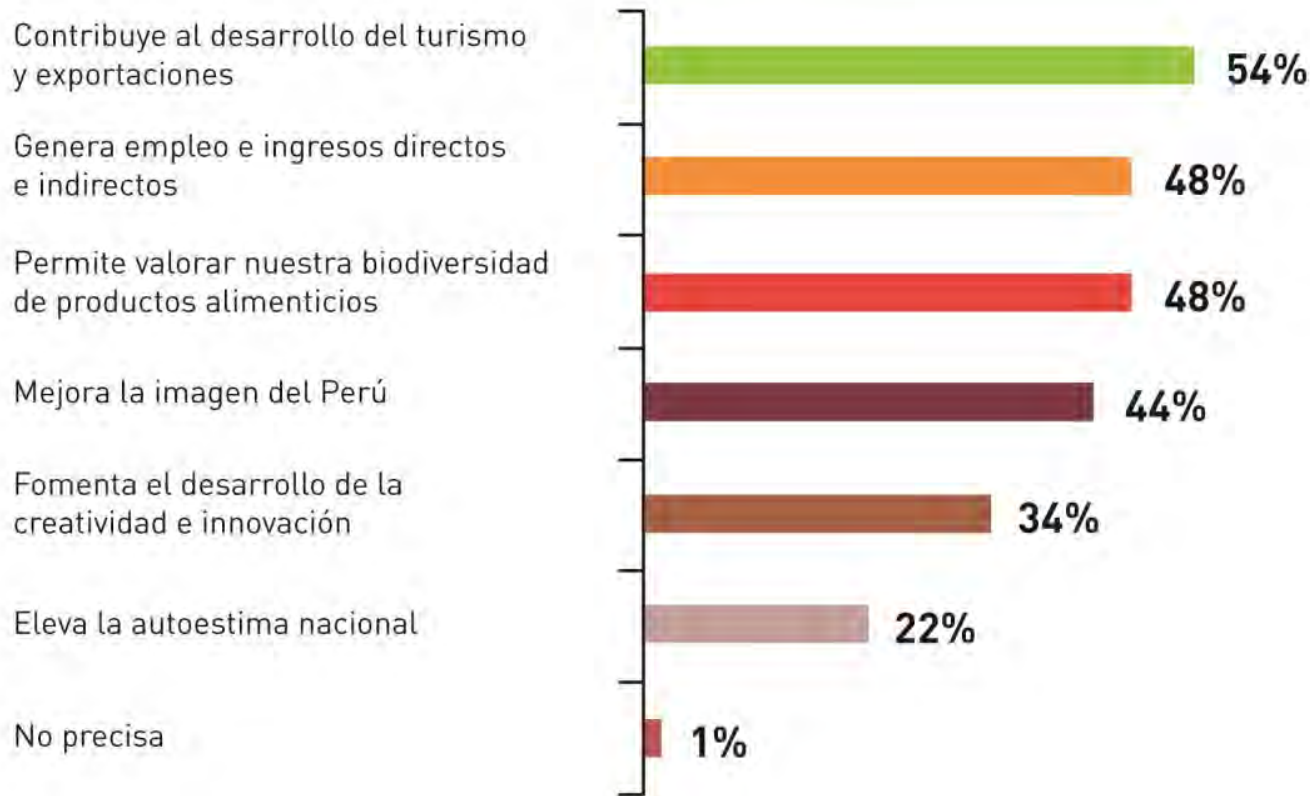

Figura 1.1 Razones para promover la gastronomía.

Fuente: Gráfico elaborado por los autores, según (Apega, 2013).

Además, los mercados están despertando interés de promotores turísticos y autoridades, pues ven en ellos un potencial cada vez mayor de oferta y atracción (Medina, 2014, p. 193). Un caso de éxito de promoción gastronómica a nivel internacional son los mercados de abastos en Europa (Ver Tabla 1.1), en donde gracias a la promoción de una imagen en común, la renovación y la modernización de sus establecimientos, el número de visitas a los mercados por turismo asciende anualmente (Ver Figura 1.2) 
Tabla 1.1

Demanda de visitantes a los mercados reinventados de Europa

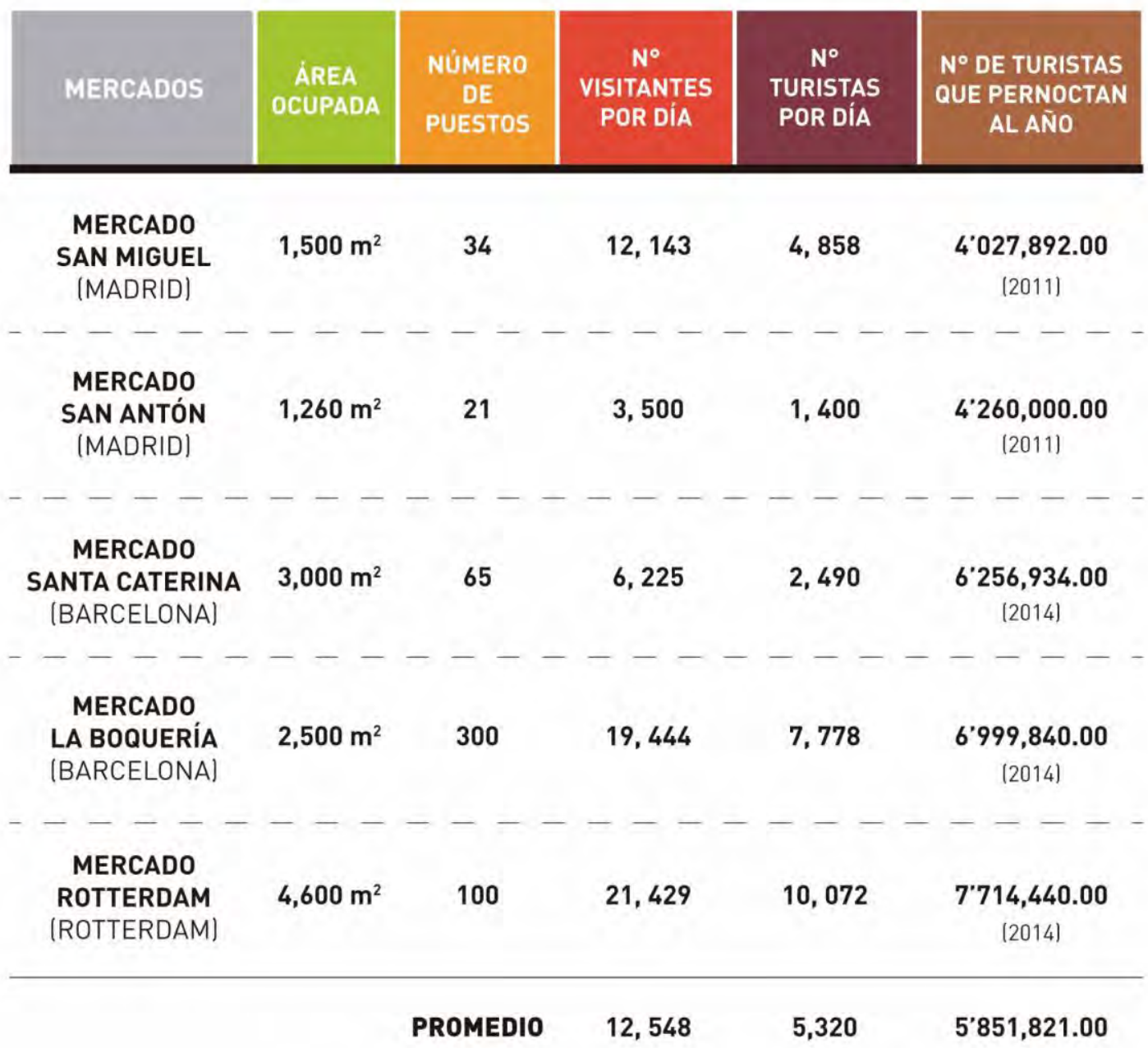

Tabla elaborada por los autores. 


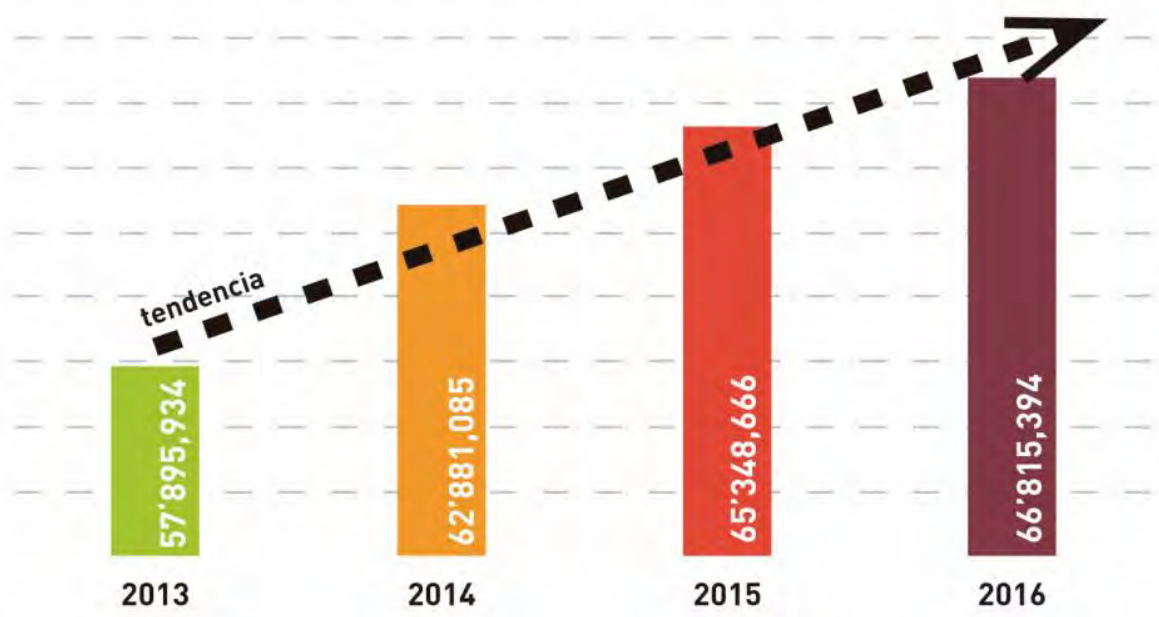

Figura $1.2 \mathrm{~N}^{\circ}$ turistas al año en mercados de Barcelona

Fuente: Gráfico elaborado por los autores, según el Ayuntamiento de Barcelona

En: http://ajuntament.barcelona.cat/mercats/es/noticia/los-mercados-de-barcelona-siguen-aumentando-elnzmero-de-visitas-con-668-millones-el-azo-2016

Un caso de éxito a nivel nacional es la Feria "Mistura" (Ver Figura 1.3), la cual ha captado gran cantidad de turistas desde su primera edición, con un público de 24 mil personas en el año 2013, incrementando a 36 mil en el año 2016 (Apega, 2016, párr. 5).

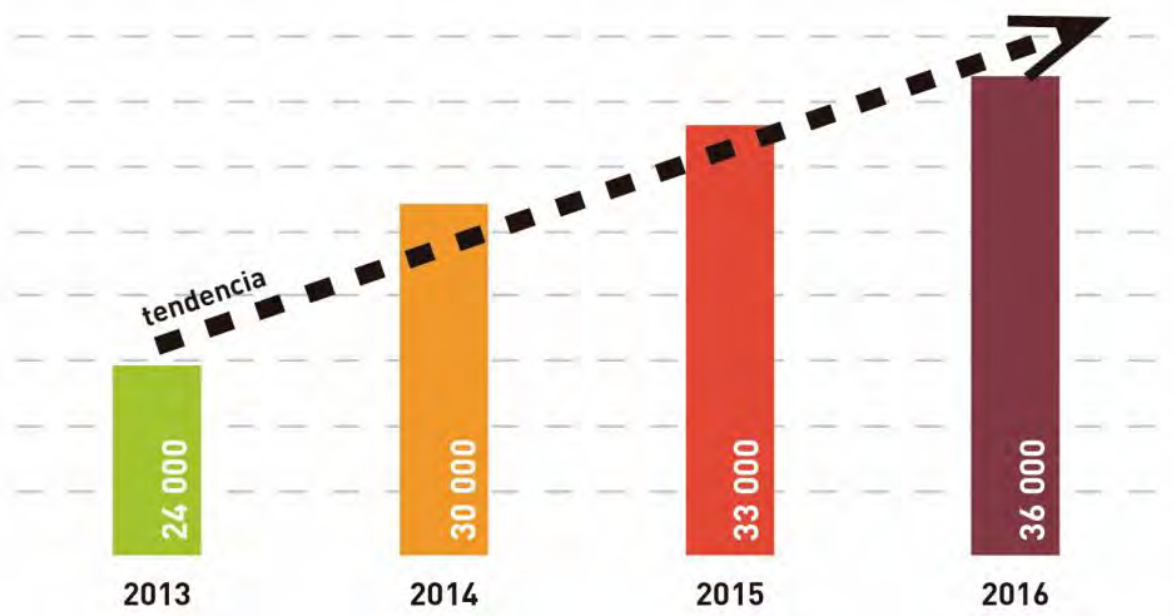

Figura $1.3 \mathrm{~N}^{\circ}$ de turistas en ediciones de Mistura

Fuente: Gráfico elaborado por los autores, según (Apega,2016). 
Según el último censo nacional de mercados de abastos realizado por el Instituto Nacional de Estadística e Informática (2017) existen 2612 mercados de abastos a nivel nacional, de los cuales el 47,2\% (1 232 mercados) pertenecen a la ciudad capital de Lima (p. 23).

Sin embargo, hay un desequilibrio de este equipamiento comercial en su red y distribución en la ciudad, ya que la gran parte de los mercados que Lima posee el 40\% se aglomeran en la zona central y norte de la ciudad, mientras que solo el $4 \%$ de ellos se ubican en el canal moderno, sector comprendido por los distritos de: Jesús María, San Borja, La Molina, Barranco, Miraflores, San Isidro y Magdalena. Este desbalance ocurre porque en los últimos años, la distribución comercial ha sido sometida a intensos procesos de cambio debido al fenómeno de globalización y la tecnología; los nuevos patrones de compra, consumo y alimentación han incentivado el surgimiento de formatos comerciales de autoservicio como los súper e hipermercados.

La dualidad comercial-social que caracteriza a los mercados, se ha deteriorado por los cambios económicos y sociales, afectando el consumo y el estilo de vida de las personas (Regalado et al., 2009, p. 22). Según Arellano (2017), se puede clasificar a estas personas como Sofisticados y Progresistas, referidos a hombres y mujeres de mediana edad, de nivel socioeconómico A, B y C, y con mayor nivel de instrucción. Cuentan con actitudes innovadoras y tecnológicas, son confiados en sí mismos, buscan experiencias más que solo una visita para realizar las compras, y ven el precio como representación de calidad (p. 8). Para ellos la actividad comercial ha cambiado y con el paso del tiempo han optado por los nuevos formatos comerciales mucho más acordes a sus demandas y que en consecuencia restan clientes a los mercados tradicionales (Rodríguez, 2014, p. 89).

Con el crecimiento de las ciudades y la globalización del mundo actual, los supermercados se extienden y comienzan aparecer en diferentes puntos de las ciudades, impactando en la trama urbana como consecuencia de su configuración espacial y sus dimensiones, desvinculándose de la ciudad y configurando un nuevo espacio completamente ajeno a ella. De esta manera, el crecimiento de este nuevo formato comercial en el Perú aumentó un 529,4\% en la última década, pasando de ser de 51 establecimientos a 321 (Grupo El Comercio, 2014; INEI 2017). 
Si bien, el número de supermercados está incrementado, el INEI (2017) enfatiza que hasta el momento "Los mercados de abastos continúan siendo la principal forma de suministro de alimentos, bienes y servicios de los consumidores a nivel nacional" (párr.1). Reflejándose en su ingreso anual ${ }^{1}$ y en el incremento del número de puestos fijos al pasar de 155765 en el 1996, a 328946 en el 2016, aumentando un 111,2\% (INEI, 2017, párr.17).

Por los problemas mencionados escogimos al distrito de Jesús María, perteneciente al canal moderno y considerado, según la clasificación de abastecimiento de Leung ${ }^{2}$ (2006), como distrito des-abastecido (Ver Figura 1.4 ), ya que cuenta con un solo mercado tradicional, el Mercado San José (p. 70). Y según el PLAM 2035, estos mercados deberían abastecer como máximo a una población de 10 mil habitantes, sin embargo, el mercado abastece a 50 mil personas, por lo que presenta un déficit de 40 mil.
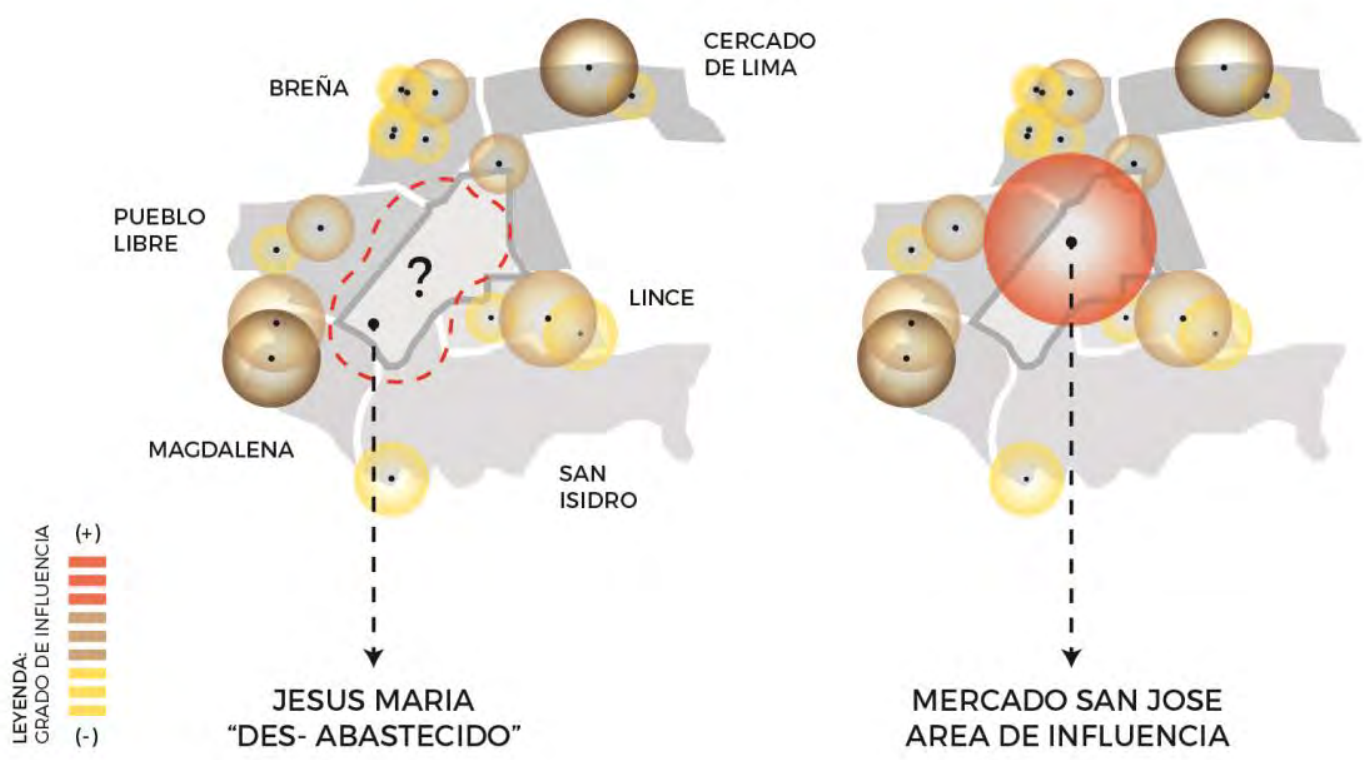

Figura 1.4 Jesús María distrito des-abastecido

Fuente: Gráfico elaborado por los autores, según (Leung, 2016).

\footnotetext{
${ }^{1}$ Los mercados de abastos tuvieron un ingreso total de S/. 239'510,446 en el 2015. El 32,5\% de los ingresos se generaron gracias a los alquileres de los puestos fijos, el 27,9\% fue por el pago de cuotas ordinarias, un 13,7\% por alquileres de los servicios higiénicos, y el 25,9\% fue por otros motivos (INEI, 2016, p.20).

${ }^{2}$ Ver Figura 6.8 ubicado en el capítulo VI: Marco Contextual.
} 
No obstante, el distrito de Jesús María se consolidó rápidamente como un espacio de servicios y comercio a escala interdistrital gracias al Mercado San José, que generó una dinámica comercial que posiciona al distrito como uno de los de mayor porcentaje de actividades económicas destinadas al comercio con un 51\% (INEI,2008).

Sin embargo, este mercado posee problemas en su infraestructura y distribución interna, incumpliendo con las normas establecidas por Defensa Civil y llevándola hacia dos clausuras. La accesibilidad es uno de los principales problemas debido a las barreras arquitectónicas presentes, las cuales impiden que se note la actividad comercial y la interacción social en su interior. Otro problema es que no existe un acceso diferenciado para las mercancías lo que muchas veces obliga a los camiones de carga estacionarse en las calles aledañas al mercado generando congestión vehicular.

El mercado también presenta problemas de adecuación física, en cuanto a la escala del proyecto, no posee una jerarquía dentro de su contexto urbano, contando con una altura de tan solo $3.00 \mathrm{~m}$. Además, presenta circulaciones irregulares y angostas $(1.00 \mathrm{~m})$ en varios tramos de su interior, impidiendo que la actividad comercial sea fluida y confortable. Añadido a esto, los puestos de venta tienen una escasa superficie comercial $\left(5 \mathrm{~m}^{2}\right)$ incumpliendo con el área mínima designada por el RNE. La carencia de dotaciones comunes también es otro problema del mercado, no teniendo zona de carga y descarga, cámaras de fríos, almacenes, vestuarios y estacionamientos para comerciantes y clientes.

Por tales motivos, en el año 2013, la Municipalidad de Jesús María desarrolló el "Plan de Desarrollo Concentrado" del distrito para el 2025, que señala como objetivo: "Promover el posicionamiento del distrito mediante la promoción y puesta en valor de sus atractivos y espacios púbicos como valor agregado a las actividades económicas" (Municipalidad de Jesús María, 2013, p. 96). 
Teniendo en cuenta la conversión la Av. Cuba como boulevard gastronómico (Ver Figura 1.5) desde el Mercado San José, aledaño a la Plaza y la Iglesia San José considerados puntos de partida del tour turístico del distrito. Esto se debe en consecuencia a la proyección de crecimiento de turistas extranjeros en Lima Metropolitana con la necesidad de incrementar la oferta de servicios turísticos de alimentación, hospedaje, y entre otros servicios.

Por el posicionamiento del distrito en el área interdistrital y su ubicación tiene todas las condiciones para ser sede de la mayor infraestructura y de servicios turísticos que necesitará Lima Metropolitana para atender adecuadamente el previsible incremento del flujo turístico. Jesús María cuenta con una oferta gastronómica de calidad en la ciudad, en un entorno agradable, que complementa con sus espacios recreativos. (Municipalidad de Jesús María, 2013, p. 78)

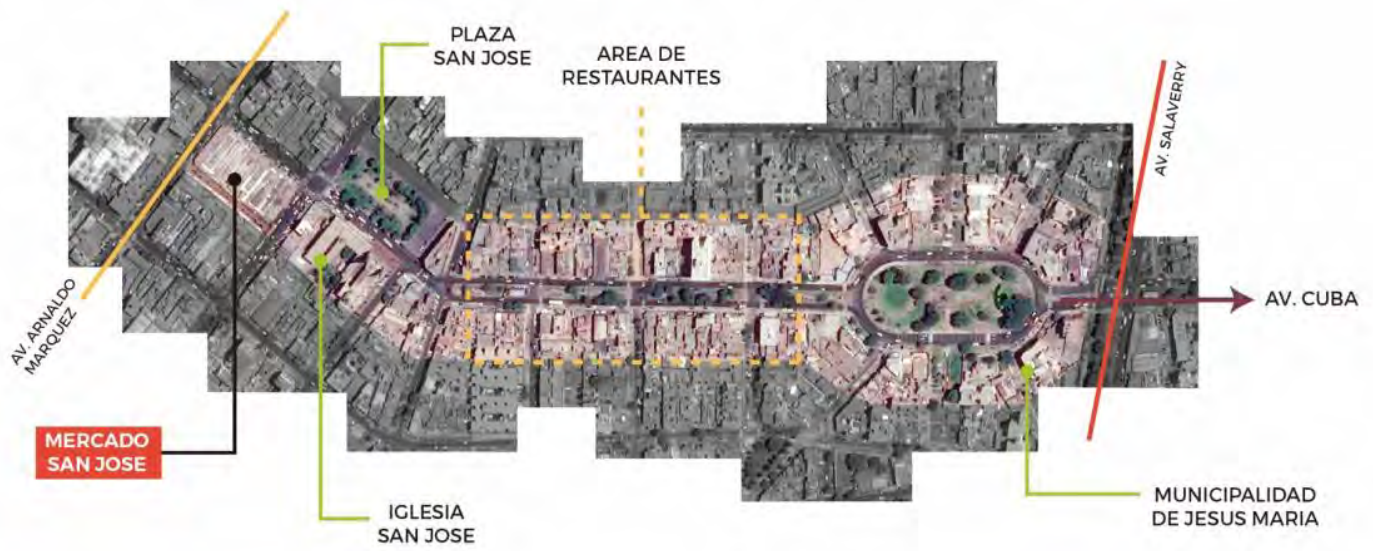

Figura 1.5 Boulevard gastronómico en la Av. Cuba

Fuente: Gráfico elaborado por los autores, según el Plan de Desarrollo de Jesús María, 2013-2025. 


\subsubsection{Planteamiento del problema}

El ser humano desde su nacimiento es un ser social, que se desarrolla poco a poco por medio de la interacción con otras personas en un proceso continuo de socialización. Es mediante la interacción que el individuo se afilia a un grupo de personas, adquiere hábitos y valores que lo ayudan a formar su identidad de acuerdo a las conductas sociales consideradas adecuadas dentro del contexto cultural en el que se encuentra (Yubero, 2005, p. 819).

Dentro de la ciudad, los espacios de carácter público son el escenario de la interacción social que reúne funciones materiales y tangibles, también es el soporte físico de las actividades cuya finalidad es satisfacer las necesidades urbanas colectivas que supera los intereses individuales para convertirse en un espacio común y colectivo (Valero, 2011, p. 7).

Las tipologías y clasificaciones existentes sobre el espacio público se basan en criterios básicos como la forma y la función, el estado formal, y la jerarquía de captación (Mantey \& Kępkowicz, 2018, p. 640). Sin embargo, la evolución de las formas de asentamiento urbano y la creciente cantidad y variedad de espacios semipúblicos administrados por asociaciones público-privadas, o completamente privadas, cuestionan esta noción heredada desde una perspectiva legal (Tonnelat, 2010, p. 1).

En consecuencia, surgen dieciséis tipologías nuevas de espacio público que modifican las categorizaciones existentes y reflejan el proceso de privatización del espacio enfocado en la especificidad social y espacial. Estas se construyen en torno a cinco criterios: los usuarios previstos, los plazos de acceso, la forma de control prevalente, las funciones previstas y las características visuales (Mantey \& Kępkowicz, 2018, p. 650). 
Dentro de esta nueva clasificación, el espacio de mercado forma parte de los “open markets" ${ }^{3}$ los cuales son espacios destinados a la realización de compras al aire libre, accesibles para todo el público en general, con apertura en días y horas seleccionadas, cumplen con una función económica y un control cívico. Son lugares importantes para reunirse e intercambiar información (Mantey \& Kępkowicz, 2018, p. 641).

El mercado de abasto como campo semántico, posee dos dimensiones. Primero, es un lugar físico donde se genera el intercambio comercial, principalmente de productos perecederos. Y segundo, es un espacio de carácter público que cumple la función de estructuración de las relaciones sociales dentro del espacio urbano (Robles, 2008, 2014).

Borja y Muxí (2003), en su estudio “El espacio público, ciudad y ciudadanía”, muestran la importancia del espacio público y lo que genera su ausencia:

El espacio público es un mecanismo fundamental para la socialización de la vida urbana. La negación de la ciudad es precisamente el aislamiento, la exclusión de la vida colectiva, la segregación. Quienes más necesitan el espacio público, su calidad, accesibilidad, seguridad son generalmente los que tienen más dificultades para acceder o estar: los niños, las mujeres, los pobres, los inmigrantes recientes... En los espacios público se expresa la diversidad, se produce el intercambio y se aprende la tolerancia. (p. 87)

Entre todos los tipos de espacio público, los mercados de abasto tienen la particularidad de abarcar gran cantidad de relaciones interpersonales que cambian dependiendo del tipo de vendedor y cliente. Dando formas de comunicación únicas y observables, que añadiéndole el factor de la cotidianidad se transforman en códigos de conducta propios de cada mercado en particular (Velarde, Castro, Carreño, Burga y Erquiaga, 2015, p. 1).

\footnotetext{
${ }^{3}$ Ver tabla 3.2. Ubicado en el capítulo III: Marco Teórico.
} 
El problema principal radica cuando sólo se reconoce al mercado de abastos como un equipamiento comercial, mas no como un espacio público de la ciudad donde las personas se reúnen a realizar actividades de ocio e interactuar entre ellos. Es un lugar de encuentro, de expresión y de manifestaciones de la sociedad, de interacción entre lo ecológico, lo biológico y lo social, al mismo tiempo en que se realizan las actividades comerciales (Siena, 2011; Gómez Benito, 2008).

Cuando un espacio público está ausente en la ciudad, no se encuentra integrado socialmente ni articulado física y simbólicamente, la ciudad se disuelve, el proceso histórico que hace avanzar las libertades individuales y colectivas se interrumpe, y la tolerancia como valores ciudadanos se ven superados por la segregación y por la codicia, por el egoísmo y la exclusión (Borja, 2011, p. 39).

Además, hoy nos encontramos dentro de una sociedad cada vez más individualista (De Julios, 1995; Verdu, 2001; Álvarez, 2009), generando que aparezcan nuevos formatos comerciales de autoservicio que obvian al comerciante, el cual es considerado como mediador social y redistribuidor en el aspecto económico y comercial, mediador social y redistribuidor cultural a nivel de intergeneracional e interétnico, conectando a clientes de diferentes generaciones, orígenes y costumbres (Robles, 2008, p. 22).

Obviar al comerciante dentro de los equipamientos comerciales provoca que las personas no satisfagan sus necesidades psicológicas (de contacto, de conocimiento, y de estímulo), impidiendo las interacciones sociales, y generando la pérdida del sentido de sociedad, de vida colectiva y significado (Gehl, 2003, p. 127).

Los nuevos formatos comerciales de autoservicio, dan origen a la descontextualización del espacio público, ya que no responden a un determinado contexto comercial y social; son vistos como grandes contenedores arquitectónicos, de estética despersonalizada, provocando cierta anti-urbanidad, al evitar toda fricción con la actividad de la ciudad y todo diálogo con el espacio público que lo limita, careciendo de identidad (Espil, 2003, p. 79). 
El reconocimiento actual del mercado como sólo un equipamiento comercial, ha generado la pérdida de su valor como espacio público y lugar de las interacciones sociales, provocando el descuido de los mercados de abasto de la ciudad, presentado problemas tanto físicos como espaciales ${ }^{4}$, así también como en el modelo de negocio, ya que no se adapta a las exigencias de los consumidores.

Para fortalecer el vínculo social-comercial del mercado con sus habitantes, se requiere de una actualización del modelo comercial acorde a las exigencias del consumidor actual, modernizándose en su infraestructura, espacialidad y relación con el entorno.

\footnotetext{
${ }^{4}$ El 64,8\% de los mercados del país cuentan con una cobertura realizada en calamina, mientras que sólo el 28,4\% tiene una cobertura de concreto armado, además, el 88,5\% de los mercados no dispone de centros de acopio ni contenedores de basura, así también sólo el 4,1\% cuenta con cámaras de frío de los cuales el 75,5\% no cumple su función, y en cuanto al abastecimiento el $84,9 \%$ no poseen área de carga y descarga (INEI, 2017).
} 


\subsection{Objetivos de la investigación}

\subsubsection{Objetivo general}

Proponer un proyecto de arquitectura que revalorice el mercado como espacio público, que reestablezca su vínculo con los habitantes, y que se convierta en un atractivo turístico para la ciudad, en el distrito de Jesús María.

\subsubsection{Objetivos específicos}

- Examinar cómo funcionan las nuevas propuestas arquitectónicas de mercados de abastos a nivel internacional, y cómo han logrado fortalecer el vínculo comercialsocial, para obtener criterios de diseño y generar el programa arquitectónico.

- Estudiar la historia de los mercados a nivel nacional e internacional enfocado a la importancia de la relación comercio y espacio público.

- Identificar teorías para obtener criterios de diseño y fortalecer la idea de mercado como espacio público y social.

- Estudiar teorías y casos de mercado como producto turístico para comprender qué características o estrategias de diseño genera que se considere como tal.

- Analizar y comprender el contexto en el que se ubica el mercado desde sus diferentes redes para obtener estrategias que ayuden a su correcto emplazamiento.

- Identificar la normativa vigente sobre mercados de abastos y contrastarla con la normativa y planes de modernización de mercados de España para complementarlos y utilizarlos en el proyecto. 


\subsection{Supuesto básico de la información}

Partiendo de la idea del mercado como lugar de estructuración de relaciones sociales la remodelación del Mercado San José recuperará su valor como espacio público, presentará una mejor relación con su entorno mostrando las interacciones sociales y comerciales en su interior, y se convertirá en un referente turístico de la ciudad a partir de generar afectos y sensaciones en las personas por su arquitectura, incrementando el número de visitantes local y extranjero que exhiba de manera idónea la cultura del país.

\subsection{Alcances y limitaciones}

\subsubsection{De la investigación}

\section{Alcances:}

- Se analizaron diversas propuestas arquitectónicas de mercados de abastos a lo largo de la historia que aproxime a la comprensión de la evolución de los espacios dedicados al intercambio comercial y su vínculo con la sociedad.

- Se realizó una caracterización de la zona del mercado y su contexto inmediato mediante un análisis de gabinete y trabajo en campo para determinar la dinámica social - urbana y del funcionamiento actual del mercado mediante entrevistas, conteo e identificación de usuarios, visitas a instituciones afines y levantamiento de la información documentaria.

- Se investigaron proyectos análogos a fin de determinar las herramientas proyectuales, programa arquitectónico, y la relación de la infraestructura con el entorno, verificando su posible incorporación en el proyecto.

- Se investigaron teorías que sustenten la importancia del mercado como un espacio público, y aquellas teorías relacionadas al diseño del mercado como producto turístico.

- Se buscó lineamientos y normativas de los mercados en Europa para complementar el reglamento nacional sobre mercados de abastos, haciendo énfasis en el programa arquitectónico y pre-dimensionamiento de áreas. 


\section{Limitaciones:}

- El tema del mercado tradicional desde el aspecto urbano y arquitectónico es relativamente reciente en el Perú, reflejándose en la poca información disponible encontrada durante la recopilación de investigaciones por lo que se consultará en trabajos desde la perspectiva social.

- La falta de información sobre las condiciones de los mercados de abasto de Lima fue una de las principales limitaciones por lo que la data cuantitativa se obtendrá por parte de estudios realizados por empresas privadas como el INEI y CCR Latinoamérica.

- No se realizará estudios de suelo, ni estudios de impacto ambiental.

- No se pretende realizar un inventario exhaustivo del estado de la infraestructura de los mercados de abastos en el país y en la ciudad de Lima, sino que se asume dicha información de fuentes bibliográficas como referencia para profundizar en el análisis propio del proyecto.

- En cuanto a la historia del distrito, la Municipalidad de Jesús María casi no cuenta con información por lo que se tuvo que complementar las pocas fuentes encontradas con imágenes de mapas históricos que muestran su evolución urbana.

\subsubsection{Del proyecto}

\section{Alcances:}

- Se diseña un mercado que cumple con los lineamientos y normativas vigentes del país, complementado con la normativa y planes de modernización de mercados de abastos actuales en Europa.

- El beneficio del proyecto es su recuperación como lugar de estructuración de relaciones sociales complementado con su actividad comercial.

- El perfil del consumidor y las dinámicas de vida de relevancia para la elaboración del mercado serán las existentes en Jesús María, distrito en el que se ubica el proyecto. 


\section{Limitaciones:}

- Se desarrollará el nuevo mercado a nivel de anteproyecto arquitectónico.

- Se presentarán planos de especialidades (estructuras, eléctricas, sanitarias y mecánicas) a nivel esquemático.

- Los costos generales y el presupuesto del proyecto serán realizados en base a ratios de construcción y precios unitarios.

\subsection{Diseño de la investigación}

El diseño de la investigación realizada es descriptivo, dado que se analizará el contexto actual del distrito de Jesús María, así como el recorrido histórico de la infraestructura de mercados en el Perú y el mundo.

Se realizó y profundizó en las teorías y enfoques arquitectónicos actuales que propongan soluciones en cuanto a criterios arquitectónicos para el diseño del mercado.

Se describieron y sintetizaron las normativas actuales que influyen en el diseño del proyecto como también en el análisis de los casos análogos desde su programa arquitectónico, estrategias proyectuales, distribución interior y aportes tecnológicos.

La segunda parte de la investigación, es decir, en la etapa del proyecto, es aplicada, ya que se concluirá con el diseño del Mercado San José de Jesús María, que recogerá todos los criterios y elementos analizados en la primera parte de la investigación.

\subsection{Metodología de la investigación}

\subsubsection{Forma de consulta y recopilación de la información}

Para la obtención de la información se indagó en fuentes primarias como datos ofrecidos por el Instituto Nacional de Estadística e Informática (INEI), informes de la Municipalidad de Jesús María en relación a los planes futuros dentro del distrito, y por entrevistas con representantes de diversas instituciones afines, como el actual director de la junta directiva del mercado, como con representantes de la Municipalidad de Jesús María, y así mismo con representantes de Apega. 
A esto se le suma fuentes secundarias, al consultar a través de libros, artículos científicos, informes y tesis de maestrías nacionales e internacionales que aporten para el análisis y diseño del mercado de abastos.

Otros elementos hallados se complementarán con visitas de campo al mercado "San José" como a su contexto inmediato para entender las dinámicas presentes y sus requerimientos.

\subsubsection{Forma de análisis de la información}

La información histórica y los referentes arquitectónicos fueron valorados desde un punto de vista espacial y proyectual estudiando sus características formales y funcionales, la evolución tipológica de los mercados en el tiempo, la cual será expresada a nivel gráfico a través de líneas de tiempo, cuadros comparativos y esquemas analíticos tipológicos.

El análisis teórico se realizó a través de mapas mentales que sinteticen los postulados principales a fin de encontrar patrones y elementos conceptuales que aporten a la toma de partido.

Los aspectos normativos fueron sintetizados y esquematizados en gráficos para una rápida visualización con el fin de que todos sean aplicados correctamente.

La zona a intervenir y su contexto fue analizado de manera gráfica a través de láminas que sinteticen las redes presentes según fuentes confiables y trabajo de campo, además de analizarlo a través de la superposición de planos y esquemas viales, entre otros, para determinar las condicionantes propias del lugar en el planteamiento del proyecto.

\subsubsection{Forma de la presentación de la información}

La información es presentada a través de una investigación escrita, dividida por capítulos que va acompañada de elementos gráficos que resuman la información y ayude a su rápida comprensión.

En la segunda parte, la información se complementa con el diseño del nuevo mercado "San José". El proceso formal será presentado en base a esquemas que sinteticen las decisiones tomadas en el proyecto, a su vez se añadirán los planos de arquitectura y de especialidades, así también como vistas o renders finales del proyecto. 


\section{CAPÍTULO II: Marco histórico - referencial}

\subsection{Antecedentes históricos del lugar}

\subsubsection{Antecedentes históricos de Jesús María}

La historia del distrito inicia en 1880 con el crecimiento en extramuros de la ciudad que se encontraba entre las tierras de cultivo del río Huatica y el río Magdalena. En aquellos días la explotación del guano era realizada por compañías francesas fortaleciendo la relación con este país, por tal motivo, el ideal de las reformas Haussmanianas estaba presente en la creación de alamedas, boulevares y ejes viales que remataban en óvalos concéntricos, realizados en el espacio dejado por los ingresos de las murallas (Kahatt, 2014, p. 39). En esta época el distrito no existía, era zona de cultivos, pero se puede notar el inicio de su trama urbana (Ver Figura 2.2).

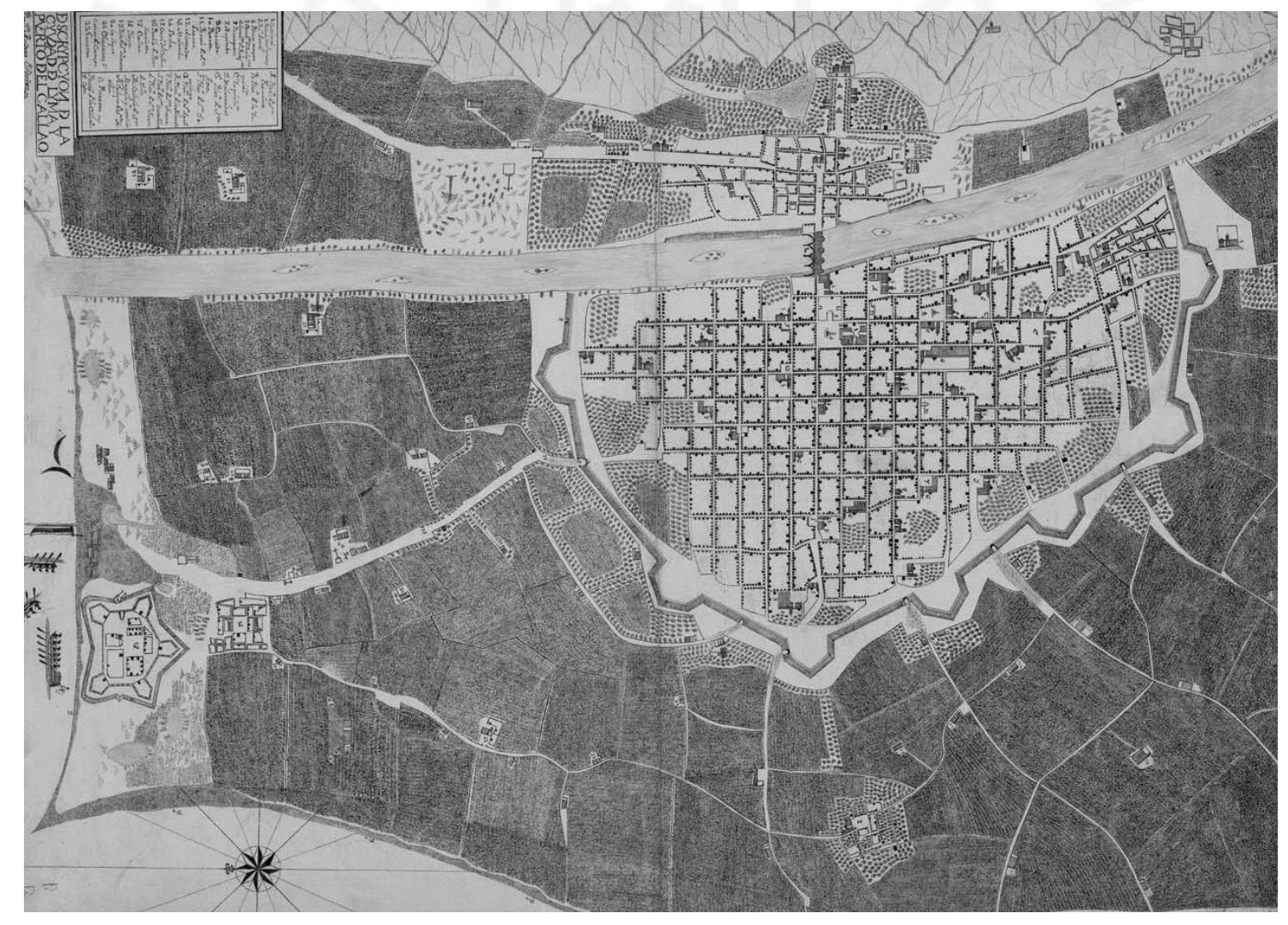

Figura 2.1 Lima Amurallada y las tierras de cultivo

Fuente: Biblioteca Nacional de España 


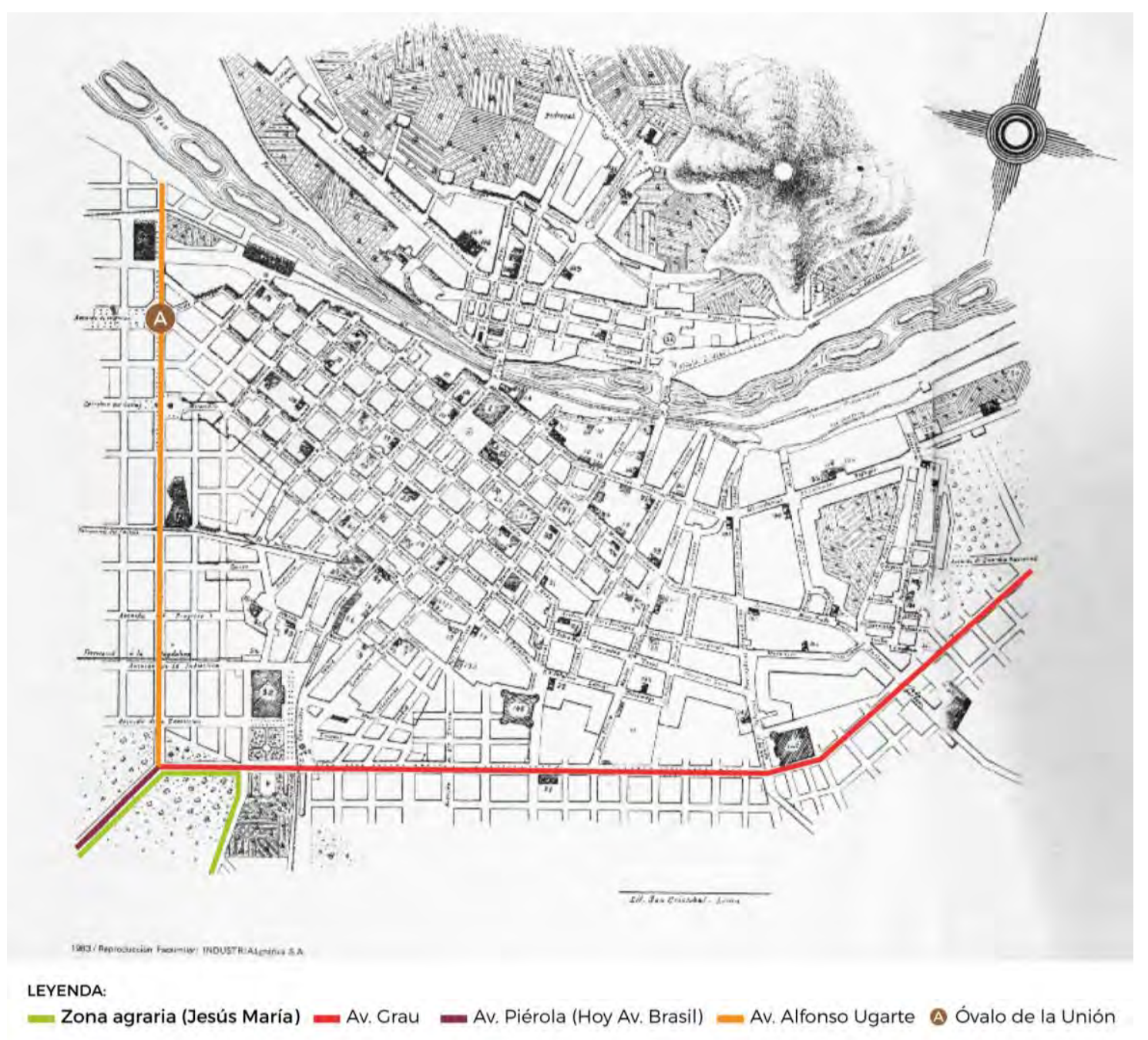

Figura 2.2 Plano de Lima_1896

Fuente: Bromley (1945). Figura editada por los autores.

El área donde se encuentra actualmente el distrito estaba ocupada por la hacienda Santa Beatriz, propiedad de los jesuitas (Ver Figura 2.3), y por la hacienda de Jesús María, que posteriormente se le designará como nombre al distrito. La hacienda Santa Beatriz, después de cambiar de dueño por muchos años, en 1901 pasó a ser propiedad de la Municipalidad de Lima, lo que resultó ser el primer bastión urbanizado (La Rosa, 2014, p. 56). 


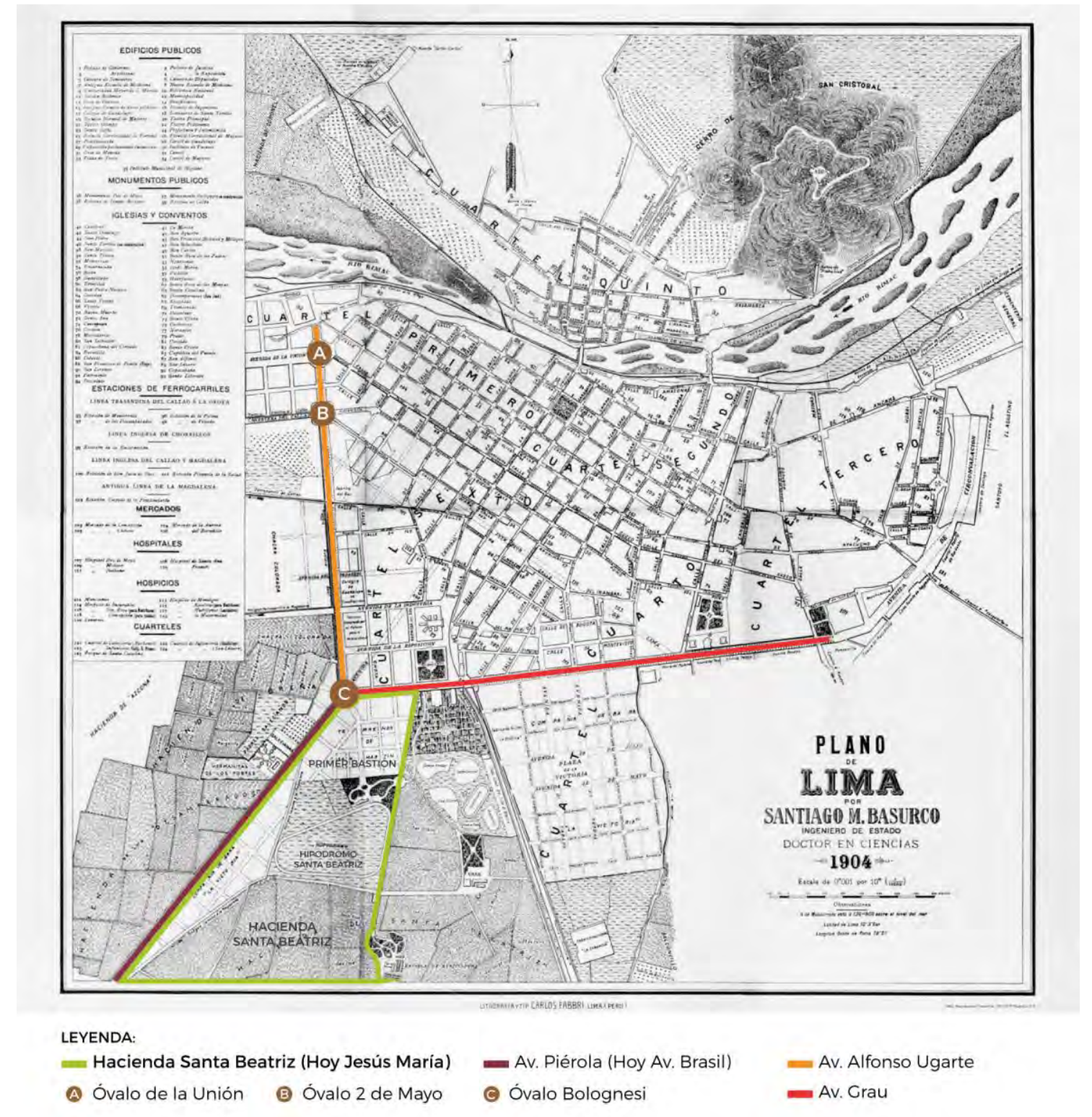

Figura 2.3 Plano de Lima_1904

Fuente: Santiago Basurco (1904). Figura editada por los autores. 
Dentro de la hacienda Santa Beatriz también se ubicaba el hipódromo inaugurado en 1903 (Ver Figura 2.4, Figura 2.5, Figura 2.6 y Figura 2.7), el cual era de propiedad del Estado y administrado por el Jockey Club, este recinto deportivo contaba con una pista de $1600 \mathrm{~m}$ x 12m de ancho, además de tribunas utilizadas por la oligarquía limeña. La huella del hipódromo se puede notar en el plano de Lima de 1904 (ver figura 2.3), y fue de gran relevancia en el gobierno de Leguía, debido a que fue sede de las celebraciones por el centenario de la Independencia del Perú, actualmente es lo que se considera el Campo de Marte.

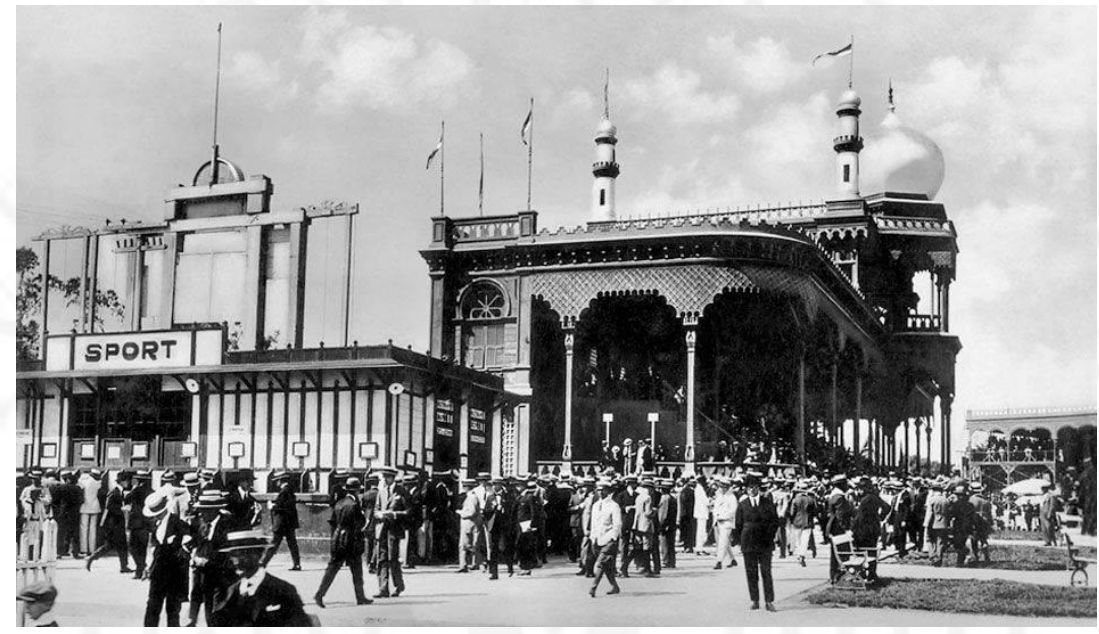

Figura 2.4 Hipódromo de Santa Beatriz_1920

Fuente: Juan Gunther Doering (1935)

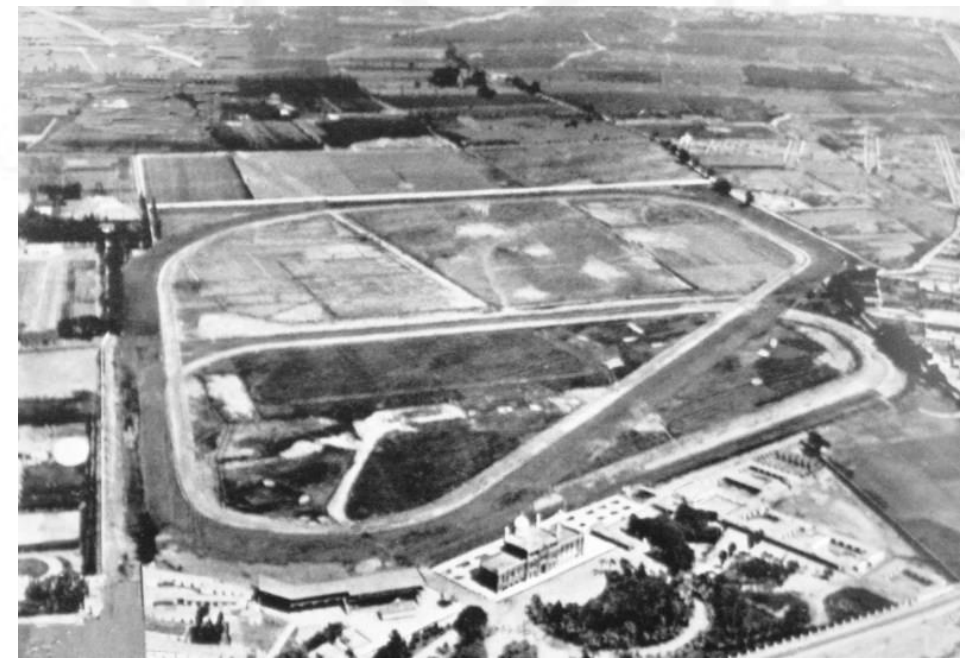

Figura 2.5 Vista aérea del Hipódromo Santa Beatriz_1920

Fuente: Lima la única

En: http://www.limalaunica.pe/2010/11/el-hipodromo-de-santa-beatriz.html 


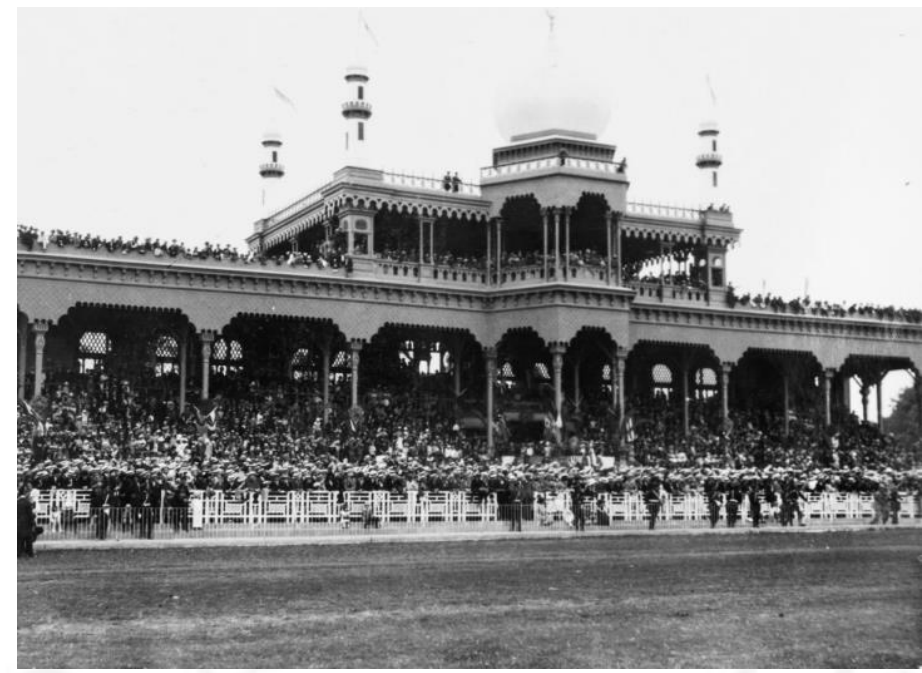

Figura 2.6 Fachada interior del Hipódromo de Santa Beatriz_1924

Fuente: Pontificia Universidad Católica del Perú

En: http://repositorio.pucp.edu.pe/index/handle/123456789/36612

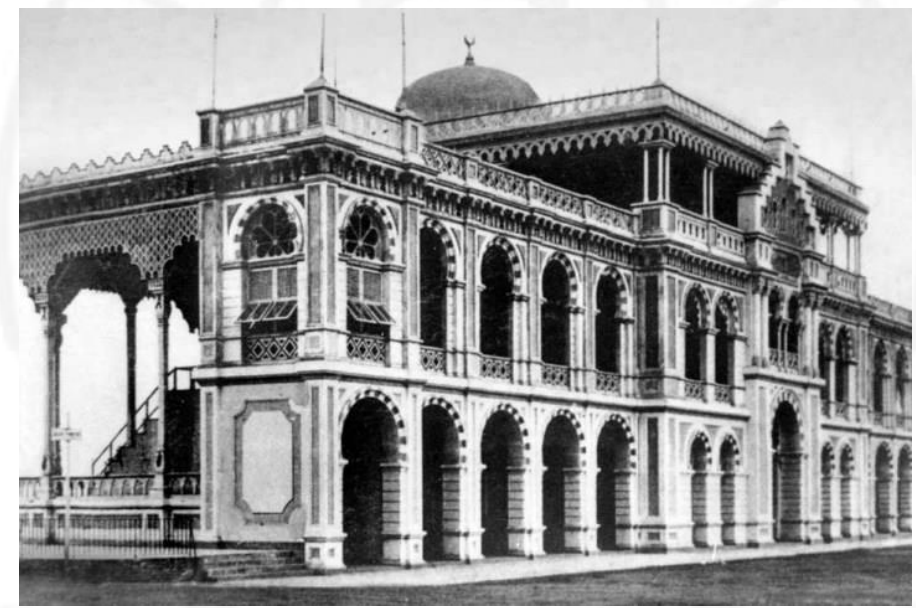

Figura 2.7 Fachada exterior del Hipódromo de Santa Beatriz

Fuente: Lima la única

En: http://www.limalaunica.pe/2010/11/el-hipodromo-de-santa-beatriz.html

El perfil agrícola del barrio de Jesús María estuvo presente hasta el año 1927 (Ver Figura 2.8), cuando en el gobierno de Augusto B. Leguía, la Escuela de Agricultura diseña el proyecto de urbanización de 32 manzanas conectadas y nuevos ejes viales como la Av. Progreso actual Av. Venezuela, La Av. Leguía actual Av. Arequipa, y los ferrocarriles Lima-Chorrillos y Lima-Magdalena lo que generó una pronta consolidación (La Rosa, 2014, p. 57). 


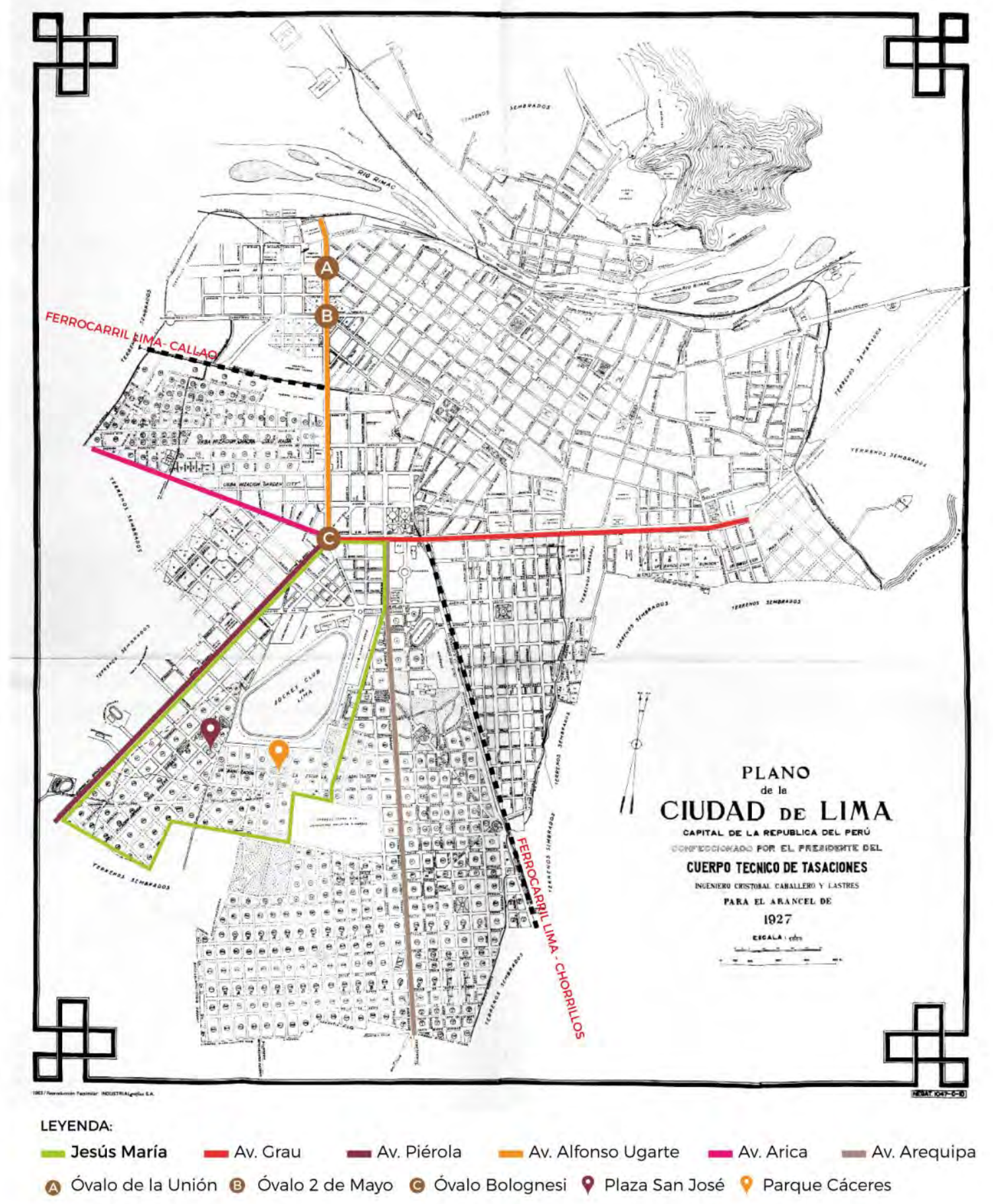

Figura 2.8 Plano de Lima_1927

Fuente: Cristóbal Caballero (1927). Figura editada por los autores. 
Alrededor de 1930 se comenzó a lotizar y poblar los alrededores del fundo "Jesús María”, por lo que Los Padres Carmelitas decidieron comprar el terreno en el corazón de la urbanización, al frente de su gran parque (hoy Plaza San José) para formar la primera iglesia del barrio. Mientras que la iglesia se encontraba en construcción, se realizó la parroquia que comenzó a funcionar en 1945, construida por el Ing. Alfredo Estremadoyro, obra cuyo objetivo era ser un templo provisional de $45 \times 12 \times 7 \mathrm{~m}$, hoy en día es el Auditorio Parroquial. Paralelamente, Manuel Vidaurre, arquitecto y constructor de varias iglesias de España y América Latina, planificó, vigiló y terminó el templo de estilo gótico, distinguiéndose de las demás iglesias de la ciudad por la fachada con dos torres de $57 \mathrm{~m}$. de largo por $23 \mathrm{~m}$. de ancho por $52 \mathrm{~m}$. de alto, y una cúpula de $33 \mathrm{~m}$. de alto, inaugurándose el 15 de octubre de 1949 (Ministerio de Comercio Exterior y Turismo, 2016, párr. 1). (Ver Figura 2.9)

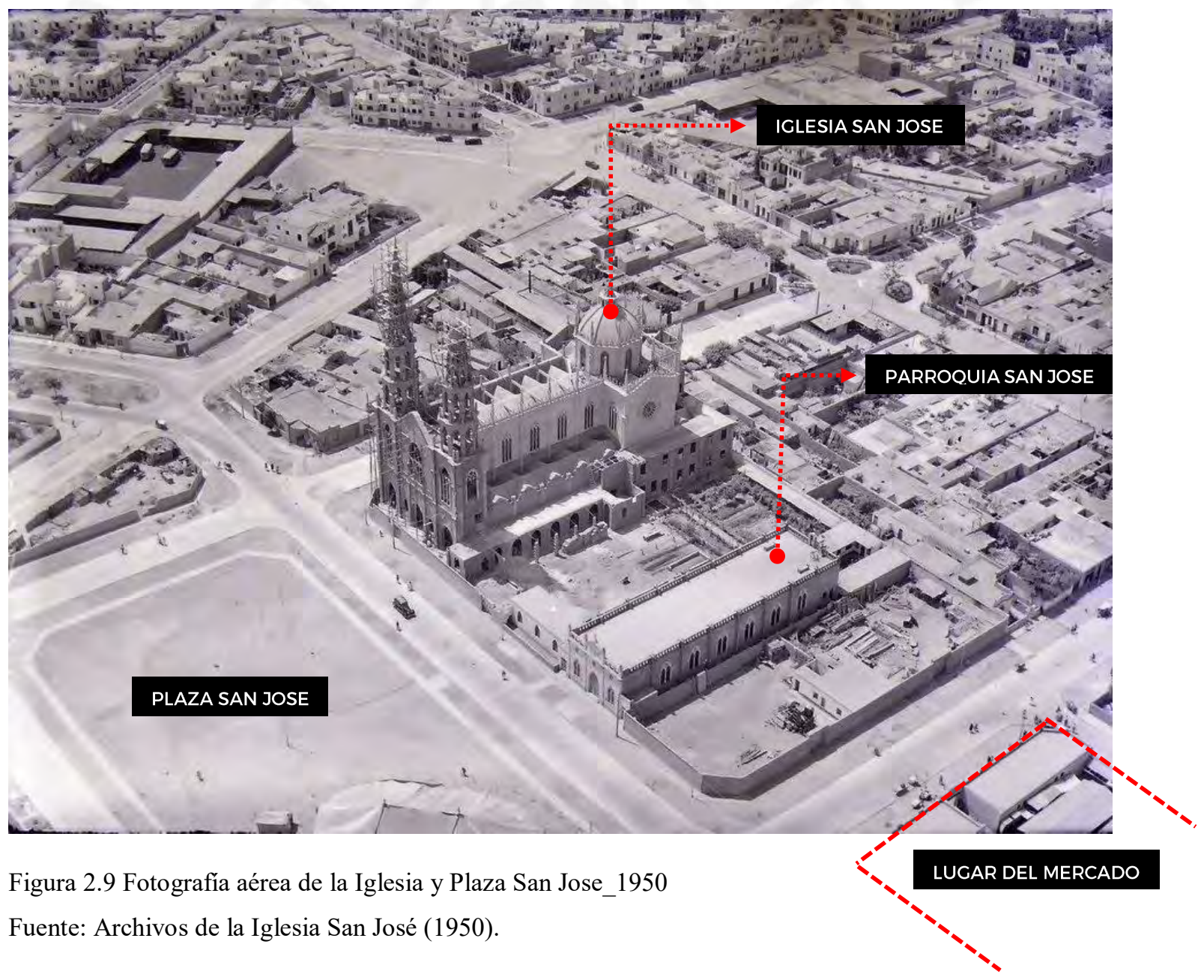


De esta manera, la ciudad deja de ser compacta y empieza a expandirse con la creación de barrios residenciales ubicados en los grandes terrenos entre los ejes creados (Ver Figura 2.11), los cuales estaban caracterizados por una tipología de estilo "chalet" de influencia norteamericana, fomentando un cambio en la escala y tipología urbana de la ciudad (Ver Figura 2.10). Dentro de esta nueva urbanidad se da la creación del barrio de Jesús María, en donde se instala gran parte de la nueva oligarquía limeña (Kahatt, 2014, p. 40).
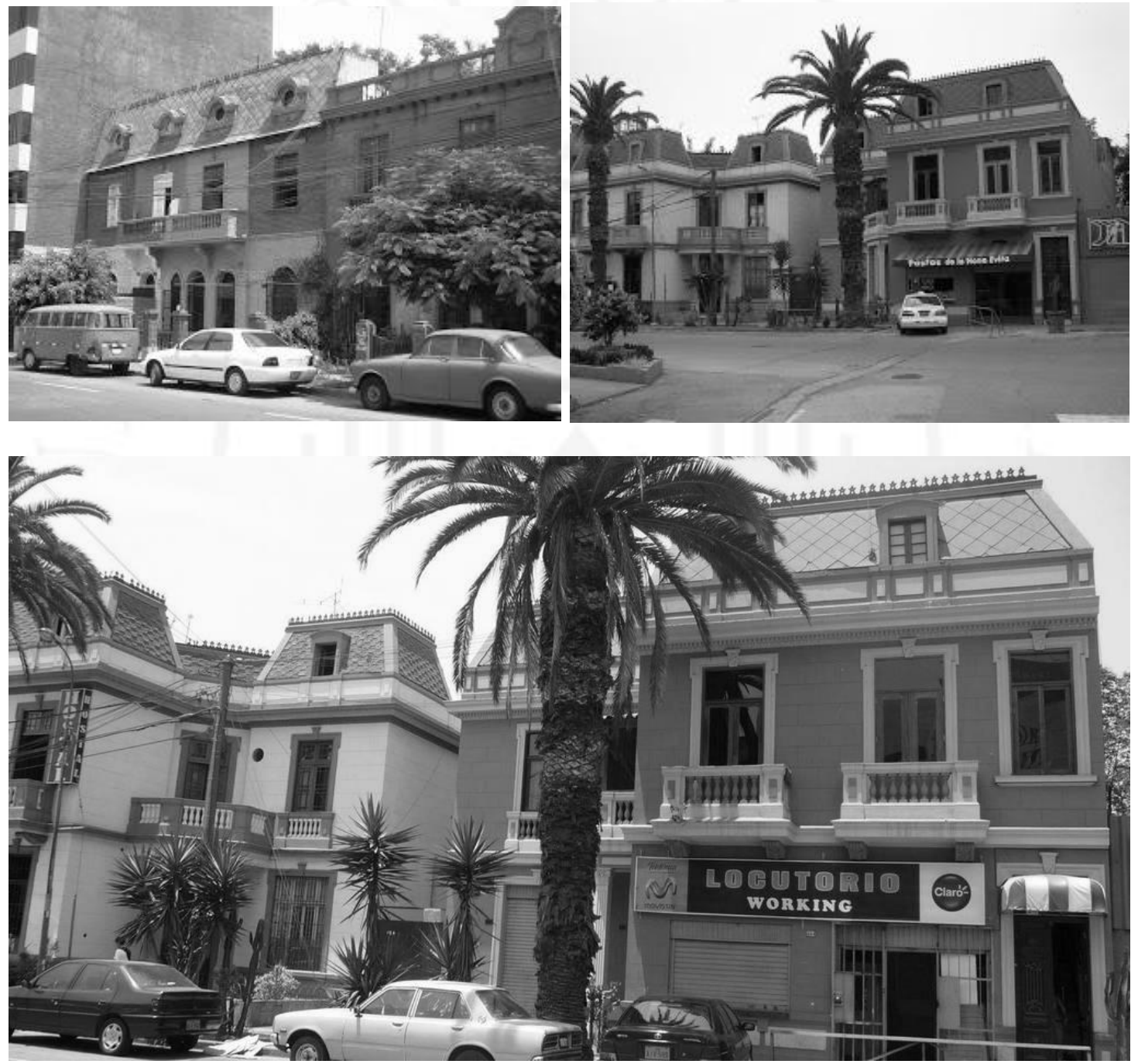

Figura 2.10 Viviendas tipo chalet

Fotografías realizadas por los autores. 


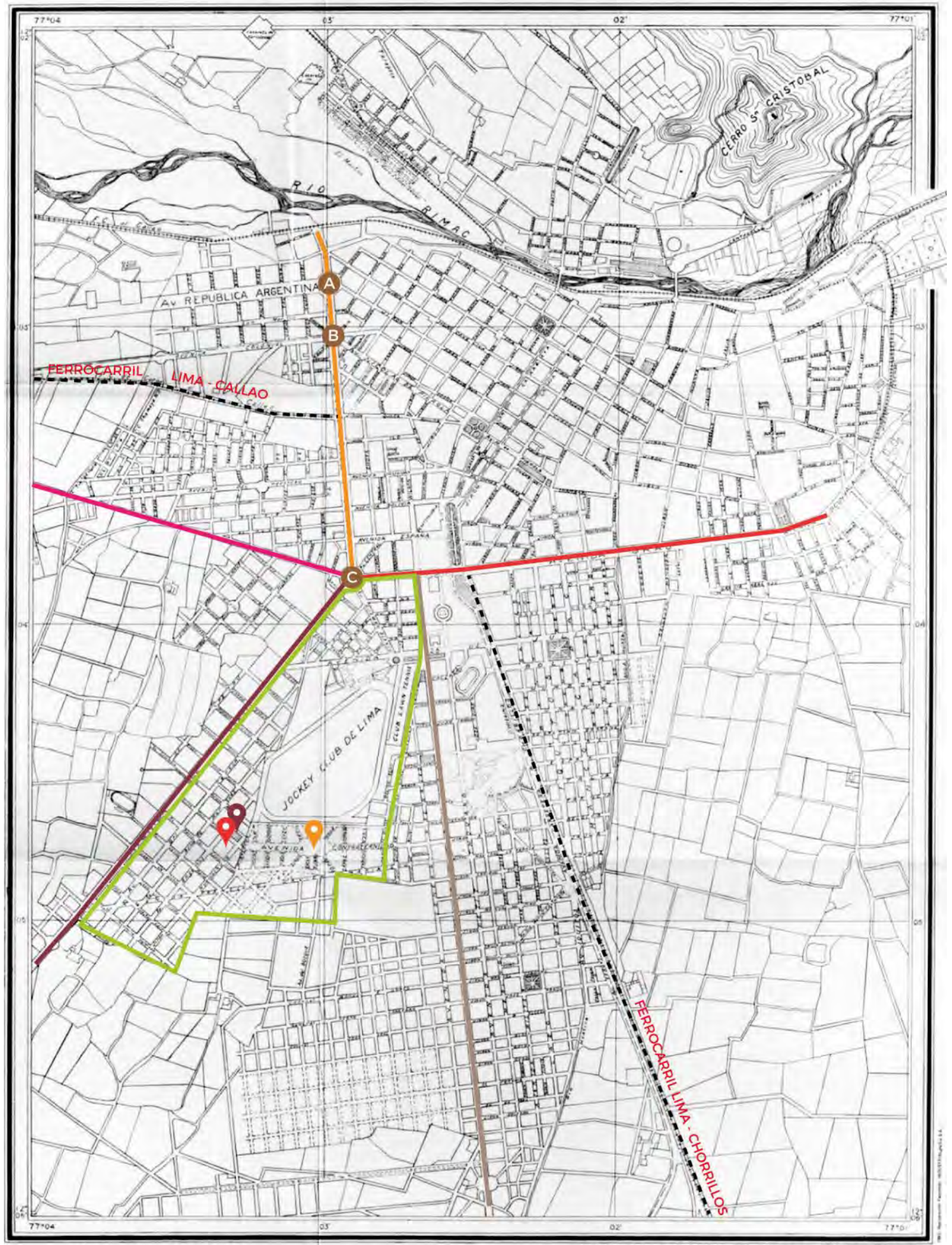

TRIANGULACION GEOPESICA DEL
SERVICIO GEOGRAFICO DEL EJERCITO

LONGITUD O. DE GREEN WICH CUERPO TECNICO DE TASACIONES DEL PERU FOTOGRTAMETRIA

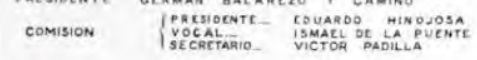

LEYENDA:

- Jesús María Av. Grau $=$ Av. Brasil $=$ Av. Alfonso Ugarte $=$ Av. Arica $=$ Av. Arequipa

A Óvalo de la Unión B Óvalo 2 de Mayo C Óvalo Bolognesi @ Plaza San José 9 Iglesia San José 9 Parque Cáceres

Figura 2.11 Plano de Lima_1935

Fuente: Servicio Geográfico del Ejército (1935). Figura editada por los autores. 
La construcción de la Av. Salaverry en 1940 (Ver Figura 2.12), otorgó un gran avance para la zona, debido a que funcionó como eje de expansión y delimitador del barrio, diferenciándose de Lima Cercado y Lince; mientras que el Campo de Marte le asignó un paisaje estético a la nueva zona residencial, generándole un aspecto de ciudad y campo (Orrego, 2010, párr. 4).

Reputados profesionales liberales, miembros de las colonias extranjeras y políticos, entre otros, ocuparon la zona. Las nuevas mansiones, a nivel arquitectónico, mostraban a la gran burguesía limeña que supo preservar los aires señoriales de antaño con los nuevos estilos (neocolonial, morisco y chalet norteamericano); casonas rodeadas de jardines y pradillos o con balcones y ventanales amplios muy republicanos. (Orrego, 2010, párr.5)

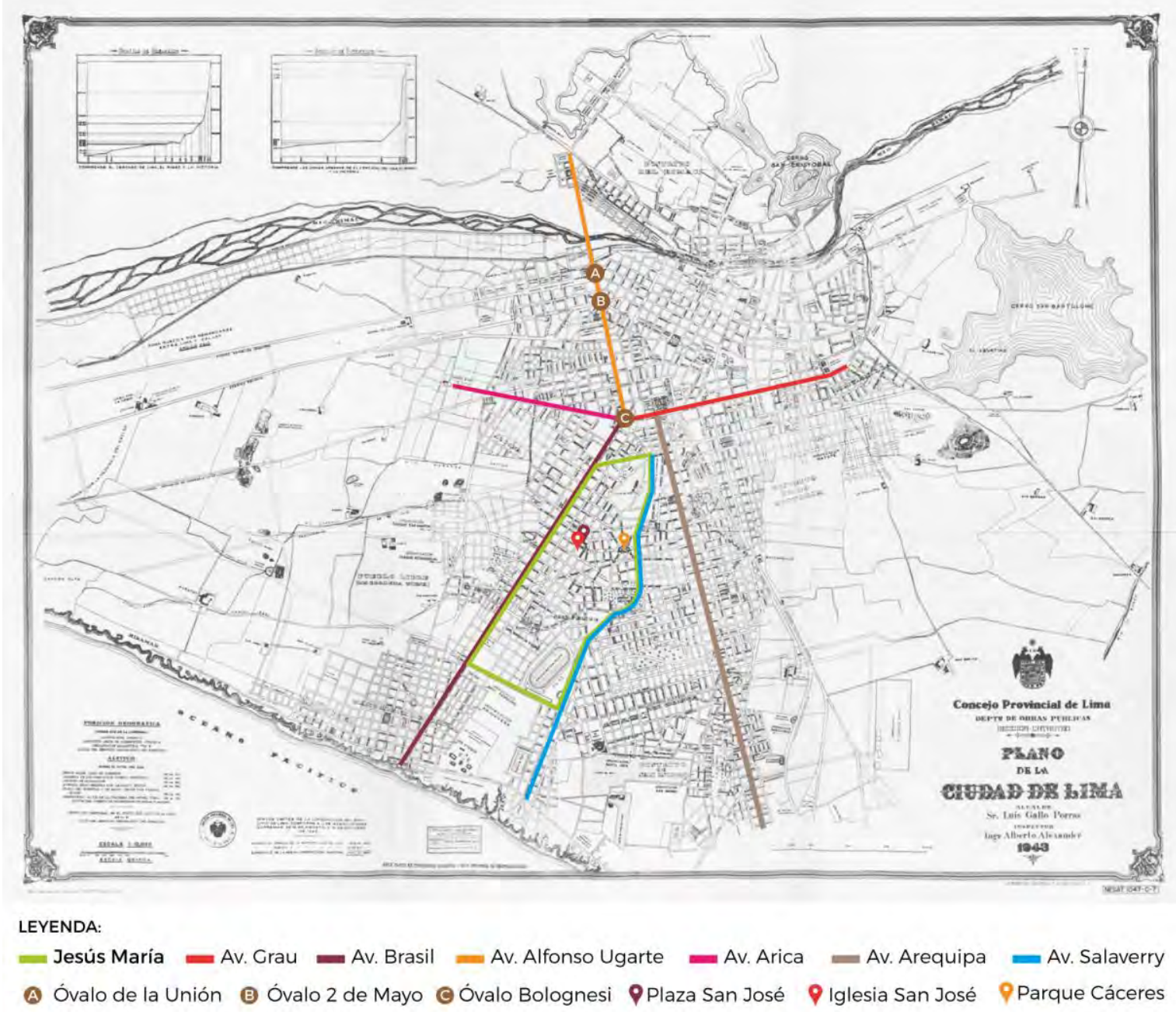

Figura 2.12 Plano de Lima_1943

Fuente: José Barbagelata (1943). Figura editada por los autores. 


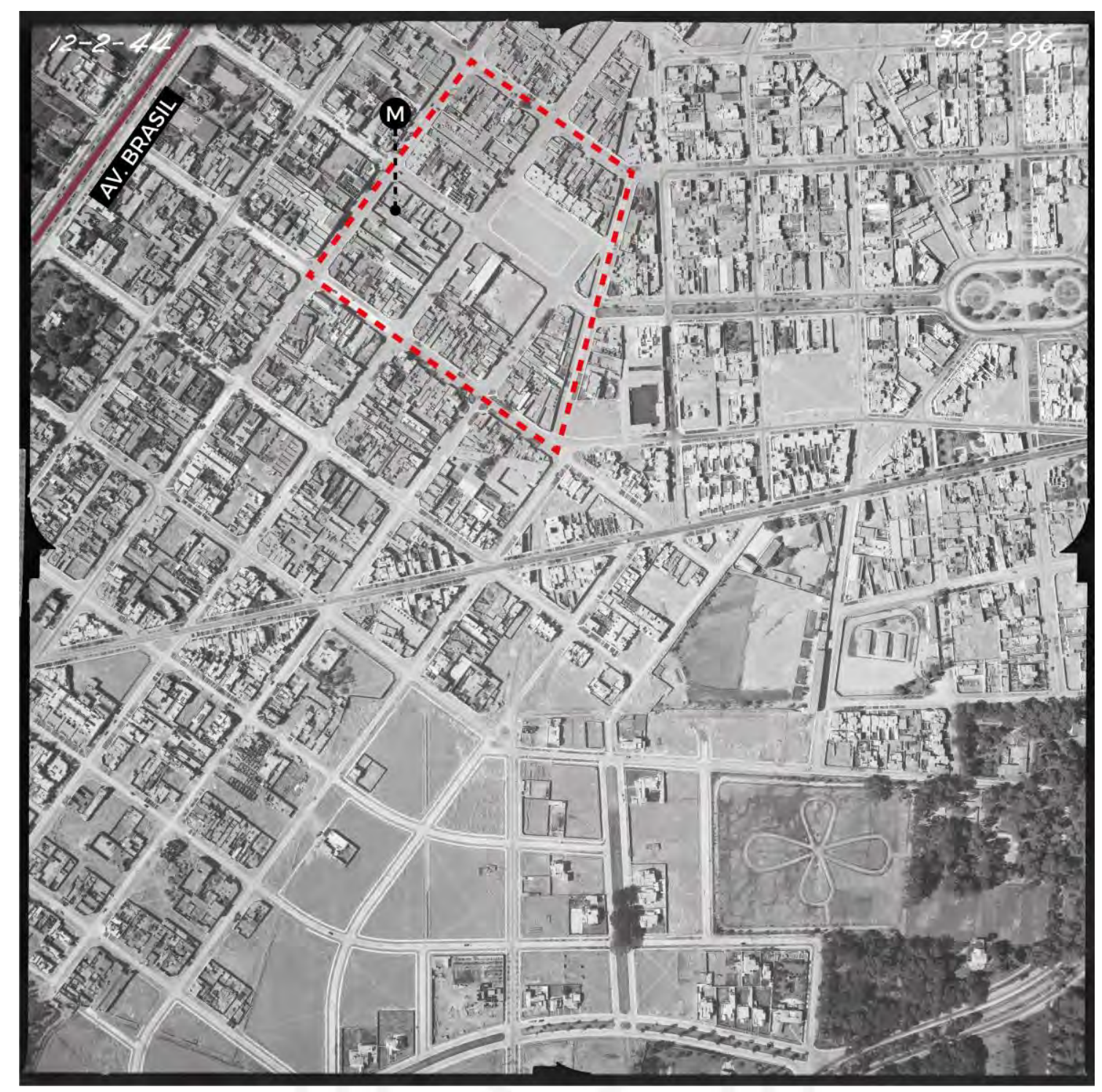

Figura 2.13 Jesús María_1944

Fuente: Servicio Aerofotográfico Nacional (1944).

En la década del 1950, se marca un hito en el desarrollo de edificios de gran altura conocidos como "rascacielos" en Lima, dados por la incorporación de nuevos materiales en la arquitectura en 1920, tales como el acero, el vidrio y el concreto armado. Se reconoce este periodo como la época de la arquitectura "moderna", que trata de romper con la arquitectura tradicional. De esta manera, se incorpora en Jesús María de edificios públicos "rascacielos" como la creación del Ministerio de Salud y Trabajo, y el Hospital del Seguro Social del Empleado, conocido hoy en día como el Hospital Rebagliati (Ver Figura 2.14). 


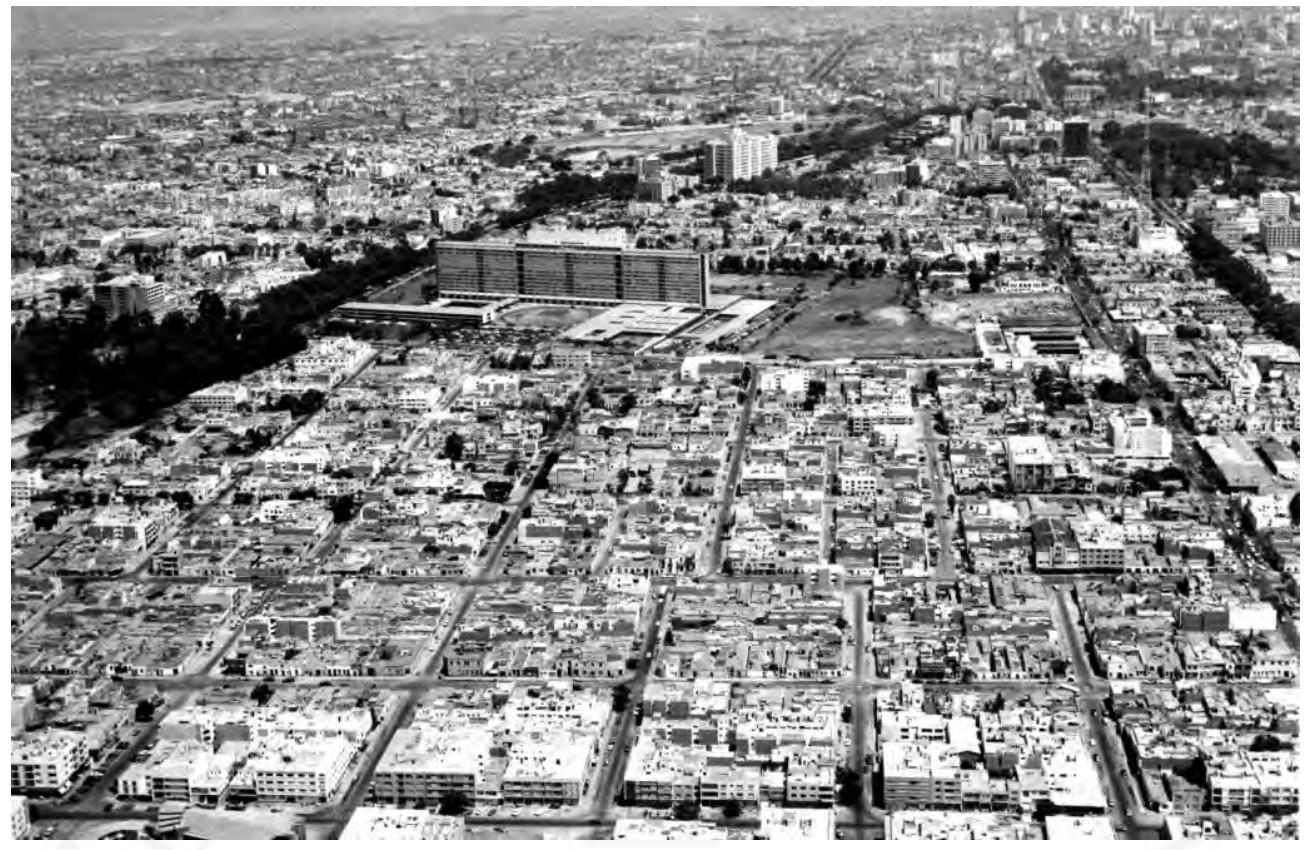

Figura 2.14 Hospital Rebagliati

Fuente: Archivo histórico El Comercio

La existencia del distrito es relativamente reciente, es en 1956 que se emite la ley que disponía la creación del mismo, pero no se promulgó hasta el 13 de diciembre de 1963 con la Ley de Creación Política del distrito №14763 (Ver Figura 2.15), a pesar de ello, no contó con administración propia hasta las elecciones municipales de 1966, teniendo como primer alcalde al Ingeniero José Benavides Muñoz (La Rosa, 2014, pág. $61)$.

El movimiento moderno además de influir en las construcciones de los equipamientos urbanos, también lo hizo con las viviendas. Es así como en 1969, en un terreno de 27 ha, se inaugura el conjunto residencial San Felipe considerado una de las obras más importantes del ex presidente Belaúnde Terry (Ver Figura 2.16). La propuesta de los arquitectos ${ }^{5}$ respondía a los objetivos del Estado sobre la vivienda social colectiva ante el fenómeno migratorio cambiando el perfil urbano del distrito (Ver Figura 2.17)

\footnotetext{
${ }^{5}$ La primera etapa de la residencial San Felipe fue diseñada por Enrique Ciriani y Mario Bernuy (1962-1964), la segunda etapa por Jacques Crousse y Oswaldo Núñez (1964-1965), y la tercera etapa estuvo a cargo de Luis Vásquez y Víctor Smirnoff (1965).
} 
LEY No. 14763

Creando el Distrito de Jesús Maria, en la Provincia de Lima.

JOSE GALVEZ, Presidente del Con. greso.

POR CUANTO

El Congres ho dodo la ley sizuiente:

EL CONGRESO DE LA REPUBLICA FERUANA.

Ha dado la ley siguiente:

ARTICULO $1^{\circ}$-Créase, en el cercado de la capital de la Provincia de cado de la capital de la Provincia de Lima, del Departamento del mismo ARTICULO $2^{\circ}$ - Los limites del Distrito serin los sisuientes:

Por el Norte, la Avenida 28 de Ju. lio hasta su intersección con la Ave. nida República de Chile; por el Este, Is Avenida República de Chile hasta su intersección con la Avenida General Arenales, sizguiendo el curso de és. to hasta el Jirón Domingo Cueto; por el Sur, el Jirón Domingo Cueto hasto su intersección con el Jirón Capa Yupanqui, siguiendo por iste hasta encontrar el Jirón Belisario Flores luego de recorrer este. continua por la Avenida Salaverry y por la Avenid Pershing hasta ompalmar en la Ave. nida Brasil; y por el Oeste, ta Avenida Brasili, desde su intersection con la Avenica Pershing hasta la Aven da 28 de Julio, lugar donde comenz esta delimitación.

1 Poder Ejecutivo para su premulgación.
Casa del Congreso, en Lima, a los veintisicte diss del mes de diciembre de mil novecientos cincuenta $y$ cinco. HECTOR BOZA, Presidente del Se. nado.

EDUARDO MIRANDA SOUSA Presidente de la Cámara de Diputados. EDUARCO FONTCUBERTA, Sena. dor Secretario.

JOSE VALDIVIA MANCHEGO, D futado Secretario.

Al señor Presidente Constitucional de la Ropública.

POR TANTO:

No habiendo sido promulgada oportunamente por el Poder Ejecutivo en observancia de lo dispuesto en el artieulo $129^{\circ}$ de la Constitueión, mart nisterio sublique y se comunique al Micumplimiento

Casa del Congreso, en Lima, a los treinta dias del mes de noviembre de mil novecientos cincuento y seis.

JOSE GALVEZ, Presidente del Congreso.

ENRIQUE MARTINELLI TIZON, Senasor Secretario dal Congreso.

ERNESTO GUZMAN. Diputado Secretario del Congresc.

Lima, 13 de Diciembre de 1963.

Cimplase, comuniģuese, registrese. publiquese $y$ archivese.

Osear Trelies Montes.

Figura 2.15 Ley de Creación del distrito Fuente: Municipalidad de Lima (2018).

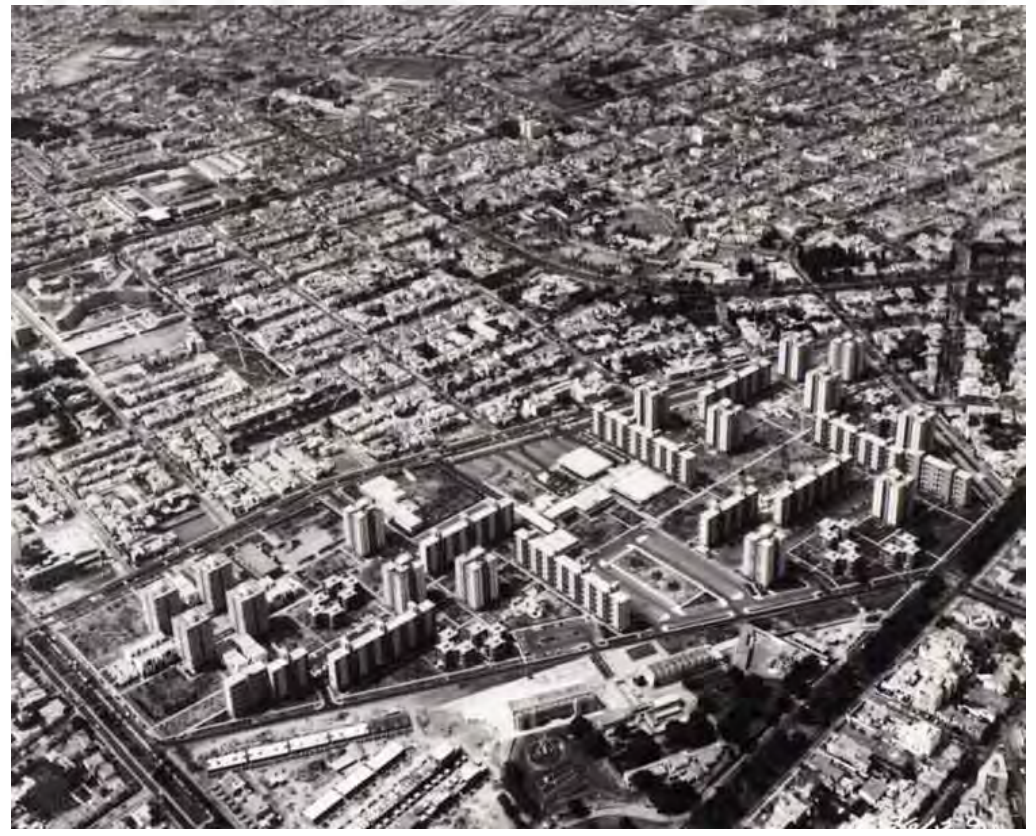

Figura 2.16 Residencial San Felipe

Fuente: Servicio Aerofotográfico Nacional (1970) 


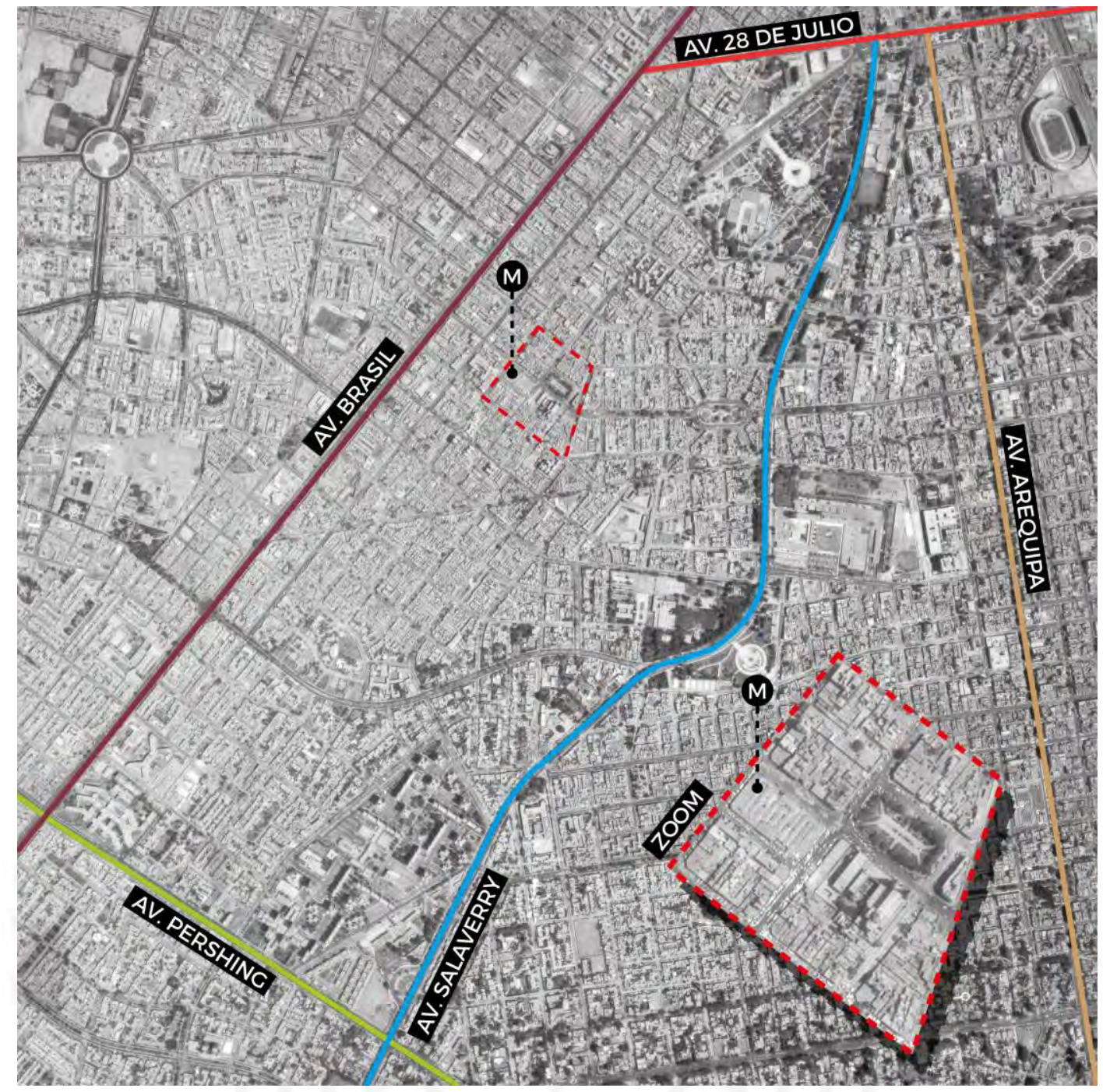

Figura 2.17 Jesús María_1984

Fuente: Servicio Aerofotográfico Nacional (1984)

A partir del año 2000 llegan los nuevos formatos comerciales de autoservicio al distrito (Ver Figura 2.18), los cuales tuvieron gran acogida por su apariencia física, por lo novedoso y por ofrecer gran variedad de productos. En aquel año, se inauguraron dos supermercados Metro en Jesús María, el primero se ubica en la Av. General Garzón, y el segundo en la Av. Pershing al frente de la Residencial San Felipe. Posteriormente, en el 2014 llegan las tiendas por departamento al distrito con el Real Plaza Salaverry del grupo Intercorp, y en el 2015 se inaugura el C.C. La Rambla en la Av. Brasil. Estos nuevos formatos comerciales apuestan por brindar lo mejor en modernidad, calidad de vida, y entretenimiento pensado como un espacio familiar que ofrece seguridad, acogida y comodidad, atributos que el consumidor actual valora. 


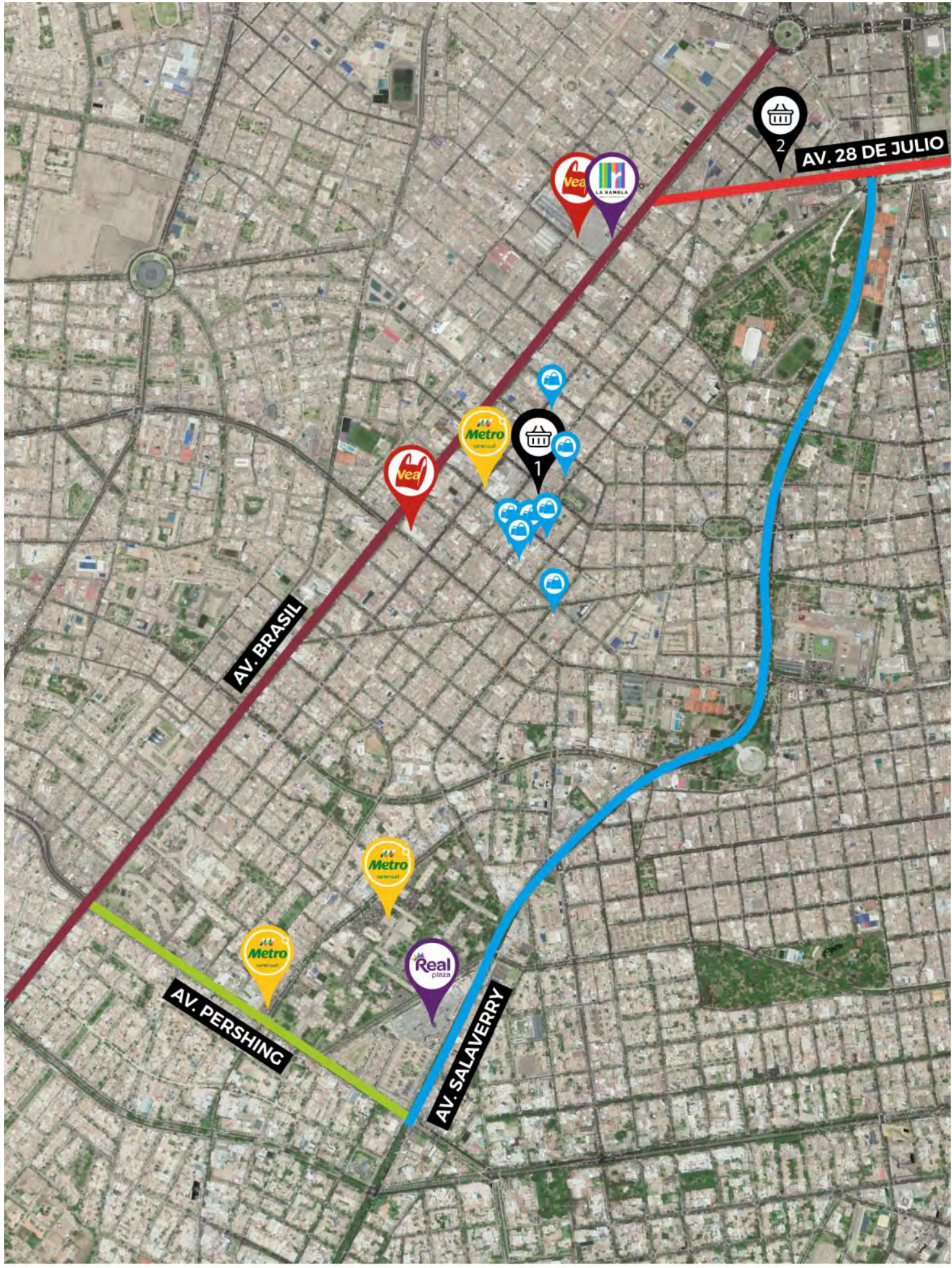
LEYENDA:

(2int)
Mupermercado
Metro

Figura 2.18 Formatos comerciales en Jesús María

Gráfico elaborado por los autores. 


\subsubsection{Antecedentes históricos del Mercado San José}

Para el año 1935 las haciendas Santa Beatriz y Jesús María se convirtieron en barrios residenciales que se consolidaron rápidamente perdiendo grandes áreas de cultivo que abastecía al sector de la primera expansión de Lima, por lo que surgió la necesidad de construir el primer mercado fundado en 1943 en un terreno al lado de la Iglesia y Plaza San José cuyo dueño era el italiano Carlos Orezzoli que cedió su propiedad a la Municipalidad de Lima como forma de pago por la gran deuda predial que poseía (Ver Figura 2.19). Este mercado estuvo administrado por la Municipalidad de Lima hasta el 1963 que se funda el distrito de Jesús María (Reaño, Reyes, \& Muñoz, 2007, p. 1).

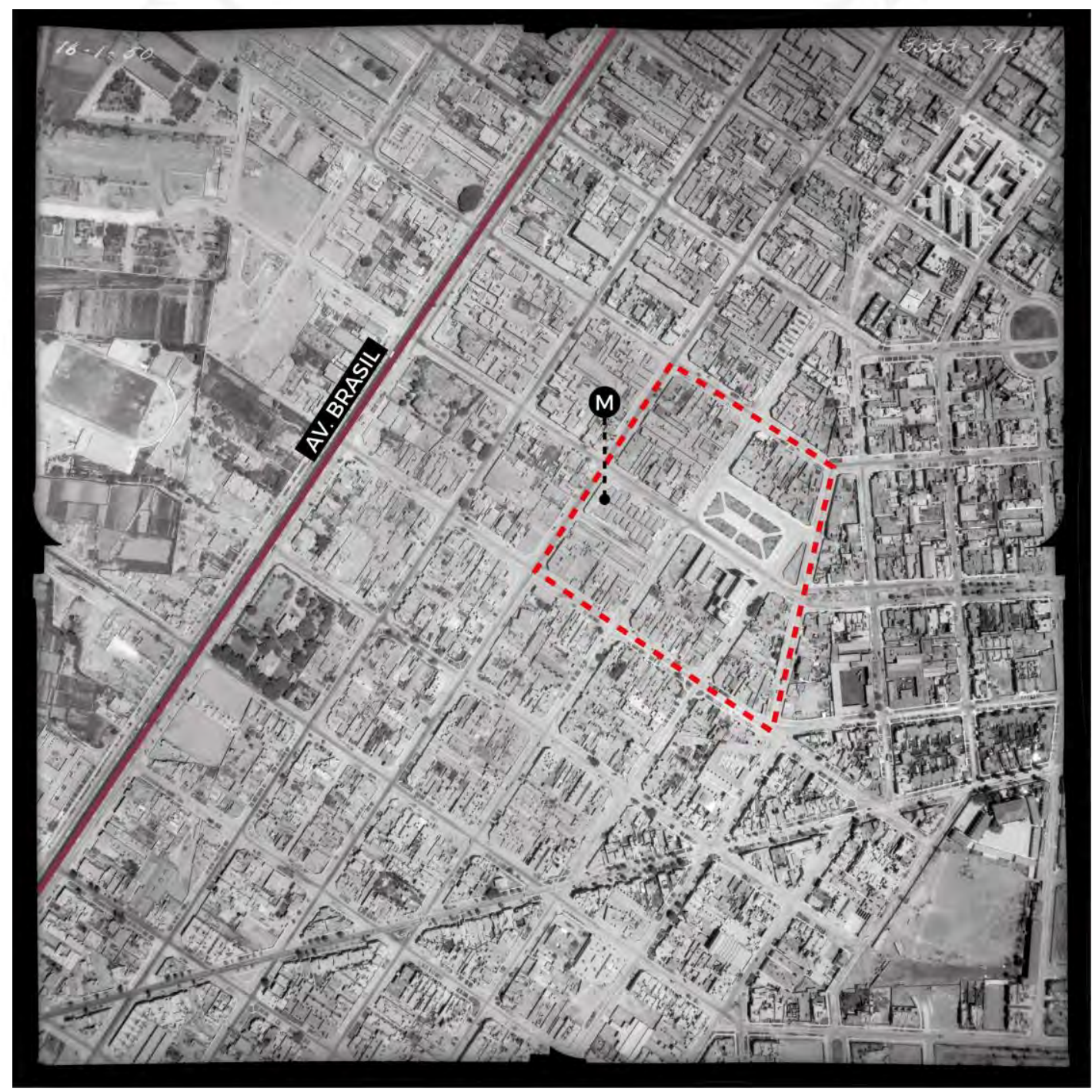

Figura 2.19 Sector del Mercado_1949

Fuente: Servicio Aerofotográfico Nacional (1949) 
Para el año 1980 Lima contaba con 290 grupos de comercio de los cuales el distrito de Jesús María era poseedor de 5 de ellos, conformado por dos mercados, un mercadillo y dos paraditas. La relación mercado-paradita que existía era de 2-2, es decir, por cada mercado existía una paradita (Ver Tabla 2.1). Esto nos indica que ante la ausencia mercados en lugares próximos a la concentración de personas se originaban estas paraditas $^{6}$ que disminuían el desplazamiento realizado por el comprador para adquirir los productos (Cabrera Neyra, 1979, p. 28).

Tabla 2.1

Tipos de comercio en Jesús María en 1980

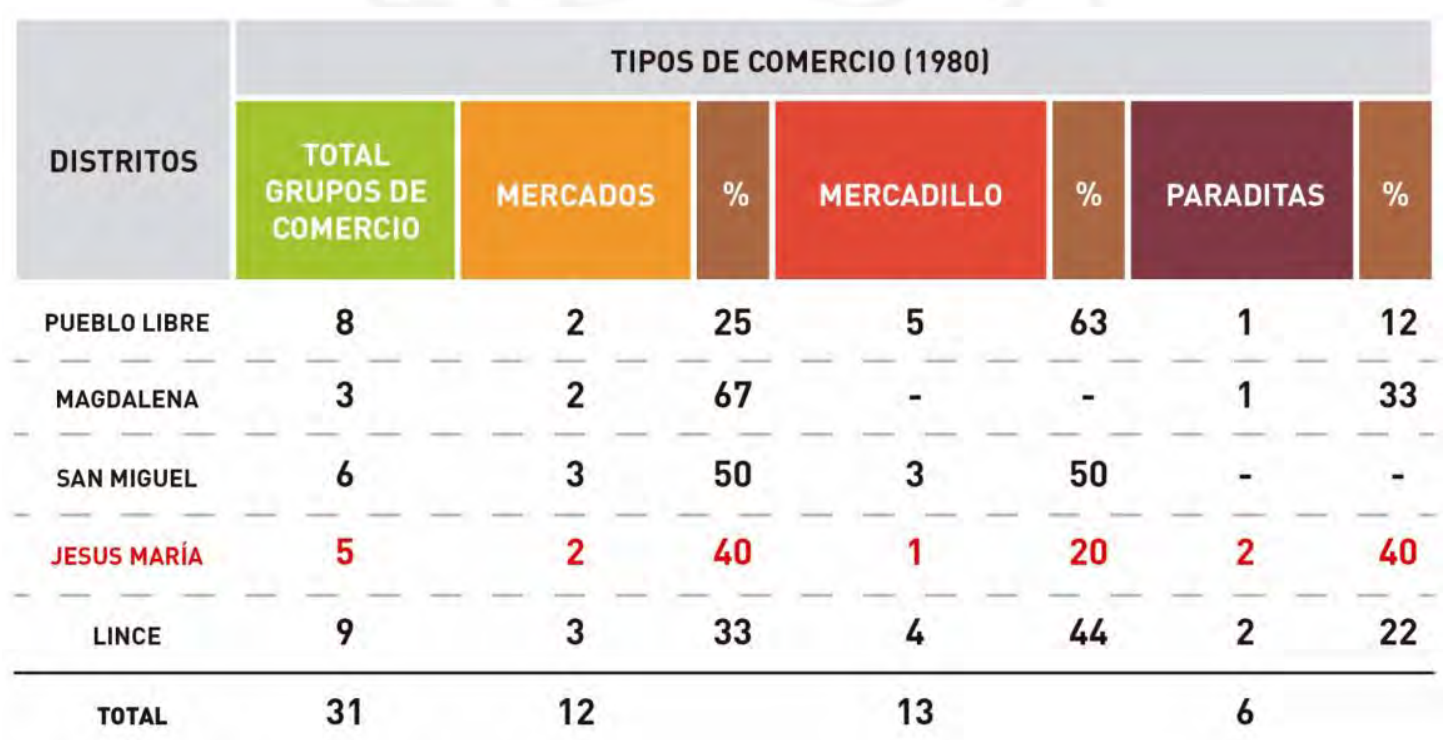

Fuente: Cabrera Neyra (1979). Tabla elaborada por los autores.

Además, el Mercado San José contaba con 140 comerciantes minoristas especializándose en el rubro de las carnes, abarrotes y verduras (Ver Figura 2.20), siendo el principal abastecedor de alimentos perecederos del distrito, teniendo una afluencia de 22500 personas (Ver Figura 2.21), un índice muy elevado para la década de los 80's, porque a nivel de Lima Metropolitana por cada mercado de abastos le correspondía atender a 10600 habitantes, siendo el distrito de Jesús María el 2do distrito que presentaba más deficiencia de servicios de mercado (Cabrera Neyra, 1979, p. 36).

\footnotetext{
${ }^{6}$ La paradita es un lugar en la vía pública en el que los comerciantes, denominados ambulantes, se ubican temporalmente para realizar sus actividades de forma precaria, la venta se realiza en carretillas, mesas o en el suelo (Cabrera Neyra, 1979, p. 27)
} 


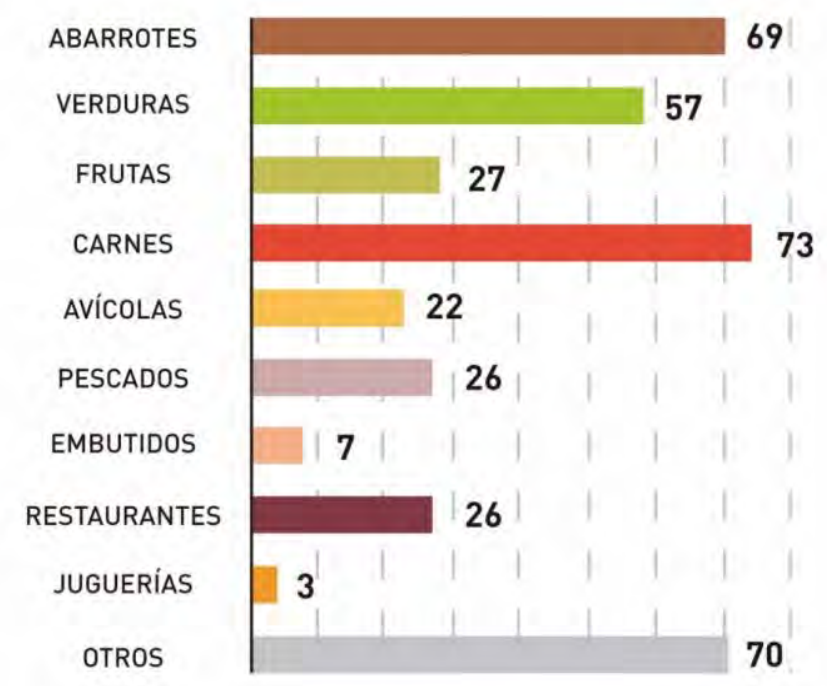

Figura $2.20 \mathrm{~N}^{\circ}$ de puestos por rubro en Jesús María en 1980

Fuente: Cabrera Neyra (1979). Gráfico elaborado por los autores.

\section{POBLACIÓN SERVIDA x MERCADO TRADICIONAL}

\section{0}

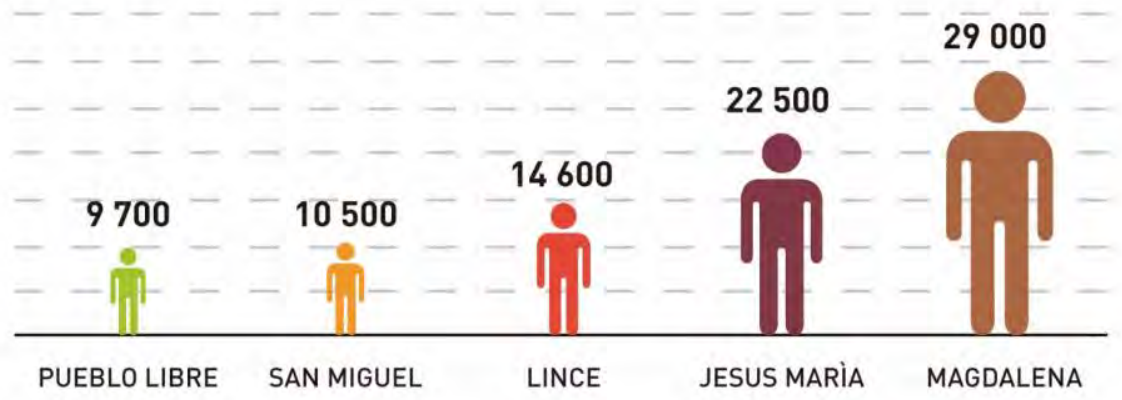

Figura 2.21 Población servida de mercados por distrito 1980

Fuente: Cabrera Neyra (1979). Gráfico elaborado por los autores.

En el año 2000 el presidente Alberto Fujimori promulga la ley de privatización de mercados públicos, por lo que se vende el mercado a 13 comerciantes formando así la Asociación de Mercaderes del Mercado San José de Jesús María que gestiona y alquila los puestos a 196 miembros. Además, la Asociación cuenta con un presidente que se elige a voto democrático cada 3 años (Reaño, Reyes, \& Muñoz, 2007, p. 1). 
En el 2004 se inaugura el Supermercado Plaza Vea en la avenida Brasil, a unas cuadras del Mercado San José, convirtiéndose en su principal competidor y generando que disminuya sus ingresos por ventas en un $30 \%$. Pero si bien las ventas son menores, el mercado sigue vigente hoy en día por ofrecer productos frescos, y porque varios de los puestos se han adaptado dejando de lado los productos perecederos para ofrecer servicios como menús (Ver Figura 2.22) (A. Villanueva, comunicación personal, 18 de noviembre de 2018).

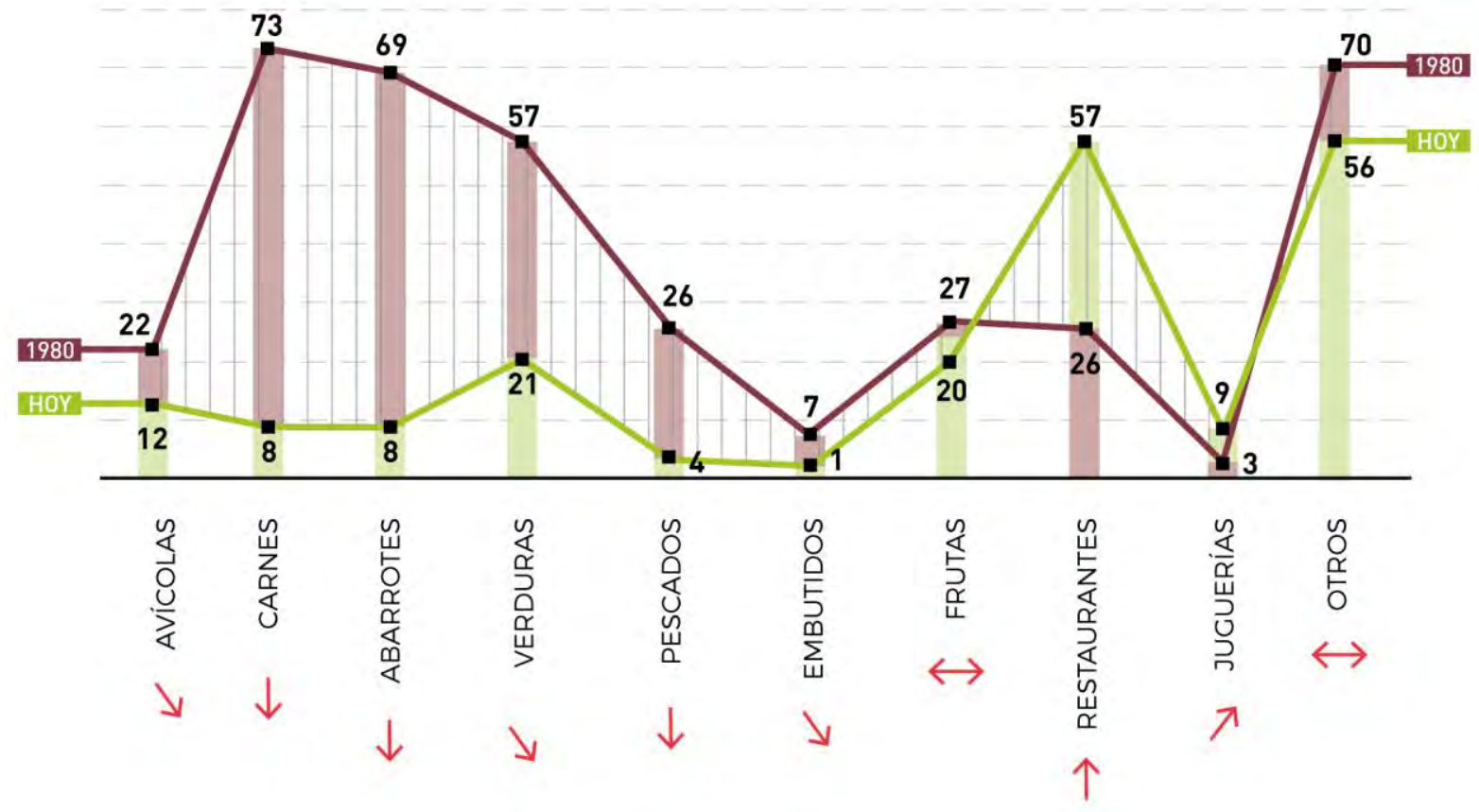

Figura 2.22 Comparación del $\mathrm{N}^{\circ}$ de puestos por rubro en 1980 y 2017

Fuente: Cabrera Neyra (1979). Gráfico elaborado por los autores. 
En los últimos años el mercado ha perdido presencia en el distrito debido a la presencia de los supermercados Metro y Plaza Vea, por lo que tuvieron que realizar ciertas renovaciones al establecimiento, por ejemplo, en el 2006 se realizó la remodelación del piso del mercado, de cemento pulido a porcelanato, y la implementación de techos de calamina, pero al no realizarles mantenimiento el 18 de mayo del 2011, el mercado es clausurado ante la falta de higiene, sanidad y seguridad ${ }^{7}$ (Ver Figura 2.23).

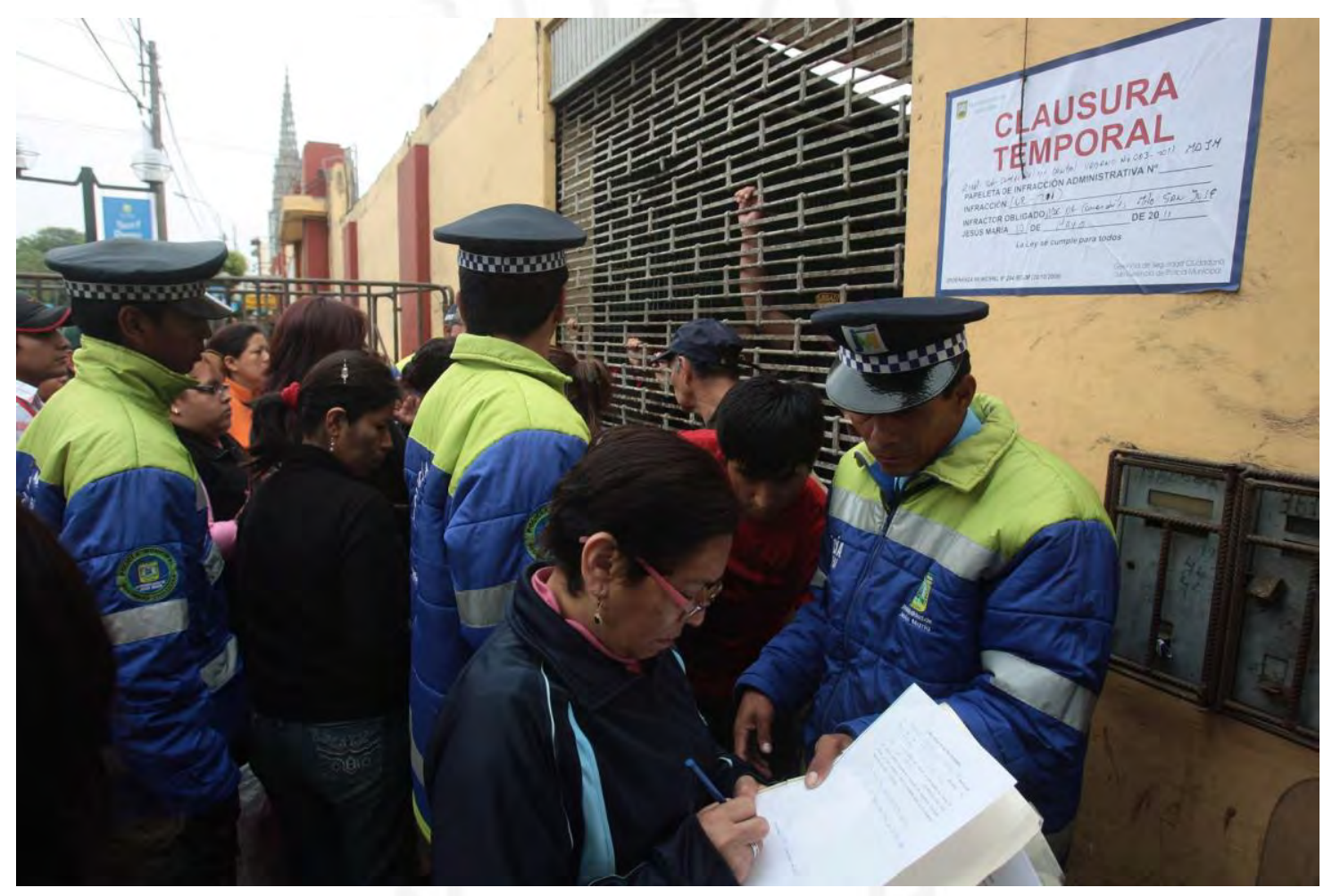

Figura 2.23 Clausura del Mercado San José

Fuente: Juan Carlos Guzmán (2011).

\footnotetext{
${ }^{7}$ El secretario técnico de Defensa Civil del municipio, Luis Rosas (2011) señaló que: "Este mercado, ubicado entre las avenidas Arnaldo Márquez, Horacio Urteaga y República Dominicana, tenía puertas y pasadizos obstruidos, techos en riesgo de colapso, pozo a tierra sin mantenimiento, entre otras irregularidades" (párr. 2). Pero en el mismo día a horas de la noche, la Junta Directiva del Mercado San José y el alcalde Enrique Ocrospoma firmaron un acta de entendimiento para subsanar las observaciones y reabrir el mercado (El comercio, 2011, párr. 1).
} 
Hoy en día el mercado sigue siendo de un solo nivel y está conformado por 196 puestos en su interior, clasificados por: carnes, avícolas, pescados, embutidos, restaurantes, juguerías, verduras, frutas y otros (venta de ropa, venta de cd's, venta de flores y venta de juguetes), siendo los puestos de menú los que le proporciona una identidad al mercado, además de poseer tres de los ganadores de la feria Mistura organizada por Apega desde el año 2010 (Ver Figura 2.24).

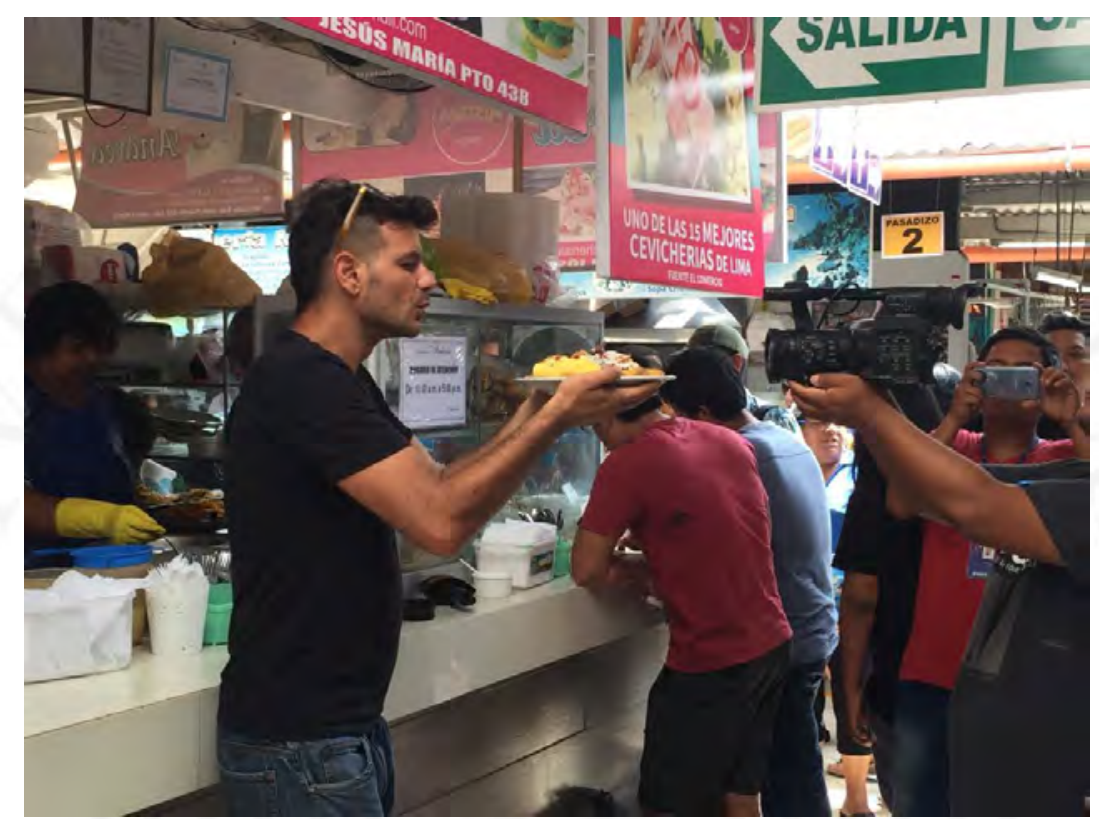

Figura 2.24 Reportaje sobre las cevicherías del Mercado San José Fotografía realizada por los autores.

De acuerdo a lo revisado en los antecedentes históricos del lugar, el proyecto debe respetar la jerarquía de la Iglesia San José y a su vez fortalecer la dinámica existente entre dicha iglesia, la plaza y el mercado. Además, el trazado urbano de la zona del distrito, que sigue vigente hasta el día de hoy, ha generado una memoria en los habitantes, por lo que no se modificarán las dimensiones y los aires del Pasaje Punta Pacochas, ni se alterará la linealidad de la configuración interna del mercado. Finalmente, el proyecto del Mercado San José ayudará a fortalecer su identidad gastronómica, ofreciendo productos perecederos y servicios como los menús. 

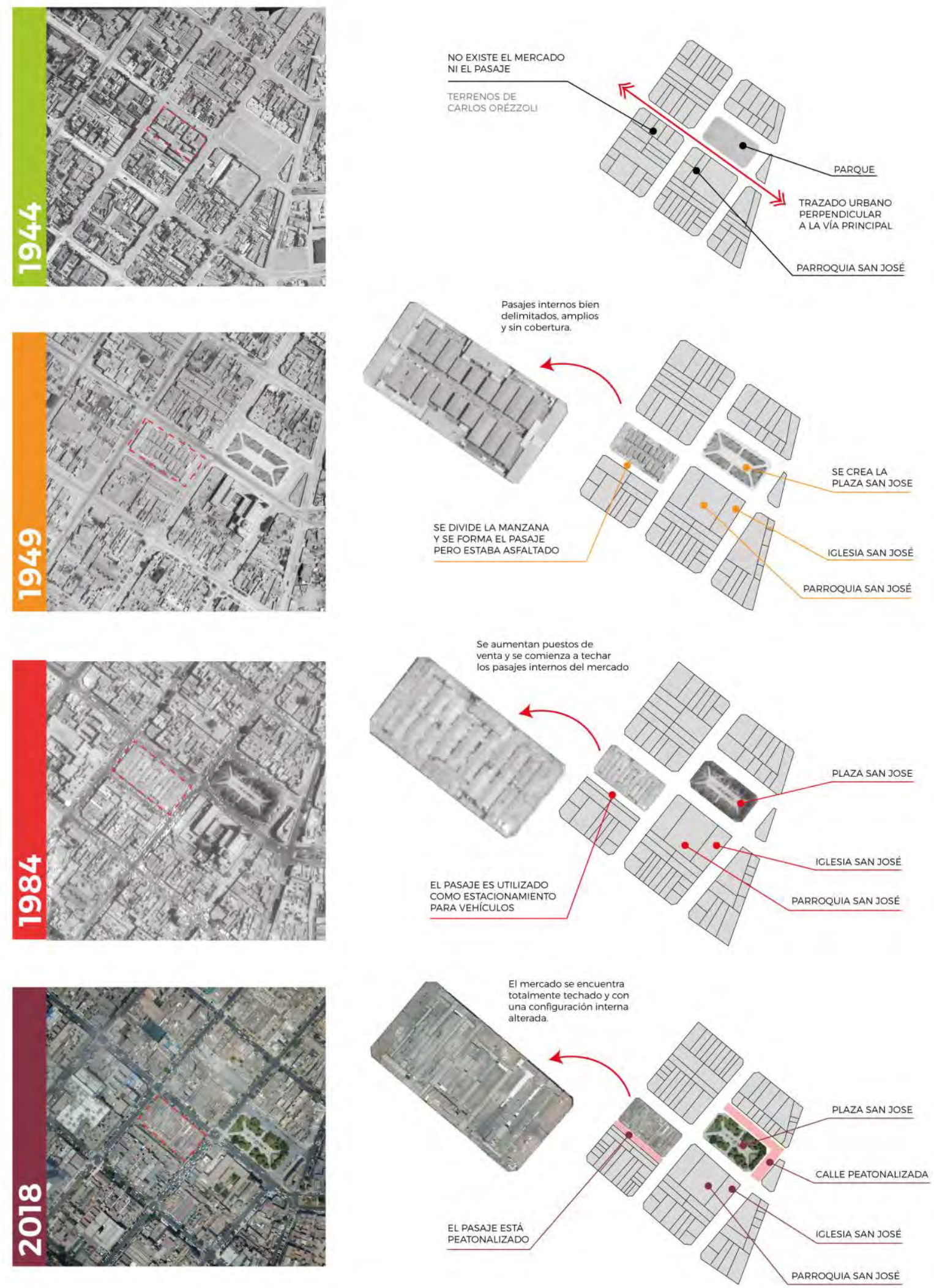

Figura 2.25 Evolución de la trama urbana alrededor del mercado

Gráfico elaborado por los autores. 


\subsection{Antecedentes históricos de los mercados de abastos}

\subsubsection{Antecedentes históricos en el mundo}

Para comprender la importancia de los mercados de abastos actuales tenemos que conocer los cambios que atravesaron a través de la historia y cómo estos están asociados al proceso de las ciudades. Los mercados cumplen roles económicos, sociales y culturales desde la antigüedad, su adaptación al tejido urbano ha demostrado una gran capacidad de supervivencia a través de los siglos (Rivarola Cores, 2015, p. 11). Es por eso que en este capítulo se estudiará la historia de los mercados enfocado en la importancia de la relación comercio - espacio público, analizando variables como relación con la calle, conexión social, y la espacialidad.

\section{De espacios abiertos a espacios cubiertos}

La noción más general que conocemos del mercado se remonta a cuando el ser humano se da cuenta que puede obtener productos que no posee, ya sea por restricciones espaciales o temporales, a modo de intercambio, es a partir de este momento cuando se constituye una relación social entre los diferentes asentamientos, generando las primeras actividades comerciales.

A pesar de que el comercio se inició en el Neolítico, la representación figurativa más antigua del mercado se puede encontrar en los dibujos egipcios en 1500 a.C, pero no muestra en qué espacio o edificio se llevaban a cabo el intercambio comercial (Coleman, 2014, p. 19).

Es recién en el siglo $\mathrm{V}$ a.C. que se puede decir que se generó y delimitó una nueva tipología de espacio público con el Ágora griega, reconocida como el sitio de reunión y lugar de vida social, comercial y política de la ciudad. Estuvo conformada por una plaza abierta ubicado en el nodo de las dos vías más importante de la ciudad, rodeada por edificios privados y públicos (Ver Figura 2.26), donde había gran interacción de los ciudadanos a lo largo del día al realizarse gran variedad de eventos como votaciones, asambleas, entre otras actividades colectivas (Ergun, 2010, p. 25). 


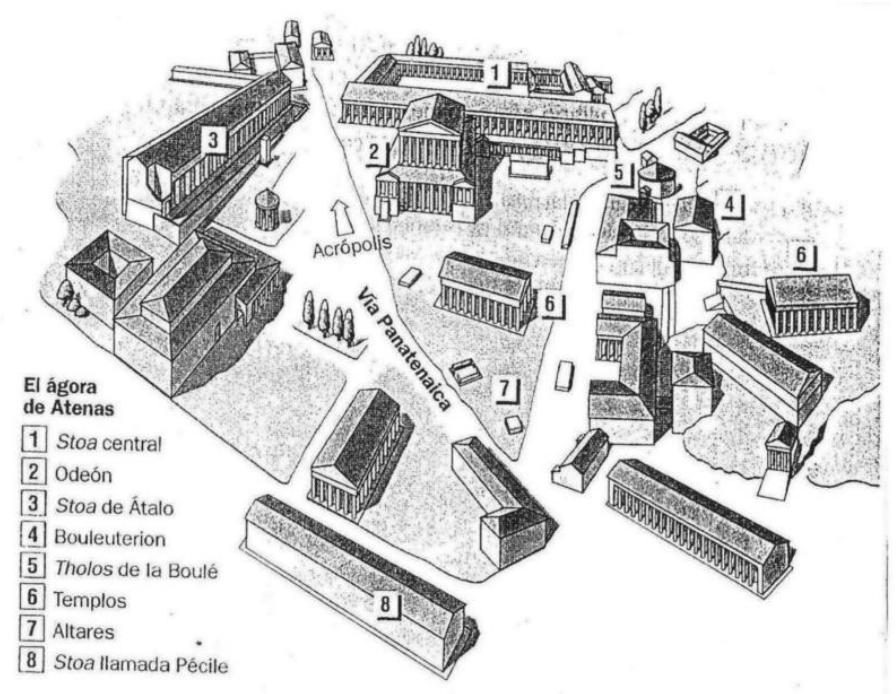

Figura 2.26 Ágora griega

Fuente: Distribución del Ágora

En: https://i.pinimg.com/originals/b7/ca/1f/b7ca1 fe2614ce5f5ca2343ce4c8e7c18.jpg

Alrededor del ágora se ubicaron diversos edificios, entre ellos, la Estoa, destinada para el uso público y comercial. Esta larga edificación realizada en piedra caliza estaba compuesta por una sucesión de columnas que delimitaban su perímetro, pero que a su vez no generaba una barrera con su entorno, sino que permitía un intercambio de flujos constante con él (Ver Figura 2.27 y Figura 2.28).

Además, la mixticidad de funciones estableció una fuerte relación entre el comercio y la actividad social, donde los comerciantes podían extender sus mercancías libremente, ya que no existían tiendas permanentes, ni puestos designados o delimitados espacialmente, es decir, primaba la libertad espacial (Coleman, 2014, p. 19).

Las tiendas podían ubicarse en el interior, cambiándolas de este modo a espacios de comercio, y uno o incluso dos niveles les dieron más espacio. Estos grandes salones no tenían ninguna función real, pero fue allí donde la gente se reunía con otras personas. (Norwich, 1984, p. 146) 


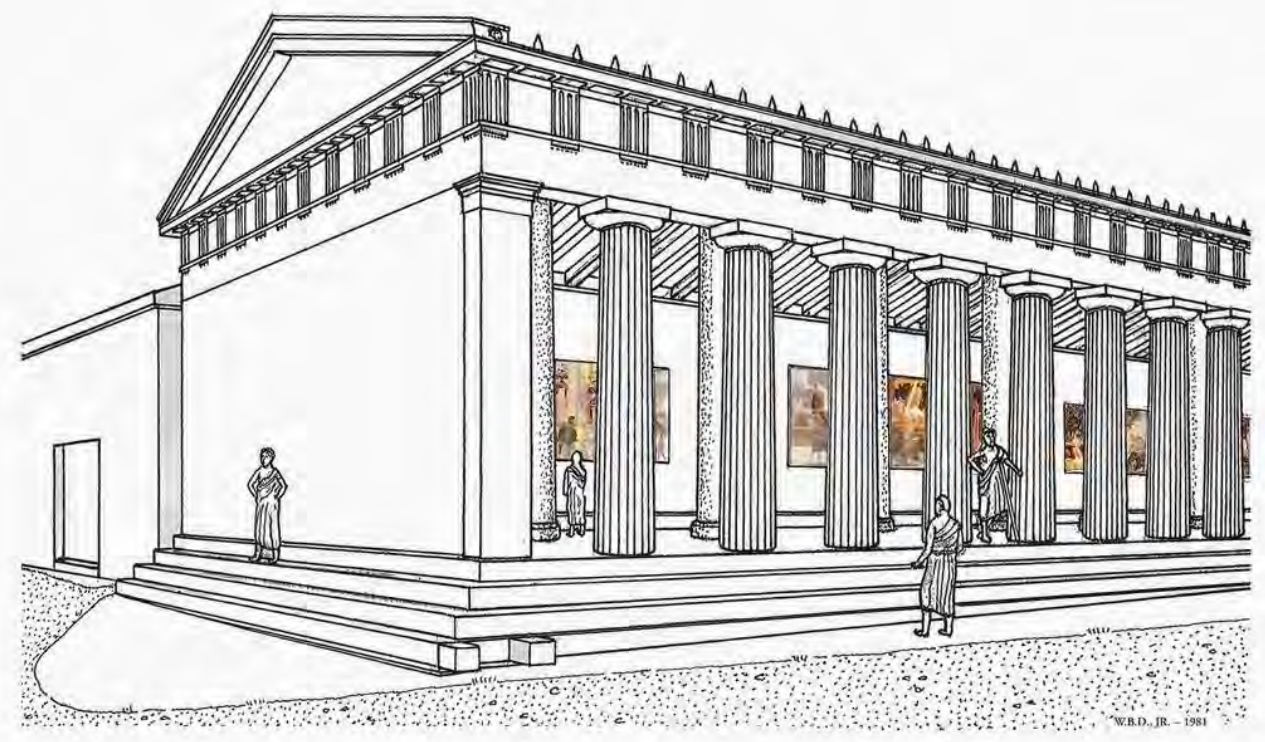

Figura 2.27 Estoa_relación con la calle

Fuente: Daniel Quesada Morales

En: http://glosarioarteugr.blogspot.com/2014/03/estoa-stoa.html

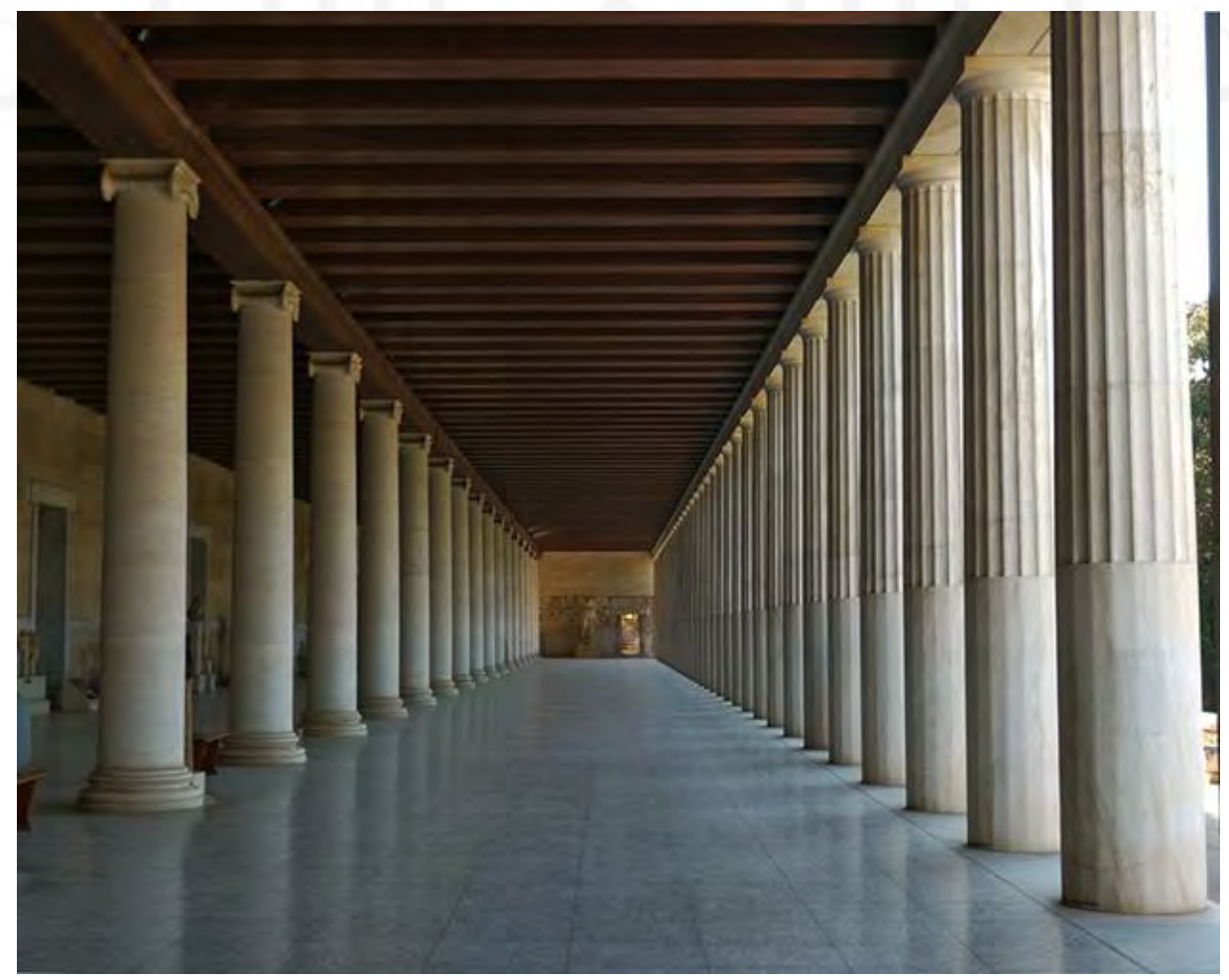

Figura 2.28 Estoa_espacialidad

Fuente: Arquiscopio

En: http://arquiscopio.com/archivo/2016/04/24/agora-de-atenas/ 
Cuando los Romanos conquistaron Grecia, adoptaron muchas de sus costumbres y tecnologías, como el Foro Romano que al igual que el Ágora eran espacios abiertos donde se desarrollaba la vida cívica y se encontraba rodeado de edificios como templos, basílicas, casas de baño y edificios estatales (Ver Figura 2.29).

El Foro Romano no era simplemente el núcleo de la ciudad antigua, para muchos era el centro del universo. Desde el nacimiento del imperio de Augusto en 31 a.C y durante casi 500 años después, Roma gobernó la mayor parte de lo que llamamos el mundo civilizado. Además, Roma era la doncella de nuestro alfabeto, líder de la organización urbana y sus instituciones jurídicas, y el creador de nuevos horizontes sorprendentes en la arquitectura. (Kidder Smith, 1990, p. 26)

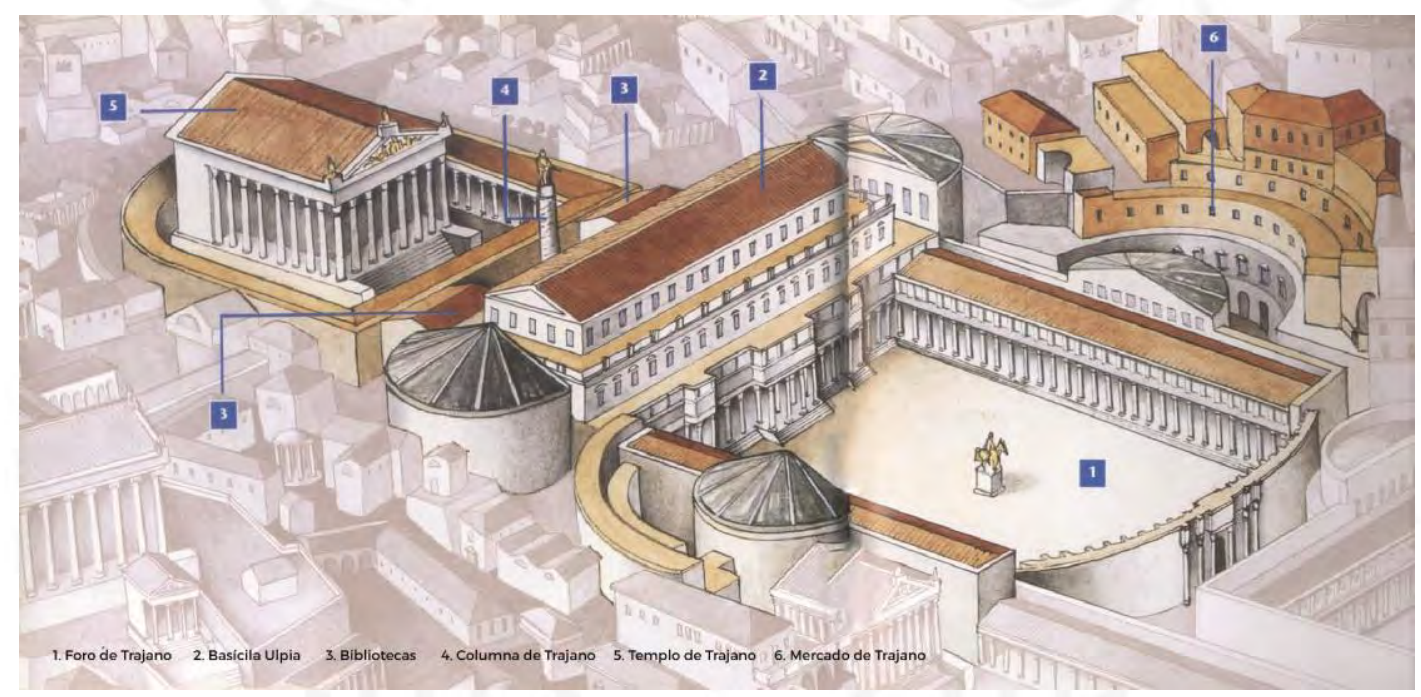

Figura 2.29 Foro Romano

Fuente: Luisa Maesano en Roma Antica, 2017

Dentro de estos foros el comercio era tan intensificado que las personas se comenzaron a especializar en la venta de ciertos productos, a tal punto que el Emperador Trajano le encargó al arquitecto Apolodoro de Damasco, alrededor del siglo II d.C, el diseño del Mercado de Trajano, el cual aportó una nueva imagen al diseño urbano, siendo revolucionario para la época. Esta edificación estaba realizada en base a ladrillos, compuesta por 150 tiendas distribuidas en seis niveles con terrazas que miraban hacia el Foro de Trajano (Coleman, 2014, p. 20) (Ver Figura 2.30); destinando los tres primeros niveles a la venta de aceites, vinos, pescados, mariscos, frutas y verduras, es decir, se origina la clasificación y zonificación de los productos dentro de una edificación comercial (Ver Figura 2.31). 


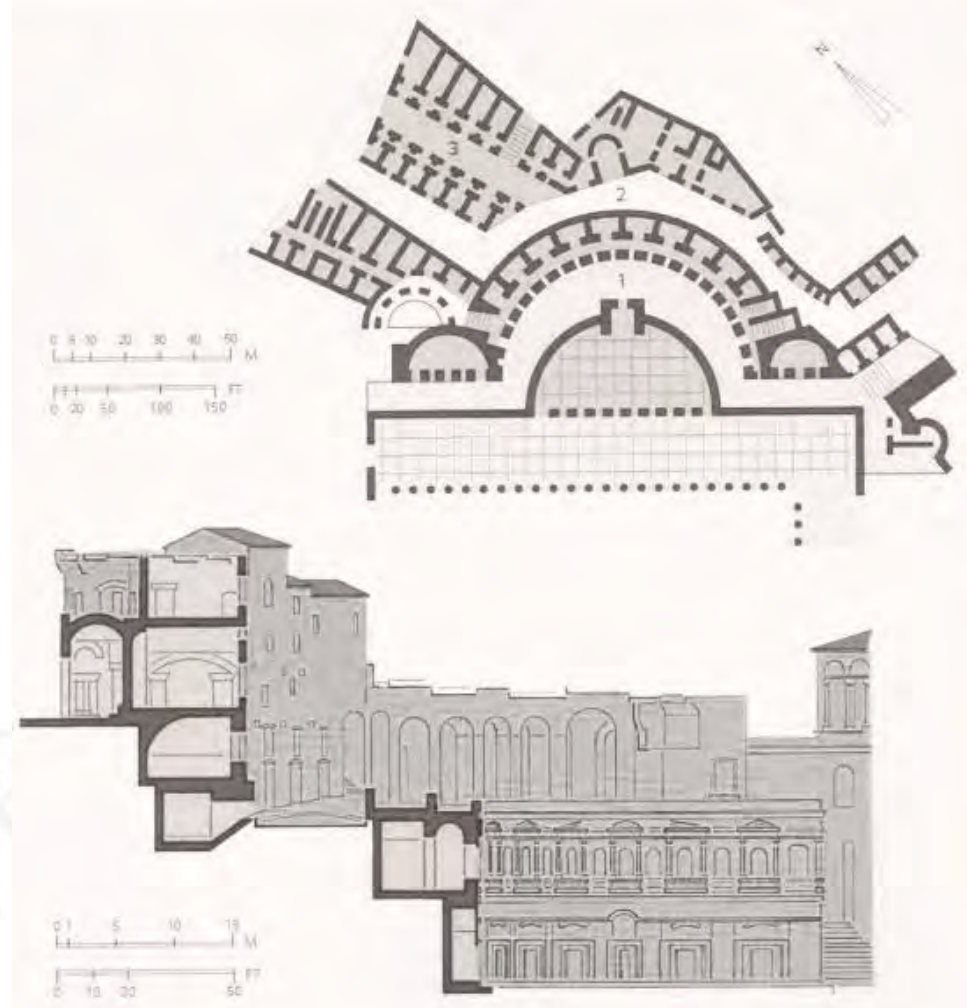

Figura 2.30 Planta del Mercado de Trajano

Fuente: Arquitectura y empresa

En: https://www.arquitecturayempresa.es/noticia/roma-los-mercados-de-trajano

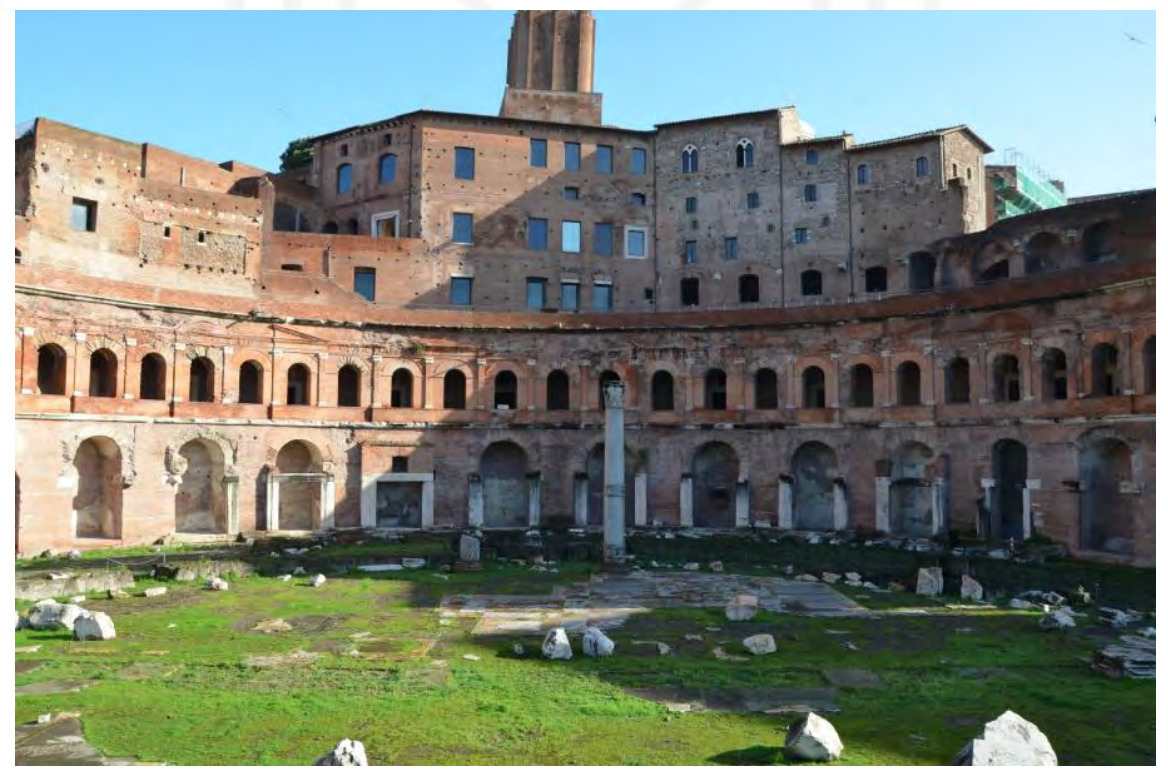

Figura 2.31 Mercado de Trajano

Fuente: Carole Raddato (2014) 
Después de la caída del Imperio Romano, las ciudades de occidente se encontraron en decadencia, y necesitaron de un motor económico para ser reconstruidas. Como respuesta a este problema, aparece la figura del mercader y el paulatino acceso del campesino a los mercados, generando una modificación en la estructura social, y es así como surge una nueva clase social: la burguesía, el cual se caracterizaba por poseer los medios de producción que progresivamente crecían (Meignen, 2010, p. 13).

Las ciudades comienzan a funcionar como mercados y dan origen a las "ferias" actividad comercial que se realizaba de manera ambulatoria cerca a las puertas de las murallas y en las explanadas abiertas aledañas al ayuntamiento ubicados al centro de la ciudad. Esta dinámica desencadenada generó un aumento demográfico en las ciudades medievales, y las actividades comerciales comienzan a ligarse hacia los puertos marítimos y fluviales (Meignen, 2010, p. 13).

Para esta época, el mercado y el ayuntamiento eran un mismo edificio y se ubicaban alrededor de una plaza, a la que se le denominó la plaza del mercado, la cual fue usada de manera similar al ágora griega como lugar de encuentro de la sociedad. Los primeros edificios eran de usos mixtos, la planta baja se mantuvo abierta entre columnas que servían como la extensión del mercado, mientras que las plantas superiores eran exclusivamente para el uso del ayuntamiento (Ver Figura 2.32), además los puestos eran removibles y sin techo, pero con el pasar de los años, cada uno de los comerciantes comenzó a techar su propio espacio (Ergun, 2010, p. 31).

La actividad comercial desarrollada en las calles y en la plaza determinaba el paisaje urbano de la época, en donde los mercaderes llevaban largos bancos de madera que servían de mostradores para exponer sus productos. Este sistema si bien ayudaba a la venta fácil y rápida, tenía sus desventajas, ya que era inseguro y anti higiénico, porque se generaba gran cantidad de desechos en las áreas públicas. Además, al no existir un orden y una distribución de los mercaderes ambulantes dentro de la plaza, ocasionaba que la actividad comercial sea caótica e incontrolable (Ver Figura 2.33). 


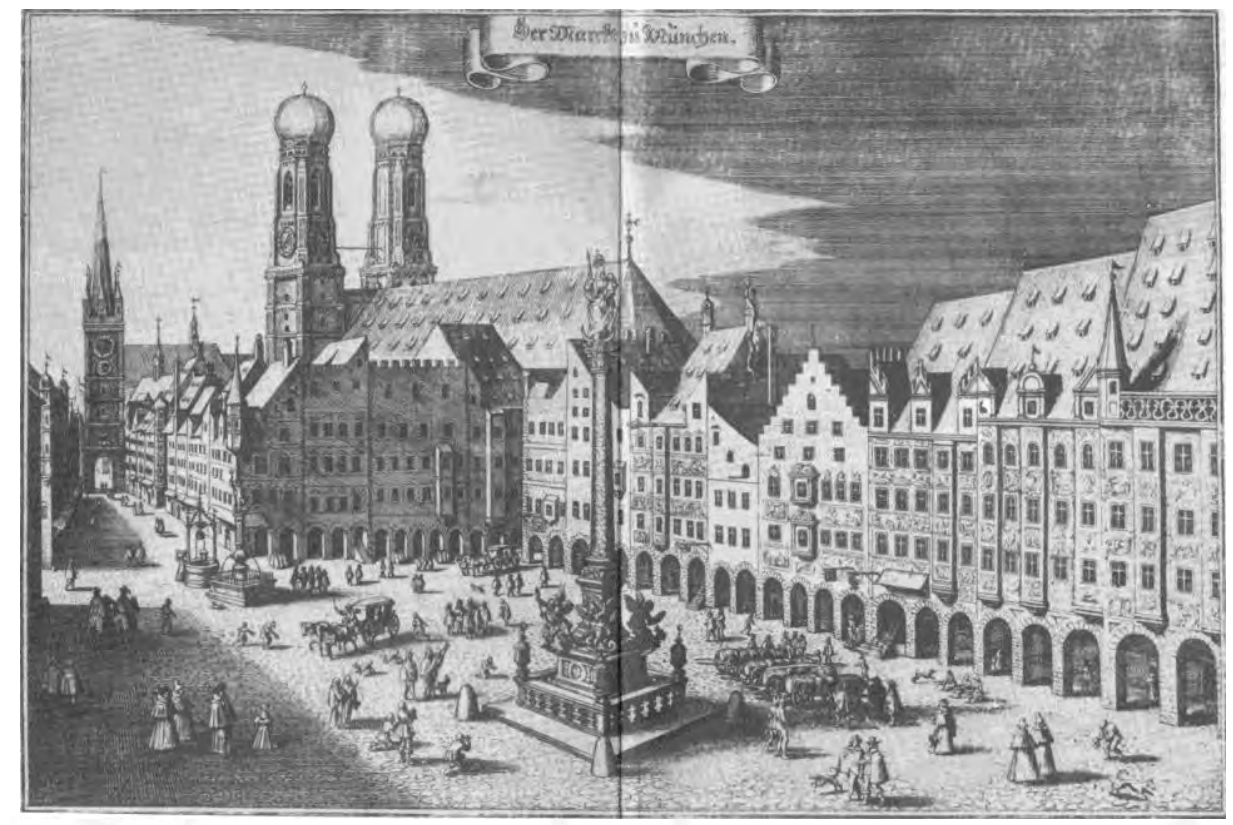

Figura 2.32 Marienplatz_Münich

Fuente: Matthaäus Merian

En: Topographia Germaniae, Edición Topographia Bavariae, 1642

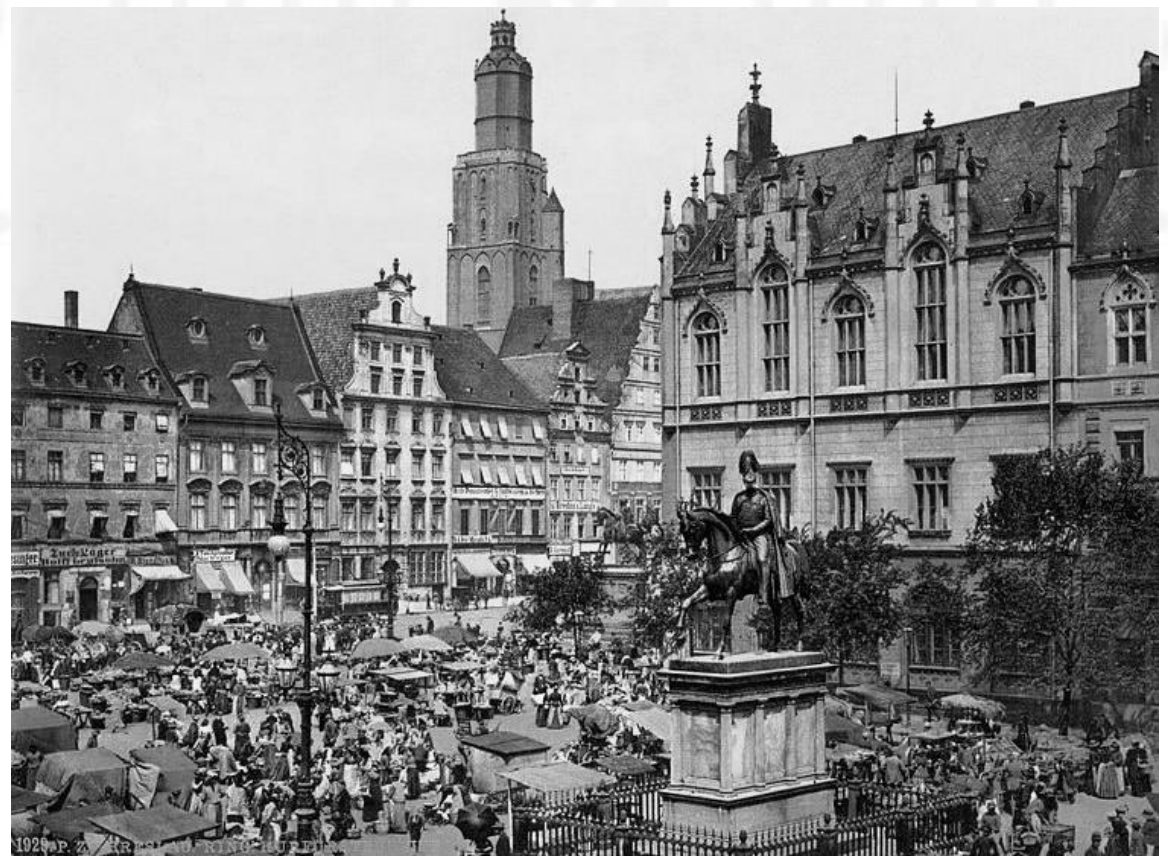

Figura 2.33 Plaza del Mercado-Wroclaw, Polonia

Fuente: Library of congress

En:https://catalog.loc.gov/vwebv/search?searchCode=LCCN\&searchArg=2002720691\&searchType=1\& permalink $=\mathrm{y}$ 
Posteriormente, alrededor del siglo XVI, Se generó una nueva tipología de puestos de venta en donde los comerciantes vivían encima del área comercial estableciendo una relación directa de vivienda, comercio, y espacio público. Estos puestos ya no sólo se encontraban en las plazas de los ayuntamientos, sino que comenzaron a distribuirse por la ciudad acortando el desplazamiento que los habitantes realizaban para conseguir sus productos (Ver Figura 2.34 y Figura 2.35). Además, eran de estructura lineal y cubrían grandes espacios del área pública formando una planta libre aporticado que delimitaba su perímetro, pero no generaba una barrera con su entorno (Coleman, 2014, p. 22).

Figura 2.34

Elevaciones del mercado medieval

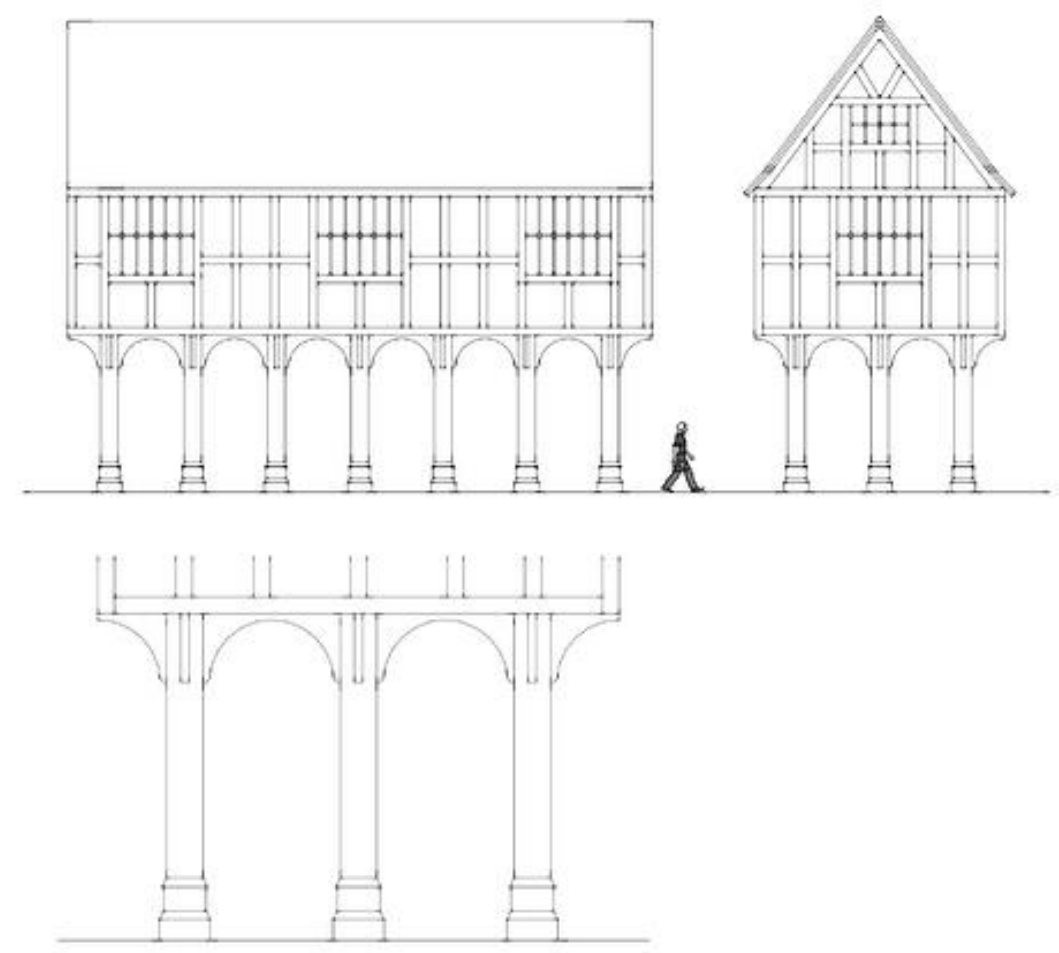

MEDIEVAL MARKET HALL by Doug Turner (33 DMedieval)

Fuente: Doug Turner

En: http://blenderartists.org/forum/showthread.php?253366-Medieval-Market-Hall-Real-Time 


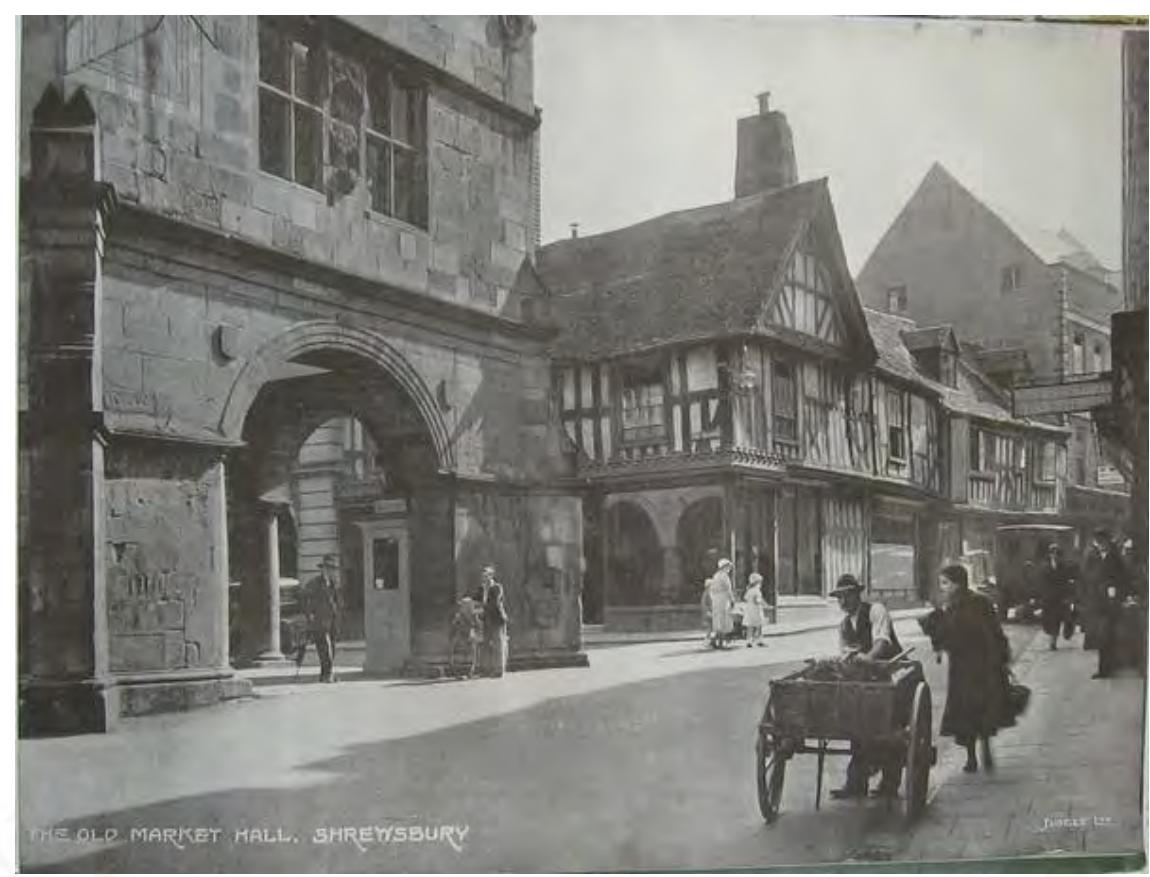

Figura 2.35 Mercado medieval_Shrewsbury, Inglaterra

Fuente: Janes / http://www.sharehistory.org/janes/uploads/3805-the-old-market-hall-shrewsbury

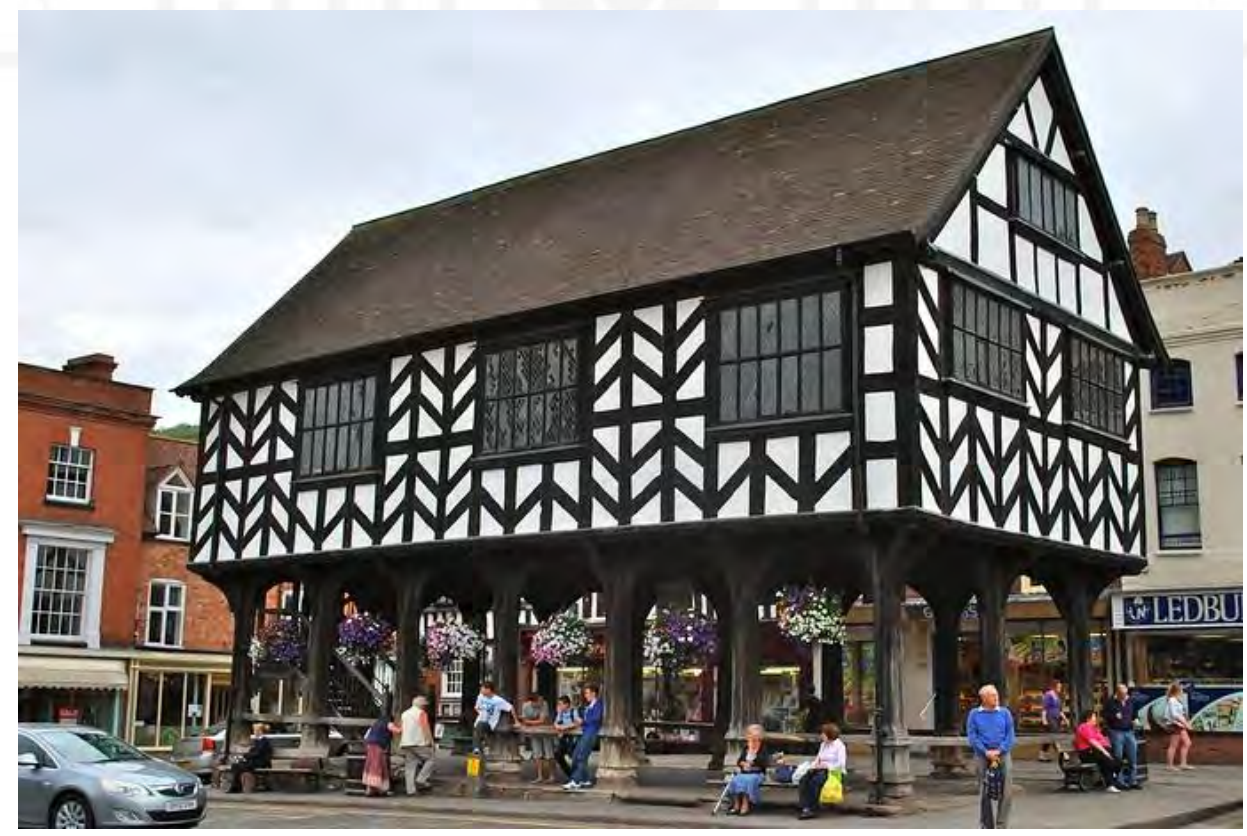

Figura 2.36 Mercado medieval_Hereford, Inglaterra

Fuente: Blender Artists / http://blenderartists.org/forum/showthread.php?253366-Medieval-Market-HallReal-Time 
Paralelamente, mientras que el comercio en Europa se daba en las plazas aledañas al ayuntamiento, en el Medio Oriente se comenzó a desarrollar una nueva tipología comercial, el Bazar Oriental, que apareció a mediados del siglo IV en las rutas comerciales más importantes de la ciudad. Los bazares no solo servían para el comercio, sino que también eran puntos de encuentro social y para realizar actividades religiosas. Además, esta tipología puede distinguirse en dos tipos: la calle cubierta que consiste en una vía que posee tiendas hacia los lados y esta techada con materiales ligeros, como bastones de madera o caña (Ver Figura 2.37); y el Souk que viene a ser una red de calles igualmente techadas (Ergun, 2010, p. 34).

A diferencia de los mercados medievales en Europa que trataban de relacionarse más con el exterior, el Bazar Oriental trata de relacionarse con su interior, es así como poco a poco fueron creciendo y evolucionando, dejando la cobertura ligera de lado para construir grandes arcos con aberturas para una mejor iluminación y ventilación (Coleman, 2014, p. 25).

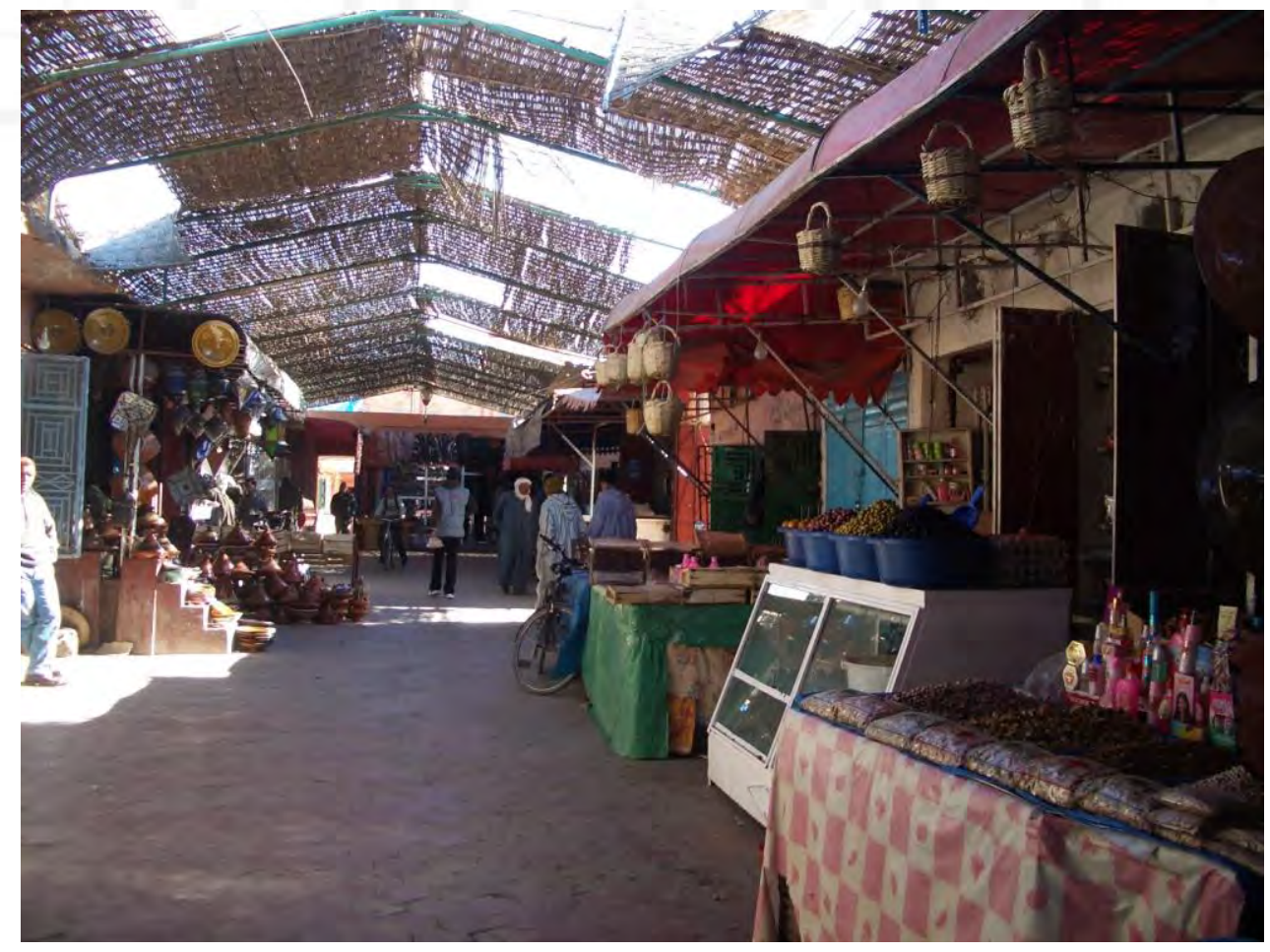

Figura 2.37 Bazar de Medio Oriente

Fuente: Theoliane, 2008 / https://commons.wikimedia.org/wiki/File:Ouarzazate_souk.jpg 
El crecimiento de los intercambios comerciales y las comunicaciones permitieron que los mercados se integren en redes de distribución más amplias, desarrollando una lógica funcional conformada en tres niveles de organización: el puesto de venta, el espacio de circulación, y el hecho de vaciar la calle, debido al caos generado en las plazas y a los problemas de insalubridad, sumado a un cambio de actitud de diferenciación del espacio público con el privado, generando que el mercado de abastos se convierta en un equipamiento que conforme la trama urbana de la ciudad (Guardia Bassols, 2007, p. 3).

Entonces, en la segunda mitad del siglo XIX se da una profunda renovación urbana debido a las reformas de Georges_Eugene Haussmann acompañado de teorías higienistas de Claude-Philibert Barthelot, generando la construcción de equipamientos de hierro como el Mercado Les Halles en París diseñado por el arquitecto Víctor Baltard (Ver Figura 2.38), el cual estaba conformado por diez pabellones metálicos que reflejaban el desarrollo tecnológico de la época (Guardia Bassols, 2007, p. 4).

Este material revoluciona la industria de la construcción con la producción estandarizada de piezas. Aparecen así piezas arquitectónicas significativas hechas con este material como lo son el Palacio de Cristal, La Torre Eiffel, numerosas estaciones de tren y mercados con grandes cubiertas metálicas. (Meignen, 2010, p. 16)

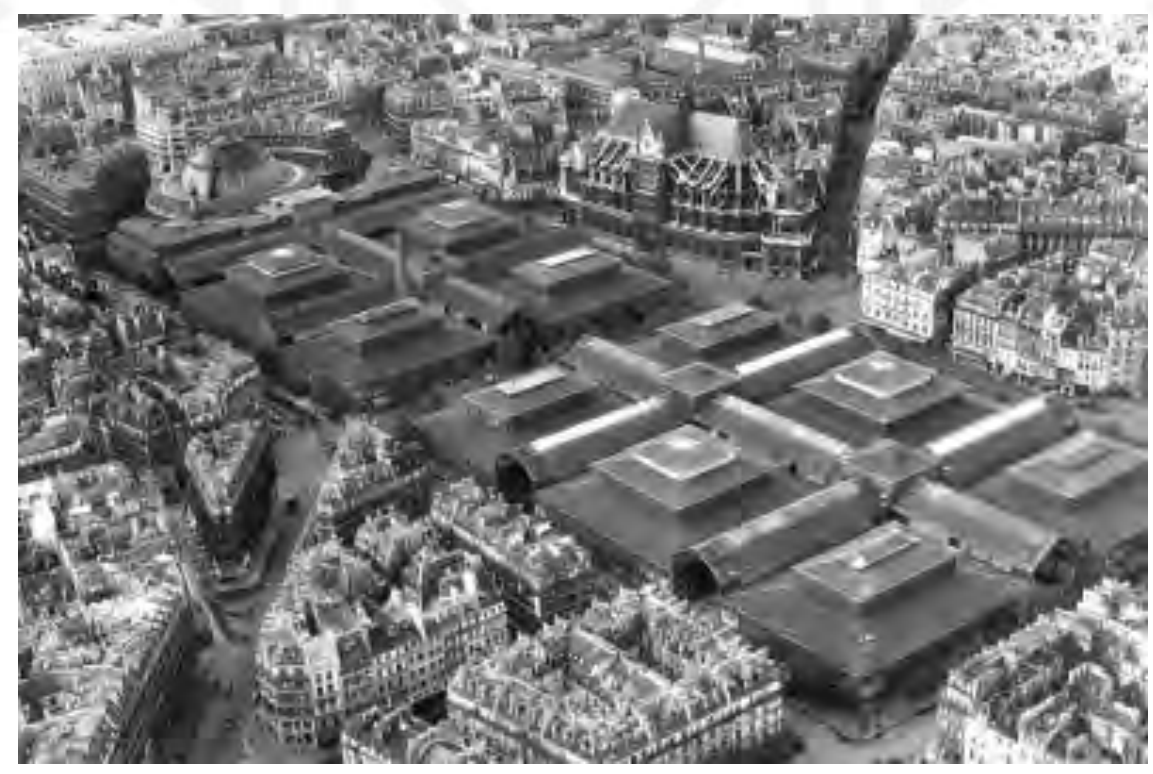

Figura 2.38 Les Halles_Vista aérea

Fuente: Arte y arquitectura / http://art1 arquitectura.blogspot.com/2011/12/en-el-vientre-de-paris.html 
El uso de este material ofrecía ventajas frente a otros sistemas constructivos, debido a su resistencia, maleabilidad y ligereza, teniendo la capacidad de cubrir grandes luces y alturas, conservando la transparencia y visibilidad (Ver Figura 2.39,Figura 2.40 y Figura 2.41); además de tener la opción de la producción en serie y el ensamblaje de piezas pre fabricadas que acortaron los plazos en la construcción (Meignen, 2010, p. 16).

La construcción de los pabellones fue progresiva, inaugurándose uno a uno para que los comerciantes vayan ocupando el mercado paralelamente al avance de la obra que culminó en 1870. Cada pabellón fue asignado con un rubro distinto al otro, lo que zonificó y organizó la actividad comercial, pero que con el pasar de los años se establecieron más rubros en los alrededores del mercado, debido a los comerciantes ambulantes (Iñiguez, 2015, párr. 6).

El éxito del Mercado Les Halles como centro del comercio en la ciudad, espacio público y punto de encuentro entre todo tipo de personas, sirvió de modelo para más de 20 mercados de abastos construidos en París, y para más de 4 centenares realizados en ciudades de provincia en Francia hasta el final del siglo. Por lo que muchos países adoptaron el modelo y rápidamente se generalizó por toda Europa y el conteniente americano (Guardia Bassols, 2007, p. 4).

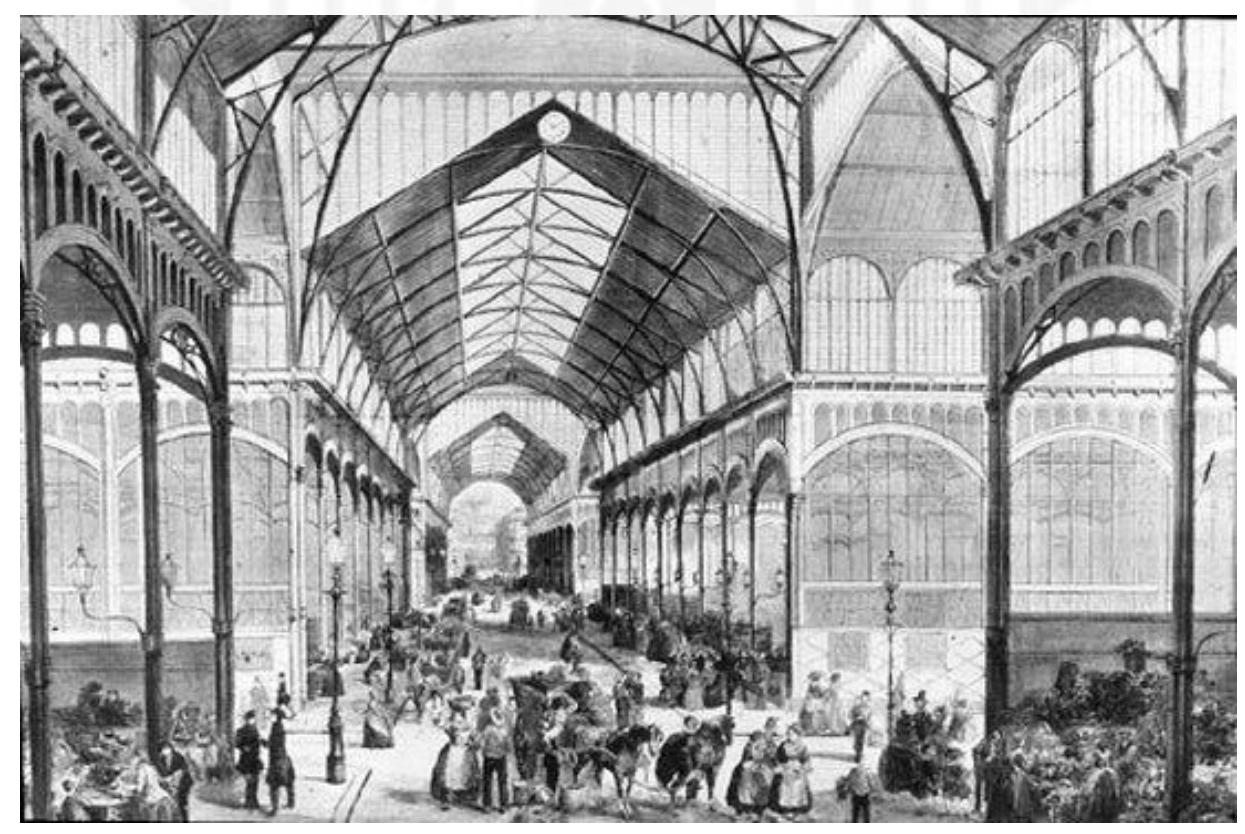

Figura 2.39 Les Halles_Vista interior

Fuente: Arte y arquitectura / http://art1 arquitectura.blogspot.com/2011/12/en-el-vientre-de-paris.html 


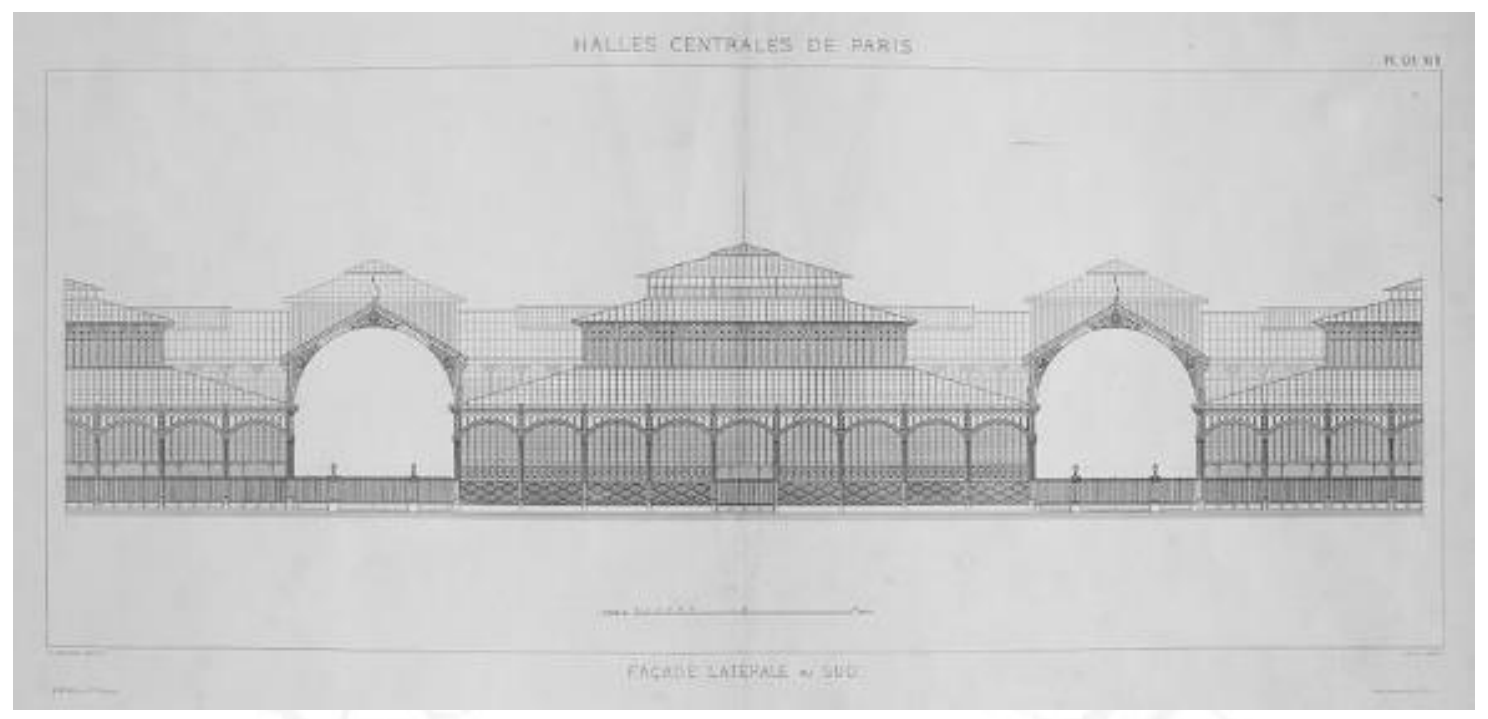

Figura 2.40 Les Halles_Elevación

Fuente: Library of Congress Prints and Photographs Division Washington /

http://loc.gov/pictures/resource/ppmsca.12632/

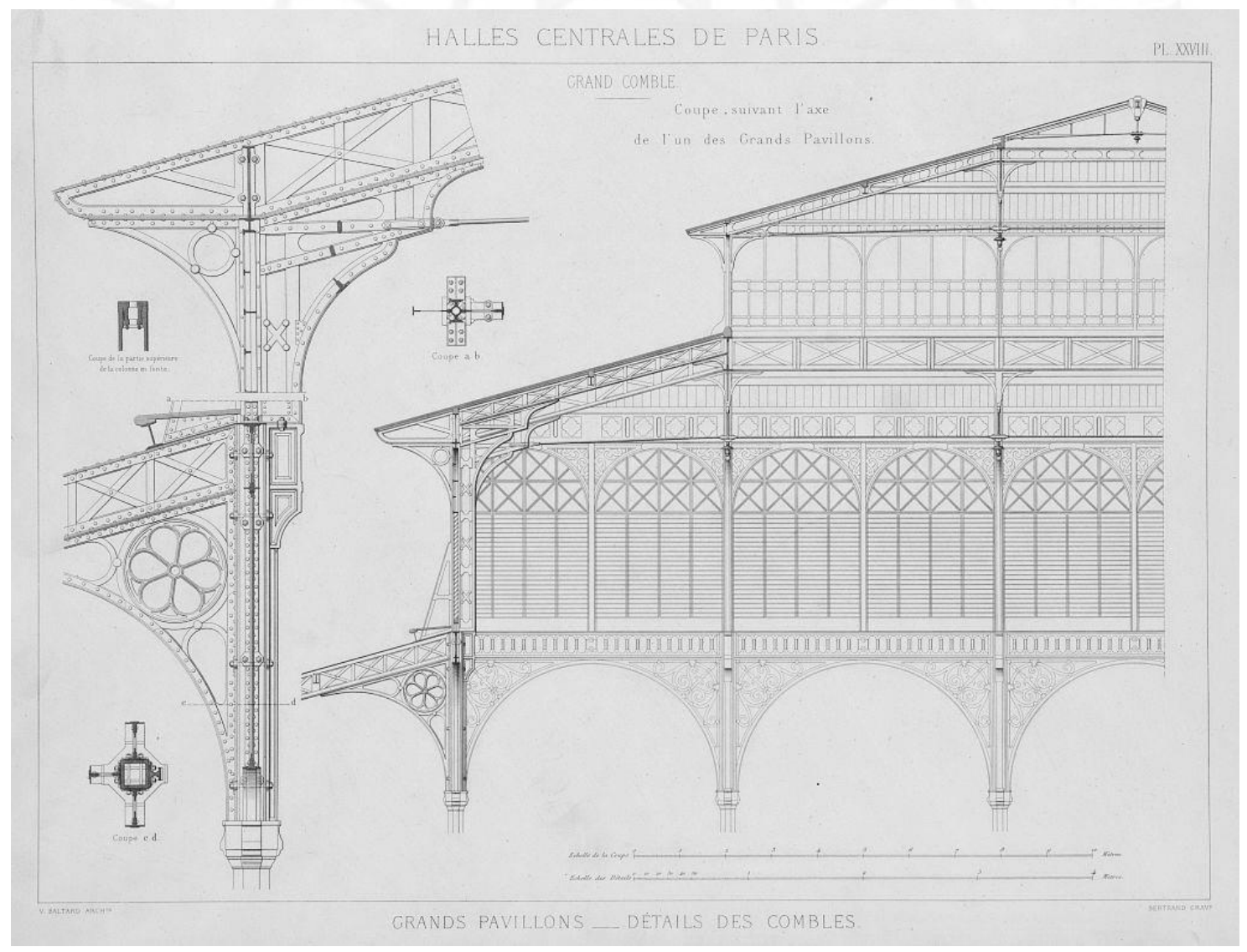

Figura 2.41 Les Halles_Estructura metálica

Fuente: Tumblr / http://archimaps.tumblr.com/image/33559820018 


\section{Declive}

Hacia fines del siglo XIX, los mercados como equipamiento comenzaban a debilitarse originado por nuevas formas de comercialización de productos como los mercados mayoristas y las cooperativas, incrementado por la caída de la agricultura tradicional. Caída que se acentuó por la Primera Guerra Mundial (1914-1918), sumado por destrucciones, falta de mantenimiento y posterior demolición de muchos de los mercados en Europa (Guardia Bassols, 2007, p. 5).

La liberación del comercio en el periodo de entreguerras, sumado al cambio de las formas de comercialización que preferían la estandarización de los productos impulsó la creación de los mercados mayoristas en las principales ciudades, perjudicando al pequeño productor agrícola. Sin embargo, todavía no se trataba de un periodo de declive definitivo, debido a que en la mayoría de las ciudades los mercados seguían operando, aunque cada vez más orientado a las clases trabajadoras, y a la no creación de nuevos mercados como en Gran Bretaña que después de la guerra ya no se generaban con la misma intensidad (Guardia Bassols, 2007, p. 5). (Ver Figura 2.42)

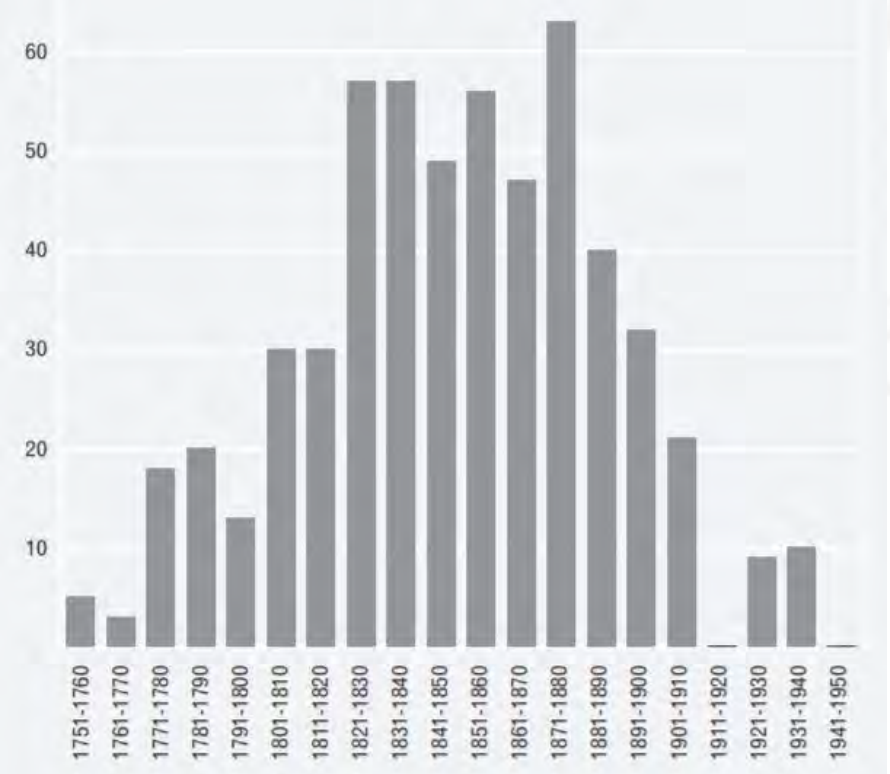

Figura 2.42 Índice de construcción de mercados en Gran Bretaña de 1751 a 1950

Fuente: James Schmiechen y Kenneth Carls

En: European Markets as Makers of Cities 
El principal problema era que conforme pasaban los años, los presupuestos públicos eran menos capaces de cubrir las necesidades de renovación de las instalaciones, por lo que los mercados que aún se encontraban en las plazas sobrevivían, mientras que los nuevos mercados cerraban uno tras otro, porque no requerían de grandes inversiones, es decir, se adaptaban con mayor flexibilidad a las nuevas situaciones (Guardia Bassols, 2007, p. 5).

El mercado como centro distribuidor de productos perecederos, organizado por pequeños comerciantes que actúan como mediadores de la distribución alimenticia y social, entró en una etapa de crisis generalizada a mediados de 1980, incitado por el crecimiento de los formatos de gran distribución transnacional que aprovechaban las ventajas fiscales y financieras (Robles, 2014, p. 141).

La crisis definitiva se precipitó, en general, en la segunda posguerra. El largo período transcurrido sin inversiones, en algunos casos las propias destrucciones de la guerra, las renovaciones de los centros históricos, la progresiva motorización de la población, diezmaron el legado heredado. (Guardia Bassols, 2007, p. 6)

Por otro lado, el avance de la tecnología permitió diversas formas de pago y de cómo adquirir los productos, las exigencias de los consumidores también cambiaron, esto añadido a la aparición del supermercado y del autoservicio llevó al empaquetado de productos a gran escala con una aprobación favorable del consumidor, es en ese momento cuando el mercado de abastos tradicional deja de ser la mejor opción para adquirir los productos del hogar (Guardia Bassols, 2007, p. 6).

Los motivos variaron según los casos, destrucciones causadas durante la guerra, incendios, falta de inversiones, renovación profunda de sus entornos urbanos. A menudo fueron objeto de modernizaciones en las que se perdió su carácter original o fueron substituidos por otras fórmulas comerciales. (Guardia Bassols, 2007, p. 6) 
El momento más dramático, sobre los cierres y destrucciones de los mercados de abastos fue la demolición del Les Halles de París en 1971 (Ver Figura 2.43 y Figura 2.44), la cual tuvo gran repercusión internacional generando que muchos ciudadanos e instituciones se opongan a posteriores demoliciones y velar su conservación.

La demolición del mercado fue porque se convirtió en un lugar lleno de comerciantes que generaban desorden, caos e insalubridad, por lo que el primer ministro Michel Debré decretó la reubicación del mercado hacia los suburbios de Rungis, para que en su lugar se construya la estación del RER, siendo una red de líneas subterráneas que mientras se esperó su construcción fue punto de prostitución y tráfico de drogas. Para muchos, la demolición, significó una gran pérdida para la identidad del pueblo francés, ya que era el único que mantuvo su función original desde el siglo XII y por ser el principal lugar de encuentro para sus habitantes (Iñiguez, 2015, párr. 9).

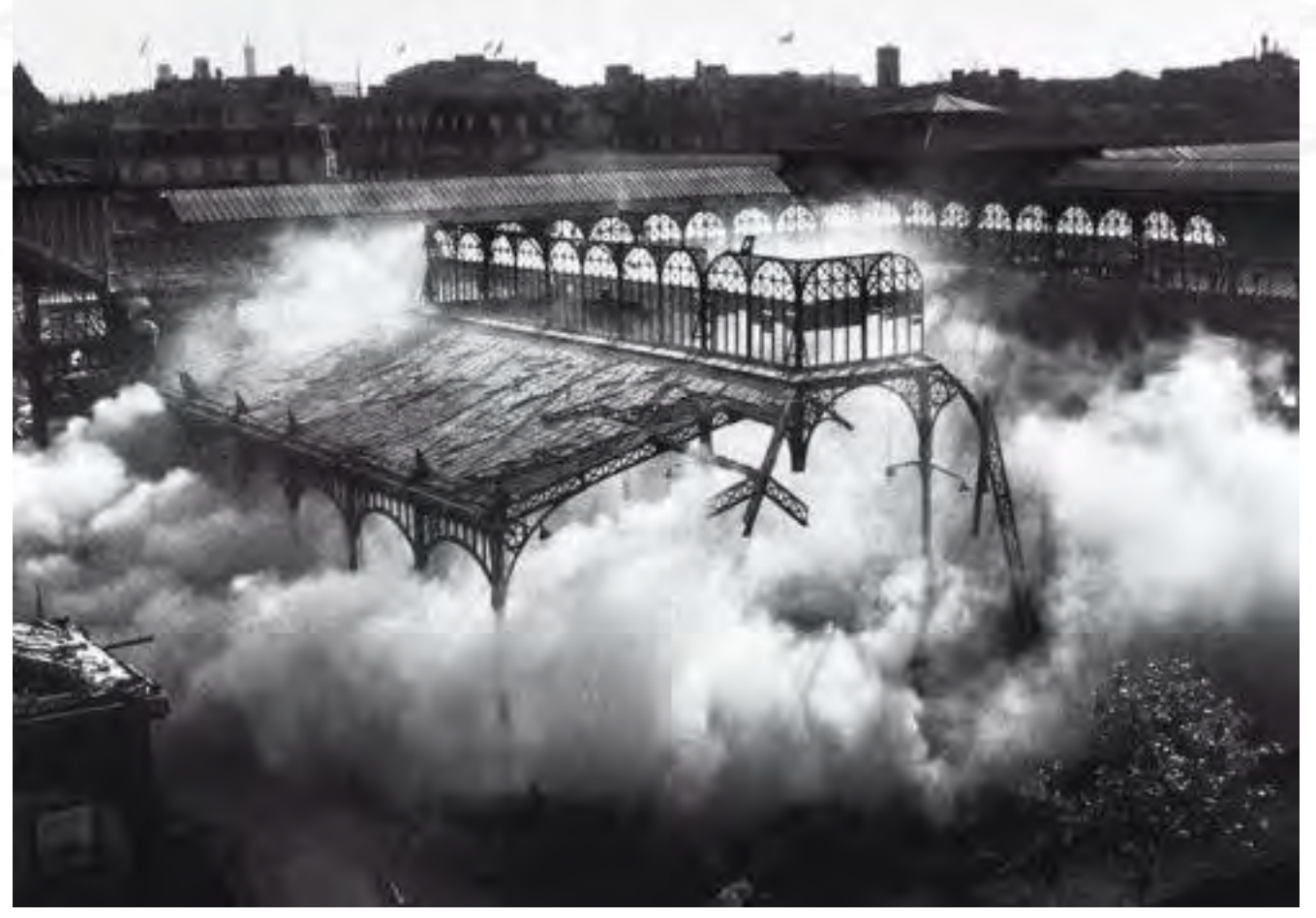

Figura 2.43 Les Halles_Demolición

Fuente: Patricia Gilbert / https://onequalitythefinest.com/2012/11/16/en-fonte/ 


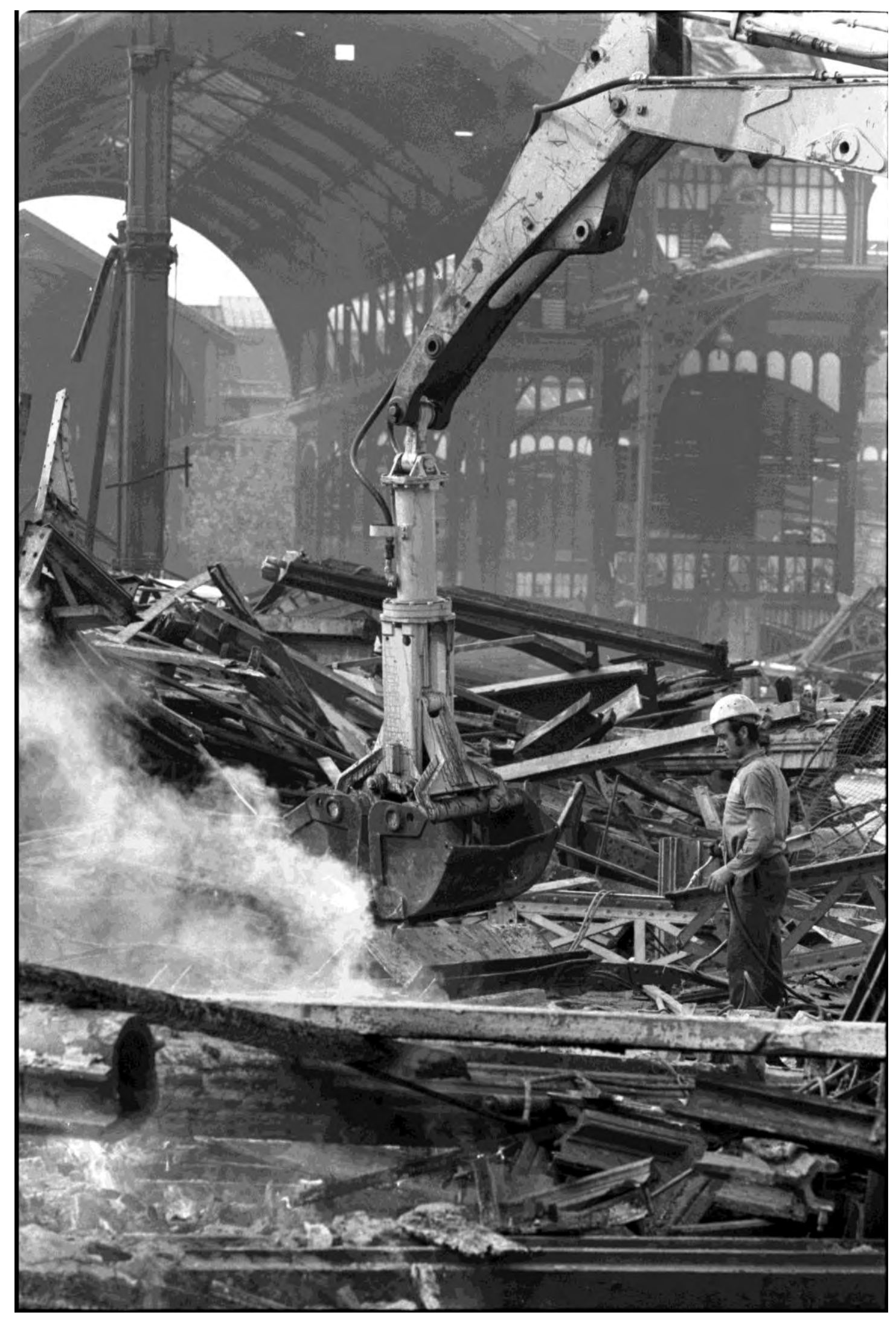

Figura 2.44 Destrucción del Les Halles_1971

Fuente: Luca Romano, 2018 /

https://upload.wikimedia.org/wikipedia/commons/4/41/Destruction_of_Les_Halles_1971.jpg 


\section{Reconversión de los mercados}

El abandono de los grandes mercados como el Les Halles de París, el Convent Garden de Londres, o el Quincey Market en Boston, fueron los más notorio del proceso generalizado de la desaparición de los mercados cubiertos, pero a partir de 1980 los mercados se desbordaron por la propia dinámica de crecimiento demográfico y por la crisis del medio de distribución alimentaria (Guardia Bassols, 2007, p. 7).

La proliferación dispersa de las unidades de distribución estaban colmando el sector y el tejido comercial tradicional se mostró incapaz de adaptarse, por lo que era necesaria la intervención los ayuntamientos o municipalidades en la organización de las actividades comerciales, por ejemplo en Barcelona se logró a través del Plan Especial del Equipamiento Comercial Alimentario aprobado en 1986, que resaltaba la trascendencia urbanística y la renovación de la red de mercados existente, apoyado con la creación del Instituto Municipal de Mercados de Barcelona en 1991 que cuenta con la misión de gestionar, administrar y modernizar los mercados municipales, y con el objetivo de mantener su aspecto social, cívica y cultural (Guardia Bassols, 2007, p. 7).

Desde finales del siglo XX se ha insistido sobre la necesidad de integrar el sector comercial como pieza esencial en la estrategia de ordenación urbanística y de revitalización de los centros urbanos, gracias a la intervención municipal. Los mercados están afrontando una gran transformación en cuanto al rol que cumplen con la ciudad como ejes de centralidad, y ejerciendo la función de la interacción y el intercambio social, cívico y cultural, a través de sus valores más preciados como el trato personalizado y el producto fresco (Rivarola Cores, 2015, p. 13).

Desde fines de los 90's se puede notar un mayor interés hacia el turismo de experiencias o emocional, tratando a los mercados bajo el enfoque de turismo gastronómico como estrategia de supervivencia (De Padua, Dutra, Teixeira, Machado, \& Tijoux, 2012; García, 2017). Los turistas actuales consideran las experiencias culinarias como un elemento distintivo a la hora de escoger un destino, por ende el turismo cultural está transformándose en un producto de vivencias únicas y experiencias enriquecedoras (García, 2017, p. 169). 
Esa búsqueda de lo local lleva a los turistas a visitar los mercados de abastos, donde se puede percibir la idiosincrasia de la gente local, su forma de expresarse, de vender, de comprar, sus hábitos alimenticios, el estilo de vida de disfrute del ocio, los gustos y costumbres gastronómicas, etc. (García, 2017, p. 169)

La llegada de turistas a los mercados permite que incrementen sus ingresos, remodelar y diversificar los puestos de venta, así también permite la remodelación del recinto arquitectónico que se encuentra bastante deteriorada y obsoleta en algunas ocasiones, proponer una oferta más orientada a los visitantes extranjeros, incrementar el número de horas de atención del establecimiento, e introducirlos en rutas turísticas (García, 2017, p. 172).

Uno de los casos de mercado como producto turístico y como elemento de regeneración urbana es el Mercado Santa Caterina ubicado en el centro histórico de Barcelona, el cual presentaba problemas en cuanto a la infraestructura de sus edificaciones, inaccesibilidad espacial, y un inadecuado sistema de equipamientos. A raíz de esto, el valor de los terrenos comenzó a disminuir drásticamente siendo ocupada por los niveles socioeconómicos más bajos, y convirtiéndose en foco de inseguridad (Baquero, 2011, p. 74).

Ante estos problemas, el Ayuntamiento de Barcelona buscó reactivar el centro histórico de Ciutat Vella, empezando a través de una infraestructura con una imagen nueva, que dote de servicios a la población, articule equipamientos futuros, e influya en la actividad económica de su alrededor, es así como se elige al Mercado Santa Caterina, cuya remodelación concluyó en el 2005, y diseñado por los arquitectos Enric Miralles y Benedetta Tagliabue en el que la cubierta se transforma en la fachada más importante del mercado, manteniendo el estilo arquitectónico y la estructura base (Baquero, 2011, p. 75) (Ver Figura 2.45). El proyecto cumplió un rol importante en la recuperación urbana de Ciutat Vella, en el que se quería reactivar el área urbana con el turismo, por medio del cambio de imagen del mercado, el desarrollo de usos mixtos, generación de nuevas viviendas, y la configuración de un espacio público que consolide al mercado como hito de la ciudad (Baquero, 2011, p. 76). 

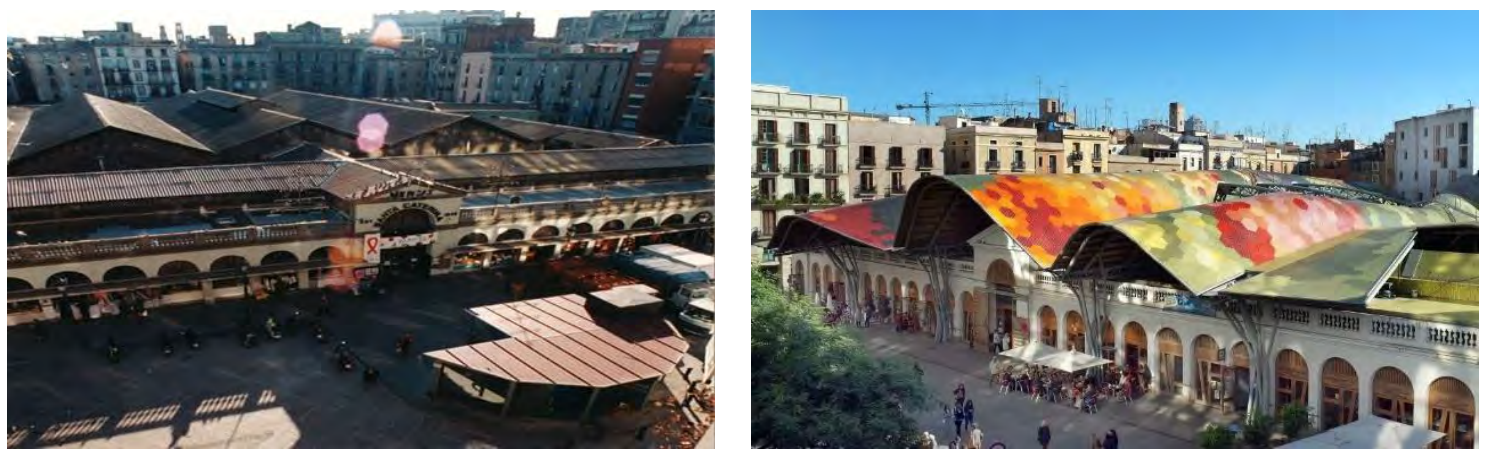

Figura 2.45 Mercado Santa Caterina antes y después

Fuente: Miastawidoki / https://urbanalia.wordpress.com/

Durante los últimos años se comienza a ver a los mercados como hitos arquitectónicos para la regeneración de una ciudad, por lo general son los museos o galerías de arte los que son escogidos, sin embargo, el Mercado de Rotterdam, diseñado por el estudio de arquitectos MVRDV, fue el proyecto de partida para la re-urbanización del barrio de Laurens y los alrededores de la estación Blaak, zonas del centro que quedaban casi desiertas después del horario comercial y laboral (López Fontanals, 2014; Miles, 2015).

El "Markthal" es un espacio multifuncional y pionero en cuanto a concepto de edificio que une en un mismo espacio 96 puestos de comida fijos, más de 20 tiendas, 8 restaurantes, un supermercado, estacionamientos y 228 viviendas en la parte superior, de las que los áticos cuentan con vistas al mercado desde el suelo de cristal de las terrazas. (López Fontanals, 2014, párr. 5)

La idea del mercado era que tenía que estar lo más abierto posible para atraer al público, y al mismo tiempo cerrarse debido a las condiciones climáticas. Entonces se optó por cerrar el mercado con vidrio a través de una fachada de red de cable de acero que necesita muy pocos elementos constructivos (Ver Figura 2.46). Gracias a esto, el interior del mercado es completamente visible desde el exterior (Ver Figura 2.47), las formas y colores de la fachada interna, y la dinámica social-comercial invitan al público a entrar al proyecto (Mark, 2014, párr. 8).

Además, la mixticidad de usos y la forma en que se combinan hizo que el mercado tenga diferentes tipos de usuarios a lo largo del día, generando una dinámica que no solo 
está pensado para los habitantes de la zona, sino que también para los turistas. Es por eso que el mercado atrajo a 6 millones de visitantes en su primer año, índice sigue en aumento, pero la afluencia de la nueva arquitectura va más allá del número de visitantes, también contribuyó a la imagen y al atractivo de Rotterdam como ciudad donde las empresas nacionales e internacionales han comenzado a invertir (Miles, 2015, párr. 5).

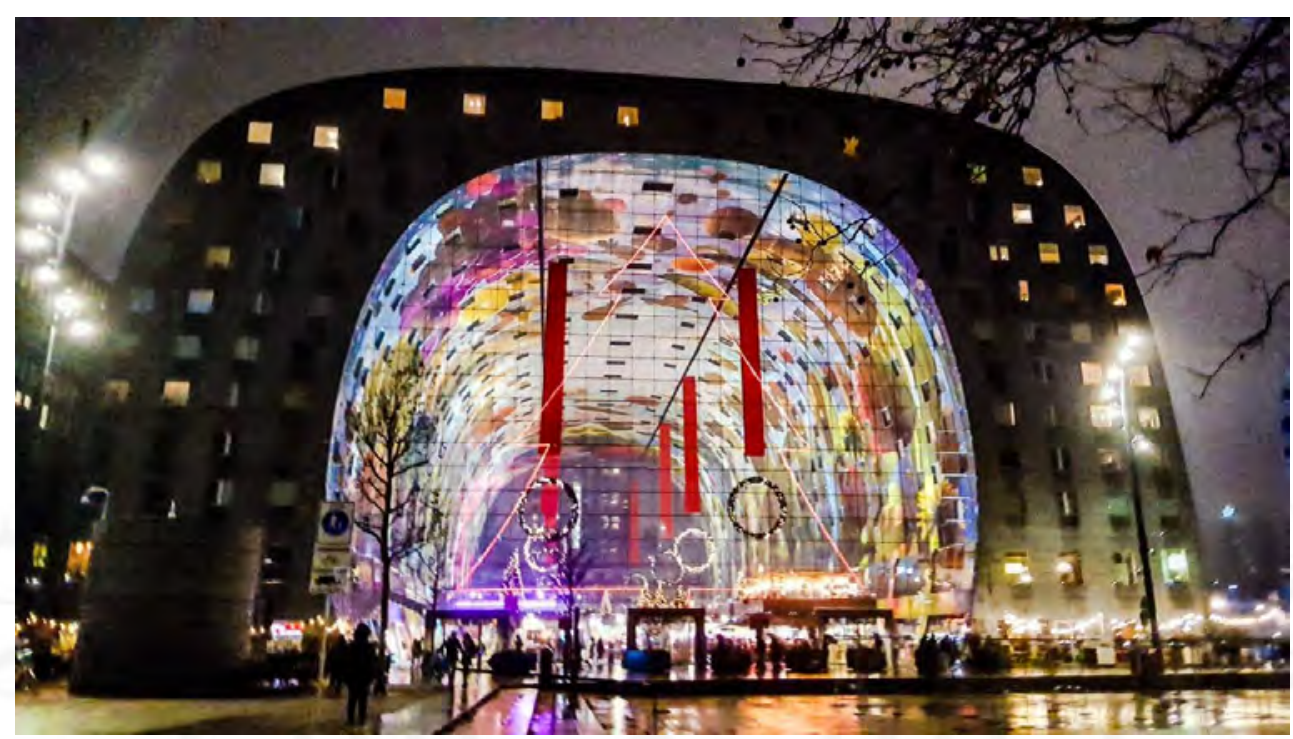

Figura 2.46 Mercado de Rotterdam

Fotografía realizada por los autores.

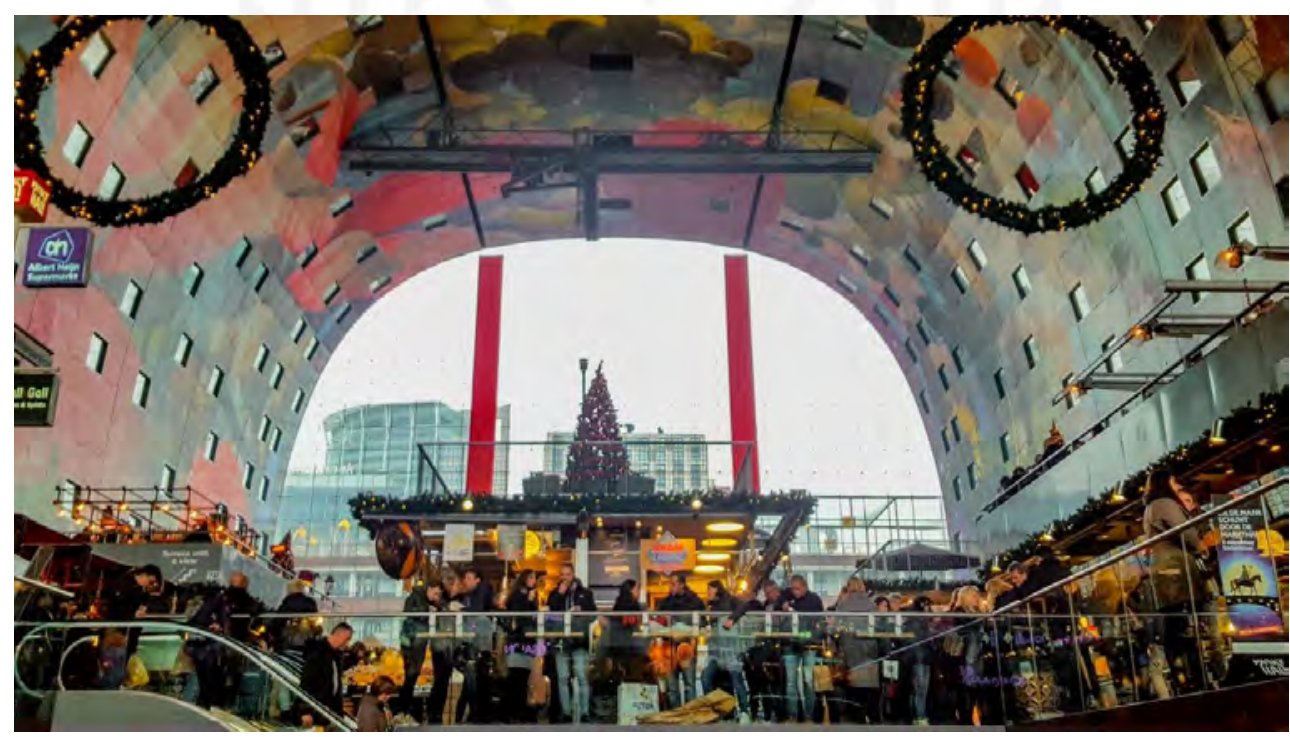

Figura 2.47 Relación interior-extereior del Markthal

Fotografía realizada por los autores. 


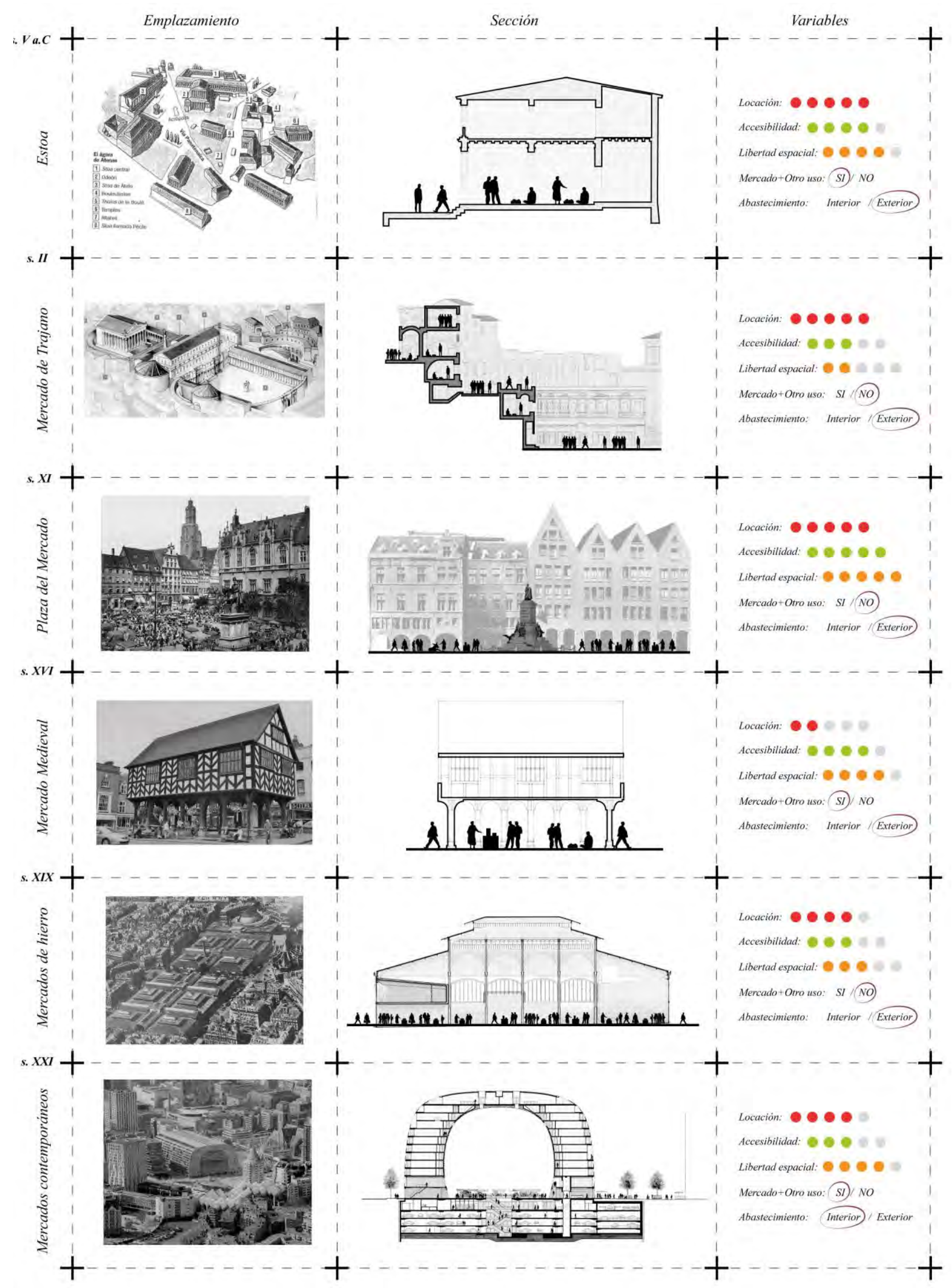

Figura 2.48 Proceso tipológico de los mercados

Gráfico elaborado por los autores. 


\subsubsection{Orígenes de los mercados tradicionales en Lima}

\subsubsection{El mercado pre-colombino}

Las plazas de mercado son un tipo de equipamiento urbano que influyeron en la transformación de las áreas urbanas y en el desarrollo de servicios estableciéndose como epicentro de la actividad urbana en los principios de la era medieval hasta la actualidad (Baquero, 2011, p. 11).

Pero la realidad de las plazas de mercados de los pueblos coloniales eran distintas, debido a que cuando los conquistadores desembarcaron vieron al mercado pre-colombino con ojos europeizados, interpretando erróneamente la interacción social que observaban (Leung, 2016, p. 22).

En las comunidades andinas el mercado y el templo estaban asociados, en la época de Túpac Yupanqui el núcleo urbano era el centro de atracción para las poblaciones de la periferia lo que permite creer que las dos actividades estaban relacionadas política y espacialmente (Leung, 2016, p. 24).

Otra diferencia era que en los mercados pre- colombinos eran lugares de trueque, que a diferencia de las plazas de mercados medieval europeo, en el Catu se realizaba una forma de intercambio que no intervenía un sistema monetario, no había un ánimo lucrativo ni espíritu comercial. Es decir, que la importancia del Catu era lograr una armonía o crear alianzas con otras sociedades incas o no incas, generando lazos políticos con los jefes mediante el trueque.

No existen patrones de asentamiento cuyo origen pueda provenir de una actividad comercial (...). No hay patrones de acumulación que avalen un desarrollo mercantil (...). No hay evidencias de transacción bajo modalidades autóctonas (...). No se aprecian innovaciones técnicas derivadas de corrientes comerciales. (Noejovich, 1993, p. 30)

El Catu o mercado pre colombino, era el lugar idóneo para los festivales, en los que se producía una necesaria re-distribución de bienes, y una interacción social particular como el reforzamiento del linaje del cacique como gran guerrero o sumo sacerdote, o donde las personas contaban sus grandes hazañas realizadas en el campo de batalla, o por sus milagros en el terreno de la brujería (Leung, 2016, p. 24). 


\subsubsection{El mercado de la Época Colonial}

El mercado europeo fue impuesto por la colonización española como símbolo de imposición de poder y control económico. Por eso, la actividad del mercado en Lima se siguió realizando en la re-urbanizada Plaza Mayor (Ver Figura 2.49), antiguo Catu, donde ocurría toda la actividad cívica y religiosa, además era el lugar idóneo para ejercer el control y el lugar más indicado para vigilar a los pobladores (Leung, 2016, p. 26).

La plaza mayor es el centro sobre el que confluye toda la vida de la ciudad. Es el lugar de encuentro para todas las funciones sociales, desde las derivadas del ejercicio del poder, hasta las de diversión y esparcimiento. A su alrededor, y abriendo a ella sus puertas, se sitúan los edificios del poder y de la religión. Allí se administra, se hace justicia, se comercia, se celebran los festejos. (De Terán, 1997, p. 70)

Entonces, se entiende a la Plaza Mayor como el centro espacial, y es ahí donde comenzó la re- urbanización de la ciudad, originando calles y manzanas entorno a una plaza regular, cuyas medidas y proporciones ya habían sido estudiadas en España. La construcción de las plazas significa la reforma más importante de vacíos centrales y la formación de los primeros grandes espacios regulares y geométricos en el interior de las ciudades en el siglo XVII (Rubert de Ventós, 2014; Leung, 2016).

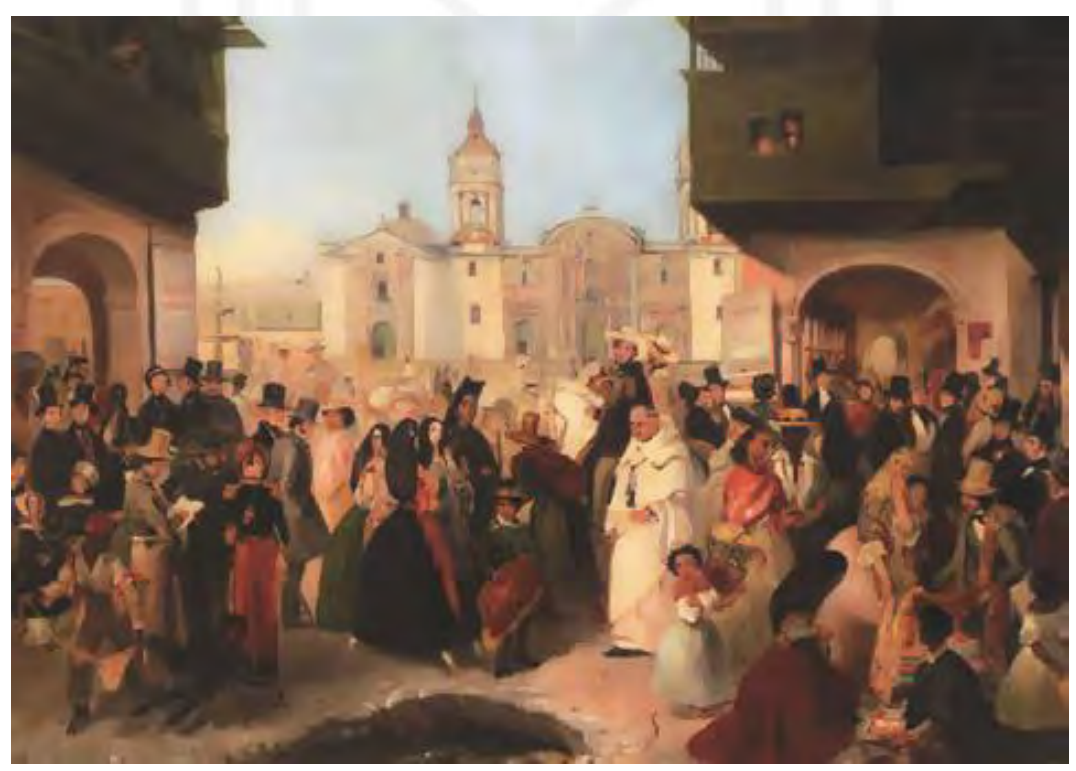

Figura 2.49 Plaza de Mayor de Lima_Época Colonial

Fuente: Johann Moritz Rugendas, 1843 
"La plaza mayor hispanoamericana es un espacio abierto al que acuden todos los habitantes de la ciudad como lugar de encuentro e intercambio, confluencia de caminos y punto de máxima accesibilidad” (De Terán, 1997, p. 148). Debido a estas características era necesario que se realice la actividad comercial en la Plaza Mayor de Lima, la cual estaba lleno de tenderos y cajoneros, los tenderos eran aquellos comerciantes que se encontraban en el interior de los portales, mientras que los cajoneros estaban en las covachas, generalmente al frente del palacio del virrey; las vivanderas estaban situadas en la explanada de la plaza, y los ambulantes o mercachifles siempre se encontraban en constante desplazamiento (Leung, 2016, p. 27).

Para la época colonial, Lima contaba con 3 plazas de mercados (Las Nazarenas, El Baratillo, y la Plaza Mayor) y también había otras 7 plazuelas generadas por la reurbanización de la colonización en las que se realizaban las actividades comerciales en menor magnitud, una de ellas era la Plaza de la Inquisición (Ver Figura 2.50) y el resto se encontraban distribuidas por la ciudad (Ver Figura 2.51).

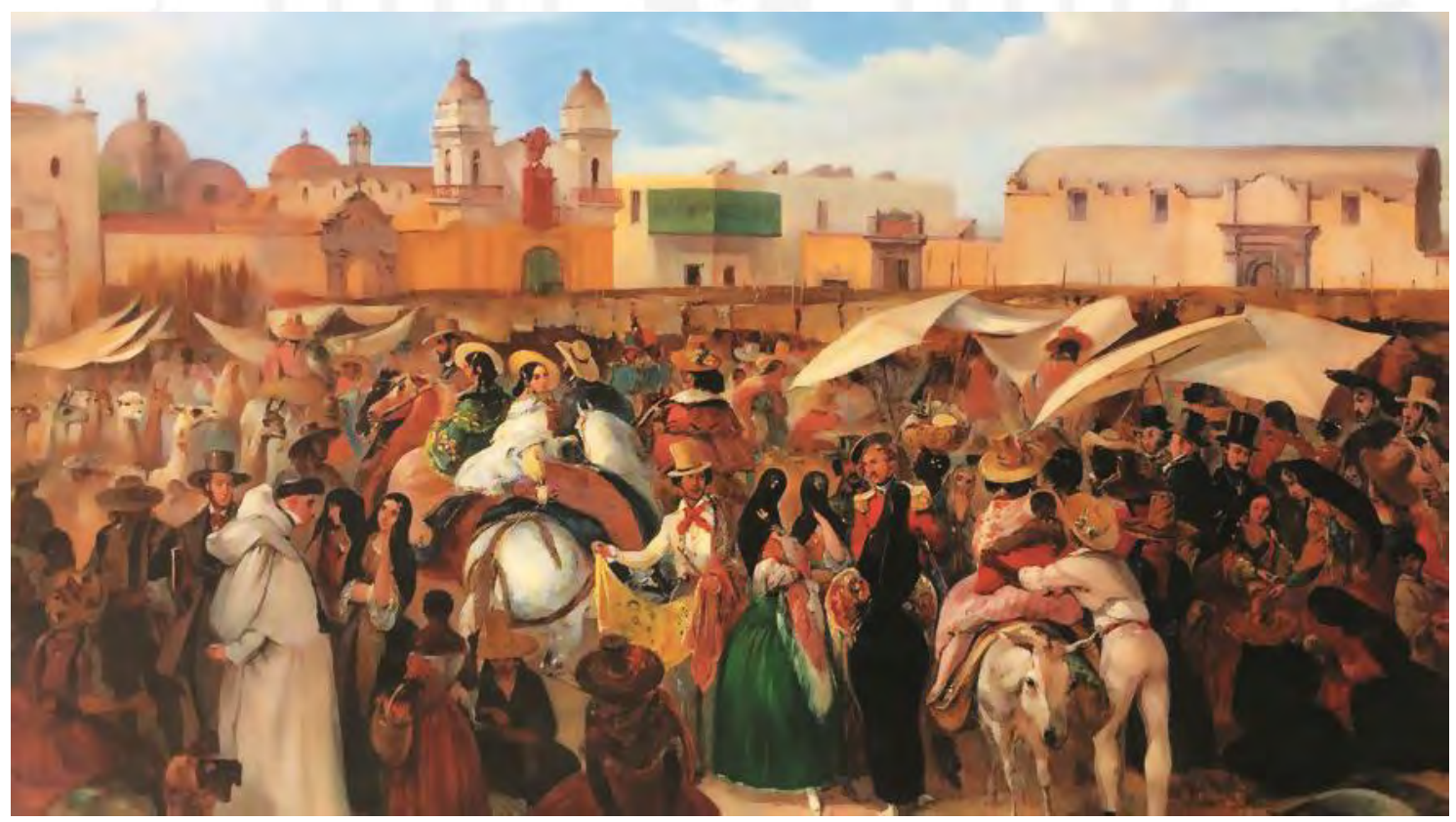

Figura 2.50 Mercado de la Plaza de la Inquisición

Fuente: Johann Moritz Rugendas, 1843 


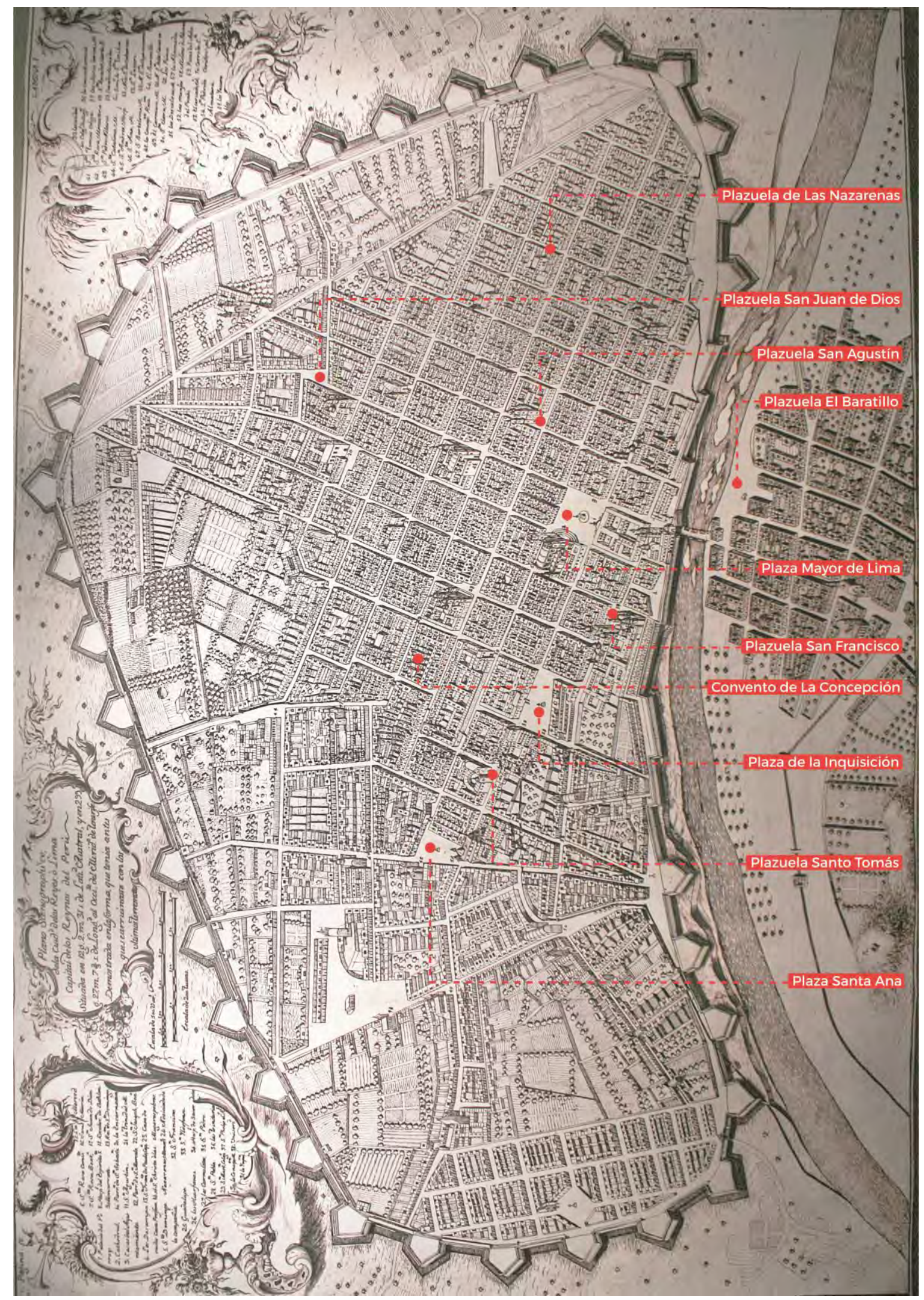

Figura 2.51 Ubicación de los mercados en la Lima Colonial

Fuente: Pedro de Nolasco, 1687 


\subsubsection{Los mercados republicanos}

A partir de la independencia del Perú, se propuso la creación del primer mercado cubierto de la ciudad, acompañado de un discurso moral progresista y principalmente por la preocupación higienista. Primero, por orden del virrey O'Higgins, se trasladó los puestos de la Plaza Mayor hacia otras plazas, concretándose la repartición de la actividad comercial en toda la ciudad (Leung, 2016, p. 29).

La ideología progresista e higienista se trasmitió con mayor fuerza mediante la construcción de equipamientos de entidad pública como casas de gobierno, legislatura palacios de justicia y ministerios, reemplazando así los antiguos edificios coloniales por las nuevas infraestructuras del simbolismo republicano (Gutiérrez, 1997, p. 261).

Dentro de este contexto se construyó el Mercado de La Concepción durante el gobierno de Ramón Castilla en el terreno del Convento de La Concepción expropiado a la iglesia, convirtiéndose en el primer mercado cubierto del país y entrando en funcionamiento en 1852 (Ver Figura 2.52). Las actividades del mercado duraron casi medio siglo, hasta que en 1905 debido a la peste bubónica que atacaba la ciudad, se decidió reconstruir el mercado (Ver Figura 2.53), por lo que los comerciantes fueron trasladados a la Plaza Santa Ana mientras el mercado estaba en construcción (Coello Rodríguez, 2014, p. 369).

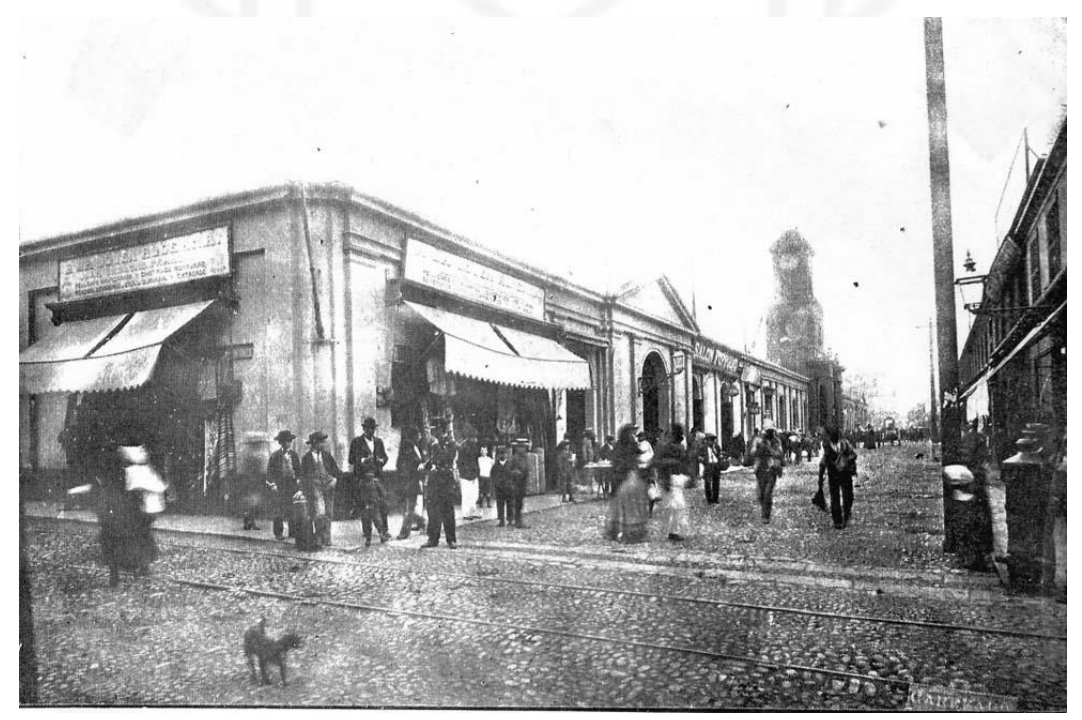

Figura 2.52 Mercado de La Concepción_1852

Fuente: Lima La Única / http://www.limalaunica.pe/2012/07/el-antiguo-mercado-de-la-concepcion.html 


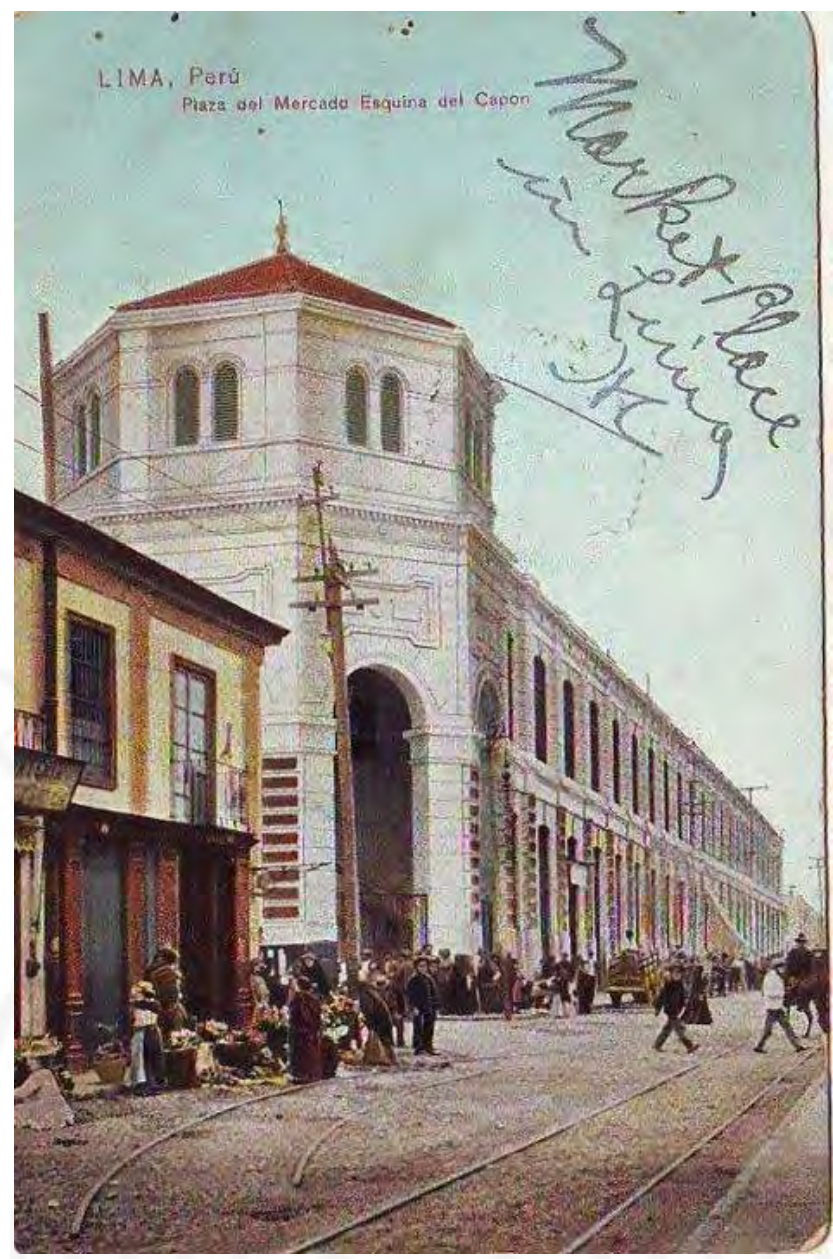

Figura 2.53 Mercado Gran Mariscal Ramón Castilla_ 1905

Fuente: Lima La Única / http://www.limalaunica.pe/2012/07/el-antiguo-mercado-de-la-concepcion.html

El mercado ocupaba toda una manzana (...) desarrollando un área de 13,000 m2. Los muros de su recinto exterior formaban las fachadas de 66 tiendas y un almacén en cada esquina o sea cuatro: unas y otros con puertas en arco hacia la calle; las de entrada al local eran 11, estando la principal hacia la calle Paz Soldán. En el interior y también en el contorno, se contaban con 60 tiendas y dos corrales, que circundaban un amplio patio cuyo centro se colocó una pila circular, rodeada de su respectivo enlosado. La pila había sido trabajada en Londres, contratada por Mariano F. Paz Soldán, durante un viaje en comisión a Europa (...) De la pila irradiaban unos pasajes, también enlosados, que dividían el patio en sectores; éste estaba cubierto por la ramada que igualmente se dividía en secciones de acuerdo con las del piso; estaba sostenida por 176 columnas. (Regal, 1967, p. 4-5) 
El mercado reconstruido cambió de nombre a Gran Mariscal Ramón Castilla hasta que en 1964 un incendio generó grandes daños en casi su totalidad, por lo que tuvo que ser demolido por segunda y última vez (Coello Rodríguez, 2014, p. 375). El actual mercado también es reconocido como el Mercado Central de Lima diseñado por el Arq. Alfredo Dammert en 1967 y que aún se encuentra en funcionamiento en el distrito de Cercado de Lima (Ver Figura 2.54 y Figura 2.55).

La construcción del primer mercado cubierto de la ciudad no es un simple paso de lo abierto a lo cubierto, sino que significó que las actividades caóticas que estaban presentes en las plazas fueron disociadas, es decir, que la frase de "ir a la plaza" dejo de significar realizar la actividad comercial, ahora las funciones se desligaron y se significan "ir al parque" e "ir al mercado".

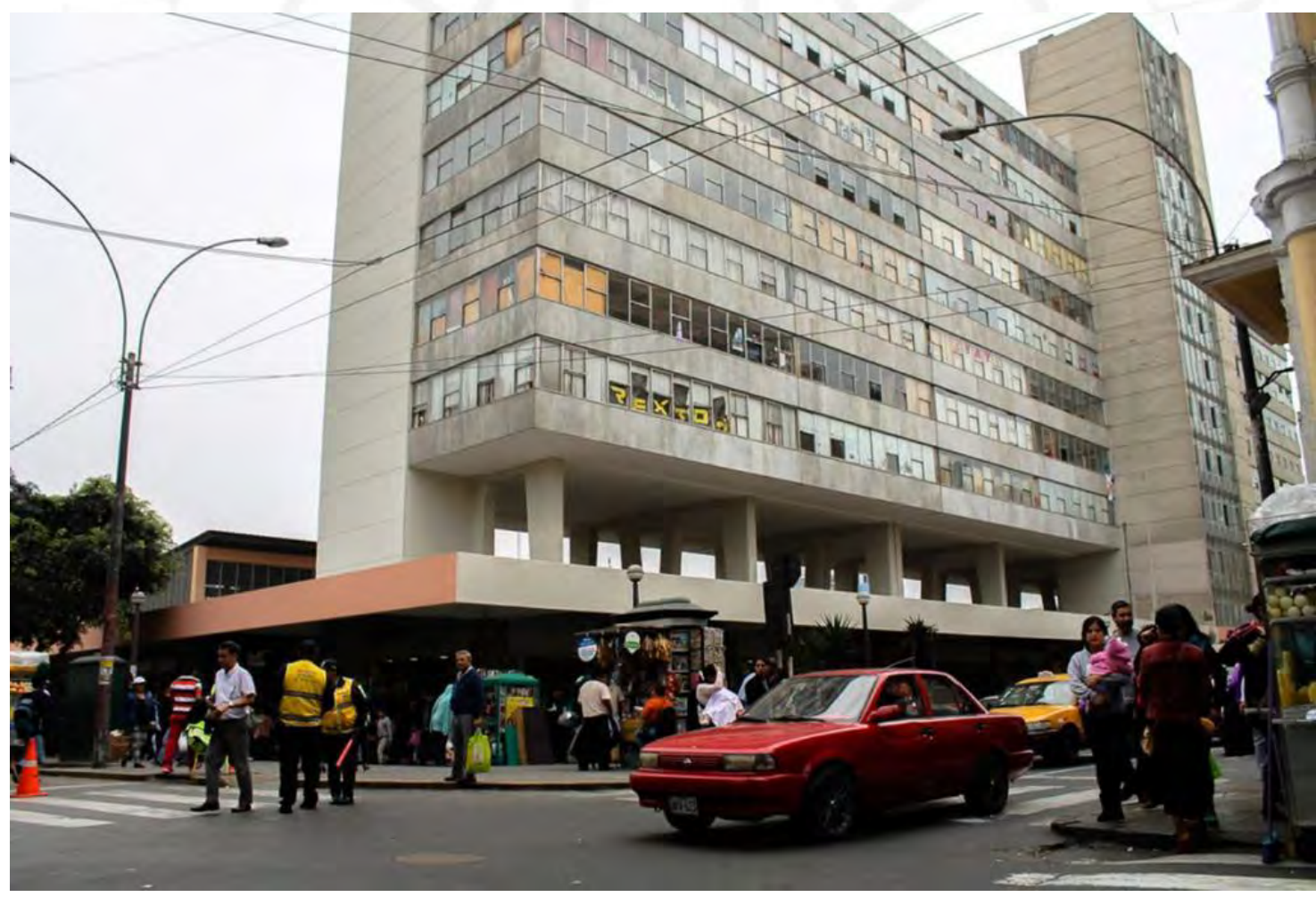

Figura 2.54 Mercado Central de Lima_Actualidad Fotografía realizada por los autores. 


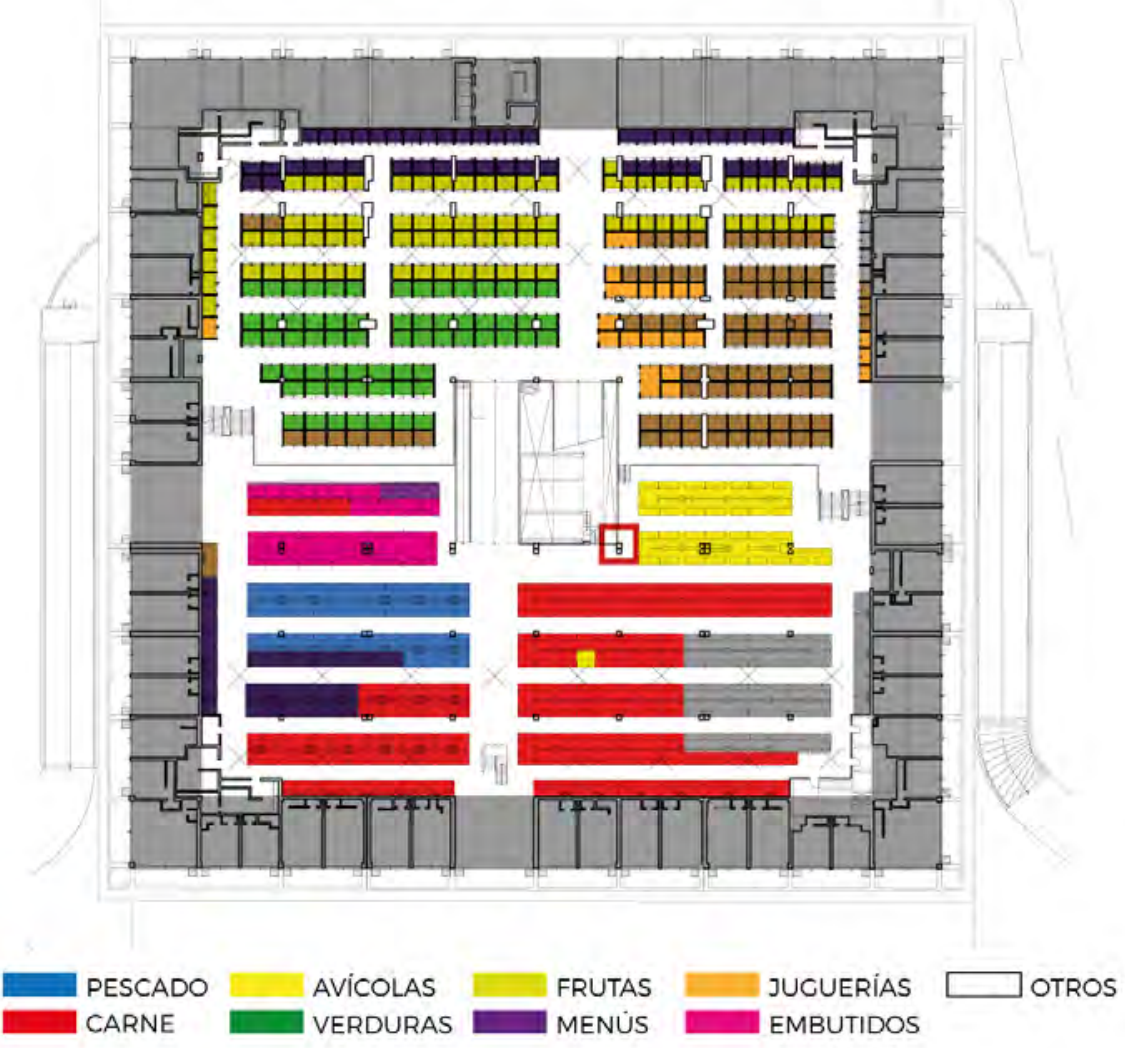

Figura 2.55 Planta del Mercado Central Gráfico elaborado por los autores.

En el siglo XX, la trama urbana de Lima no fue capaz de soportar la crisis de inmigraciones del interior del país hacia la ciudad, mientras la población aumentaba, el espacio urbano se informalizaba junto con otras actividades económicas, es así como surgió el comercio ambulante desarrollado en las calles y cercanos a los mercados que abastecían a la nueva población (De Soto, 1986, p. 63).

El proceso de expansión urbana en extramuros se aceleró en 1920 cuando se da el primer proceso de conurbación entre Lima Cercado y los pueblos satélites del sur como La Victoria, Miraflores, Barranco y Chorrillos; y del oeste de la ciudad como La Punta y Magdalena, proceso que duró hasta 1954 con un modelo de ciudad jardín de baja densidad, de manera expansiva y fragmentada, de esta forma muchas de las haciendas se urbanizaron sin un criterio urbanístico, y cada una de ellas ante la necesidad de abastecerse de alimentos crearon sus propios mercados (Ver Figura 2.56, Figura 2.57 y Figura 2.58). 


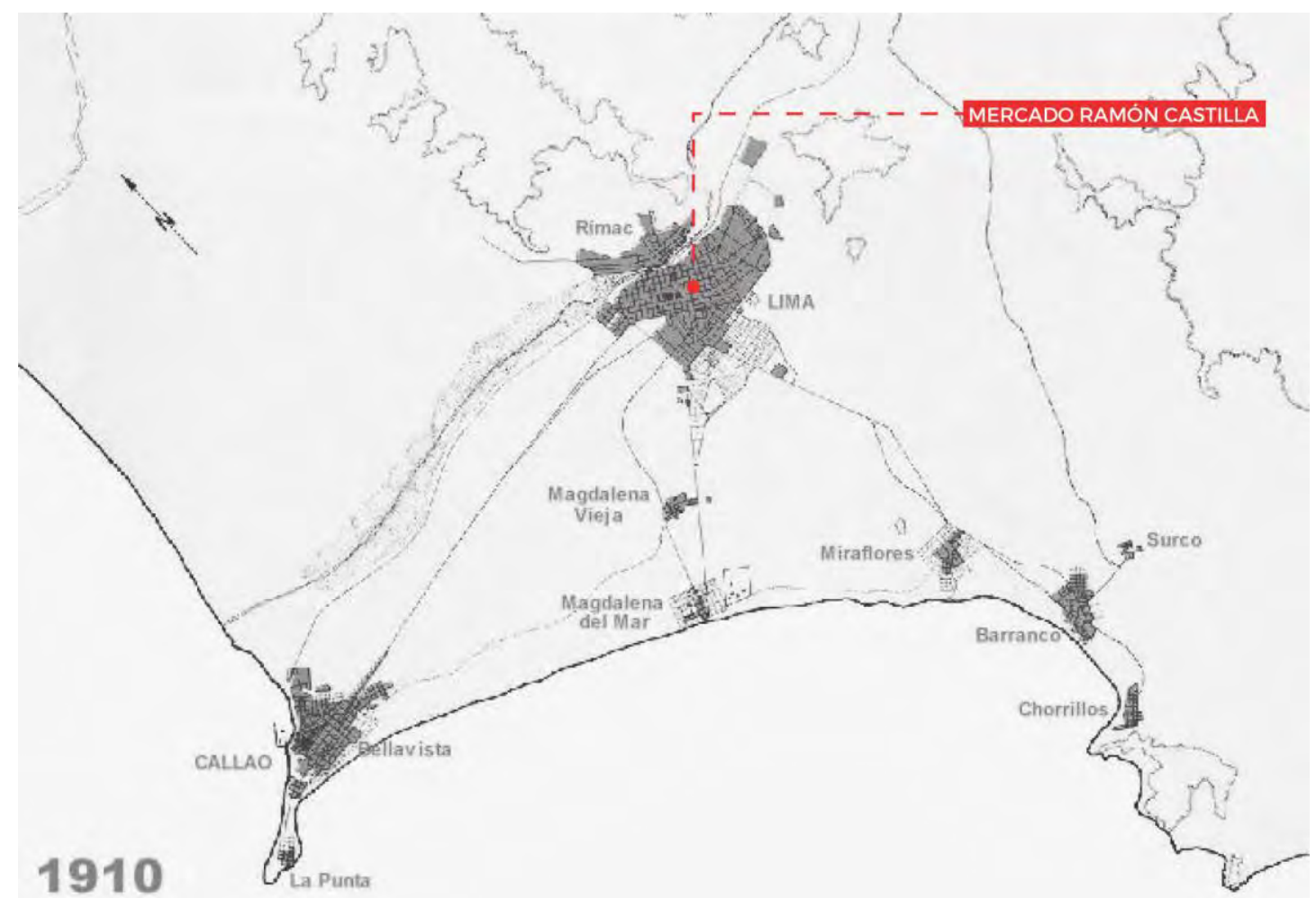

Figura 2.56 Evolución de Lima_1910

Fuente: Edgardo Reyes, 2005

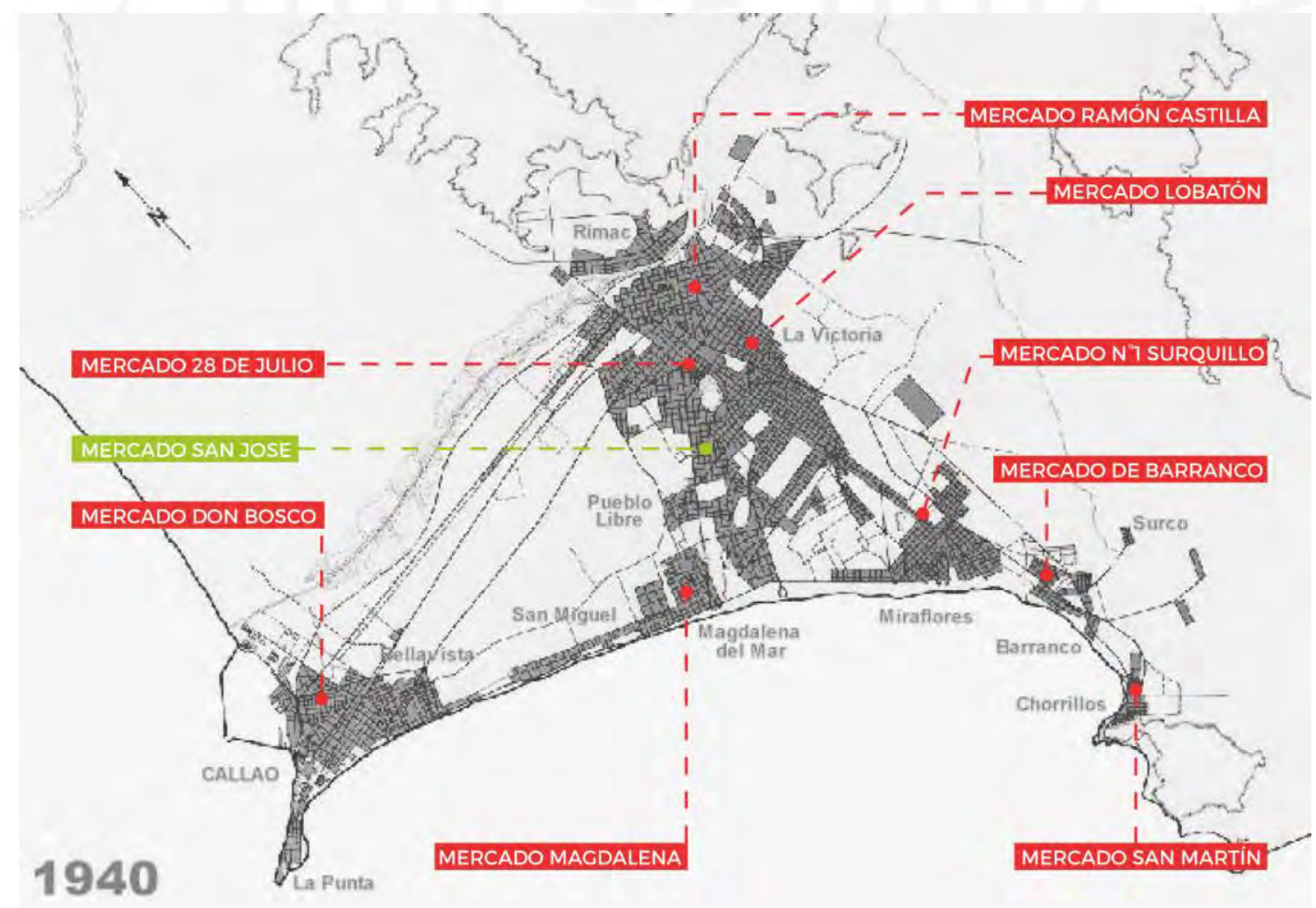

Figura 2.57 Evolución de Lima_1940

Fuente: Edgardo Reyes, 2005 


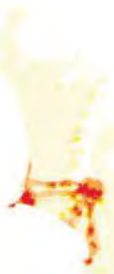

1960

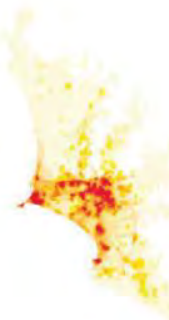

1980

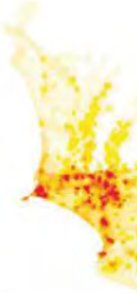

1990

Figura 2.58 Crecimiento de la ciudad + mercados

Fuente: Leung, 2016

Uno de los primeros mercados en realizarse dentro del proceso de conurbación de la ciudad fue el Mercado Modelo 28 de Julio ubicado en el distrito de Cercado de Lima al límite con los distritos de Jesús María y Breña. El mercado fue diseñado por el Arq. Ricardo De la Jaxa Malachowski en 1927, cuya edificación de estilo neoclásico tiene una composición que sigue las características de la Escuela de Beaux Arts (Ver Figura 2.59), como la simetría en el diseño de la fachada y en la configuración interna de sus puestos (Ver Figura 2.60), jerarquía de espacios con grandes entradas y escalinatas, la precisión en el diseño presentado en los detalles arquitectónicos de las balaustradas y pilastras, así también como el sutil uso de la policromía, y los acabados de mármol (Ver Figura 2.61).

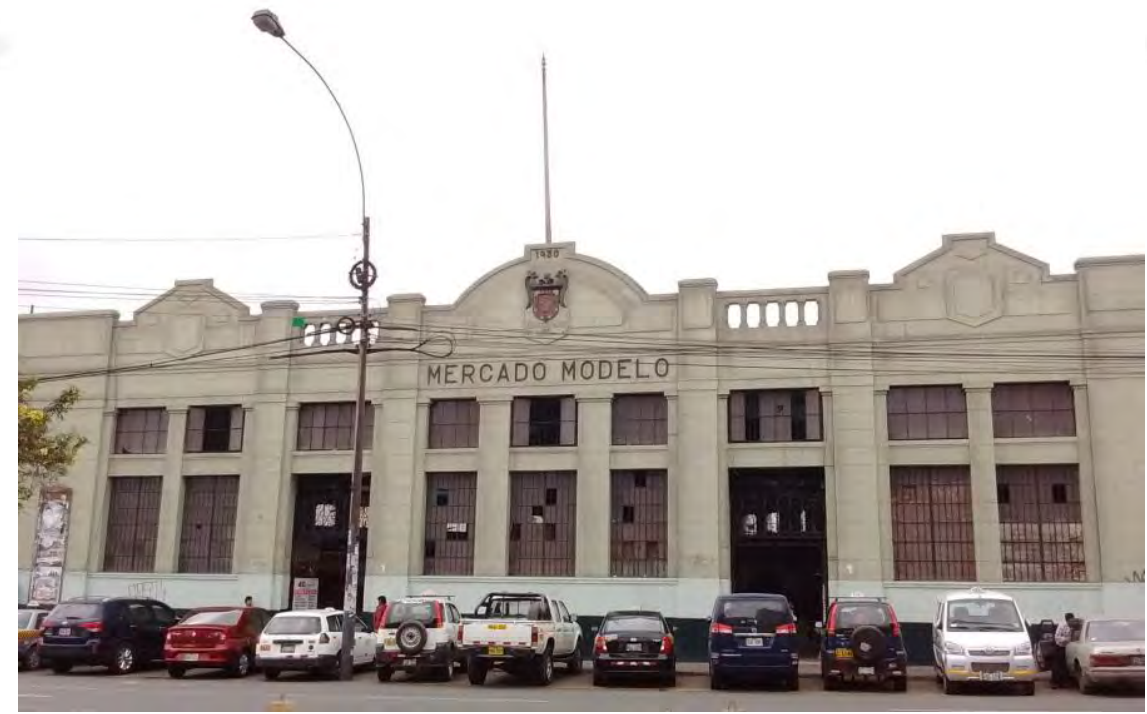

Figura 2.59 Mercado Modelo 28 de Julio

Fuente: Johnattan Rupire, 2016 


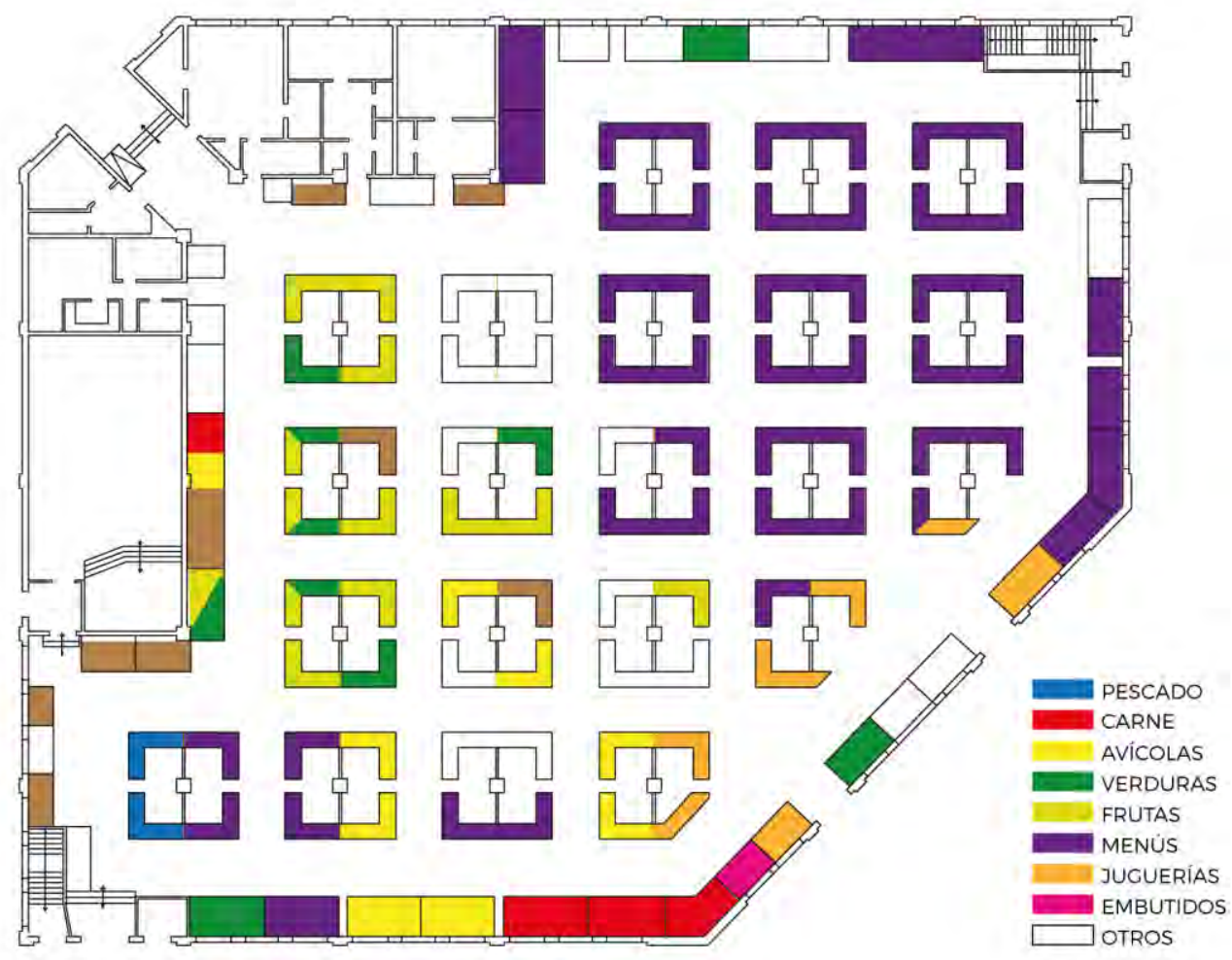

Figura 2.60 Planta del Mercado Modelo 28 de Julio Gráfico elaborado por los autores.

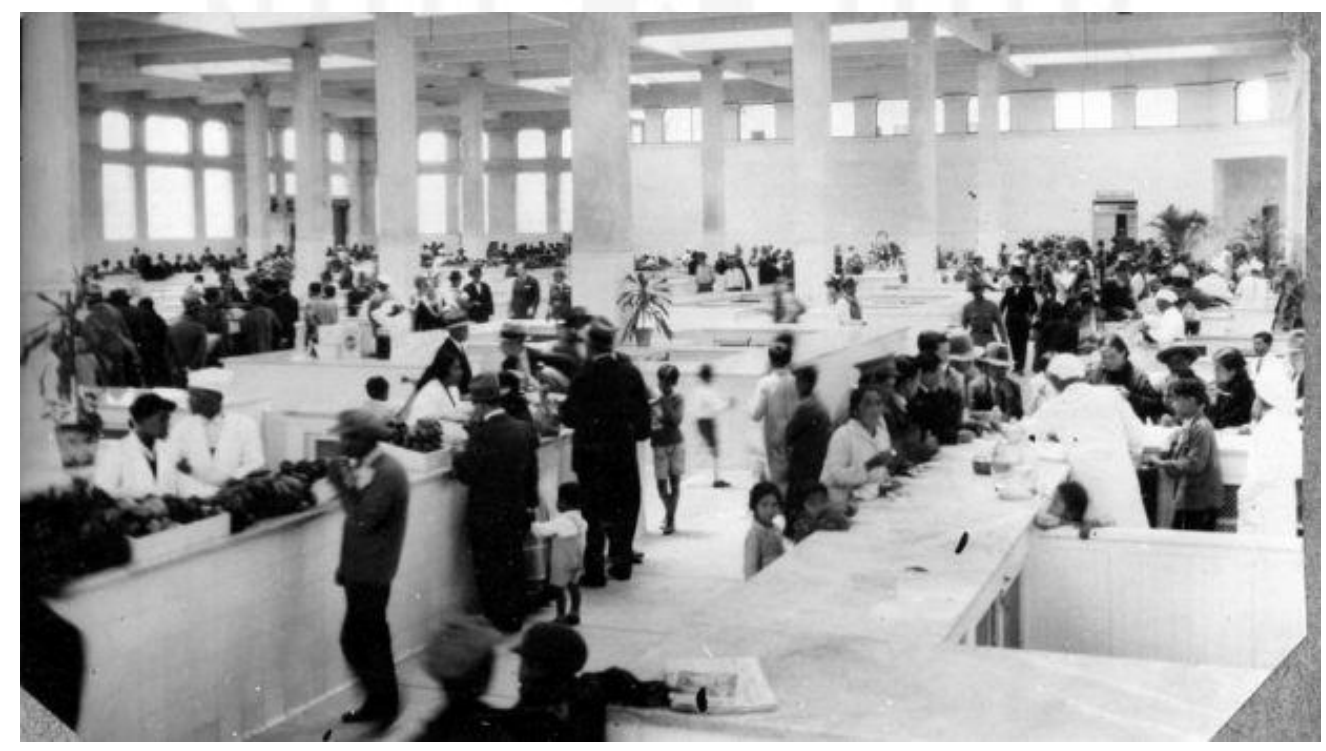

Figura 2.61 Interior del Mercado Modelo 28 de Julio

Fuente: El Comercio, 2015 /https://elcomercio.pe/gastronomia/peruana/mercados-lima-mirada-pasadopresente- 252278 
Años después, en 1936 se inaugura el Mercado Magdalena al frente de la Plaza Túpac Amaru (Ver Figura 2.62), la cual tomó un papel protagónico dentro del distrito de Magdalena del Mar convirtiéndose en un área de ocio donde se realizaban diferentes actividades a lo largo del día, y que en consecuencia atrajo a gran cantidad de personas lo que permitió activar la zona y así generar más flujo alrededor del mercado que en sus principios funcionó como plaza al aire libre (Ver Figura 2.63) donde se vendían productos en unos puestos muy precarios hechos a base de madera y esteras (Rivarola Cores, 2015, p. 68). La informalidad en el proceso de creación de este mercado se ve reflejado hasta el día de hoy en su distribución interna (Ver Figura 2.64).

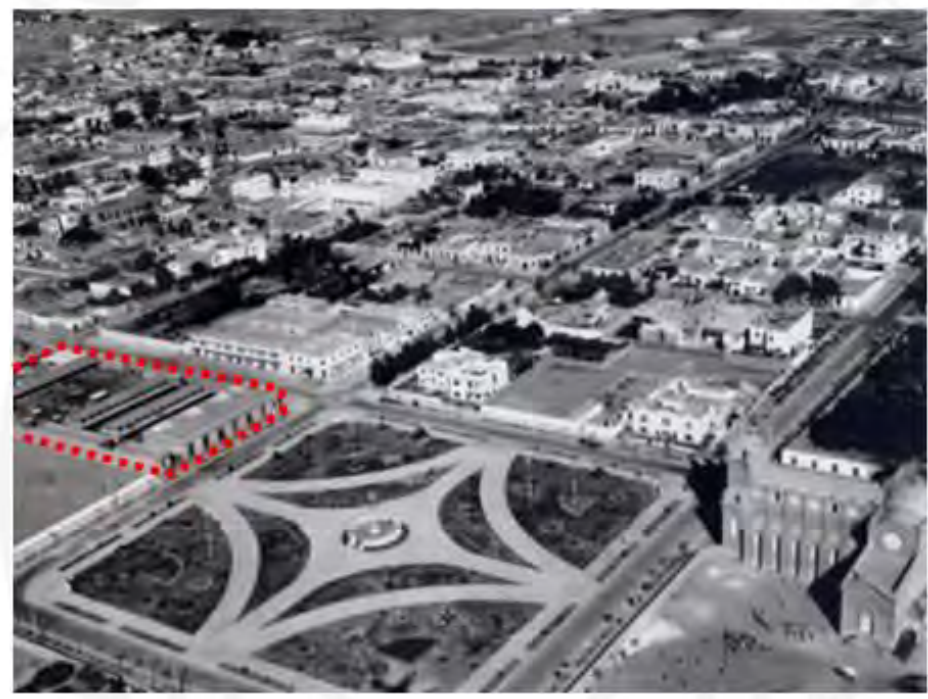

Figura 2.62 Mercado Magdalena y Plaza Túpac Amaru Fuente: Rivarola Cores, 2015

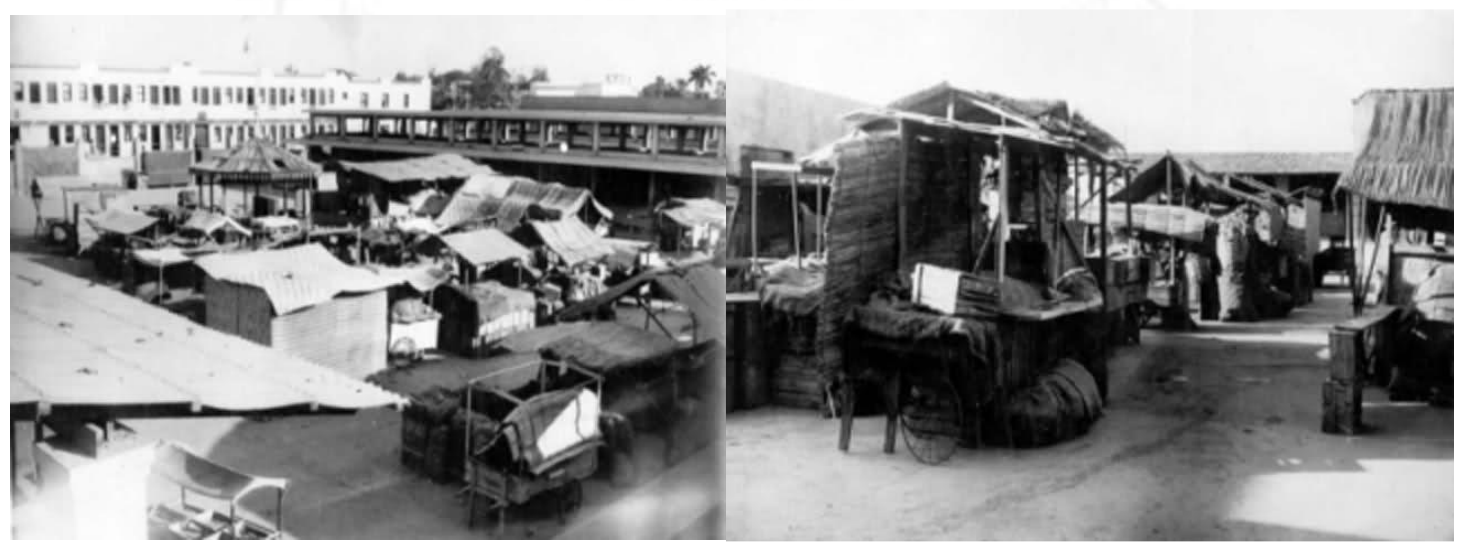

Figura 2.63 Interior del Mercado Magdalena

Fuente: Rivarola Cores, 2015 


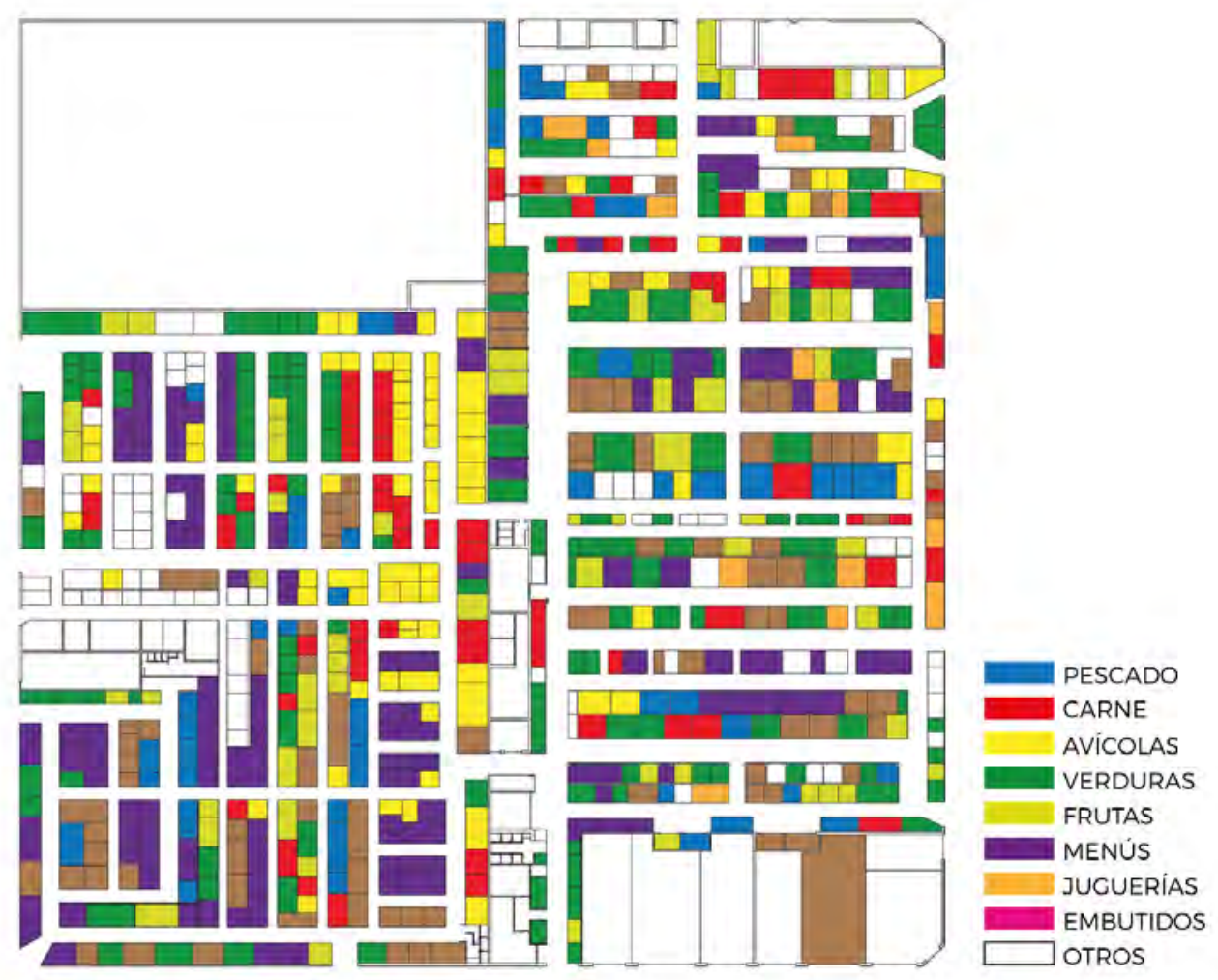

Figura 2.64 Planta del Mercado Magdalena

Gráfico elaborado por los autores.

Bajo esta etapa de crisis sobre poblacional también se crea el Mercado $\mathrm{N}^{\circ} 1$ de Surquillo diseñado en 1937 por el Arq. Alfredo Dammert, ubicado en un área de $4300 \mathrm{~m}^{2}$ estaba conformado por dos cuerpos volumétricos con diferentes criterios espaciales, constructivos y funcionales (Ver Figura 2.65 y Figura 2.66).

El sistema constructivo de la zona perimétrica es a base de muros portantes, mientras que la zona central que se encuentra destinada al comercio es de gran tamaño y de planta ovalada, desprovista de columnas intermedias, logrando la máxima flexibilidad y fluidez en las circulaciones. La sección espacial, indica la estructura asimilable a una parábola, con una cobertura curva de losa de concreto armado. La expresión arquitectónica refleja expresividad estructural, y un lenguaje racionalista estilo buque. (Universidad Nacional de Ingeniería, 1994) 


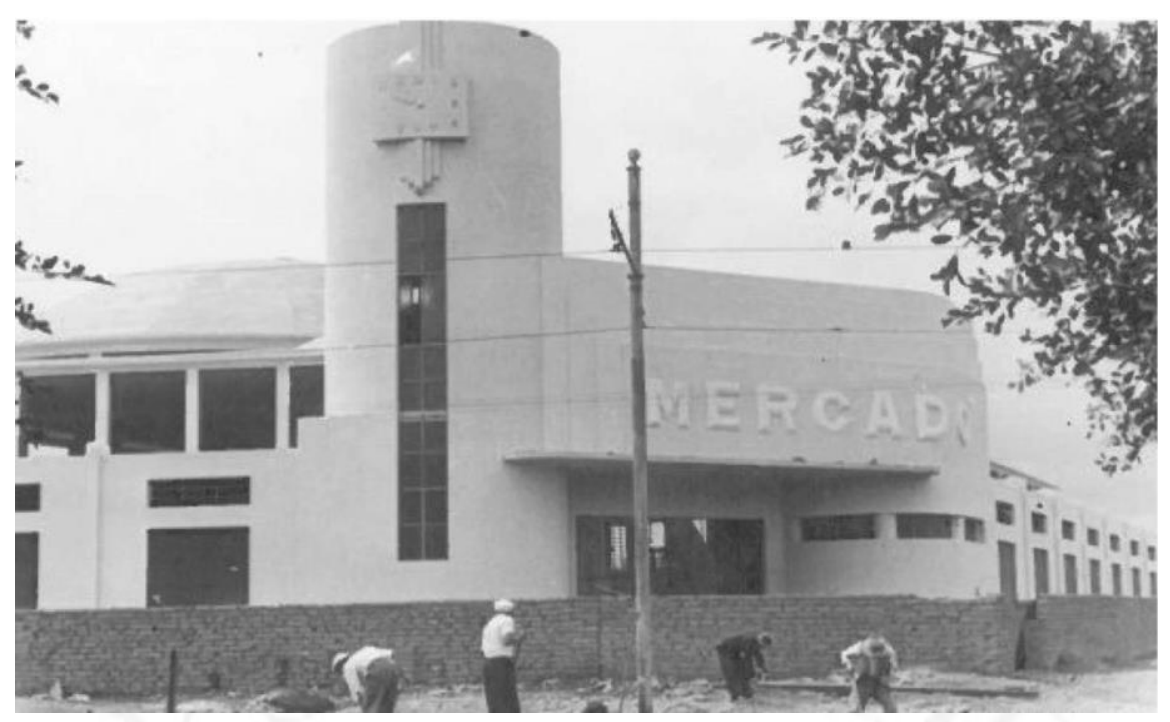

Figura 2.65 Mercado $\mathrm{N}^{\circ} 1$ de Surquillo

Fuente: Archivos del Mercado $\mathrm{N}^{\circ} 1$ de Surquillo,

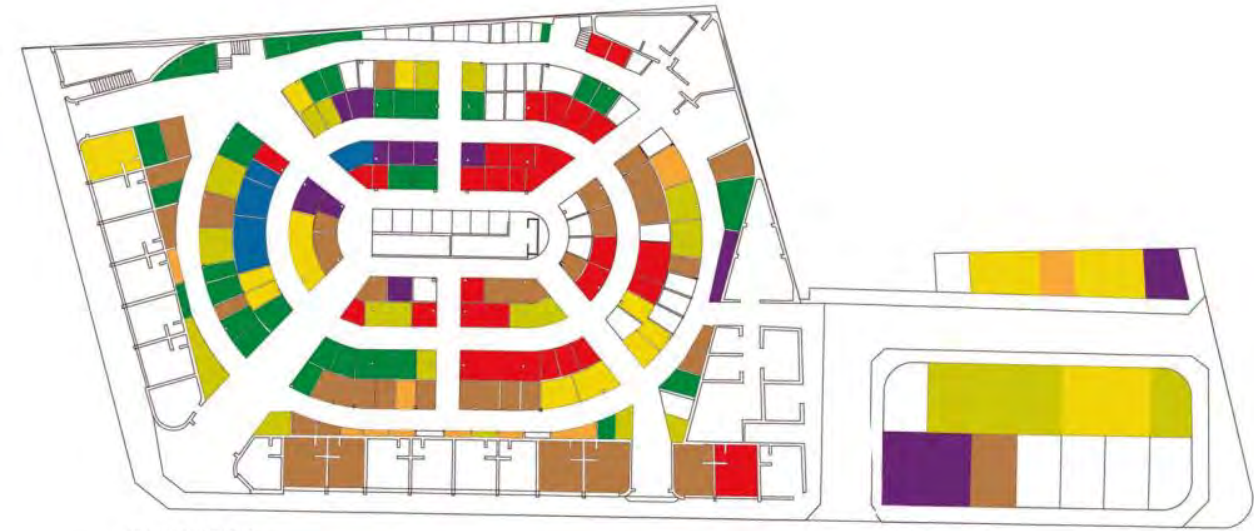

PLANTA 1
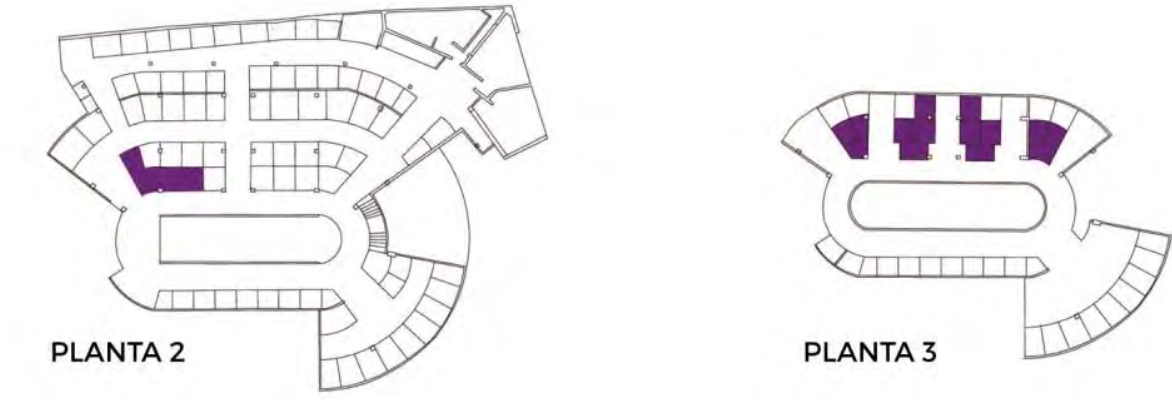

$\begin{array}{llll}\text { PESCADO } & \text { AVICOLAS } & \text { FRUTAS } & \text { JUCUERIAS } \\ \text { CARNE } & \text { MERDURAS } & \text { MENUSOS }\end{array}$

Figura 2.66 Planta del Mercado $\mathrm{N}^{\circ} 1$ de Surquillo

Gráfico elaborado por los autores. 
Entonces para facilitar la adquisición de productos y frenar con la multiplicación descontrolada de mercados de abasto, se creó el Mercado Mayorista $\mathrm{N}^{\circ} 1$ "La Parada" (Ver Figura 2.67) en 1940 que funcionó como espacio centralizador entre los comerciantes de los mercados y el producto agrícola que provenía del interior del país (Leung, 2016, p. 32).

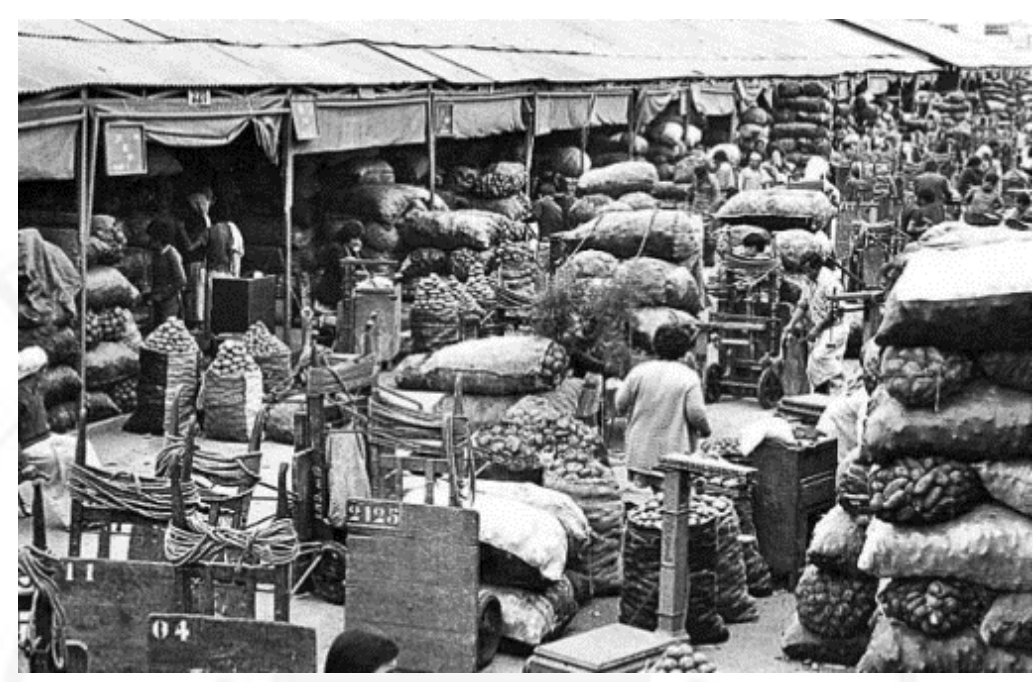

Figura 2.67 Mercado Mayorista $\mathrm{N}^{\circ} 1$ "La parada"

Fuente: Canal N / http://canaln.pe/actualidad/historia-ambulantes-lima-como-eran-principales-centrosinformales-n137544

Alrededor de 1950 se crean las "unidades vecinales" promovidas por el estado para suplir el déficit de vivienda existente, estos agrupamientos de carácter moderno además de dotar de vivienda, tenían todos los servicios urbanos y sociales necesarios, como comisarías, parroquias, colegios, parques y centros de abasto. Es así como bajo estas nuevas unidades vecinales nacen los mercados "Pool" conocidos como centros de abastos como piezas complementarias, es decir que la actividad del mercado es una de las dinámicas, pero no la única (Leung, 2016, p. 100).

Un ejemplo de este tipo es el Mercado Santa Rosa que se encuentra dentro de la Unidad Vecinal Palomino en la Av. Venezuela, construido en 1970 bajo el diseño de los arquitectos Luis Miró Quesada, Santiago Agurto, Fernando Correa y Fernando Sánchez Griñan (Ver Figura 2.68 y Figura 2.69). 
La cubierta es de hormigón armado, formado por una secuencia de bóvedas y que es apreciable desde la distancia, anunciando la actividad. Es un edificio de dos niveles, construido con material noble y cuenta con los servicios de infraestructura necesarios. (Leung, 2016, p. 103)
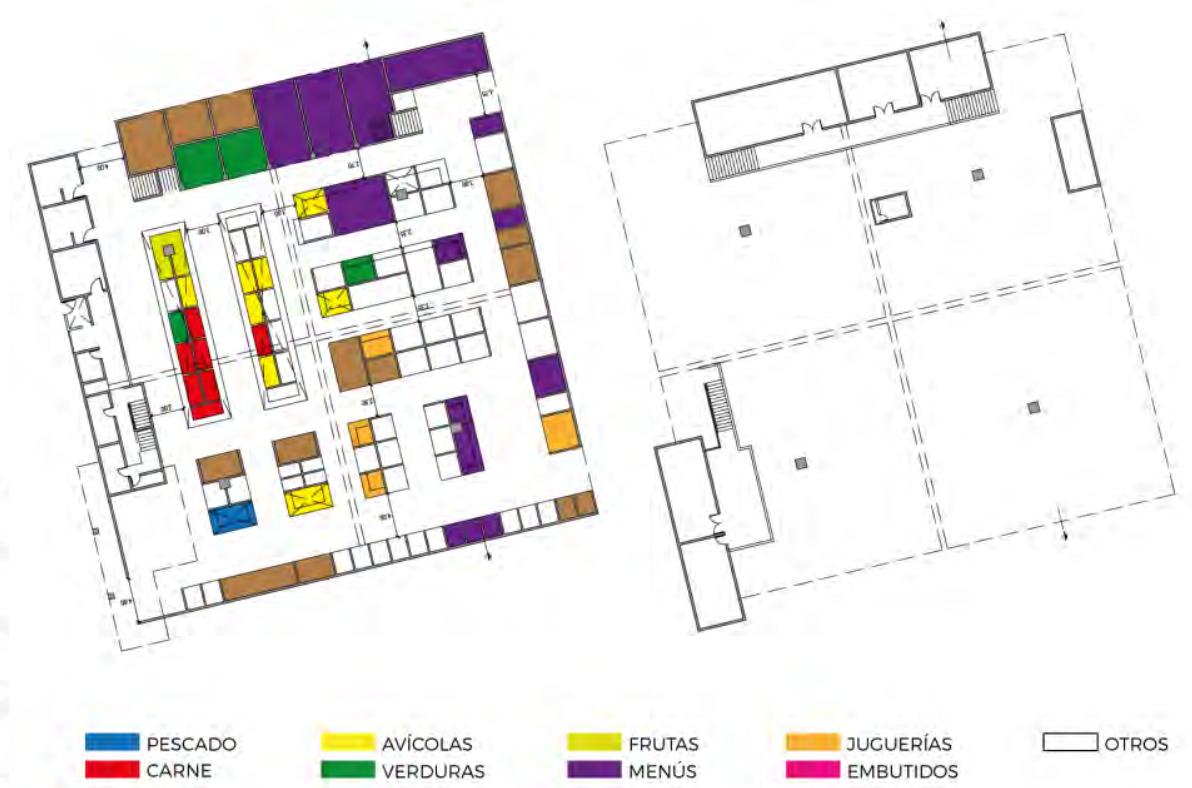

Figura 2.68 Mercado Santa Rosa Gráfico elaborado por los autores.

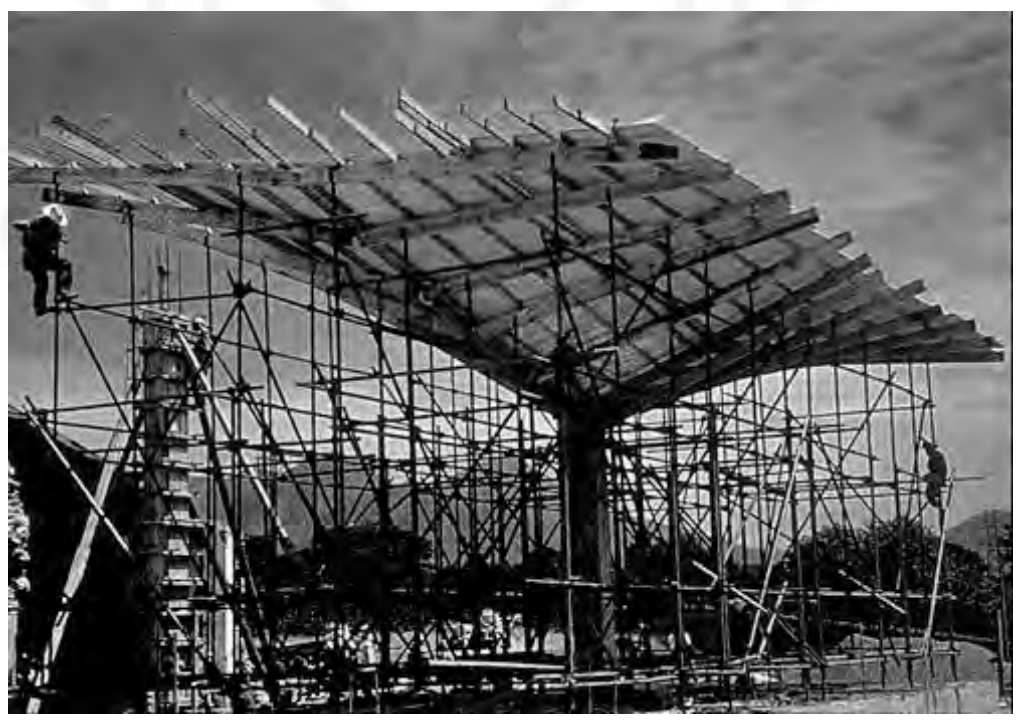

Figura 2.69 Paraboloide similar al del Mercado Santa Rosa

Fuente: Mike Murguía / http://sitioaureo.blogspot.com/2010/08/felix-candela-y-la-arquitectura.html 
Durante los siguientes años aparecen nuevos formatos comerciales en Lima, los supermercados, que en 1953 hacen su aparición con el famoso "Supermarket" de los hermanos Aldo y Orlando Olcese, el primero de este tipo estuvo ubicado en la Av. Larco y contó con una inversión de dos millones de soles (Ver Figura 2.70). Estos formatos comerciales tuvieron un rápido crecimiento económico en la ciudad; sin embargo, no es hasta los años noventa que empezaron a posicionarse con mayor fuerza.

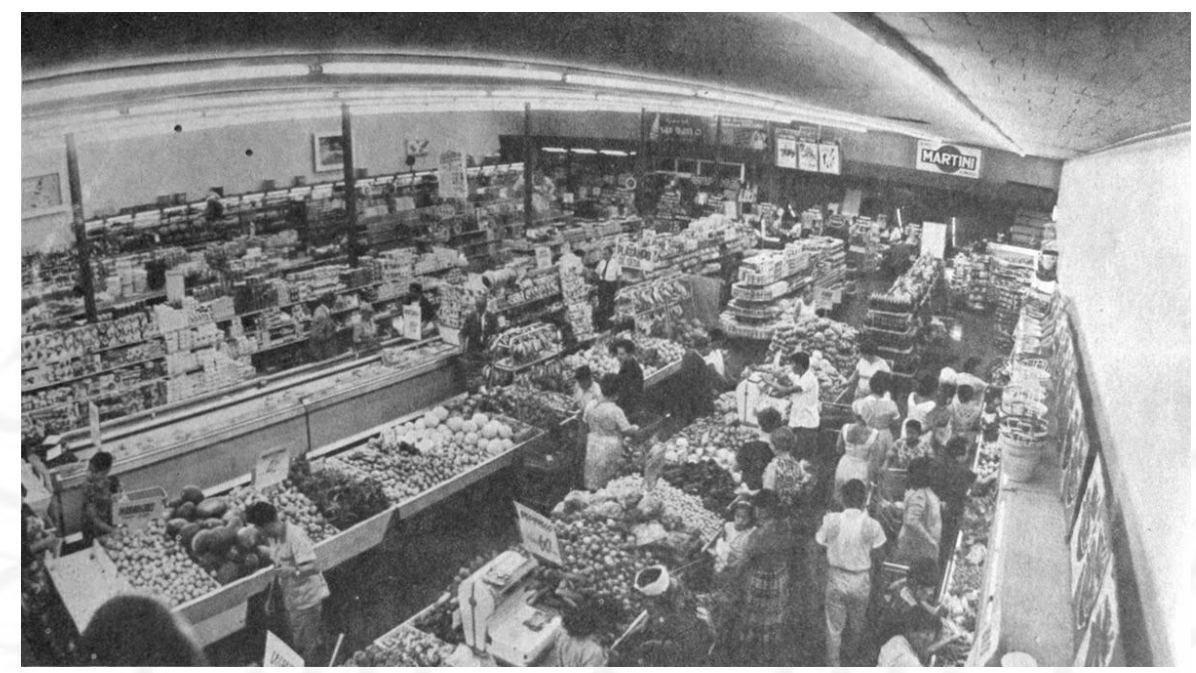

Figura 2.70 Interior Supermarket S.A.

Fuente: Lima Setentas / http://imasetentas.blogspot.com/2014/10/interior-de-otro-supermarket.html

Actualmente el Perú posee 2612 mercados de abasto que involucran a casi tres millones de micros y pequeños comerciantes, siendo uno de los grupos más grandes y potenciales en la economía del país, además continúa siendo el formato comercial de preferencia de las familias peruanas, pero su crecimiento durante los últimos años ha sido mucho menor que el de los supermercados, los cuales han aumentado en un 529,4\% del 2007 al 2016, mientras que los mercados tradicionales un 62,7\% de 1990 al 2016 (Ver Tabla 2.2 y Tabla 2.3).

Esto se debe a que en los distritos que tienen familias con mayor ingreso económico han cambiado sus hábitos de consumo que se acomoda mejor con el formato comercial de autoservicio, relegando al mercado de abastos y caracterizándolo como un lugar inseguro, desordenado y anti higiénico, por lo que la propuesta arquitectónica del Mercado San José deberá revalorizar el espacio público del mercado, perdido durante los últimos años. 
Tabla 2.2

Crecimiento de los supermercados en Perú

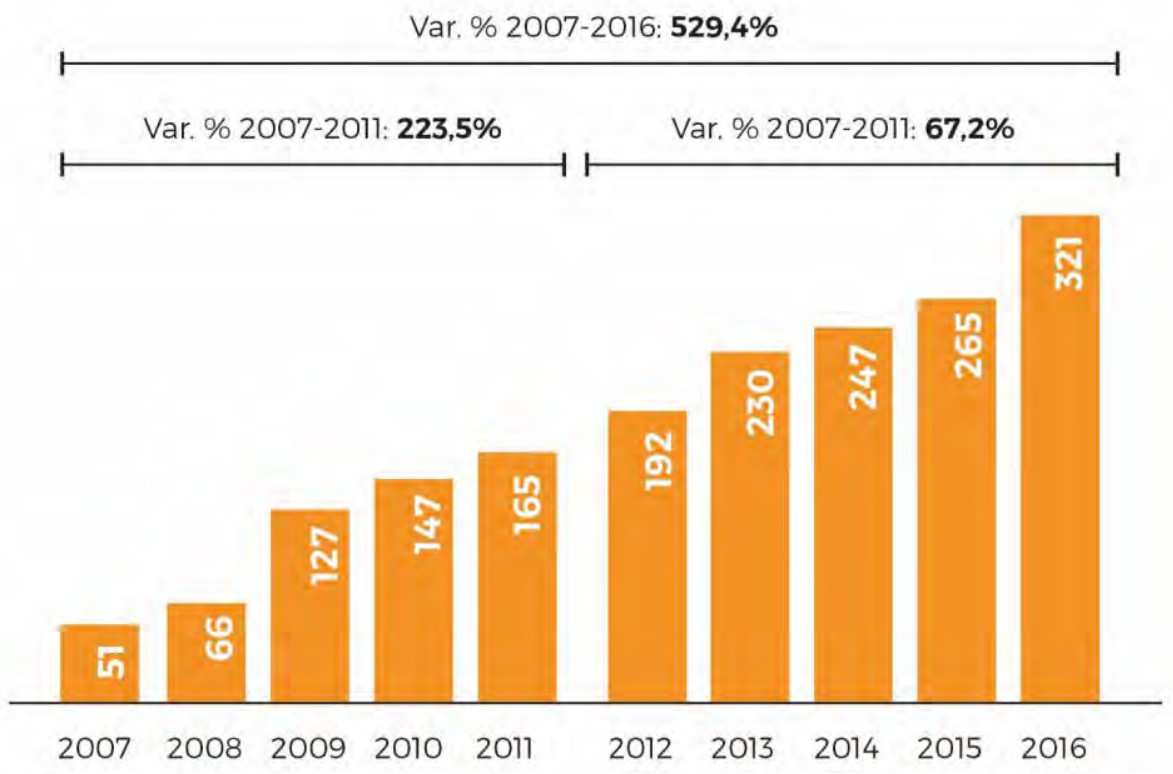

Fuente: INEI, 2016

En: Encuesta Económica Anual 2016

Tabla 2.3

Mercados por año de inicio de operaciones

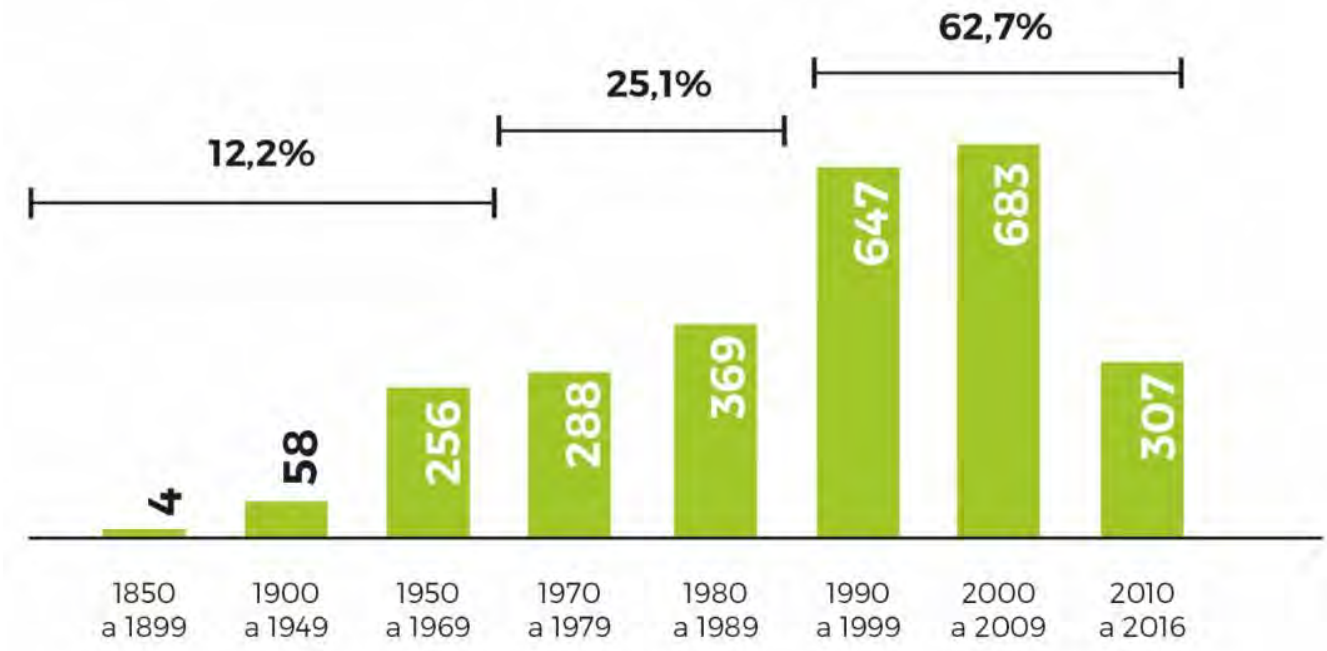

Fuente: INEI, 2017

En: Censo Nacional de Mercados de Abastos 2016 


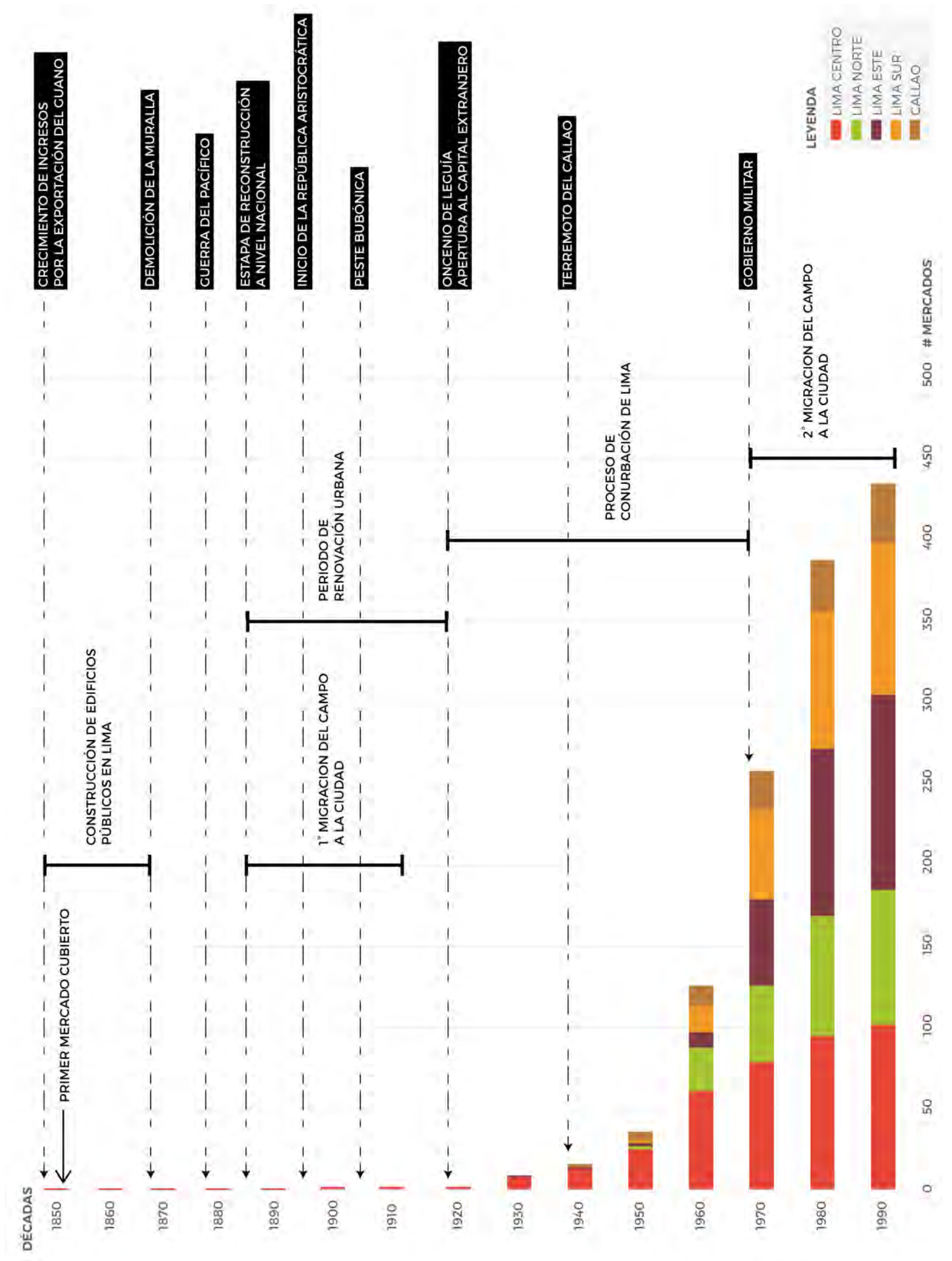

Figura 2.71 Línea de tiempo de los mercados de Lima

Gráfico elaborado por los autores. 
Tabla 2.4

Conteo de mercados por sector de Lima
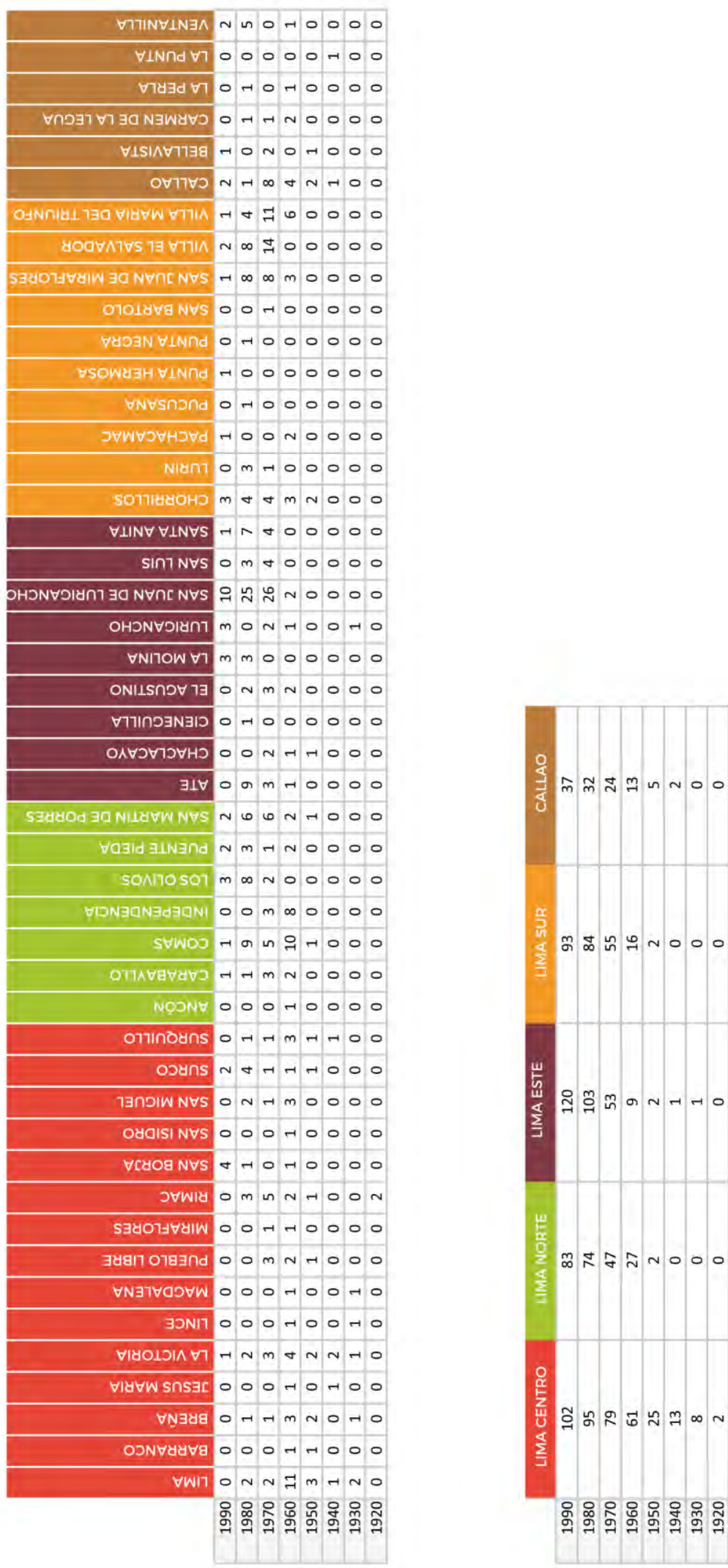

Gráfico elaborado por los autores. 


\subsection{Datos actualizados del distrito}

El distrito de Jesús María está ubicado en la zona central de la ciudad de Lima, localizado a 103 m.s.n.m. con un área de 457 ha, el cual representa al 0,18\% de la superficie de la provincia de Lima (Ver Figura 2.72). El 100\% de la superficie de este distrito es área urbana y tiene como límite al distrito de Lima Cercado por el lado norte, a los distritos de Lince y San Isidro por el lado este, al distrito de Magdalena por el lado sur, y a los distritos de Breña y Pueblo Libre por el lado oeste (Municipalidad de Jesús María, 2016, p. 18).

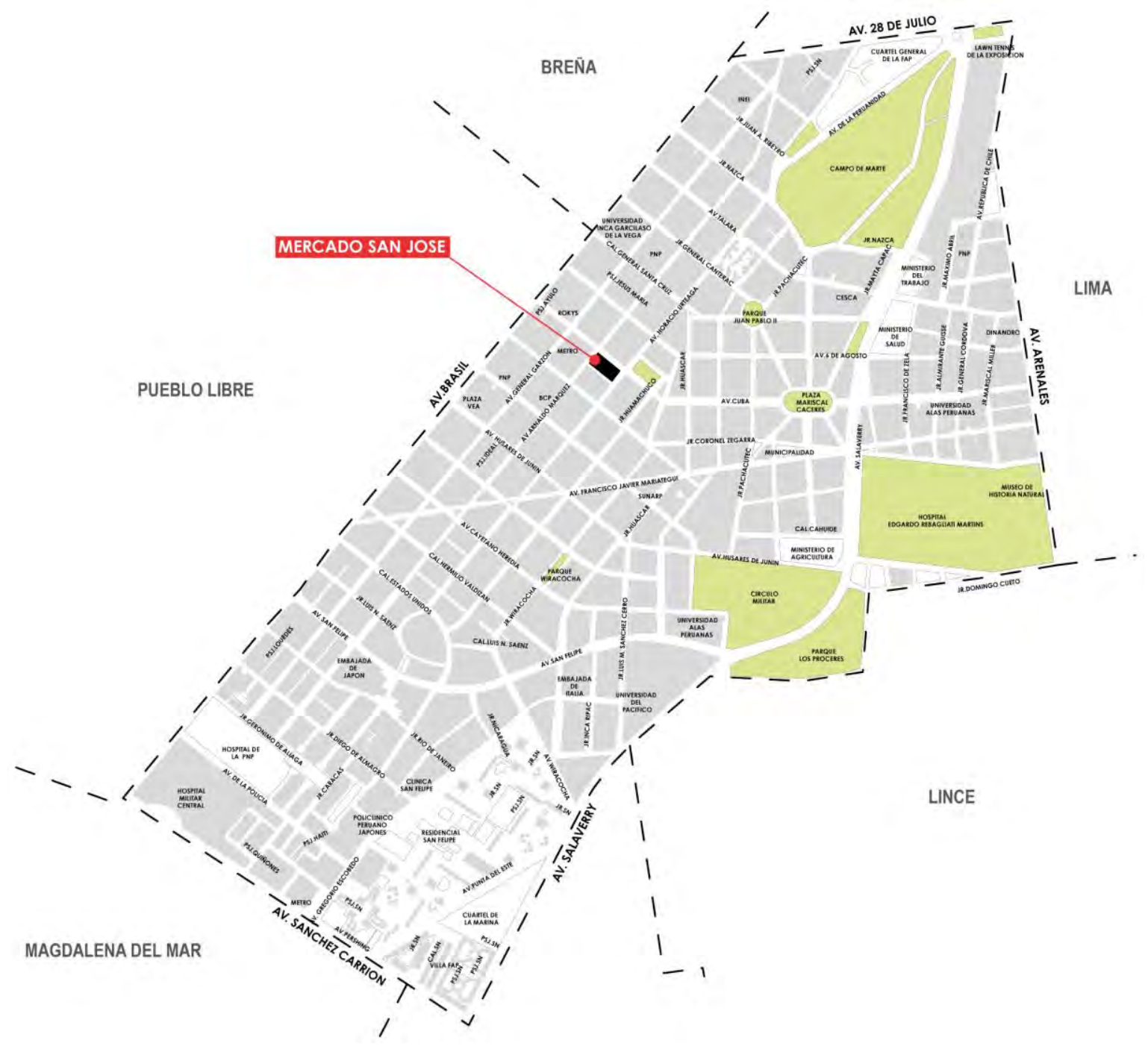

Figura 2.72 Mapa del distrito de Jesús María

Gráfico elaborado por los autores. 


\section{Población y PEA}

Jesús María tiene una población de 71589 personas al año 2015, y se estima que para el 2017 el número ascienda a 71680 habitantes y una densidad poblacional de 15685 hab/ $\mathrm{km}^{2}$ según el INEI; sin embargo, debido a un incremento en la construcción habría una variación en la estimación y este número aumentaría a 80 mil habitantes (Instituto Nacional de Estadística e Informática, 2017, p. 62).

Además, Jesús María cuenta con una población de 32245 hombres y 39344 mujeres, es decir un 45,04\% y 54,96\% respectivamente, con una composición de edades de 0 a 19 años con un porcentaje del $21,79 \%$, de 20 a 39 años representando al 30,53\% de la población total del distrito, de 40 a 59 años un $26,51 \%$, y un $21,17 \%$ de personas con 60 años a más (INEI, 2017, p. 66). Por otro lado, la población económicamente activa (PEA) dentro del distrito es de $96.5 \%$ lo que indica que hay un bajo nivel de personas desempleadas en Jesús María, y en cuanto a la actividad económica a la que se dedican mayormente los vecinos son las actividades empresariales y al comercio (Municipalidad de Jesús María, 2013, p. 22).

\section{Tabla 2.5}

PEA ocupada según actividad económica

\begin{tabular}{|l|r|r|}
\hline \multicolumn{1}{|c|}{ PEA ocupada según actividad económica } & $\mathbf{N}^{\circ}$ de casos & \multicolumn{1}{c|}{$\%$} \\
\hline 1) Actividades Empresariales, inmobiliarias y alquileres & 5,680 & 18.80 \\
\hline 2) Comercio & 4,582 & 15.20 \\
\hline 3) Servicios sociales y de salud & 2,902 & 9.60 \\
\hline 4) Enseñanza & 2,606 & 8.60 \\
\hline 5) Admin.púb. y defensa; p. segur.soc.afil & 2,109 & 7.00 \\
\hline 6) Trans., almac. y comunicaciones & 1,919 & 6.40 \\
\hline 7) Industrias manufactureras & 1,820 & 6.00 \\
\hline 8) Otras activ. serv.comun.soc y personales & 1,720 & 5.70 \\
\hline 9) Actividad económica no especificada & 1,523 & 5.00 \\
\hline 10)Hoteles y restaurantes & 1,393 & 4.60 \\
\hline 11)Hogares privados con servicio doméstico & 1,391 & 4.60 \\
\hline 12)Intermediación financiera & 997 & 3.30 \\
\hline 13)Construcción & 710 & 2.40 \\
\hline 14)Venta, mant.y rep. veh.autom.y motoc & 369 & 1.20 \\
\hline 15)Explotación de minas y canteras & 179 & 0.60 \\
\hline 16)Agric., ganadería, caza y silvicultura & 148 & 0.50 \\
\hline 17)Suministro de electricidad, gas y agua & 59 & 0.20 \\
\hline 18)Pesca & 48 & 0.20 \\
\hline 19)Organiz. y órganos extraterritoriales & 4 & 0.00 \\
\hline TOTAL & $\mathbf{3 0 , 1 5 9}$ & $\mathbf{1 0 0 . 0 0}$ \\
\hline
\end{tabular}

Fuente: INEI, 2007

En: Plan de Desarrollo Económico Local de Jesús María 2013-2025 
En cuanto a la situación socio-económica de los habitantes del distrito de Jesús María, esta puede ser definida por su posicionamiento como distrito a nivel nacional. Entonces comparando el distrito nacionalmente en cuanto a población este ocupa el lugar $79^{\circ}$, y a nivel educativo se posiciona en el puesto $14^{\circ}$; asimismo, se encuentra en el puesto $19^{\circ}$ en esperanza de vida con un promedio de 76 años, y en cuanto a alfabetismo este ocupa el $6^{\circ}$ puesto a nivel nacional (Municipalidad de Jesús María, 2013, p. 23).

Además, casi la totalidad de la población del distrito posee un ingreso per cápita por hogar mayor a 1330 soles, lo que se considera como estrato medio alto (Ver Figura 2.73). Es mediante estos factores que podemos concluir que el distrito ocupa el 5to puesto a nivel nacional en cuanto al índice de desarrollo humano con 0.7359 y también se puede considerar que el nivel de pobreza es inexistente (Municipalidad de Jesús María, 2013, p. 24).

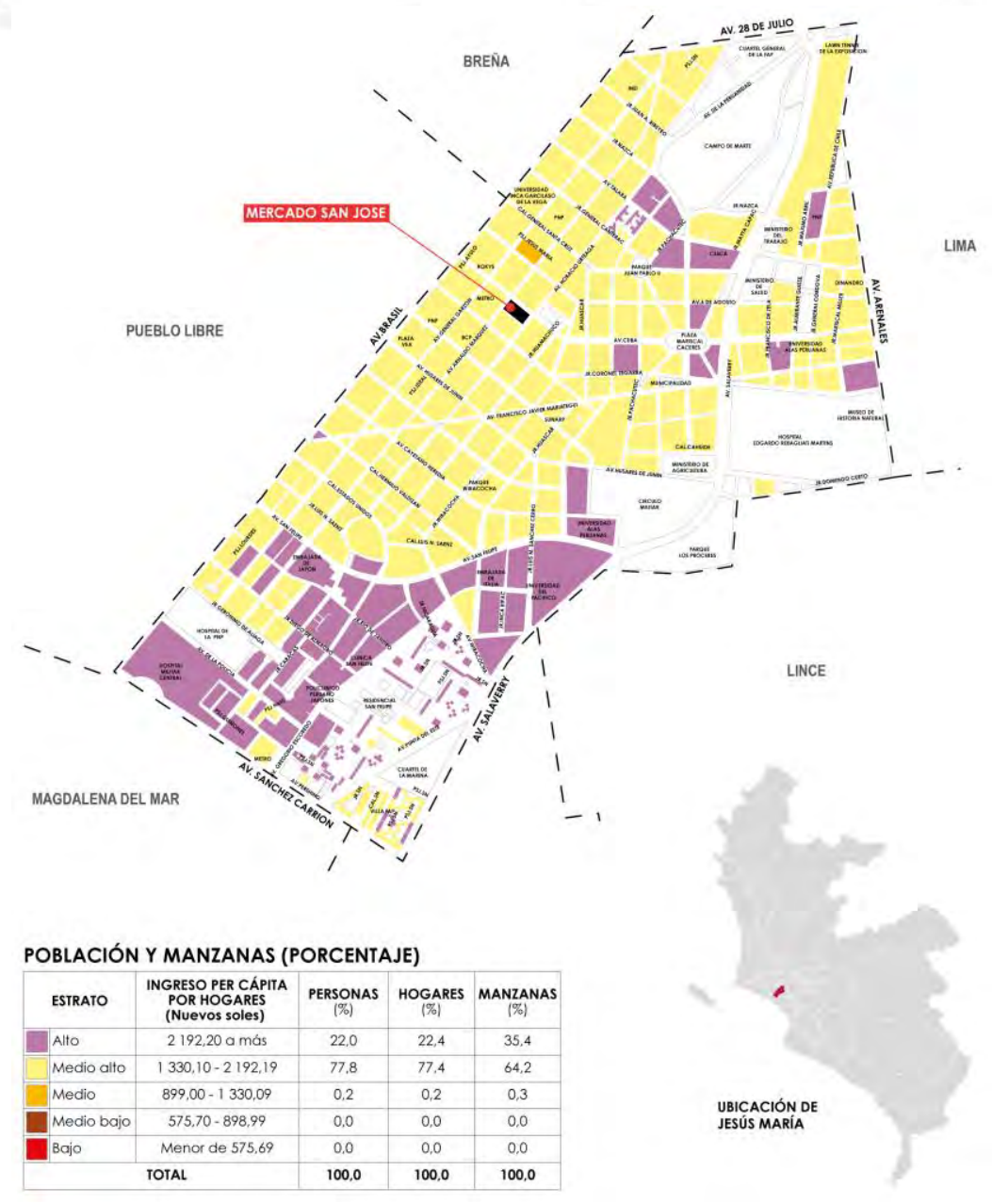

Figura 2.73 Ingreso per cápita de Jesús María por manzana

Fuente: INEI, 2016 / Planos Estratificados de Lima Metropolitana a Nivel de Manzana 2016. 
Por otro lado, las actividades económicas que predominan en el distrito son el comercio y los servicios, ya que se identificaron a 4739 empresas de las cuales el 51\% pertenece al comercio al por mayor y al por menor, seguido de un $25 \%$ por los servicios de comida, alojamiento, servicios sociales relacionados con la salud humana y otras actividades de servicio. Además, estas actividades comerciales se aglomeran en 4 áreas (Ver Figura 2.74), el primero y más importante es la del "Damero Comercial" cuyo centro es el Mercado San José, lugar donde se originó el posicionamiento del distrito como centro comercial interdistrital con ventas en productos de primera necesidad; considerado el más antiguo de todos los sectores y en donde se concentra la mayor cantidad de ventas (Municipalidad de Jesús María, 2013, p. 27).

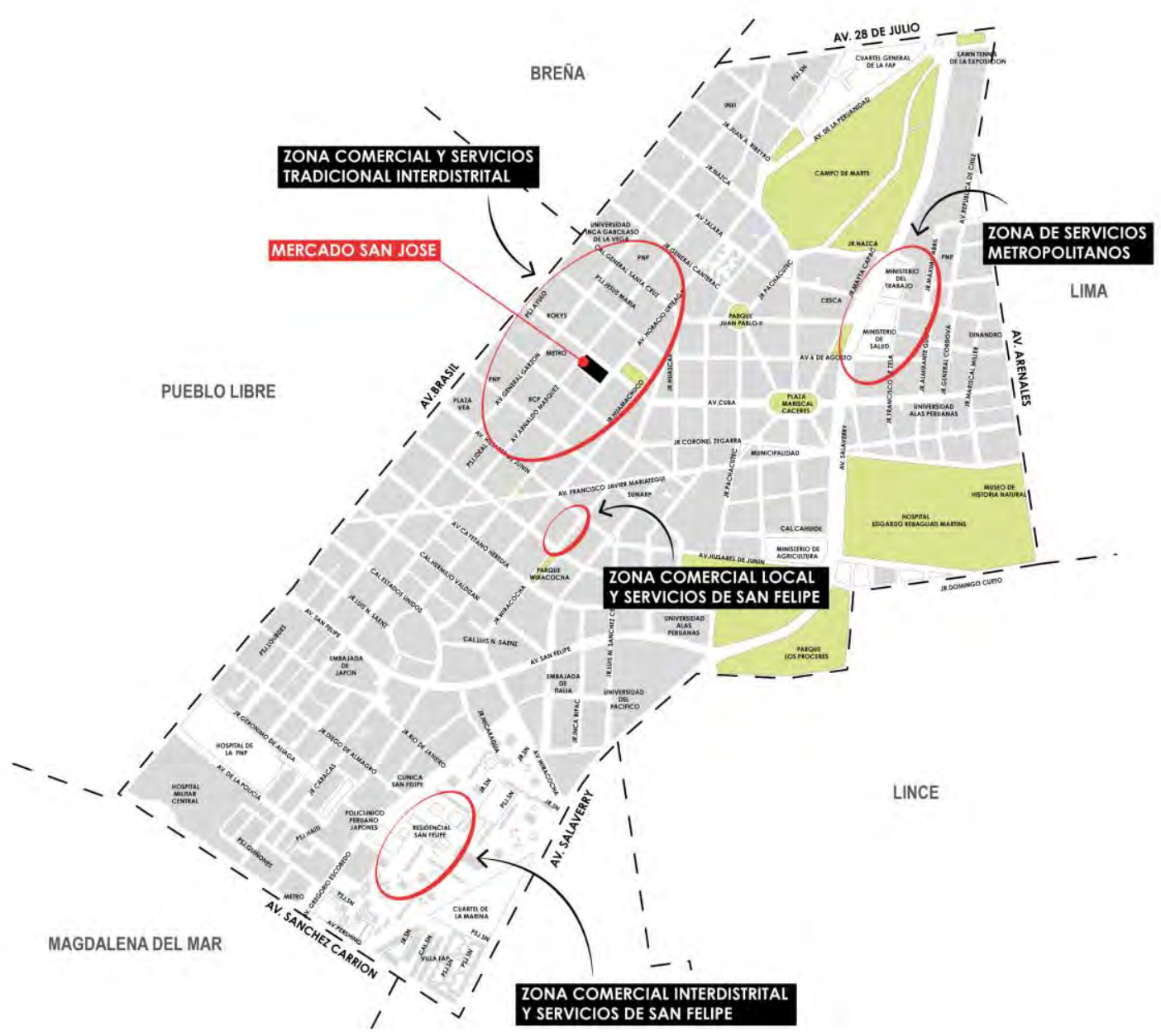

Figura 2.74 Ubicación de las centralidades económicas de Jesús María

Fuente: Municipalidad de Jesús María, 2013. Gráfico elaborado por los autores.

En: Plan de Desarrollo Económico Local de Jesús María 2013-2025 
La segunda zona de las actividades comerciales es en el centro comercial del conjunto residencial San Felipe de carácter vecinal que incluye mercados de autoservicio alrededor como el supermercado "Metro" que tiene un alcance local e interdistrital, pero en menor volumen que el Damero Comercial. La tercera zona es el centro comercial del Shopping mall Huiracocha de alcance local y conformado por negocios de restaurantes, bazares, venta de ropa, entre otros que se expanden por la Av. Mariátegui, y calles Huamachuco y Húsares de Junín. La última zona está conformada por servicios institucionales y empresariales que se encuentran entre la Av. Cuba, Av. Arenales y la Av. Salaverry en donde los ministerios han generado cierto comercio y servicios por gastronomía (Municipalidad de Jesús María, 2013, p. 28).

De acuerdo a los datos actualizados del distrito podemos concluir que hay una gran cantidad de jóvenes adultos que viven en Jesús María y que poseen un mayor nivel de instrucción. Además, cuentan con un ingreso per cápita mayor a 1330 soles y un 22\% de la población supera los 2192 soles, por lo que el nivel socioeconómico que predomina es el $\mathrm{B}$ y el $\mathrm{C}$ con un $48,8 \%$ y $22,7 \%$ respectivamente, y el NSE A es casi un $20 \%$. Entonces, según el perfil del consumidor actual realizado por Arellano (2017) los habitantes del distrito cumplen las características de ser Sofisticados y Progresistas, es por ello que los vecinos de Jesús María prefieren realizar sus compras en los formatos de autoservicio que se adaptan mejor a sus estilos de vida y exigencias, por tal motivo el proyecto del Mercado San José deberá responder a estas exigencias del perfil del consumidor a través del programa arquitectónico, infraestructura y la adecuación física. 


\subsection{Conclusiones parciales}

La relación del intercambio comercial y el espacio público se puede encontrar desde el origen de las ciudades, las cuales se mantuvieron a pesar de los cambios tipológicos a consecuencia de conquistas, cambios sociales, cambios políticos, y avances tecnológicos, los cuales afectaron la locación de los mercados y su grado de accesibilidad con su entorno. Al estudiar y analizar la evolución de los mercados tanto en el mundo como en la realidad local, podemos concluir el mercado surge como consecuencia de la necesidad del ser humano en satisfacer ciertas carencias a cambio de un excedente, este acto está inscrito en un espacio que difiere de características tanto morfológicas, sociales, religiosas y culturales propias del lugar.

La ubicación de los mercados dentro de la trama urbana de la ciudad ha sido clave para su desarrollo, debido al impacto económico que generan, pero muchos de ellos se han visto opacados por el proceso evolutivo de las ciudades y al crecimiento demográfico, es por tales motivos que los mercados que presentan mayor afluencia de personas son los que se encuentran mejor ubicados. Este es el caso del Mercado San José que posee una localización privilegiada gracias a su cercanía con atractivos culturales como la Iglesia San José, la Plaza San José, las numerosas viviendas estilo chalet, entre otros. Además, el distrito de Jesús María está ubicado cerca al Centro Histórico de Lima y camino hacia los Balnearios (Ver Figura 2.75), presentando la oportunidad de que el mercado sea considerado como un producto turístico, similar al Mercado Santa Caterina o el Mercado de Rotterdam. Por tal motivo la propuesta del mercado tendrá que tener un programa con usos mixtos pensado para el visitante local y extranjero, haciendo que la actividad del mercado involucre a diferentes actores y funcione la mayor cantidad de horas al día.

Además, al analizar la evolución de la trama urbana de la zona en el que se ubica el Mercado San José, se puede notar la importancia del Pasaje Punta Pacochas, la linealidad de la configuración interna de los puestos de venta, y la disminución del ancho de los pasillos internos. Por lo que se respetará la memoria generada en los habitantes del distrito y no se modificarán sus dimensiones, pero sí se devolverá la anchura de los pasillos internos respetando su configuración lineal. 


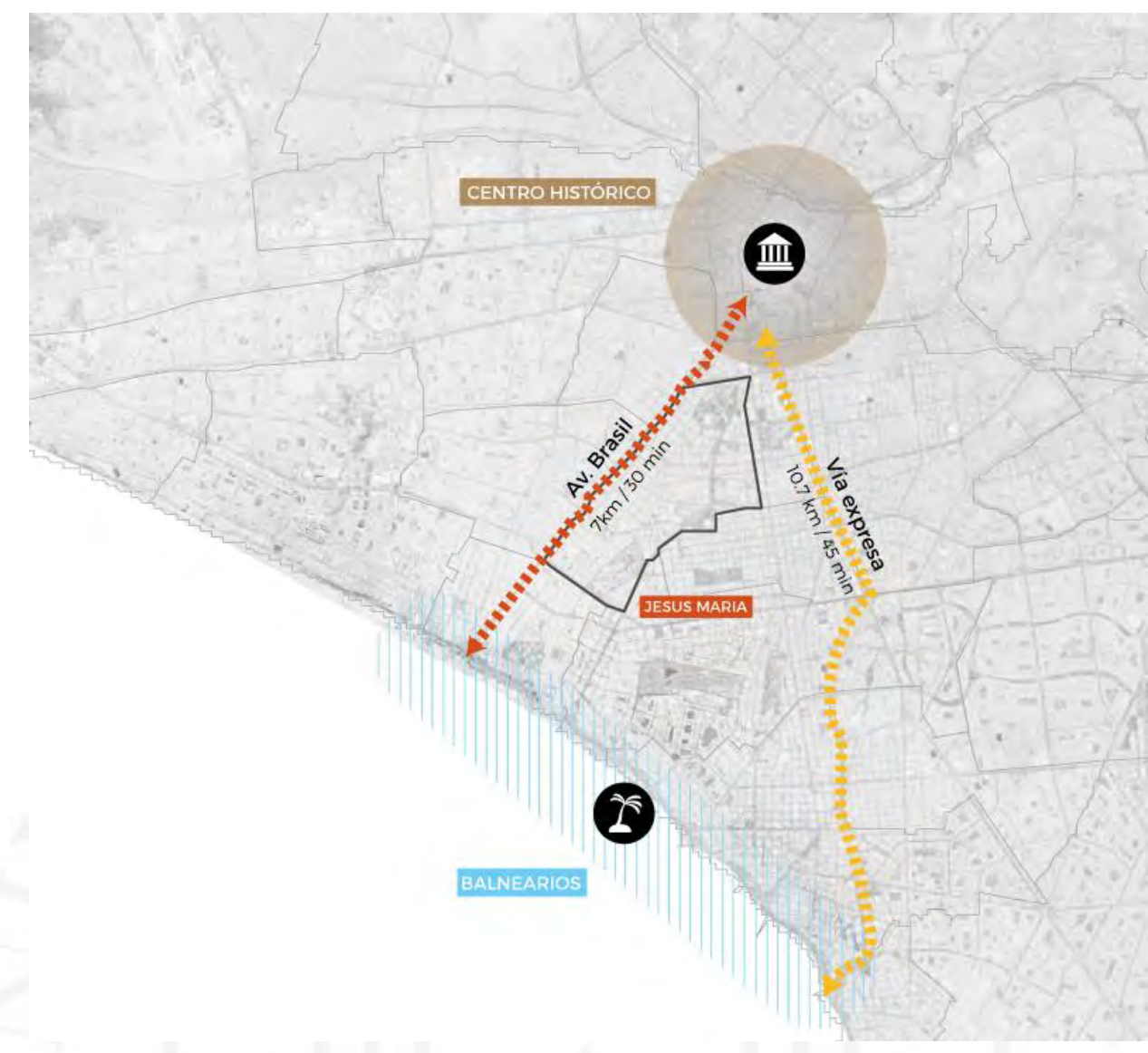

Figura 2.75 Localización de Jesús María Gráfico elaborado por los autores.

El grado de accesibilidad también es una característica principal de los mercados como en la Estoa y en el Mercado de Trajano que se ubicaban en las vías más importantes de la ciudad, sin barreras arquitectónicas que impedían su relación con la calle y su contexto urbano, intercambiando así flujos de manera constante, y sin ninguna restricción horaria. En el caso del Mercado San José si bien a escala urbana se encuentra en el centro del distrito y en las vías más importantes, a escala peatonal este no posee un buen grado de accesibilidad, debido a que la actividad del mercado está contenida y no se relaciona con su entorno, por lo que se evitará generar muros perimetrales para que el mercado funcione como la plaza del mercado medieval en la que se podía entrar y salir del mercado de manera fluida, pero a su vez evitando que el mercado sea totalmente libre, debido a que la actividad comercial se puede volver caótica y traer problemas de higiene y salubridad. 
Los avances tecnológicos influyeron en los mercados de abasto a lo largo de la historia ya sea a través de su arquitectura o en su funcionamiento interno, como en los mercados realizados en hierro. Actualmente la tecnología ha generado nuevas formas de pago y nuevas formas de adquirir los productos, cambiando el perfil del consumidor, por lo que el mercado de abasto debería haberse adaptado a sus nuevas exigencias, pero no ha sido así, generando que aparezcan nuevos formatos comerciales que sí lo hagan, relegando al mercado y afectando en sus ingresos por ventas. Por tal motivo el Mercado San José debe ofrecer una experiencia más que solo una visita para realizar las compras, modernizarse en su infraestructura, espacialidad y relación con el entorno para poder subsistir.

En el Perú también estuvo presente todo este proceso tipológico de los mercados de abasto, debido a la influencia de los españoles impuesta en la época colonial, pero ellos vieron al mercado pre-colombino de acuerdo a su experiencia en Europa, interpretando erróneamente la interacción social que observaban. En las comunidades andinas el Catu era lugar de treque en el que no existía un ánimo lucrativo, sino que el objetivo era lograr crear alianzas con otras sociedades y conseguir productos para alimentarse. Es por eso que se debe reforzar la idea del mercado como lugar de interacción social, incorporando la idea de la plaza del mercado en el que se compartían las funciones de ocio y comercio en un mismo terreno.

Finalmente, se puede inferir que los mercados de abasto se encuentran ligados directamente al índice demográfico de la ciudad en donde están ubicados (Ver

Figura 2.76), y a la distancia entre sus mercados, esto se debe principalmente a la necesidad de abastecimiento de la población. El Mercado San José no es la excepción, debido a que se creó bajo esta necesidad, por lo que en un principio sus puestos de venta estaban destinados a productos perecederos, pero ante la llegada de los supermercados tuvieron que cambiar de rubro para que su negocio sea rentable, por lo que se plantea recuperar los puestos de productos perecederos, debido al rol que tiene el mercado de abastecer a los habitantes del lugar en el que se encuentra. 

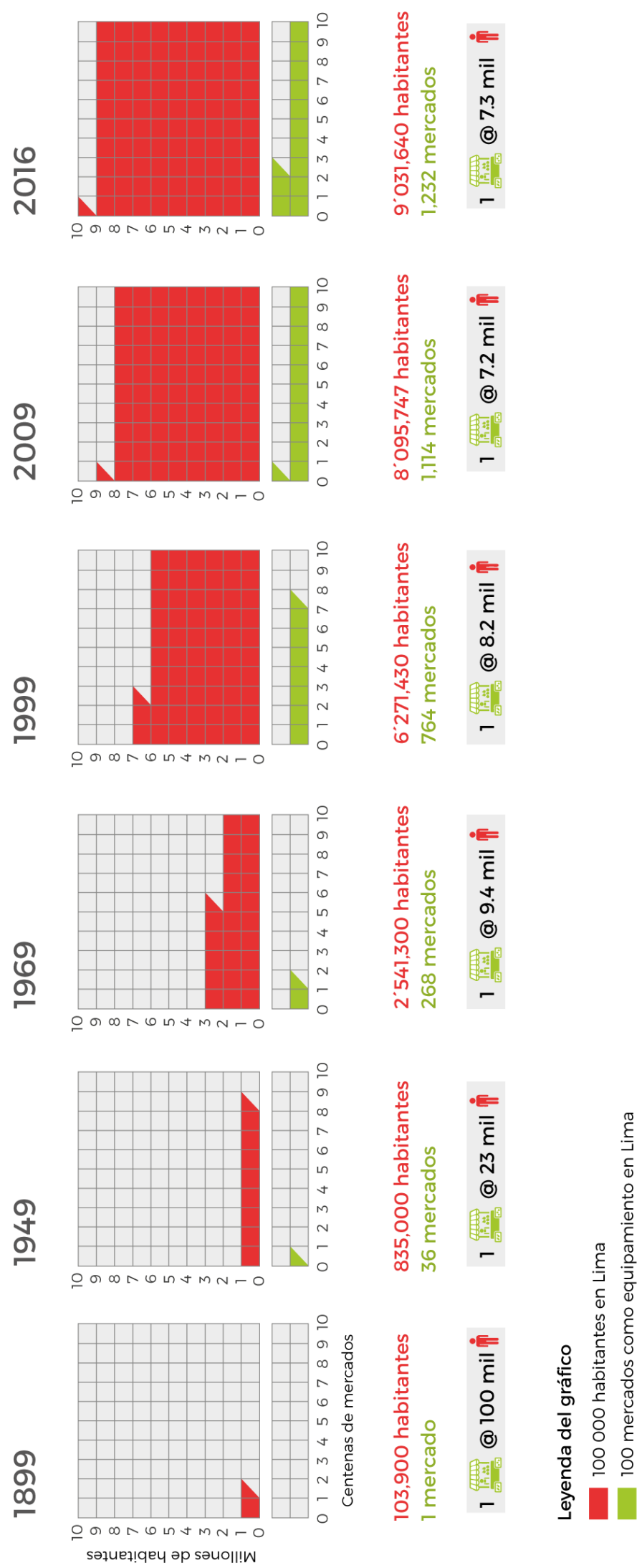

Figura 2.76 Población vs Mercados (1899-2016)

Gráfico elaborado por los autores. 


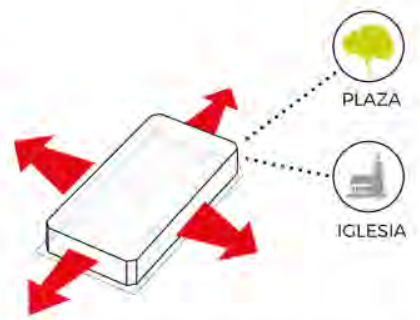

RELACIÓN CON EL ENTORNO CONEXIÓN HISTÓRICA

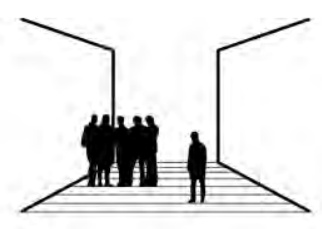

RESPETAR EL PASAJE TRAMA URBANA

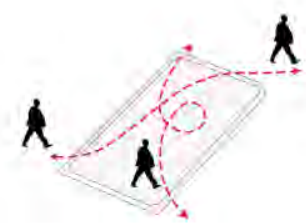

SUPRIMIR BARRERAS ARQ ALTO GRADO DE ACCESIBILIDAD

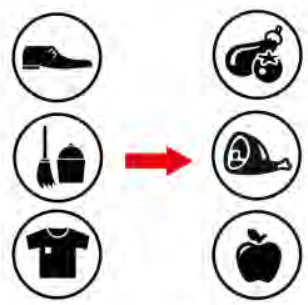

CAMBIOS DE RUBRO VENTA DE PRODUCTOS PERECEDEROS

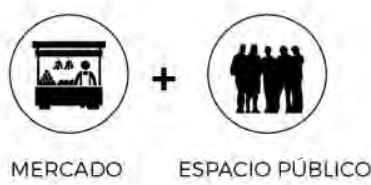

COMBINAR FUNCIONES MERCADOY ESPACIO PÚBLICO

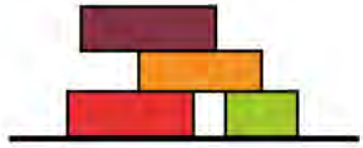

USOS MIXTOS

PROGRAMA PARA EL LOCAL Y EL TURISTA

Figura 2.77 Lógicas_Marco histórico

Gráfico elaborado por los autores. 


\section{CAPÍTULO III: Marco teórico}

\subsection{El mercado como espacio público}

\subsubsection{Espacio público y su valor en la sociedad}

El término de espacio público comprende a todas aquellas áreas de la ciudad destinadas - por su naturaleza, uso o afectación- a la satisfacción de necesidades urbanas colectivas. Son el telón de fondo e hilo conductor entre la ciudad y la ciudadanía (Acosta, 2018, p. 78). Es donde se construye la memoria colectiva y se manifiestan las identidades múltiples y las fusiones en proceso (Borja, 2012, p. 205). También, son espacio público las plazas y parques de los barrios, los mercados, los mercadillos, los locales de ocio y deportivos, los teatros y cines, las calles y los que se configuran continuamente en la red (Siena, 2011). De esta manera, los espacios públicos son un ingrediente esencial para la sostenibilidad de las ciudades y brindan valores políticos, sociales, económicos, de salud pública y de biodiversidad (Tonnelat, 2010, p. 3). (Ver Figura 3.1)

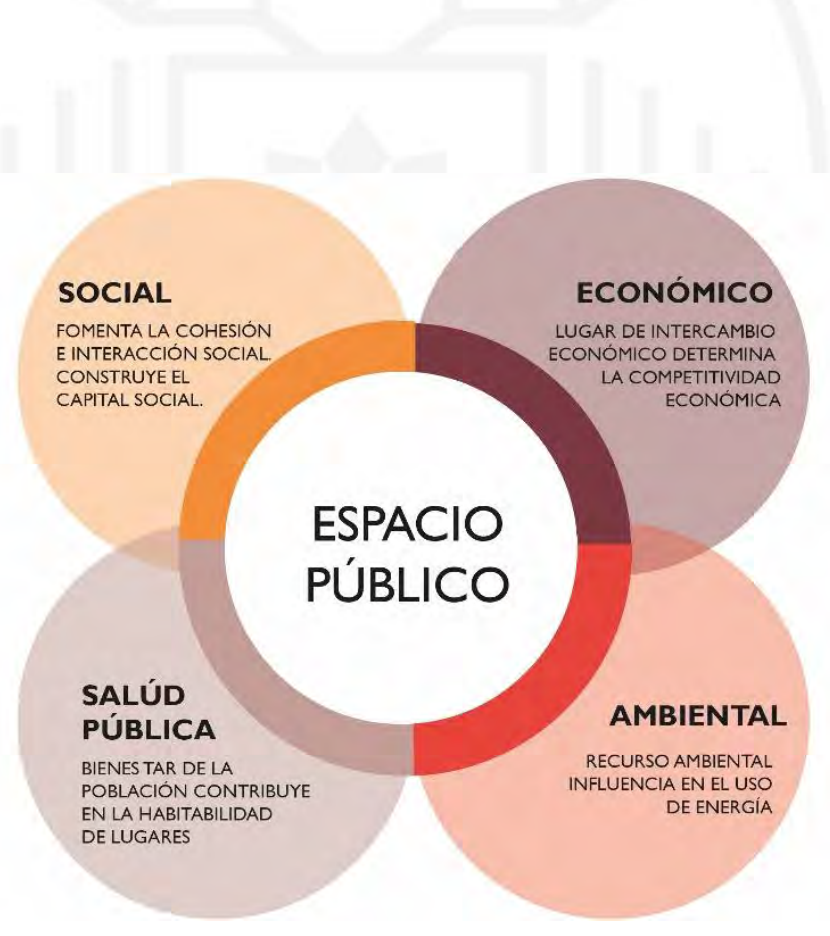

Figura 3.1 Beneficios del espacio público

Gráfico elaborado por los autores, según (Carmona et al., 2008). 
Socialmente, ofrece beneficios de aprendizaje a los niños, nutre las habilidades sociales y cognitivas; y puede ayudar a reducir los incidentes de delincuencia y comportamiento antisocial. También, promueve la vecindad y la cohesión social al proporcionar un lugar para el intercambio social y vida de las comunidades. Económicamente, tienen un impacto positivo en el valor de los precios de las propiedades, aumenta el valor de la tierra y los niveles de inversión (Carmona, Magalhães, y Hammond, 2008, p. 7). Además, en la salud pública, alienta el ejercicio con beneficios para la salud reduciendo el estrés y mejorando la salud mental; mientras que ambientalmente, puede lograr a fomentar el uso de modos de transportes sostenibles, mejorar la calidad del aire y reducir los efectos de la contaminación (Carmona et al. 2008, p. 7).

\subsubsection{Tipo de actividades y la calidad de sus espacios}

Por otro lado, Gehl (1971) sostiene que, las actividades humanas desarrolladas en los espacios públicos son influenciadas por una serie de condiciones físicas de las cuales dependen su grado de permanencia en el espacio. De esta manera, clasifica las actividades exteriores en tres grandes categorías: actividades necesarias, son todas las actividades en las que tenemos que participar; actividades opcionales, son aquellas en las que elegimos hacer si el tiempo y el lugar son propicios y actividades resultantes (sociales), son todas las actividades que dependen de la presencia de otros en el espacio público (p. 9). (Ver Figura 3.2) 


\section{CALIDAD EN EL ESPACIO FÍSICO}

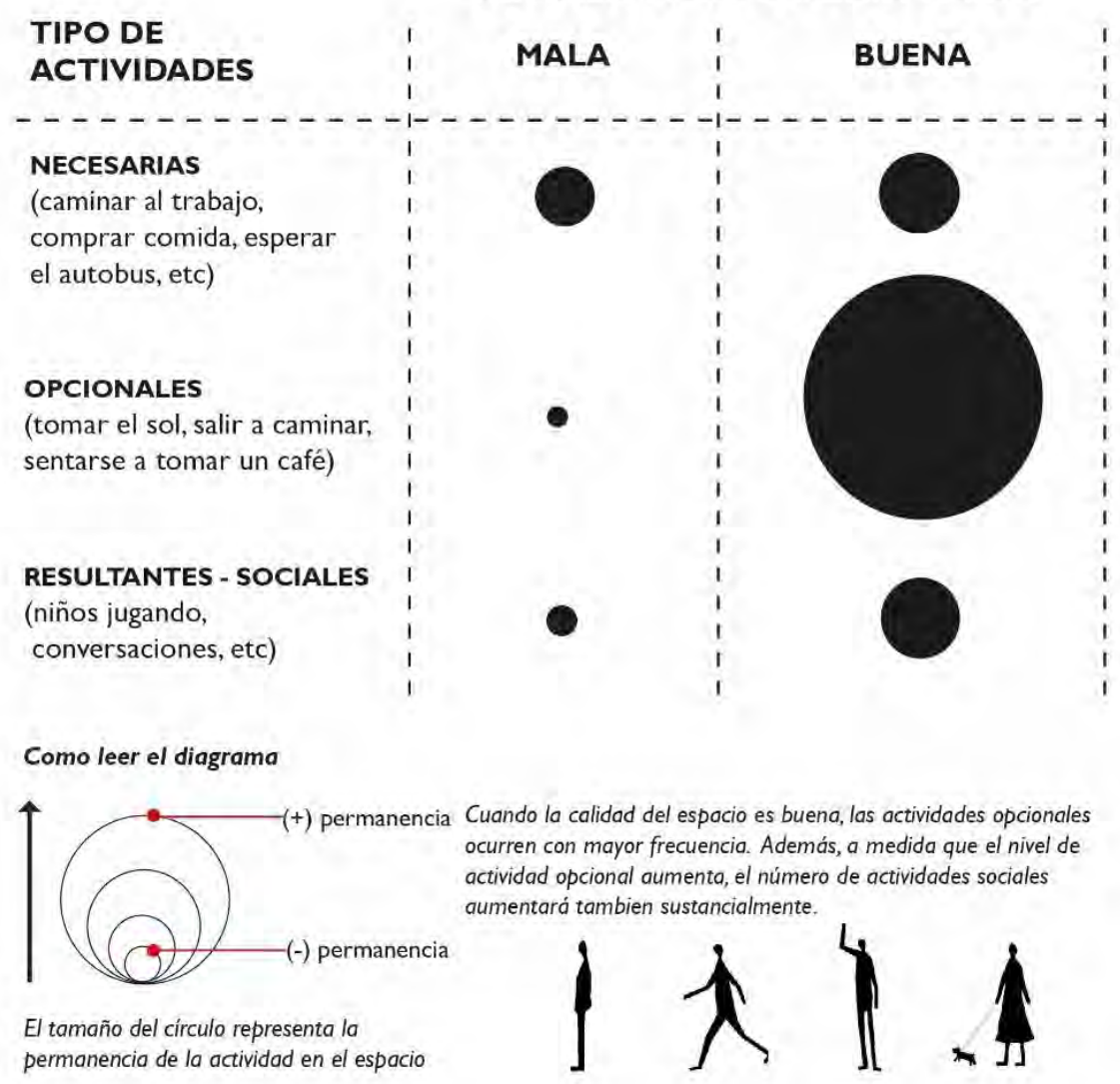

Figura 3.2 Calidad de espacios vs Duración en el espacio

Gráfico elaborado por los autores, según Gehl (1971).

De esta manera, las actividades necesarias tienen poca relación con la calidad física del medio ambiente ya que se desarrollan diariamente para que la vida continúe. Por el contrario, las actividades opcionales solo se llevarán a cabo si las condiciones del lugar son óptimas, es decir, funcionan como medidores de calidad del espacio público, afectando la percepción del espacio de los usuarios según el grado de permanencia, haciéndolo más o menos "habitable".

Finalmente, las actividades sociales ocurren independientemente del contexto físico; sin embargo, su calidad e intensidad se verán afectadas por el número de personas y su estabilidad prolongada en el espacio público (Gehl J. , 1971, p. 11). Asimismo, toma como base a las variables de protección, comodidad y agrado para la creación de doce principios que evalúan la calidad del espacio público según la experiencia humana (Ver Figura 3.3). 

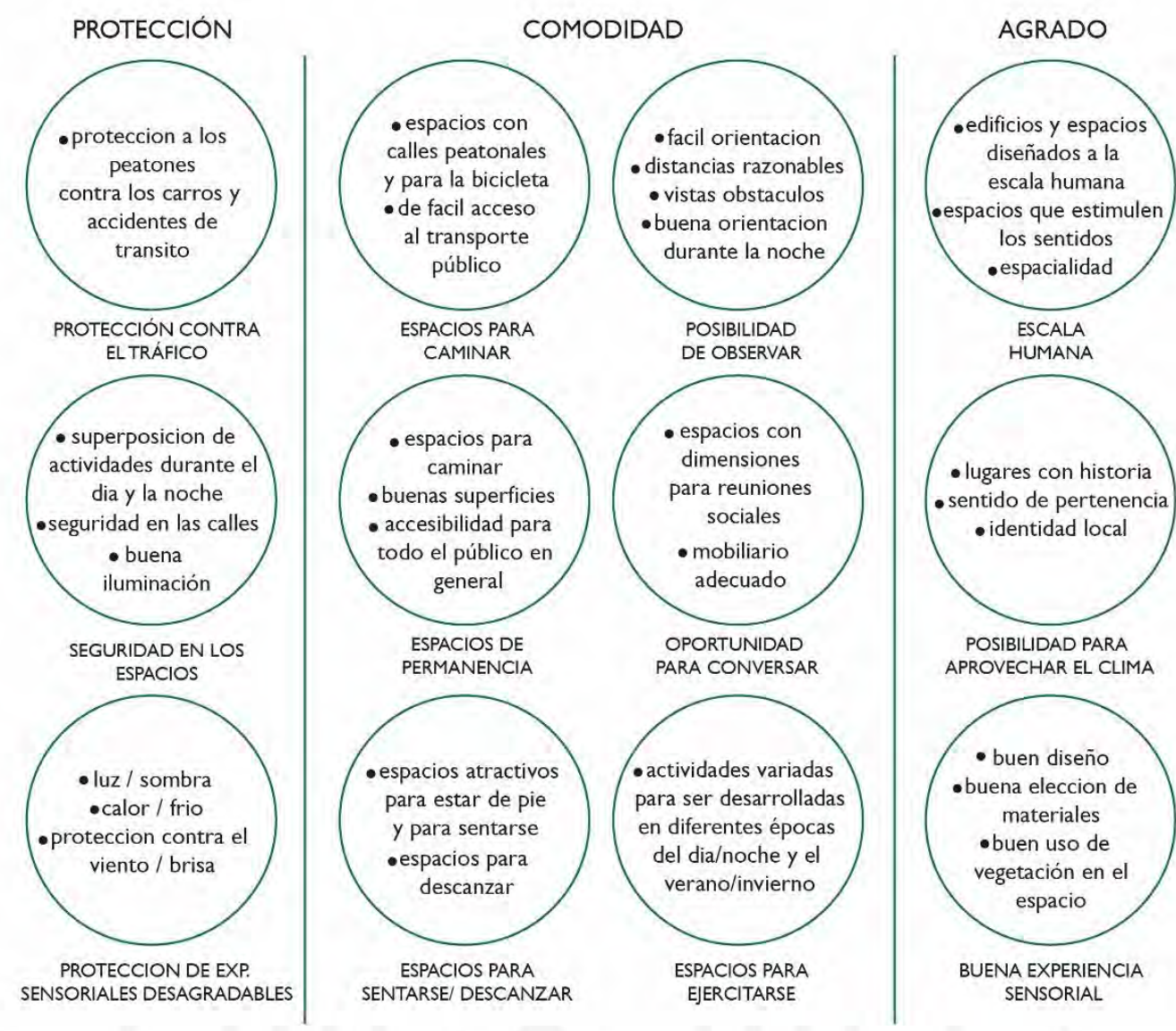

Figura 3.3 Principios de clasificación de un buen espacio público Gráfico elaborado por los autores, según Gehl (1971)

Ian Bentley (1985) complementa esta teoría y sostiene que, el diseño del espacio afecta en las elecciones de las personas en muchos sentidos, desde decidir a qué lugares si acudir y a cuáles no, hasta la elección de experiencias sensoriales (p.9). En este sentido, selecciona siete cualidades básicas (Ver

Figura 3.4) que se deben de tomar en consideración para generar un buen diseño del espacio de manera que responda correctamente a las experiencias humanas, siendo estas las siguientes:

1. Permeabilidad: Mide el grado de accesibilidad en un espacio. Solo los espacios más accesibles pueden ofrecer opciones de cómo moverse a través de este. 
2. Variedad: es la posibilidad de experiencias que un espacio puede ofrecer. En este criterio se evalúa la demanda de ciertos usos en el lugar y que tan amplia debe ser esta variedad para que sea funcionalmente factible.

3. Legibilidad: Es la facilidad de entender el trazado, la distribución y el diseño del lugar que se percibe gracias a los elementos que conforman el espacio, como: ejes, intersecciones, cualidades espaciales, etc.

4. Versatilidad: Contempla variedad de usos en un mismo espacio. Ve los diferentes propósitos que se pueden emplear en un solo lugar.

5. Imagen apropiada: Da a conocer la variedad de opciones que te ofrece el lugar a partir del lenguaje arquitectónico. Además, ayuda a la percepción e interpretación del espacio por parte de las personas.

6. Riqueza perceptiva: Mide las opciones de experiencias sensitivas para las personas. Esta riqueza dependerá de que tan visibles o no deben ser algunos espacios, la materialidad y técnicas constructivas.

7. Personalización: en esta etapa, el usuario tiene la oportunidad de poner su propio sello en el lugar. Ello dependerá de la capacidad del espacio para soportar la personalización de los usuarios sin perjudicar el diseño (Bently, Alcock, Murrain, McGlynn, \& Smith, 1985, p. 9).

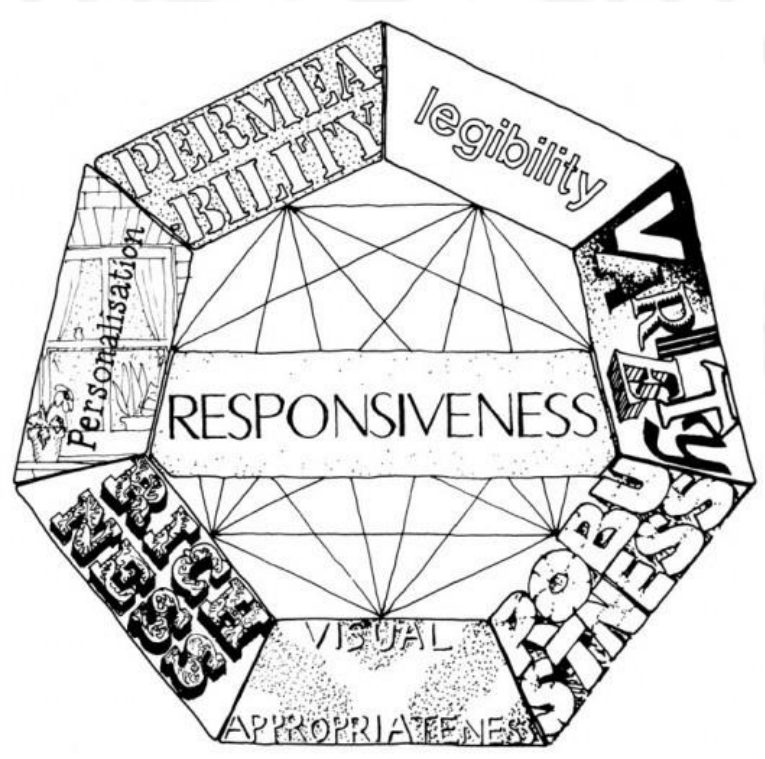

Figura 3.4 Cualidades para un buen diseño de edificios y espacios al aire libre

En:http://www.vitruvius.com.br/media/images/magazines/grid_9/9a47e02ab439_bentley041_usar.jpeg 


\subsubsection{Clasificación del espacio público contemporáneo}

Históricamente, el espacio público es reconocido por ser un "espacio abierto", es decir, las calles, parques y áreas de recreación, plazas y otros espacios al aire libre de propiedad pública y administrados, a diferencia del dominio privado de la vivienda y el trabajo. Sin embargo, la introducción de nuevos parámetros para la movilidad como el ferrocarril, los tranvías y finalmente el automóvil se genera un cambio en las dimensiones de las calles de la ciudad. Con el ensanchamiento de vías para el automóvil, los espacios públicos como se conocían pasan a restringirse y la calle pierde sus calidades como espacio de socialización (Centeno, 2006, p. 19). Asimismo, la evolución de las formas de asentamiento urbano y la creciente cantidad y variedad de espacios semipúblicos administrados por asociaciones público-privadas o completamente privadas cuestionan esta noción heredada (Tonnelat, 2010, p. 1).

Entonces, el término del espacio público empieza a tener definiciones múltiples $\mathrm{y}$, en ocasiones, contradictorias, provocando que la categorización del mismo sea más difícil a medida que los espacios públicos y privados se entrelazan cada vez más.

En una sociedad en la que cada vez más la vida cotidiana transcurre en la esfera privada - casas privadas, en computadoras privadas, en automóviles privados, lugares de trabajo privados y centros comerciales estrictamente controlados y privatizados- hay indicios claros de que la ciudad y los espacios de la ciudad se les ha dado un nuevo e influyente papel como espacio público y foro. (Gehl \& Gemzøe, 2000, p. 20)

Esta posición sustenta el abandono que algunos de los sectores sociales de mayores recursos hacen del espacio público para desarrollar su vida urbana en espacios cerrados, destinos que no necesitan expresar mayor relación con la trama urbana y que no los exponen a encuentros pluri-sociales y que son en principio evitados en nombre de la seguridad (Centeno, 2006, p. 3). De esta manera, una nueva tipología de espacio público modifica las categorizaciones existentes y refleja el proceso de privatización del espacio con énfasis en lo social y espacial. Esta se construye en torno a cinco criterios reflejados en la Tabla 3.1 (Mantey y Kepkowicz, 2018, p. 641). 
Tabla 3.1

Criterios de una nueva tipología de espacios públicos urbanos

\begin{tabular}{|c|c|c|c|c|}
\hline USUARIOS & $\begin{array}{c}\text { TIEMPO DE } \\
\text { ACCESO }\end{array}$ & $\begin{array}{c}\text { CONTROL DE } \\
\text { ACCESO }\end{array}$ & FUNCIONES & $\begin{array}{c}\text { CARACTERISTICAS } \\
\text { VISUALES }\end{array}$ \\
\hline $\begin{array}{l}\text { - Todo el público en } \\
\text { - general } \\
\text { - Todo el público con } \\
\text { - Gruponción de consumir } \\
\text { - Usuarios privados }\end{array}$ & $\begin{array}{l}\text { - Las } 24 \text { horas } \\
\text { - Todos los dias en el } \\
\text { horario establecido } \\
\text { - Todos los dias en } \\
\text { horas seleccionadas } \\
\text { - Días y horas } \\
\text { seleccionadas } \\
\text { - Ocasionalmente }\end{array}$ & $\begin{array}{l}\text { - Sin control alguno } \\
\text { - Control cívico } \\
\text { - Control en acceso } \\
\text { - Monitoreo } \\
\text { - Personal de seguridad } \\
\text { - Control del propietario }\end{array}$ & $\begin{array}{l}\text { - Recreacional } \\
\text { - Social } \\
\text { - Cultural } \\
\text { - Económica } \\
\text { - Movilidad } \\
\text { - Técnica } \\
\text { - Composición } \\
\text { - Representativa }\end{array}$ & $\begin{array}{l}\text { Ubicación: } \\
\text { - Exterior } \\
\text { - Interior } \\
\\
\text { Tipo de mobiliario: } \\
\text { - Mobiliario recreacional } \\
\text { - Mobiliario básico } \\
\text { - Sin mobiliario }\end{array}$ \\
\hline
\end{tabular}

Tabla elaborada por los autores, según Mantey y Kepkowicz (2018)

\subsubsection{Usuarios}

De esta manera, la identificación de lugares a pesar de haber sido creados para grupos específicos, funcionan como espacios públicos de forma regular o bajo ciertas circunstancias, enriqueciendo así el espacio local para encuentros e integración de personas. Se divide en cuatro grupos de espacios (Ver Figura 3.5): (1) para todo el público sin restricciones de acceso, (2) Espacio para todo el público, pero en el que los consumidores eleven el valor comercial del lugar, (3) espacio para grupos seleccionados (el tipo de público "correcto") que maximiza el volumen y la eficiencia del lugar y (4) para usuarios privados (Mantey et al. 2018, p. 641).
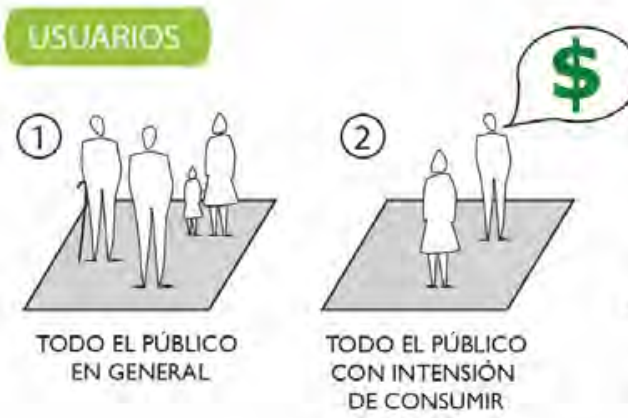

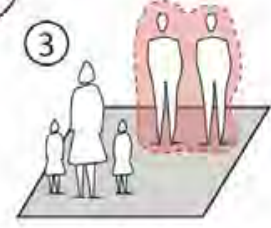

GRUPOS SELECCIONADOS

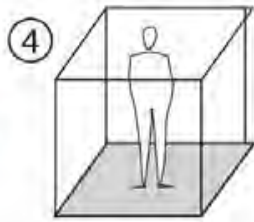

USUARIOS PRIVADOS

Figura 3.5 Usuarios en el espacio público

Gráfico elaborado por los autores, según Mantey y Kepkowicz (2018). 


\subsubsection{Tiempo de acceso}

Se emplean generalmente en espacios a puertas cerradas, de carácter semipúblicos y privados. Sin embargo, este límite de acceso también se da en espacios al aire libre con el propósito de tener un control, seguridad y mantenimiento adecuado. Este criterio de acceso asume cinco situaciones (Ver Figura 3.6). (1) acceso de veinticuatro horas, (2) acceso diario durante las horas de apertura, (3) acceso todos los días durante las horas seleccionadas, (4) acceso en días seleccionados y horas seleccionadas y (5) acceso ocasional (Mantey et al. 2018, p. 641).

\section{TIEMPO DE ACCESO}

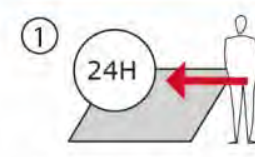

ACCESO LAS 24 HORAS

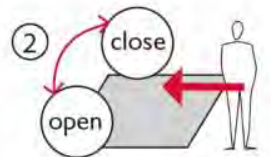

ACCESOTODOS LOS DIAS ACCESO TODOS LOS DIAS
EN EL HORARIO ESTABLECIDO

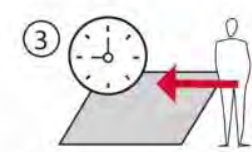
ACCESO TODOS LOS DIAS
EN HORAS SELECCIONADAS SELECCIONADAS
(4)

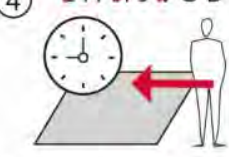

ACCESO SOLO EN DIAS Y HORAS SELECCIONADAS

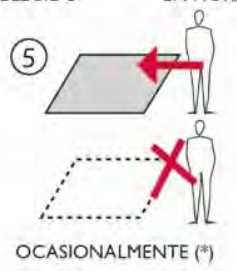

OCASIONALMENTE (*)

(*) Esta valoración de tiempo se emplea para aquellos eventos o celebraciones con acceso durante una temporada muy pocas veces en el año. Un ejemplo son algunas discotecas al sur de Lima, que abren sus puertas al público solo durante la temporada de verano.

Figura 3.6 Tiempo de acceso al espacio público

Gráfico elaborado por los autores, según Mantey y Kepkowicz (2018).

\subsubsection{Control de acceso}

En la era del privatismo, la necesidad de cercar y controlar no solo afecta a las casas privadas y las urbanizaciones, sino también al espacio público, dando una falsa sensación de seguridad y espacios inaccesibles para los usuarios. Sin embargo, la falta de administración también conduce a la formación de espacios que evocan sentimientos negativos (Mantey et al. 2018, p. 644). Este criterio se divide en seis formas de supervisión (Ver Figura 3.7): (1) no hay formas visibles de control, (2) control cívico, (3) acceso, (4) monitoreo, (5) guardias de seguridad (6) propietario privado (Mantey et al. 2018, p. 644). 


\section{CONTROL DE ACCESO}
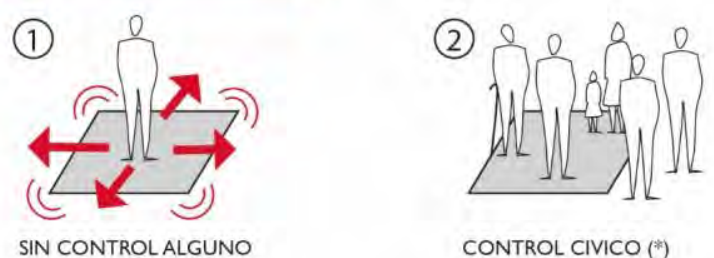

CONTROL CIVICO (*)

(4)

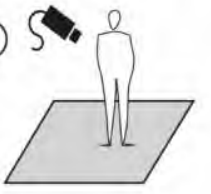

MONITOREO

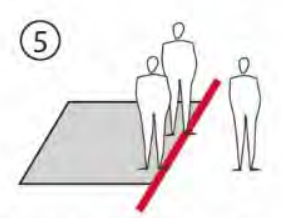

PERSONAL DE SEGURIDAD
(3)

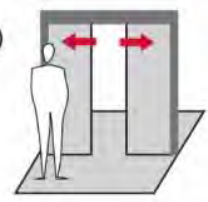

CONTROL ENACCESO

(6)

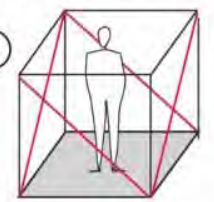

CONTROL DEL PROPIETARIO

(*) Implica la participación personal de los residentes de un lugar para mantener el espacio en el nivel correcto y evitar conductas no deseadas.

Figura 3.7 Control de acceso en el espacio público

Gráfico elaborado por los autores, según Mantey y Kepkowicz (2018).

\subsubsection{Función}

Las funciones previstas determinan las actividades posibles para realizar en el espacio público y reflejan su uso principal. Para el propósito de una nueva tipología, se han definido ocho tipos de funciones (Ver Figura 3.8): (1) función recreativa, es la capacidad de participar en conductas fuera de las tareas profesionales, sociales y domésticas, que tienen como objetivo el descanso, la autoestima, y entretenimiento; (2) la función social, es la capacidad de influir a las personas tanto en la integración del sistema social local como en su eficiencia operativa o utilidad; (3) función cultural, es el cultivo del patrimonio cultural y los valores asociados con él, incluidos los religiosos y otros valores simbólicos o históricos; (4) función económica, son los espacio que concentran tiendas, servicios y empleos; (5) función de movilidad, un son los espacios que permiten el flujo de las personas (como rutas peatonales y de ciclistas que permiten pasar tiempo de ocio al aire libre cerca de atractivas áreas naturales); (6) función técnica, son los espacios, infraestructuras e instalaciones dedicados a la organización del transporte de personas; (7) función de composición, elemento importante define la concentración de las personas y su actividad; y (8) función representativa, son los espacios u objetos que manifiestan el poder de la autoridad (Mantey et al. 2018, p. 644). 


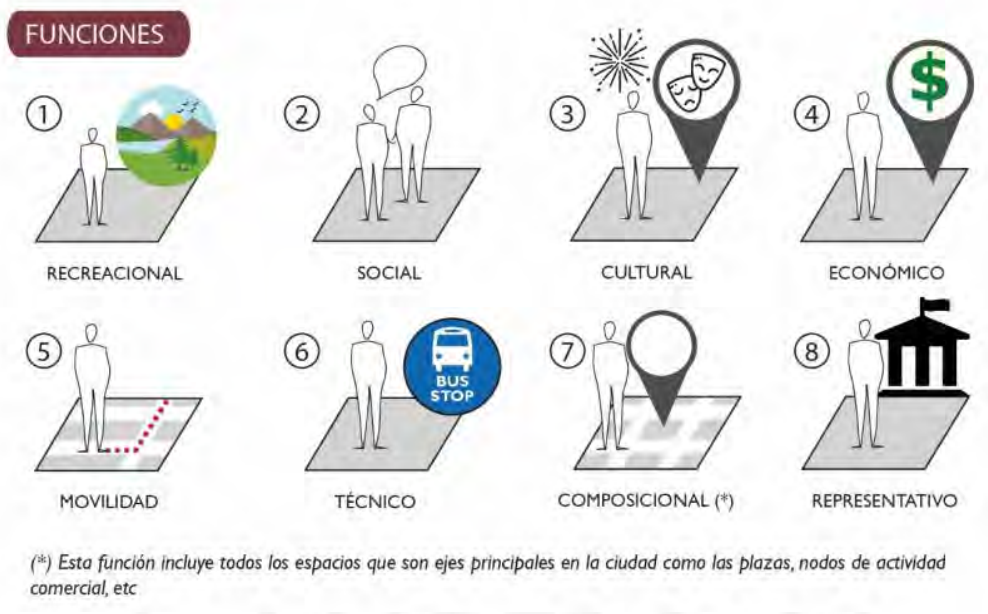

Figura 3.8 Funciones en el espacio público

Gráfico elaborado por los autores, según Mantey y Kepkowicz (2018).

\subsubsection{Características visuales}

Son todas aquellas características que hacen que el espacio sea reconocible como público y refleje sus funciones. Las características visuales abarcan (Ver Figura 3.9): (1) tipo de ubicación (espacio exterior / abierto o interior / techo) y (2) tipos de equipo: equipo recreativo profesional, equipo básico que alienta a las personas a permanecer en el lugar (principalmente asientos), equipo provisional, o ningún equipo (Mantey et al. 2018, p. 645-649).

\section{CARACTERISTICAS VISUALES}

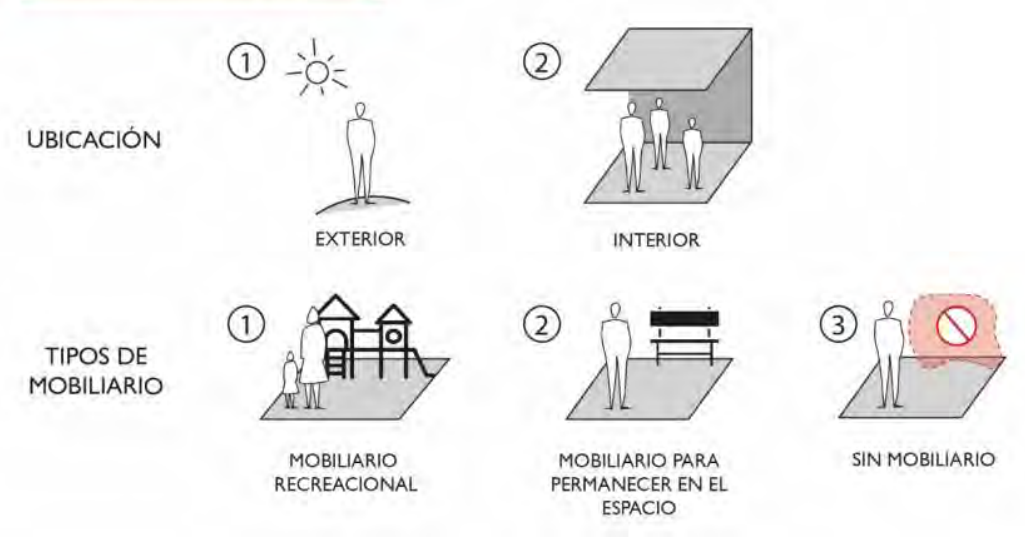

Figura 3.9 Características visuales de los espacios públicos

Gráfico elaborado por los autores, según Mantey y Kepkowicz (2018). 
Estos cinco criterios previamente descritos, configuran la base de una nueva tipología de espacios públicos de la ciudad contemporánea (Ver Tabla 3.2) que se clasifica en dieciséis tipos de espacios (Mantey et al. 2018, p. 645-649).

Tabla 3.2

Tipología de espacios públicos de la ciudad contemporánea

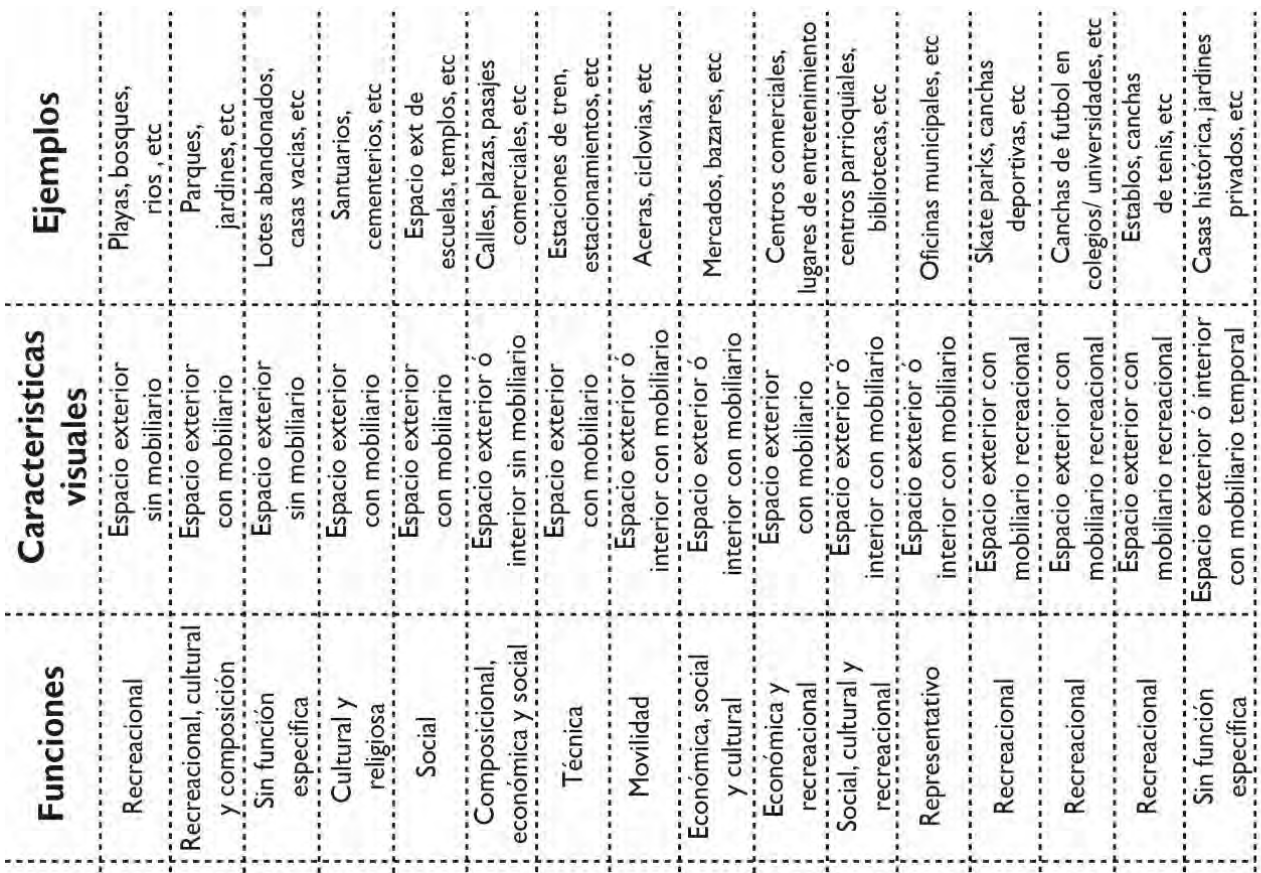

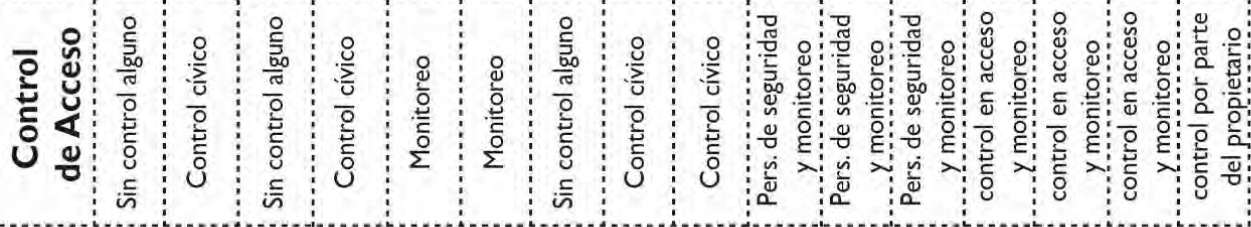

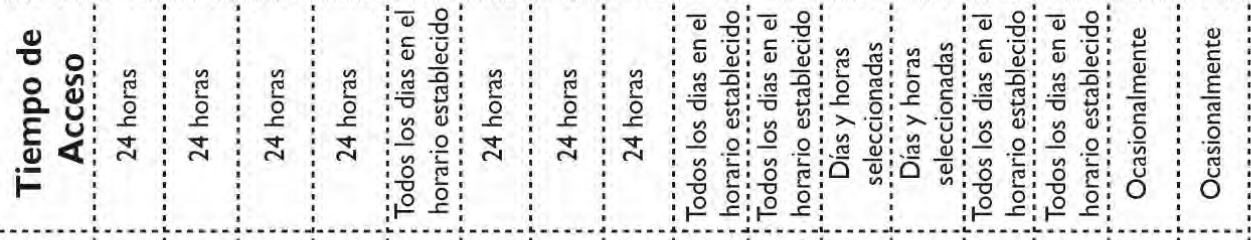
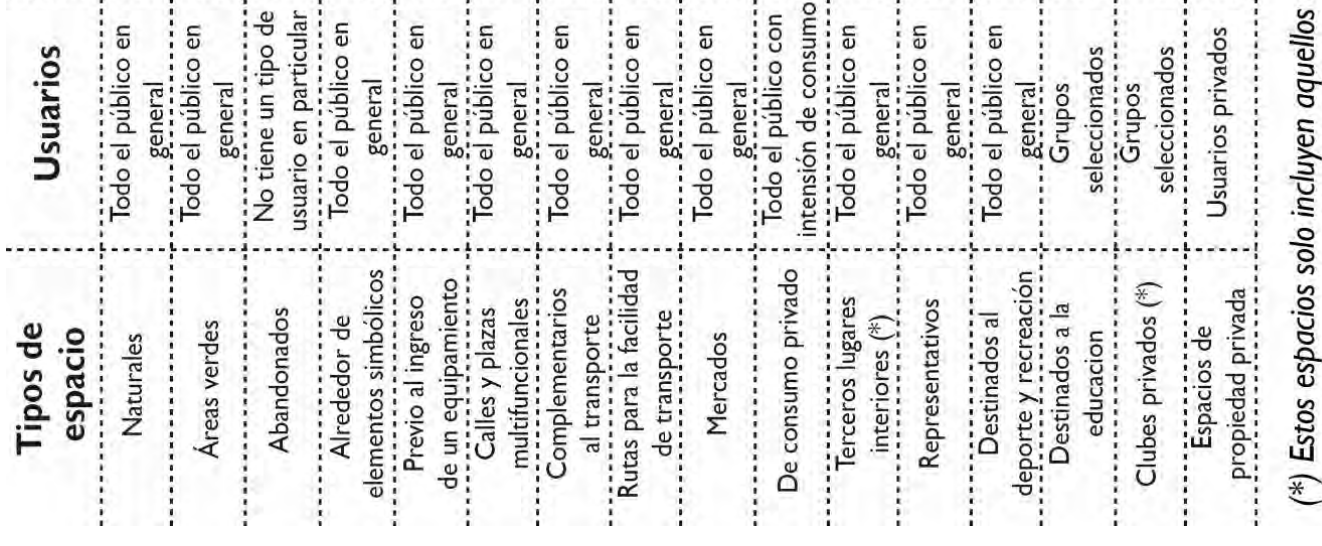

Tabla elaborada por los autores, según Mantey y Kepkowicz (2018). 
Tabla 3.3

Combinación de variables y tiempo de acceso de la nueva clasificación

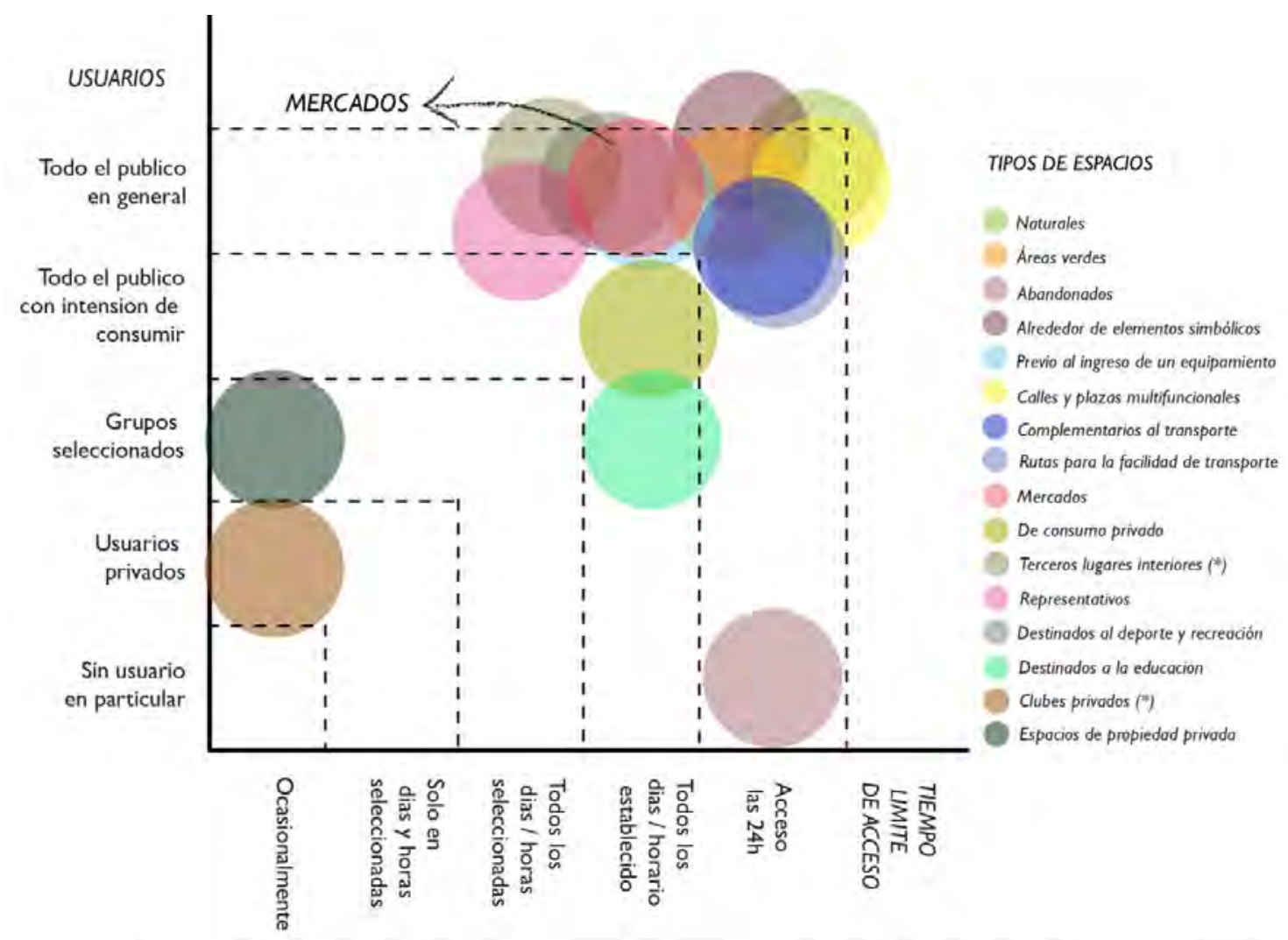

Tabla elaborada por los autores, según Mantey y Kepkowicz (2018).

\subsubsection{Espacios públicos en las ciudades peruanas}

De acuerdo al Artículo $3^{\circ}$ del proyecto de ley de "Gestión de Espacios Públicos en el Perú”, define al espacio público como:

Aquellas áreas públicas destinadas al uso público que se sitúan en la ciudad, cuya administración, conservación y mantenimiento corresponde a una entidad pública; sobre ellos, el Estado ejerce su potestad administrativa, reglamentaria y de tutela conforme a la ley. Es aquel territorio de la ciudad en las que el interés general sea manifiesto y que constituyan zonas para el uso o disfrute colectivo, equitativo, incluyente y seguro; tales como: las zonas para recreación pública (activa o pasiva) áreas verdes, parques, plazas, infraestructura vial, playas, lagos, ríos, lomas costeras, complejos y losas deportivas, reservas naturales, patrimonio cultural e histórico y otros, y en general, todas las zonas existentes o debidamente proyectadas. (Proyecto de Ley No 1311) 
Sin embargo, muchos de los espacios en el Perú, especialmente en Lima, están siendo tomados por iniciativas privadas que promueven un cambio en el uso de estos espacios como nuevas fuentes de ingreso, recayendo en ellos, una mayor presión de su uso en la ciudad. Según Artículo 59 de la Ley Orgánica de Municipalidades (LOM), establece que los bienes municipales pueden ser transferidos, concesionados en uso o explotación, arrendados o modificar su estado de posesión o propiedad, por acuerdo del Concejo Municipal. Por otro lado, el Artículo 65 de la LOM establece lo siguiente:

Las municipalidades están facultadas para ceder en uso o conceder en explotación bienes de su propiedad, en favor de personas jurídicas del sector privado, a condición de que sean destinados exclusivamente a la realización de obras o servicios de interés o necesidad social, y fijando un plazo. (Ley Orgánica de Municipalidades, Ley No 27972)

En consecuencia, la administración pública ha tomado esta práctica de manera constante, aprovechando el espacio público (subsuelo, superficie y aires) para iniciativas privadas con el fin de optimizar el uso del suelo y así generar nuevos espacios comerciales y de disfrute para la ciudadanía (Acosta, 2018, p. 79). En este sentido, el espacio público actual, es valorado por la expectativa de rentabilidad financiera que pueda generar, quedando relegado, su valor ambiental, cultural y de recreación que estos espacios solían tener. Asimismo, muchas calles, fueron resignando su carácter de espacio público para adquirir la función de vía de circulación, en un escenario donde la movilidad estructura la vida urbana actual de la ciudad. (Centeno, 2006, p. 3). Tal como describe Ludeña con respecto a degradación de muchas áreas consolidadas de la ciudad (como se citó en Takano y Tokeshi, 2007):

Con el nacimiento de grandes shoppings o centros comerciales se produjo una expansión de los campos feriales informales. En este contexto, la calle urbana como espacio público empieza a desaparecer para ser reemplazada por una extensa red de autopistas que acentúan la segregación. (p. 12) 


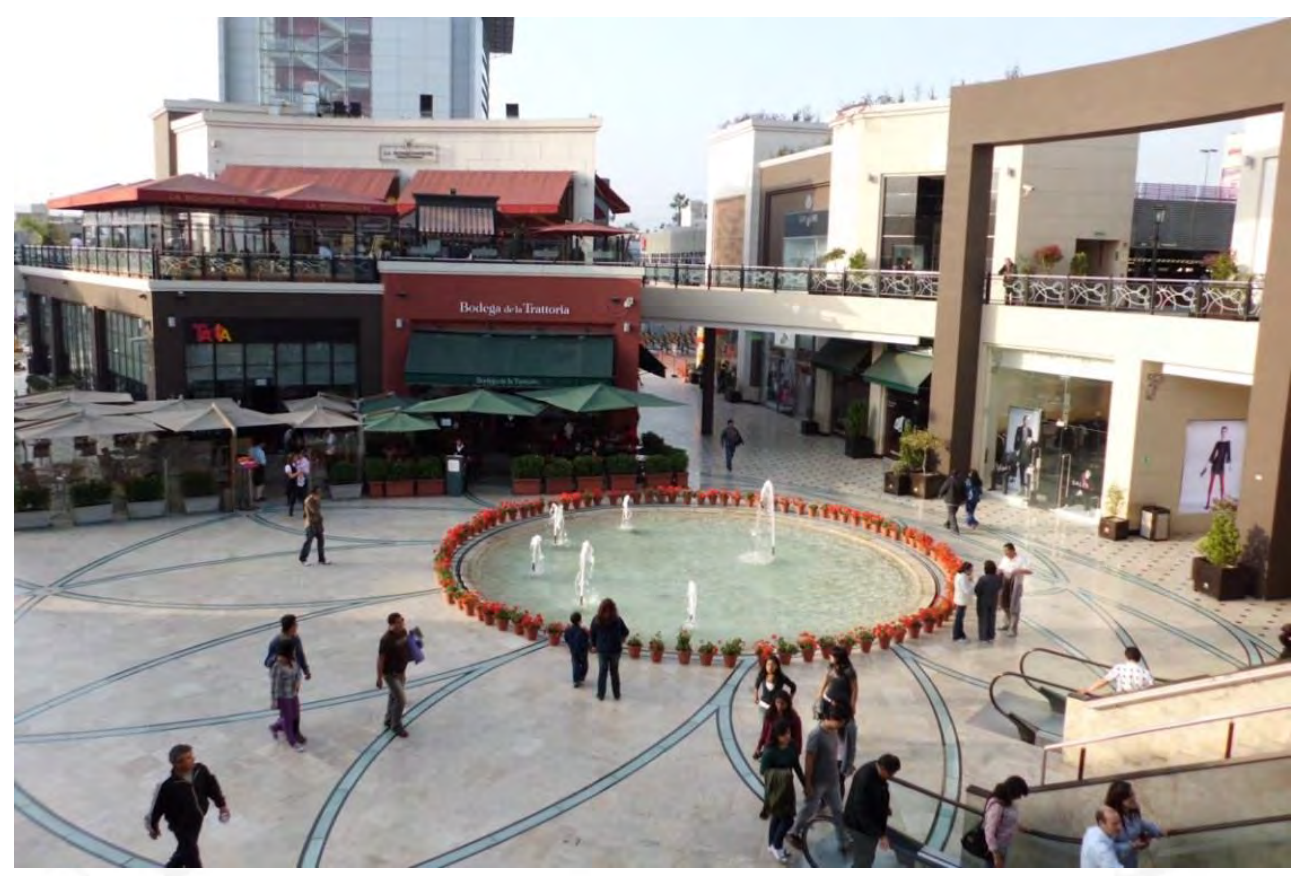

Figura 3.10 Jockey plaza y elementos de espacio público

Fuente:http://www.costosperu.com/wpcontent/uploads/2016/07/hv_contratistas_entrega_ampliacion_jock ey_plaza_revista_costos.jpg

Los grandes centros comerciales comienzan a ser presentados como los grandes espacios públicos contemporáneos (Ver Figura 3.10). Estas grandes superficies recrean calles, plazoletas equipadas con piletas y bancas como elementos que suelen componer los espacios públicos. Este modelo comercial logra tener un gran poder de convocatoria para los habitantes de la ciudad moderna, convirtiendo la actividad de consumir en una de las principales de la vida cotidiana (Centeno, 2006, p. 40). Son espacios que carecen de identidad, lo que acerca su interpretación a los no lugares ${ }^{8}$ como meros espacios de tránsito.

\footnotetext{
${ }^{8}$ Se toma la definición de Marc Auge, como se citó en (Espil, 2003): Los no lugares son, por definición aquellos lugares del anonimato: supermercados, shoppings, aeropuertos, club house, el espacio público de los barrios cerrados. No posee identidad, no tiene relación con localismos ni referencias históricas (...) a modo de ejemplo, en el supermercado uno mira, elige, pesa, paga con tarjeta y se va. La sumatoria de los no lugares da como resultado la no ciudad (pág. 79).
} 


\subsubsection{Beneficio de los mercados como espacio público}

Bajo el análisis de clasificación de los espacios públicos contemporáneos se puede afirmar que, desde la perspectiva social, los mercados son espacios públicos, pues son lugares de encuentro, expresión y manifestación de la sociedad. Son espacios en los que se realizan actividades de la rutina diaria mediante el intercambio de bienes y servicios, y el bienestar de los ciudadanos; siendo en definitiva un paradigma de integración de la actividad comercial en el espacio público (Siena, 2011). Además, son espacios que proveen necesidades psicológicas implícitas que el ser humano demanda. En este sentido, Gehl (1971) clasifica estas necesidades y las divide en tres grupos tales como: necesidad de contacto, necesidad de conocimiento y necesidad de estímulo.

La satisfacción de las necesidades psicológicas no suelen ser un objetivo tan directo y deliberado como las necesidades físicas básicas como comer, beber, dormir, etcétera (...) El hecho de que los adultos que trabajan en casa, se pasen comprando como medio día, (...) y el hecho de que las salidas a comprar se distribuyan regularmente a lo largo de la semana, aunque tal vez sería más fácil hacer la compra una vez por semana, hacen que resulte de manera natural asumir que muchas salidas diarias para comprar no tienen que ver solo con adquirir provisiones (...) en este contexto, la salida para comprar es tanto una excursión con ese fin como un pretexto, o una ocasión, para el contacto y el estímulo. (p. 115)

Entonces, los mercados representan mucho más que un lugar en donde solo se compra y se vende, pues las relaciones comerciales se encuentran inscritas en una red tanto simbólicas como sociales entre los comerciantes y clientes, que son la base de la función mercantil (Ver Figura 3.11). Son lugares privilegiados para la observación de los cambios sociodemográficos del entorno urbano, las transformaciones económicas y culturales de los hábitos de consumo; y de políticas públicas sobre la ciudad. 


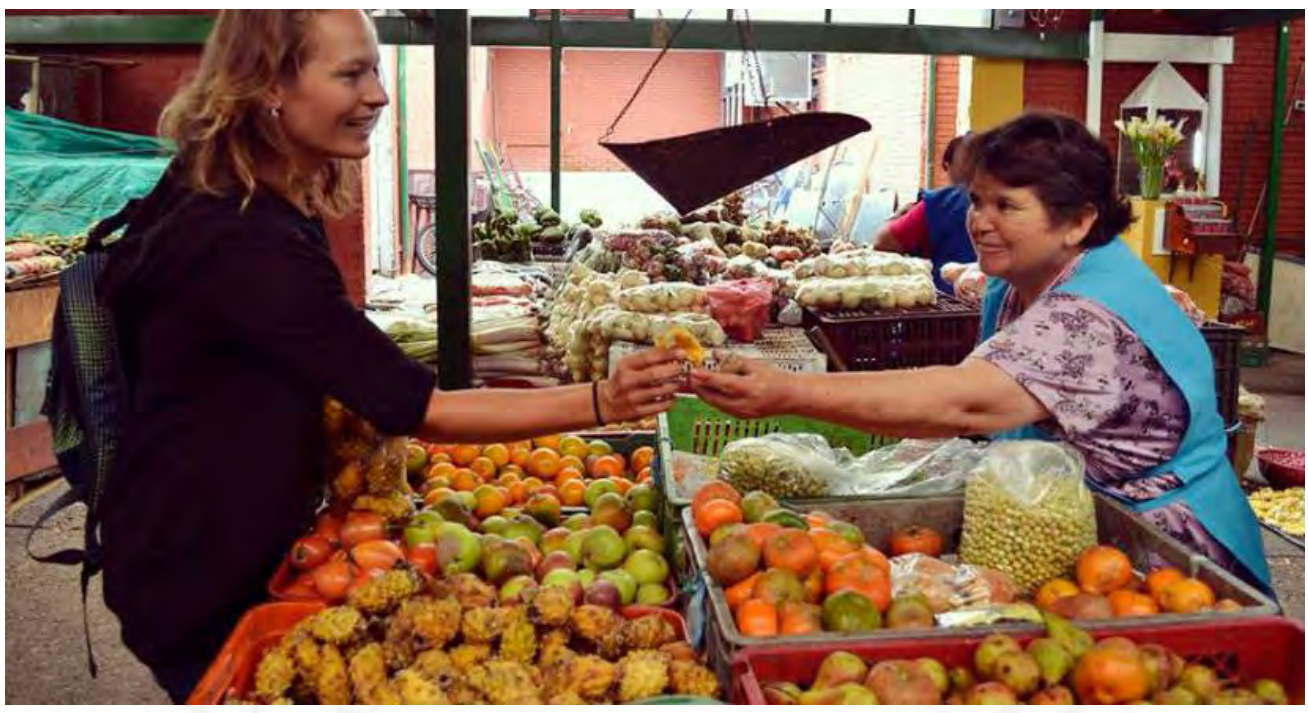

Figura 3.11 Interacción social entre comerciante y cliente

En: http://pamacultur.blogspot.com/2016/02/turismo-alternativo-en-bogota-con-plaza.html

Por otro lado, Project for Public Spaces (PPS) ${ }^{9}$ argumenta que los beneficios de los mercados son numerosos, pero quizás más importante sea la forma en la que los mercados funcionan como centros cívicos de los vecindarios (Project for Public Spaces, 2010, párr. 2). En este sentido selecciona seis beneficios más representativos de estos espacios comerciales (Ver Figura 3.12), siendo estos los siguientes:

1. Proporciona oportunidad económica

2. Link entre economías urbanas y rurales

3. Reúne gente diversa

4. Promueve la salud publica

5. Crea un espacio público activo

6. Renueva centros urbanos

\footnotetext{
${ }^{9}$ Project for Public Spaces (PPS), fundada en 1975, es una organización sin fines de lucro dedicada a ayudar a las personas a crear y mantener espacios públicos que construyan comunidades sólidas. Cuentan con proyectos en más de 3000 comunidades en 47 países en los 50 estados de EE. UU.
} 


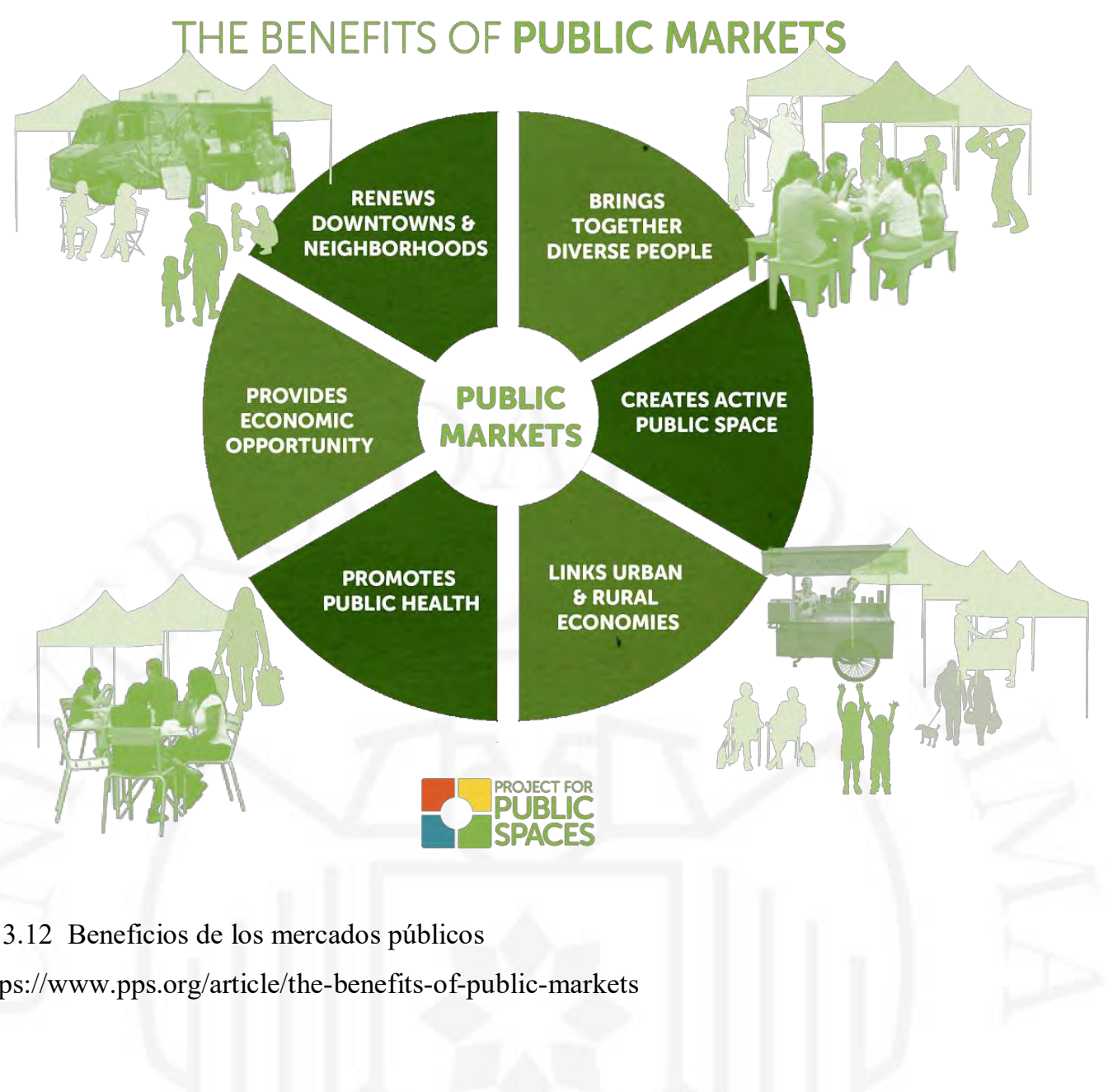

La experiencia es una de las cualidades que caracteriza la preferencia de las personas hacia estos espacios. Ver a otras personas, las oportunidades de conversación improvisada, los placeres sensoriales inesperados, es lo que atrae a la gente una y otra vez (O'NEIL, 2005, párr. 2). Sin embargo, estas cualidades no ocurren espontáneamente, ya que el diseño del mercado debe planificarse para que estas situaciones sucedan. 


\subsection{Límite como espacio de encuentro}

\subsubsection{Concepto del límite en la arquitectura}

El objetivo del análisis de la teoría del límite para el proyecto del mercado San José de Jesús María, es analizar los espacios definidos por los diversos tratamientos de los límites a través del tiempo y sus respectivas características como densidad, textura, color, transparencia, opacidad, luminosidad, etc. Luego, al finalizar el análisis, se podrá definir bajo que conceptos se diseñará el envolvente del mercado, si deseamos devolverle la condición de espacio público.

Primero, para plantear esta teoría es importante analizar la idea central del límite y las diferentes connotaciones que este término ha tenido a lo largo de la historia. Si analizamos el origen de la palabra, según la Real Academia Española, el término proviene del latín limes que significa "línea real o imaginaria que separa dos terrenos, dos países, dos territorios". Sin embargo, esta definición no está completa, ya que el límite opera de manera ambigua. Es disyuntivo, porque marca la diferencia entre dos espacios; pero también es conjuntivo, porque une el contenido con lo externo. (Rosales Meana, 2013, p. 28).

Complementando esta posición y siguiendo el pensamiento de Foucault, se puede afirmar que el límite supone una transgresión y una apertura, en el cual "el límite no es donde alguna cosa cesa, sino, como los griegos habían observado, es donde alguna cosa comienza a ser" (Vorträge und Aufsätze, 1954, p.183). A partir de estas definiciones, el interés de investigación es considerar ambas posturas, destacando la imagen del límite como umbral que marca la entrada y ofrece la oportunidad a nuevas opciones para el diseño del límite del mercado a diseñar.

\subsubsection{Límite y su variación en el tiempo}

En los inicios de la arquitectura, el límite se define por las construcciones monolíticas, que marcaban de manera ficticia el espacio. En ellas el esculpido, moldeado o excavado bastaba para la delimitación espacial (Martínez, 2013, p. 9). Por otro lado, las cuevas eran el espacio protector del hombre, que luego fueron sustituidas por construcciones improvisadas con elementos naturales como troncos y ramas, tal como describe Marc Antonie Laugier en "ensayos sobre la arquitectura” (como se citó en Ibaceta, 2015): 
(...) El hombre desea hacerse un alojamiento que lo abrigue sin sepultarlo (...) esta especie de techo es cubierto con hojas lo suficientemente apretadas de modo que ni el sol ni la lluvia puedan atravesarlo, y he aquí al hombre alojado. (p. 6)

Posteriormente, los troncos y ramas serian reemplazados por los elementos compositivos de la arquitectura clásica, en donde la columna y su ubicación en el espacio, determinaría límites penetrables en los templos griegos desde cualquier orientación y se comenzaría a evidenciar la ambigua relación entre el interior y el exterior por medio de la gradación de espacios (Ver Figura 3.13).
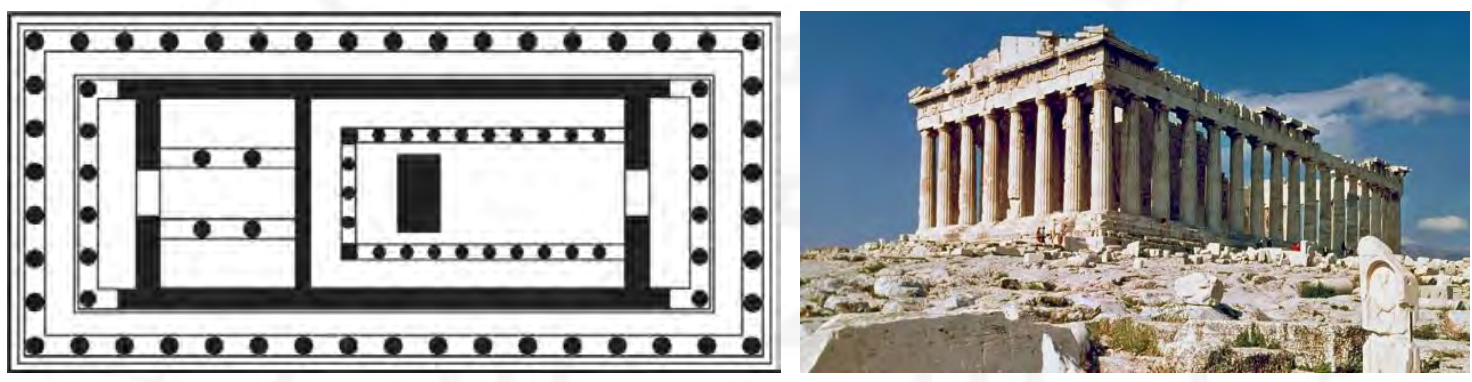

Figura 3.13 Límite permeable - El Partenón

En: http://www.xtec.cat/ jarrimad/grecia/partenon\%20planta.png (izquierda) https://ilmalpaese.files.wordpress.com/2015/02/tempio-greco.jpg (derecha)

Con el paso del tiempo, los límites crean un contorno que se modifica de acuerdo a las diferentes épocas en las que se sitúa, siendo estos durante la época medieval los que definan el frente de las calles y luego, durante el gótico, este límite será trabajado con esbeltez, y en una búsqueda constante de la luz en el espacio, seguido del barroco, en el que se definirá por una piel gruesa con formas onduladas y un interés por deshacer la fachada por medio de un exceso de pintura y escultura en los elementos arquitectónicos del edificio (Martínez, 2013, p. 9).

Si bien, todas estas facetas el límite son distintas, se crean bajo un mismo denominador que es el de la inclusión y exclusión (Ver Figura 3.14). Es en este momento que el límite se define por ser preciso y finito, que, por medio de aberturas y cerramientos propios de cada época se logran mantener la diferencia marcada entre el interior respecto al exterior (Ruiz, 2013, p. 22). 

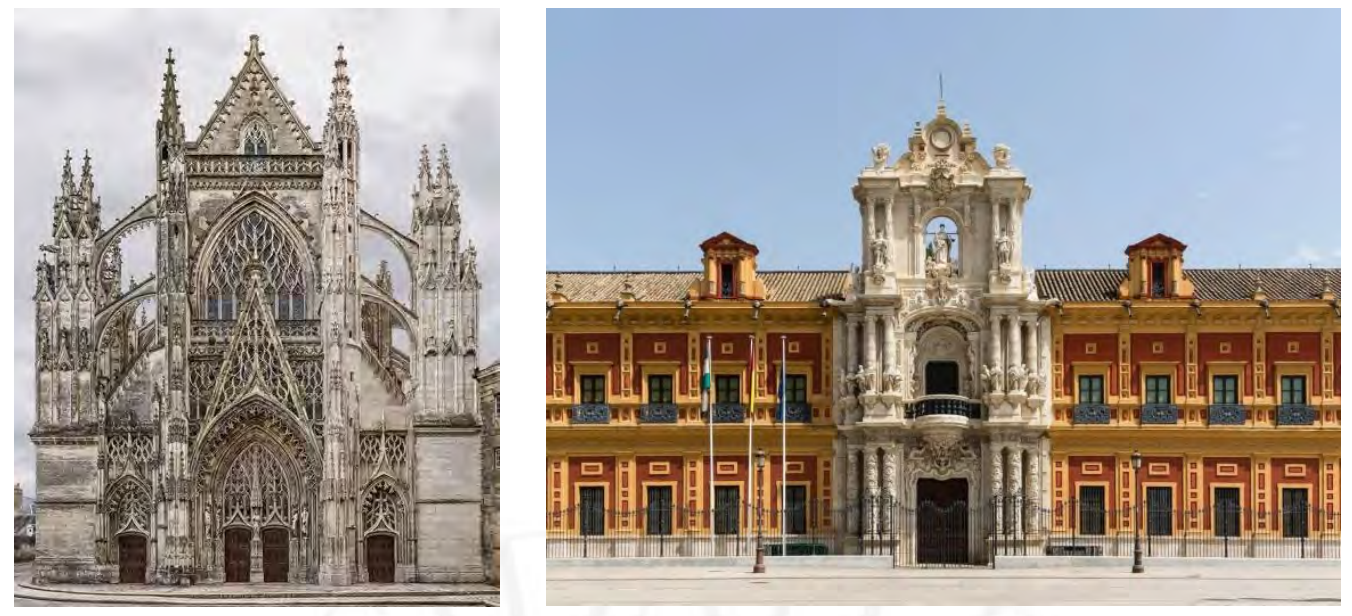

Figura 3.14 Arquitectura gótica (derecha) y barroco (izquierda)

En: http://www.markus-brunetti.de/ (derecha) y https://andaluciainformacion.es/ronda/725181/un-millonde-euros-para-vigilar-el-palacio-de-san-telmo/ (izquierda)

Sin embargo, en el siglo XX ocurre un cambio al momento de abordar la forma, el límite y el espacio; la arquitectura moderna "rompe y supera este orden cerrado y jerárquico y, al experimentar con nuevos sistemas de relaciones mucho más flexibles, ofrece una libertad que incluye desde la tecnología de la construcción de edificios hasta la conformación de los espacios libres” (Montaner, 2008, p. 13).

"De esta manera, la arquitectura pasa a ser de oclusiva, condicionada por las cargas que descienden por el espesor de un muro, a tener una capacidad diafragmática, ayudando así, a establecer unas relaciones contextuales más ricas” (García, 2013, p. 10). A causa de ello, se pone en crisis el modelo Beaux arts ${ }^{10}$ y la arquitectura comienza a perder peso y masa. Las antiguas fachadas de piedra se reemplazan por vidrio con perfiles metálicos en búsqueda del sol, aire y vistas; y el cerramiento opta la libertad de elección de poder ser independiente a la planta o al sistema estructural (Ver Figura 3.15).

${ }^{10}$ Caracterizado por la simetría, la jerarquía de espacios, referencias a estilos históricos y la abundancia de detalles y elementos decorativos. 

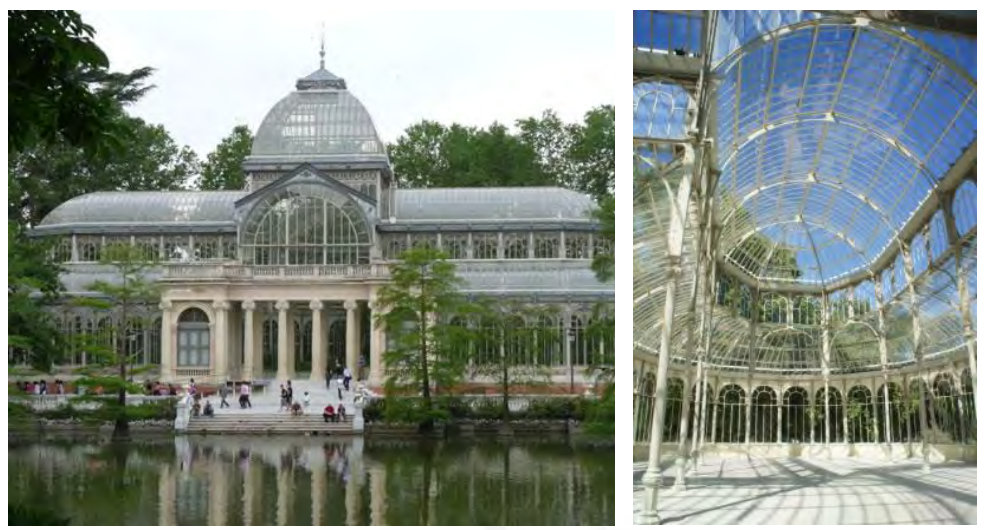

Figura 3.15 Exterior e interior del Palacio de Cristal del Retiro de Madrid.

En: http://elretiroyyo.com/palacio_cristal/palacio_cristal.html (derecha)

https://www.trover.com/d/zTkE-palacio-de-cristal-madrid-spain (izquierda)

En 1926, aparece Le Corbusier con los cinco puntos de la arquitectura, comprendidas como aquellas condiciones arquitectónicas que permiten ahondar en el sistema de planta unificada, y siendo la planta libre, la condición que permita liberar la fachada por medio del pilotis (Ver Figura 3.16 y Figura 3.17). "El volumen y la superficie son los elementos a través de los cuales se manifiesta la arquitectura. El volumen y la superficie están determinados por el plano" (Corbusier, 1977, p. 16).
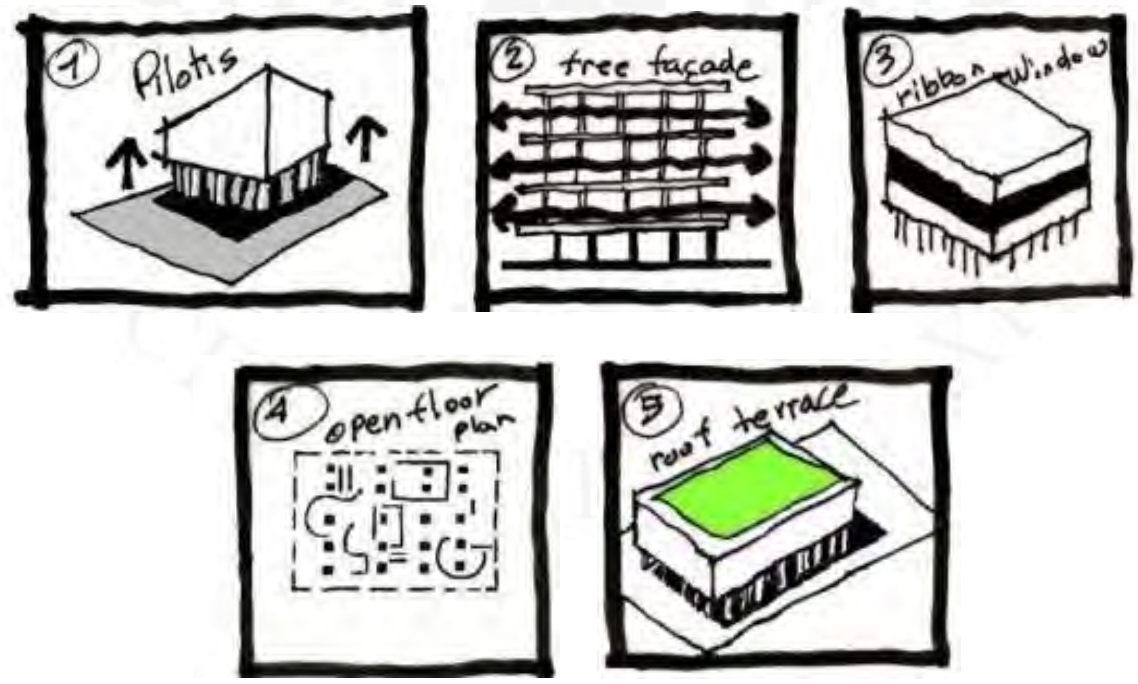

Figura 3.16 Cinco puntos de la arquitectura moderna por Le Corbusier.

En: https://bridgetcogley.wordpress.com/2016/09/15/a-place-on-pilotis-the-foundation-of-tel-avivsarchitecture/ 


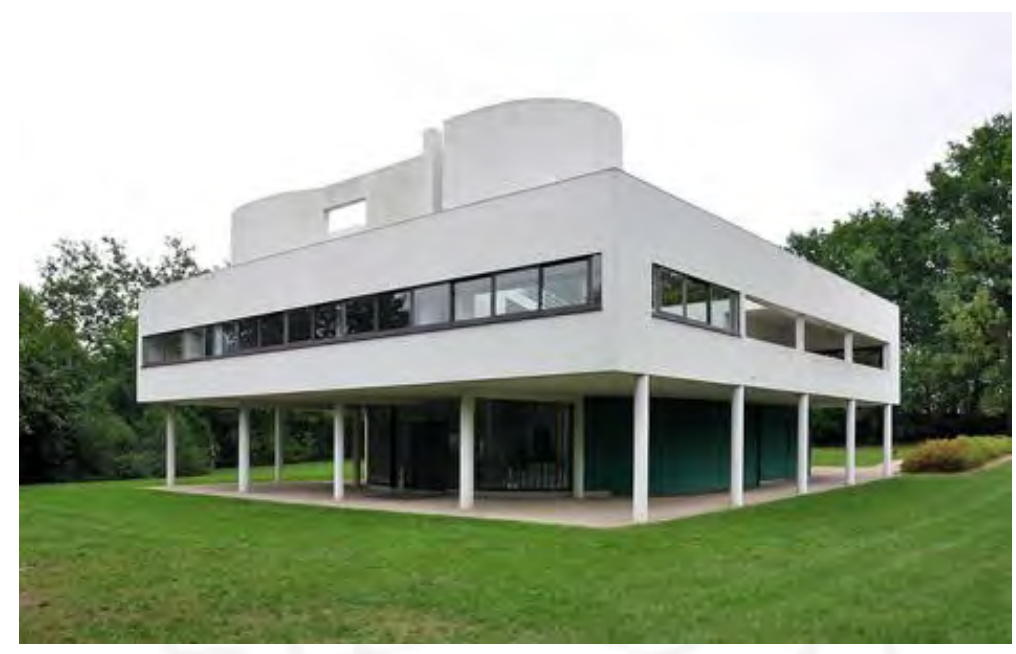

Figura 3.17 Villa Savoye de Le Corbusier

En: https://bridgetcogley.wordpress.com/2016/09/15/a-place-on-pilotis-the-foundation-of-tel-avivsarchitecture/

De igual manera, Mies van der Rohe, desarrolla una arquitectura liviana y transparente, sin establecer relación con el entorno (Ver Figura 3.18 y Figura 3.19). Una nueva arquitectura minimalista, de técnicas precisas y ausente de decoración; en donde la organización modular -esqueleto de hormigón, acero y piel autónoma- ofrece al espacio interior ser un espacio flexible, sin límites ni divisiones y que responde a diferentes funciones.

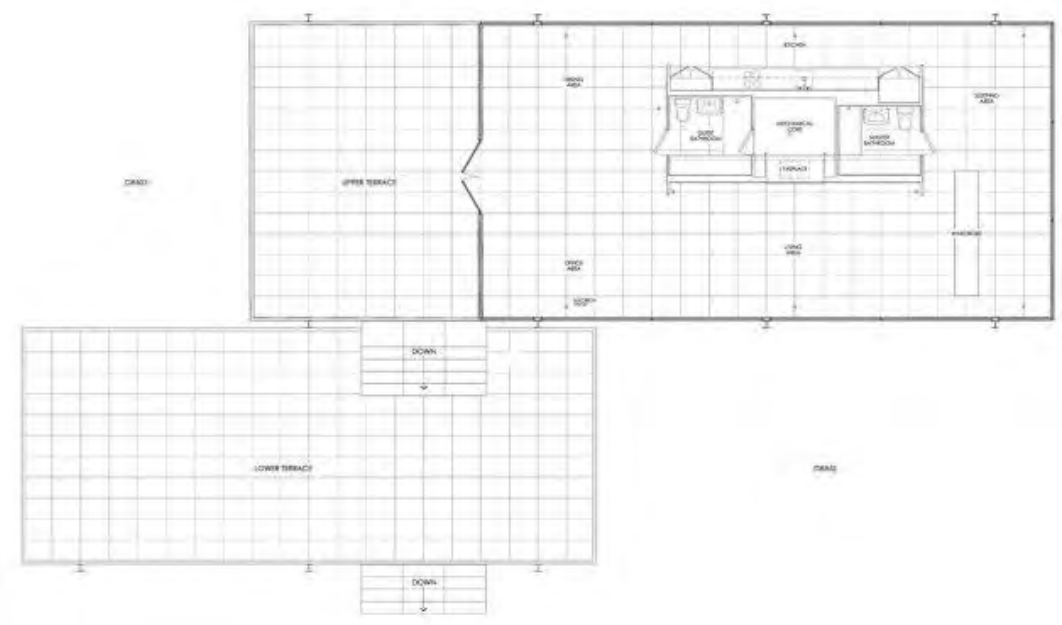

Figura 3.18 Planta de la Casa Fransworth

En: https://elementosdecomposicion.files.wordpress.com/2012/04/ts-20110726t212340farnsworth_house_story_2_large.jpg? $\mathrm{w}=639 \mathrm{\& h}=377$ 


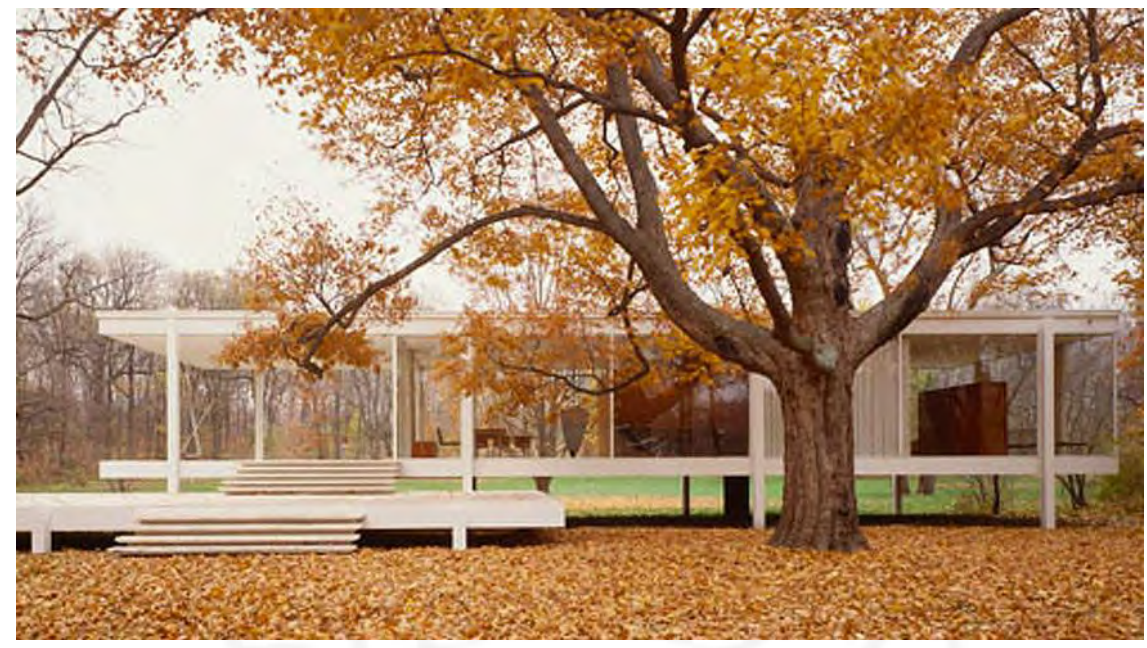

Figura 3.19 Fotografía de la Casa Fransworth

En: https://www.revistaad.es/arquitectura/galerias/casas-iconicas/7251/image/585755

Sin embargo, Frank Lloyd Wright, con influencia en la arquitectura japonesa, desarrolla una arquitectura en donde la riqueza arquitectónica no dependerá de la decoración aplicada, sino del adecuado uso del espacio y pone énfasis en querer “eliminar" los límites imprecisos entre interior y exterior (tal como se cita en Norberg Schulz, 2005):

Dejemos que las paredes, los techos y los suelos lleguen a ser no sólo partícipes en otros, sino partes unos de otros, afectándose y alterándose mutuamente; continuidad en todo (...) En vez de muchas cosas, una cosa. (p. 46)

De esta manera, la fluidez y la flexibilidad del espacio, responderá a las necesidades del usuario y al estudio de cómo se comporta el contexto (García, 2013, p. 10). Frank Lloyd Wright, buscaba principalmente en sus diseños, conseguir la indiferenciación del espacio de la casa con el jardín (Ver Figura 3.20). Estas cualidades espaciales se ven reflejadas en los voladizos, huecos continuos y la disolución habitaciones interiores por medio de pantallas murales, con la intención de orientar el espacio en vez de delimitarlo (García, 2013, p. 13). 
Figura 3.20

Apertura de la chimenea central en la Casa Robie (1910)

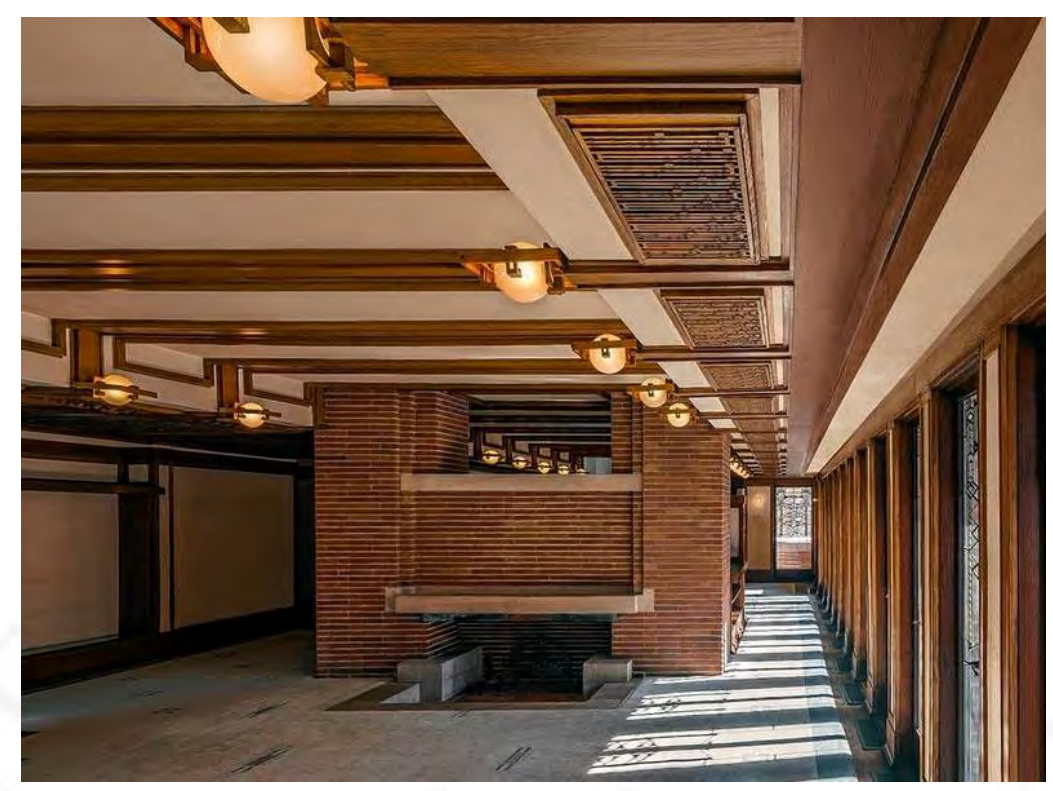

En: https://www.wsj.com/articles/frank-lloyd-wrights-robie-house-where-family-life-met-tragedy1452803482

Por otro lado, en la década de los años sesenta y setenta, surge una corriente a modo de entender el límite por la interconexión de elementos, que permiten deshacer jerarquías entre estructura y partes. Un claro ejemplo son las mega-estructuras de Yona Friedman o de Constant Nieuwenhuys ${ }^{11}$, basado en planteamientos situacionistas ${ }^{12}$, proponen un sistema de estructuras tridimensionales que se adaptan a las transformaciones de la sociedad, en donde la movilidad y la desorientación aumentan la interacción social (Ruiz, 2013, p. 26; Wigley, 1998, p. 14).

${ }^{11}$ Constant Nieuwenhuys (1920-2005). Artista holandés, fundador del grupo CoBra y perteneciente a la Internacional Situacionista (IS). Obra: New Babylon Nord (1971). Es el diseño de una ciudad utópica anticapitalista.

${ }^{12}$ Las propuestas situacionistas forman parte del urbanismo unitario, entendido como unión de todos los medios artísticos y extra-artísticos que intervienen en "una composición integral del medio" como pintura, cine, arquitectura, graffiti, iluminación, etc. Se trata de la construcción de situaciones o "construcción concreta de los ambientes momentáneos de la vida y su transformación en una cualidad afectiva superior", de forma que los situacionistas pretenden intervenir tanto en los elementos materiales que nos rodean como en los comportamientos de las personas. 
En "New Babylon" de Constant, se realizan una serie de maquetas, textos, grabados, acuarelas, collages, etc. (Ver Figura 3.21 y Figura 3.22) en donde el artista busca representar la futura "ciudad cubierta" con espacios de forma asimétrica e irregular que logran provocan una confusa definición del límite (Carrasco, 2005, p. 51).

La espacialidad es social. Los espacios como dimensión psíquica (espacio abstracto) no pueden separarse del espacio de acción (espacio concreto). Cada transformación del espacio, sin importar cuán pequeña, es entendida como una intervención directa en la vida social que desencadena una reacción de respuestas. Las nuevas formas de comportamiento evolucionan, solo para ser desafiadas por el siguiente movimiento espacial y así sucesivamente. (Wigley, 1998, p. 14).

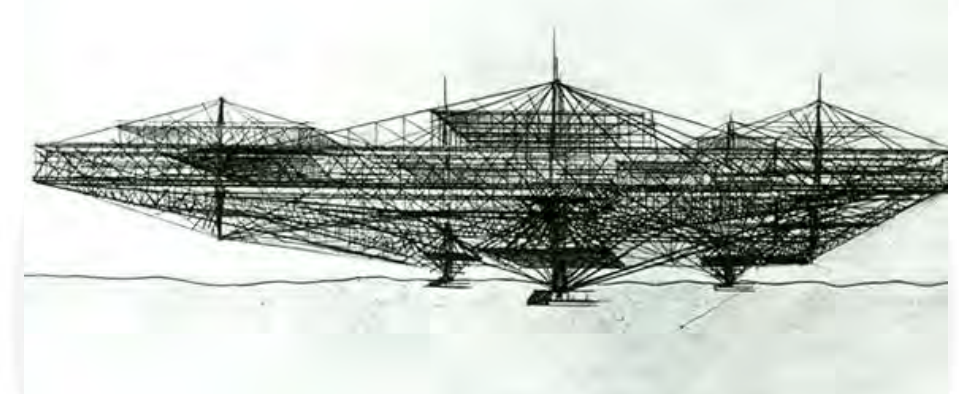

Figura 3.21 Bocetos de New Babylon de Constant

En: https://veredes.es/blog/en/constant-la-utopia-cobra-vida-miquel-lacasta-codorniu/

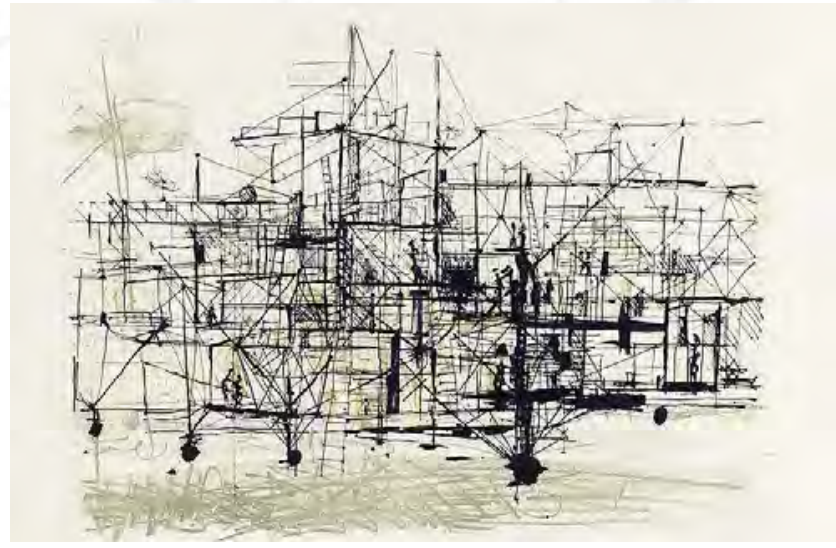

Figura 3.22 Relaciones espaciales al interior de New Babylon.

En:https://www.invaluable.com/auction-lot/new-babylon,-signed-lithograph-by-constant-156-c$766 \mathrm{~b} 9356 \mathrm{c} 6$ 


\subsubsection{Envolvente como membrana activa - Límite físico}

En la historia de la arquitectura, reconocidos arquitectos han opinado sobre la relación entre el interior y el exterior de una edificación a través del ornamento. Venturi en “Complejidad y contradicción de la arquitectura" afirma que no hay arquitectura sin contradicción y complejidad, de tal manera que, el envolvente arquitectónico, debe generar contraste del interior con el exterior, evitando reflejar externamente su riqueza espacial interna. De esta manera, Venturi propone proyectar desde el interior para luego dar forma a la configuración exterior, en donde se muestren las intenciones interiores. Asimismo, Van Eyck, hace referencia al uso de espacios intermedios entre la fachada y los espacios internos, que sirvan como articuladores y comunicadores de la actividad que se realiza en el interior, esto permita a su vez una mayor flexibilidad en el diseño de la fachada teniendo la posibilidad de otorgarle una profundidad y no algo meramente decorativo u ornamental.

La arquitectura debería concebirse como una configuración de lugares intermedios claramente definidos. Esto no implica una transformación continua o un aplazamiento interminable del lugar y la ocasión. Por el contrario, implica un rompimiento con el concepto contemporáneo (digamos enfermedad) de la continuidad espacial y la tendencia a borrar todas las articulaciones entre espacios, es decir, entre el exterior y el interior, entre un espacio y otro (entre una realidad y otra). En su lugar la transición debe articularse por medio de lugares intermedios definidos que permiten el conocimiento simultáneo de lo que es significativo al otro lado. Un espacio intermedio en este sentido proporciona el terreno común donde las polaridades conflictivas pueden ser fenómenos gemelos. (Van Eyck, 1962, p. 602)

Sin embargo, Farshid Moussavi (2008), recalca que el ornamento como envolvente, no es una fachada decorativa que se desentiende de los demás elementos arquitectónicos, sino que es aquel que los integra para producir afectos y sensaciones en los espectadores (p. 3). (Ver Figura 3.23) 

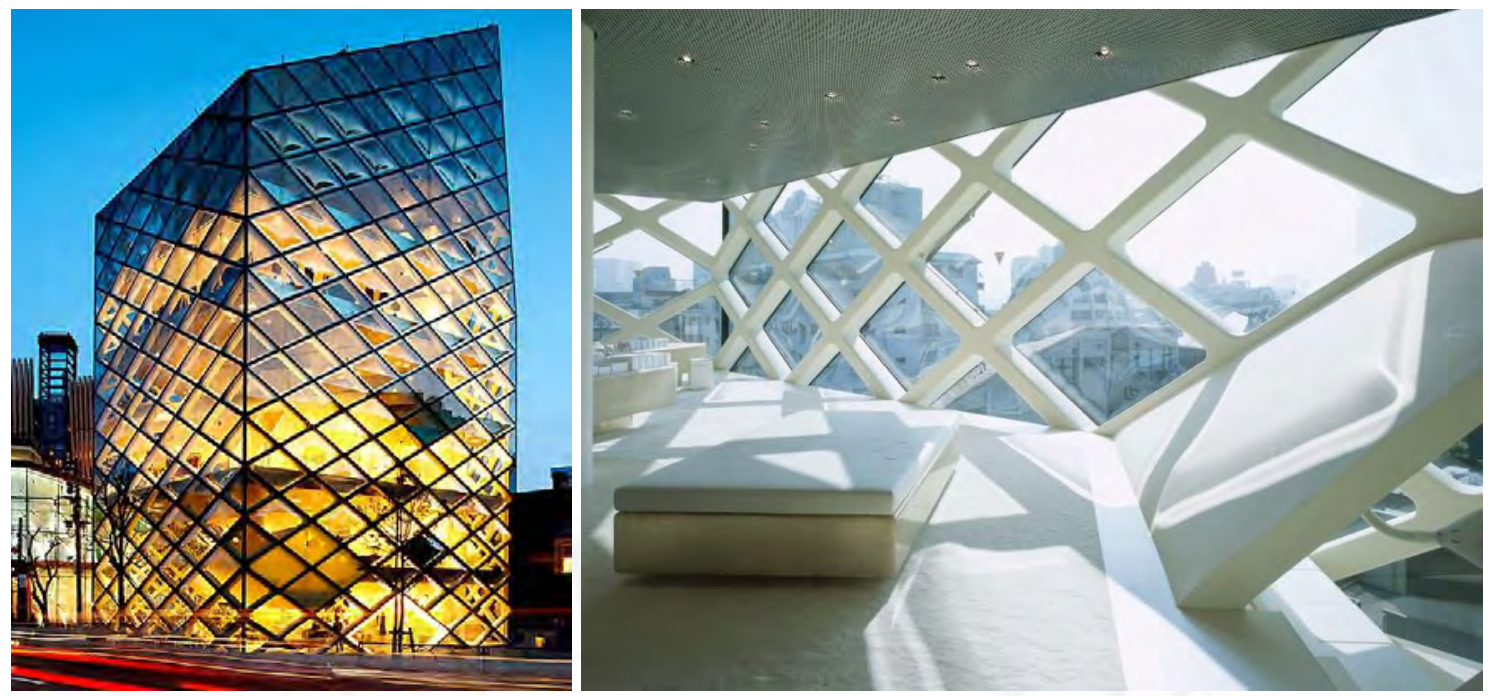

Figura 3.23 Fachada + estructura_Tiendra Prada en Tokio

En: https://floresnoasfaltoblog.files.wordpress.com/2014/12/5g8ns6cyb6t5d68z.jpeg (izquierda) http://www.prada.com/content/dam/prada/SPECIAL\%20PROJECTS/EPICENTERS/covertokyo.jpg/_jcr_content/renditions/cq5dam.web.1280.1280.jpeg (derecha)

Las pantallas perforadas, las plegaduras, serigrafías, cerámicos personalizados y pieles estructurales, son ejemplos de materiales ornamentales que se han incorporado durante el siglo XXI. Los nuevos sistemas constructivos incrementan las posibilidades de diferenciación y personalización, ya que "La interacción entre profundidad (forma, estructura, pantalla o superficie) y material (programa, imagen o color) dan origen al ornamento que transmite un afecto único en cada caso" (Moussavi \& Cubo, 2008, p. 5). Exactamente estas percepciones únicas logradas por los nuevos sistemas constructivos, son los mismos por los que Jeffrey Kipnis (1997) se maravilló de los proyectos realizados por los arquitectos Herzog \& De Meuron, diciendo:

Ya me había dado cuenta de la habilidad de su arquitectura para insinuarse dentro de mi psique era un poderoso efecto que, guste o no, debe ser considerado seriamente. Más aún cuando lo que sucedió fue que el trabajo de HdM no se introdujo en mí a la fuerza contra mi voluntad, en virtud de ninguna polémica; más bien se deslizó dentro de mi conciencia a través de mi voluntad, como un virus informático, eludiendo cualquier y toda resistencia al tiempo que empezaba a reprogramar mis pensamientos y sentimientos arquitectónicos. (p. 23) 
Por otro lado, Herzog y De Meuron (2002) sostienen que el ornamento está vivo al integrar el envolvente, el espacio y la cobertura, produciéndose una curiosa sensación de libertad que permite tener diferentes espacialidades a partir de lo alto - bajo, lejanía cercanía, oscuridad - claridad. (Ver Figura 3.24 y Figura 3.25). Sus diseños no solo muestran la complejidad de sus proyectos desde su interior, sino que también utilizan la "Arquitectura Cosmética", la cual, no solo es una herramienta decorativa, sino que combina la profundidad y materialidad, siendo más visceral que intelectual, más atmosférico que estético.
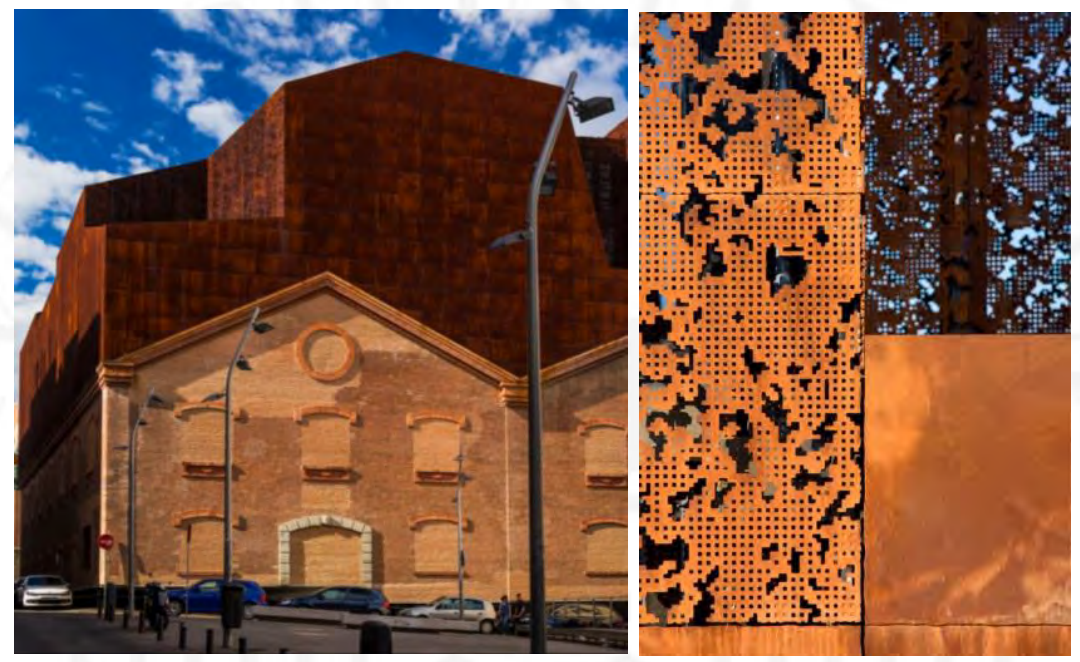

Figura 3.24 Fachada del Caixa Forum de HdM

En: https://www.cosasdearquitectos.com/wp-content/uploads/CaixaForum-Madrid-17.jpg (izquierda) https://i.pinimg.com/originals/b8/0d/7c/b80d7c0453e9a428065e00f03f4c4df8.jpg (derecha)
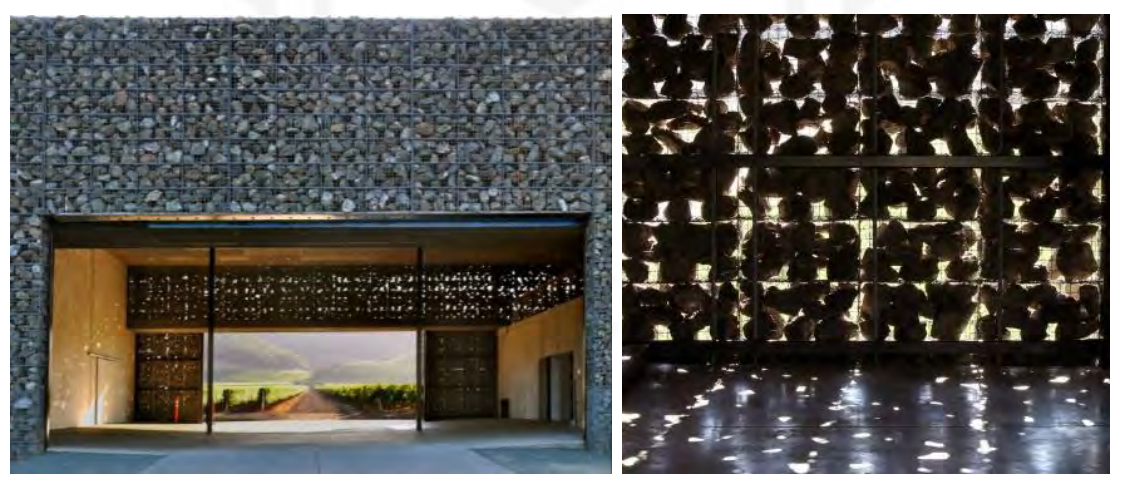

Figura 3.25 Fachada del Dominus Winery de HdM

En: https://i.pinimg.com/originals/aa/6c/1e/aa6cle78269645a46ea488642256c428.jpg (izquierda) http://www.dominusestate.com/wp-content/uploads/2015/03/winery-features-02.jpg (derecha) 


\subsubsection{Arquitectura de límites difusos (Toyo Ito)}

\subsubsection{Límite como espacio de interacciones sociales}

La liberación del plano vertical en la arquitectura contemporánea ha contribuido a la idea de la desmaterialización del límite, otorgando la posibilidad de considerarlo como un plano abierto al exterior, evitando el concepto de barrera y aceptando su condición como espacio de relación (García, 2013, p. 31). En este contexto, el arquitecto Toyo Ito, expresa su inquietud y preocupación acerca la rigidez que sufre la arquitectura pública y señala lo siguiente (como se citó en García, 2013):

No importa nada si el edificio tiene una expresión geométrica o si por el contrario adopta una expresión orgánica, con más pliegues, etc. Lo que en realidad me gustaría explicar es la duda que tengo respecto al límite de los edificios, que separa claramente el mundo exterior del interior. Es una duda hacia el modo de ser de la arquitectura, demasiado independiente y conclusa. (p. 32)

Critica la práctica en el diseño de aislar la arquitectura como piezas independientes, negando la relación que tiene el ser humano con todos los sistemas del exterior.

Es una realidad el hecho de que cuanto más encerrados vivimos más degradado permanece el exterior y más se deterioran nuestras relaciones sociales. El ser humano es social por naturaleza, arrebatarle esta condición sería negarle una parte fundamental de su razón de ser, o más justamente de su ser; mucho más perjudicial que, por ejemplo, el hecho de no conseguir unas condiciones térmicas óptimas. (García, 2013, p. 32)

\subsubsection{Arquitectura libre de límites espaciales}

Hoy en día, ante el constante cambio por medio de la globalización, la sociedad está buscando espacios flexibles, de manera que pueda adaptarse a diferentes tiempos y funciones. Es ante esta nueva necesidad que el arquitecto Toyo Ito desarrolla una arquitectura que gira entorno del hombre dándole énfasis en sus experiencias y libre organización (Ruiz, 2013, p. 73). 
Asimismo, la ligereza de la estructura y materiales están presentes para los diseños de límites difusos propuestos por Toyo Ito, además de la escala del edificio y las proporciones del espacio interno, de tal manera que, si la propuesta arquitectónica exige una gran altura, su efecto de esbeltez se consideraría en relación a la ramificación de sus elementos constructivos. Por otro lado, la transparencia es un aspecto clave, pues nos deja ver el interior del edificio mostrándonos como es el espacio y que actividades se desarrollan en él (García, 2013, p. 33).

Por ejemplo, en la biblioteca de la Universidad de Arte de Tama en Tokio (Ver Figura 3.26 y 3.27), el límite entre el edificio y el entorno es casi inexistente, como consecuencia del sistema estructural del edificio, compuesto por una "distribución de columnas que conforman una trama curvada e irregular, que permite cubrir grandes distancias con el mínimo número de apoyos" (Ruiz, 2013, p. 84). La permeabilidad de este edificio es lograda gracias a sus amplias arquerías que generan amplias visuales a través de todo el proyecto. Por lo tanto, se crea un edificio de gran apertura con una circulación continua y cuyo límite funciona más a manera de percepción que una presencia física.

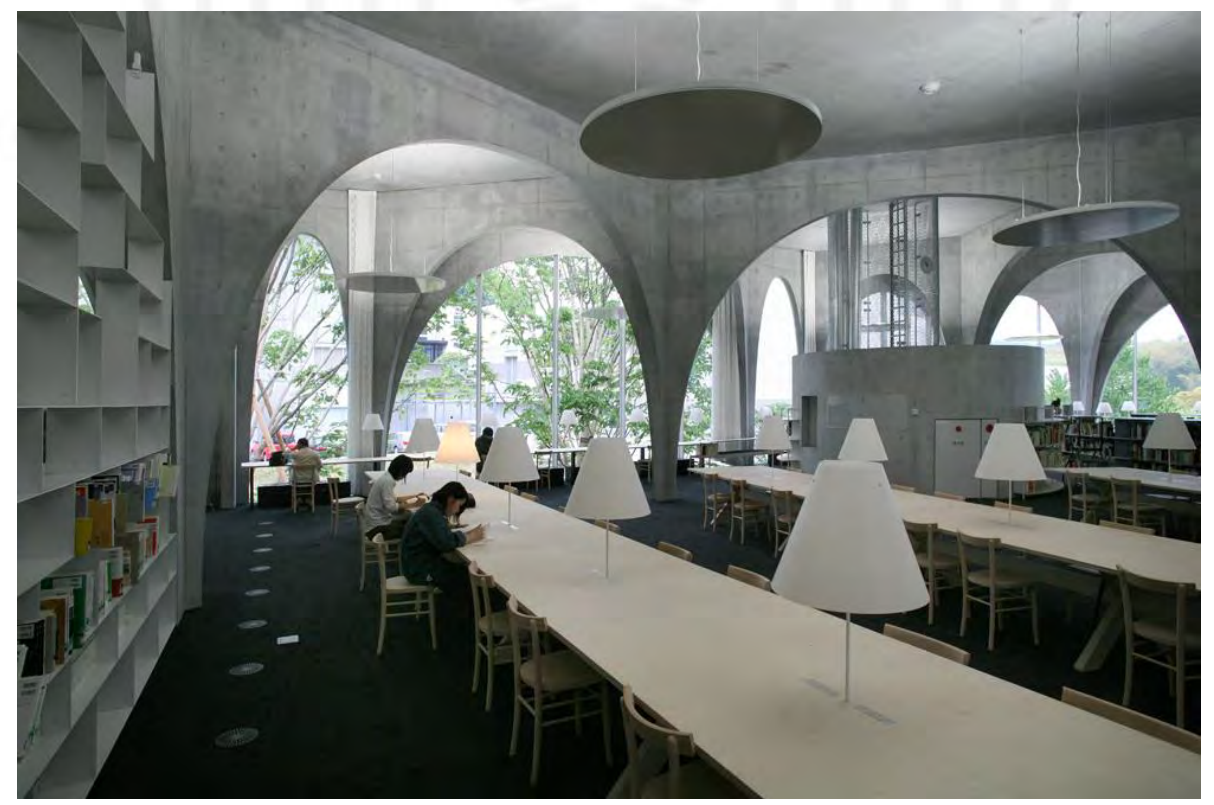

Figura 3.26 Interior de la biblioteca de la Universidad de Arte de Tama En: http://gastv.mx/wp-content/uploads/2014/06/estrellas225.jpg 


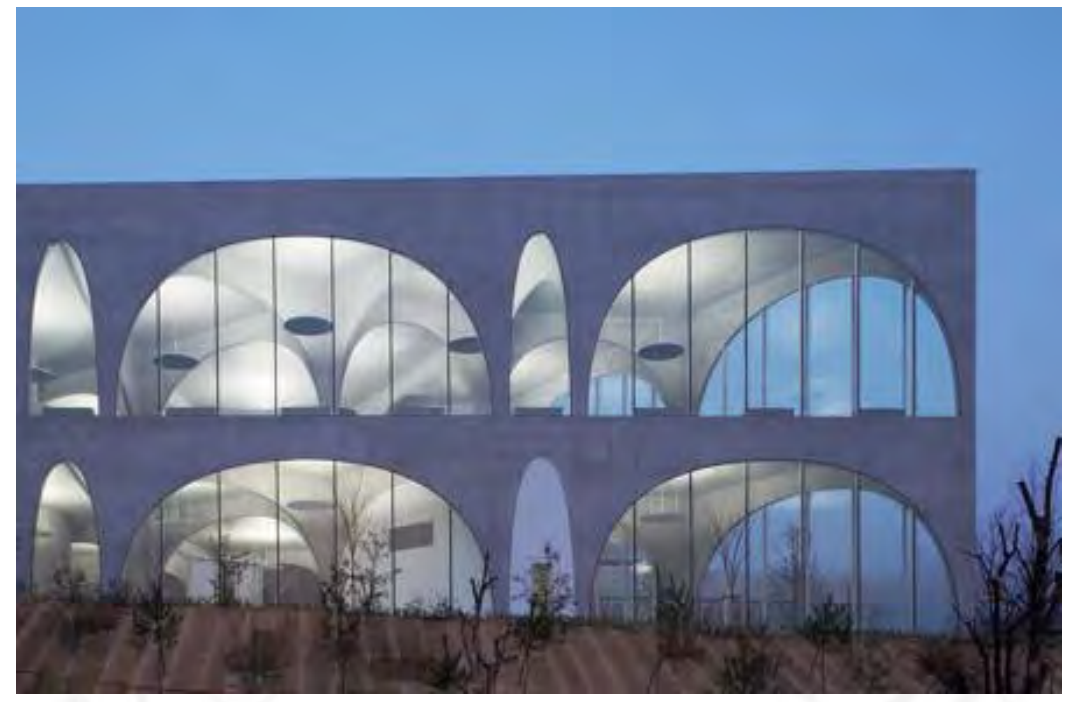

Figura 3.27 Fachada de la biblioteca de la Universidad de Arte de Tama En: https://es.wikiarquitectura.com/wp-content/uploads/2017/01/TAU_1.jpg

También las casas Silver Hut (1984) y la Magomezawa (1987) son dos de los proyectos que mejor representan la teoría de límite difuso, ya que correcto uso de materiales como mallas y entramados metálicos, permiten la conexión con el paisaje y la calle, logrando evidenciar el contexto exterior hacia el interior (Ver Figura 3.28 y 3.29).

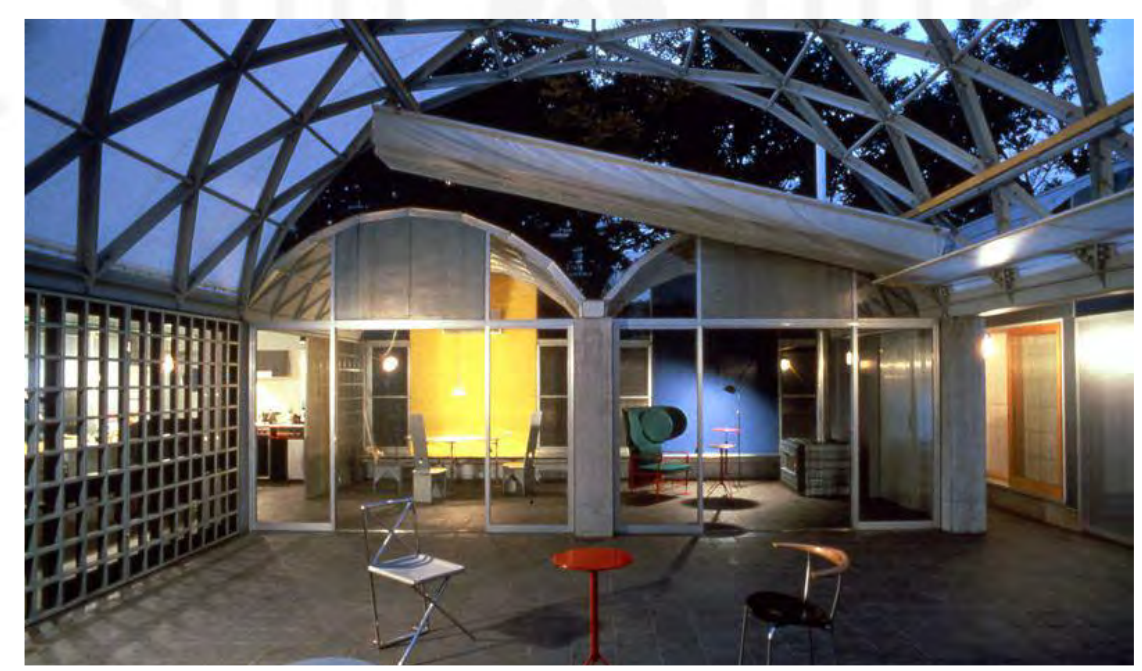

Figura 3.28 Interior de la Casa Silver Hut

Fuente: Martínez, 2013 


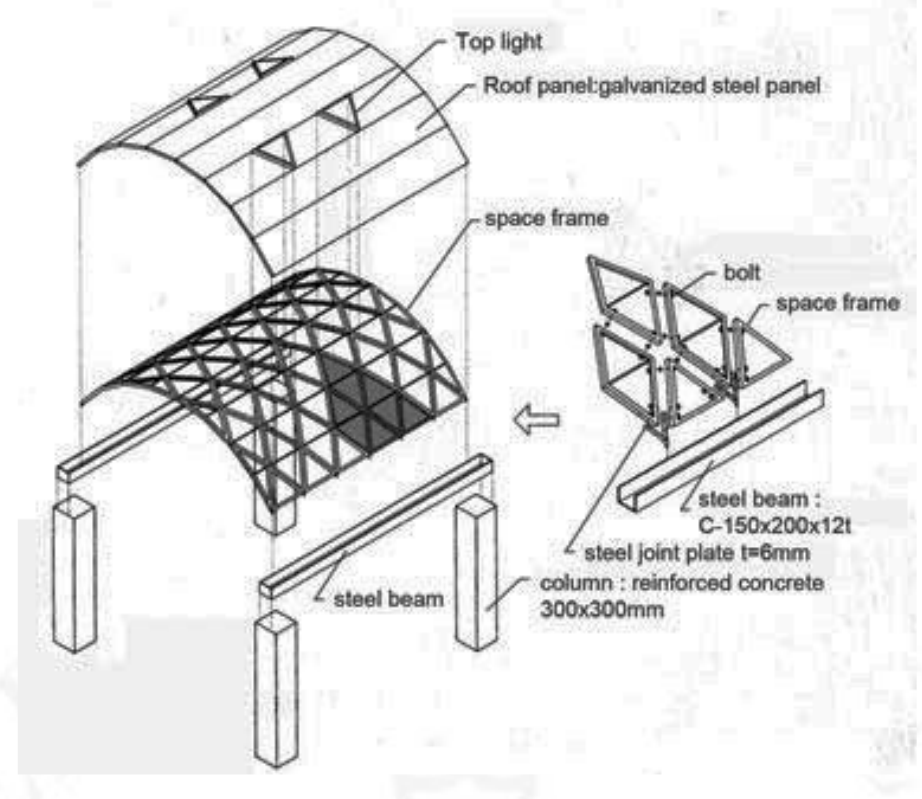

Figura 3.29 Axonometría constructiva de la Casa Silver Hut

Fuente: Martínez, 2013

Esta variable de ligereza puede partir también de un proceso de ocultación de la estructura pesada, como por ejemplo ocurre en el Caixa Fórum de Madrid diseñado por Herzog y De Meuron, donde la estructura se encuentra en los núcleos de circulación vertical y se apoya de forma perimetral en la "fachada trasera" (ver figura 3.30 y 3.31 ).

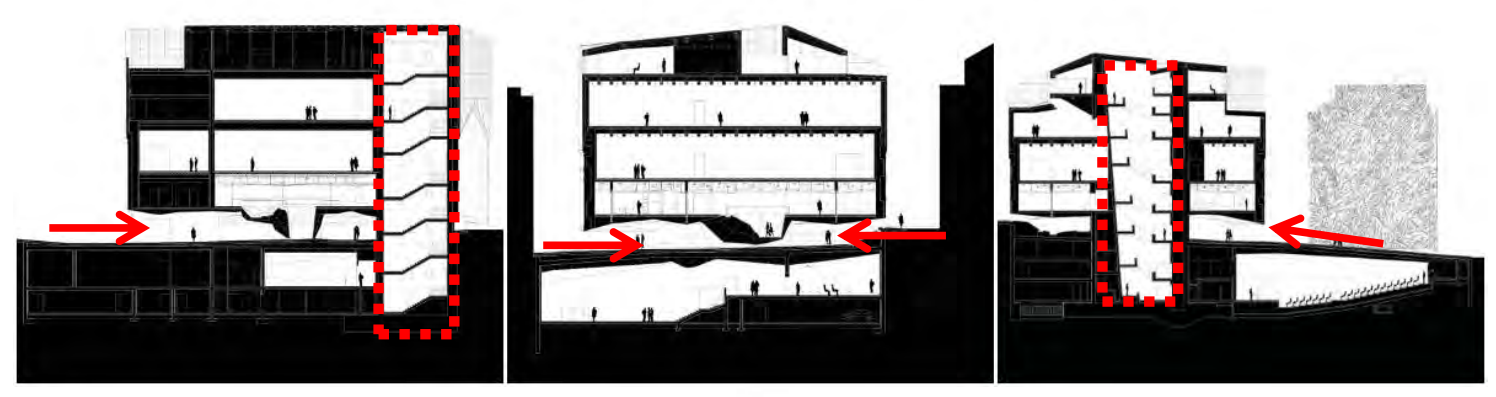

Figura 3.30 Cortes del Caixa Fórum.

Fuente: https://cienmilcuartos.files.wordpress.com/2013/10/collage-011.jpg 


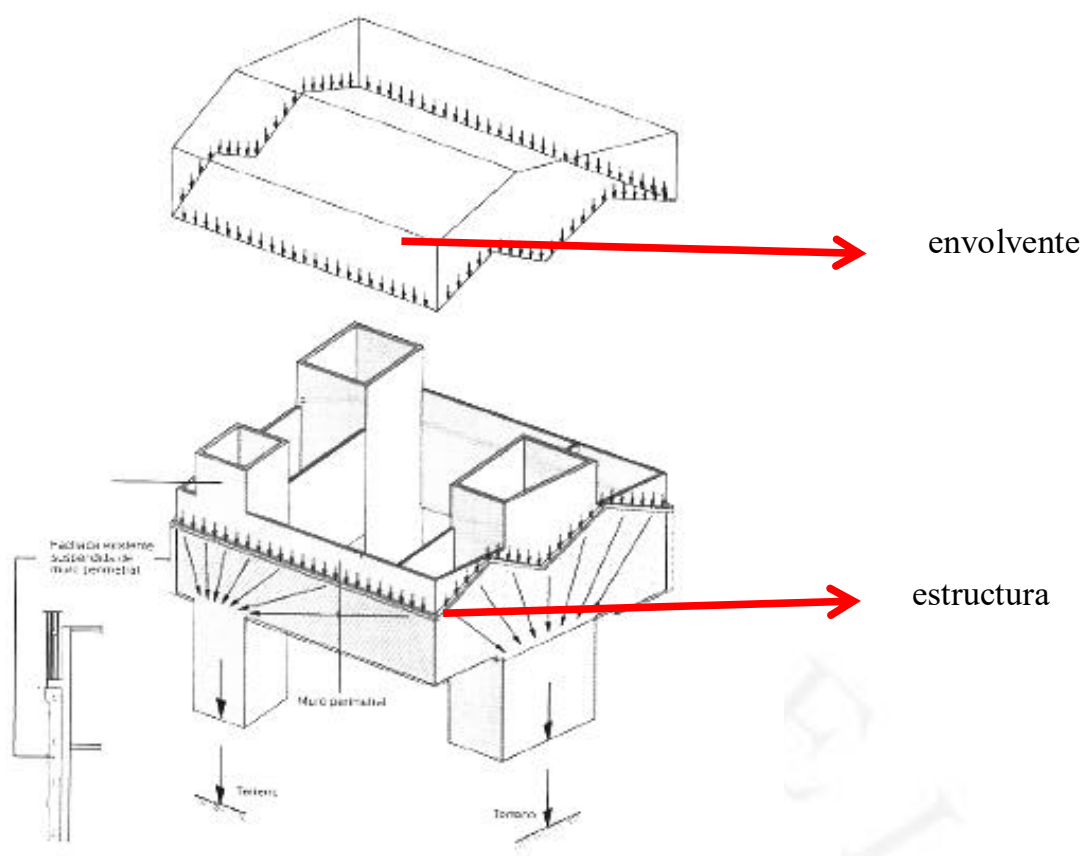

Figura 3.31 Axonometría estructural del Caixa Fórum

Fuente: https://circarq.files.wordpress.com/2013/10/caixaforum_esquema_estructural.png

\subsubsection{La inmaterialidad del límite en la arquitectura}

Toyo Ito plantea, que el significado y la condición de la palabra lugar han cambiado. Asimismo, sostiene, que el fenómeno de los desplazamientos en las ciudades ha provocado un comportamiento de tipo "nómada" en los ciudadanos (como se citó en Gámez, 2014):

Conforme aumentan los desplazamientos, en consecuencia y como es lógico, se acorta el tiempo de estancia de la gente en cada punto, aumentando en razón inversa el tiempo dedicado a desplazarse. (...) El destino se convierte en punto de paso y el desplazamiento viene a desempeñar el papel protagonista. (...) El desplazamiento ya no es el tiempo pasajero que se tarda entre puntos de un desplazamiento, sino que ha llegado a ser algo sumamente esencial e indispensable en la constitución de la sociedad informatizada. (p.103) 
Ante este cambio en las ciudades, el arquitecto argumenta, que los edificios de la ciudad ya no representan ser los puntos del destino y que, con el paso del tiempo, estos se han transformado en puntos de paso. Durante este periodo se apunta a la idea del uso del cristal como material en la fachada de tal manera que exista entre el programa arquitectónico y el programa urbano una transparencia que permita experimentar las nuevas actividades del edificio y del espacio exterior mientras se yuxtaponen y se viven simultáneamente (Gámez, 2014, p.103).

Esta virtud se define como la transición de materialidad, es decir, es la pérdida progresiva del material al superponer capas en la fachada del edificio, generando transiciones graduales de transparencia, con la finalidad de permitir al usuario percibir la “inmaterialidad". Por ejemplo, si tenemos un vidrio sin ningún objeto detrás, no entenderíamos su transparencia. De igual manera, las sucesiones de capas y su profundidad nos permiten entender la transparencia del material respecto al otro (García, 2013, p. 34). La arquitectura japonesa nos enseña que el espesor de los límites en una edificación, permite al usuario verse participe del disfrute de lo público, compartiendo un sentimiento de lo común, identidad y propiedad colectiva.

Un ejemplo de esta condición de transición material sucede en el edificio Cartier de Jean Nouvel (Ver Figura 3.32) pues la malla metálica colocada delante del vidrio a una distancia prudencial en la fachada, permite percibir la profundidad del vacío intersticial. La permeabilidad visual de la fachada también es importante en esta arquitectura, pues en este caso, el proceso de acercamiento del usuario al edificio es parte de la percepción de la inmaterialidad (Ver Figura 3.33). Asimismo, una correcta elección de apertura y espesor de la malla puede variar la percepción que se desea en el edificio, ya que una malla con huecos muy cerrados, a determinada distancia, puede opacar la fachada, sin embargo, una con huecos más espaciados, puede no percibirse. Finalmente, la fragmentación de elementos en la fachada también contribuye a la inmaterialidad, pues ayuda a perder la noción de la escala de la arquitectura. 


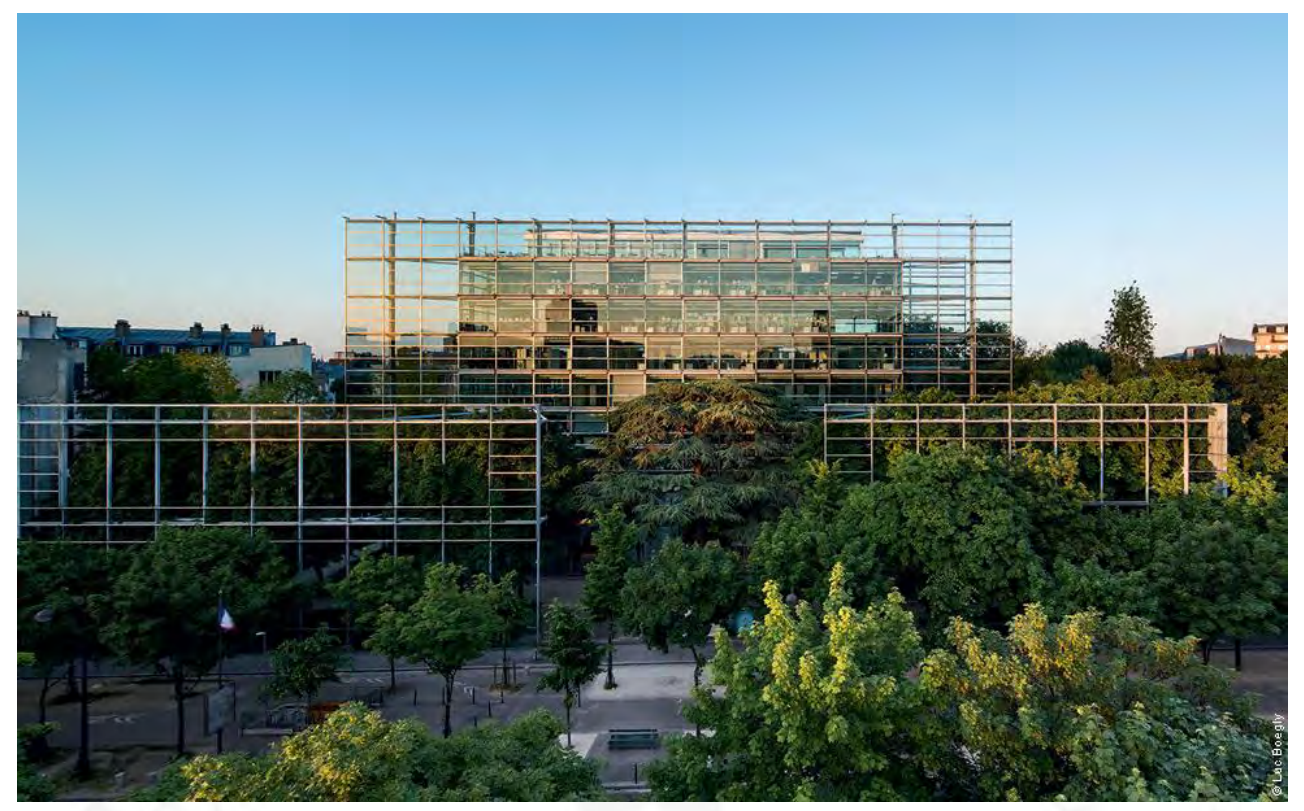

Figura 3.32 Fachada de la Fundación Cartier de Jean Nouvel

En:https://www.cartier.es/es/la-maison/compromisos/fondation-cartier-pour-lart-contemporain.html

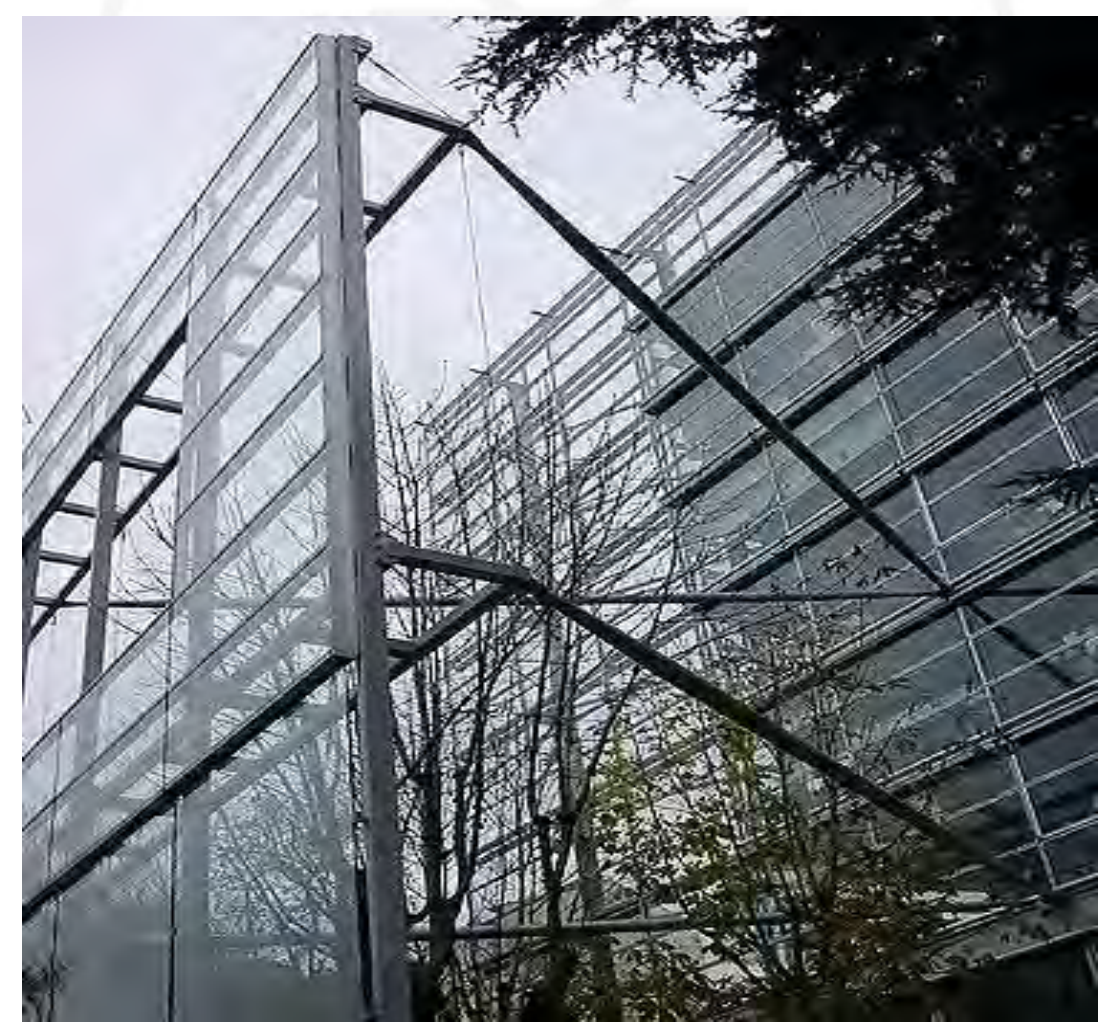

Figura 3.33 Superposición de capas en la fachada de la Fundación Cartier

En: https://c2.staticflickr.com/2/1428/1118560562_3165e8a7a0_z.jpg?zZ=1 


\subsection{Límite en los establecimientos comerciales en el Perú}

Tal como se describió anteriormente los limites en la arquitectura evolucionan con el paso del tiempo tanto en sus formas como en su materialidad, provocando el aislamiento de un espacio interno de su exterior o contrariamente a ello, integrándolo a su contexto. Sin embargo, en esta etapa de la investigación, aún queda la duda por saber qué características tienen y el funcionamiento de los límites arquitectónicos en el Perú, en especial los de carácter comercial. A continuación, se analizarán algunos proyectos comerciales peruanos que manifiestan de una mejor manera la cualidad del límite como umbral, espacio de transición y envolvente ligero y delgado.

Hacia 1945, los principios de la arquitectura moderna internacional comenzaron a ser plasmados en la arquitectura peruana y es así como desde el año 1945 hasta el año 1965, arquitectos peruanos influenciados por la arquitectura del siglo XX, empiezan a proyectar esta condición de "apertura" de la envolvente en sus proyectos, constituyendo un gran aporte para la arquitectura limeña de la época. Por ejemplo, edificio comercial "El Dorado" (1967), presenta un sistema estructural de pórticos y el uso del cristal como material en la fachada, logra visualizar la actividad desarrollada en el interior (Ver Figura 3.34).

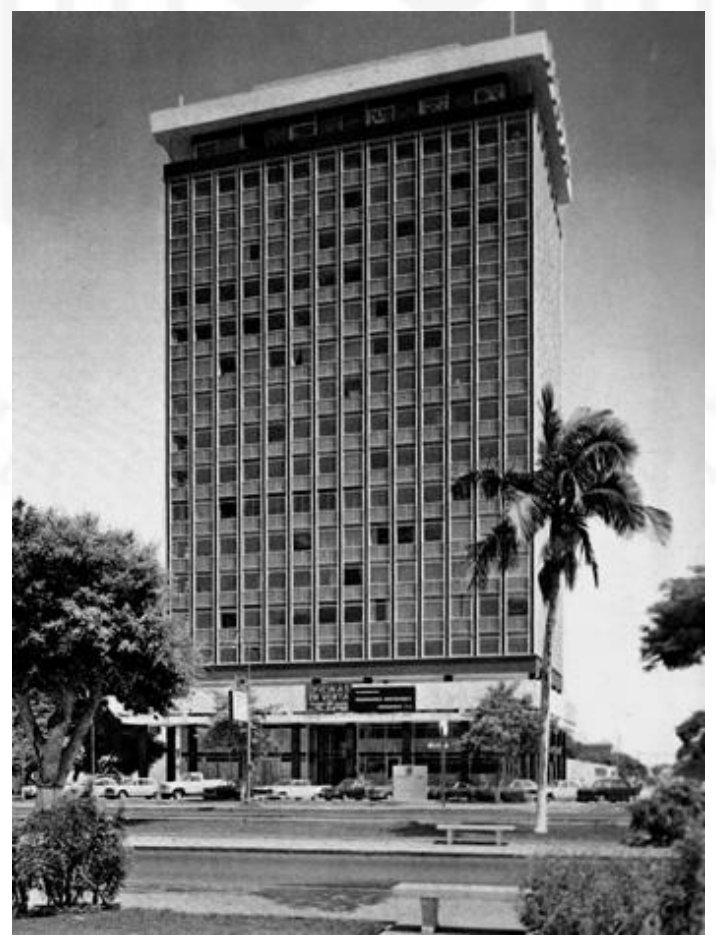

Figura 3.34 Fachada edificio comercial_El Dorado (Raúl Morey-1967)

En: http://cammp.ulima.edu.pe/edificios/edificio-comercial-el-dorado/ 
"Este armonioso conjunto de concreto, cristal y aluminio dorado, ofrece amplias áreas iluminadas con luz natural, con todos los ambientes al exterior. En la planta baja dispone de locales comerciales, y en el segundo piso existe una gran playa de estacionamiento" (Acevedo \& Llona, 2016). Además, presenta en la fachada frontal un pasaje porticado que funciona como espacio intermedio entre la calle y el ingreso al edificio (Ver Figura 3.35).

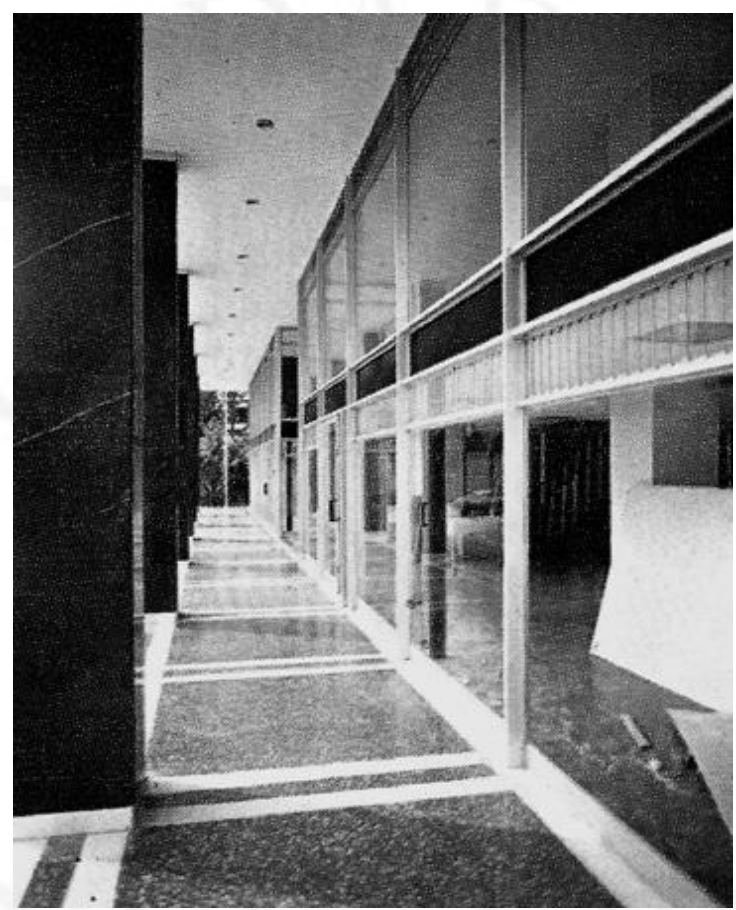

Figura 3.35 Límite del edificio comercial_El Dorado (Raúl Morey-1967)

En: http://cammp.ulima.edu.pe/edificios/edificio-comercial-el-dorado/

Asimismo, los edificios comerciales como Sociedad Mercantil en Limatambo (1959) y la tienda Ferrand y Cía (1960) también mantienen un límite transparente y liviano por el uso del cristal y el aluminio en sus fachadas. Además, presentan un límite virtual originado por los aleros en la parte superior en ambas fachadas que delimitan el ingreso principal del edificio sin necesidad de cerrar el espacio (Ver Figura 3.36).

Cada una de estas zonas es accesible a través de una entrada particular, por una amplia mampara de aluminio en la fachada, que por sus grandes ventanas le permite a toda la tienda convertirse en escaparate. (Acevedo \& Llona, 2016) 

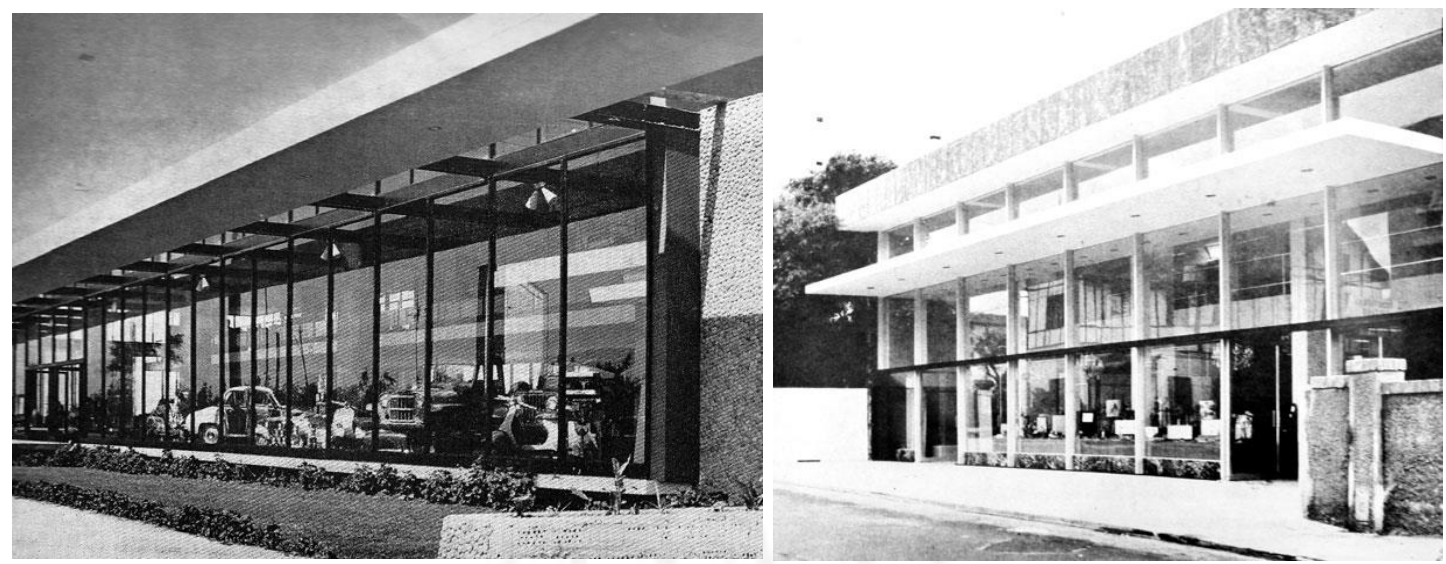

Figura 3.36 Comparación_Sociedad Mercantil vs Tienda Ferrand y Cia

Local de la Sociedad Mercantil en Limatambo (izquierda) y Tienda Ferrand y Cia (derecha)

En (izquierda): http:/cammp.ulima.edu.pe/edificios/local-sociedad-mercantil-en-limatambo/

En (derecha): http://cammp.ulima.edu.pe/edificios/tienda-ferrand-y-cia/

Por ejemplo, durante la época del prehispánico, las esquinas de las plazas y calles de anchas vías eran los principales medios para el desarrollo la actividad mercantil de la ciudad. Los vendedores se ubicaban detrás de sus productos que iban colocando en filas y montoncillos, de manera que no tapaban sus productos y los exhibían durante el intercambio (Ver Figura 3.37). Por lo tanto, se puede afirmar que el límite entre ofertante y estaba dado por el mismo espacio que ocupada el producto y esta variaba. un límite no visible, ni estable pero dinámico, ya que mutaba de acuerdo a la ubicación del mobiliario en el espacio.

Con el paso del tiempo, el mercado comienza a delimitarse al situarse en un espacio ya definido e importante, en la plaza mayor, que posteriormente llevara el apelativo de "tiánguez" ${ }^{13} \mathrm{o}$ "Catú". Era un espacio abierto, rodeado de edificios públicos, con mesas de mercachifles, tenderetes y tendejones de madera que iban instalados en los portales y lado oeste de la plaza. Empiezan a colocarse los productos sobre mesas o

\footnotetext{
${ }^{13}$ El apelativo de "tianguez" tiene su origen en la palabra náhuatl tianquiztli, que significaba mercado ferial. Fue traída al Perú por los conquistadores españoles. En cuanto catu según el Lexicon o Vocabulario de la Lengua General del Perú de Fray Domingo de Santo Tomás (Valladolid, 1560) catu (en plural catucona), es el "mercado, lugar donde se merca”. Diego González Holguín, en su Vocabulario de la Lengua General de todo el Perú, llamada Lengua Quichua o del Inca (Lima, 1608) define el katu como "mercado de cosas de comer"
} 
tablones de manera para exhibir de mejor manera su producto. "La venta de productos en mesas improvisadas, cestos en el suelo y platones con alimentos ofrecidos al paso, continuaba bien entrado el siglo XIX” (Negro, 2009, pág. 12). (Ver Figura 3.38)
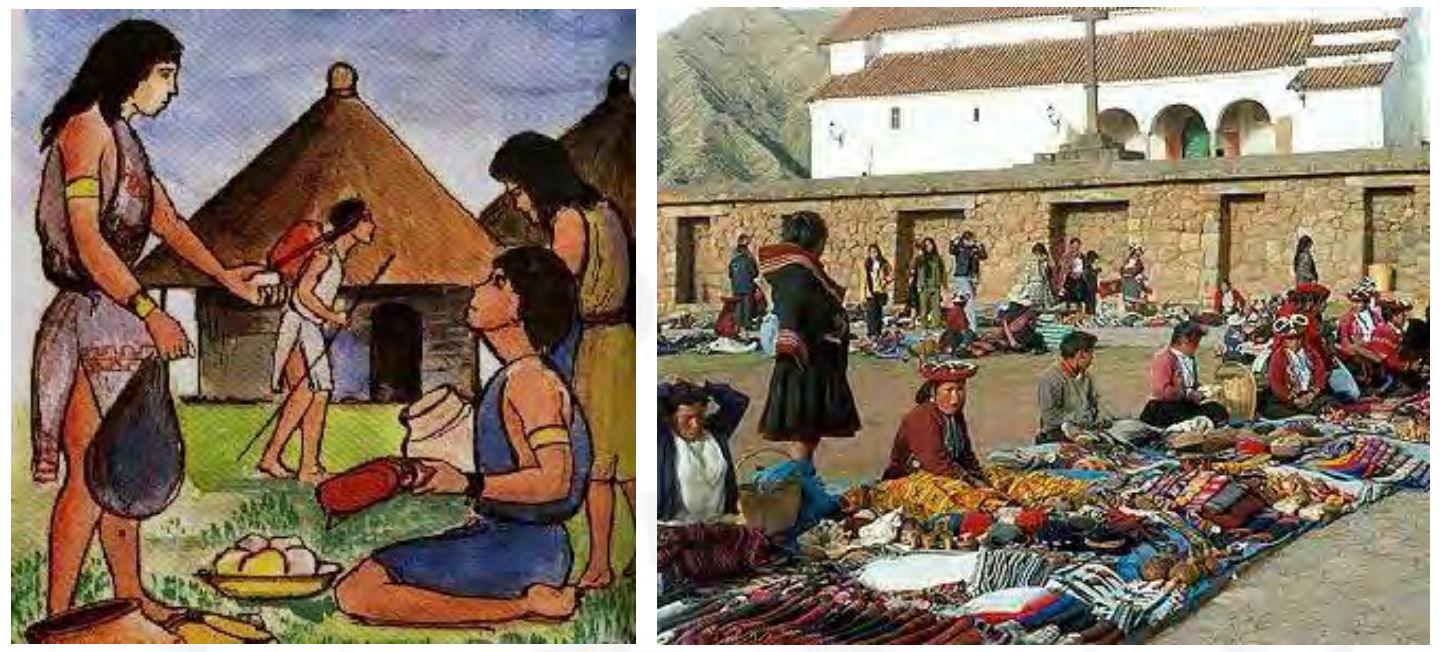

Figura 3.37 Intercambio comercial y Mercado de Chincheros

En: https://www.sutori.com/story/los-periodos-de-la-prehistoria--nnfAapH6fdpRNdTZzT6pkhAu y https://www.go2peru.com/spa/guia_viajes/cuzco/alrededor_cuzco.htm

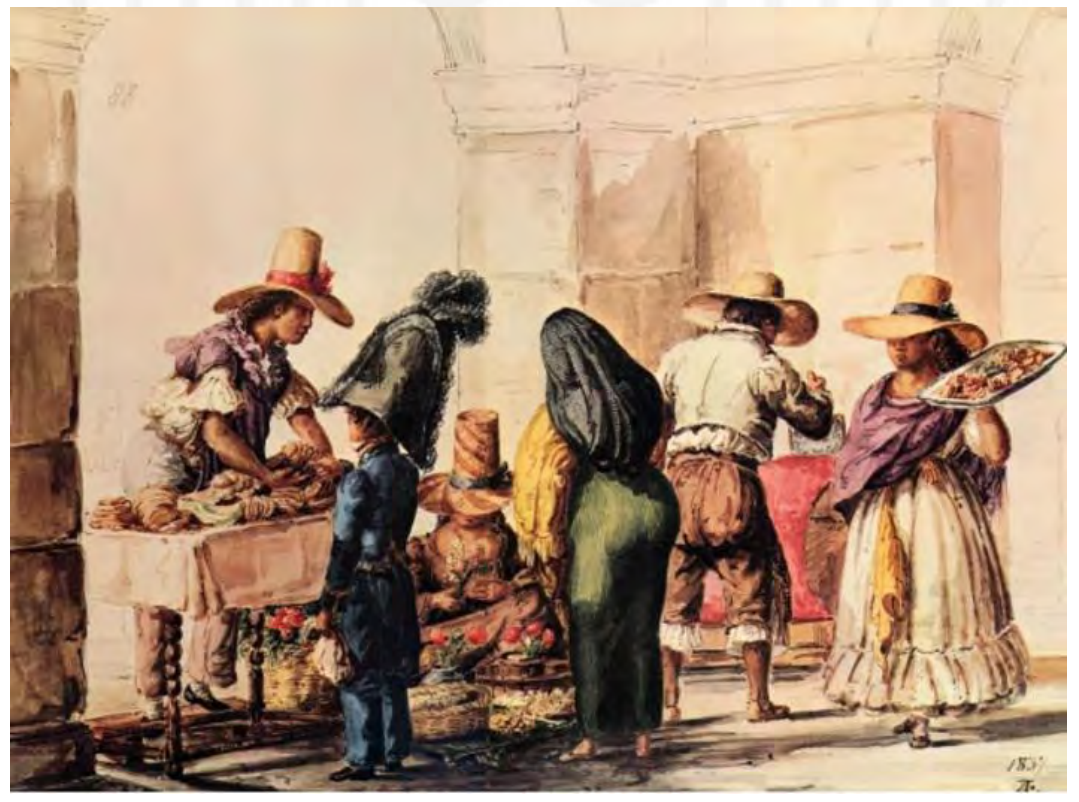

Figura 3.38 Actividad comercial en la Plaza Mayor

Fuente: Acuarela de Leonce Angrand_ 1837

En: https://cicopperu.files.wordpress.com/2015/10/plaza-mayor-de-lima-ocaso-de-un-simbolo.pdf 
Por lo tanto, los edificios que rodean la plaza, así como también el mobiliario para la venta y compra de productos del mismo mercado ayudan a definir el límite del espacio del mercado de manera más "virtual" y desordenado pero que no es ajeno a su entorno, pues necesita de este para llevarse a cabo.

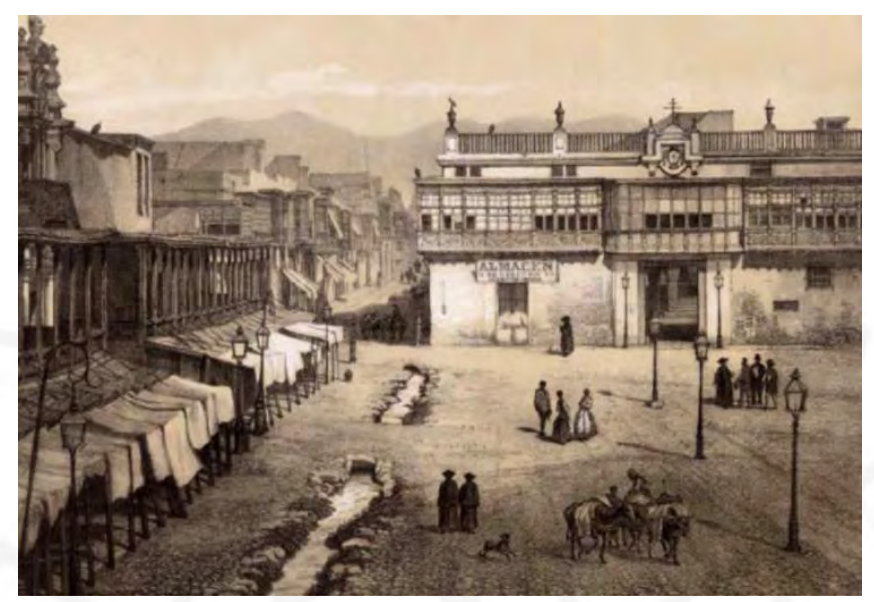

Figura 3.39 Cajones y tenderetes comerciales de 1865

En:https://cicopperu.files.wordpress.com/2015/10/plaza-mayor-de-lima-ocaso-de-un-simbolo.pdf

Sin embargo, con la independencia del Perú en 1821 el espacio para el mercado cambia definitivamente de aspecto, distribución espacial y funcionamiento con la finalidad de ordenar el comercio ambulatorio. Este pasa de un espacio abierto a uno cerrado dentro de la trama urbana de la ciudad, apartándola de los espacios públicos abiertos para que cumpla con los estándares de higiene y salubridad (Negro, 2009, p. 20).

Es así como surge el primer mercado de la ciudad, el Mercado Central de Lima, que, a pesar de ser construido en 1967, no presenta las mismas características que los edificios comerciales de la época moderna, pues contiene en su perímetro módulos de venta que inicialmente funcionaban como depósitos de los productos que se ofertaban en las calles. Sin embargo, luego de desplazar el comercio de la calle al interior del equipamiento, las tiendas ubicadas como fachada en el exterior del edificio comienzan a funcionar como barreras, negándole a la actividad del mercado del interior su relación directa con el entorno. Por otro lado, su accesibilidad comienza a limitarse, ya que en los $13000 \mathrm{~m} 2$ que tiene el mercado, solo cuenta con un ingreso en cada una de sus cuatro fachadas. 

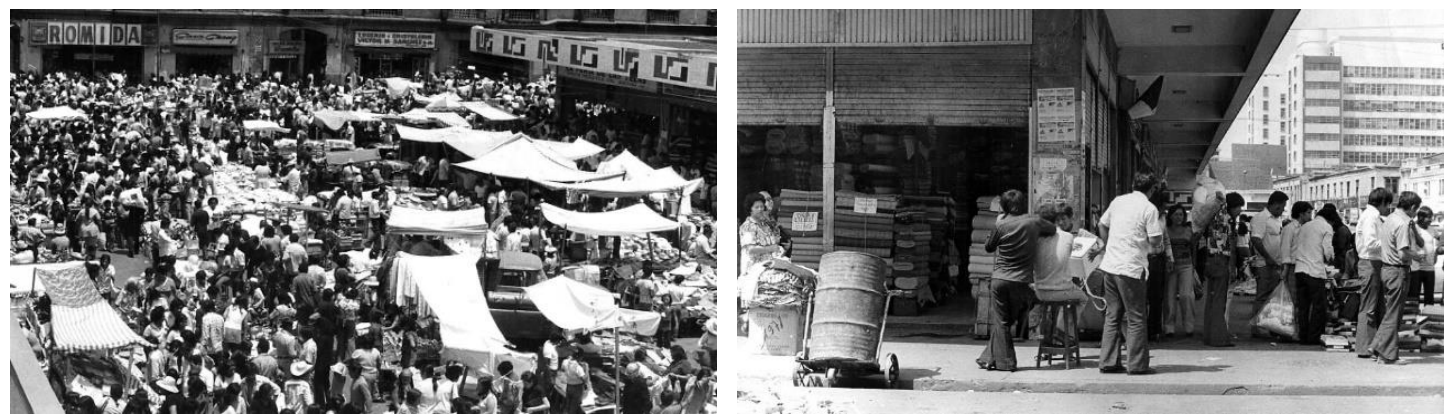

Figura 3.40 Actividad comercial al exterior del Mercado Central de Lima

En:https://elcomercio.pe/somos/mercado-central-cumple-50-anos-imagenes-ineditas-inauguracion-fotos441511 ? foto $=8$

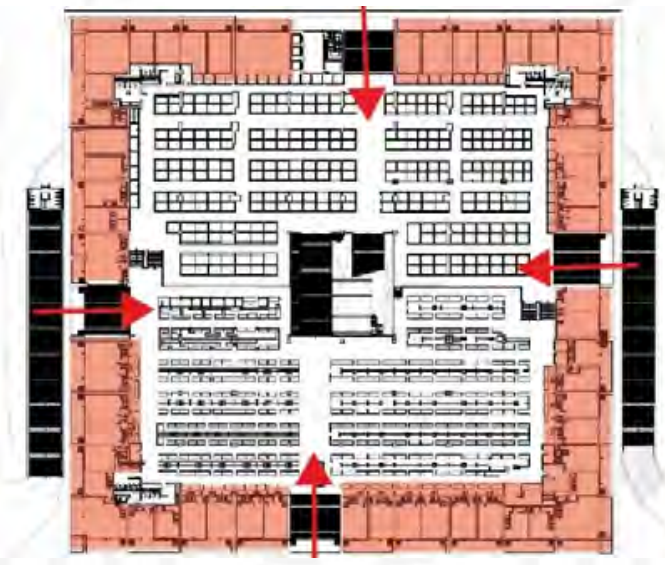

Figura 3.41 Primera planta_Mercado Central de Lima Gráfico elaborado por los autores

Un caso similar, es el mercado $\mathrm{N}^{\circ} 1$ de Surquillo construido en 1937 , que, a pesar de contar con una fachada más permeable con cinco ingresos, dos en su fachada principal con frente a la Av. Paseo de la Republica y tres ingresos en su fachada lateral con frente a la calle peatonal Narcizo de la Colina, cuenta también con un el límite compuesto por módulos de venta que dificultan la visual de la actividad comercial desarrollada al interior del mercado (Ver figura 3.42, 3.43 y 3.44 ). 


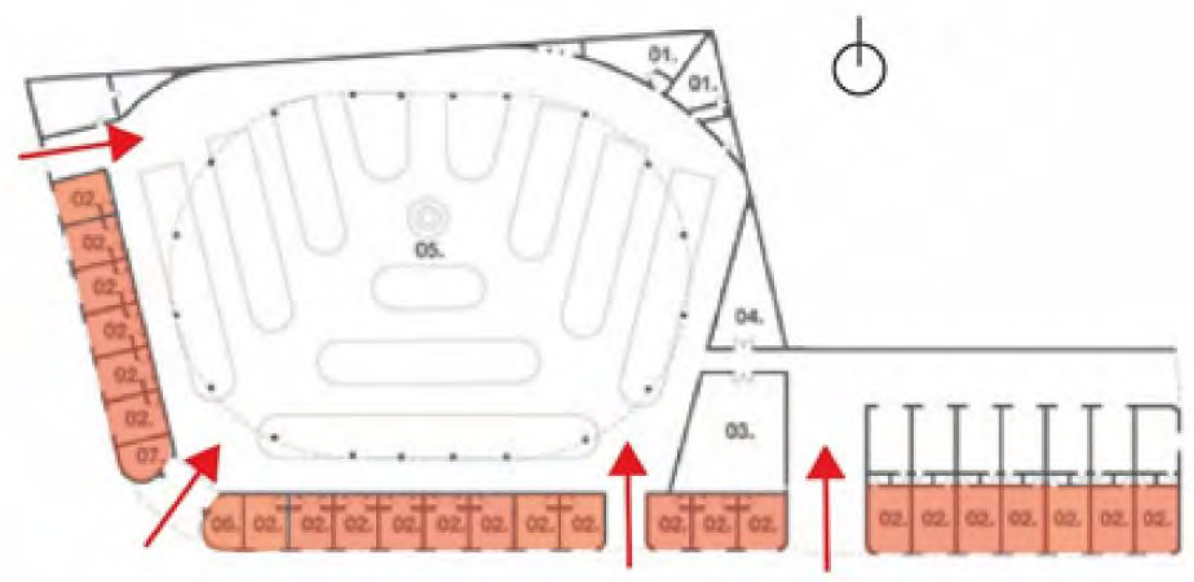

Figura 3.42 Primera planta_Mercado $\mathrm{N}^{\circ} 1$ de Surquillo

En: http://cammp.ulima.edu.pe/edificios/mercado-de-surquillo-2/

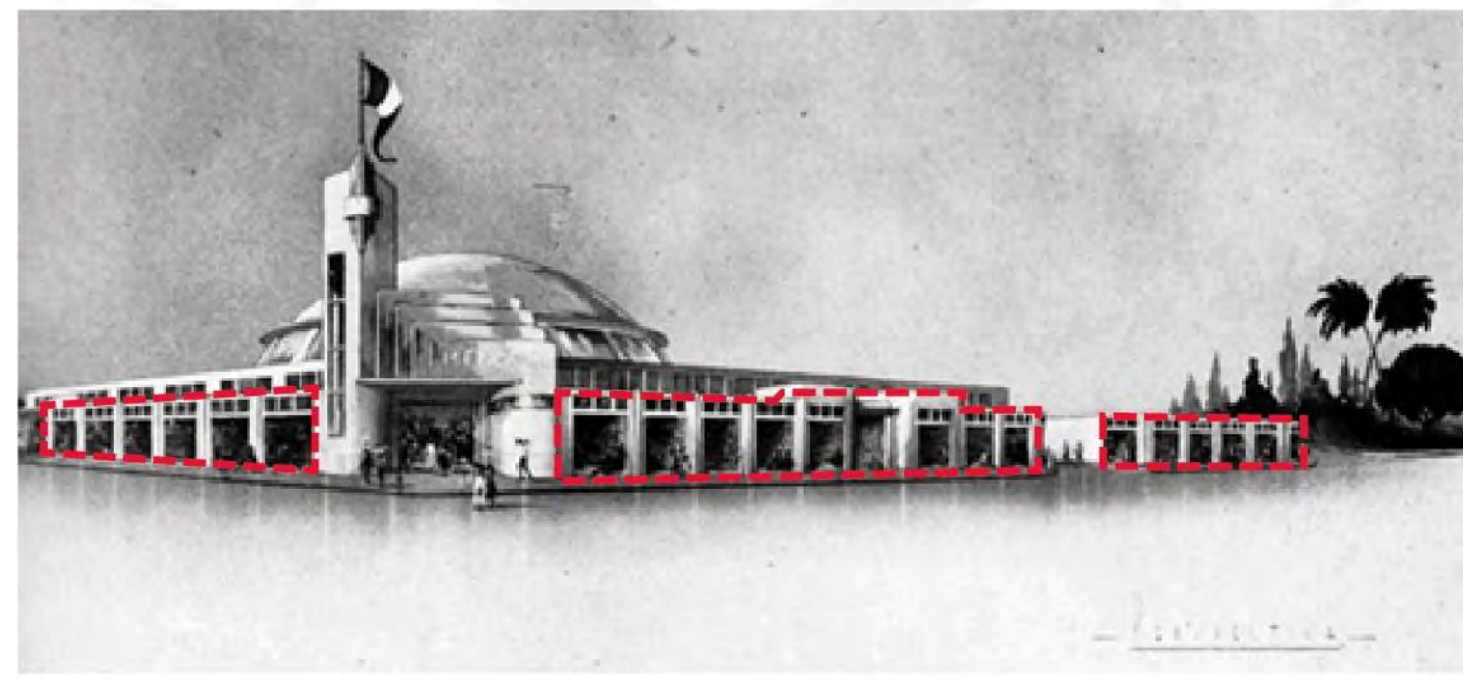

Figura 3.43 Fachada del Mercado $\mathrm{N}^{\circ} 1$ de Surquillo

En: http://cammp.ulima.edu.pe/edificios/mercado-de-surquillo-2/ 


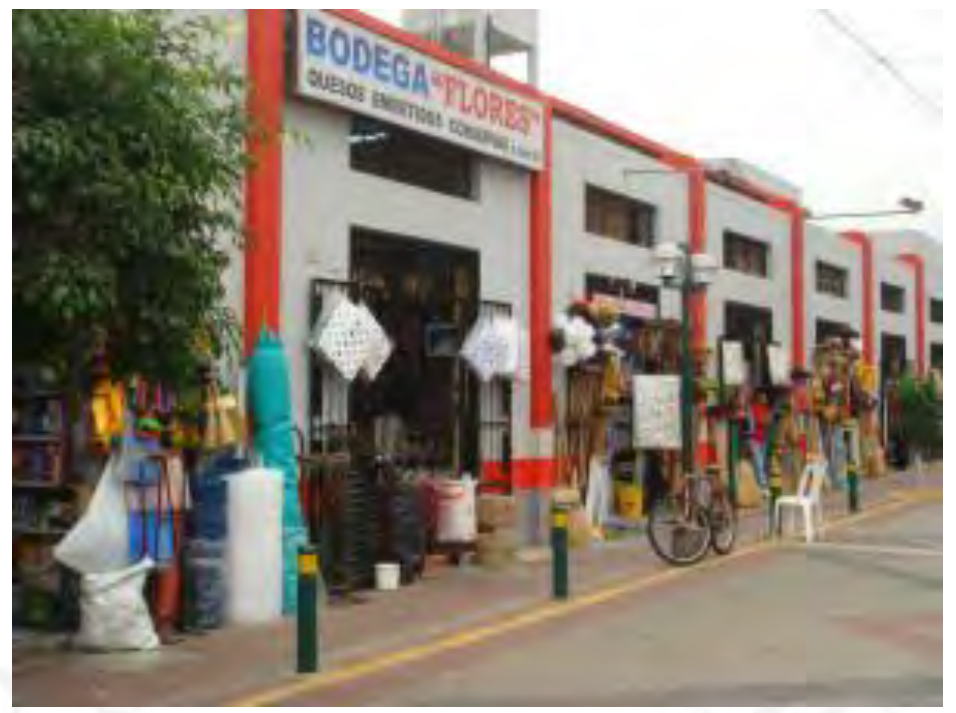

Figura 3.44 Puestos de venta en fachada_Mercado Nº1 de Surquillo

En:https://karencitadeperu.wordpress.com/2010/05/10/the-market-in-surquillo-el-mercado-en-surquillo/

Por lo tanto, habiendo analizado la evolución del espacio comercial y la de los mercados tomando en cuenta los ejemplos del mercado central de Lima y $\mathrm{N}^{\circ} 1$ de Surquillo, podemos concluir que el espacio mercantil siempre ha estado definido por un límite dinámico, ya que en muchas ocasiones el mismo producto era el que delimitaba y dividía el espacio entre los pobladores durante el trueque.

Asimismo, durante la época colonial y tres siglos posteriores, el mercado forma parte del espacio público principal de la ciudad y su límite, a pesar de seguir siendo dinámico, comienza a desordenarse por la falta de control y excesivos puestos en el lugar como los tendejones y tenderetes del tianguis. Asimismo, la falta de higiene y salubridad en la plaza del mercado, obliga a llevar la actividad mercantil a un espacio contenido y cerrado, cuyo límite estará definido por la cobertura del equipamiento que será el protagonista del diseño ya que se encargada de la ventilación y protección de los productos sobre todo perecederos que albergará el mercado. Sin embargo, esta nueva forma de comercialización en el espacio, llevara a la actividad mercantil a desligarse de su entorno, con puestos de venta en el perímetro, muros ciegos o estacionamientos para vehículos privados, negando la función tan pública que siempre tuvo el mercado con los pobladores y con su entorno. 


\subsection{Mercados como nuevos exponentes turísticos}

\subsubsection{Nuevas experiencias para la cultura del consumo}

La arquitectura dista mucho de ser solo el oficio artesanal de construir casas y edificios en la ciudad, pues cada hecho construido es a su modo, la respuesta de ideales sociales, morales y éticos, establecidos en comunidad a través de la historia. Cada edificio construido, se representa como un dispositivo de identidad colectiva, donde se representa la cultura en sí misma (Simone, 2009, p. 2). Así, la construcción y diseño del espacio deberá ser algo significativo, tanto de manera individual, en la construcción de identidad personal y reconocimiento propio del entorno, en torno a la civilización vinculada a una cultura.

El consumo de bienes y servicios en nuestra sociedad, tiene un significado y una función que va más allá de las necesidades básicas de abastecimiento, pues el acto de compra forma parte de procesos psicológicos complejos que ayudan a la creación y confrontación de la identidad del ser humano (Simone, 2009, p. 3). A través de la compra; estilos, códigos y valores, son asimilados por las personas en una producción activa y comprometida de la relación ser-sociedad. Por lo tanto, los espacios comerciales como los mercados de abastos, no son solo lugares para el intercambio de bienes entre productores y consumidores, o son solo símbolo de infraestructura económica, también representan la cultura del consumo del ser humano de la época.

\subsubsection{Calidad espacial para desarrollar buenas experiencias}

\subsubsection{Condiciones espaciales de los sentidos humanos}

Sin embargo, en un mundo globalizado, donde la homogeneización forma parte de la cotidianeidad, construir nuevas experiencias, son los acontecimientos más buscados hoy en día por parte de los consumidores. Estas nuevas experiencias son entendidas como situaciones personales, con un significado emocional importante y que se fundamentan en la interacción de los estímulos (Gomes, de Azevedo, y Gomes, 2013, p. 344). Debido a ello, en las técnicas del marketing moderno, se utiliza al neuro-marketing como estrategia para mejorar el comportamiento de compra, el cual, apoyado en la neurociencia, tiene como objetivo poder entender mejor el proceso del cerebro al momento de la toma de decisiones ya que muchas surgen de manera subjetiva, a través 
del sentido de la vista. En otras palabras, "la imagen visual comunica y evoca emociones por lo cual contribuye enormemente a la respuesta que los usuarios tienen ante un producto o servicio" (Elguera Chumpitazi, 2017, pág. 19). Por lo tanto, para poder comprender mejor esta comunicación no verbal, existente en las imágenes de los productos y en los espacios comerciales, Bruno Munari (1983) nos explica con mayor detalle su clasificación, la casual y la intencional. La primera, se presenta de manera natural y $\sin$ alteraciones; mientras que la segunda, se da a través del diseño arquitectónico y la atmosfera, que tendrán como objetivo comunicar o desarrollar una experiencia sensorial agradable y motivadora (pp. 79-82). (Ver Figura 3.45)

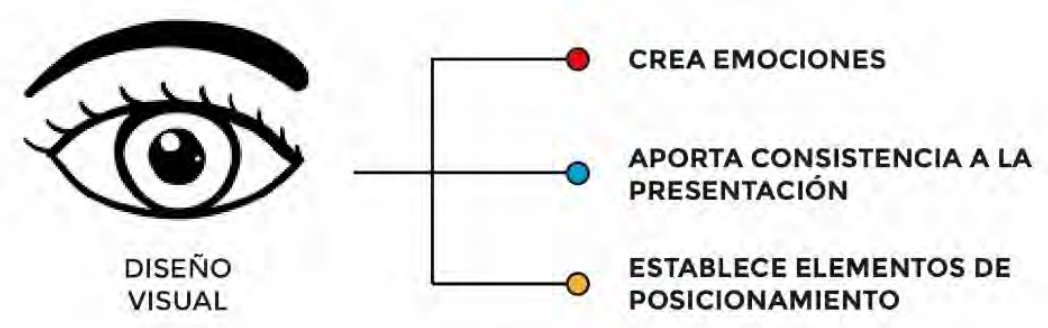

Figura 3.45 Aportes del diseño visual Gráfico realizado por los autores.

Complementando con esta teoría, Gehl (1971) asegura que el estudio de los sentidos humanos y las dimensiones de sus condiciones espaciales, ayudan a comprenden mejor la percepción humana y hacer recordar buenas experiencias. Por ejemplo, cuando se camina por la calle, el eje del ojo humano se dirige aproximadamente diez grados hacia abajo para no tropezar, es decir, una persona cuando camina no ve prácticamente nada más que el suelo y lo que está pasando en su alrededor. Por lo tanto, los eventos que deseen ser percibidos, deberán tener lugar frente al espectador y aproximadamente a su mismo nivel (p.63). Por ello, con el propósito de analizar las posibilidades y limitaciones de los sentidos humanos, Gehl, menciona cinco variables que ayudarán a promover o prevenir el contacto entre personas. Estas se medirán dependiendo de determinadas características del espacio como: la accesibilidad, la permeabilidad, la distancia, entre otras (Ver Figura 3.46). 


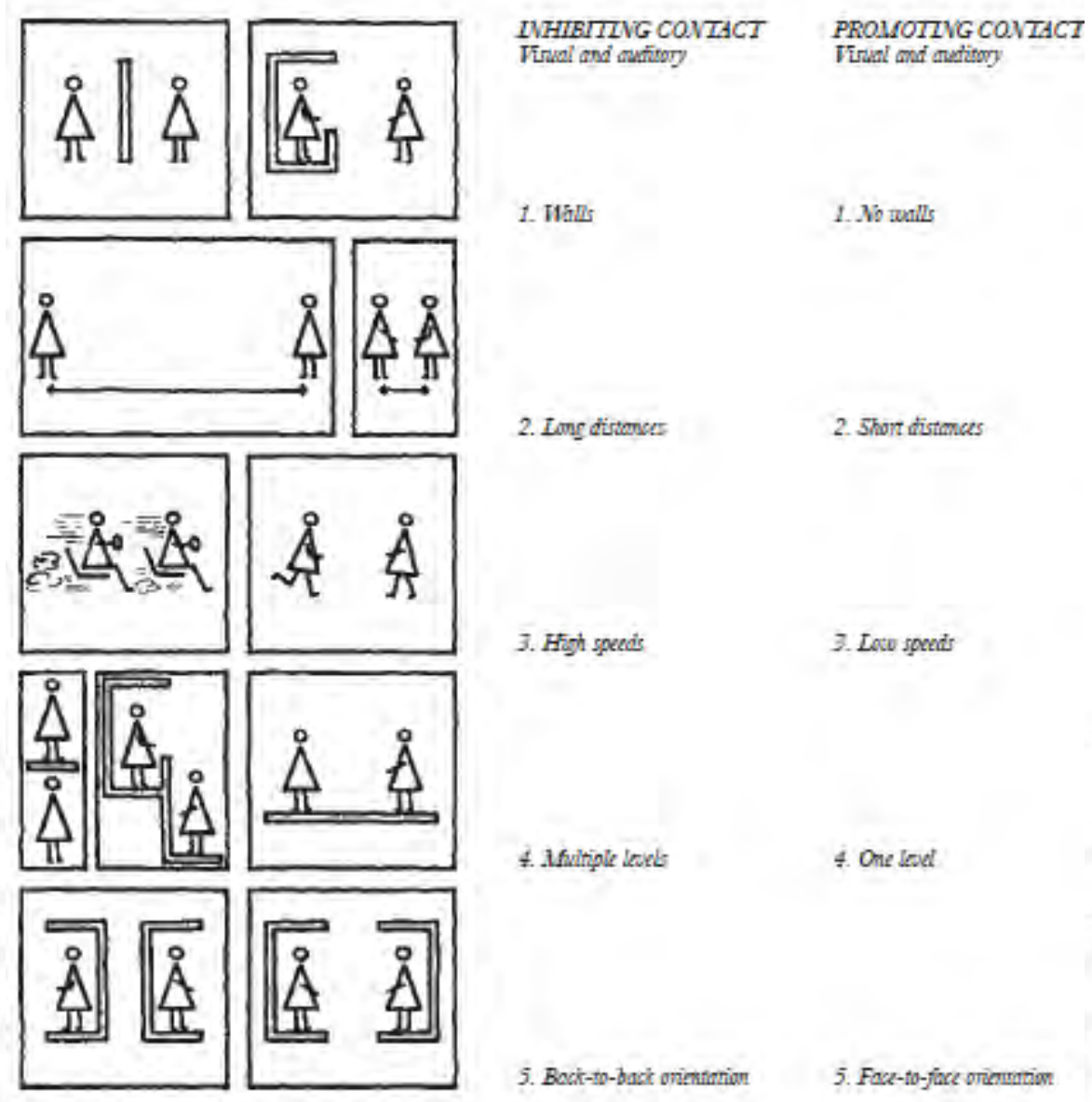

Figura 3.46 Cinco variables que determinan aislamiento en un espacio Fuente: (Gehl, 1971, p. 62)

Asimismo, es importante entender el funcionamiento del proceso perceptivo del ser humano para poder comprender como la arquitectura, ambientación y determinados estímulos pueden provocar determinadas experiencias. En este proceso, el individuo lo inicia con la captura de información, ya sea de una imagen, un objeto o una situación real, generando una percepción de lo observado (percepción selectiva). Sin embargo, durante esta etapa, el cerebro descartara aquellos impulsos visuales negativos que atenten en contra de su percepción selectiva como: el ruido, la saturación o congestión visual; este proceso se le conoce como percepción puntual. Luego, estas dos percepciones combinadas generarán una sensación nueva que, contrastada con una sensación previa darán como resultado una experiencia. Finalmente, será esta nueva experiencia la que determine si es una respuesta emotiva o racional para retención de recuerdos agradables (Elguera Chumpitazi, 2017, pág. 20). (Ver Figura 3.47) 


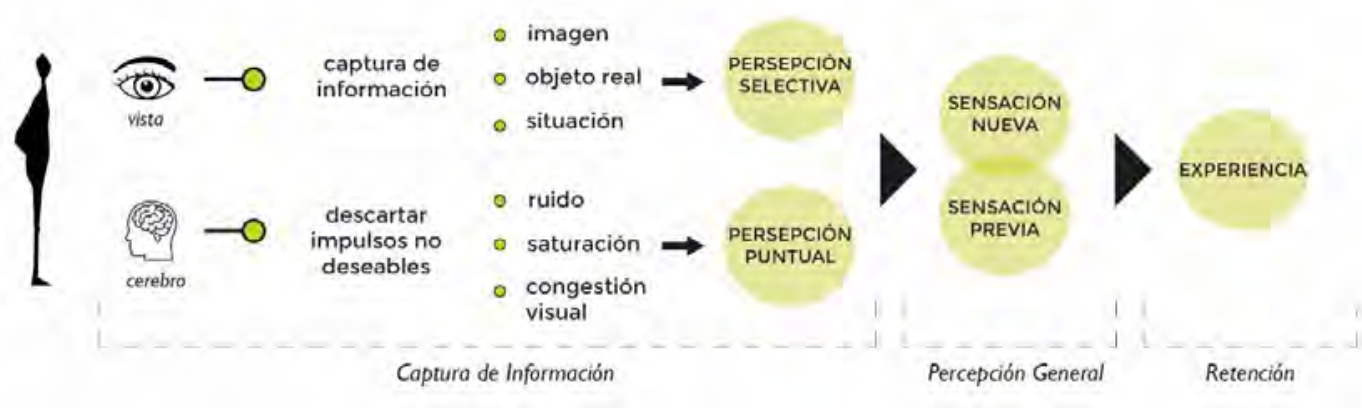

Figura 3.47 Proceso perceptivo del ser humano Gráfico realizado por los autores.

\subsubsection{Atmósfera y espacio sensoriales}

Por otro lado, Kotler, precursor de la influencia del ambiente físico para el espacio comercial, define que la atmósfera será la encargada de producir efectos específicos en los individuos y para que esto suceda, el espacio deberá ser "teatralizado" (como se citó en Gomes Teixeira, et al., 2013):

Este concepto de teatralización del espacio, proviene del marketing sensorial, y es a través de ella, que el lugar comercial, exhibe sus productos y servicios ofrecidos al público. (p.41)

Por lo tanto, la atmosfera del lugar sera la encargada de organizar el espacio para un correcto desplazamiento haciéndola más ordenada, fácil y placentera, con la finalidad de lograr un impacto positivo al momento de realizar una compra. Además, tiene como objetivo incidir en el estado afectivo de los consumidores ya que considera, como parte de su diseño, los tres aspectos básicos del ser humano el estado cognitivo, el estado afectivo y el estado conativo (Diez De Castro, Landa Bercebal, \& Navarro García, 2006, pág. 163). (Ver Figura 3.48)

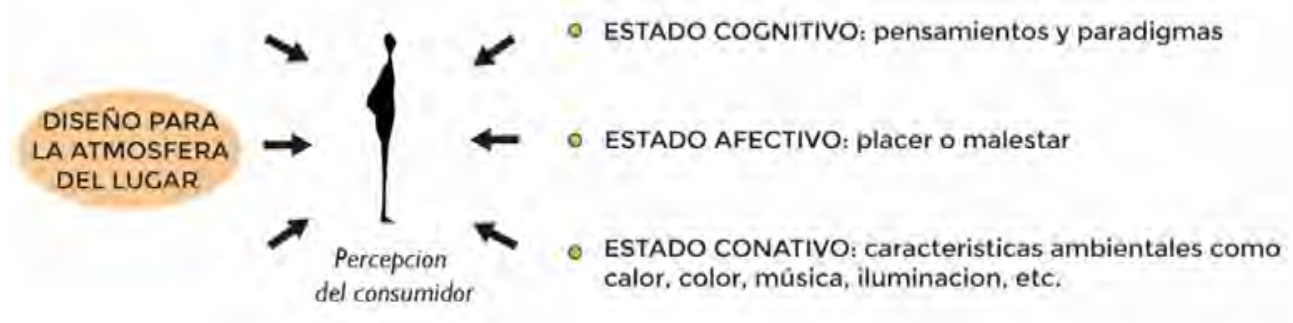

Figura 3.48 Aspectos básicos para la creación de armósferas del lugar Gráfico elaborado por los autores. 
En esta atmosfera creada, se manipulan varios elementos a través de la gestión de la “escenografía” como la iluminación, la decoración y la música, buscando ofrecer formas de consumo distintas, llevando al consumidor a realizar compras emocionales o por impulso, centrándose en el disfrute de la compra mas no en la de satisfacer alguna necesidad previa. Por esta razón, se necesitará de los cinco sentidos del consumidor para intensificar sus reacciones y proporcionar experiencias de consumo únicas. Por ejemplo, Rieunier y Daucé (2002) aseguran que gran parte de la información al interior de un espacio comercial es visual (en un $80 \%$ ), por lo tanto, el uso de colores, formas e iluminación, juegan un papel fundamental en la estimulación para el consumidor. (Ver Tabla 3.4) Además, los colores pueden afectar el comportamiento del consumidor (p. 46).

Tabla 3.4

Resumen de componentes de la atmósfera

FACTORES

$\begin{array}{ll}\text { TACTILES } & \begin{array}{l}\text { - Materiales [alfombra, parquet, muebles, acero, madera, etc.] } \\ \text { - La temperatura de la tienda, la humedad del aire }\end{array} \\ \text { SONIDO } & \begin{array}{l}\text {-La emisión de música ambiental. } \\ \text { - El ruido generado por la tienda [muebles frigoríficos, etc] }\end{array} \\ \text { GUSTO } & \begin{array}{l}\text { - Degustaciones ofrecidas en el punto de venta [tés, dulces, etc. ]. } \\ \text { - Los productos que se ofrecen en los cafés y restaurantes }\end{array} \\ \text { OLFATO } & \begin{array}{l}\text { - Aromas de atmósfera difusa [incienso, difusores de aromas]. } \\ \text { - Olores relacionados con la tienda y su entorno exterior cercano }\end{array} \\ \text { VISUALES } & \begin{array}{l}\text { - La luz utilizada y arquitectura interior [formas, altura de techo, etc.] } \\ \text { - El espacio que ofrecen los pasillos. }\end{array}\end{array}$

SOCIALES - El estilo y la densidad de los clientes

Fuente: (Rieunier y Daucé, 2002, pág. 47)

De igual manera, el arquitecto Peter Zumthor en la conferencia titulada “Atmosferas" (Solnick, Kannenberg, Eckerman, \& Waller, 1980), da a conocer 9 principios para la creación de atmosferas arquitectónicas con fuerte carga emotiva. Estas se resumen en la siguiente tabla (Ver Tabla 3.5). 
Tabla 3.5

Relación de condiciones y factores de percepción

\begin{tabular}{|c|c|c|c|c|}
\hline ARQ. ZUMTHOR & SENTIDOS & PERCEPCIÓN & $\begin{array}{l}\text { CONDICIONES DE } \\
\text { DISENNO }\end{array}$ & FACTORES \\
\hline $\begin{array}{l}\text { EI cuerpo de la } \\
\text { arquitectura }\end{array}$ & Todos & Fisiológico & Diseño exterior, interior & Afectivos \\
\hline $\begin{array}{c}\text { La consonancia de los } \\
\text { materiales }\end{array}$ & Visual & Päicologico & $\begin{array}{l}\text { Diseño exterior, } \\
\text { interior, ambientación }\end{array}$ & Cognitivos \\
\hline 日 sonido del espacio & Auditivo & Fisiológico & $\begin{array}{l}\text { Condiciones } \\
\text { ambientales }\end{array}$ & Conativos \\
\hline $\begin{array}{c}\text { La temperatura del } \\
\text { espacio }\end{array}$ & Visual & Psicológico/Fisiológico & $\begin{array}{c}\text { Condiciones } \\
\text { ambientales, color }\end{array}$ & Conativos \\
\hline Las cosas a mi alrededor & Visual & Psicológico & Atmósfera, productos & Cognitivos \\
\hline $\begin{array}{l}\text { Entre al sosiego y b } \\
\text { seducción }\end{array}$ & Visual & Psicologico & Atmósfera & Conativos \\
\hline $\begin{array}{l}\text { La tension entre el } \\
\text { interior y exterior }\end{array}$ & Visual & Fisiológico/Psicológico & Atmóstera, vitrinas & Cognitivos \\
\hline Grados de intimidad & Visual & Psicologico. & $\begin{array}{l}\text { Atmósfera, espacios } \\
\text { diferenciađos }\end{array}$ & Afectivos \\
\hline La luz sobre las cosas & Visual & Fisiológico & $\begin{array}{l}\text { Condiciones } \\
\text { ambientales, Iluminactón }\end{array}$ & Conativos \\
\hline
\end{tabular}

Fuente: (Elguera Chumpitazi, 2017)

Podemos observar que en la mayoría de situaciones, el aspecto visual resulta ser el más relevante de los sentidos, pues se encuentra presente la percepción de los materiales, la temperatura del espacio, la relación exterior e interior, espacios diferenciados y la iluminación de los productos (Elguera Chumpitazi, 2017, pág. 23).

\subsubsection{Turismo cultural y los mercados tradicionales}

\subsubsection{Turismo de experiencias en los nuevos mercados}

Actualmente nos encontramos frente al boom del turismo cultural el cual ha afectado de manera positiva la situación de los mercados tradicionales en Europa y países de Latinoamérica, logrando convertir estos espacios comerciales en los nuevos exponentes turísticos, identitario de las ciudades y han logrado promocionar una imagen atractiva para el visitante (Crespi y Domínguez, 2016, p.402). 
Además, Bramwell y Rawding (1996) señalan la importancia del turismo en la ciudad y cómo este afecta en la construcción de identidad de los ciudadanos: "Es necesario atraer turistas, captar el interés de inversores y gobiernos oficiales, y construir seguridad, comodidad y orgullo entre los residentes" (p. 201).

Por otro lado, Julie Richards (como se citó en Crespi y Domínguez, 2016) manifiesta que existe un nuevo turismo cultural y como este ha cambiado al pasar los años:

En el pasado, el turismo cultural estaba asociado con gente "culta". Hoy, el turismo cultural (y urbano) incluye muchos atractivos populares (...) y la vida diaria de las comunidades locales se ha extendido de los recursos asociados con el patrimonio fijo, tangible del pasado hacia los productos intangibles de la cultura contemporánea. (p. 403)

El aspecto de lo "local" se ha relacionado automáticamente con el deseo de lo "auténtico" y se ha logrado a convertir en un elemento clave para el desarrollo de la industria del turismo (Taylor, 2001, p.7). En este sentido, la alimentación local tendrá un papel protagónico y de gran interés por parte de los turistas y consumidores locales. Es en esta búsqueda que los turistas se ven atraídos actualmente por los mercados de abastos ofreciendo la particularidad de poder comer como uno más y formar parte de las costumbres de aquel territorio de manera social. Son en estos lugares que se percibe la idiosincrasia de la gente local, sus maneras de expresarse, de comprar, de vender, su manera de comer etc. (Crespi y Domínguez, 2016, p. 403).

\subsubsection{Aspectos sociales, culturales y urbanos de los mercados}

Desde el aspecto urbano, si nos referimos al termino de relaciones urbanas Kevin Lynch (1984) dice que los mercados son nodos en la ciudad, ya que generan interconexiones urbanas que hacen que los barrios tengan el movimiento necesario de personas manteniéndolos constantemente activos, influyendo en la construcción de "la calidad de identidad e imagen de una ciudad, así como la activación de su contexto urbano inmediato, generando sinergia social y cultural” (Lynch, 1984, pág. 30). Por ejemplo, el mercado de santa Caterina, que, gracias a su proceso de renovación, fomento el crecimiento de la economía en su zona de influencia y revalorizo su contexto, convirtiéndolo en un espacio deseable para visitar. 
Desde un punto de vista social, algunos mercados tradicionales han incorporado nuevos actores comerciales como consecuencia de un potencial desarrollo económico y cambios en las costumbres de los consumidores. Entre estos, están los mercados que han sabido fomentar una oferta especializada al transformar los productos frescos y de calidad que ofrecen, en platos de comida típica del lugar, preparados al instante, logrando atraer equitativamente al público tradicional, al mismo tiempo que a los turistas.

Un ejemplo claro es el mercado "La Boquería". Cuenta con doscientos cincuenta puestos entre tradicionales y productos orientados hacia turistas como: zumos frescos, frutas cortadas, platos preparados, dulces, etc. productos que un turista pueda consumir fácilmente en su visita, sin olvidar los tradicionales puestos de carne, pescado, entre otros (Crespi y Domínguez, 2016, p. 411).

Por lo tanto, es importante que los mercados no dejen de ofrecer productos frescos como principal diferenciacion, ademas la venta de comida al paso, generando una complementariedad en la oferta y logrando mantener una ventaja competitiva frente a los supermercados privados. 


\subsection{Conclusiones parciales}

\subsubsection{Del espacio público}

Después de analizar el concepto del espacio público y su variación en el tiempo se puede concluir que si bien en términos jurídicos el mercado no podemos definirlo de carácter público, ya que su gestión administrativa es regulada por municipios o juntas directivas de propietarios del mismo mercado, si lo enfocamos desde la perspectiva social, económico, ambiental, de salud pública y a las formas de apropiación del espacio; lo que tenemos es el resultado de un espacio de reunión pública de la comunidad, organizado y rodeado de una multiplicidad de oportunidades de consumo que ofertan los distintos módulos comerciales desde su interior.

Entonces, podemos afirmar que el mercado es espacio privado con función pública, ya que forma parte del desenvolvimiento y la construcción de relaciones sociales en una ciudad. Además, el mercado abastece las necesidades básicas que el ser humano demanda, como la alimentación y la vestimenta, pero también nutre las necesidades psicológicas que son implícitas en nuestro cuerpo por medio del contacto y el estímulo que se manifiestan al momento de salir a comprar.

Con la introducción de nuevas tecnologías y la evolución de las ciudades, los espacios públicos de las ciudades peruanas, están experimentando los mismos conflictos de privatización mencionados por Stéphane Tonnelat al inicio de este análisis, pasando por iniciativas privadas que proponen el desarrollo de plataformas comerciales, estacionamientos y otras formas de aprovechamiento en busca de nuevas fuentes de ingreso aún a costa de la desnaturalización de lo público. Si bien, estos lugares agregan nuevos matices en las ciudades donde el habitante tiene la libertad de caminar y elegir la opción de compra que mejor le acomode, estos no cubren las necesidades humanas que éstos satisfacen, sino parcialmente. 
Por otro lado, esta práctica constante por parte de la administración pública del aprovechamiento del espacio público para iniciativas privadas, ha ocasionado en paralelo el abandono y el desaprovechamiento de los mercados tradicionales, llegando estos a sufrir una crisis de identidad actualmente en algunas ciudades peruanas. Entonces, si queremos devolverle al mercado su condición de espacio público, es necesario diseñar un espacio atractivo y con una buena calidad física del espacio para el desenvolvimiento de las actividades humanas, abarcando desde las actividades necesarias (hacer las compras, transitar, etc.) como las actividades opcionales (sentarse a disfrutar del día, sentarse a comer algo, etc.) (Ver Figura 3.49).

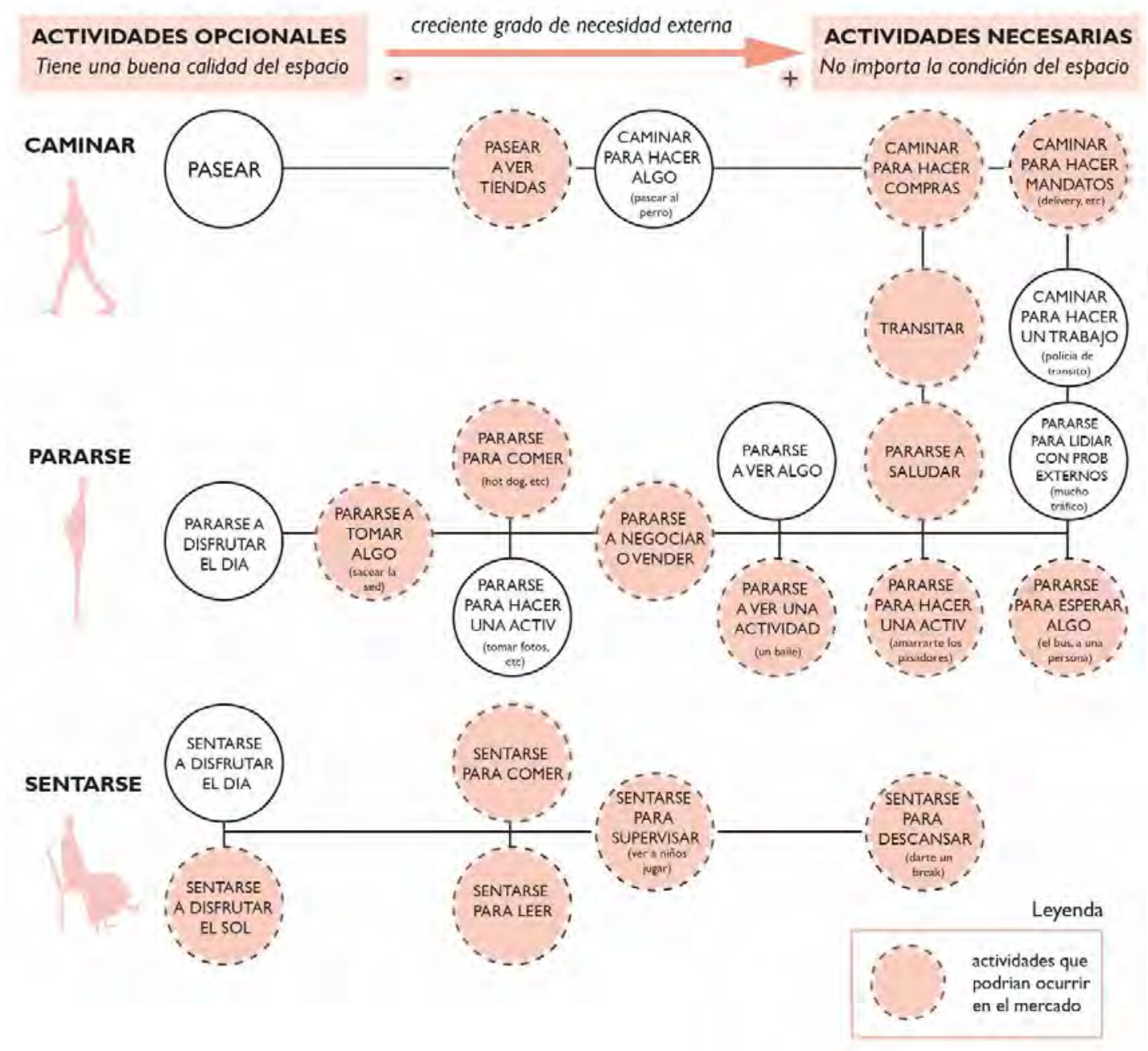

Figura 3.49 Actividades opcionales y necesarias desarrolladas en el espacio público Gráfico elaborado por los autores. 
Asimismo, una buena calidad del espacio influirá en el desarrollo y grado de permanencia de las actividades opcionales, afectando la percepción de los usuarios en el espacio, haciendo del mercado un lugar más habitable. Para lograrlo, es necesario tener presente como parte del diseño, los doce principios creados por Jan Gehl, que evalúan el grado de calidad del espacio, con la finalidad brindarle al usuario una buena experiencia del espacio (Ver Figura 3.50).

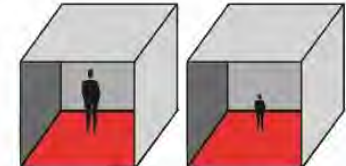

ESCALA HUMANA DISEÑAR ESPACIOS QUE VAYAN DE ACUERDO A LA ESCALA HUMANA Y ENTORNO DEL LUCAR

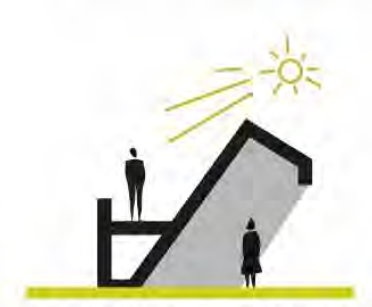

ESPACIOS DE LUZ/SOMBRA

CUBRIR Y ABRIR ESPACIOS DEPENDIENDO DE LA ACTIVIDAD A DESARROLLAR PARA BRINDAR COMODIDAD

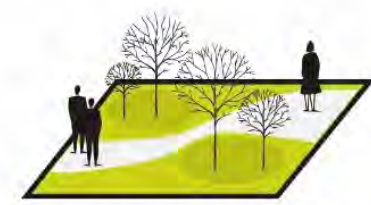

VEGETACION EN EL ESPACIO

INSERTAR PLAZAS CON VEGETACION COMO PUNTOS DE ENCUENTRO AL INTERIOR DEL PROYECTO

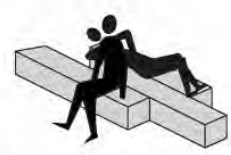

MOBILIARIO FLEXIBLE

DISEÑAR MOBILIARIOS QUE SE ADAPTEN A DIFERENTES ACTIVIDADES Y USUARIOS

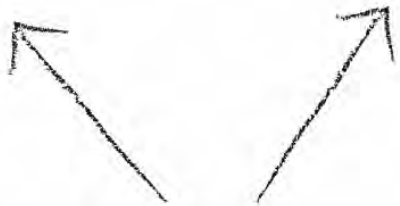

VARIABLES PARA EL DISEÑO DEL MERCADO

"Teoria de espacio publico segun Jan Gehl"

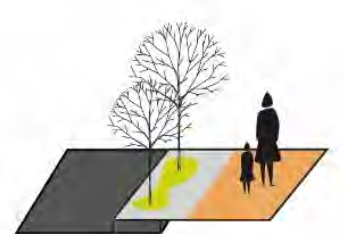
PROTECCIÓN EN EL PERIMETRO USO DE VEGETACION COMO COLCHON VERDE PARA PROTECCION CONTRA RUIDOS

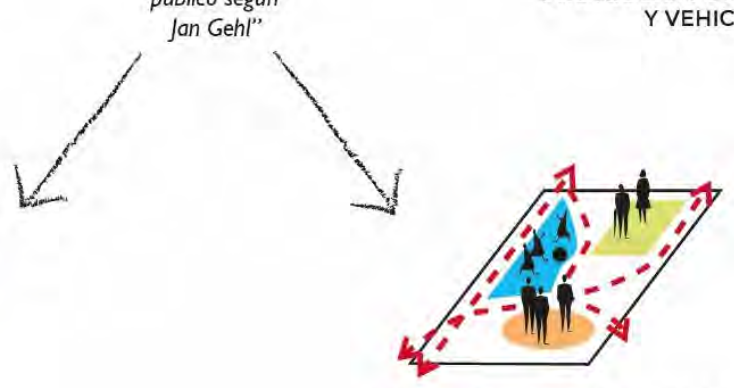

ACCESIBILIDAD PARA TODOS DISEÑAR ESPACIOS ACCESIBLES PARA EL PUBLICO DE TODAS LAS EDADES (NIÑOS, ADULTOS Y ANCIANOS)

Figura 3.50 Lógicas de diseño según teoría de Jan Gehl.

Gráfico elaborado por los autores. 
Entonces, a partir de lo cualitativo se podrá recuperar la condición de espacio público del mercado, y generar una mayor animación y vitalidad del espacio. Sin embargo, estas cualidades dependerán de algunos factores mencionados por Bentley como: la permeabilidad, variedad, legitimidad, versatilidad, imagen apropiada y riqueza perceptiva del espacio, de tal manera que, al hablar del mercado, no se reduzca solo la imagen de pasillos y módulos de venta, sino que adopte todas las posibilidades que caminar libremente por la ciudad caracteriza (Ver Figura 3.51).

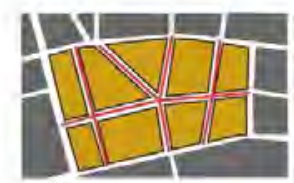

PERMEABILIDAD GENERAR MAYOR INGRESOS AL PROYECTO Y MEJORAR SU ACCESIBILIDAD

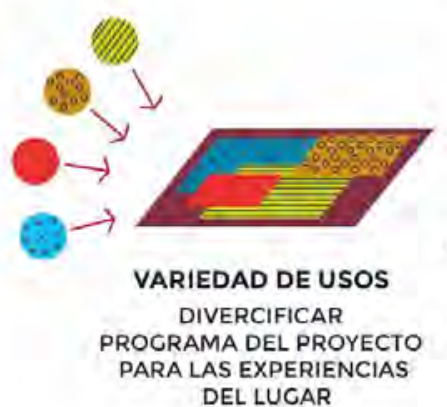
DEL LUCAR

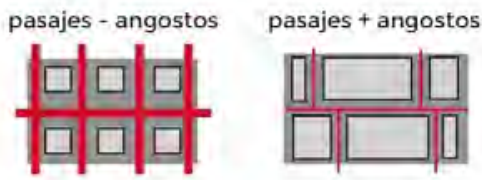

DIMENSIONES DE PASAJES

DIMENSIONAR PASAJES PARA LOGRAR ESPACIOS MAS PUBLICOS O MAS PRIVADOS

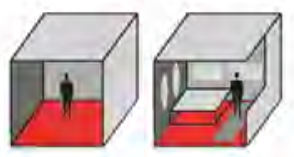

PERSONALIZACIÓN

PERSONALIZAR PUESTOS DE VENTA DE ACUERDO A SU PROGRAMA

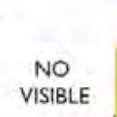
NO
VISIBLE

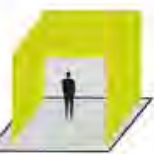
VISIBLE

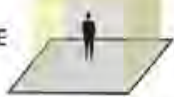

RIQUEZA PERCEPTIVA DEFINIR MATERIALIDAD Y TECNICA CONSTRUCTIVA PARA MEJORAR EXPERIENCIAS SENSITIVAS DE LAS PERSONAS
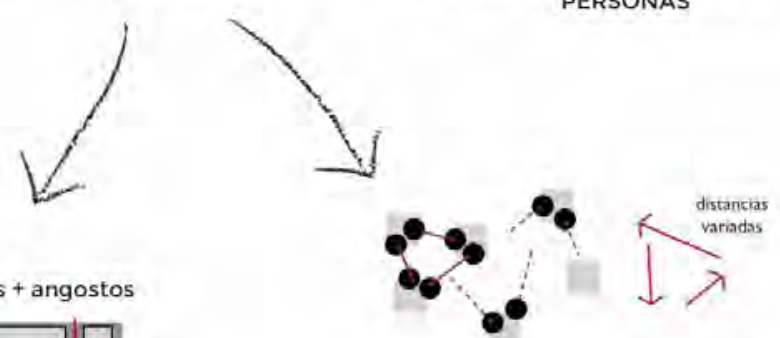

VERSATILIDAD DEL ESPACIO

ADECUAR LA DISTANCIAS Y UBICACION DE MOBILIARIOS Y LOGRAR LA INTERACCION DE LAS PERSONAS EN EL ESPACIO

Figura 3.51 Lógicas de diseño según teoría de Bentley

Gráfico elaborado por los autores. 


\subsubsection{De los límites}

Al analizar la teoría del límite podemos afirmar que un espacio empieza a existir cuando este comienza a ser encerrado, conformado y estructurado por aquello que lo limita, es decir, el espacio en sí mismo carece de forma y su luminosidad, sus dimensiones y su escala derivaran por completo de sus límites, siendo estos elementos materiales o virtuales. Entonces, es a partir de esta limitación del espacio que la arquitectura empieza a existir.

A lo largo de la historia, el concepto del límite en la arquitectura es más o menos estable durante largos periodos y sus cambios ocurrirán como consecuencia de acontecimientos históricos como, nuevas formas de comunicación, la introducción de nuevas tecnologías, nuevos materiales y también los cambios de relaciones sociales de una sociedad. Si durante la época barroca, el límite del edificio se definía por espacios escenográficos de la época religiosa, rompiendo la linealidad y desmaterializando las fachadas con formas curvas y espacios abiertos; durante el movimiento moderno, el límite tendera a desdibujarse, presentando una continuidad entre el interior y el exterior del edificio por efecto de la transparencia del vidrio.

Con la introducción de nuevos materiales, arquitectura se modifica, el espacio interior empieza a ganar protagonismo y la arquitectura pasa de ser oclusiva, a tener una capacidad más de diafragma (García, 2013, p. 10), es decir, como "lámina movible o porosa que intercepta o regula la comunicación entre dos partes" (Real Academia Española, 2019) estableciendo relaciones contextuales más complejas. Asimismo, la presencia de la tecnología, favorece el diseño de formas más flexibles, haciendo que el envolvente reduzca su imagen como frontera.

Hoy en día, nos encontramos en un mundo en donde la diferencia entre el ámbito público y privado es cada vez más compleja "el espacio de la ciudad se configura hoy más por el espacio de los demás - acontecimientos de todo tipo- que por la propia y justa presencia de aquello que entendíamos por espacio urbano. La idea de limite ha perdido precisión, es algo difuso" (Gausa, y et al., 2001, p. 184). De esta manera, recordando brevemente la teoría del espacio público analizada en el capítulo anterior, debemos tener 
presente que los espacios públicos contemporáneos, están experimentando conflictos de privatización por parte de iniciativas privadas, que proponen otras formas de aprovechamiento de lo público. Entonces, ante esta dicotomía, de las áreas públicas "privadas" (como centros comerciales, centros culturales, etc.) debemos preguntarnos ¿qué tratamiento de límite es el más adecuado para re vincular espacio público del edificio y el espacio público urbano?

Ante esta situación, el arquitecto Toyo Ito, hace énfasis a un nuevo tratamiento del límite, conocido como teoría de los límites difusos, enfocada en la existencia de un entorno dinámico, activo y mutable, y el interés por crear un lugar para ser vivido, obligan al arquitecto diseñar una arquitectura fluida. En este nuevo tratamiento, los límites reaccionan al entorno y opera con una envolvente que semeja una piel de condición ambigua (Ruiz, 2013, p. 49).

La arquitectura se vuelve permeable, se rompen los márgenes entre el interior y el exterior y empieza a ser considerada como un objeto (...) El control —y no la forma- del espacio vacío se convierte en el tema del proyecto. (...) Los arquitectos descubren dicho espacio, y luego reestructuran de tal modo que lo vuelven diverso, no estático sino dinámico, capaz de ser interactivo y flexible, pero siempre especialmente ligado al usuario, quien se convierte en el vínculo entre la idea y la realidad física, y en el catalizador de la creación del espacio. (Galofaro, 2004, p. 30-31)

A partir de estas teorías, es necesario tener en cuenta la idea central del límite como un espacio difuso, propuesta por Toyo Ito, para el diseño de la envolvente de nuestro mercado, ya que, a través de esta continuidad y fluidez en el espacio, seremos capaces de devolverle al mercado su condición de espacio público, logrando establecer un lugar en el que sea posible desempeñar diferentes actividades de manera simultánea. Asimismo, a través de un sistema flexible, seremos capaces de "disolver" ese límite que actualmente evita al mercado de relacionarse con su contexto, siendo capaces de romper con la idea de frontera entre el exterior e interior.

El límite hacia el exterior, depende de esa fina capa de separación, que pone en relación dos mundos destinados a interactuar para enriquecerse. Si ese límite está excesivamente caracterizado o tiene una presencia desproporcionada, difícilmente el 
intercambio de experiencias podrá realizarse de una manera espontánea. En este sentido, la condición de la envolvente de nuestro mercado, dependerá de factores como el espesor, la escala, la transición del material y trasparencia necesaria con la finalidad de poder exhibir la multiplicidad de relaciones tanto económicas, sociales y culturales vividas al interior del mercado y semejar que este sigue siendo parte del espacio público de la ciudad a pesar de ser un espacio contenido por la envolvente. Pero sobre todo y aún más importante es poder permitirle al usuario verse participe del disfrute de lo público, compartiendo un sentimiento de lo común y creando identidad en la ciudad.

Por otro lado, el diseño de nuestra envolvente basada en la flexibilidad del espacio, buscará romper con el diseño convencional de los mercados basados en 3 grandes capas horizontales tal cual nosotros hemos ido analizando. Estas se dividen en: los puestos de venta, el espacio entre los puestos de venta y la envolvente, y la propia envolvente (cubierta del mercado). En este sentido, en nuestro diseño se buscará fusionar estas tres capas en la medida que el envolvente pueda ser envolvente, espacio público, y configure parte de los puestos de venta. La idea nace a partir de entender el límite de la edificación no solo en su horizontalidad, sino también en su verticalidad, basándonos en la definición del límite como un elemento indeterminado que afronta diferentes situaciones y no segrega espacios, sino que los une.
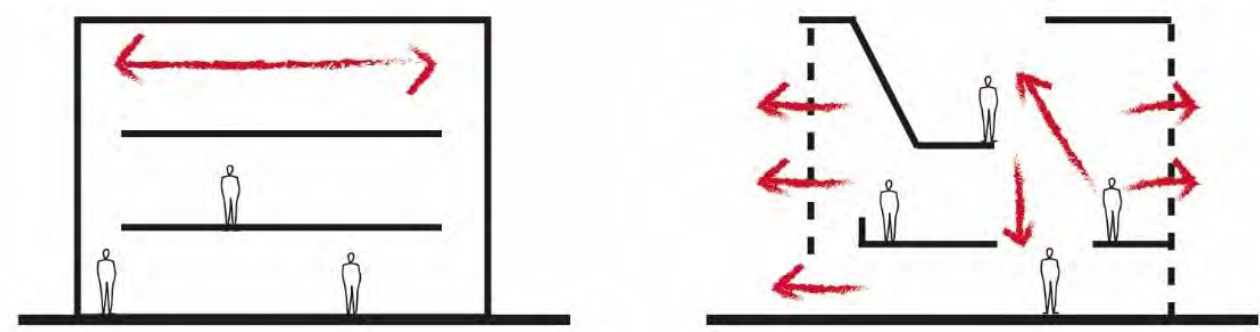

Figura 3.52 Romper el límite a través del envolvente Gráfico elaborado por los autores.

Desde lo espacial interpretado a través de envolventes, se acredita la superación de binomios físicos establecidos como interior-exterior, arriba-abajo, suelo-cubierta, fondofigura, local-global y el límite es un elemento indeterminado que afronta diferentes situaciones: define el lugar, condiciona el movimiento y especifica el vínculo con el contexto. (Ruiz, 2013, p. 273) 
La extensión del ámbito público al espacio privado por medio de la envolvente del mercado, ampliaría el espacio del equipamiento comercial y se recibiría a cambio estímulos impuestos por la tendencia y el mercado, es decir, si retomando los conceptos vistos en la teoría del espacio público, el estímulo que se genera al ver a otras personas comprar contribuiría con la persuasión de la envolvente como escaparate del producto comercial o de la acción de consumo.

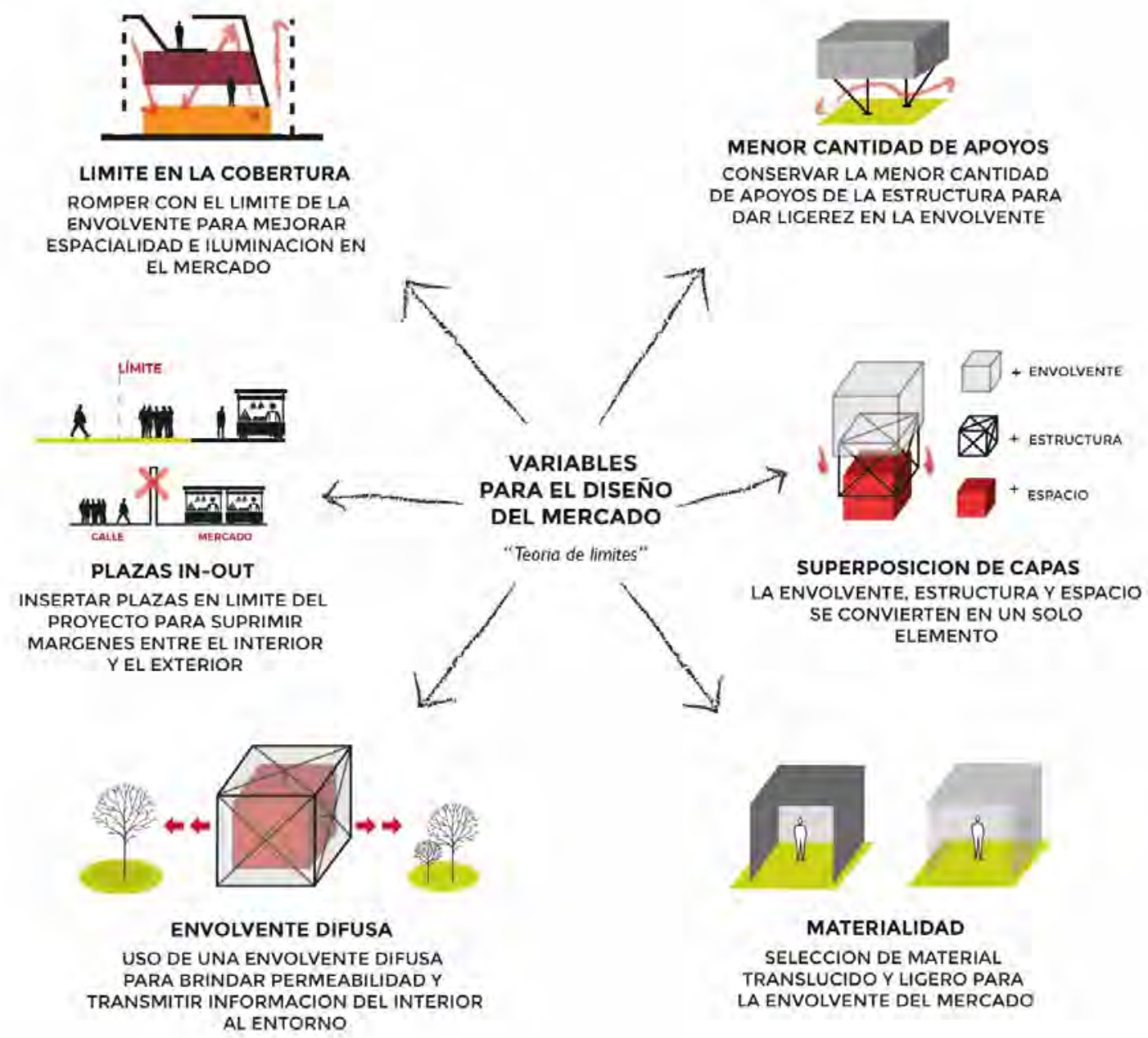

Figura 3.53 Lógicas de diseño_ Teoría de límites

Gráfico elaborado por los autores. 


\subsubsection{Del mercado y el turismo}

Hoy en día, el acto de consumo tiene un significado y una función que va mucho más allá de las necesidades básicas de abastecimiento; pues por medio de estas acciones, se constituye la identidad personal y social. En este sentido, el espacio físico en el que se desarrolle esta actividad, tendrá un papel determinante para la sociedad, pues también será un espacio para la cultura de consumo. Por lo tanto, los mercados de abastos no solo representan el lugar en el que se intercambian los bienes entre productores y consumidores, ni tampoco un símbolo de la infraestructura económica, sino como "lugar imaginario y simbólico para la representación del sujeto en la cultura del consumo" (Simone, 2009, p. 3).

Ante esta gran responsabilidad en torno a los mercados, algunas ciudades de Europa y de latinoamerica, presenciaron que estos espacios presentaban diversas fisonomias en funcion al grado de tusitificacion que pueda darse en ellos $\mathrm{y}$, en un mundo globalizado, en donde la sociedad busca experimentar nuevas situaciones de compra, nace esta nueva tipologia de mercados. Son espacios que atraen por su capacidad de vivir experiencias nuevas y propias del lugar, mezclado al turista con el poblador y su vida cotidiana. "los comerciantes viven principalmente de sus vecinos y de las familias, pero la llegada de los turistas permite incrementar ingresos y mejorar la imagen de estos mercados" (Crespi y Domínguez, 2016, p. 403). En este sentido, los mercados se han convertido en uno de los recursos mas promocionados en donde lo local y lo turístico van de la mano, compartiendo y recreando experiencias de compras a un precio, variedad y calidad notoria.

Sin embargo, para lograr esta nueva experiencia de compra en los mercados tradicionales de lima, será necesaria la aplicación de algunos criterios de diseño, que ayudaran a mejorar los servicios al interior del mercado y su relación con su entorno. Por ejemplo, el diseño de espacios interiores bajo el concepto "atmosfera" analizados previamente en este capítulo, de manera que sus diversos elementos que la conforman como la materialidad, la luz, las dimensiones espaciales, los olores, la saturación de colores, la música, etc., logren producir experiencias únicas y memorables en los usuarios con determinado significado emocional. Asimismo, incorporar el uso de factores como 
señalización, distribución y técnicas de representación, ya que ayudaran a darle una mejor orientación a la atmosfera de manera que sea más entendible y agradable. Además de la actualización de sistemas tecnológicos para el pago de productos, con la finalidad de poder hacer uso de tarjetas como métodos de pago o compras online.

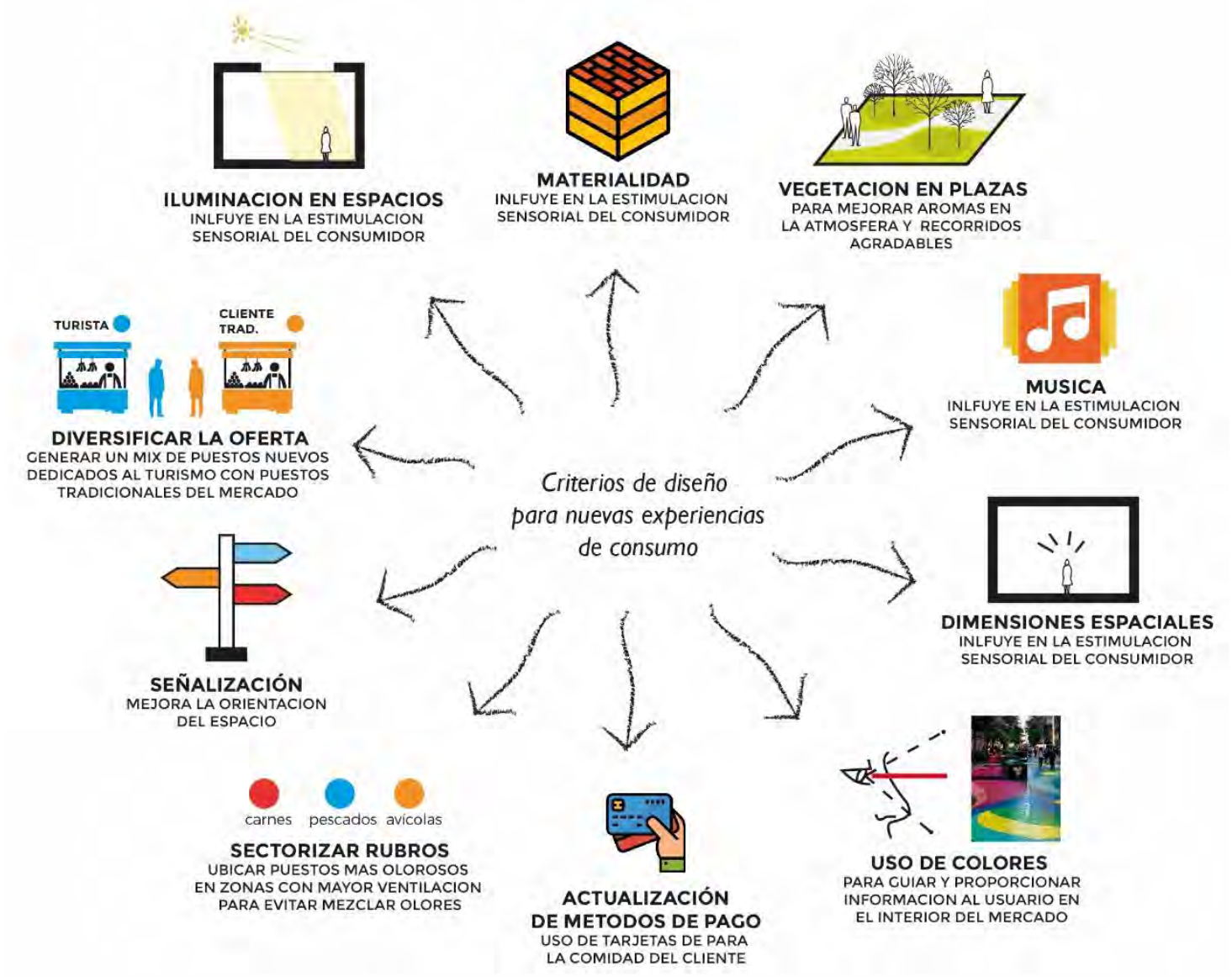

Figura 3.54 Criterios de diseño para nuevas experiencias de consumo

Gráfico elaborado por los autores.

También se deberá tener en cuenta, la incorporación de beneficios sociales, culturales y urbanos, de manera que no solo de prevea la rentabilidad económica, sino también la de los compradores y visitantes al mercado. Por ello, para los beneficios sociales hemos considerado el contar con horarios de atención extendidos, tener en el programa un patio de comidas gastronómico, así como también contar con servicio de entrega a domicilio y ventas online. Por otro lado, para los beneficios culturales, se ha tomado en cuenta la realización de actividades durante días festivos o fines de semana, la capacitación permanente a comerciantes y campañas de consumo saludable. 
Finalmente, para los beneficios urbanos, hemos considerado la integración del comercio con su entorno, el diseño de un tratamiento paisajístico y peatonalización, la ejecución de zonas de juegos para niños y un incremento en la iluminación tanto interior como exterior del mercado.

\begin{tabular}{|c|c|c|c|}
\hline \multirow{3}{*}{$\begin{array}{l}\text { Beneficios } \\
\text { Sociales }\end{array}$} & HORARIO EXTENDIDO & $\begin{array}{l}\text { TENER UN HORARIO DE ATENCIÓN } \\
\text { EXTENDIDO }\end{array}$ & \multirow{7}{*}{ - - - - - • 常问 } \\
\hline & PATIOS DE COMIDAS & $\begin{array}{l}\text { CONTAR CON UN ESPACIO GASTRONOMICO } \\
\text { PARA LA VENTA DE COMIDA }\end{array}$ & \\
\hline & SERVICIOS ONLINE & $\begin{array}{l}\text { GENERAR UNA PAGINA WEB PARA } \\
\text { COMPRAR ONLINE DE PRODUCTOSY } \\
\text { SERVICIO DELIVERY }\end{array}$ & \\
\hline \multirow{2}{*}{$\begin{array}{l}\text { Beneficios } \\
\text { Culturales }\end{array}$} & $\begin{array}{l}\text { PLAZAS } \\
\text { COMO ESCENARIO }\end{array}$ & $\begin{array}{l}\text { GENERAR PLAZAS INTERNAS QUE SIRVAN } \\
\text { COMO ESCENARIO PARA EL DESARROLLO } \\
\text { DE EVENTOS SOCIALES PARA LOS } \\
\text { USUARIOS DEL MERCADO }\end{array}$ & \\
\hline & $\begin{array}{l}\text { TRATAMIENTO DEL } \\
\text { ESPACIO PUBLICO }\end{array}$ & $\begin{array}{l}\text { DISEÑAR DEL ESPACIO PUBLICO } \\
\text { DESDE LA ILUMINACION, DISEÑO DEL } \\
\text { PAVIMENTO, SENAALIZACION. } \\
\text { SOMBRA, ETC }\end{array}$ & \\
\hline \multirow{2}{*}{$\begin{array}{l}\text { Beneficios } \\
\text { Urbanos }\end{array}$} & $\begin{array}{l}\text { NUEVOS ESPACIOS } \\
\text { PARA USUARIOS DEL } \\
\text { MERCADO }\end{array}$ & $\begin{array}{l}\text { PENSAR EN TODOS LOS USUARIOS DEL } \\
\text { MERCADO IMPLEMENTANDO ZONA DE } \\
\text { JUEGOS PARA NINNOS Y ESPACIOS PARA } \\
\text { EL ADULTO MAYOR. }\end{array}$ & \\
\hline & $\begin{array}{l}\text { TRANSPARENCIA EN } \\
\text { FACHADA }\end{array}$ & $\begin{array}{l}\text { USO DE MATERIALES TRANSLUCIDOS QUE } \\
\text { EN LA FACHADA DEL MERCADO CON } \\
\text { LA FINALIDAD DE VINCULAR COMERCIO } \\
\text { CON EL EXTERIOR }\end{array}$ & \\
\hline
\end{tabular}

Figura 3.55 Beneficios sociales,culturales y urbanos para el diseño del mercado Gráfico elaborado por los autores.

Al incluir todos estos criterios analizados para nuestra propuesta de diseño, podremos obtener un modelo de mercado en el que se diversifiquen sus productos por medio de la innovacion y mantengan su posicionamiento en el mercado turístico, sin la necesidad de abandonar su deber con la comunidad local. Estas cualidades lo convertiran en un mercado sostenible y esta sostenibilidad sera la clave. 


\section{CAPÍTULO IV: Marco normativo}

\subsection{Estándares arquitectónicos}

A continuación, en esta sección se revisará la normativa nacional e internacional sobre mercados de abastos para contrastarlos y considerar las mejores alternativas de diseño en la propuesta del Mercado San José. A su vez, la comparación entre normativas nos ayudará a determinar cuáles deben ser modificadas en un futuro para que los mercados del país tengan un correcto funcionamiento.

\subsubsection{Neufert}

El Neufert es un manual para proyectar edificios basado en las dimensiones, experiencias y conocimientos adquiridos por profesionales y en la investigación de los ámbitos humanos, bajo una visión abierta a nuevas posibilidades y exigencias (Neufert, 2016, p. 6). Dentro de este manual podemos encontrar un capítulo destinado al comercio que incluye a los mercados de abasto que sugiere lo siguiente:

Accesos: Cada espacio comercial debe tener como mínimo 2 puertas con una anchura de $0.30 \mathrm{~m}$ por cada $100 \mathrm{~m} 2$ de superficie, siempre con una dimensión mínima de $2 \mathrm{~m}$ (Neufert, 2016, p. 267).

Pasillos: Las superficies completa o parcialmente cubiertas que comunican con los puestos de venta y sirven para la circulación de clientes, deben contar con un ancho mínimo de $5 \mathrm{~m}$ (Neufert, 2016, p. 267).

Puertas: Las entradas a los locales comerciales deben estar libres de barreras arquitectónicas con una anchura mínima de $2 \mathrm{~m}$ y una altura de $2.2 \mathrm{~m}$ mínimo (Neufert, 2016, p. 267).

Estantería: Exponer todos los productos a la venta de forma visible. Tener en cuenta los recorridos en el interior de la tienda. Los estantes no deben colocarse por encima del alcance de la mano (Neufert, 2016, p. 274).

- Estante más alto $1.80 \mathrm{~m}$.

- Estante inferior a $30 \mathrm{~cm}$ por encima del suelo.

- El espacio de circulación entre los estantes debe ser mayor a $90 \mathrm{~cm}$. 

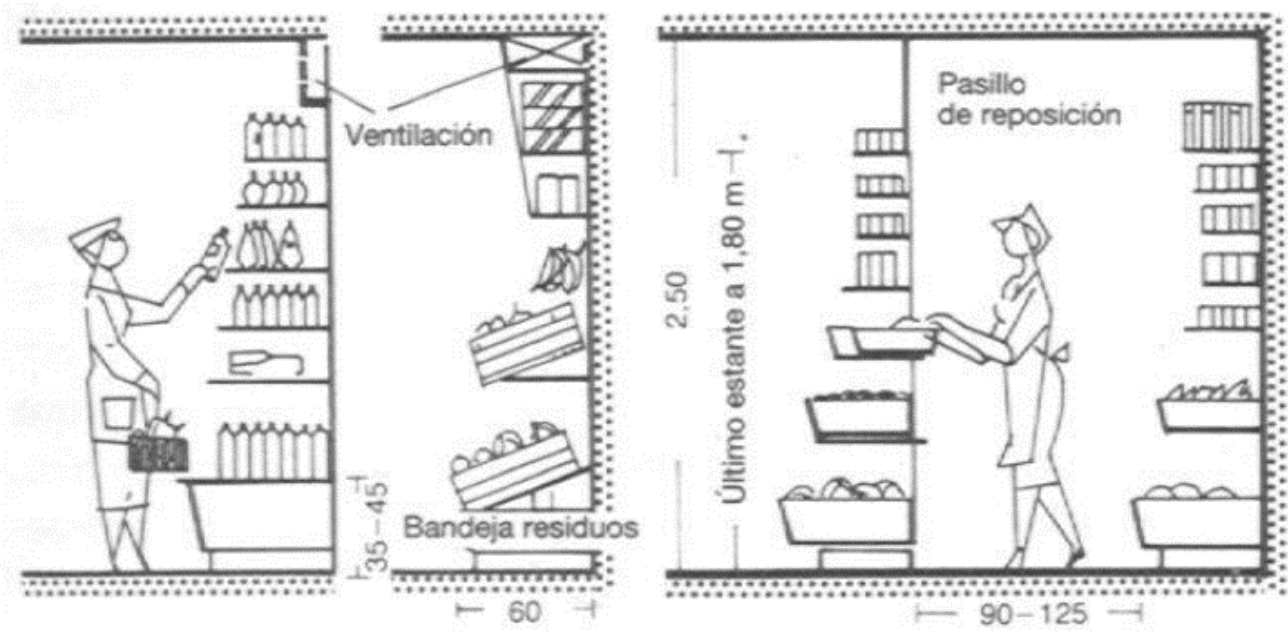

Figura 4.1 Neufert_Productos de forma visible

Fuente: Neufert, 2016

\section{Puesto de pescado}

Los pescados, por estropearse rápidamente, se han de mantener a baja temperatura. Sin embargo, el pescado ahumado, a diferencia de pescado fresco, se ha de almacenar en un lugar absolutamente seco. El pescado despende un fuerte olor, por lo que las pescaderías se han de rodear con esclusas o cortinas de aire con suelo y paredes lavables. (Neufert, 2016, p. 273)
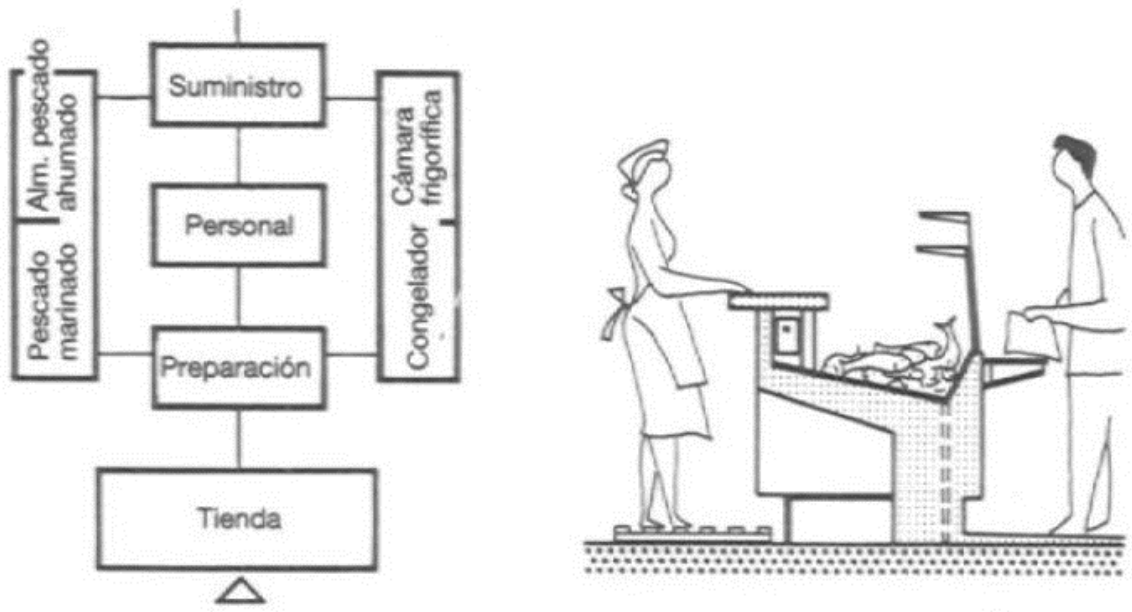

Figura 4.2 Neufert_Puesto de pescados

Fuente: Neufert, 2016 


\section{Puesto de carnes y avícolas}

A menudo incorporada en las carnicerías. Con almacén exclusivamente para las ventas del día. Prever la colocación de una máquina de desplumar y soflamar en la zona de trabajo. Como las aves captan los olores se han de guardar por separado en la tienda y en la cámara frigorífica. Mostrador y paredes: mármol azulejo, mosaico, materiales lavables. (Neufert, 2016, p. 273)
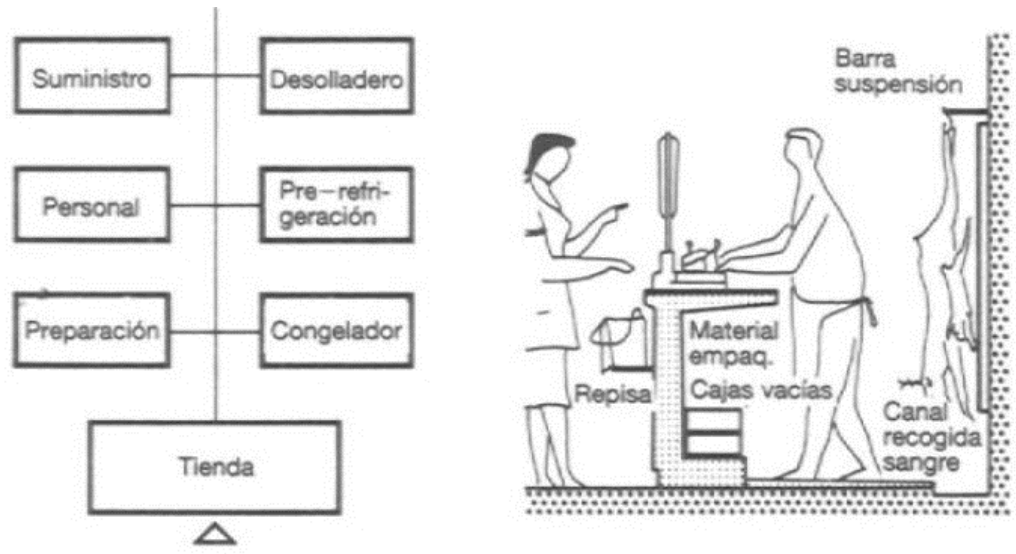

Figura 4.3 Neufert_Puesto de carnes y avícolas

Fuente: Neufert, 2016

\section{Fruterías y verdulerías.}

Guardar la verdura fresca en un lugar fresco, pero sin refrigeración, en estados naturales o preparados para cocinar. Guardar las patatas en salas oscuras. La venta suele realizarse en las mismas cajas de suministro (cajas, cestas, bandejas, etc.). Prever una bandeja de recogida de residuos debajo del estante inferior. (Neufert, 2016, p. 273)
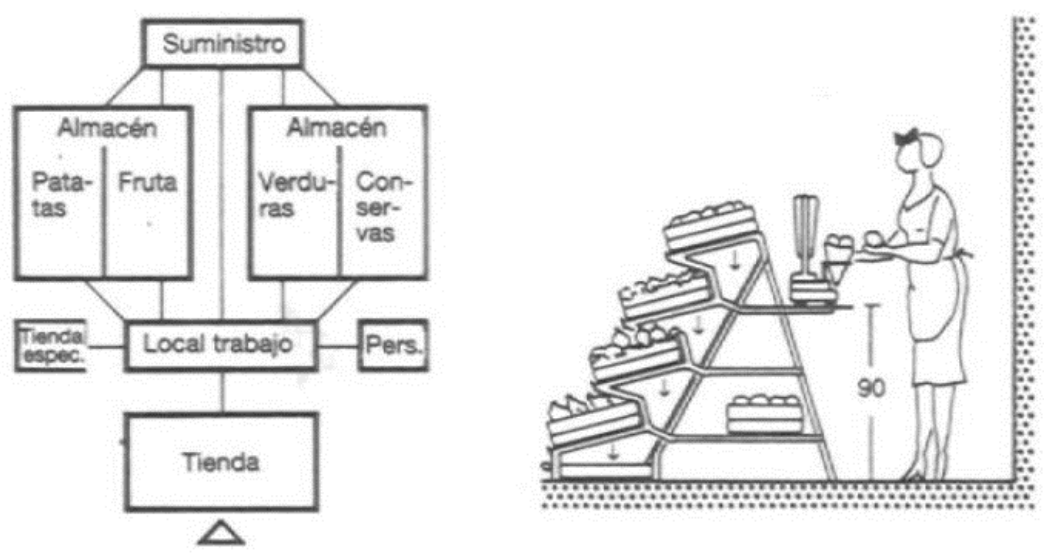

Figura 4.4 Neufert_Puesto de verduras y frutas

Fuente: Neufert, 2016 


\section{Zonas de carga y descarga}

En el caso de comercios de más de $200 \mathrm{~m}^{2}$ deberán disponer de una superficie para aparcar camiones. Los vehículos deben en lo posible entrar y salir en sentido único hacia adelante. Para patio cubiertos de carga y descarga, la altura libre mínima es de $4.90 \mathrm{~m}$. Anchura de rampas rectas de un carril mín. $3.50 \mathrm{~m}$, con tráfico en ambos sentidos mín. $6.75 \mathrm{~m}$. Las rampas no deberían tener pendientes superiores al $10 \%$ y los cambios de pendiente de más del 8\%. (Neufert, 2016, p. 470)

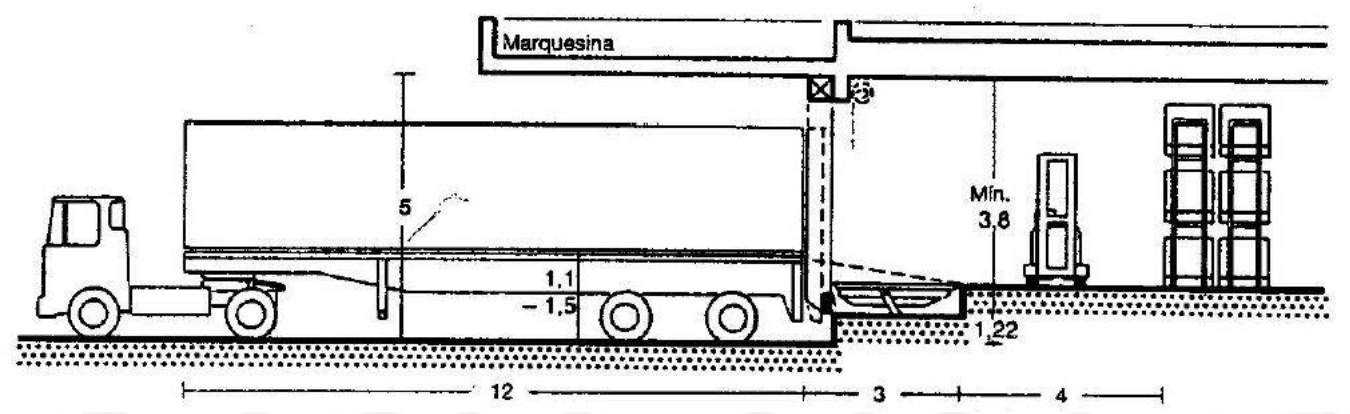

Figura 4.5 Medidas zonas de carga y descarga

Fuente: Neufert, 2016 


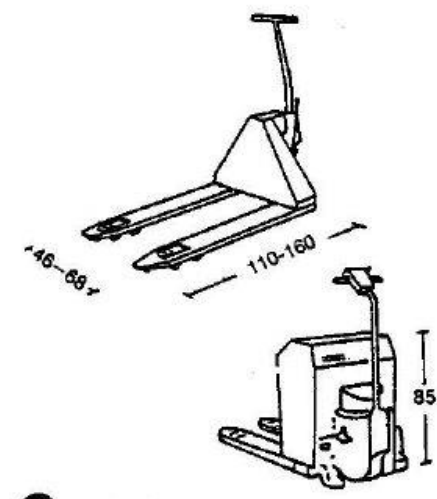

(1) Apiladora

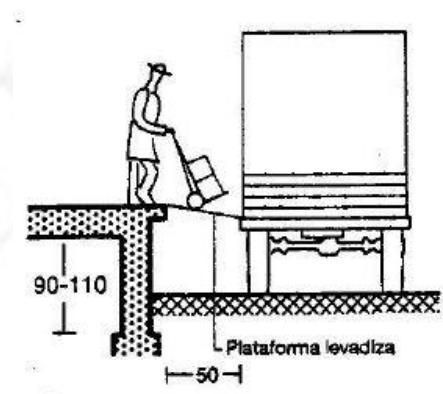

(3) Plataforma levadiza y móvil de carga

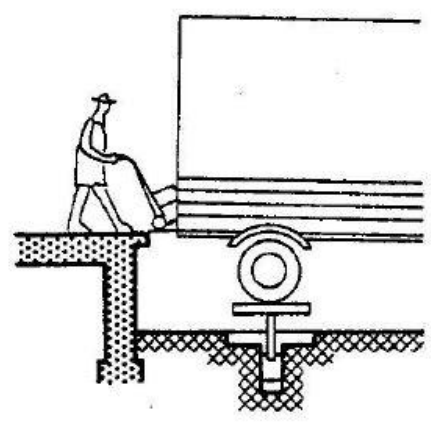

(5) Elevador bajo el eje posterior

Plataforma de tijeras y accionamiento hidráulico para compensar la diferencia de nivel entre el muelle de carga y el camión

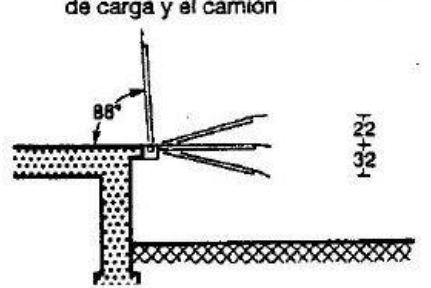

\begin{tabular}{|l|l|l|}
\hline Long. $\mathrm{mm}$ & Ancho mm & Carga adm. $\mathrm{kg}$ \\
\hline 1.500 & 1.500 & 3.000 \\
1.750 & 1.500 & 3.000 \\
1.750 & 1.750 & 5.000 \\
\hline
\end{tabular}

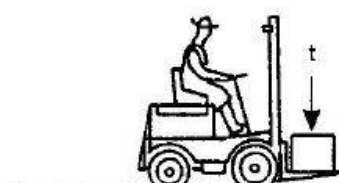

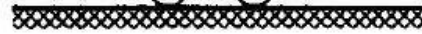

Carga admisible, $\mathrm{t} \quad 2,\left.5|3,5|^{7}\right|^{13}$ \begin{tabular}{ll|l|l|l|l} 
Ancho, mm: & 1 & 1 & 1,2 & $1,5 \mathrm{~m}$ \\
Longitud, mm: & 2,4 & 2,8 & 3,4 & $3,6 \mathrm{~m}$
\end{tabular}

(2) Medidas

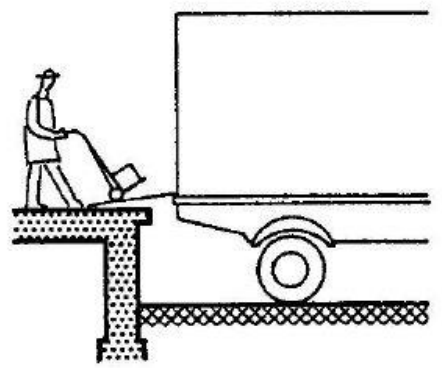

(4) Plancha de carga, móvil

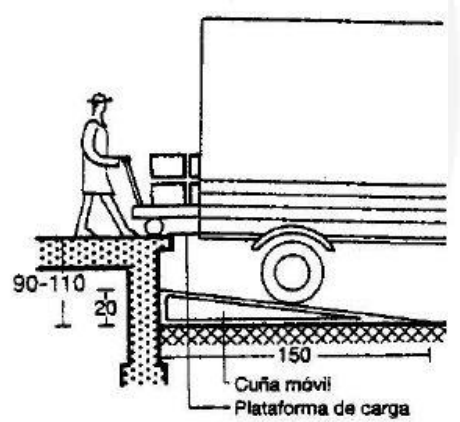

6 Rampa de nivelación móvil

8 Compensación de altura entre patio y camión

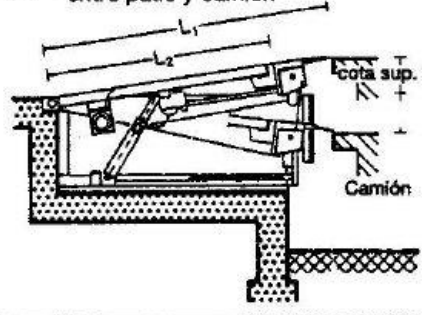

\begin{tabular}{|llllll|}
\hline$O$ & $\cup$ & $L_{1}$ & $L_{2}$ & B & $\begin{array}{l}\text { Carga } \\
\text { adm. } k g\end{array}$ \\
\hline
\end{tabular}

$290300 \quad 2.3002 .0001 .5003 .000$

$\begin{array}{lllllll}360 & 300 & 2.800 & 2.500 & 1.750 & 4.000\end{array}$

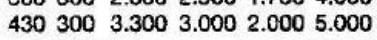

Figura 4.6 Muelles de carga

Fuente: Neufert, 2016 


\section{Cuartos de basura}

Los residuos tienen que recogerse por separado en contenedores apropiados. Para ello se prevén almacenes de residuos de acceso fácil y seguro para los servicios de recogida dentro del edificio o superficies correspondientes fuera del edificio para el almacenamiento temporal. Los almacenes de residuos para la eliminación de basuras comerciales deben estar situados a ras de la calle y cerca de la recepción de mercancías. Sus dimensiones dependen del tamaño de las basuras correspondientes y necesitan un espacio de unos 90-200 m2. (Neufert, 2016, p. 473)

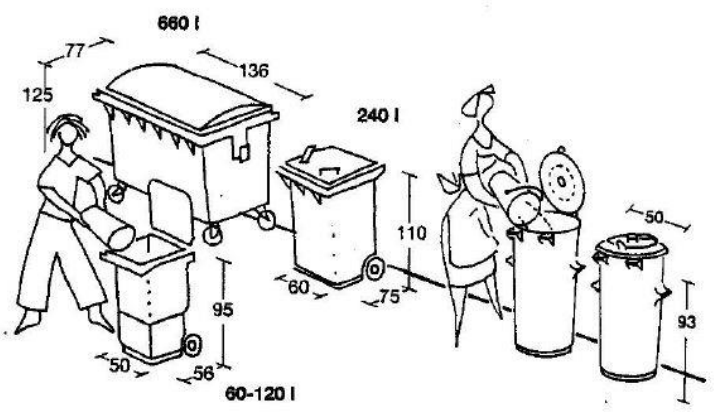

1 Contenedores de basura (en parte según DIN EN 840)

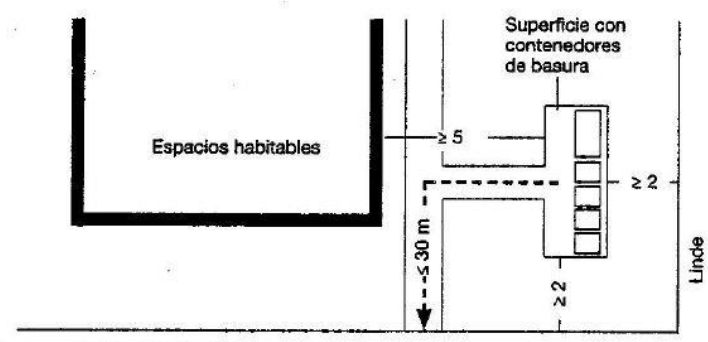

Camino transitable

(2) Distribución de superficies para contenedores de basura

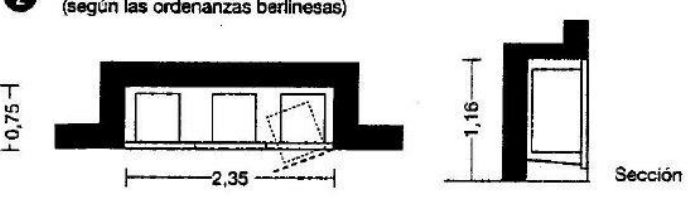

(3) Armario empotrado para $360 \mathrm{I}$ de basura doméstica (esquema))

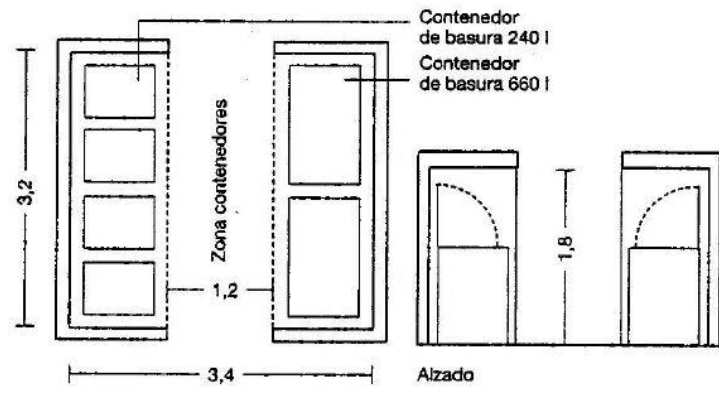

(4) Superficies cubiertas para contenedores de basura

Figura 4.7 Medidas cuarto de basura

Fuente: Neufert, 2016 


\subsubsection{Plazola}

Plazola define al mercado como:

Un lugar público donde concurren comerciantes y compradores que van a realizar alguna transacción comercial, que a su vez es un elemento primordial en la economía de cualquier país, porque en él convergen elementos como la oferta y la demanda, además tiene la función principal de albergar transacciones comerciales entre el comprador y vendedor, principalmente de alimentos y enseres domésticos. (Plazola, 2001, p. 597)

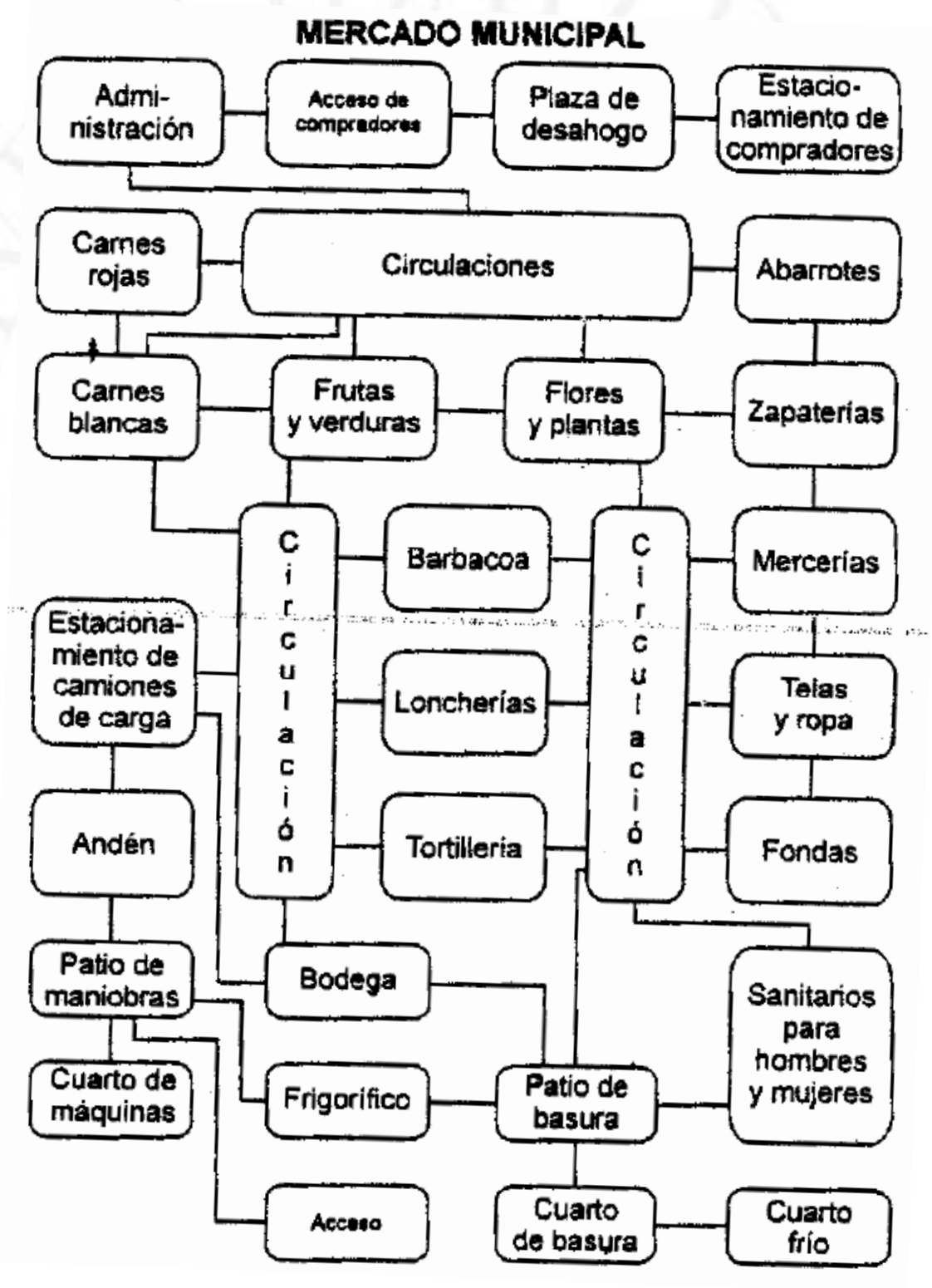

Figura 4.8 Diagrama funcional

Fuente: Plazola, 2001 


\section{Acceso}

El acceso principal se desplazará hacia atrás con respecto a la banqueta perimetral para tener mayor amplitud. Por lo general se protege de cortinas metálicas. Los secundarios se comunican en forma directa con la circulación perimetral, se interrelacionarán con los corredores de circulación interna que comunican con los puestos. El ancho de la puerta es variable de 2.40 a $3.00 \mathrm{~m}$. (Plazola, 2001, p. 609)

El patio de maniobras se debe localizar en una calle secundaria amplia. El andén para carga y descarga que da acceso a los productos del mercado, tendrá un ancho mínimo de $3.00 \mathrm{~m}$ y relación directa con la zona de alimentos preparados. (Plazola, 2001, p. 609)

\section{Puestos de alimentos}

Los puestos tendrán acceso directo a la calle, a la plaza o a alguna circulación intermedia, se solucionan en plan libre para ser distribuidos cada uno según las necesidades del cliente. Se parte de un módulo de $0.30 \mathrm{~m}$ porque es compatible con el espacio y los materiales existentes en el mercado, entonces la profundidad de un puesto varía de $1.80 \mathrm{~m}$ a $3.60 \mathrm{~m}$, y el frente de $2.10 \mathrm{~m}$ a $4.20 \mathrm{~m}$. (Plazola, 2001, p. 610)

Para la iluminación y ventilación de los puestos de venta, lo mejor es utilizar elementos naturales para resolver estos problemas y no recurrir a sistemas de tipo mecánico, debido a su costo elevado e innecesario; además se permitirá la entra del sol a cierta hora para que el local no se encuentre en estado húmedo, ya que afecta a la mercancía. (Plazola, 2001, p. 616)

En las circulaciones internas del puesto, se recomienda un ancho mínimo de $1.05 \mathrm{~m}$ de preferencia de $1.20 \mathrm{~m}$ a $1.80 \mathrm{~m}$. Además, se recomienda que la altura de los muros tenga una altura mínima de $3.00 \mathrm{~m}$ y óptima de $3.60 \mathrm{~m}$. Dentro del plan general de los puestos se debe considerar un espacio para situar refrigeradores, el cual debe estar ventilado para evitar el calentamiento de los mismos. (Plazola, 2001, p. 618) 


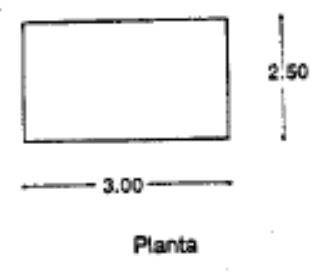

Area de puestos

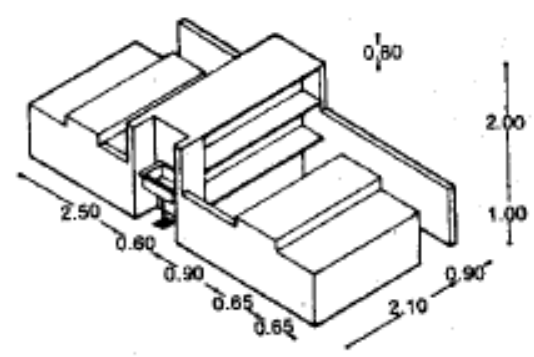

Iscombtrico
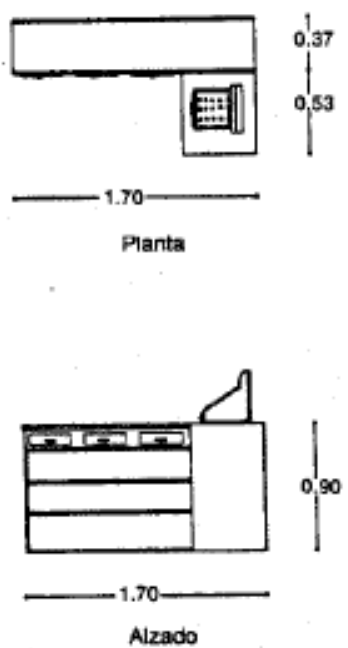

Modulocaja

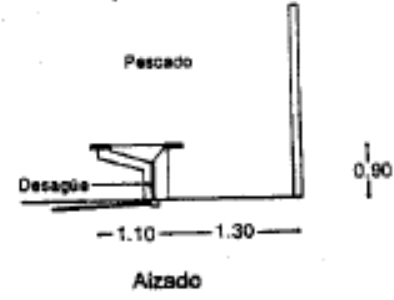

Pescado

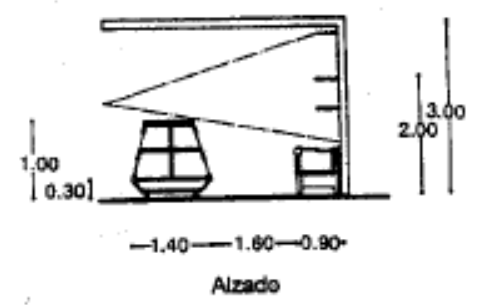

Estantes y pasillos

Figura 4.9 Plazola_Medidas de puesto en general

Fuente: Plazola, 2001
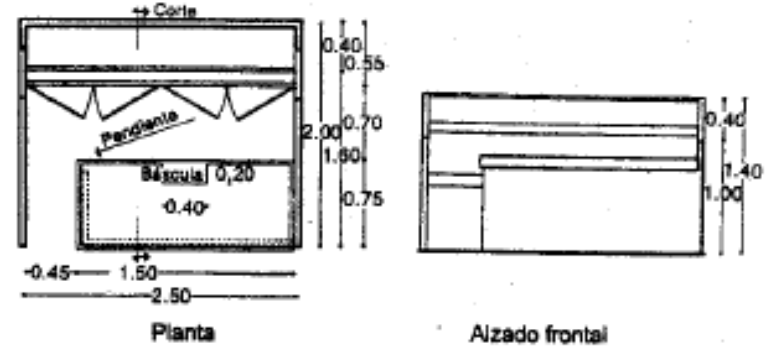

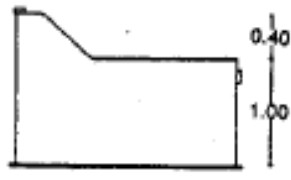

Alzado latera

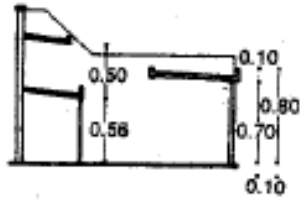

Corte

Figura 4.10 Plazola_Puesto de frutas y verduras

Fuente: Plazola, 2001

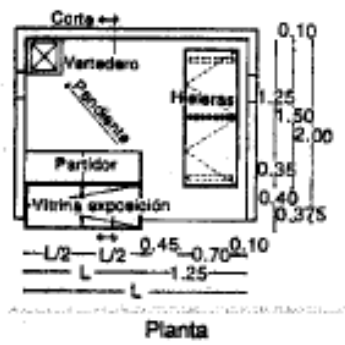

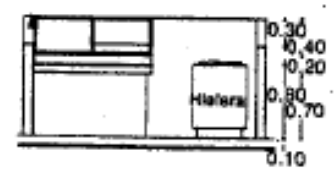

Alzado fronta

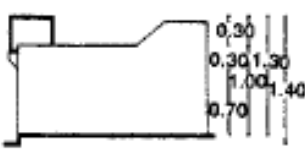

Alzado latera:

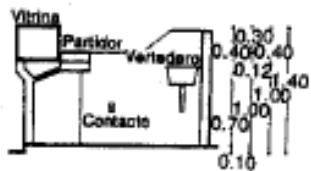

Corto

Figura 4.11 Plazola_Puesto de pescado

Fuente: Plazola, 2001 

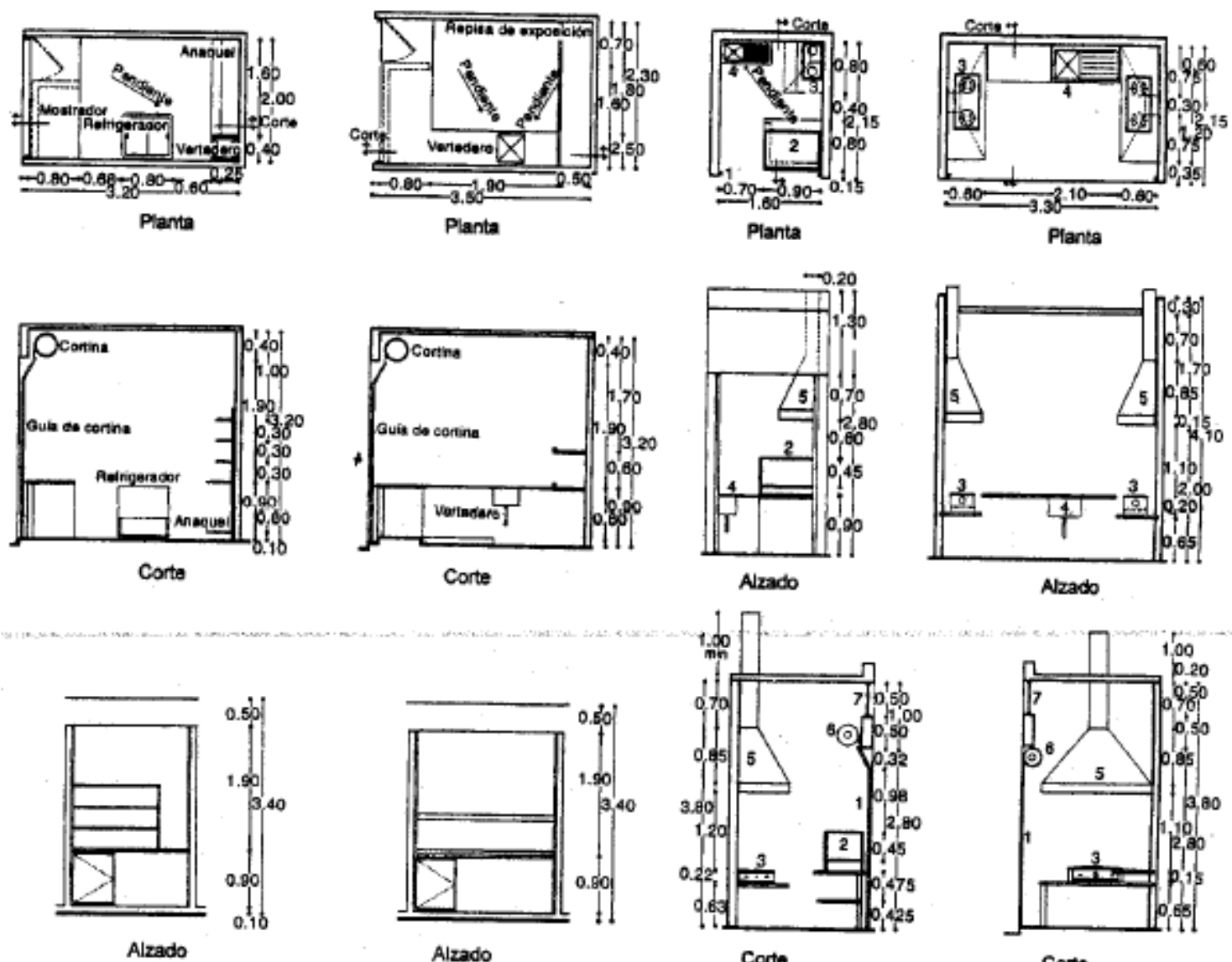

Módulo de refrescos

1. Guia de cortina

2. Vitrina

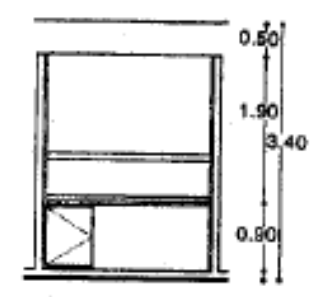

Alzado

Módulo de jugos

3. Estufa

4. Vertodero

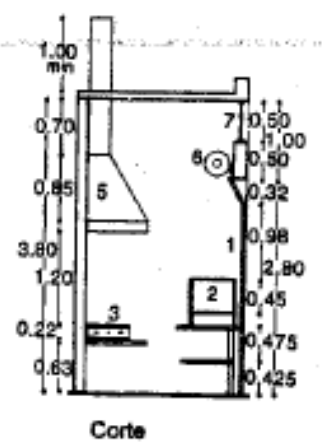

Antojitos

5. Campana 6.' Cortina

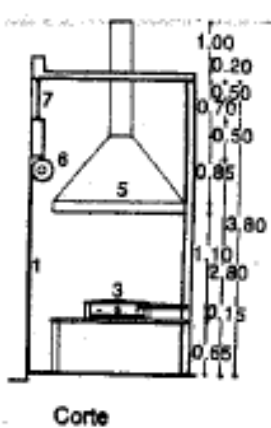

7. Vantana con ventilación

Figura 4.12 Plazola_Puesto de jugos y comida

Fuente: Plazola, 2001

\section{Circulaciones}

Es la parte encargada de distribuir a las personas, locatarios y productos a los diferentes ambientes que posee el mercado, se recomienda un ancho mínimo de $2.40 \mathrm{~m}$. Además, los corredores deben ser lineales y claramente definidos e interrelacionados entre sí para que el comprador pueda transitar fácilmente (Plazola, 2001, p. 610). 

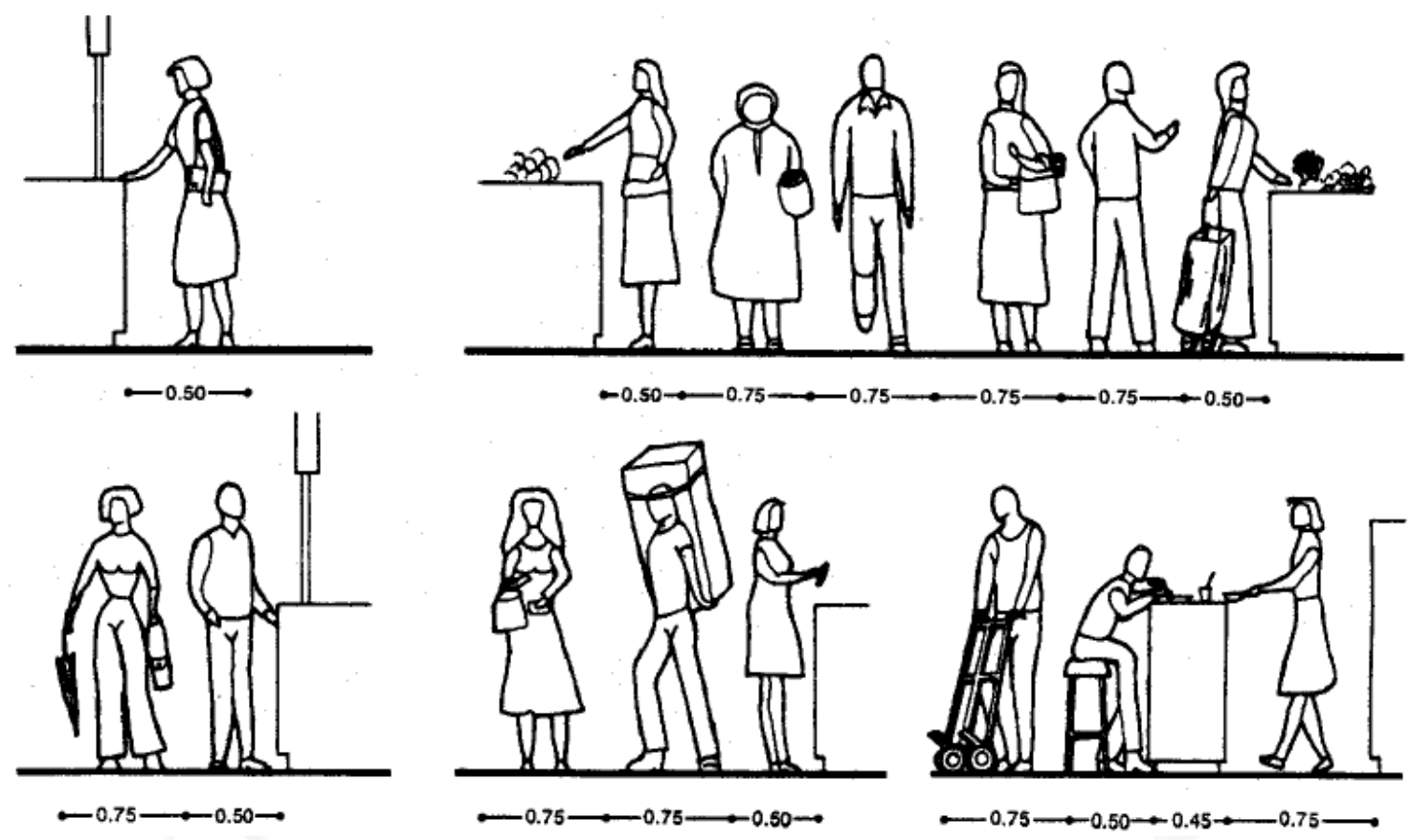

Figura 4.13 Plazola_Circulaciones

Fuente: Plazola, 2001

\section{Sanitarios públicos para hombres y mujeres}

Se instalan en el espacio menos rentable, fuera de la visibilidad de los compradores, de preferencia en alguna esquina próxima a la calle o en la planta alta del mercado, además consta de sección de hombres y mujeres y un vestíbulo de distribución, que a su vez tendrán ventilación natural hacia algún ducto para evitar el mal olor invadido en alguna zona comercial. (Plazola, 2001, p. 611)

\section{Tabla 4.1}

Servicios Higiénicos_Plazola

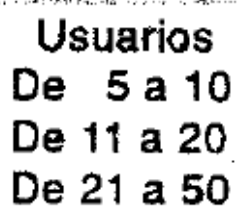

Escusados
2
3
4

Lavabos
2
3
4

Fuente: Plazola, 2001 


\section{Pisos}

Los pisos se construyen con una losa de concreto armada, seleccionada con juntas para evitar fisuras al producirse el empuje del terreno. El terminado y los pisos que se utilicen deben ser de material antiderrapante. Tendrán una pendiente de $1 \%$ hacia las coladeras con rejilla. (Plazola, 2001, p. 611)

\section{Basura}

En este género de edificios se han plantado las nuevas condiciones de higiene en cuanto a los nuevos sistemas de transporte y circulación de la basura. Para recolectar la basura se debe buscar un lugar independiente delos locales de venta. De contar con un depósito para su tratamiento o eliminación. Este cuarto se sitúa cerca de un andén de carga y descarga de mercancía para facilitar su recolección. (Plazola, 2001, p. 611)

\section{Estacionamientos}

Deberán estar alejados de los puestos de venta, ya que cuando los patios de maniobras son invadidos por vehículos de los comerciantes o clientes, obstaculizan las actividades mercantiles y operativas. El número mínimo de cajones será de 1 por $150 \mathrm{~m}^{2}$ construidos. (Plazola, 2001, p. 614)

\section{Vestíbulo de manipulación de productos}

"Es un espacio de transición que une el acceso de servicio, el área de exhibición, las bodegas de productos y el cuarto de basura" (Plazola, 2001, p. 618).

\section{Almacén de productos}

$\mathrm{Su}$ acceso se localiza cerca del estacionamiento de proveedores. Se puede considerar en plan libre, cuya delimitación de productos se realice mediante franjas amarilla o con tarimas. En este caso los productos se apilan. La altura es importante ya que influye en el volumen de la mercancía. (Plazola, 2001, p. 618)

\section{Cuartos de aseo}

El espacio debe ser suficiente para que se pueda instalar un fregadero, lavadero, y armario para guardar cubetas, jergas, escobas, mechudos, jaladores y detergentes. Los casilleros se sitúan contiguos al cuarto de aseo, estos pueden quedar empotrados a los muros con $0.50 \mathrm{~m}$ de frente por $0.45 \mathrm{~m}$ de profundidad. (Plazola, 2001, p. 618) 


\subsubsection{Reglamento Nacional de Edificaciones}

La sección A 0.70 rige las normas técnicas sobre el diseño arquitectónico de establecimientos comerciales, incluyendo el mercado de abastos, por lo que se tomará en cuenta las áreas mínimas y programa requerido para un buen funcionamiento del mercado que se propone. A continuación, se citarán los artículos que influirán directamente en el proyecto.

\section{Capítulo I: Aspectos Generales}

Artículo 1.- "Se denomina edificación comercial a aquella destinada a desarrollar actividades cuya finalidad es la comercialización de bienes o servicios" (Reglamento Nacional de Edificaciones, 2016, p. 117).

Artículo 2.- Locales comerciales agrupados_Mercados:

Local bajo una gestión centralizada, que en base a un programa unitario desarrolla actividades de venta de productos destinados al consumo humano o la limpieza y mantenimiento del hogar. Complementariamente podrán contar con un expendio de comida y bebidas, guarderías y servicios comunales, así como locales administrativos y financieros. (RNE, 2016, p. 118)

\section{Capitulo II: Condiciones de habitabilidad y funcionalidad.}

Artículo 4.- "Los proyectos (...) deberán contar con un Estudio de Impacto Vial que proponga una solución que resuelva el acceso y salida de los vehículos sin afectar el funcionamiento de las vías, desde las que se accede" (RNE, 2016, p. 119).

Artículo 7.- "Las edificaciones comerciales deberán contar con ventilación natural o artificial. La ventilación natural podrá ser cenital o mediante vanos a patios o zonas abiertas. El área mínima de los vanos que abren deberá ser superior al 10\% del área del ambiente que ventilan" (RNE, 2016, p. 120). 
Artículo 9.- El número de personas de una edificación de Mercados Minoristas es de $2.0 \mathrm{~m}^{2}$ por persona en base al área de venta, y en el caso de algún proyecto con dos o más tipos de establecimiento se calculará cada área según uso, y si comparten la misma área deberá considerarse el de mayor aforo (RNE, 2016, p. 120). (Ver Tabla 4.2)

Tabla 4.2

Aforo según edificación comercial_RNE

\begin{tabular}{|l|c|}
\hline \multicolumn{1}{|c|}{ CLASIFICACION } & AFORO \\
\hline Tienda independiente en primer piso (nivel de acceso) & $2.8 \mathrm{~m}^{2}$ por persona \\
\hline Tienda independiente en segundo piso & $5.6 \mathrm{~m}^{2}$ por persona \\
\hline Tienda independiente interconectada de dos niveles & $3.7 \mathrm{~m}^{2}$ por persona \\
\hline
\end{tabular}

Locales de expendio de comidas y bebidas

\begin{tabular}{|l|l|}
\hline Restaurante, cafetería (cocina) & $9.3 \mathrm{~m}^{2}$ por persona \\
\hline Restaurante, cafetería (área de mesas) & $1.5 \mathrm{~m}^{2}$ por persona \\
\hline Comida rápida, comida el paso (cocina) & $5.0 \mathrm{~m}^{2}$ por persona \\
\hline Comida rápida, o al paso (área de mesas, área de atención) & $1.5 \mathrm{~m}^{2}$ por persona \\
\hline
\end{tabular}

Locales de expendio de combustibles

\begin{tabular}{|l|l|}
\hline Establecimiento de venta de combustibles (grifo, gasocentro) & $25 \mathrm{~m}^{2}$ por vehículo \\
\hline Estación de servicio & $25 \mathrm{~m}^{2}$ por vehículo \\
\hline Locales bancarios y de intermediación financiera & $5.0 \mathrm{~m}^{2}$ por persona \\
\hline Locales para eventos, salones de baile & $1.5 \mathrm{~m}^{2}$ por persona \\
\hline Bares, discotecas y pubs & $1.0 \mathrm{~m}^{2}$ por persona \\
\hline Casinos y salas de juego & $3.3 \mathrm{~m}^{2}$ por persona \\
\hline
\end{tabular}

\begin{tabular}{|l|c|}
\hline Locales de espectáculos con asientos fijos & Número de asientos \\
\hline Parques de diversiones y de recreo. & $4.0 \mathrm{~m}^{2}$ por persona \\
\hline Spa, baños turcos, sauna, baños de vapor & $10.0 \mathrm{~m}^{2}$ por persona \\
\hline Gimnasios, fisicoculturismo (área con maquinas) & $4.6 \mathrm{~m}^{2}$ por persona \\
\hline Gimnasios, fisicoculturismo (área sin maquinas) & $1.4 \mathrm{~m}^{2}$ por persona \\
\hline Tienda por departamentos & $3.0 \mathrm{~m}^{2}$ por persona \\
\hline Supermercado & $2.5 \mathrm{~m}^{2}$ por persona \\
\hline Tienda de mejoramiento del hogar & $3.0 \mathrm{~m}^{2}$ por persona \\
\hline Otras tienda de autoservicio & $2.5 \mathrm{~m}^{2}$ por persona \\
\hline Mercado mayorista & $5.0 \mathrm{~m}^{2}$ por persona \\
\hline Mercado minorista & $2.0 \mathrm{~m}^{2}$ por persona \\
\hline Galería comercial & $2.0 \mathrm{~m}^{2}$ por persona \\
\hline Galería ferial & $2.0 \mathrm{~m}^{2}$ por persona \\
\hline
\end{tabular}

Fuente: Reglamento Nacional de Edificaciones, 2016. 
Artículo 10.- "La altura libre mínima de piso terminado a cielo raso en las edificaciones comerciales será de 3.00m” (RNE, 2016, p. 121).

\section{Capitulo III: Características de los componentes}

Artículo 11.- "Los accesos de las edificaciones comerciales deberán contar con al menos un ingreso accesible para personas con discapacidad, y a partir de $1000 \mathrm{~m} 2$ techados, con ingresos diferenciados para público y para mercadería" (RNE, 2016, p. 121).

Artículo 12.- "Las dimensiones de los vanos para la instalación de puertas de acceso, comunicación y salida deberán calcularse según el uso de los ambientes a los que dan acceso y al tipo de usuario que las empleará, cumpliendo los siguientes requisitos"

a) La altura mínima será de $2.10 \mathrm{~m}$

b) Los anchos mínimos de los vanos para las puertas serán según la Tabla 4.3.

Tabla 4.3

Anchos mínimos de vanos de puertas_RNE

\begin{tabular}{|l|l|}
\hline Ingreso principal & $1.00 \mathrm{~m}$ \\
\hline Dependencias interiores & $0.90 \mathrm{~m}$ \\
\hline Servicios higiénicos & $0.80 \mathrm{~m}$ \\
\hline Servicios higiénicos para discapacitados & $0.90 \mathrm{~m}$. \\
\hline
\end{tabular}

Fuente: Reglamento Nacional de Edificaciones, 2016.

Artículo 12.- "El ancho mínimo de los pasajes es de 2.40m los mismos que deben permanecer libres de objetos, mobiliario, mercadería o cualquier obstáculo. Los pasajes principales deben tener un ancho mínimo de 3.00m” (RNE, 2016, p. 122).

Artículo 13.- "Los pisos en mercados (...) serán de material impermeable, antideslizante y liso, fáciles de limpiar y se les dará pendiente de por lo menos $1.5 \%$ hacia las canaletas o sumideros de desagüe; de existir” (RNE, 2016, p. 122). 
Artículo 18.- "Los puestos de comercialización en los mercados se construirán de material no inflamable, las superficies que están en contacto directo con el alimento deben ser fáciles de limpiar y desinfectar" (RNE, 2016, p. 122).

El diseño de las instalaciones será apropiado para la exhibición y la comercialización de alimentos en forma inocua; considera una zona de depósito para almacenar mercadería ligera; requiere de instalaciones eléctricas y sanitarias en caso que lo exija la actividad comercial a desarrollar. (RNE, 2016, p. 122)

Las áreas mínimas de los puestos de venta son por tipo de producto (Ver Tabla 4.4).

Tabla 4.4

Área mínima de los puestos de venta_RNE

\begin{tabular}{|l|c|}
\hline Carnes, pescado y productos perecibles & $6 \mathrm{~m}^{2}$ \\
\hline Abarrotes, mercería y cocina & $8 \mathrm{~m}^{2}$ \\
\hline Otros productos & $6 \mathrm{~m}^{2}$ \\
\hline
\end{tabular}

Fuente: Reglamento Nacional de Edificaciones, 2016.

Artículo 19.- "El área de elaboración de alimentos, será con pisos de material no absorbente, resistentes, antideslizantes, (...) y de materiales que permitan su mantenimiento" (RNE, 2016, p. 122).

Las paredes tendrán superficies lisas, no absorbentes y revestidas de material o pintura que permitan ser lavados sin deterioro. Los techos estarán construidos de forma que no acumule polvo ni vapores de consideración, de fácil limpieza y siempre deben estar en condiciones que eviten contaminación a los productos. (RNE, 2016, p. 122).

\section{Capitulo IV: Dotación de servicios}

Artículo 24.- "Las edificaciones para mercados (...) estarán provistas de servicios sanitarios para empleados, considerando $10 \mathrm{~m} 2$ por persona, según lo que se establece a continuación” (RNE, 2016, p. 125). (Ver Tabla 4.5) 
Tabla 4.5

Dotación de servicios por $\mathrm{N}^{\circ}$ de empleado

\begin{tabular}{|lcc|}
\hline Numero de empleados & Hombres & Mujeres \\
\hline De 1 a 5 empleados & \multicolumn{2}{c|}{$1 \mathrm{~L}, 1 \mathrm{u}, 11$} \\
De 6 a 20 empleados & 1L, 1u, 11 & 1L, 11 \\
De 21 a 60 empleados & 2L, 2u, 21 & 2L, 21 \\
De 61 a 150 empleados & 1L, 1u, 11 & 1L, 11 \\
Por cada 100 empleados adicionales $1 \mathrm{~L}, 1 \mathrm{u}, 11$ & 1L, 11 \\
\hline
\end{tabular}

Fuente: Reglamento Nacional de Edificaciones, 2016

“Adicionalmente a los servicios sanitarios para los empleados se preverán servicios sanitarios para el público en base al cálculo del número de ocupantes según el artículo $8^{\circ}$ de esta norma, conforme a lo siguiente" (RNE, 2016, p. 125). (Ver Tabla 4.6)

Tabla 4.6

Dotación de servicios para comensales

\begin{tabular}{|lll|}
\hline Numero de personas & Hombres & Mujeres \\
\hline De 1 a 100 & $1 \mathrm{~L}, 1 \mathrm{u}, 11$ & $1 \mathrm{~L}, 11$ \\
De 101 a 250 personas & $2 \mathrm{~L}, 2 \mathrm{u}, 21$ & $2 \mathrm{~L}, 21$ \\
Por cada 250 personas adicionales & $1 \mathrm{~L}, 1 \mathrm{u}, 11$ & $1 \mathrm{~L}, 11$ \\
\hline
\end{tabular}

Fuente: Reglamento Nacional de Edificaciones, 2016.

Artículo 31.- "Las edificaciones comerciales deberán contar con áreas de estacionamiento, que podrán localizarse dentro del predio del que se edifica, en las vías que lo habilitan, y en predios colindantes" (RNE, 2016, p. 127). El número mínimo de estacionamientos para un mercado minorista para el personal y público es de 1 estacionamiento cada 10 personas. Además, debe ser multiplicado por el factor de rango de atención del local, de acuerdo a la zonificación urbana y a la ubicación geográfica de cada ciudad (Ver Tabla 4.7).

Tabla 4.7

Factor de atención del local

\begin{tabular}{|l|l|c|c|c|c|}
\hline Tipo de comercio & Hombres & \multirow{2}{*}{ Lima } & \multicolumn{3}{|c|}{$\begin{array}{l}\text { Otras ciudades } \\
\text { Costa Sierra Selva }\end{array}$} \\
\cline { 1 - 2 } \cline { 5 - 7 } Comercio interdistrital C-7 y Metropolitano & Mas de 300, 000 Hab & \multirow{2}{*}{1} & 0.8 & 0.8 & 0.7 \\
\hline Comercio Distrital C-5 & $100,000-300,000 \mathrm{Hab}$ & & 0.7 & 0.7 & 0.6 \\
\hline Comercio Zonal o Sectorial C-3 & $30,000-100,000$ Hab & 0.9 & 0.6 & 0.6 & 0.5 \\
\hline Comercio Local C-1 y Vecinal C-2 & Hasta 30,000 Hab & 0.6 & 0.4 & 0.4 & 0.3 \\
\hline
\end{tabular}

Fuente: Reglamento Nacional de Edificaciones, 2016. 
Artículo 32.- En edificaciones comerciales en las cuales se haya establecido ingresos diferenciados para personas y para abastecimiento, la entrega y recepción deberá realizarse dentro del lote, para lo cual se necesita un patio de maniobras para vehículos de carga (RNE, 2016, p. 129).

“Deberá proveerse de un mínimo de espacios para estacionamiento de vehículos de carga de acuerdo al análisis de las necesidades del establecimiento. En caso de no contarse con dicho análisis se empleará la siguiente tabla” (RNE, 2016, p. 129). (Ver Tabla 4.8)

Tabla 4.8

Estacionamiento para vehículos de carga

\begin{tabular}{|c|c|}
\hline De 1 a $500 \mathrm{~m}^{2}$ de área techada & 1 estacionamiento \\
\hline De 501 a $1,500 \mathrm{~m}^{2}$ de área techada & 2 estacionamientos \\
\hline De 1,500 a $3,000 \mathrm{~m}^{2}$ de área techada & 3 estacionamientos \\
\hline Más de $3,000 \mathrm{~m}^{2}$ de área techada & 4 estacionamientos \\
\hline
\end{tabular}

Fuente: Reglamento Nacional de Edificaciones, 2016.

Artículo 33.- "En los mercados minoristas (...) se considerará espacios para depósitos de mercadería, cuya área será como mínimo el $25 \%$ del área de venta, extendida como la suma de las áreas de los puestos de venta, las áreas para la exposición de los productos y las áreas que ocupan las circulaciones abiertas al público” (RNE, 2016, p. 129).

Se preverá de cámaras frigoríficas para carnes y pescados. La dimensión de la cámara frigorífica de carnes permitirá un volumen de $0.02 \mathrm{~m} 3$ por $\mathrm{m}^{2}$.de área de venta. La dimensión de la cámara frigorífica de pescado permitirá un volumen mínimo de $0.06 \mathrm{~m}^{3}$ por $\mathrm{m}^{2}$ de área de venta. La dimensión de la cámara fría para productos diversos con una capacidad de $0.03 \mathrm{~m}^{3}$ por $\mathrm{m}^{2}$ de área de venta. (RNE, 2016, p. 129).

Artículo 34.- "El área mínima del ambiente para el acopio y evacuación de residuos, se determinará en base a la superficie de venta. Para mercados minoristas será de $0.02 \mathrm{~m}^{3}$ por $\mathrm{m}^{2}$ de superficie de venta" (RNE, 2016, p. 129). 


\subsubsection{Ayuntamiento de Madrid}

\section{Ordenanza de Mercados de Madrid}

\section{Capítulo 2: Condiciones Técnicas}

\section{Artículo 8.- Superficie y distribución de los establecimientos}

Los locales comerciales de alimentación tendrán una superficie mínima de $20 \mathrm{~m}^{2}$. De la superficie de cada local comercial se destinarán como mínimo $4 \mathrm{~m}^{2}$ a la instalación de un almacén, o de una cámara frigorífica según sea la actividad que se ejerza. (Ayuntamiento de Madrid, 2010, p. 3)

Cuando la actividad que se ejerza necesite la instalación de zona de horneado, obrador o zona de envasado, las dimensiones mínimas del local comercial deberán ser de treinta 30 $\mathrm{m}^{2}$ si es monovalente y $48 \mathrm{~m}^{2}$ si es polivalente. (Ayuntamiento de Madrid, 2010, p. 3)

En todo caso el Mercado dispondrá de cámaras frigoríficas independientes para carnes, frutas y verduras, pescados, aves y huevos y caza, con las condiciones técnicas que imponga la normativa vigente. (Ayuntamiento de Madrid, 2010, p. 3)

\section{Artículo 10.- Mezcla comercial}

Del total de la superficie de los establecimientos del Mercado de Distrito el 65\% como mínimo deberá ser destinada necesariamente al comercio minorista de la alimentación. El número de establecimientos dedicados a cada especialidad de venta se establecerá de acuerdo con las circunstancias que en cada caso establezca el estudio de viabilidad comercial. Las tiendas exteriores si las hubiere no podrán dedicarse al comercio minorista de la alimentación. (Ayuntamiento de Madrid, 2010,p. 4)

\section{Artículo 17.- Aparcamiento}

El aparcamiento se dedicará a uso exclusivo de los usuarios consumidores del Mercado durante el horario comercial. Fuera del horario comercial podrá dedicarse para uso de rotación quedando incomunicado con el interior del Mercado. (Ayuntamiento de Madrid, 2010, p. 5) 


\section{Ordenanza de Comercio Minorista de la Alimentación}

\section{Sección Segunda. - Instalaciones y Exposición de Alimentos}

\section{Artículo 15.- Instalaciones y condiciones exigibles a los establecimientos comerciales}

"Los establecimientos de comercio minorista de la alimentación dispondrán, en la sala de ventas o lugar próximo al puesto de trabajo, de pila de tamaño adecuado dotada de agua potable caliente y fría" (Ayuntamiento de Madrid, 2003, p. 5).

"De cualquier forma, dispondrán de las debidas instalaciones para limpieza y desinfección de los instrumentos y materiales de trabajo" (Ayuntamiento de Madrid, 2003, p. 5)

"Las trastiendas o almacenes de reposición dispondrán de medios suficientes para que los alimentos se conserven adecuadamente" (Ayuntamiento de Madrid, 2003, p. 5).

“Todos los alimentos se depositarán en anaqueles, estanterías o vitrinas o cualquier otro medio de exposición que impida su contacto con el suelo" (Ayuntamiento de Madrid, 2003, p. 5).

\section{Artículo 16.- Depósito de residuos}

Los establecimientos del comercio minorista de la alimentación dispondrán de un cuarto de basuras de dimensiones suficientes, convenientemente aislado y dotado de medios e instalaciones que garanticen el mantenimiento de las condiciones idóneas para su uso en el que deberán ubicarse los contenedores de residuos hasta su recogida por el servicio de Limpieza. (Ayuntamiento de Madrid, 2003, p. 6)

Dicho cuarto de basuras en ningún caso podrá comunicar directamente con las zonas de manipulación o almacenamiento de alimentos, ni constituir, por su emplazamiento y/o estado de conservación y mantenimiento, foco de contaminación o insalubridad. (Ayuntamiento de Madrid, 2003, p. 6)

\section{Artículo 19.- Condiciones de mobiliario}

Los escaparates, estanterías, mostradores, así como los elementos de decoración, serán de materiales resistentes, impermeables y de fácil limpieza, no presentarán irregularidades que puedan ser causa de contaminación. En el caso de que el mobiliario no se encuentre adosado al piso, se dispondrá de un espacio libre, no inferior a 20 centímetros desde el nivel del suelo, para permitir su limpieza. (Ayuntamiento de Madrid, 2003, p. 6) 


\section{Título II: Condiciones Técnicas}

\section{Artículo 30.- Superficie mínima de venta}

En ningún caso la superficie de venta de los establecimientos del comercio minorista de la alimentación será inferior a 15 metros cuadrados para los monovalentes o especializados y 40 metros cuadrados para los polivalentes, disponiendo además de un almacén o trastienda para la conservación de los productos, debidamente acondicionado y diferenciado de la sala de ventas, con una superficie de, al menos, el 10 por 100 de la superficie total del establecimiento y nunca inferior a 3 metros cuadrados. (Ayuntamiento de Madrid, 2003, p. 11)

\section{Artículo 32.- Servicios higiénicos}

La dotación de servicios higiénicos para uso del personal en los establecimientos de comercio minorista de alimentación será la siguiente: Hasta 100 metros cuadrados de superficie total, un retrete y un lavabo; por cada 200 metros cuadrados adicionales o fracción superior a 100 metros cuadrados se aumentará un retrete y un lavabo, separándose para cada uno de los sexos. (Ayuntamiento de Madrid, 2003, p. 11)

Los servicios higiénicos se mantendrán en las debidas condiciones de limpieza, desinfección y desodorización y sus elementos en adecuadas condiciones de conservación. Existirán cuartos, vestuarios y/o taquillas individuales para guardar la ropa y calzado del personal. Las taquillas podrán ubicarse en el anteaseo del servicio de personal. Los establecimientos de comercio minorista de la alimentación con superficie de venta superior de 750 metros cuadrados dispondrán además de servicios higiénicos para uso público. (Ayuntamiento de Madrid, 2003, p. 11)

\section{Tabla 4.9}

Servicios higiénicos_Ayuntamiento de Madrid

\begin{tabular}{|l|c|c|}
\hline $\begin{array}{l}\text { DIMENSIONES DEL LOCAL } \\
\text { (Superficie Total) }\end{array}$ & RETRETES & LAVABOS \\
\hline Hasta $200 \mathrm{~m} 2$ & 1 & 1 \\
\hline De 201 a $300 \mathrm{~m} 2$ & 2 & 2 \\
\hline De 301 a $400 \mathrm{~m} 2$ & 2 & 2 \\
\hline De 401 a $600 \mathrm{~m} 2$ & 3 & 3 \\
\hline De 601 a $800 \mathrm{~m} 2$ & 4 & 4 \\
\hline
\end{tabular}

Fuente: Ayuntamiento de Madrid, 2003 


\section{Artículo 35.- Ventilación}

"La ventilación de piezas locales podrá resolverse mediante alguna de las siguientes soluciones, sin perjuicio de las limitaciones que se establecen para los distintos usos y, en su caso, en las normas zonales" (Ayuntamiento de Madrid, 2003, p. 12).

La ventilación puede ser natural directa, mediante huecos abiertos o practicables directamente al exterior. También es permitido que sea natural conducida mediante conductos o elementos similares que, sin interposición de elementos mecánicos, comuniquen el local o pieza con el exterior, produciéndose la renovación del aire por la diferencia de presión existente entre el interior y el exterior. Y la ventilación forzada debe ser mediante dispositivos mecánicos de impulsión o extracción de aire. (Ayuntamiento de Madrid, 2003, p. 12)

\section{Artículo 36.- Circulación interior}

En los establecimientos del comercio minorista de la alimentación con superficie de venta superior a 750 metros cuadrados, todos los recorridos accesibles al público tendrán una anchura mínima de 2 metros; los desniveles se salvarán con la misma anchura mediante rampas y escaleras. (Ayuntamiento de Madrid, 2003, p. 12)

\section{Artículo 38.- Condiciones exigidas a los pavimentos, suelos y techos}

Los suelos serán fijos, de materiales no absorbentes, resistentes, antideslizantes, no atacables por los productos empleados en su limpieza y de materiales que permitan su mantenimiento en adecuadas condiciones de higiene. Podrán ser continuos o de piezas perfectamente adosadas, no admitiéndose como pavimento definitivo las placas de cemento con junta de dilatación descubierta. Las paredes y techos serán de material liso, no tóxico, no absorbente y de fácil limpieza y desinfección. (Ayuntamiento de Madrid, 2003, p. 13) 


\subsubsection{Plan de Modernización de los Mercados Municipales}

En España se generó un nuevo concepto de mercado municipal, el Mercado de 2da Generación, el cual se apoya directamente al Plan de Modernización de los Mercados Municipales de Andalucía. Esta denominación empleada para los nuevos mercados de abastos, y consiste en dinamizar y reconvertir su sistema actual para que estén conformes a las necesidades del perfil de los nuevos consumidores del s.XXI y revaloricen el entorno en donde están emplazados.

\section{Planes de actuación comercial}

\section{Oficina técnica de Gestión}

La Oficina Técnica de Gestión es necesaria para llevar a cabo la centralización de la gestión de una forma profesionalizada (...) deberá regirla un gerente, pero en los mercados que no dispongan de recursos suficientes para la gestión externa, hay que procurar que un encargado realiza las funciones. (Junta de Andalucía, 2006, p. 81)

Con el fin de tener una estructura organizativa funcional del mercado y facilitar así las labores de gestión de dicho mercado, es recomendable la existencia de una oficina en el propio inmueble con suficiente espacio para los recursos humanos, técnicos y materiales necesarios para la gestión del mercado. (Junta de Andalucía, 2006, p. 81)

\section{Horario Comercial}

Un horario flexible permitirá incrementar las ventas en el sentido de que los consumidores que tienen poco tiempo y necesitan un horario más amplio para realizar las compras, tendrían la oportunidad de hacer las compras en el mercado. La flexibilidad de horarios puede ser importante para una mayor posibilidad de ventas del mercado hacia aun segmento de consumidores que se ve abocado a realizar las compras en otros espacios de consumo con horarios más amplios (...) que, si bien realizaban las compras cotidianas en el mercado, se han visto obligados a realizarlas en otros formatos, al incorporarse la mujer al mercado laboral. (Junta de Andalucía, 2006, p. 82) 


\section{Imagen Corporativa}

La imagen del mercado va más allá de un simple logotipo, es una combinación de atributos (nombre, término, símbolo, diseño) que trata de identificar un producto y diferenciarlo de los competidores, así pues, la imagen corporativa, debe dotar al Mercado Municipal de una imagen y personalidad propia. (Junta de Andalucía, 2006, p. 85)

\section{Otros medios de pago}

La tarjeta propia funciona como fórmula de fidelización del cliente al agilizarse la compra, lo que potencia que se fomente su uso en el comercio. Otro medio es el servicio de consigna de un Mercado es un servicio añadido al cliente para que pueda realizar las compras en el mercado desde su domicilio, hacer otras gestiones o compras y recogerlas posteriormente. (Junta de Andalucía, 2006, p. 86)

\section{Implementación de carros o cestos de compra}

Los mercados que posean una buena movilidad interna y espacio suficiente en sus pasillos, pueden optar a la introducción de carros y cestos de la compra, con la intención de proporcionar una mayor comodidad a los clientes. La ubicación de los carros de compra se deberá destinar en los espacios muertos, algunas plazas de aparcamiento o espacios dedicados exclusivamente para ello. (Junta de Andalucía, 2006, p. 88)

\section{Implementación de servicio de guardería}

Los mercados con suficiente entidad pueden contar con un servicio de guardería para los hijos de los clientes facilitando tanto sus compras en el mercado como en el entorno comercial. Del mismo modo el servicio de guardería se puede ofertar también a los hijos de los comerciantes, fomentando el empleo de la mujer y facilitando la ampliación de los horarios del mercado, aprovechando la mano de obra familiar. (Junta de Andalucía, 2006, p. 88) 


\section{Aparcamiento para clientes}

Es conocida la necesidad de plazas de aparcamiento para las zonas comerciales, siendo la escasez de aparcamientos uno de los principales factores disuasorios en el acto de compra de los consumidores. Un Mercado de 2da Generación, moderno y accesible, no puede estar repleto de coches mal aparcados, bien sea en doble fila o por problemas derivados del no cumplimiento de los horarios establecidos para carga y descarga. Se utiliza un ratio de 8 plazas x cada $100 \mathrm{~m}^{2}$ de superficie de venta. (Junta de Andalucía, 2006, p. 89)

\section{Servicios básicos}

Los Mercados de 2da Generación están obligados a ofrecer unos servicios básicos mínimos con la finalidad de dar la presentación más completa posible a los consumidores como:

- Servicios de mantenimiento

- Servicios de limpieza

- Correcta iluminación

- Climatización

- Instalaciones no visibles de agua, gas y electricidad

- Muelles de carga

- Cámara frigorífica

- Recogida de residuos

\section{Oferta o mix comercial del mercado}

Con el fin de adaptarse a la demanda del área de influencia, cada Mercado debe desarrollar una oferta o mix comercial complementaria a su entorno (...) mientras mayor superficie comercial tenga el mercado, tendrá más posibilidad de ampliar la oferta de productos y servicios. A continuación, se indica una tabla donde se establece un mix óptimo ideal en alimentación perecedera y productos tradicionales de un mercado. (Junta de Andalucía, 2006, p. 97) 
Tabla 4.10

Mix comercial óptimo

\begin{tabular}{|l|l|}
\hline Productos & $\%$ de SBC \\
\hline Frutas y Verduras & $40 \%$ \\
\hline Pescado y Marisco & $30 \%$ \\
\hline Carnes y Charcuteria & $25 \%$ \\
\hline Alimentación Seca y Otros & $5 \%$ \\
\hline
\end{tabular}

Fuente: Junta de Andalucía, 2006

Pero este mix comercial dependerá de la zona en la que se encuentre el mercado, por ejemplo, los que se encuentran más cercanos a la costa suelen tener un mayor número de puestos de pescado y mariscos que los que se encuentran en la zona central, donde predominan los puestos de carne, mientras que los mercados ubicados en zonas turísticas tener variedad de oferta, se puede contemplar incluir supermercado, galería comercial, ocio y restauración, siempre como complementariedad de la alimentación perecedera (Junta de Andalucía, 2006, p. 97).

El acto de compra se puede asociar de forma natural a una actividad lúdica, divertida, que ocupa el tiempo de ocio, el cual proporciona un mayor de nivel de satisfacción y esparcimiento en los mercados. Dentro de la oferta de ocio y restauración se podrá contar con posibilidades como restaurantes, recreativos, gimnasios, teatros, salas de proyección, exposiciones, entre otras posibilidades, pero debe ser definido en base a lo que necesita la zona del mercado (Junta de Andalucía, 2006, p. 99).

\section{Localización}

Una de las principales fortalezas que han conseguido que los mercados sigan funcionando al día de hoy, es su centralidad, tanto a nivel municipal como a nivel de barrio. Esta fortaleza es importante que se siga poniendo en valor. Por tanto, los mercados municipales que ya están implantados y tienen posibilidades de éxito, tendrán que remodelarse física y funcionalmente. (Junta de Andalucía, 2006, p. 102) 


\section{Acceso y tránsito}

Para el tránsito sin dificultades de los clientes, es necesario utilizar diferentes criterios que contribuyan a la optimización de la circulación interna: número y tipo de puertas, acceso diferenciado para mercancías, amplitud de pilares y conformar una plataforma única. (Junta de Andalucía, 2006, p. 102)

La entrada al inmueble constituye el elemento que separa al cliente del interior del mercado. En este sentido, es fundamental que se diseñe para potenciar la facilidad de acceso, de modo que la entrada no suponga una barrera para el cliente, y, por el contrario, le invite a entrar. Por lo que deben ofrecer 4 puertas de acceso o más y una amplitud de pasillos de 5 a 7m. (Junta de Andalucía, 2006, p. 102)

\section{Sala de formación}

Debido a las importantes carencias formativas detectadas en los comerciantes de los mercados municipales, se hace necesario un Plan Formativo Continuo que consiga adecuar su formación a la actual demanda y la aplicación de nuevas tecnologías (...) por lo que se recomienda instalar una sala de formación donde se impartan cursos tanto técnicos como comerciales. (Junta de Andalucía, 2006, p. 109)

\section{Superficie del puesto de venta}

La distribución de la superficie del punto de venta debe buscar facilitar la compra del cliente con una correcta exposición, y la propia actividad comercial que el empresario debe ejercer, pudiéndose mover libremente por el punto de venta. La superficie total del punto de venta en $\mathrm{m}^{2}$ dependerá del producto que se ofrece, pero es aconsejable que se sitúe entorno a los 15-25 $\mathrm{m}^{2}$ como superficie óptima para la actividad comercial. (Junta de Andalucía, 2006, p. 112) 
Tabla 4.11

Plan de actuación_Gestión y Política Comercial

\begin{tabular}{|c|c|c|}
\hline \multicolumn{3}{|c|}{$\begin{array}{c}\text { Plan de Actuación Comercial en los Mercados Municipales Grandes } \\
\text { Línea de Actuación: Gestión y Política Comercial }\end{array}$} \\
\hline Medidas de Actuación & Acciones & Actuación \\
\hline \multicolumn{3}{|l|}{ Tipo de Gestión } \\
\hline \multirow[t]{3}{*}{ Gestión Interna } & Gestión Directa Municipal (con o sin órgano especial) & No \\
\hline & Organismo Autónomo & No \\
\hline & S.A.M. o S.A. & Si \\
\hline \multirow[t]{3}{*}{ Gestión Externa } & Concesión & Sí \\
\hline & Autogestión & Si \\
\hline & Sociedad Mercantil o Cooperativa con Capital Mixto & Si \\
\hline \multirow[t]{3}{*}{ Oficina Técnica de Gestión } & Gerente & sí \\
\hline & Encargado & No \\
\hline & Oficina en el Mercado & Sil \\
\hline \multirow[t]{13}{*}{ Politica Comercial } & Horario Comercial & Jornada Continua \\
\hline & Imagen Corporativa & Si \\
\hline & Tarjeta Propia & Recomendable \\
\hline & Servicio a Domicilio Conjunto & Sí \\
\hline & Consigna & Sí \\
\hline & Carros/Cestos de Compra & Sí \\
\hline & Guardería & Recomendable \\
\hline & Servicios Bancarios & Si \\
\hline & Caja Única & No \\
\hline & Aparcamientos para Clientes & Si \\
\hline & Compra on line & Si \\
\hline & Servicios Básicos & Si \\
\hline & Formación al Comerciante & Sí \\
\hline \multirow[t]{4}{*}{ Promocion y Comunicación } & Aplicaciones de la Imagen Corporativa (bolsa, carteleria, etc.) & Si \\
\hline & Campañas de Captación de Clientes (Navidad, Rebajas, Verano...) & Continuas \\
\hline & Campañas de Fidelización de Clientes (Bonos, Descuentos $\ldots .$. ) & Continuas \\
\hline & Campañas Internas de Captación de Comerciantes & Si (Actividad Media-Baja) \\
\hline \multirow[t]{7}{*}{ Oferta Comercial } & Alimentaria Perecedera Completa & Si \\
\hline & Alimentación Completa & Si \\
\hline & Supermercado & Sí (Hasta $700 \mathrm{~m}^{2}$ ) \\
\hline & Área de Libre Servicios (PLS) & Si \\
\hline & Galeria Comercial & Si \\
\hline & Ocio y Restauración & Si \\
\hline & Transformación del Producto & Si \\
\hline
\end{tabular}

Fuente: Junta de Andalucía, 2006 
Tabla 4.12

Plan de actuación_Adecuación Física y Funcional

\begin{tabular}{|c|c|c|}
\hline \multicolumn{3}{|c|}{$\begin{array}{l}\text { Plan de Actuación Comercial en los Mercados Municipales Grandes } \\
\text { Línea de Actuación: Adecuación Física y Funcional del Inmueble }\end{array}$} \\
\hline Medidas de Actuación & Acciones & Actuación \\
\hline \multirow[t]{2}{*}{ Localización } & Céntrica Ciudad o Barrio & Si \\
\hline & Dentro de Zona Comercial (ACD, CCA) & Sî \\
\hline Superficie Comercial & $\mathrm{m}^{2}$ de SBC & De $500-1.000 \mathrm{~m}^{2}$ \\
\hline \multirow[t]{4}{*}{ Acceso y Tránsito } & $N^{\circ}$ de Puertas & De 4 en Adelante \\
\hline & Acceso Diferenciado de Mercancias & Si \\
\hline & Amplitud de Pasillos & 5-7 m \\
\hline & Plataforma Única & Si \\
\hline \multirow[t]{3}{*}{ Infraestructuras } & Instalaciones No Visibles & Sí \\
\hline & Climatización Conjunta Integral & Si \\
\hline & Islas Ecológicas & Si \\
\hline \multirow[t]{9}{*}{ Dotaciones Comunes } & Áreas de Basura & Si \\
\hline & Muelles de Carga & Si \\
\hline & Cámaras de Frio Comunes & Si \\
\hline & Área de Despiece & Si \\
\hline & Área de Embalaje & Si \\
\hline & Envasadoras/Etiquetadoras & Si \\
\hline & Vestuarios & Si \\
\hline & Almacén & Sí \\
\hline & Aparcamientos para Comerciantes & Si \\
\hline \multirow[t]{4}{*}{ Servicios Internos } & Mantenimiento & Permanente \\
\hline & Seguridad & Si \\
\hline & Sala de Formación & Recomendable \\
\hline & Limpieza & Permanente \\
\hline \multirow[t]{8}{*}{ Merchandising } & Imagen Integral & Si \\
\hline & Rotulismo Integral & Sí \\
\hline & Interiorismo (equipamiento y mobiliario) & Si \\
\hline & Ambientación (música, luminosidad, colores, ...) & Si \\
\hline & Señalética & Si \\
\hline & Distribución por Espacio (secciones, servicios, puntos de venta, etc.) & Si \\
\hline & Eliminación de Barreras & Sí \\
\hline & Zonas de Descanso & Si \\
\hline \multirow[t]{2}{*}{ Puntos de Venta } & Identificación/Rotulación & Si \\
\hline & Superficie del Puesto de Venta & $15-25 \mathrm{~m}^{2}$ \\
\hline
\end{tabular}

Fuente: Junta de Andalucía, 2006 


\subsection{Instituciones afines}

\subsubsection{Ministerio de la Producción}

El Ministerio de la Producción tiene como finalidad diseñar, establecer, ejecutar y supervisar, en armonía con la política general y los planes de gobierno, política nacionales y sectoriales aplicables a los sectores de pesquería y de micro y pequeña empresa e industria, asumiendo rectoría respecto de ellas (Ministerio de la Producción, 2018).

\section{Capítulo 1: Aspectos Generales}

\section{Artículo 1.- Objetivo}

La presente norma de mercados de abastos es de alcance nacional, y busca fomentar el desarrollo de la productividad y competitividad de mercados de abastos mayoristas y minoristas, que permita generar rápidamente proyectos con estándares de calidad que contribuyen a garantizar la seguridad alimentaria urbana y rural y a revalorar los patrones culturales, gastronómicos y tradicionales propios de cada lugar. (Ministerio de la Producción, 2017, p. 13)

\section{Artículo 3.- Planificación de los Mercados de Abastos}

Los Mercados de Abastos, mayoristas y minoristas, públicos y privados, constituyen un sistema que además de cumplir la función social de garantizar el abastecimiento y distribución de alimentos a todos los sectores de la población, es un equipamiento urbano con potencial económico, social, turístico y cultural ya que expresa la riqueza gastronómica y tradiciones del lugar, y como tal deben ser considerados en la planificación urbana y territorial de cada localidad. (PRODUCE, 2017, p. 14)

\section{Capítulo 2: Condiciones de habitabilidad y funcionalidad}

\section{Artículo 8.- Criterios de diseño de Mercados de Abastos}

Los ambientes deberán tener el tamaño adecuado para la instalación, operación y mantenimiento de los equipos, así como para la circulación del personal y el traslado de materiales o productos. Asimismo, estarán ubicados según la secuencia lógica del proceso, desde la recepción de los productos hasta el despacho al consumidor minimizando los riesgos de contaminación directa o cruzada. La altura mínima de piso terminado a cielo raso en los mercados será de 3.00 m. (PRODUCE, 2017, p. 19) 


\section{Artículo 9.- Áreas diferenciadas en los mercados de abasto}

Se distinguen 5 áreas diferenciadas en un mercado de abastos (Ver Figura 4.14)

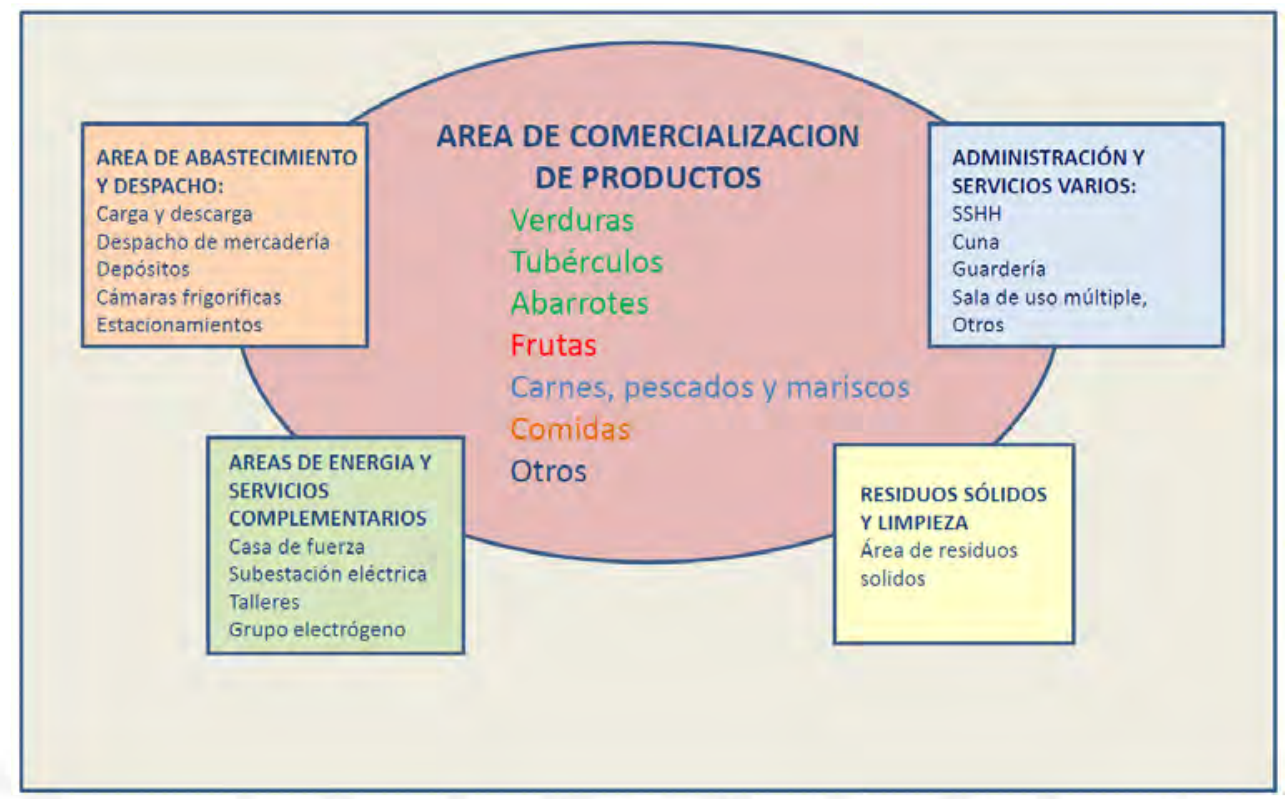

Figura 4.14 Partes de un mercado según Produce

Fuente: Ministerio de la Producción, 2017

\subsection{Del área de comercialización}

La distribución de las secciones será por tipo de alimento, de tal manera que evite la contaminación cruzada, bien sea por efecto de la circulación de los equipos rodantes, del personal, de la proximidad a los servicios higiénicos, del colector de residuos sólidos o de cualquier otro punto de contaminación. El diseño de las instalaciones será apropiado para la exhibición y comercialización de los alimentos en forma inocua y requiere de instalaciones eléctricas y sanitarias de acuerdo a la actividad comercial a desarrollar. (PRODUCE, 2017, p. 21)

Tabla 4.13

Áreas mínimas de puestos de venta_Produce

\begin{tabular}{|l|l|}
\hline Carnes, pescados y productos perecibles & $6 \mathrm{~m} 2$. \\
\hline Abarrotes, mercería y cocina & $8 \mathrm{~m} 2$. \\
\hline Otros productos & $6 \mathrm{~m} 2$. \\
\hline
\end{tabular}

Fuente: Ministerio de la Producción, 2017 


\subsection{Del área de abastecimiento y despacho}

Además, deberá contar con área de carga y descarga, considerando que áreas mayores de $1000 \mathrm{~m} 2$ deberán tener accesos diferenciados tanto para la mercancía separado del público, incluyendo un andén de descarga.

Tabla 4.14

Ratio para estacionamientos_Produce

\begin{tabular}{|l|l|l|}
\hline Estacionamiento & Para el personal & Para el público \\
\hline Mercado de Abastos & 1 por cada 10 personas & 1 por cada 10 personas \\
\hline
\end{tabular}

Fuente: Ministerio de la Producción, 2017

Este a su vez se debe multiplicar con el factor de rango de atención del local que se encuentra en el Reglamento Nacional de Edificaciones A.070 (Ver Tabla 4.14). Y en cuanto a las cámaras frigoríficas se maneja un ratio en base al tipo de producto (Ver Tabla 4.15).

"Para los mercados de abastos existentes que no cuenten con la dotación suficiente de estacionamientos, se evaluará su pertinencia de acuerdo a las condiciones de la localidad y a su preexistencia" (PRODUCE, 2017, p. 22).

Tabla 4.15

Ratio para cámaras frigoríficas_Produce

\begin{tabular}{|l|l|}
\hline Tipo & Área de Cámara \\
\hline Carnes & $0.02 \mathrm{~m} 3 \times \mathrm{m} 2$. de área de ventas \\
\hline Pescados & $0.06 \mathrm{~m} 3 \times \mathrm{m} 2$. de área de ventas \\
\hline Otros & $0.03 \mathrm{~m} 2 \times \mathrm{m} 2$. de área de ventas \\
\hline
\end{tabular}

Almacenes: área mínima: 25\% del área de venta.

Fuente: Ministerio de la Producción, 2017 


\subsection{Del área de residuos sólidos y limpieza}

Los mercados deberán contar con un ambiente para recolectar los residuos sólidos, los cuales deberán encontrarse alejadas del área de comercialización y de los almacenes. Sus paredes y pisos serán de fácil limpieza, y el sistema de ventilación, natural o forzado deberá estar protegido contra roedores y plagas. (PRODUCE, 2017, p. 21)

Tabla 4.16

Ratio de áreas de residuos

\begin{tabular}{|l|l|}
\hline Ambiente para basura mercado mayorista & $0.015 \mathrm{~m} 3 \times \mathrm{m} 2$ de área de venta \\
\hline Ambiente para basura mercado minorista & $0.020 \mathrm{~m} 3 \times \mathrm{m} 2$ de área de venta \\
\hline Ambiente de limpieza & $6 \mathrm{~m} 2 .+$ lavatorio \\
\hline
\end{tabular}

Fuente: Ministerio de la Producción, 2017

\subsection{Del área de administración y servicios varios}

Deberá contar como mínimo con una oficina administrativa, que será el centro de coordinación de operaciones y control. El área destinada para este y otros servicios dependerá del proyecto, aunque se recomienda complementar la actividad de comercialización del mercado con servicios que permitan utilizar la infraestructura a jornada completa para hacerla más productiva. (PRODUCE, 2017, p. 23)

\section{Artículo 12.- Aforo}

El número máximo de personas que se puede admitir en el mercado se calcula en base al área de venta de cada establecimiento, entendiéndose como tal la superficie en la que se exponen las mercancías o se prestan los servicios con carácter habitual y permanente, y a la cual puede acceder la clientela para hacer sus compras. (PRODUCE, 2017, p. 25)

Tabla 4.17

Aforo según edificación comercial_Produce

\begin{tabular}{|l|l|}
\hline CLASIFICACIÓN & AFORO \\
\hline MERCADO MAYORISTA & 1 persona por cada 5.0 M2. \\
\hline MERCADO MINORISTA & 1 persona por cada 2.0 M2 \\
\hline & \\
\hline COMIDA RAPIDA, COMIDA AL PASO (COCINA) & 1 persona por cada 5.0 M2 \\
\hline COMIDA RAPIDA, COMIDA AL PASO (AREA DE MESAS O ATENCIÓN) & 1 persona por cada 1.5 M2 \\
\hline & \\
\hline OFICINAS & 1 persona por cada 9.5 M2 \\
\hline
\end{tabular}

Fuente: Ministerio de la Producción, 2017 


\section{Capítulo 3: Característica de los componentes}

\section{Artículo 13.- Circulación}

“Las puertas de acceso serán como mínimo en número de 2 en mercados de 150 puestos o menos, debiendo ubicarse en puntos extremos y aumentando una puerta por cada 100 puestos adicionales" (PRODUCE, 2017, p. 26).

"Las dimensiones de los vanos para la instalación de puertas de acceso, comunicación y salida deberán calcularse de acuerdo al ambiente al que sirven” (PRODUCE, 2017, p. 26).

Tabla 4.18

Anchos mínimos de vanos de puertas_Produce

\begin{tabular}{|l|l|}
\hline Ingreso principal & $2.30 \mathrm{~m}$ (altura) $\times 3.00 \mathrm{~m}$ (ancho) \\
\hline Altura puerta interior & $2.10 \mathrm{~m}$ \\
\hline Dependencias interiores & $0.90 \mathrm{~m}$ \\
\hline Servicios higiénicos & $0.80 \mathrm{~m}$ \\
\hline Servicios higiénicos para discapacitados & $0.90 \mathrm{~m}$ \\
\hline Puertas de Evacuación & Según N.T. A.130 \\
\hline
\end{tabular}

Fuente: Ministerio de la Producción, 2017

Los pasadizos tendrán una amplitud suficiente para asegurar el tránsito fluido; en cualquier caso su anchura no debe ser menor de $2.40 \mathrm{~m}$, y en ningún caso se utilizarán como áreas de almacenamiento temporal o permanente ni de exhibición de los alimentos. Los pasadizos estarán interrelacionados unos con otros, de manera que exista fluidez hacia las puertas de salida, sin que queden puntos ciegos. Los pasajes principales deberán tener un ancho mínimo de 3.00 m. (PRODUCE, 2017, p. 27)

\section{Capítulo 4: Dotación de servicios}

Artículo 14.- Instalaciones sanitarias

El almacenamiento del agua podrá hacerse en cisternas o tanques elevados ubicados en lugares no expuestos a filtraciones o contaminación, y manteniéndose en ellos su potabilidad, no debiendo contener ésta niveles menores a $0,5 \mathrm{ppm}$ de cloro residual. Tendrán además una capacidad mínima de 100 litros por puesto que expenda alimentos perecederos. (PRODUCE, 2017, p. 28) 
Asimismo, deberá contar con sumideros de mínimo 6 pulgadas de diámetro distribuidos por todos los pasadizos, y estarán cubiertos con rejillas metálicas desmontables a fin de evitar el ingreso de roedores e insectos al establecimiento. Contará también con trampas para sólidos con el fin de recuperarlos para su disposición; las cajas de registro con tapa se distribuirán cada $300 \mathrm{~m} 2$ o por cada 50 puestos. (PRODUCE, 2017, p. 28)

\section{Artículo 15.- Servicios higiénicos}

La cantidad de aparatos sanitarios es la misma que se emplea en el Reglamento Nacional de Edificaciones (Ver Tabla 4.5 y Tabla 4.6).

\subsubsection{Ministerio de Salud}

El Ministerio de Salud tiene la misión de proteger la dignidad personal, promoviendo la salud, previniendo las enfermedades y garantizando la atención integral de salud de todos los habitantes del país; proponiendo y conduciendo los lineamientos de políticas sanitarias en concertación con todos los sectores públicos y los actores sociales. (Ministerio de Salud, 2018)

Título II: De los Mercados de Abasto

\section{Capítulo 1: De la ubicación y estructura física}

\section{Artículo 10.- Estructura física}

a) “Los pisos serán de material impermeable, inadsorbente, antideslizante y liso, no tendrán grietas y serán fáciles de limpiar y desinfectar. Se les dará una pendiente que permita que los líquidos escurran hacia los sumideros, evitando su acumulación” (Ministerio de Salud, 2003, p. 2).

b) "En las áreas de comercialización, los ángulos entre las paredes, entre las paredes y los pisos, y entre las paredes y los techos, serán abovedados y continuos para facilitar la limpieza y evitar la acumulación de elementos extraños" (MINSA, 2003, p. 2).

c) "Los techos deberán ser de material impermeable, inadsorbente, liso, sin grietas y fáciles de limpiar, de tal manera que se impida la acumulación de suciedad" (MINSA, 2003, p. 2). 
d) "Las puertas de acceso serán como mínimo en número de dos (2) en mercados de 150 puestos o menos, debiendo ubicarse en puntos extremos y aumentando una puerta por cada 100 puestos adicionales" (MINSA, 2003, p. 2).

e) “Las ventanas y otras aberturas se diseñarán de manera tal que se evite la acumulación de suciedad y sean fáciles de limpiar" (MINSA, 2003, p. 2).

f) “Los pasadizos tendrán una amplitud suficiente para asegurar el tránsito fluido; en cualquier caso, su anchura no debe ser menor de 2 m" (MINSA, 2003, p. 2).

\section{Capítulo 2: De las instalaciones sanitarias}

\section{Artículo 14.- Servicios higiénicos, vestuarios y duchas}

Los vestuarios y duchas deben ser independientes al resto de los servicios higiénicos, separados hombres de mujeres, no deben tener una comunicación directa con el área de venta de los alimentos ni los almacenes, ni con cualquier otro ambiente que incluya productos perecederos (MINSA, 2003, p. 5).

Tabla 4.19

Dotación de servicios por número de personas

\begin{tabular}{|c|c|c|c|c|}
\hline $\begin{array}{c}\text { Número de } \\
\text { personas }\end{array}$ & Inodoros & Lavatorios & Urinarios & Duchas \\
\hline de 1 a 15 & 1 & 2 & 1 & 1 \\
\hline de 16 a 50 & 3 & 5 & 2 & 3 \\
\hline de 50 a 100 & 5 & 10 & 4 & 6 \\
\hline más de 100 & 1 aparato sanitario adicional por cada 50 personas \\
\hline
\end{tabular}

Fuente: Ministerio de Salud, 2003

\section{Capítulo 4: De los puestos de venta}

\section{Artículo 16.- De la distribución}

"La distribución de las secciones será por tipo de alimento, de tal manera que evite la contaminación cruzada" (MINSA, 2003, p. 5).

\section{Artículo 17.- De los puestos de comercialización}

Los puestos de comercialización de alimentos en los mercados se construirán de material no inflamable, fáciles de limpiar y desinfectar; se deben mantener en buen estado de conservación y el diseño de las instalaciones será apropiado para la exhibición y comercialización de los alimentos en forma inocua. (MINSA, 2003, p. 6). 


\section{Título III: De las buenas prácticas de manipulación}

\section{Capítulo 3: De la recepción y almacenamiento de los alimentos}

\section{Artículo 24.- Del almacén de productos secos}

Los alimentos no deben estar en contacto con el piso, sino que se colocarán tarimas, anaqueles o parihuelas en buenas condiciones y limpias a una distancia no menor a $0.20 \mathrm{~m}$ del piso y se dejará una distancia de $0.50 \mathrm{~m}$ entre hileras y entre la pared. Además, para los alimentos contenidos en sacos, bolsas o cajas se aplicarán de manera entrecruzada con una altura máxima de $3.00 \mathrm{~m}$ y no menos de $0.60 \mathrm{~m}$ de distancia con el techo. (MINSA, 2003, p. 8)

\section{Artículo 25.- Del almacén de frío}

Los alimentos de origen vegetal deberán estar separados de los de origen animal, para evitar la transferencia de olores indeseables y evitar la contaminación cruzada. Además, los alimentos se colocarán en anaqueles o tarimas con una distancia mínima de $0.10 \mathrm{~m}$ del piso, $0.15 \mathrm{~m}$ de las paredes, y de $0.50 \mathrm{~m}$ respecto al techo. (MINSA, 2003, p. 8) 


\subsubsection{Instituto Nacional de Defensa Civil}

Mediante la Ley No 29664, se crea el Sistema Nacional de Gestión del Riesgo de Desastres - SINAGERD, como un sistema interinstitucional, sinérgico, descentralizado, transversal y participativo, con la finalidad de identificar y reducir los riesgos asociados a peligros o minimizar sus efectos, así como evitar la generación de nuevos riesgos, preparación y atención ante situaciones de desastre mediante el establecimiento de principios, lineamientos de política, componentes, procesos e instrumentos de la Gestión del Riesgo de Desastres (Instituto Nacional de Defensa Civil, 2018).

\section{Condiciones que debe implementar y/o mantener el mercado}

\section{Especialidad de Arquitectura}

- "Las puertas de acceso/salida del mercado deben ser de igual ancho de los pasajes que en ellas desembocan. No deben ser menores a $3.00 \mathrm{~m}$ de ancho" (Municipalidad de Lima, 2013, p. 20).

- "Los pasadizos principales deben medir $3.00 \mathrm{~m}$ y los secundarios $2.40 \mathrm{~m}$ " (Municipalidad de Lima, 2013, p. 20).

- “Los pasajes de circulación, escaleras, accesos y salidas de evacuación no deben presentar obstrucciones" (Municipalidad de Lima, 2013, p. 20).

- "En caso de que los puestos contaran con altillos, el acceso a estos deberá estar ubicado en el interio de cada puesto. Para ello se sugiere la colocación de escalera de gato con barra de llegada" (Municipalidad de Lima, 2013, p. 20).

- "El ancho mínimo será de $1.20 \mathrm{~m}$. y deberan tener pasamanos a ambos lados, además cada paso debe medir de 28 a 30cm y cada contrapaso de 16 a $17 \mathrm{~cm}$ " (Municipalidad de Lima, 2013, p. 20).

- "Las gradas, rampas y diferencias del piso deberán ser pintadas con pintura de tráfico de color amarillo con líneas de 5 a 10cm de ancho" (Municipalidad de Lima, 2013, p. 21).

- "Todos los puestos deben estar enumerados y deben coincidir con los planos del mercado" (Municipalidad de Lima, 2013, p. 21). 


\section{Especialidad de Ingeniería Civil}

- "Los vidrios primarios de las ventanas, vitrinas, mostradores y espejos que por sus dimensiones o ubicación representan un riesgo deben ser protegidos con láminas anti impacto" (Municipalidad de Lima, 2013, p. 22).

- "Los techos inclinados de los puestos de venta deben contar con un sistema de evacuación de aguas pluviales. Estos deberán estar correctamente sujetos a la estructura" (Municipalidad de Lima, 2013, p. 22).

- "Los puestos de venta que cuenten con tabiquería de madera deberán ser protegidos con retardante al fuego" (Municipalidad de Lima, 2013, p. 23).

- "Los paneles publicitarios adosados deben ser fijados correctamente a la estructura de la fachada del local” (Municipalidad de Lima, 2013, p. 23).

\subsubsection{Municipalidad de Lima y el BID}

\section{Guía para la competitividad de Mercados de Abasto}

"En la actualidad los empresarios vienen enfrentándose a nuevos paradigmas, cambios en la economía, nueva tecnología, nuevos competidores que vienen afectando los hábitos de compra de los consumidores" (Municipalidad de Lima, 2013, p. 68).

Frente a esta realidad podemos afirmar que ya no es suficiente contar con un buen producto sino que es necesaria la incorporación de mejores prácticas de gestión que considere estrategias de promoción comercial y un servicio de calidad para los clientes convirtiendo el mercado en un lugar más atractivo para la compra diaria. (Municipalidad de Lima, 2013, p. 68).

\section{Beneficios de la promoción comercial}

- Incremento de las ventas diarias.

- Mayor satisfacción y experiencia de los consumidores.

- Mayor interacción social con los proveedores y distribuidores.

- Mejor conocimiento del consumidor.

- Desarrollo de una gestión profesional por parte de los miembros de la organización. 
Tabla 4.20

Servicios complementarios al mercado

\begin{tabular}{|c|c|}
\hline \multicolumn{2}{|c|}{ SERVICIOS QUE PUEDEN OFRECER LOS MERCADOS DE ABASTO } \\
\hline \multirow{4}{*}{$\begin{array}{c}\text { ACCIONES COMERCIALES } \\
\text { YDE PROMOCION } \\
\text { CONJUNTA DELOS } \\
\text { COMERCIANTES }\end{array}$} & Horarios amplios, adaptados a la disponibilidad de tiempos. \\
\hline & Marca y logo del mercado \\
\hline & Técnicas de promoción: ofertas, degustación, cocina regional, sorteos. \\
\hline & Talleres nutricionales, visitas de colegios y celebracion de fechas festivas. \\
\hline \multirow{11}{*}{$\begin{array}{c}\text { DESARROLLO DE NUEVOS } \\
\text { SERVICIOS CON VALOR } \\
\text { AGREGADO }\end{array}$} & Reparto a domicilio. \\
\hline & Estacionamiento para clientes. \\
\hline & Pagos con tarjeta. \\
\hline & Implementación de carritos de compras. \\
\hline & Oficina de consumo y atención al cliente. \\
\hline & Patio de comidas. \\
\hline & Platos para consumir en el mercado. \\
\hline & Zona de juegos para niños. \\
\hline & Guardería de niños. \\
\hline & Lactarios para bebes, hijos de clientas y comerciantes. \\
\hline & Vigilancia y seguridad. \\
\hline \multirow{5}{*}{ DISENO Y CONFORT } & Actualización y mejora del diseño y disposición de las instalaciones. \\
\hline & Incorporación de escaleras electricas y ascensores. \\
\hline & Cambios en el ambiente físico interior adaptados a gustos modernos \\
\hline & Buena iluminación \\
\hline & Senalización dentro del mercado. \\
\hline \multirow{3}{*}{ MERCHANDISING } & Illuminación y exhibición de productos \\
\hline & Elementos de imagen externa del mercado: carteles, pintado de exteriores \\
\hline & Elementos de imagen interna: numeración y rotulación homogénea de los puestos, \\
\hline \multirow{6}{*}{$\begin{array}{l}\text { SERVICIOS } \\
\text { FUNCIONAMIENTO } \\
\text { INTERNO }\end{array}$} & Organización de movimientos y flujos al interior del mercado. \\
\hline & Regulación de zona de carga y descarga. \\
\hline & Almacenamiento, evacuación y tratamiento de residuos sólidos. \\
\hline & Base de datos de comerciantes y clientes. \\
\hline & Registro de ingreso de productos al mercado. \\
\hline & Asesoria y capacitación permanente de comerciantes. \\
\hline
\end{tabular}

Fuente: Alonso, Estrada, \& Sartorius, 2007

En: Los Mercados Minoristas como Motor para el Desarrollo Económico, Social y Cultural de una Ciudad 


\section{Mejorar la oferta o Mezcla-Comercial}

Otra forma de mejorar la mezcla comercial es, por ejemplo, a través de nuevos puestos o paradas que ofrezcan productos gourmet, delicatessen, con denominación de origen protegida, especialidades regionales, productos orgánicos o ecológicos, platos preparados y listos para consumir, o una buena oferta de restaurantes. Una oferta adicional de ocio, servicios sociales y culturales también complementa el atractivo del mercado. (Alonso, Estrada, \& Sartorius, 2007, p. 10)

\section{Dimensionamiento óptimo de los puestos de venta}

En algunos mercados se presenta el problema de que existe un número excesivo de puesteros de pequeño tamaño, dedicados al mismo rubro de productos, ofreciendo, sin embargo, unos niveles bajos de calidad en la prestación del servicio y una productividad muy baja. (Alonso, Estrada, \& Sartorius, 2007, p. 15)

En el caso de los puestos de alimentos frescos, una dimensión óptima se puede establecer entre los 15 y los $20 \mathrm{~m}^{2}$ de superficie comercial, dependiendo del tamaño y tipo de mercado donde se ubica, dando prioridad a los metros lineales o de exposición al público de cada puesto. (Alonso, Estrada, \& Sartorius, 2007, p. 15)

\section{Adecuación de espacios para descarga de la mercadería}

"El área de carga y descarga se debe situar en el sótano y dispone de muelles elevados para atraque de vehículos de abastecimiento y con dotación de sistemas mecánicos de comunicación y transporte hasta los puestos comerciales correspondientes" (Alonso, Estrada, \& Sartorius, 2007, p. 18).

También en el sótano y con el objetivo de rentabilizar la superficie comercial disponible, se dispone de una sala de almacenamiento y manipulación de productos, así como un servicio de consigna frigorífica. Los efectos han sido muy favorables. Además de no producirse los problemas citados anteriormente, la nueva diagramación de la sección de carga y descarga facilita el almacenamiento de mercadería y el tratamiento de residuos. (Alonso, Estrada, \& Sartorius, 2007, p. 18) 


\section{Implementación de Sistemas de Seguridad}

Siendo la seguridad un elemento fundamental para el correcto funcionamiento del mercado, en muchos casos se ha recurrido a la contratación de seguridad privada, así como el establecimiento de instalaciones informatizadas para el control continuo por parte de los servicios de vigilancia. Por ejemplo, una central de alarmas, que permita al instante observar cualquier anomalía, es un excelente complemento a los servicios públicos de policía. (Alonso, Estrada, \& Sartorius, 2007, p. 19)

\section{Remodelación de la Oferta Comercial}

Muchos mercados han ampliado su oferta comercial, combinando una serie de servicios de alimentación, restaurantes y tiendas de venta de productos variados tales como los que podrían encontrarse en un supermercado. En estos establecimientos es común encontrar una oferta comercial muy amplia, con productos de precios accesibles, productos exclusivos, exóticos o gourmets o productos típicamente regionales, productos ecológicos y artesanales conjuntamente con diversos tipos de restaurantes, comidas por encargo y otra oferta cultural complementaria con arte, actuaciones o exposiciones. (Alonso, Estrada, \& Sartorius, 2007, p. 22)

\section{Acciones conjuntas de comunicación y promoción}

Es posible y conveniente que los comerciantes de los mercados minoristas tomen iniciativas en este sentido a través de las asociaciones de comerciantes de los mercados y/o el ente gestor. Algunas actividades de promoción realizadas conjuntamente por los comerciantes de muchos mercados exitosos han consistido en la realización de las siguientes actuaciones. (Alonso, Estrada, \& Sartorius, 2007, p. 23)

- Algunos mercados en Barcelona han creado recientemente el distintivo de Restaurantes del Mercado. Se trata de un signo de calidad asociado a restaurantes que compran sus productos frescos en los mercados.

- También el programa de la Cocina del Mercado cuenta con la participación de los más prestigios chefs y restauradores de la ciudad y consiste en eventos de difusión de la calidad de los productos frescos de los mercados.

- Asimismo, en algunas ciudades se han creado rutas turísticas que incluyen visitas por los mercados, generalmente en colaboración con el patronato de turismo de la ciudad, en los que se explica el desarrollo de la ciudad a través de la evolución de los mercados. 


\subsubsection{Municipalidad de Jesús María}

\section{Plan de Desarrollo Económico Local}

La Visión de desarrollo, para su realización, es decir para que sea realidad, necesita que sus ejes sean coherentes y pertinentes. La Visión de Desarrollo u Objetivo Central, señala que al 2025 el territorio no sólo ha consolidado su vocación económico-territorial en el área centro, sino que también es soporte de una buena calidad de vida de sus vecinos, y además se ha articulado plenamente al eje central de Lima, es decir al eje Cercado-San Isidro -Miraflores. (Municipalidad de Jesús María, 2013, p. 57)

“Esto nos lleva a la formulación de varios objetivos estratégico de cuya realización depende el cumplimiento de la visión. Estos objetivos deben corresponder a elementos necesarios de trabajar a partir de políticas, programas y actividades" (Municipalidad de Jesús María, 2013, p. 57).

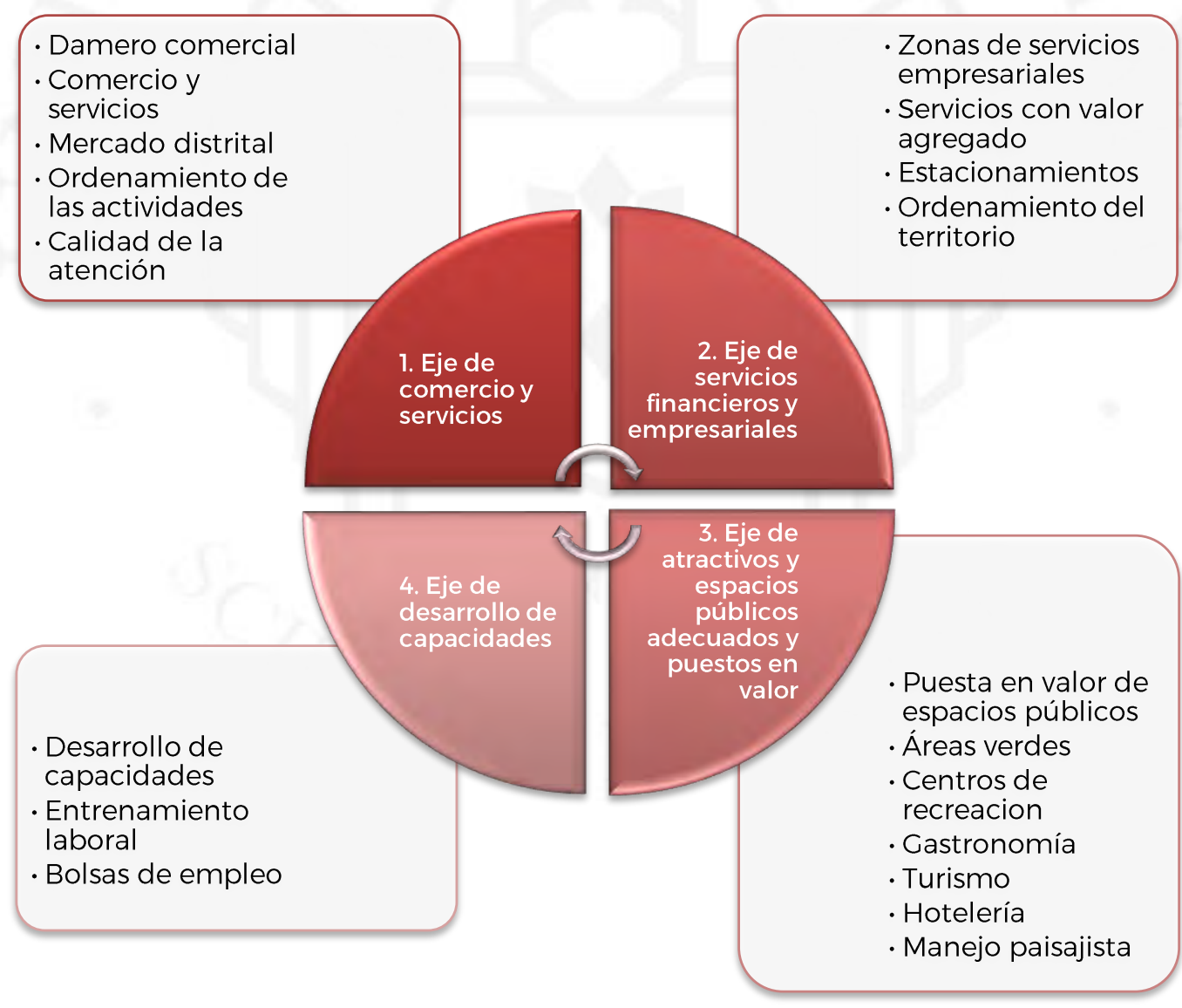

Figura 4.15 Temas de los eje del distrito de Jesús María

Fuente: Municipalidad de Jesús María

En: Plan de Desarrollo Económico Local de Jesús María 2013-2025 


\section{III.- Eje de atractivos y espacios públicos adecuados y puestos en valor}

Objetivo: "Promover el posicionamiento del distrito mediante la promoción y puesta en valor de sus atractivos y espacios públicos como valor agregado a las actividades económicas" (Municipalidad de Jesús María, 2013, p. 77).

Asimismo, y por el posicionamiento del distrito en el área interdistrital y su ubicación tiene todas las condiciones para ser sede de la mayor infraestructura y de servicios turísticos que necesitará Lima Metropolitana para atender adecuadamente el previsible incremento del flujo turístico. (Municipalidad de Jesús María, 2013, p. 78)

Por eso es factible promover la instalación de la inversión privada de calidad y con estándares internacionales en Jesús María, en el sector turismo. Pero además establecer algunos atractivos que hagan más atrayente al poblador de otros distritos llegar hasta Jesús María de compras y en plan recreativo como un tema agregado. (Municipalidad de Jesús María, 2013, p. 78)

Para este objetivo se aprecia que el principal resultado sería el siguiente:

Jesús María cuenta con una oferta gastronómica de calidad en la ciudad, en un entorno agradable, que complementa con sus espacios recreativos, así como cuenta con una importante oferta hotelera de calidad. (Municipalidad de Jesús María, 2013, p. 78)

\section{Zona Prioritaria de Intervención y formas de implementación}

En este objetivo destaca la intervención en dos espacios del distrito. El primero es la Av. Cuba como boulevard gastronómico desde la Plaza San José y la Av. Salaverry y la Av. Mariátegui como potencial zona hotelera debido a su equidistancia del Centro y San Isidro como por la cercanía a instalaciones deportivas que serán sedes de los Juegos Panamericanos del 2019. (Municipalidad de Jesús María, 2013, p. 78) 


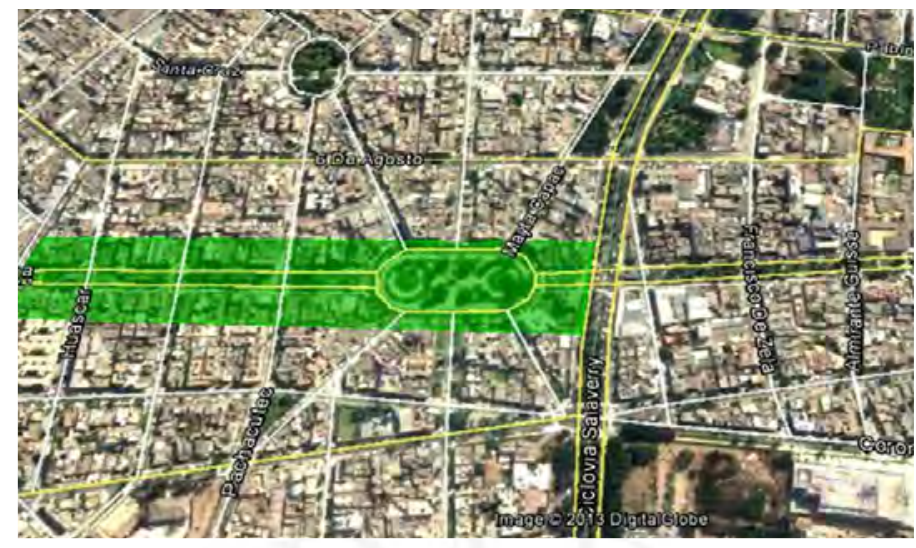

Figura 4.16 Boulevard gastronómico de Jesús María

Fuente: Municipalidad de Jesús María

En: Plan de Desarrollo Económico Local de Jesús María 2013-2025

Las estrategias específicas para este objetivo son las siguientes:

$\mathbf{1}^{\mathbf{0}}$ Declarar de interés, mediante Ordenanza, el establecimiento de la Zona gastronómica y la zona de hotelería (Avs. Cuba y Mariátegui), a fin de facilitar posteriores iniciativas privadas. $\mathbf{2}^{\mathbf{0}}$ Informar a los inversionistas en gastronomía y turismo de la propuesta de estas nuevas zonas para la inversión para activar el mercado inmobiliario de estas zonas. $\mathbf{3}^{\mathbf{0}}$ Promover al distrito, en los medios de comunicación masivos, como destino gastronómico en Lima. (Municipalidad de Jesús María, 2013, p. 79)

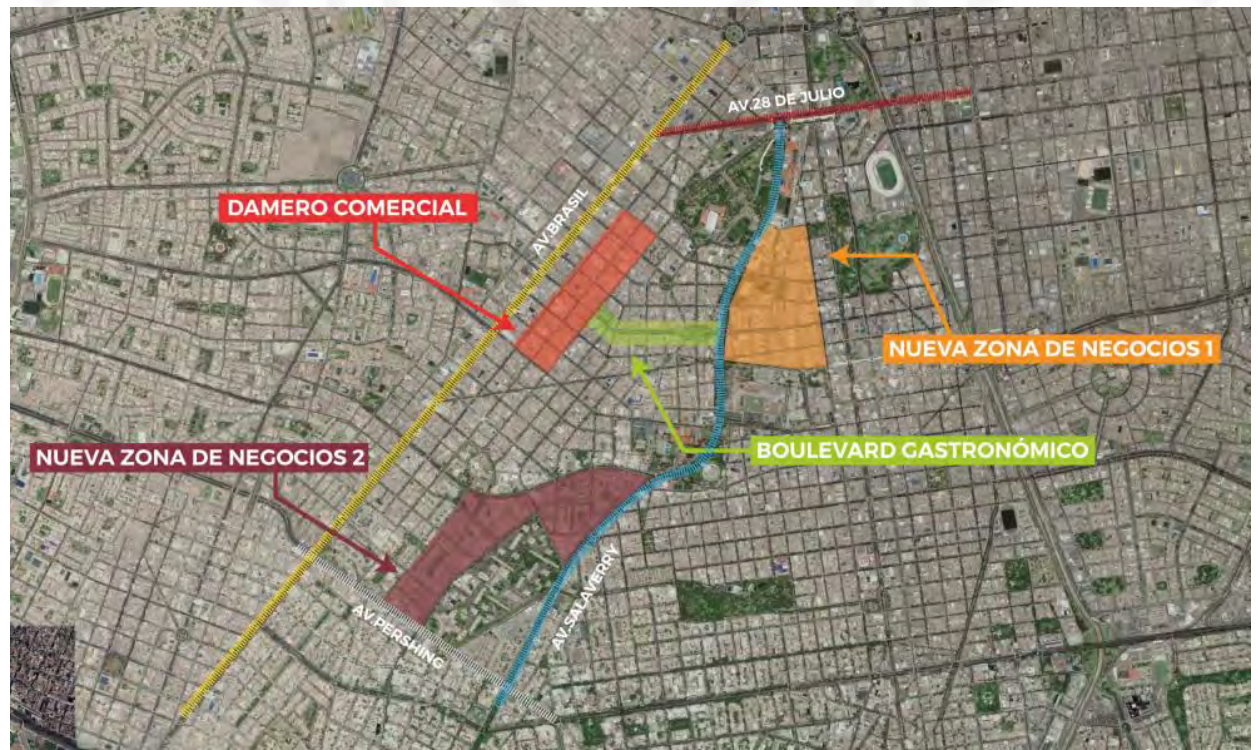

Figura 4.17 Zonas de intervención del Plan de Desarrollo

Fuente: Municipalidad de Jesús María

En: Plan de Desarrollo Económico Local de Jesús María 2013-2025 
Tabla 4.21

Acciones a realizar del objetivo

ACCIONES

DETALLE

Programa de internacionalización $y$ desarrollo turístico de Jesús María mediante la inversión privada.

Implementación del corredor gastronómico y turístico en la Av. Cuba.

Puesta en valor del entorno de la Plaza San José.

\section{Desarrollo del turismo} gastronómico en el distrito.

Fuente: Municipalidad de Jesús María

En: Plan de Desarrollo Económico Local de Jesús María 2013-2025
Este es un programa señalado en el Plan de Desarrollo Concertado que busca generar las facilidades la inversión privada en el ramo de hotelería para que ingrese al distrito con establecimientos de alta calidad, para lo cual se ha reservado la Av. Mariátegui para tal fin.

Por su ubicación como corredor entre el Damero Comercial y la futura Nueva Zona de Negocios 1, la Av. Cuba tiene la posibilidad de convertirse en un boulevard gastronómico para lo cual se darán las facilidades y que se conectaría con la Plaza San José.

La emblemática Plaza San José es parte del damero comercial y puede ser la interface con el boulevard Cuba, en ese sentido se debe poner en valor todos sus frentes facilitando la implementación de negocios aparentes del ramo de comidas y bebidas (cafés, restobar y afines). Asimismo, implica un manejo paisajista para convertirlo en un punto de encuentro de los visitantes al distrito.

Promover mediante eventos la gastronomía peruana y en especial de los establecimientos del distrito de forma de tener ferias periódicas a lo largo del año, especializadas por regiones o platos (feria del cebiche, feria de la comida norteña, feria arequipeña, etc.), que generen en la población de la ciudad una visita constante al distrito.

\section{RESPONSABLE}

Sub Gerencia de Promoción de Inversión Privada, Cooperación Técnica y Proyectos Especiales/ Gerencia de Desarrollo Urbano y Ambiental.

Sub Gerencia de Promoción de Inversión Privada, Cooperación Técnica y

Proyectos

Gerencia de Desarrollo Urbano y Ambiental

Sub Gerencia de Promoción Social y Económica 


\subsection{Conclusiones parciales}

El diseño del Mercado San José de Jesús María debe cumplir con el Reglamento Nacional de Edificaciones, particularmente con la norma A0.70, el cual es la sección sobre establecimientos comerciales e incluye pautas sobre la habitabilidad, funcionalidad, dotación de servicios y seguridad, con especial consideración al confort del cliente y los comerciantes. Pero consideramos que hay algunas normas que no promueven que los mercados de abasto mejoren en general, por lo que se comparó la normativa local con estándares arquitectónicos como Neufert y Plazola, y con normativas internacionales como la Ordenanza de Mercados del Ayuntamiento de Madrid y el Plan de Modernización de los Mercados Municipales de la Junta de Andalucía.

Una norma del R.N.E que consideramos que debería modificarse en un futuro es sobre los accesos a los mercados, el cual consideran tan solo 2 puertas como mínimo cuando el mercado posee menos de 150 puestos de venta, y 1 puerta adicional por cada 100 puestos. Si se desea que los mercados de abasto tengan una mejor relación con su entorno, se deben evitar las barreras arquitectónicas perimetrales para tener un mayor grado de accesibilidad peatonalmente, por ende, tienen que contar con un número mayor de entradas al establecimiento. Entonces optaremos por tener 4 ingresos como mínimo en la propuesta según lo regido por la Junta de Andalucía, y contarán con un ancho mínimo de 2.40, según lo recomendado en Plazola.

Además, la propuesta del mercado contará con desniveles separando la venta de productos perecederos de los puestos de servicio para complementar la actividad de comercialización del mercado y utilizar la infraestructura a jornada completa y hacerla más productiva. Estos desniveles son permitidos por Produce, el Reglamento Nacional de Edificaciones y por la Municipalidad de Lima y el BID, pero se debe tener en cuenta que deben ser accesibles para discapacitados.

En cuanto a la circulación de los mercados, utilizaremos un ancho mínimo de $3 \mathrm{~m}$ para los pasajes principales, y $2.40 \mathrm{~m}$ para los secundarios, según lo establecido en el Reglamento Nacional de Edificaciones, Produce y Defensa Civil. Esta decisión se debe a que la propuesta del Mercado San José tendrá buena cantidad de accesos para los 
clientes, permitiendo un flujo constante y evitando la acumulación de personas en diferentes sectores del mercado. Pero también recomendamos que, si otras propuestas de diseño de mercados de abasto tienen pocos ingresos, sus pasillos principales deben medir $5 \mathrm{~m}$ y los secundarios un ancho de $3 \mathrm{~m}$ según lo recomendado por la Junta de Andalucía.

Para los puestos de venta, el R.N.E sugiere que las dimensiones de los puestos de productos perecibles tengan un área mínima de $6 \mathrm{~m}^{2}$ y $8 \mathrm{~m}^{2}$ para los puestos de abarrotes y comidas. Nosotros consideramos que es un ratio óptimo para realizar el actividad comercial, y mantener como mínimo la cantidad de puestos actual, ya que si optamos por lo recomendado por la Junta de Andalucía o por el Ayuntamiento de Madrid, la cantidad de puestos sería mucho menor, y por ende, la cantidad de comerciantes también se reduciría, dejando sin trabajo a muchos de los que están actualmente laborando en el Mercado San José. Además, los puestos tendrán una altura mínima de $3 \mathrm{~m}$, según lo recomendado en Plazola.

En cuanto al almacenamiento de los productos, la propuesta del mercado optará por almacenes generales con estanterías para cada puesto de venta, ubicados en el sótano, los cuales podrán ser trasladados de un nivel a otro a través de montacargas para su posterior distribución. El área del almacén general será según lo recomendado en el R.N.E, Produce, y la Municipalidad Metropolitana de Lima con el BID, que consideran que debe ser un $25 \%$ del área de venta. Para las cámaras frigoríficas consideraremos las áreas mínimas recomendadas en el Neufert, debido a que necesitaremos más área de lo que establece la normativa nacional, ya que también tendremos servicios de menús ofreciendo platos cocidos y pre cocidos.

Dentro de las normativas seleccionadas para realizar la propuesta del mercado también se analizó el programa y la mezcla comercial que cada uno recomienda, decidiendo por aquellos que propongan nuevos servicios con valor agregado, una correcta administración del mercado, con dotaciones comunes y servicios de funcionamiento interno, aparte de la venta de productos perecederos. Esto es importante, ya que el mercado contemporáneo debe tener una oferta comercial completa, para que el cliente local y extranjero encuentre todo dentro de un solo lugar, además la mixticidad de usos y los servicios con valor agregado complementarán la actividad de comercial del mercado, generando que tenga mayor afluencia en diferentes momentos del día. 
Para el cálculo de estacionamientos para el uso público del mercado se tomó en cuenta el ratio designado por la Ordenanza \#1076 MML que consta de 1 estacionamiento cada 25 puestos de venta, por ende, se requieren 9 estacionamientos en total, pero en la propuesta se consideran 25 plazas. En cuanto al área de abastecimiento se consideran 4 estacionamientos por más de $3000 \mathrm{~m} 2$ de área techada, de los cuales nosotros consideramos tener 6 plazas para una mayor rotación de vehículos de carga y descarga. Para las oficinas, según el parámetro se considera 1 estacionamiento por cada $50 \mathrm{~m} 2$, obteniendo un mínimo de 33 estacionamientos, de los cuales se consideran para la propuesta 39 estacionamientos.

Tabla 4.22

Cálculo plazas de estacionamiento

\begin{tabular}{|l|c|c|c|}
\hline & Ratio & Se necesita & Propuesta \\
\hline $\begin{array}{l}\text { Estacionamiento para uso } \\
\text { público del mercado } \\
\text { (Ordenanza \#1076- MML) }\end{array}$ & $\begin{array}{l}1 \text { cada } 25 \\
\text { puestos }\end{array}$ & 9 estacionamientos & 25 estacionamientos \\
\hline $\begin{array}{l}\text { Estacionamiento para } \\
\text { abastecimiento (R.N.E) }\end{array}$ & $\begin{array}{c}+3 \text { mil m2 } \\
\text { techados }\end{array}$ & 4 estacionamientos & 6 estacionamientos \\
\hline $\begin{array}{l}\text { Estacionamiento para } \\
\text { oficinas (Parámetro) }\end{array}$ & 1 cada $50 \mathrm{~m} 2$ & 33 estacionamientos & 39 estacionamientos \\
\hline
\end{tabular}

Con respecto al cálculo del almacenamiento y acopio de desechos se toma en cuenta lo designado por el Reglamento Nacional de Edificaciones (R.N.E). Para el almacenamiento se requiere como mínimo un $25 \%$ del área de venta para mercados minoristas necesitando $416 \mathrm{~m} 2$, sin embargo, para la propuesta contamos con $469 \mathrm{~m} 2$. Y para el área de acopio de basura se considera un $0.02 \mathrm{~m} 3$ por $\mathrm{m} 2$ de superficie de venta, requiriendo $33.28 \mathrm{~m} 3$ de los cuales contamos con $75 \mathrm{~m} 3$.

Tabla 4.23

Cálculo de almacenamiento y acopio de desechos

\begin{tabular}{|l|c|c|c|}
\hline & Ratio & $\begin{array}{c}\text { Se } \\
\text { necesita }\end{array}$ & Propuesta \\
\hline Almacenamiento (artículo 33) & $25 \%$ del área de venta & $416 \mathrm{~m} 2$ & $469 \mathrm{~m} 2$ \\
\hline Acopio de basura & $\begin{array}{c}0.02 \mathrm{~m} 3 \times \mathrm{m} 2 \text { de } \\
\text { superficie de venta }\end{array}$ & $33.28 \mathrm{~m} 3$ & $75 \mathrm{~m} 3$ \\
\hline
\end{tabular}


Tabla 4.24

Comparación de estándares arquitectónicos

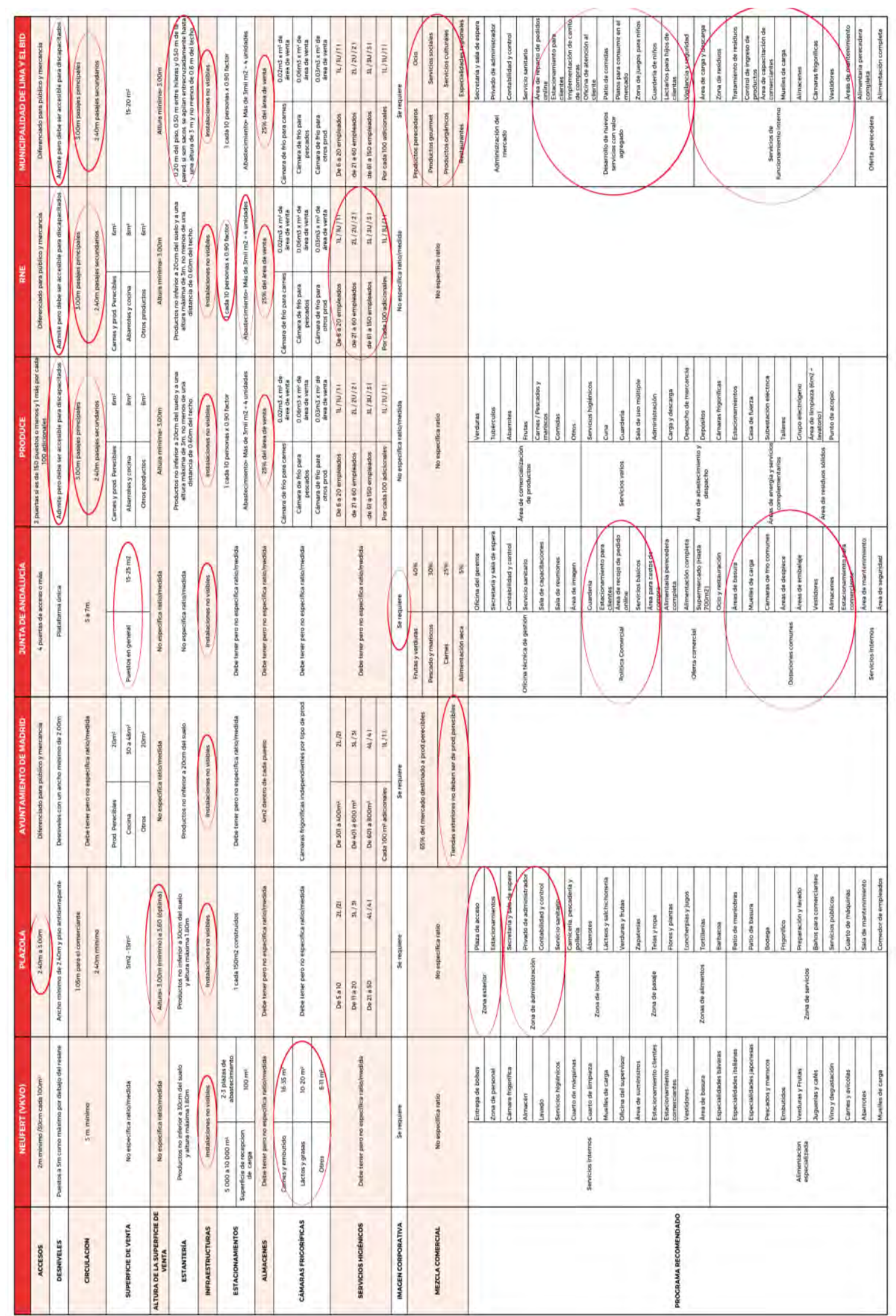




\section{CAPÍTULO V: Marco operativo}

En el presente capítulo se analizarán casos análogos y casos proyectuales pertinentes a la investigación. Los proyectos análogos serán para comprender las características, el funcionamiento y el programa que poseen para que el mercado pueda ser considerado como un producto turístico que satisfaga las demandas de los clientes locales y extranjeros, por lo que se decidió analizar dos proyectos ubicados en España, debido a las remodelaciones que han realizado en sus mercados durante los últimos años, mostrándose como casos de éxito; y un caso local de mercado con usos mixtos.

Para el análisis de estos proyectos se utilizarán las siguientes variables:

- Historia: Se dará a conocer el contexto en el que se formó el mercado, los sucesos importantes, el concepto, y su impacto social.

- Relación con el entorno: Se realizará un plano de localización a una escala macro donde se muestren las vías principales y los equipamientos a su alrededor, así también se realizará un plano a una escala más micro que nos permita entender la relación del proyecto con el entorno inmediato. Seguido de un análisis viario, en la que se señalarán las vías principales, paraderos, estaciones, calles peatonales.

- Flujos y accesos: Se identificarán los accesos peatonales y vehiculares, y la densidad de flujos internos del mercado, así como los de su entorno inmediato. Además, se realizará un corte que determine los espacios que son de carácter público y privado para conocer su grado de accesibilidad.

- Programa: En cuanto al programa se identificarán en planta y corte los rubros a los que pertenecen los puestos de venta, como las áreas administrativas y de servicio del mercado. También se realizará un cuadro de áreas y gráficos de porcentaje para identificar los paquetes y el porcentaje de rubros del proyecto.

- Aporte tecnológico: Se explicará el sistema constructivo de la cobertura empleada de los mercados mediante esquemas y detalles constructivos.

Mientras que los casos proyectuales son para analizar sistemas constructivos de cubiertas que nos brindará soluciones para cubrir grandes áreas y generar espacialidades diferentes con ellas debido al material. Finalmente, la intención es determinar los aspectos más relevantes que se puedan adoptar para el proyecto del mercado y fortalecer la dualidad de espacio público y comercio. 


\subsection{Estudio de casos análogos}

\subsubsection{Mercado Santa Caterina}

El Mercado Santa Caterina se encuentra ubicado en el barrio Sant Pere, Barcelona, que aún mantiene su configuración urbana medieval, con calles estrechas y retorcidas. El terreno que ocupa actualmente el mercado había sido de la Iglesia y Convento de Santa Caterina, construida en 1286 como la primera iglesia gótica de Barcelona, pero en 1825 fueron destruidos por la quema de conventos, ante esto el ayuntamiento aprovecho el área desocupada para construir el mercado, cuyas obras se iniciaron en 1844, después del decreto real que estipulaba llevar el nombre de Plaza-Mercado Isabell II, el cual se terminó ignorando y adoptando el antiguo nombre del convento "Santa Caterina". Cuatro años después, en 1848 se inaugura el mercado diseñado por el Arq. Josep Mas Vila (Ver Figura 5.1) reconocido por ser el primer mercado con cubierta de hierro y de cierre perimetral de la ciudad (Noguera, 2011, p. 47).

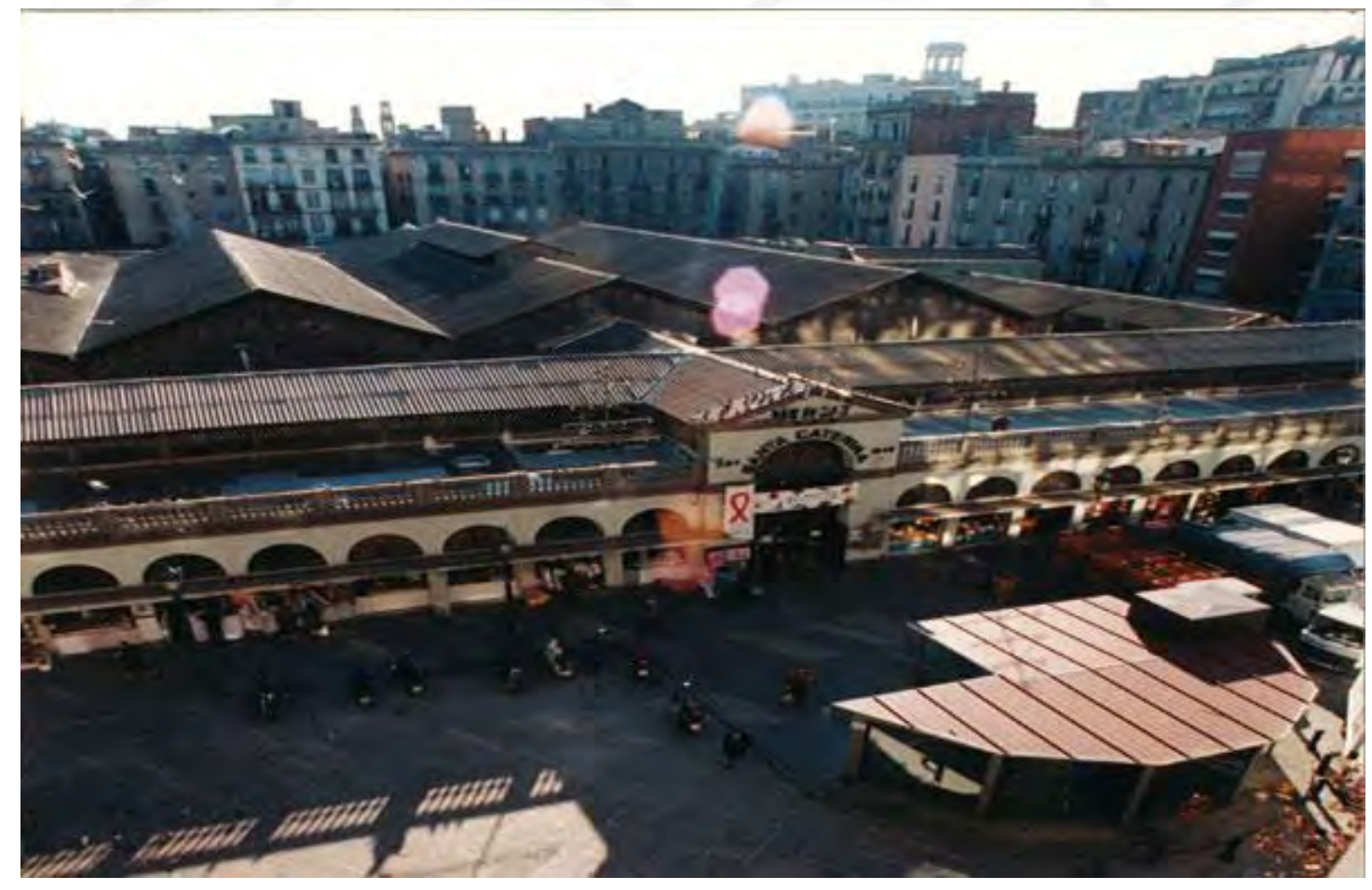

Figura 5.1 Mercado Santa Caterina_1848

Fuente: Ayuntamiento de Barcelona

En: http://ajuntament.barcelona.cat/mercats/es/content/mercado-de-santa-caterina-0.html 
El centro histórico de Barcelona comenzó a presentar problemas en cuanto a la infraestructura de sus edificaciones, inaccesibilidad espacial y un inadecuado sistema de equipamientos que generaba el declive de la actividad económica, social y cultural. El valor de los terrenos comenzó a disminuir drásticamente, lo que comenzó a ser ocupada por los niveles socioeconómicos más marginados y siendo foco de inseguridad (Ver Figura 5.2). Ante estos problemas, el Ayuntamiento de Barcelona buscaba reactivar este sector de la ciudad a través de una infraestructura con una imagen nueva y que a su vez dote de servicios a la población, articule equipamientos futuros, edificaciones de valor monumental e influya en la actividad económica de su alrededor, este era el mercado.

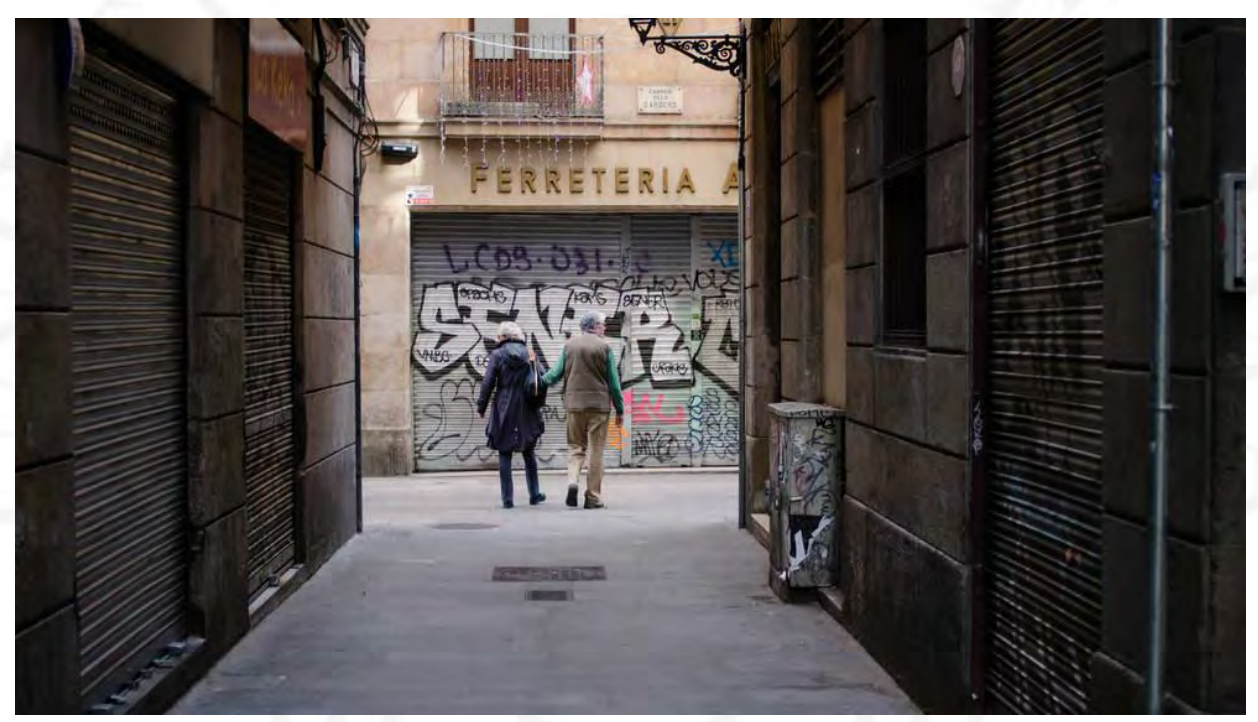

Figura 5.2 Inseguridad en el barrio Sant Pere Fuente: Airbnb

En: https://www.airbnb.es/locations/barcelona/sant-pere-santa-caterina-i-la-ribera

Para esta remodelación se convocó a concurso en abril de 1997 en donde el Arq. Enric Miralles logró el cometido. Para él era todo un reto realizar esta remodelación por el hecho de que el mercado se encontraba dentro de una zona histórica de Barcelona teniendo así limitaciones. Él no quería simplemente derrumbar un patrimonio de la ciudad, sino todo lo contrario.

Es como pensar y repensar las cosas. Y la arquitectura no es más que un modo de pensar sobre la realidad, así es pues como las nuevas construcciones se sobreponen a las existentes. Se mezclan, se confunden para hacer aparecer ese lugar en sus mejores cualidades. (Miralles, 2006, p. 32) 
El proyecto jugó un papel importante en la recuperación urbanística de Ciutat Vella, cuya finalidad era reactivar el área urbana con el turismo por medio del cambio de imagen del mercado, el desarrollo de usos mixtos, la generación de nuevas viviendas y la configuración de un espacio público que consolide al mercado como un proyecto íntegro a nivel socio - espacial fortaleciendo el sentido de hito en la ciudad (Ver Lámina 5.2).

Miralles decía: "El proyecto no debe insistir en un momento concreto del tiempo, sino instalarse en él” (Miralles, 2006, p. 40). Por lo que comenzó a criticar el planteamiento existente y luego propuso un modelo que permita adaptarse a la complejidad del lugar, es decir, un proyecto que piense más allá que la anchura de la calle y la altura de los edificios (ver figura 5.3).

Un modelo donde no sea tan fácil distinguir entre rehabilitación y nueva construcción. Donde las plazas, el trazado continuo de ensanchamientos pasa por encima de la calle como único mecanismo urbano Se reduce el número de puestos de venta, racionalizando los sistemas de acceso y servicios, aportando espacio público y densidad residencial. (Miralles, 2006, p. 44)

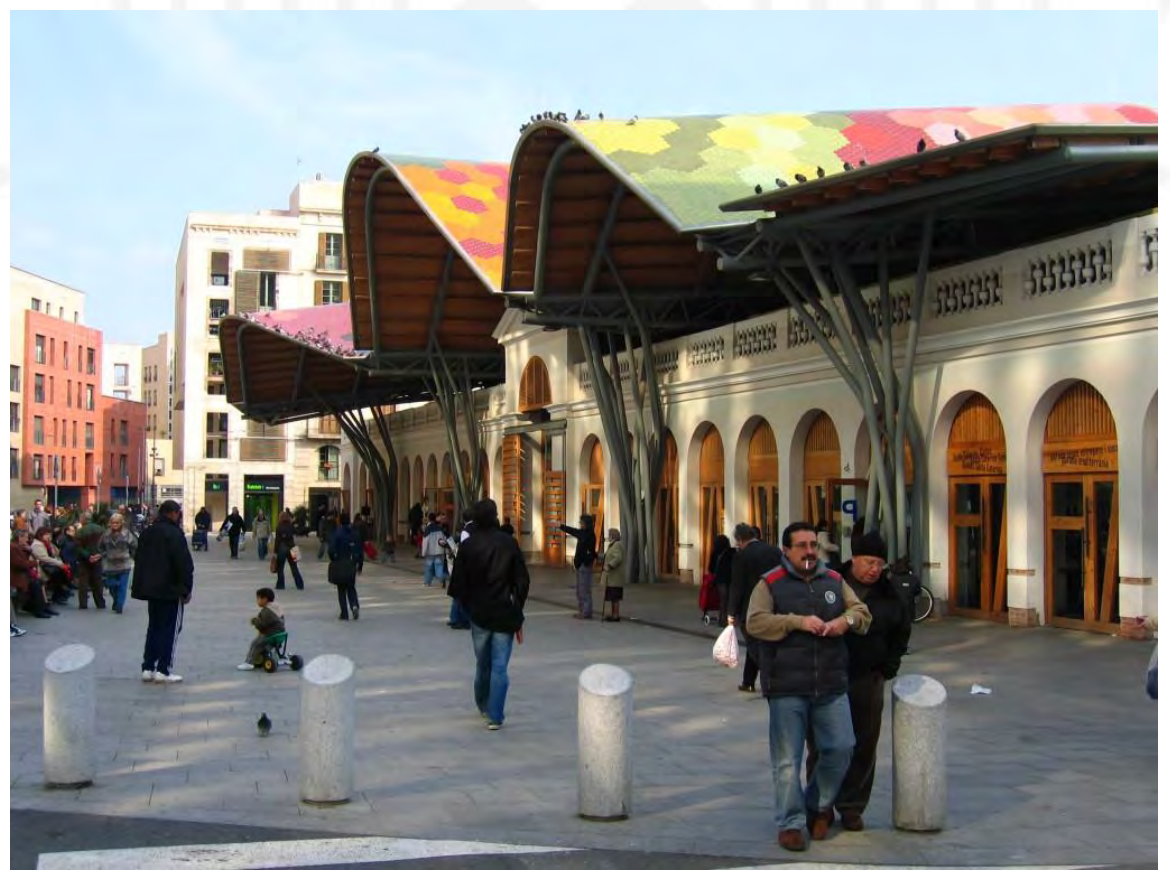

Figura 5.3 Mercado Santa Caterina_2018

Fuente: MIMOA

En: https://www.mimoa.eu/projects/Spain/Barcelona.html 
Lámina 5.1

Datos Generales_Mercado Santa Caterina

\section{MERCADO SANTA CATERINA}

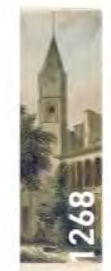
iglesia y
convento

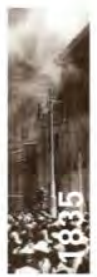

quema de

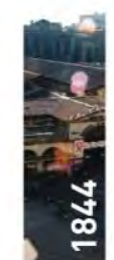

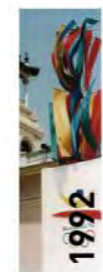

juegos olimpicos

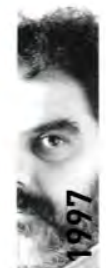

EMBT

gana concurso

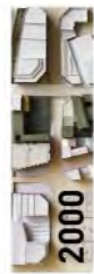

plan 22ब

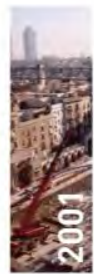

inicia reforma

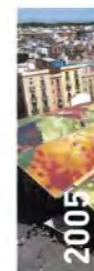

finaliza reforma

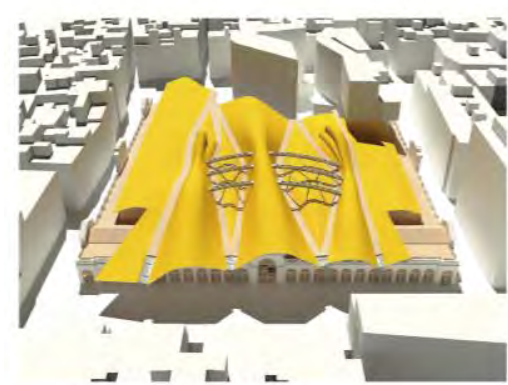

La toma de partido del mercado es "un modelo donde no sea tan fácil distinguir entre rehabilitación y nueva construcción".

Esto se logra al conservar las fachadas perimetrales consideradas patrimonioyrealizando una cobertura que se adapta a la complejidad del lugar.

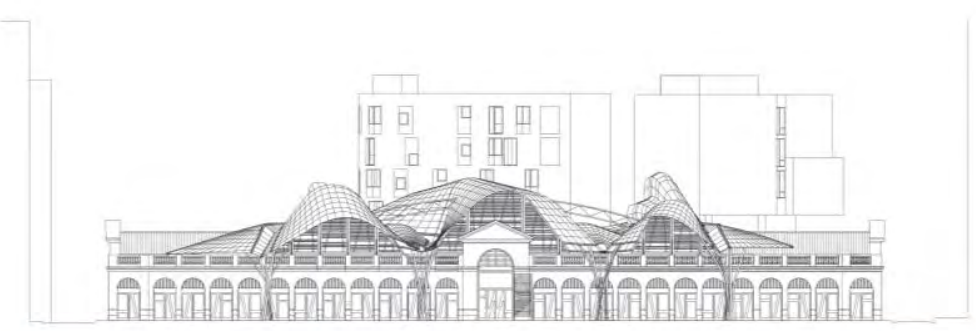

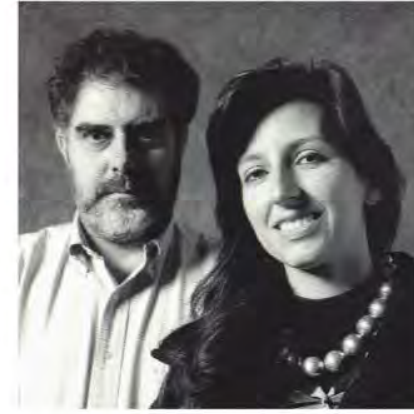

Miralles Tagliabue EMBT es un reconocido estudio de arquitectura internacional formado por Enric Miralles y Benedetta Tagliabue en 1994.

Enric Miralles (12 de febrero de 1955 - 3 de julio del 2000) fue un arquitecto español, graduado de la Escuela de Arquitectura de Barcelona en la Universidad Politécnica de Cataluña en 1978.

Estuvo casado con Benedetta Tagliabue (nacido el 24 de junio de 1963) arquitecta italiana conocida por sus diseños que son sensibles al contexto y aún así experimentales en su enfoque de formas y materiales.

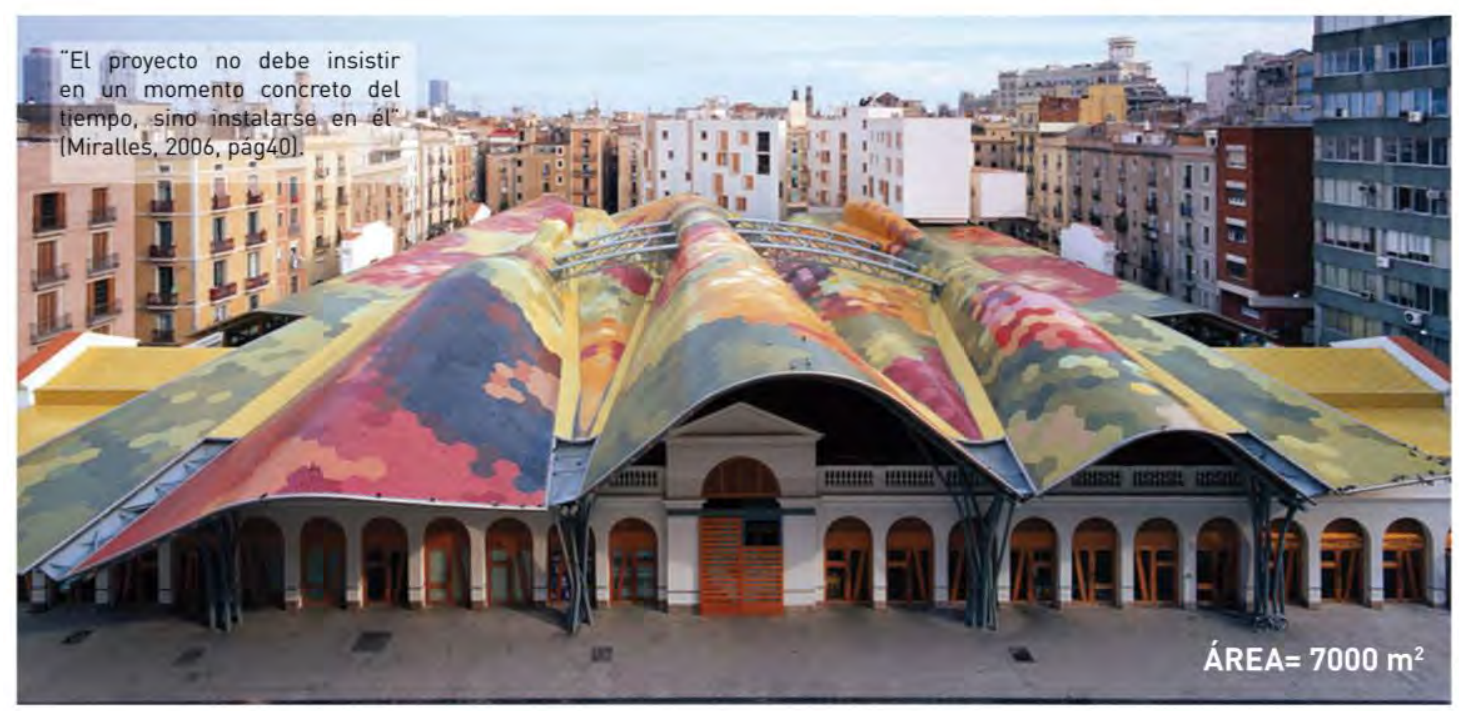

DATOS GENERALES

Gráfico elaborado por los autores. 
Lámina 5.2

Localización_Mercado Santa Caterina

\section{MERCADO SANTA CATERINA}

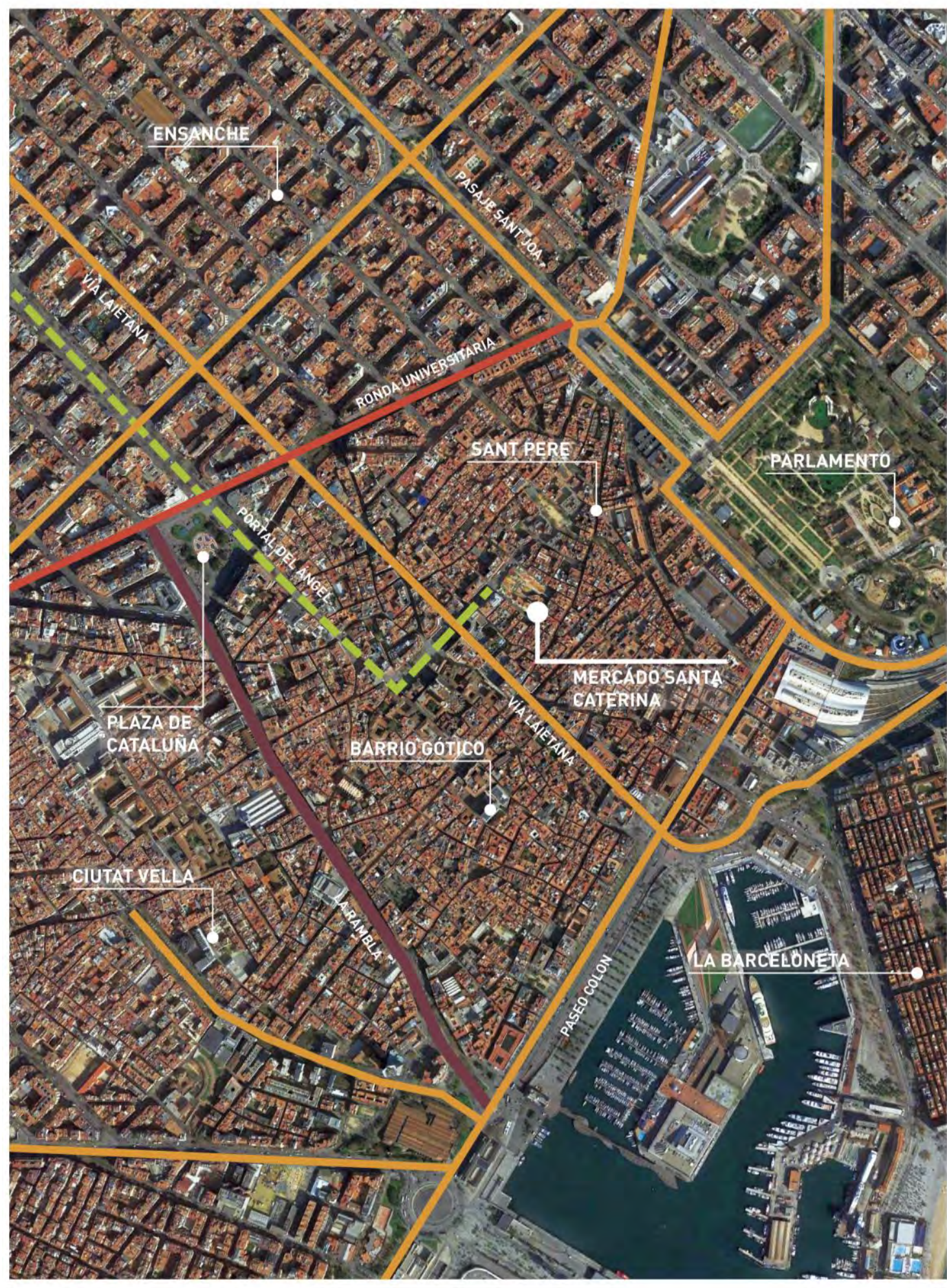

LOCALIZACIÓN

Gráfico elaborado por los autores. 


\section{Relación con el entorno}

El proyecto, como se mencionó anteriormente, se encuentra en el barrio Sant Pere y además forma parte de un tour turístico que inicia desde la Plaza de Cataluña, pasa por la Catedral de Barcelona y termina en el Mercado Santa Caterina, unidos por la calle peatonal el Portal del Ángel. También el mercado está próximo a paraderos de la Vía Laietana y de la Ronda Universitaria, mas no pasan líneas o buses metropolitanos directamente por el mercado, sino que se le da prioridad al peatón y al uso de bicicletas (Ver Figura 5.4).

Figura 5.4

Conexión del Mercado Santa Caterina

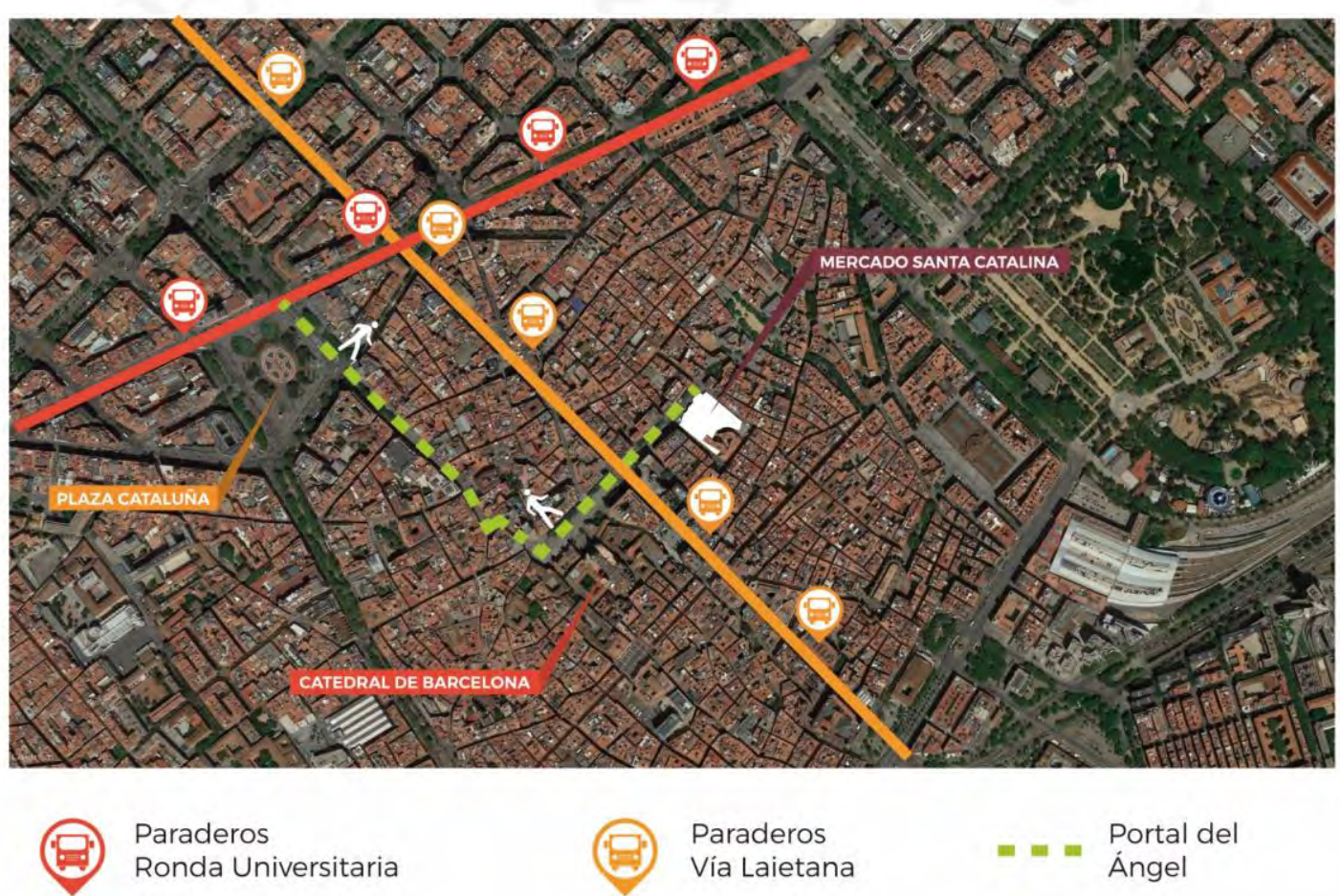

Gráfico elaborado por los autores.

El mercado al encontrarse dentro de una zona histórica y con una configuración urbana orgánica, no puede crecer mucho en altura, sino generaría más callejones dentro del barrio, y por ende lugares inseguros, entonces, en lugar de aumentar el número de pisos, Miralles diseñó la cubierta del mercado con la finalidad de ser la quinta fachada del proyecto, la cual también se pueda contemplar desde diferentes puntos de vista de los edificios vecinos de gran altura (Ver Figura 5.5). 
Figura 5.5

Emplazamiento del Mercado Santa Caterina

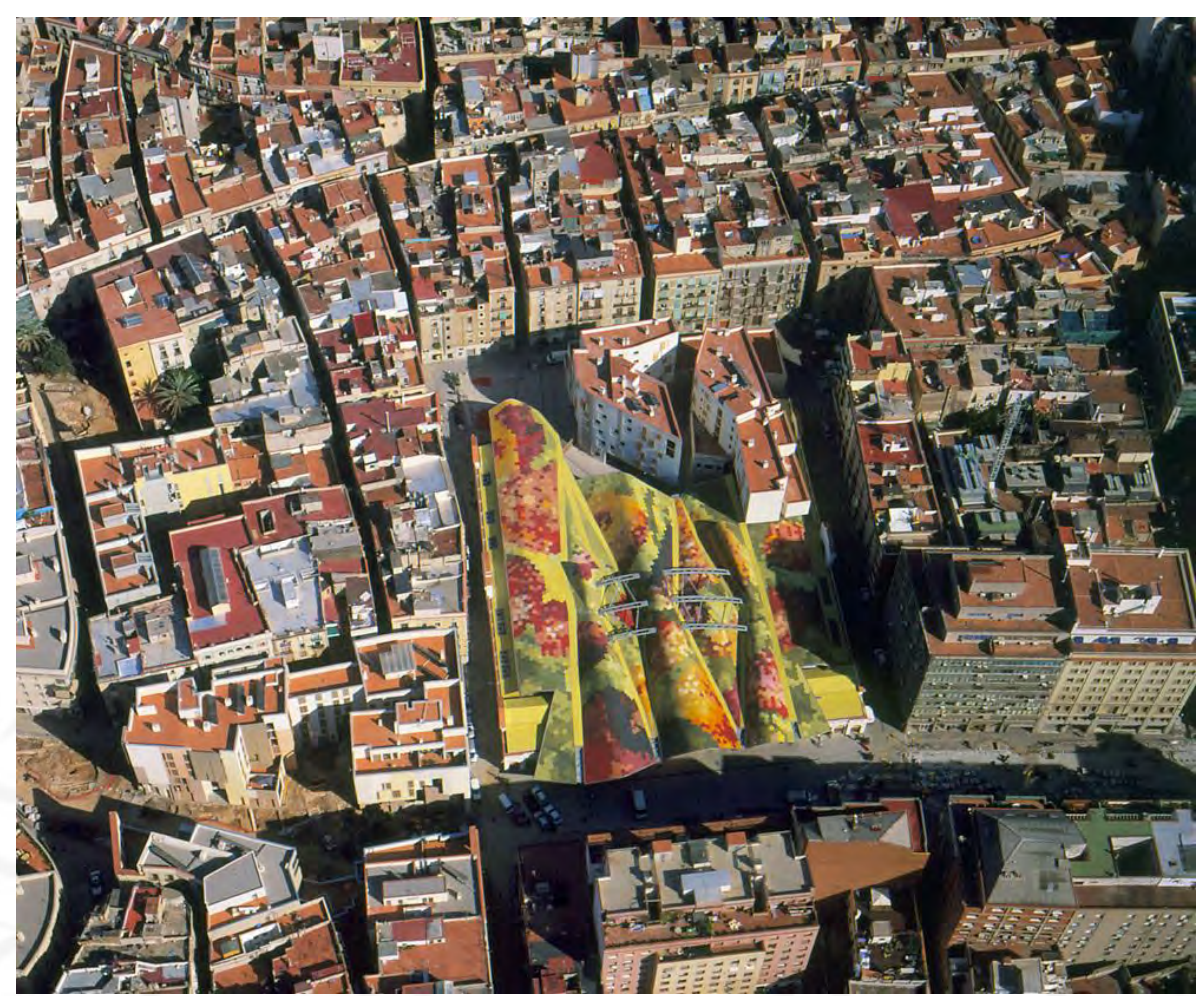

Fuente: Archdaily

En: https://www.archdaily.com/279576/ceramica-cumella-shaping-ideas/santa-caterina-market-10.html

La trama orgánica propia de las urbes medievales que posee el barrio Sant Pere hizo que Miralles relacione la configuración interior de los puestos del mercado con esta, cambiando la percepción interna de los consumidores al no encontrarse con una configuración lineal, sino que al ingresar al mercado se encontrarán con un puesto de venta que se exhibe desde diferentes ángulos (Ver Lámina 5.3). 
Lámina 5.3

Relación con el entorno_Mercado Santa Caterina

\section{MERCADO SANTA CATERINA}

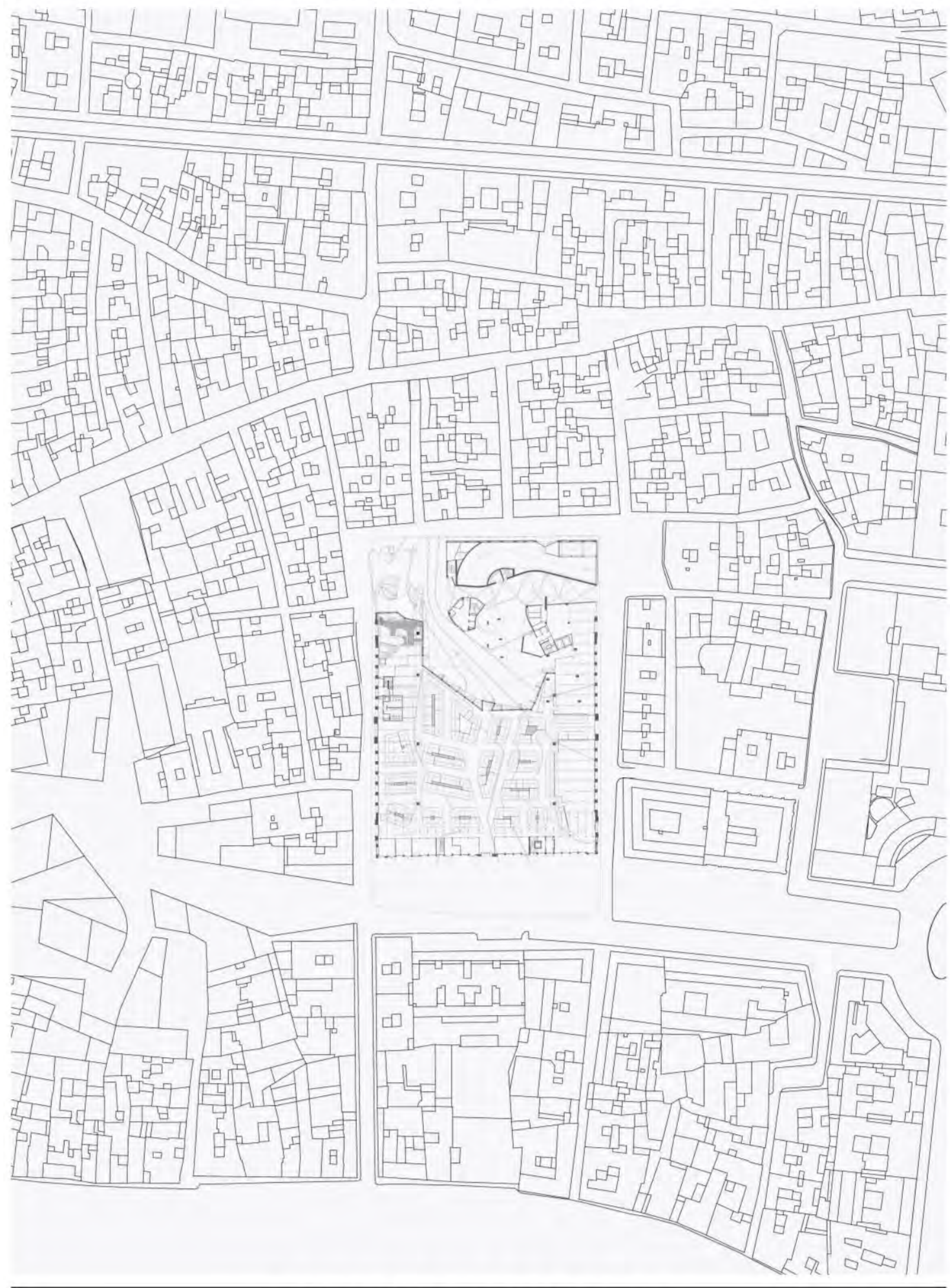

RELACIÓN CON EL ENTORNO

Gráfico elaborado por los autores. 


\section{Flujos y accesos}

El flujo vehicular y peatonal es mucho más denso en la Av. Cambo, que posee 2 carriles y que mantiene su ancho de vía desde la plaza de la catedral hasta el mercado, además esta avenida define bien el espacio para el peatón y el espacio vehicular, generando una diferenciación mediante el pavimento entre la calzada y la acera (Noguera, 2011, p. 48).

Las demás calles aledañas al mercado tienen una configuración similar entre ellas, siendo calles estrechas y sinuosas, típicas del casco antiguo de la ciudad, la mayoría son de plataforma única sin cambio de materiales, ya que por normativa de los cascos antiguos están destinadas exclusivamente para el uso peatonal y solo pueden entrar vehículos que abastezcan al mercado o al comercio posterior y a los residentes de las viviendas cercanas.

El mercado además cuenta con dos plazas, una dentro de los límites del mercado (Joan Capri) y otra aledaña (Santa Caterina) que dan respiro a la trama urbana angosta y a su vez genera espacios de ocio. La plaza Joan Capri es netamente de servicio, donde el pavimento del mercado que venía elevado, comienza a descender hacia el nivel de la calzada configurando el espacio público para el peatón estableciendo el límite el mercado como un espacio de encuentro, dotado de mobiliario urbano y en donde se realizan diferentes actividades festivas a lo largo del año (Ver Figura 5.6).

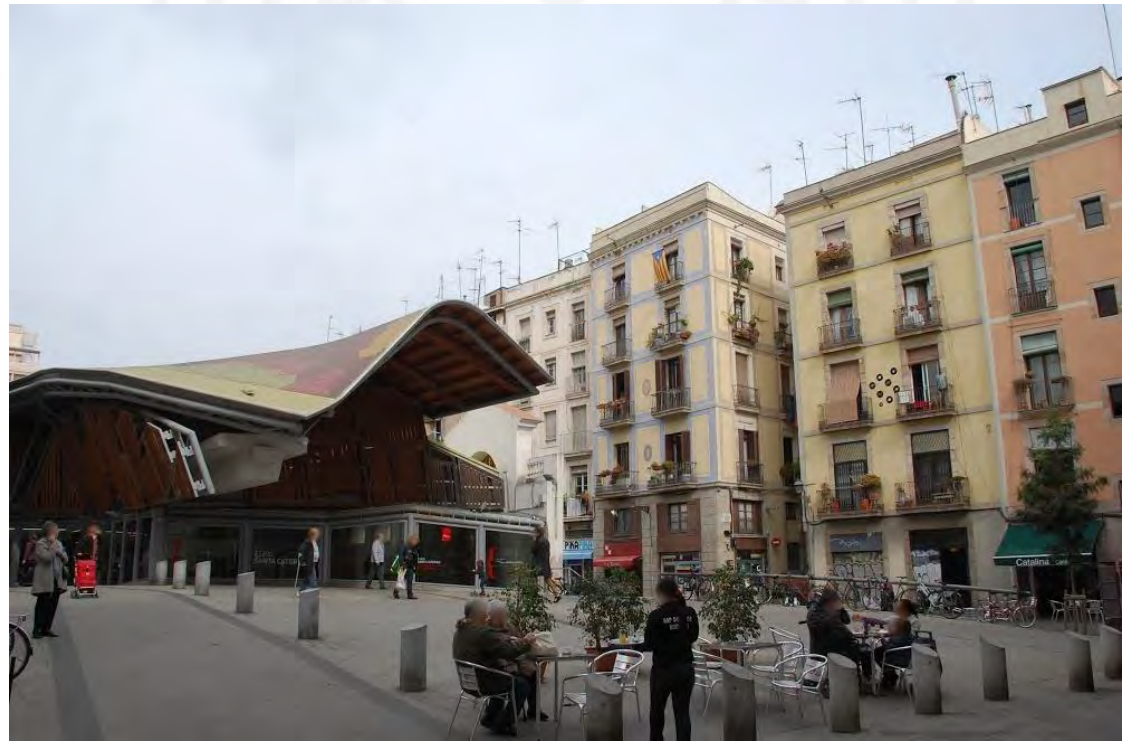

Figura 5.6 Plaza Joan Capri

Fuente: Juan Jesús Orío

En: https://www.panoramio.com/user/565824?with_photo_id=105654468 
En cuanto a los accesos, el mercado posee seis entradas perimetrales que permiten un desplazamiento fluido al poder ingresar y salir fácilmente por las distintas calles de alrededor y no ingresar o salir siempre por la entrada principal de la Av. Cambó (Ver Lámina 5.4).

En el interior del mercado, el main market es principalmente el espacio público del mercado, el cual está compuesto por todos los puestos de venta que en este mercado en particular se encuentran agrupados y no expuestos de forma lineal, lo que permite un flujo más libre y menos predecible en su interior. Miralles trató de generar una experiencia única en los consumidores, invitándolos a recorrer todo el mercado a no exponer visualmente a los puestos en una primera vista, sino que tienes que desplazarte dentro del mercado para encontrar los productos. Se puede pensar que, al no tener una circulación clara y lineal, dificulte el encuentro con los ingresos y las salidas, sin embargo, para evitar este problema, jerarquizó la circulación que lleva a las salidas principales del mercado (Ver Figura 5.7 y Figura 5.8).

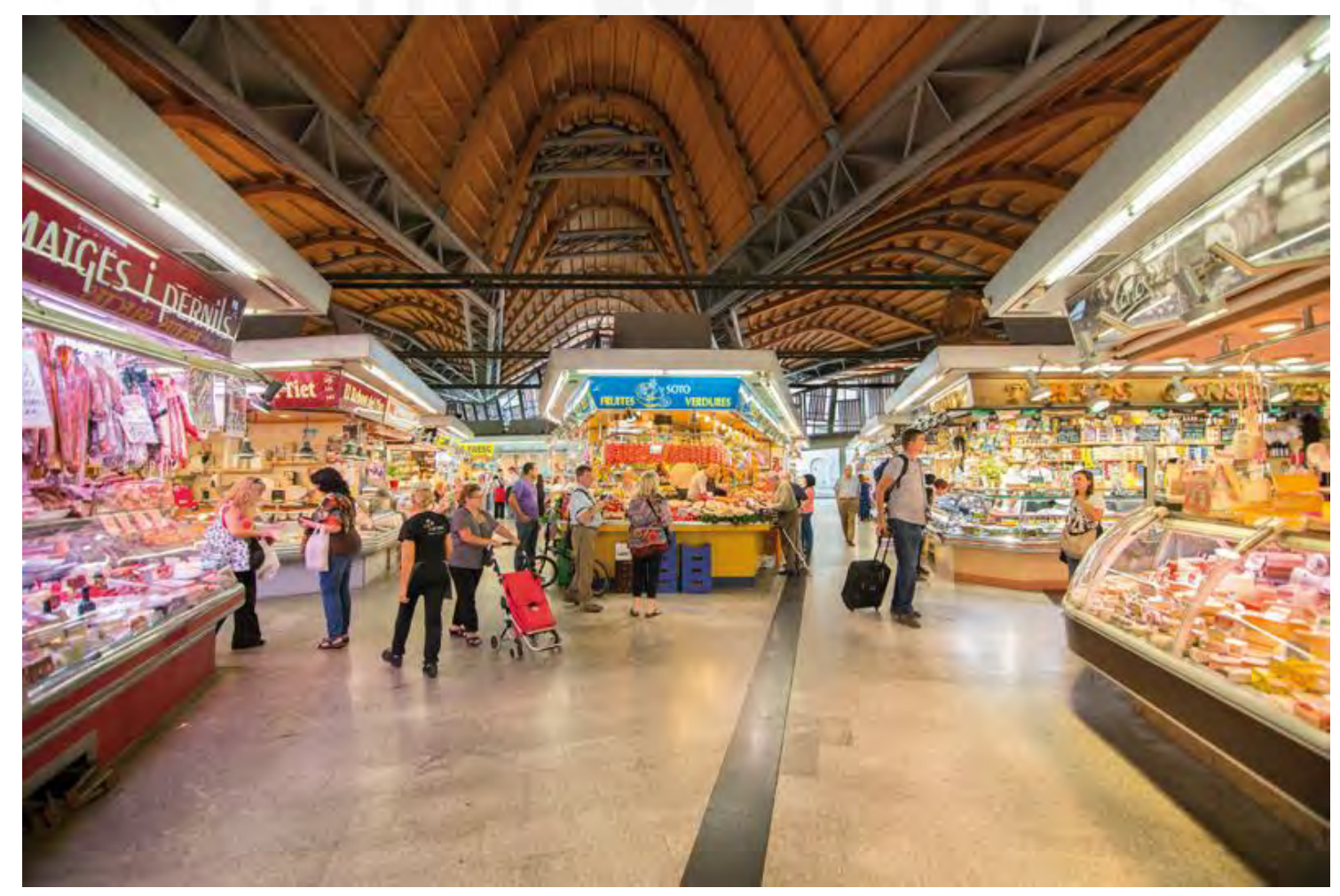

Figura 5.7 Puestos del Mercado Santa Caterina

Fuente: Buena Vibra

En: https://buenavibra.es/por-el-mundo/comer-beber/llamativo-mercado-de-santa-caterina-de-barcelona/ 


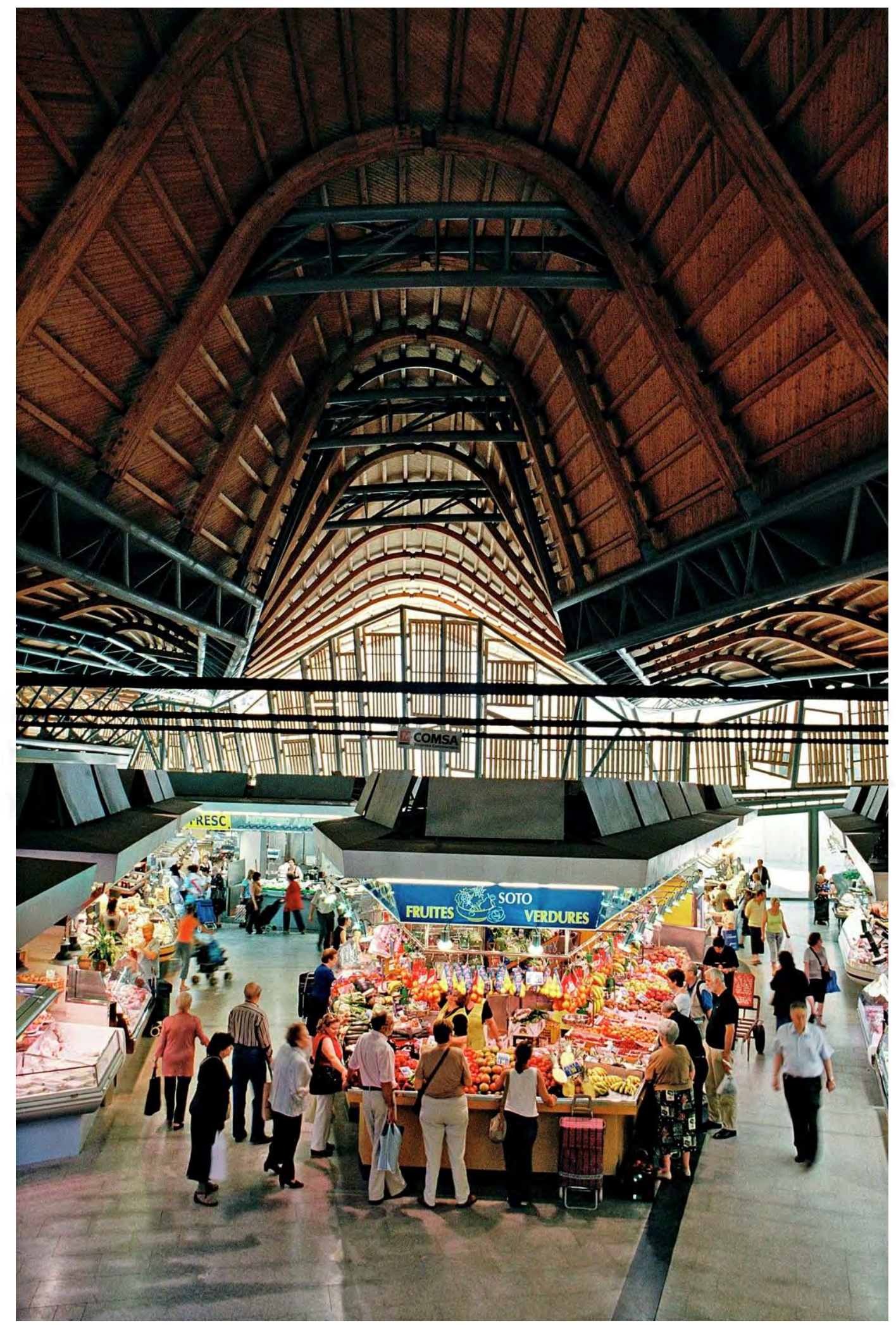

Figura 5.8 Interior del Mercado Santa Caterina

Fuente: Alex Gaultier

En:https://images.adsttc.com/media/images/5641/4d85/e58e/cedc/5d00/0059/large_jpg/SANTA_CATER INA_Alex_Gaultier_(3).jpg?1447120232 
Lámina 5.4

Flujos y accesos_Mercado Santa Caterina

\section{MERCADO SANTA CATERINA}
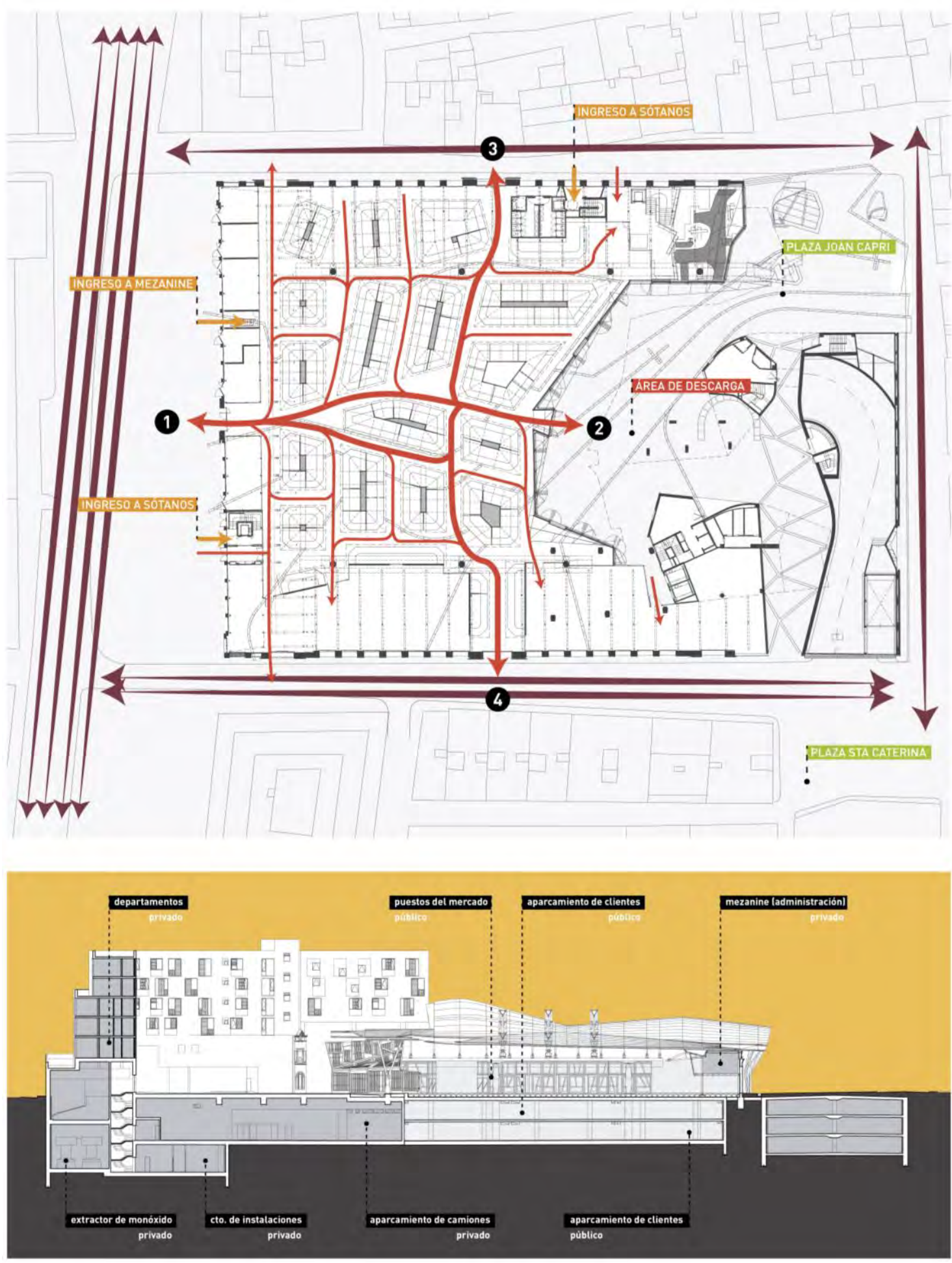

FLUJOS Y NIVEL DE PRIVACIDAD

Gráfico elaborado por los autores. 


\section{Programa}

El proyecto que se le encargó a Miralles, no solo era la remodelación del mercado, sino que también comprendía en realizar dos plataformas subterráneas para estacionamientos para uso privado y para el abastecimiento de productos, además de la construcción de viviendas para los adultos mayores con 40 departamentos, y finalmente en mantener los restos arqueológicos encontrados del antiguo convento y usarlos como piezas de museo en lo subterráneo (Ver Figura 5.9).

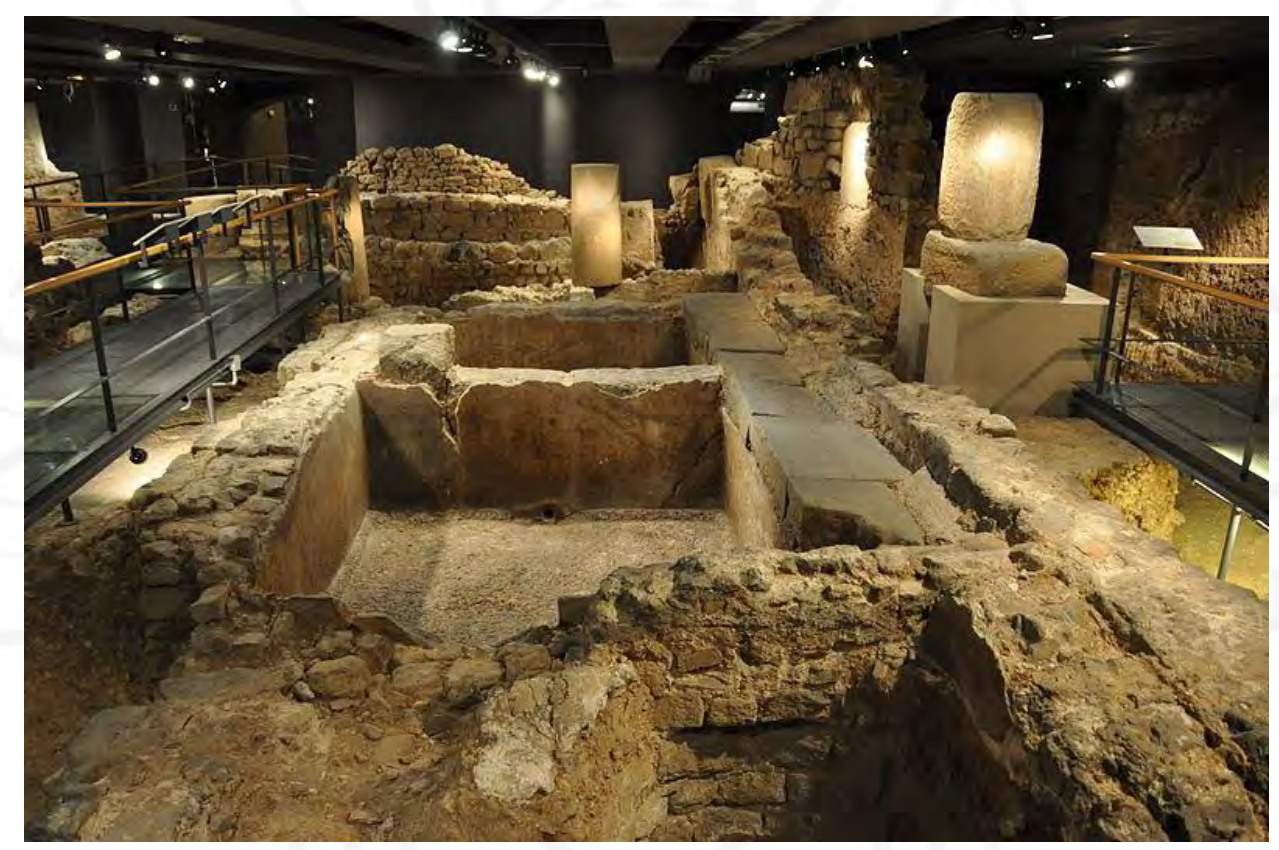

Figura 5.9 Restos arqueológicos del convento

Fuente: JosepBC, 2013

En:https://nl.wikipedia.org/wiki/Bestand:MUHBA_subsol_cetaria_factoria_de_sala\%C3\%B3_de_peix_i garum.JPG

En cuanto al mercado, este centra todo su programa en la primera planta, cuyos espacios mayormente son configurados por los mismos puestos de venta y por el comercio complementario en su perímetro. El proyecto se caracteriza por vender pescados, sean estos frescos, conservados o mariscos, debido a su cercanía con el mar, además posee una buena cantidad de puestos de frutas y verduras. El mercado también vende productos envasados, tiene bodegas, bares y restaurantes (Ver Figura 5.10), los cuales bordean el mercado y que permiten que el mercado tenga actividad tanto de día como de noche (Ver Lámina 5.5 y Lámina 5.6). 


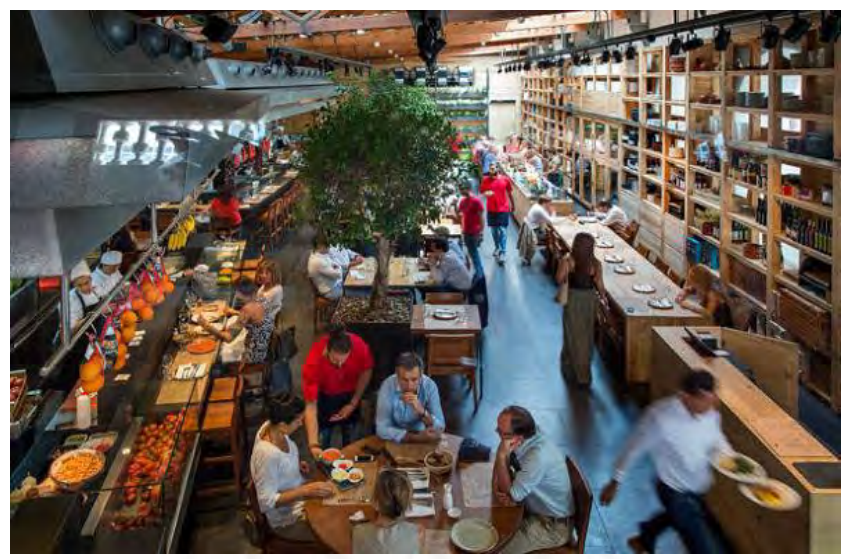

Figura 5.10 Restaurante Cuines Santa Caterina

Fuente: Buena Vibra

En: https://buenavibra.es/por-el-mundo/comer-beber/llamativo-mercado-de-santa-caterina-de-barcelona/

El mercado también cuenta con espacios privados, estos lo comprenden el área de guardianía y seguridad, las oficinas administrativas, sala de reuniones, sala de capacitaciones y servicios higiénicos para el personal administrativo. Estos se encuentran en la fachada frontal del mercado, pero en un segundo nivel y la escalera de acceso no se nota a simple vista lo que corrobora su nivel de privacidad (Ver Figura 5.11).

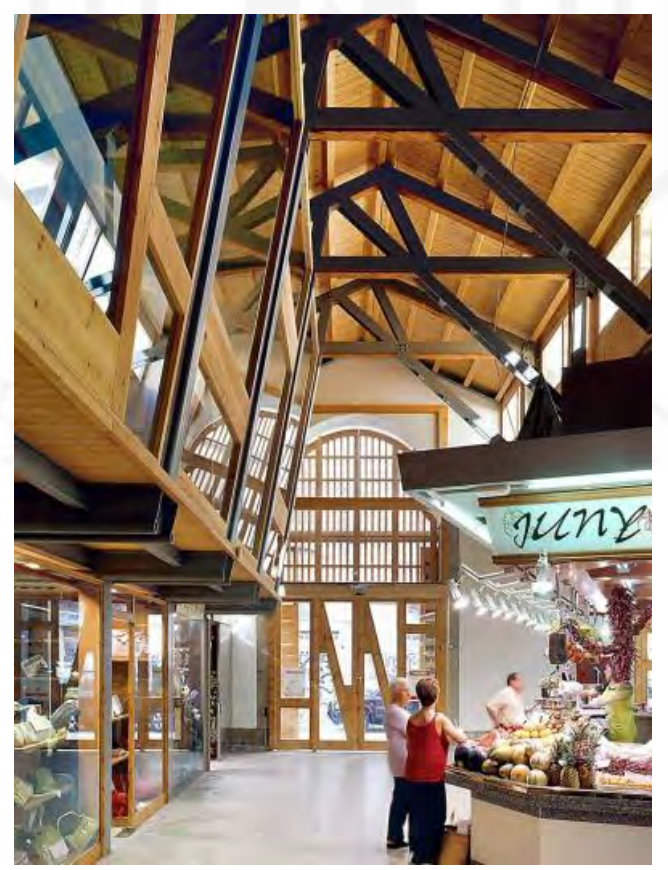

Figura 5.11 Zona administrativa en 2do nivel

Fuente: Cool Cities

En: https://www.cool-cities.com/mercat-de-santa-caterina-1562/ 
Lámina 5.5

Programa_Mercado Santa Caterina

\section{MERCADO SANTA CATERINA}
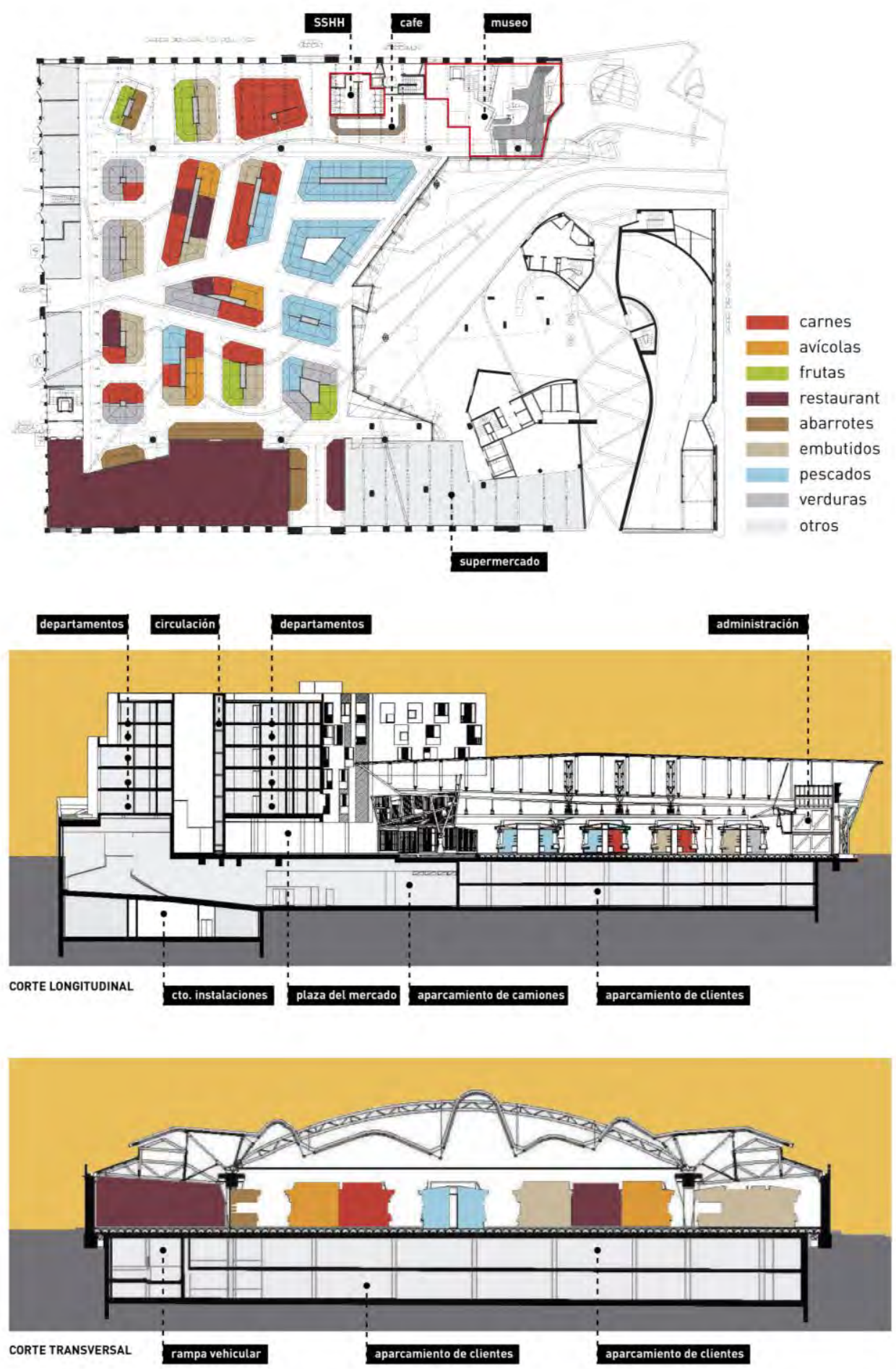

PROGRAMA

Gráfico elaborado por los autores. 
Lámina 5.6

Cuadro de áreas_Mercado Santa Caterina

\section{MERCADO SANTA CATERINA}

\begin{tabular}{|c|c|c|c|c|}
\hline SECTOR GENERAL & SECTOR & AMBIENTE & CANTIDAD & ÁREA \\
\hline \multirow{10}{*}{ MAIN MARKET } & \multirow{8}{*}{ Perecederos } & restaurantes & 6 & 440.8 \\
\hline & & carnes & 10 & 180.9 \\
\hline & & avicolas & 3 & 43.5 \\
\hline & & frutas & 5 & 73.31 \\
\hline & & abarrotes & 4 & 87.5 \\
\hline & & embutidos & 10 & 96.9 \\
\hline & & pescados & 17 & 266.3 \\
\hline & & verduras & 7 & 108 \\
\hline & \multirow{2}{*}{ No Perecederos } & supermercado & 1 & 331.5 \\
\hline & & bodega & 6 & 195.65 \\
\hline \multirow{12}{*}{ ÁREA DE SERVICIOS } & \multirow{2}{*}{ Servicios Higíenicos } & sshh damas & 1 & 16.7 \\
\hline & & sshh varones & 1 & 15.4 \\
\hline & \multirow{3}{*}{ Servicios Auxiliares } & área de residuos & & 50 \\
\hline & & área de abastecimiento & & 520.5 \\
\hline & & estacionamiento de clientes & & 6044 \\
\hline & \multirow{7}{*}{ Área Administrativa } & guardianía y seguridad & & 25 \\
\hline & & cto.de limpieza & & 10 \\
\hline & & oficina de gestion & & 20 \\
\hline & & sala de reuniones & & 35 \\
\hline & & sshh & & 15 \\
\hline & & sala de capacitaciones & & 50 \\
\hline & & oficina del administrador & & 20 \\
\hline PLAZAS & Externa & plaza del mercado & & 555.5 \\
\hline \multirow{2}{*}{ COMPLEMENTO } & Zona arqueológica & museo & & 900 \\
\hline & Vivienda & departamentos & & 4200 \\
\hline
\end{tabular}
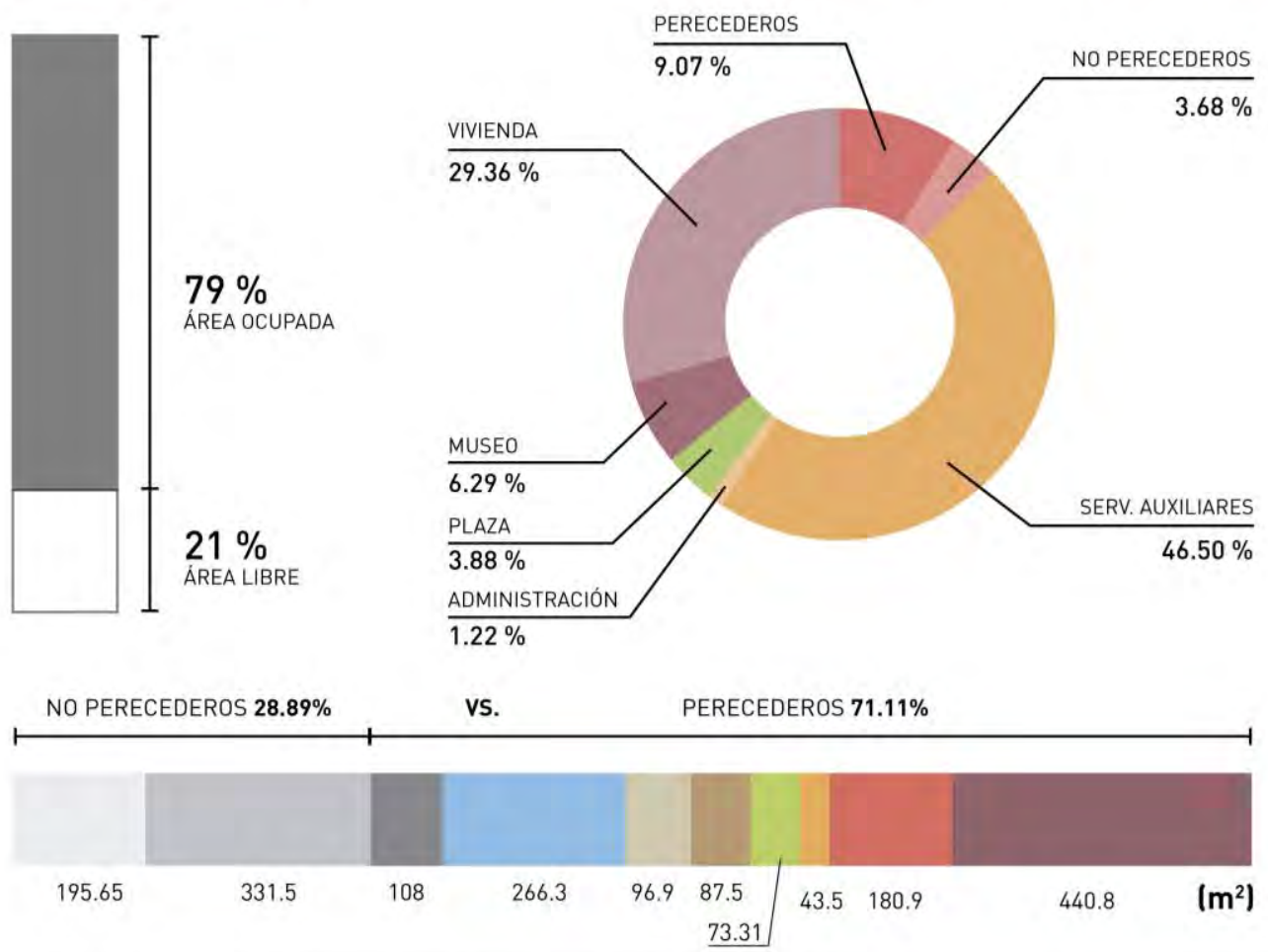

\section{CUADRO DE ÁREAS}

Gráfico elaborado por los autores. 


\section{Aporte tecnológico}

La cubierta del mercado es sin duda alguna la parte más atractiva e importante del proyecto, la cual cubre como una manta $5500 \mathrm{~m}^{2}$ de las actividades que se generan dentro del mercado. El concepto de la cubierta parte de la metáfora de las olas del mar coloreado por frutas y verduras, realizados de cerámicos con forma de hexágonos diseñados por el ceramista Toni Camella que utiliza la técnica de el "Trecadis" gaudiniano asentados sobre $2 \mathrm{~cm}$ de mortero, y toda la cubierta en sí, soporta un peso de $92 \mathrm{Kg} / \mathrm{m}^{2}$ (Ver Figura 5.12).

Los apoyos principales están formados por dos vigas pos-tensadas una de $43 \mathrm{~m}$ de largo, y la segunda de $72 \mathrm{~m}$, que descansan sobre columnas compuestas de acero con forma de ramas de árboles. Estas dos grandes vigas se encuentran unidas por tres arcos metálicos de celosía, separados uno del otro a 6.50m. En los lados del mercado también se construyeron unos paneles de madera, de los cuales el 70\% formaba parte del antiguo mercado, siendo restauradas y sometidas a tratamiento anti-xilófago que lo protegen de insectos, además están estructuradas en base a arcos funiculares pre-fabricados (Ver Lámina 5.7) y se calcula que se requirió aproximadamente 10 mil dovelas para completarlos (Pixel Publishing, 2005, p. 59).
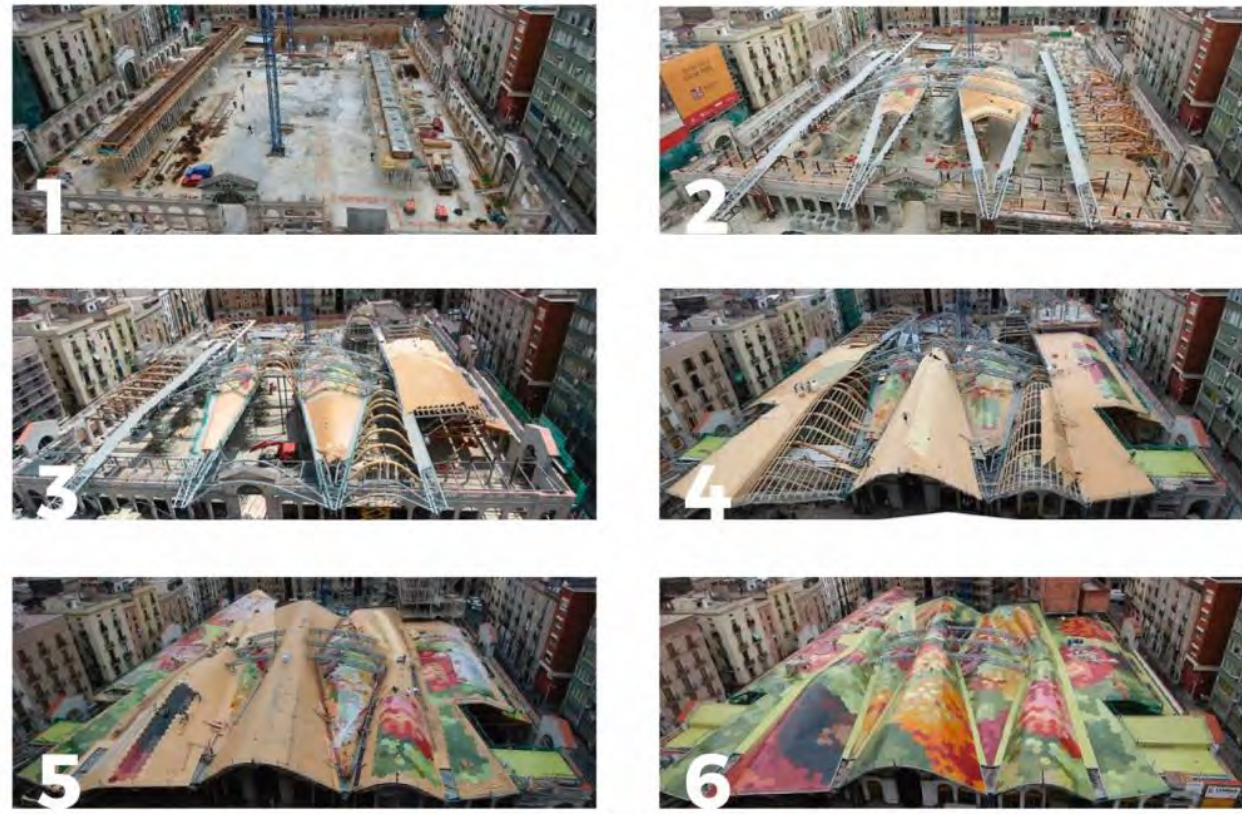

Figura 5.12 Proceso constructivo de la cubierta

Fuente: Amazing Architecture

En: https://arquitecturaespectacular.blogspot.pe/2010/03/mercado-santa-caterina.html 
Lámina 5.7

Aporte tecnológico_Mercado Santa Caterina

\section{MERCADO SANTA CATERINA}

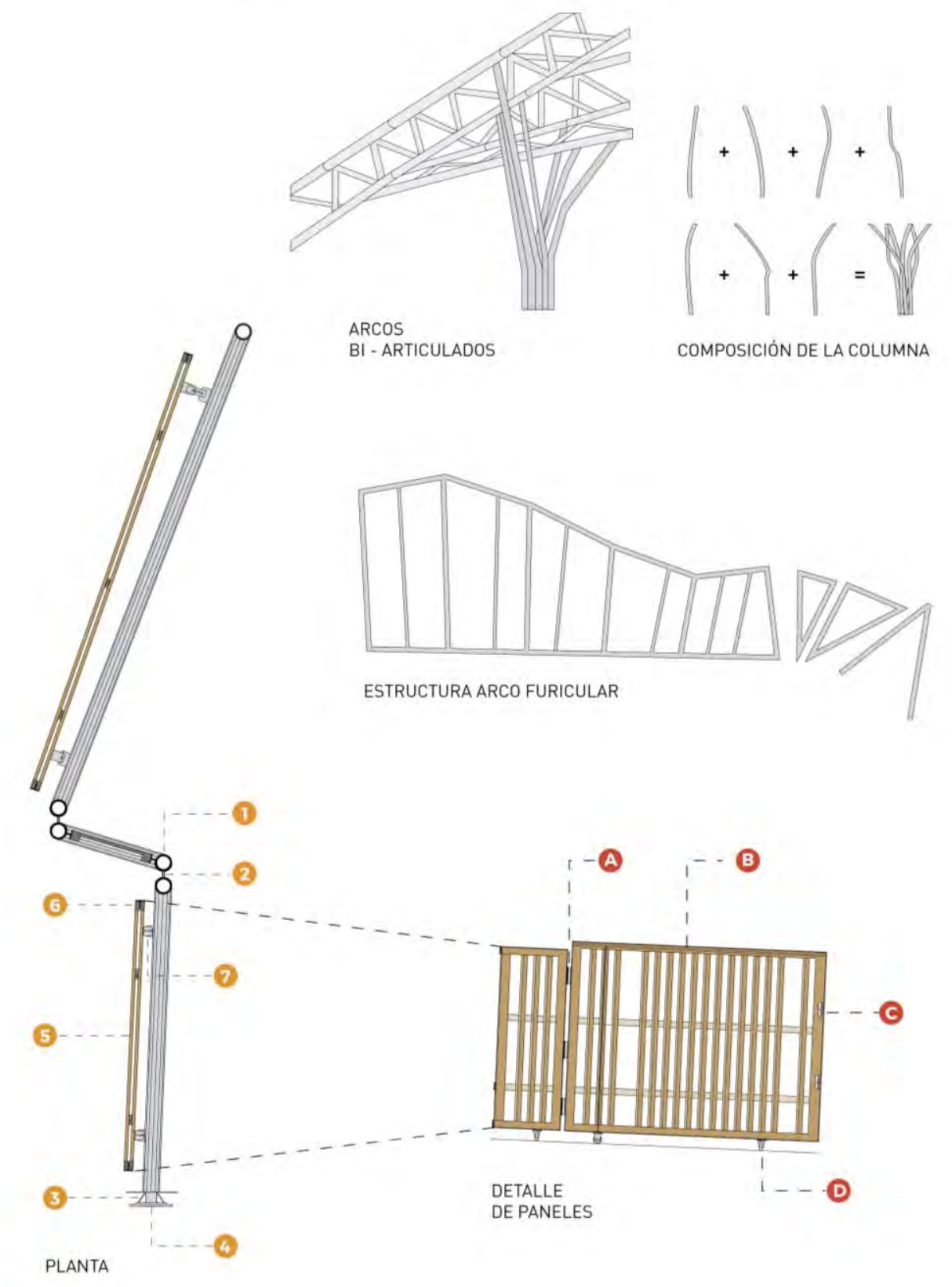
(1) Tubo de acero
(2) Platina de acero $E=8$
(3) Apoyo de acero $E=8$
(4) Placa de anclaje

(5) Panel de madera

A Bisagra

6) Perfil en $T E=8$

(7) Elemento de conexión

B Guía superior

C Sistema de bloqueo

D Rueda giratoria

\section{APORTE TECNOLÓGICO}

Gráfico elaborado por los autores. 


\subsubsection{Mercado Dels Encants}

El Mercado Del Encants se encuentra ubicado en el barrio de la Eixample, entre la Av. Maridiana, las calles Caspe y Castillejos, frente al antiguo Bosquet Del Encants de la ciudad de Barcelona, España. Este mercado es la fusión de los mercados medievales Los Encants y La Fira, unificados en el s.XIX. El primero nace hacia el año 1200, por las actividades de las subastas públicas y ventas en la ciudad, ubicándose durante siglo en diferentes plazas de la ciudad, partiendo de la plaza Sant Jaume a la plaza Nova, y finalmente a la Voltes Dels Fusters, en Llotja, en donde se instalaron durante 500 años (Ver Figura 5.13). El segundo comienza en 1800, situándose en el Paseo Nuevo, fuera de las murallas de la ciudad, sin embargo, durante la Guerra Francesa, se trasladan a la Rambla y se cambia el nombre de Fira de Bellcaire a Encants Vells. Posteriormente, la urbanización del ensanche de Barcelona obligó al ayuntamiento a trasladar el mercado de la Fira de Bellcaire a la Av. Mistral, creando el mayor complejo comercial de la época con un total de 800 puestos (Gómez Wilkinson, 2016, párr. 3).

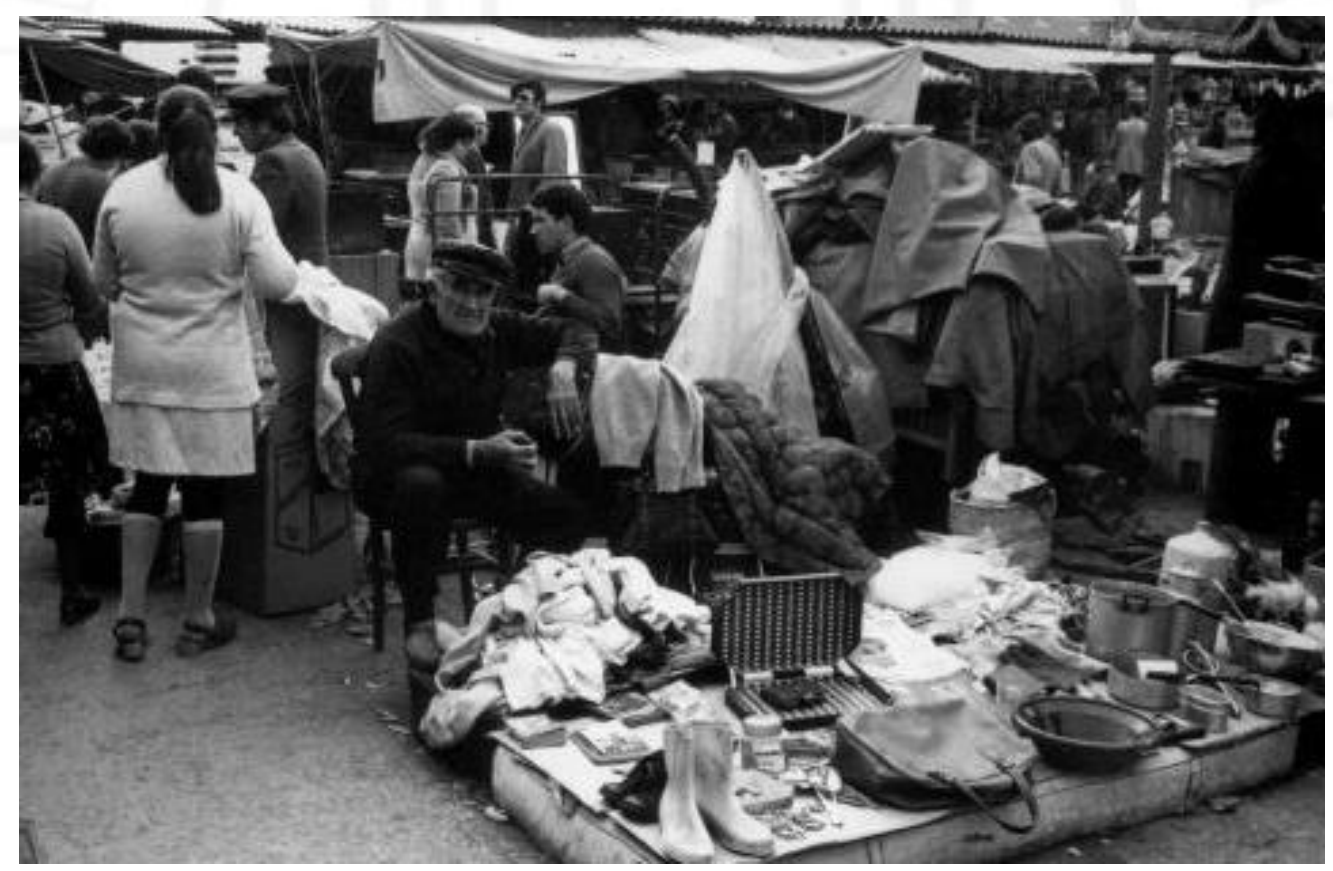

Figura 5.13 Antiguo Mercado Dels Encants

Fuente: Encants de Barcelona

En: http://www.encantsbcn.com/es/content/los-encants-y-sus-siete-traslados 
Un ciclo después, se da la Exposición Internacional de 1929 cuyo principal objetivo era dar a conocer adelantos tecnológicos de la industria catalana, y por motivos de esta exposición se generaron una serie de reformas urbanas, obligando a que el mercado se traslade nuevamente hacia la plaza Las Glorias. Durante este periodo, el mercado se vio afectado por encontrarse en una zona llena de cambios y vías no panificadas que acentúan más el carácter desordenado y no estable del mercado. Recién en el 2006 se aprobó el nuevo emplazamiento del mercado, ubicado al frente de la plaza de Las Glorias, junto al Teatro Nacional, después en el 2009, empezaron las obras que durarán 4 años, inaugurando el nuevo mercado en el 2013 (Ver Figura 5.14).

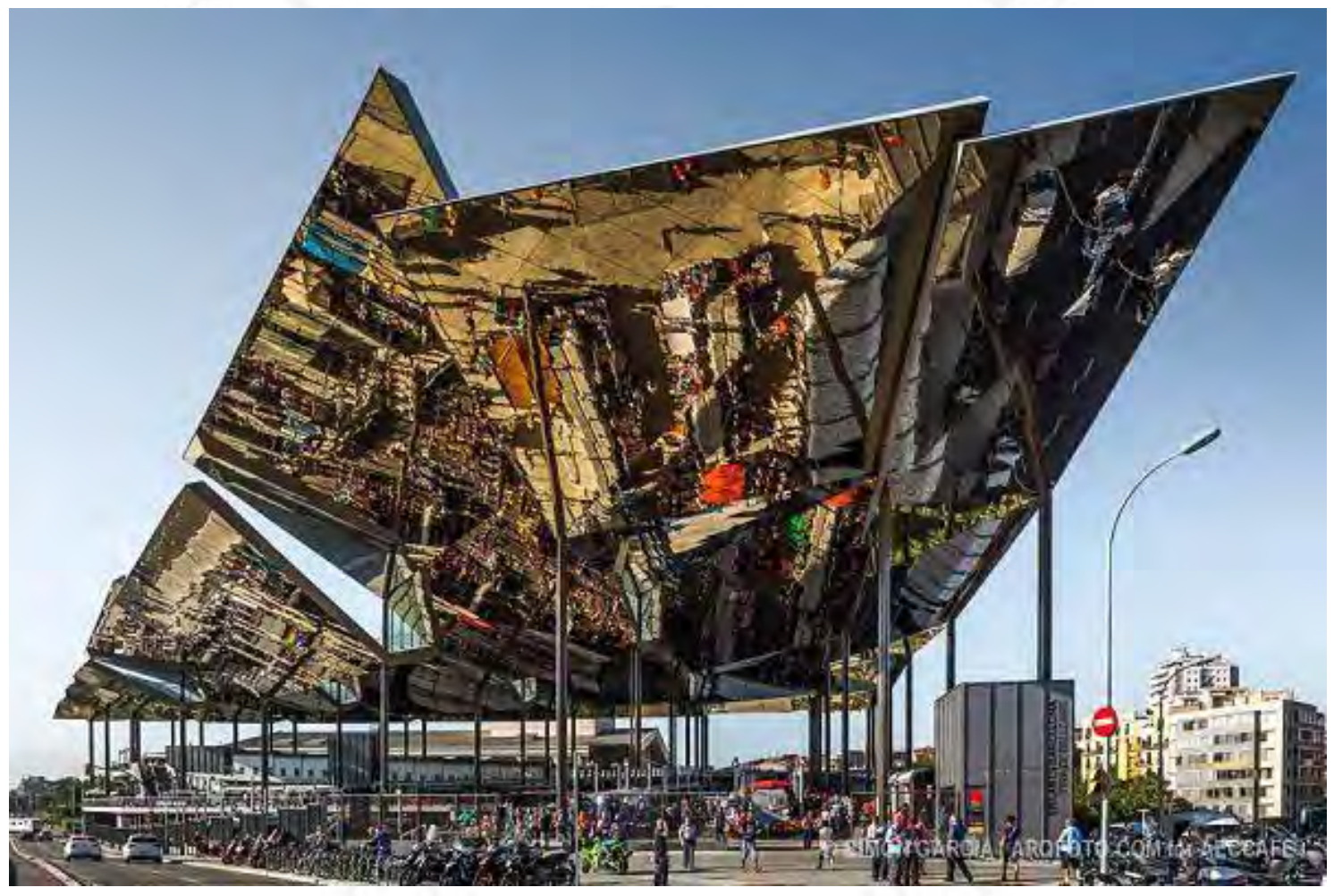

Figura 5.14 Nuevo Mercado Dels Encants

Fuente: Rafael Vargas

En: https://upcommons.upc.edu/bitstream/handle/2117/86003/Encants+Barcelona.pdf 
Para el diseño del mercado se tiene en cuenta la centralidad que conforma el mercado como equipamiento, la informalidad como carácter esencial del mercado desde sus orígenes y la necesidad de generar una relación con los equipamientos culturales que rodean el terreno del mercado. A partir de estas necesidades, se plantea como idea principal generar un proyecto que contenga una fuerte identidad volumétrica con la finalidad de monumentalizar el carácter popular que define al mercado (Costales Calvo, 2014, p. 5).

Sin dejar de lado la organización informal de comercio del Mercado Dels Encants, que se caracterizaba por situarse en las calles al aire libre, se plantó un edificio abierto con niveles que representarían las calles de la ciudad y se elimina la idea de muro como contenedor del espacio, dejando que los propios módulos de venta delimiten los niveles (Ver Figura 5.15 y Figura 5.16).

Además, el Arq. Fermín Vázquez rechazó el modelo de centro comercial y planteó un espacio continuo para el mercado, configurado por planos inclinados entrelazados, generando de recorridos desde su ingreso hasta el último nivel; creando una experiencia similar a la de pasear por las calles (Ver Figura 5.17).

El diseño de las casetas contribuye a un soporte neutro para la oferta multicolor y variopinta de la mercancía. Por medio del plegado de los suelos se concilian las diferentes cotas de las calles perimetrales y se desdibujan los niveles de acceso. (Costales Calvo, 2014, p. 5).

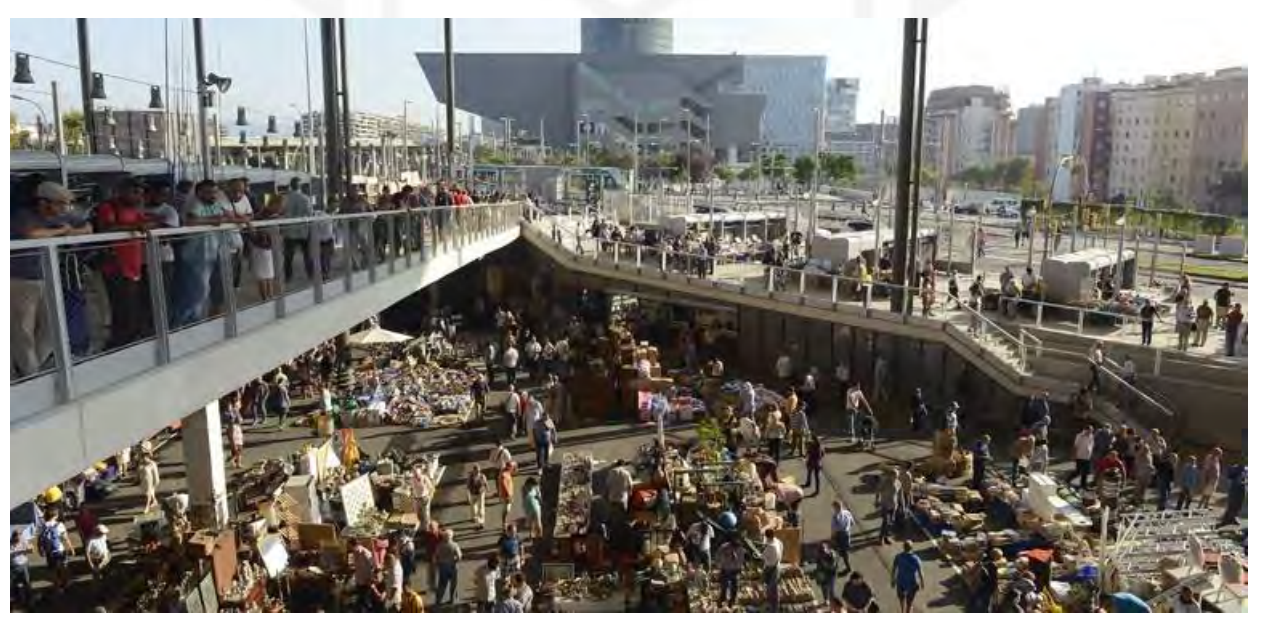

Figura 5.15 Interior del Mercado Dels Encants

Fuente: Barcelona Home

En:http://barcelona-home.com/blog/wp-content/upload/2013/10/encants-vells-market-barcelona-spain.jpg 


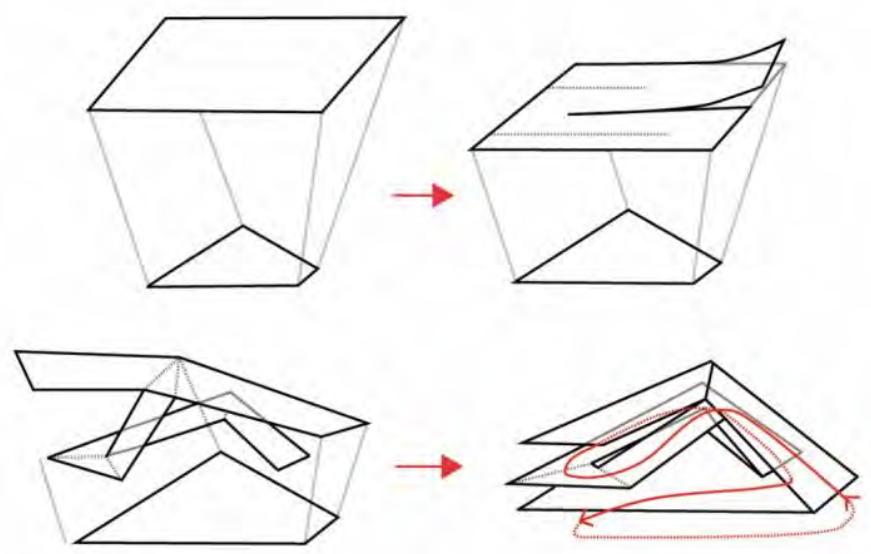

Figura 5.16 Mercado Dels Encants_Concepto

Fuente: B270

En: http://b720.com/es/portafolio/mercat-dels-encants/

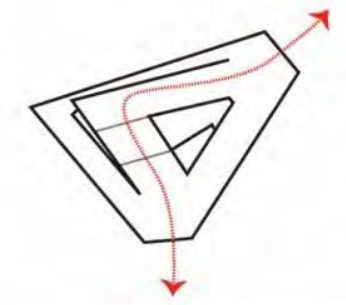

CIRCULACION PLATAFORMA

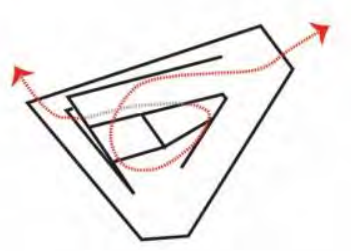

CIRCULACION EN DESPLIEGUE

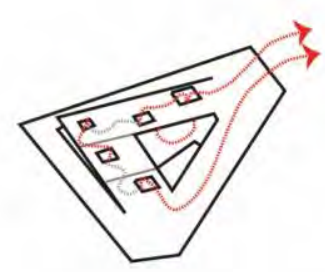

CIRCULACION VERTICAL

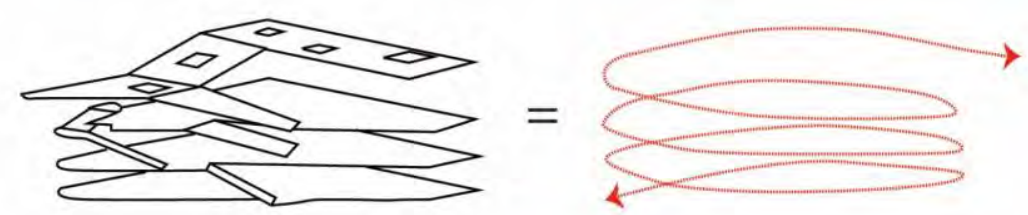

Figura 5.17 Mercado Dels Encants_Circulación

Fuente: B270

En: http://b720.com/es/portafolio/mercat-dels-encants/

Por otro lado, se toma en cuenta una gran cubierta hecha en base de acero inoxidable, recubierto por aluminio y zinc, conformada por planos quebrados de anchos variables, la cual le dará personalidad al proyecto y lo posicionará como hito de la ciudad; además protegerlo de los fuertes vientos y la radiación solar. 
Lámina 5.8

Datos generales_Mercado Dels Encants

\section{MERCADO DELS ENCANTS}
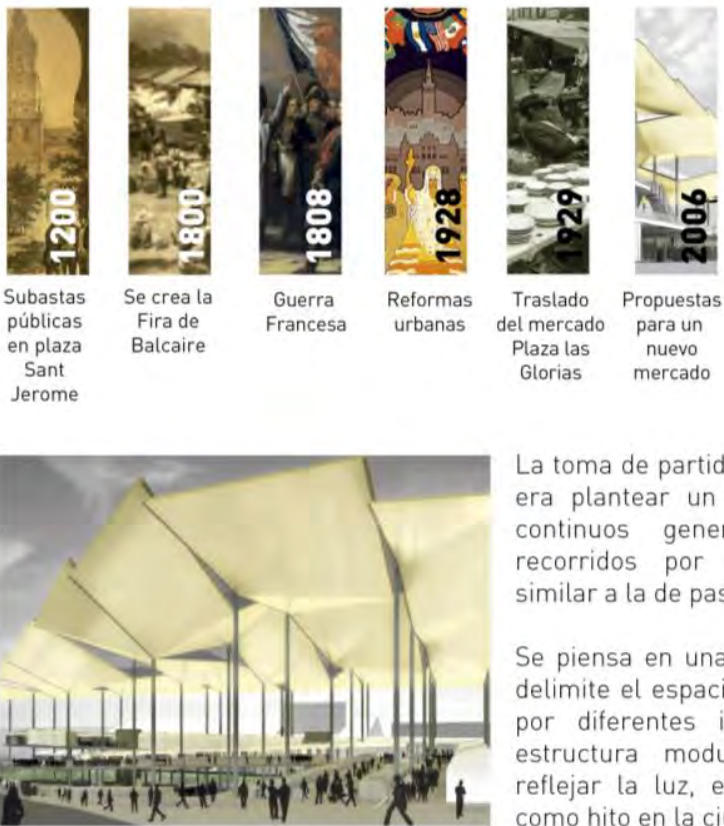

La toma de partido del nuevo mercado era plantear un edificio con niveles continuos generando libertad de recorridos por medio de rampas similar a la de pasear por la ciudad.

Se piensa en una gran cobertura que delimite el espacio y al mismo tiempo por diferentes inclinaciones en su estructura modular sea capaz de reflejar la luz, el paisaje y funcione como hito en la ciudad.

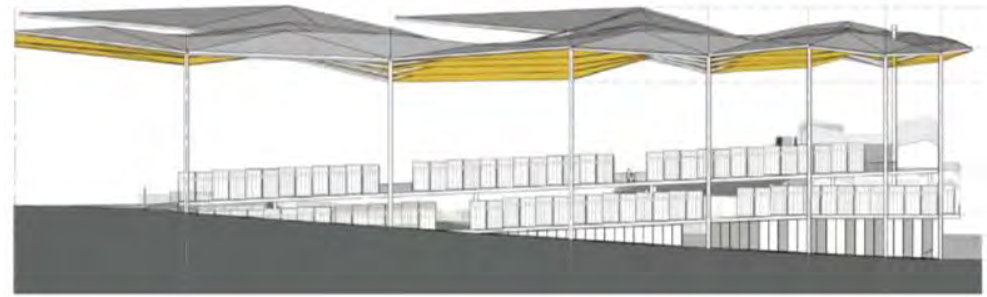

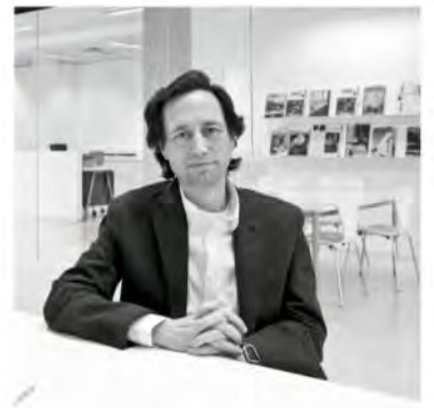

b720 Fermín Vázquez Arquitectos es un estudio, fundado en 1997 y liderado por Fermín Vázquez junto con Ana Bassat.

Sus diseños se caracterizan por una arquitectura contemporánea comprometida con el uso responsable de los recursos naturales.

Su coherencia se basa en una metodología de trabajo propia, evitando deliberadamente la elaboración de un estilo o formalismos. Cada proyecto es una búsqueda específica, con clientes y sociedad como referentes irrenunciables. La respuesta a programa, contexto, presupuesto y tiempo es necesariamente única.

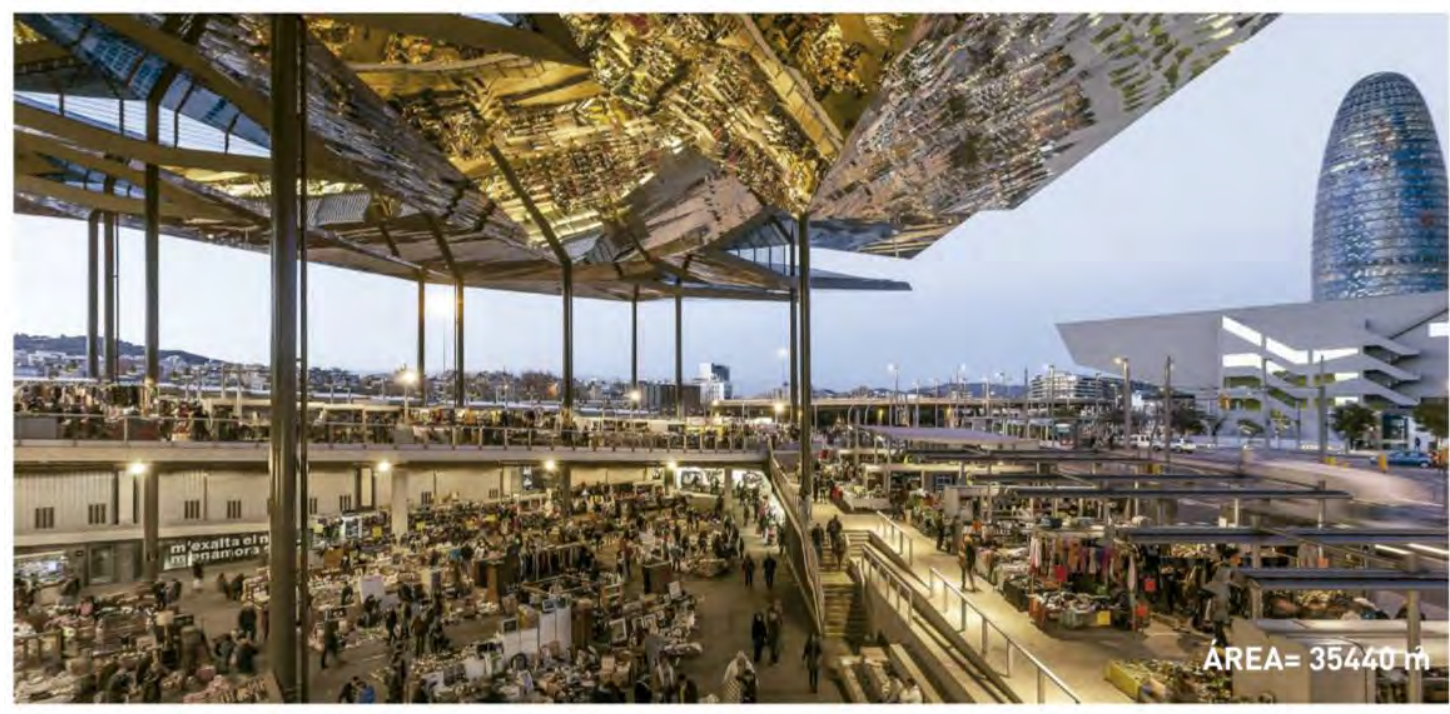

\section{DATOS GENERALES}

Gráfico elaborado por los autores. 
Lámina 5.9

Localización_Mercado Dels Encants

\section{MERCADO DELS ENCANTS}

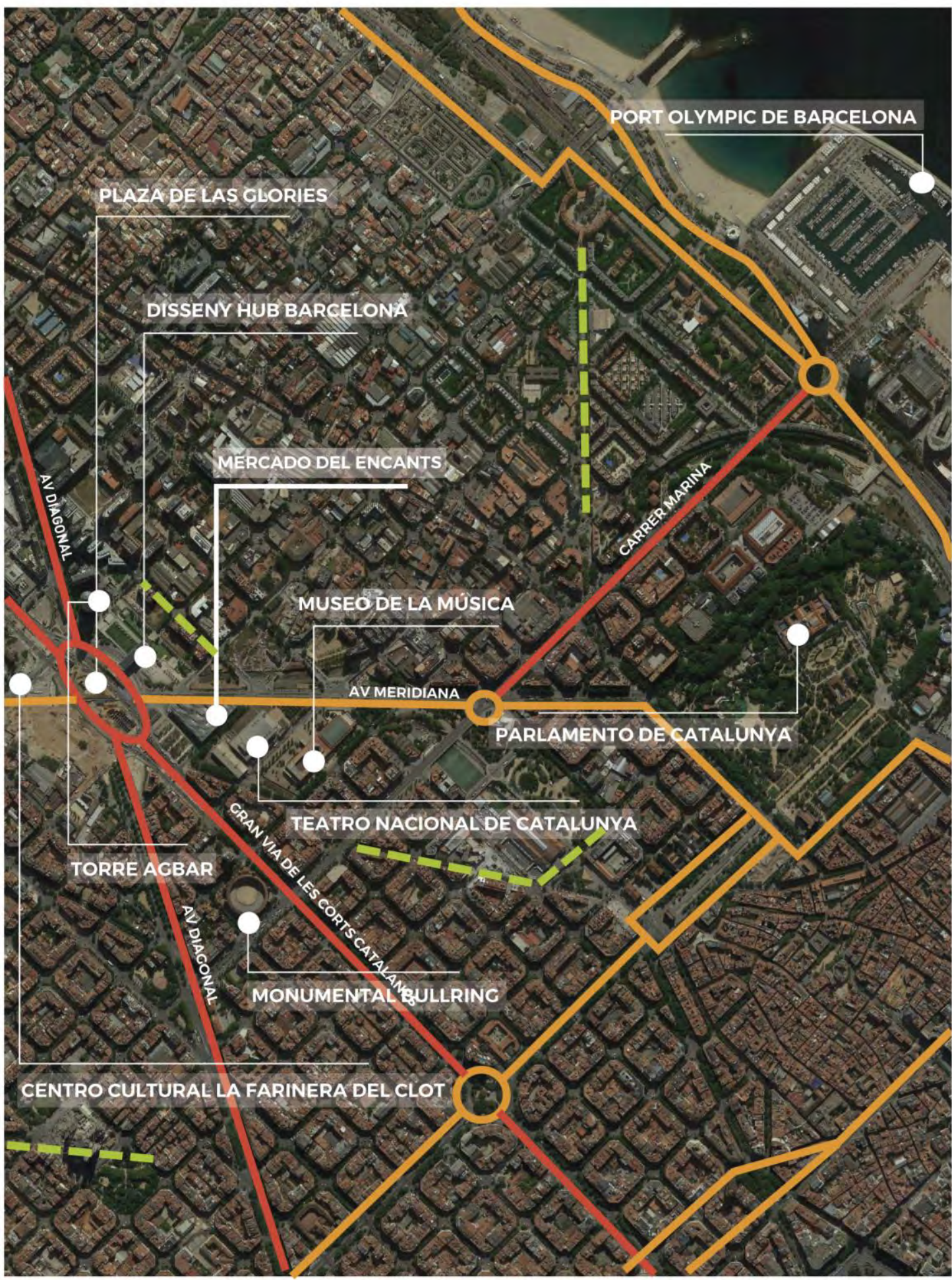

LOCALIZACIÓN

Gráfico elaborado por los autores. 


\section{Relación con el entorno}

El mercado se encuentra en el barrio de la Eixample y está delimitado por la Av. Meridiana, la Calle Caspe y la Castillejos, considerado como lugar estratégico y de fácil acceso para diferentes medios de transporte. Además, está rodeado de un notable grupo de equipamientos culturales importantes para la ciudad como: el Museo de la Música de Barcelona, el Gran Teatro Nacional de Catalunya, el Centro Comercial de las Glories, el Disseny Hub de Barcelona, la Torre Agbar y el jardín del Bosque de Encantes.

Se puede acceder al proyecto usando el metro, con la línea L1, cuyo paradero se encuentra a una cuadra del mercado. También, existen paraderos de buses alrededor del proyecto, concentrados en la Gran Vía de les Cortes Catalanes y en la calle Carrer de los Castillejos, a la espalda del mercado (Ver Figura 5.18). El tranvía también ofrece la posibilidad de acceso al mercado, con las líneas T4, T5 y T6, que se toman en el paradero "Las Glorias" ubicado al frente de la puerta principal del mercado.

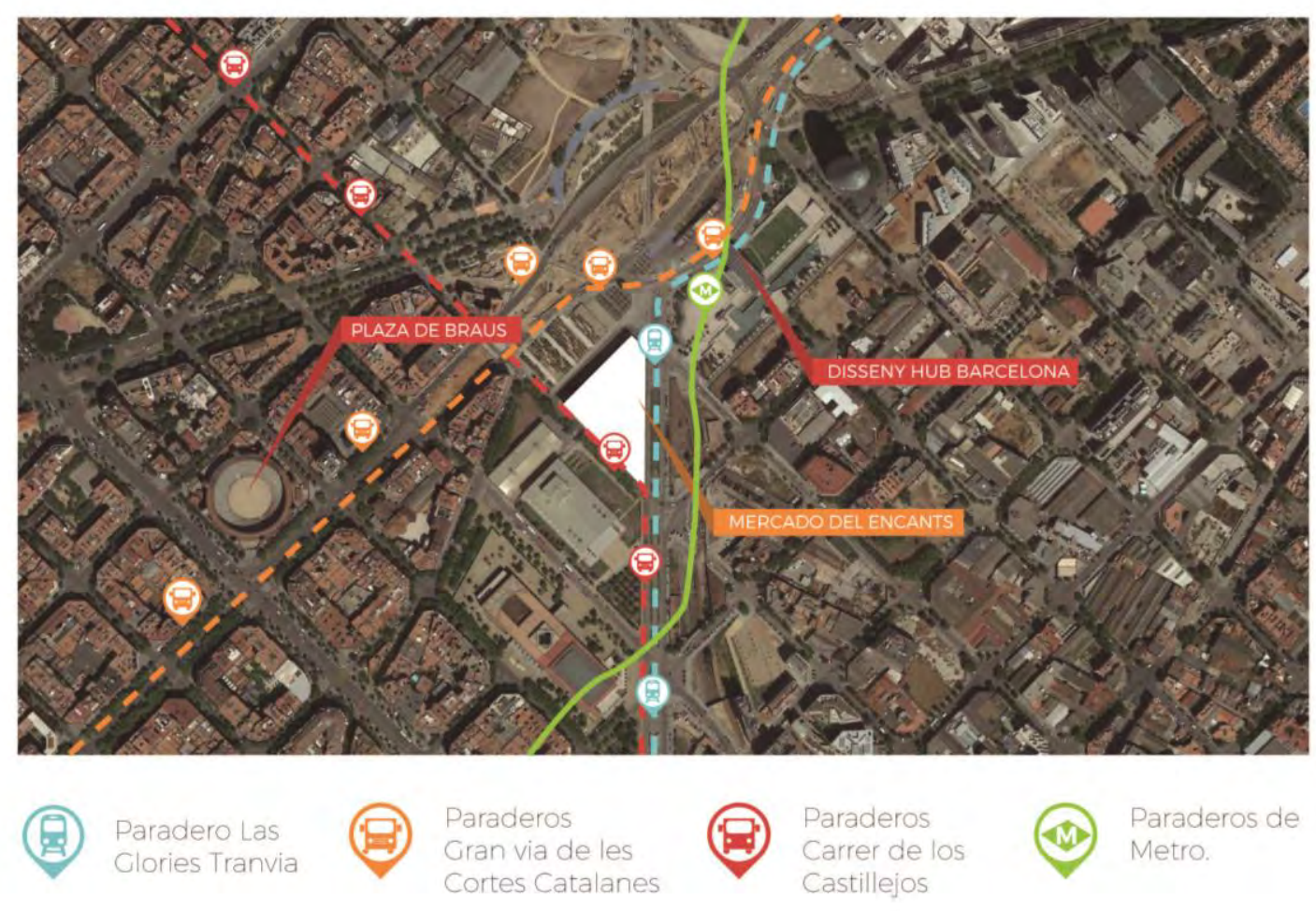

Figura 5.18 Conexión del Mercado Dels Encants

Gráfico elaborado por los autores. 
El acceso a los estacionamientos para vehículos privados y zona de descarga se encuentra en la calle Carrer de Castillejos, mientras que el acceso peatonal se da por la Av. Meridiana que posee dos carriles y está dotada de una serie de paraderos para buses, del tranvía y del metro, facilitando el acceso para el peatón. De esta manera, la fachada principal del mercado está orientada hacia la Av. Meridiana que cuenta con 9 entradas, y la entrada principal se encuentra en el cruce de la Av. Meridiana con La Gran Vía de Cortes Catalanes. Además, existen otras 11 entradas al proyecto por la calle Castillejos, de configuración más estrecha. La tercera calle del proyecto solo cuenta con 2 accesos, y es de uso más privado, debido a que se encuentra la parte administrativa del mercado.

El edificio del mercado se considera por ser un equipamiento permeable que se abre al público e impide barreras arquitectónicas en su configuración interior. Esto se ve reflejado en la cantidad de accesos peatonales distribuidos alrededor del proyecto y la delimitación del proyecto con la calle por medio de los propios puestos de venta. Entonces, a partir de este análisis de accesibilidad, se puede concluir que la facilidad de vías de acceso influye con una alta cantidad de afluencia de personas, tanto habitantes como los turistas de la ciudad (Ver Figura 5.19 y Lámina 5.10).

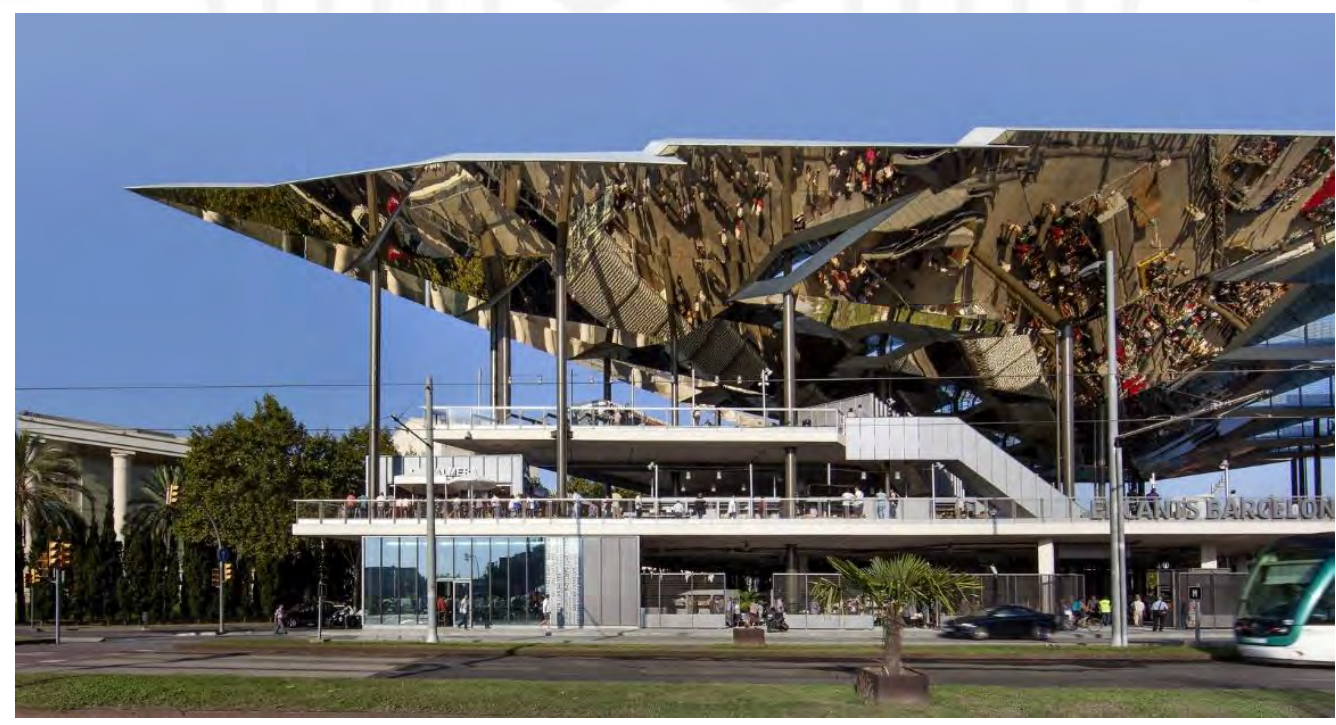

Figura 5.19 Mercado Dels Encants_Ingreso Fuente: Rafael Vargas En:https://images.adsttc.com/media/images/529d/43db/e8e4/4eca/5b00/0051/large_jpg/ENCN_7949.jpg? 1386038202 
Lámina 5.10

Relación con el entorno_Mercado Dels Encants

\section{MERCADO DELS ENCANTS}

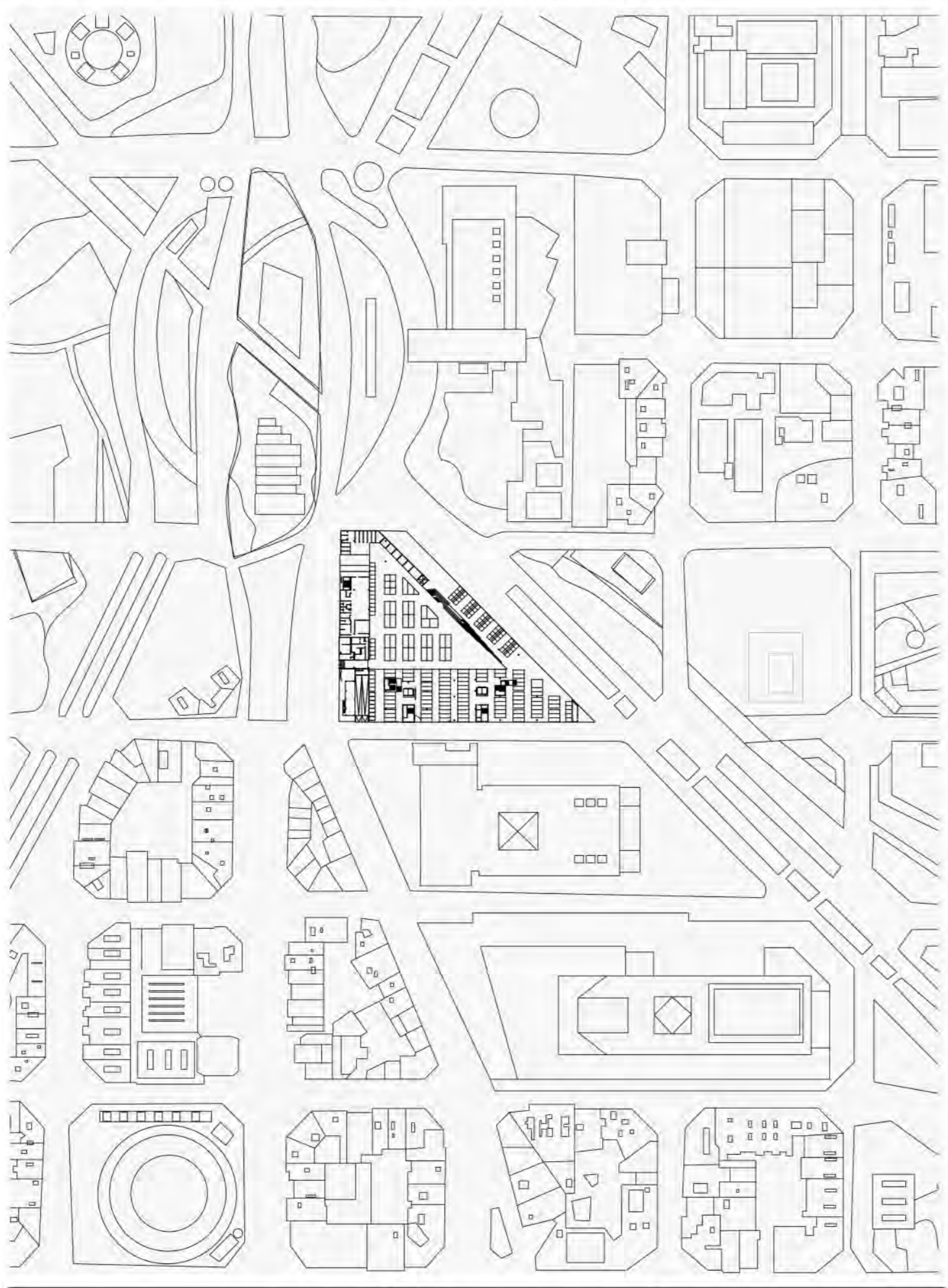

RELACIÓN CON EL ENTORNO

Gráfico elaborado por los autores. 


\section{Flujos y acceso}

El mercado antiguo poseía un área de $15000 \mathrm{~m}^{2}$; sin embargo, en el 2006 se aprueba el nuevo emplazamiento para el traslado del mercado, donde se encuentra ubicado actualmente, en un terreno que cumple con la mitad de la superficie que antiguamente tenía. Además, posee una cobertura de $8000 \mathrm{~m}^{2}$ que cubre toda su superficie, obteniendo un $100 \%$ de área techada y un $0 \%$ de área libre.

Siguiendo con el concepto del mercado en la calle, se diseña el Mercado Dels Encants como un edificio abierto, sin muros que lo delimiten, con una totalidad de 20 accesos, exhibiendo sus productos en una plaza central, conocida como la zona de subasta y delimitando el perímetro del por medio de la gran cobertura que lo protege. A pesar de que se da una circulación fluida en todo el edificio, los módulos de venta rompen con ese esquema y generan una circulación más rígida y ortogonal al interior de las calles del mercado, brindando cierto equilibrio al proyecto (Ver Lámina 5.11).

Estos módulos de venta se encuentran alineados uno al costado del otro y cuentan con una dimensión $4.00 \mathrm{~m}$ de ancho, $5.30 \mathrm{~m}$ de largo y $2.50 \mathrm{~m}$ de alto en la fachada, medida que luego cambia al interior del módulo y aumenta a 3.50m (Ver Figura 5.20). Este cambio de altura en la configuración de los módulos, es una estrategia de diseño para desviar la visual del usuario al interior del mercado y se vea reflejado la actividad comercial en la cubierta del edificio.

Por otro lado, el material y color del acero de los módulos de venta influyen como elemento que neutraliza los colores de los productos que se ofertan en el mercado. La empresa Arcelor Mittal, fue la encargada del suministro de material y construcción de las casetas de venta:

ArcelorMittal Construcción España suministró en total $2.700 \mathrm{~m}^{2}$ de paneles Araquil 1150 para los 479 puestos del mercado y $5600 \mathrm{~m}^{2}$ de chapas curvadas Hacierco para las 266 tiendas. Mientras que los paneles Araquil 1150 tienen un espesor de $35 \mathrm{~mm}$ y están prelacados en Hairplus color Opale, las chapas Hacierco, de 0,75mm de espesor, están fabricadas de acero con el recubrimiento metálico Krystal que contiene un 55\% de aluminio, $43,4 \%$ de zinc y un poco de silicio y presenta un recubrimiento aleado que asegura la protección contra la corrosión. (ArcelorMittal Europe, 2013, párr.3) 
De esta manera, el material utilizado en los puestos logra cumplir 3 funciones elementales en el mercado, ya sea como elemento que brinda equilibrio en los recorridos con circulaciones más ortogonales, como color que neutraliza la multiplicidad de colores de los productos que se exhiben, y como elemento que por repetición configura una fachada (Ver Figura 5.21).
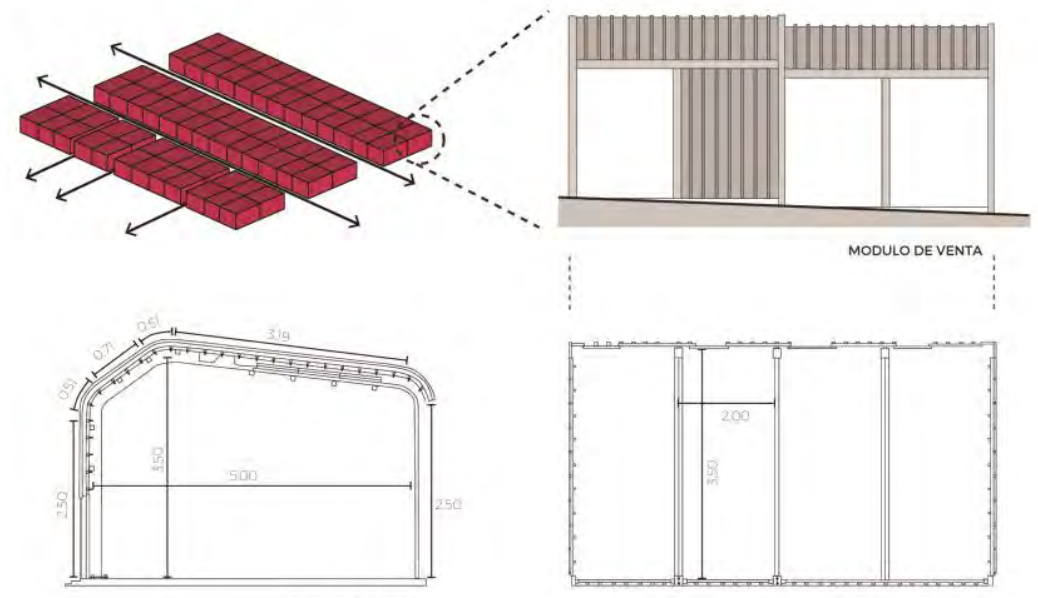

CORTE TRANSVERSAL

CORTE LONCITUDINAL

Figura 5.20 Mercado Dels Encants_Puestos Gráfico elaborado por los autores.

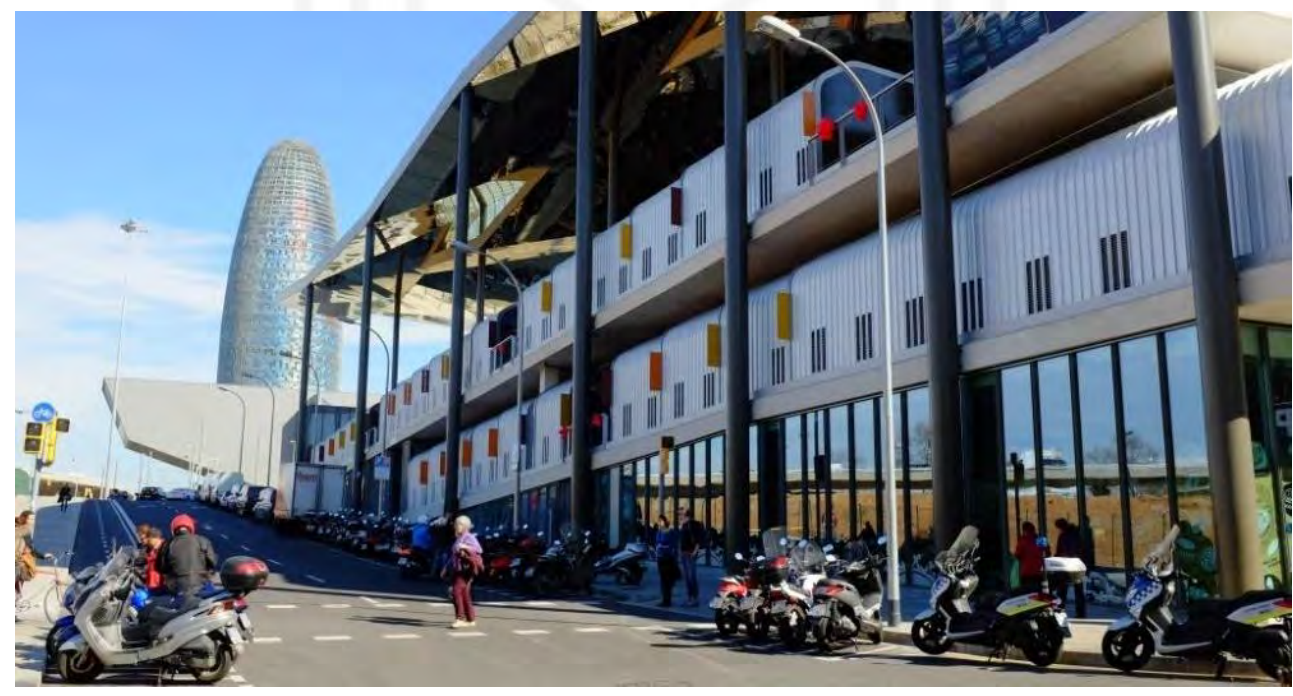

Figura 5.21 Mercado Dels Encants_Fachada de puestos

Fuente: Constructalia - ArcelorMittal

En:http://constructalia.arcelormittal.com/es/casos_practicos/espana/mercat_dels_encants_vells_barcelona 
Lámina 5.11

Flujos_Mercado Dels Encants

\section{MERCADO DELS ENCANTS}
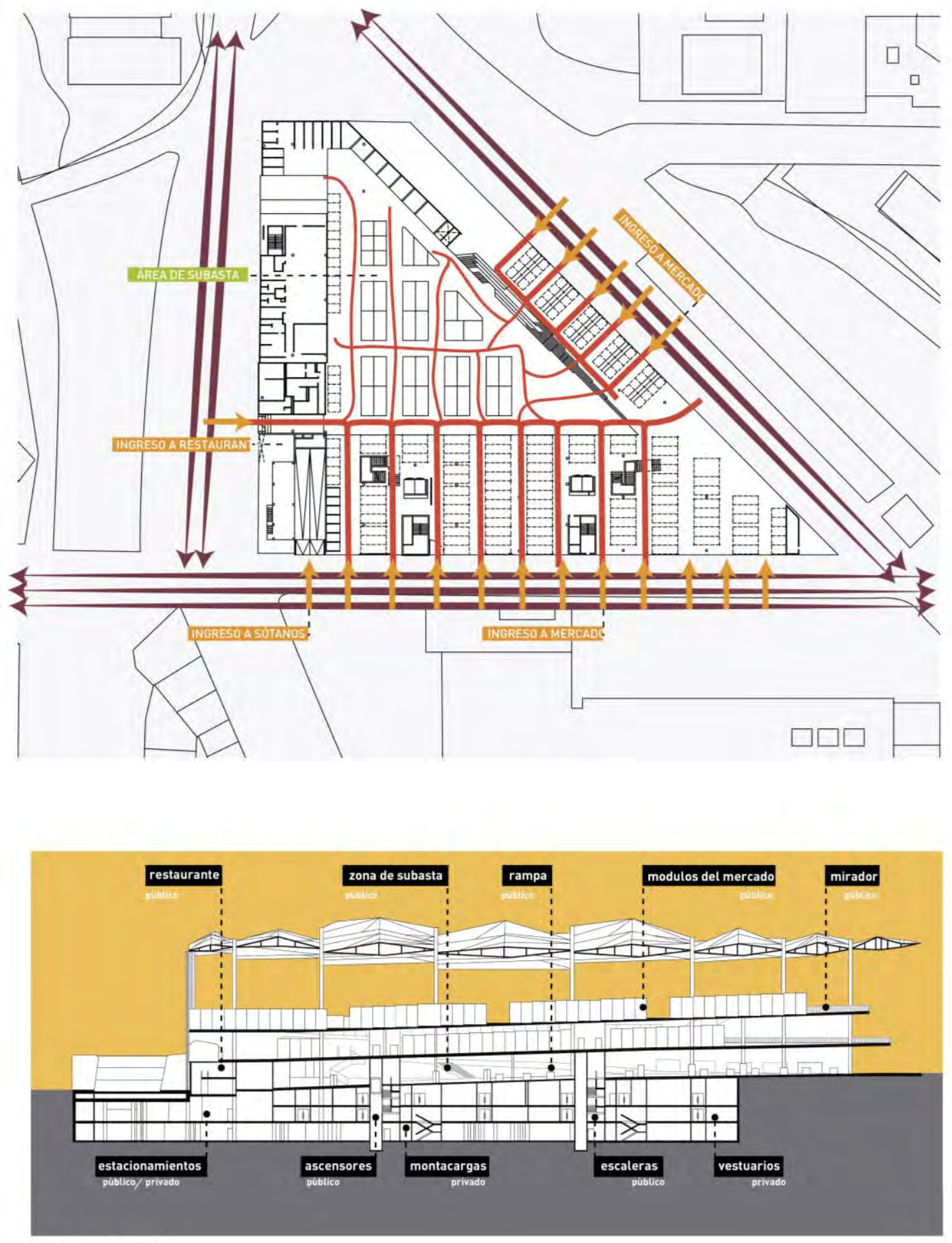

CORTE LONGITUDINAL

FLUJOS Y NIVEL DE PRIVACIDAD

Gráfico elaborado por los autores. 


\section{Programa y circulaciones}

El mercado cuenta con una superficie total $33.306 \mathrm{~m}^{2}$ de área construida que se divide en 4 niveles que son: el sótano, primer nivel, segundo nivel y tercer nivel. Está conformado por unos 500 comerciantes con 274 comercios conformado por 78 tiendas, 156 paradas y 39 espacios para subasta. La venta de productos se caracteriza por artículos de antigüedad y de segunda mano como: mobiliario para el hogar, venta de ropa, libros y discos viejos, maquinaria y electrodomésticos. Además, el mercado ofrece productos actuales de confección, hogar, decoración, ferretería, entre otros.

Se establecen dos tipos de circulaciones en el proyecto, la circulación horizontal y la circulación vertical. Con respecto a la circulación horizontal, se conforma mediante rampas que distribuyen a los diferentes niveles del mercado con calles internas clasificadas por una letra y color para una mejor orientación y ordenamiento del comercio en el proyecto. Mientras que la circulación vertical, conformada por 3 ascensores de uso público, 3 escaleras, 1 escalera mecánica y un montacargas, distribuidos en todo el proyecto, comunicando las 3 plantas.

La zona más privada del Mercado del Encants se encuentra en el sótano, con almacenes y depósitos para los comerciantes, servicios higiénicos, vestuarios, 300 estacionamientos para clientes y vendedores del mercado y 24 estacionamientos destinados para la zona de descarga de productos. Luego en el primer nivel, el mercado cuenta con zona de oficinas administrativas, servicios higiénicos, vestuarios y una sala polivalente, en donde se llevan a cabo actividades, talleres y exposiciones. La zona de subasta es uno de los espacios más importantes del mercado que cuenta con un área de $666 \mathrm{~m}^{2}$ y está conformada por un gran patio central en donde se exhiben los productos a ofertar en el mismo suelo, como en las calles de la ciudad. Además, cuentan con un cajero automático y un puesto de información en donde se puede obtener una guía-mapa de la distribución de todos los establecimientos comerciales en función al producto de venta. Los espacios semipúblicos, en este nivel, lo conforman un restaurante y una cafetería, orientados para los trabajadores cercanos, ya que ofrecen menús y una carta, con horarios y accesos independientes al mercado (Ver Lámina 5.12). 
El segundo nivel es en su totalidad de carácter público, ya que solo contiene tiendas, salvo de una cafetería pequeña cafetería como espacio semipúblico que se encuentra integrada a un mirador para poder visualizar la ciudad (Ver Lámina 5.13 y Lámina 5.14). Finalmente, el tercer nivel, se le otorga el nombre de "Street Food" (Ver Figura 5.22), conformado por seis de los nueve locales de comida que contiene el mercado como: mediterránea, oriental, pastas, pizzas, pescados y mariscos. Cerca de estos locales se distribuyen mesas y bancas, y se concluye el recorrido con un mirador (Ver Figura 5.23).

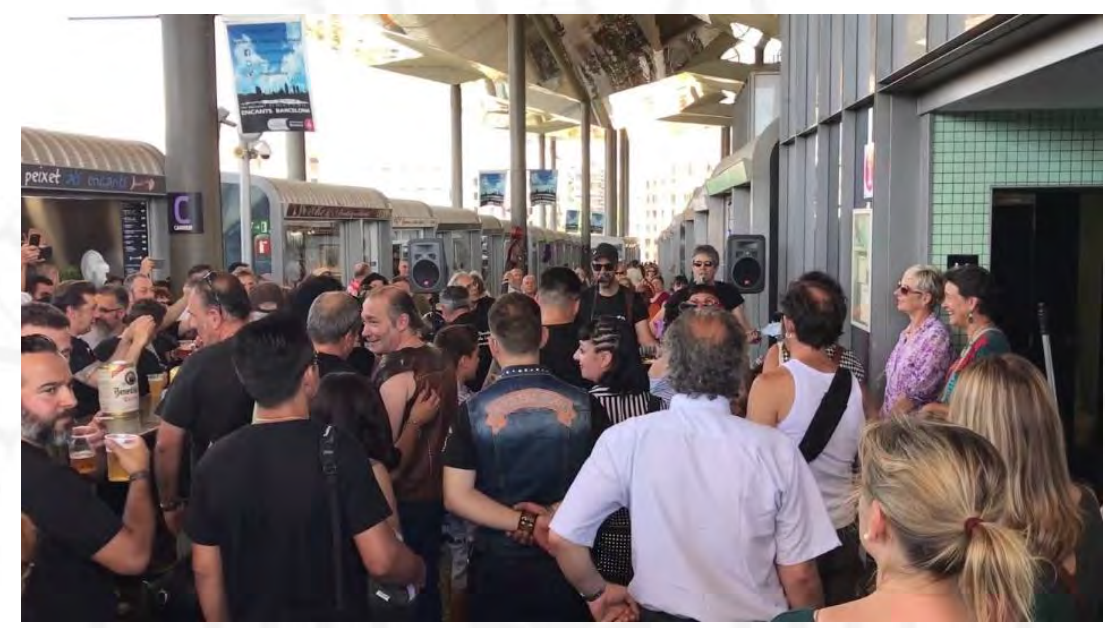

Figura 5.22 Mercado Dels Encants__Street Food Fuente: El Periódico

En:https://www.elperiodico.com/es/barcelona/20131110/los-encants-se-abren-paso-como-atraccionciudadana-2830913

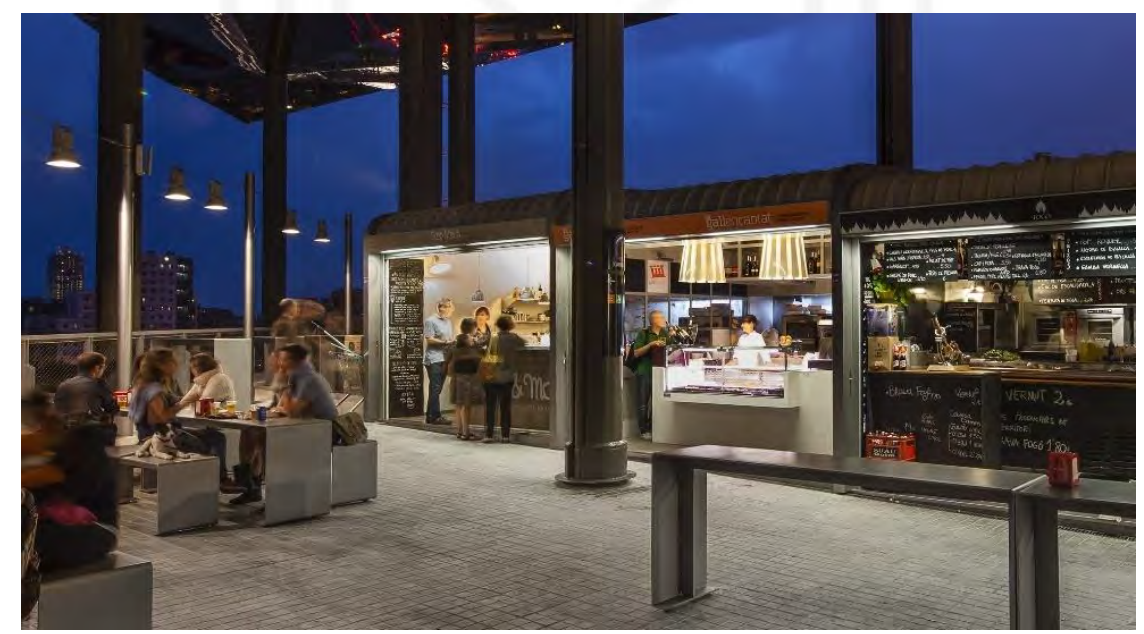

Figura 5.23 Mercado Dels Encants_Puestos Street Food Fuente: Rafael Vargas

En:https:/images.adsttc.com/media/images/529d/4389/e8e4/4e55/3d00/004e/large_jpg/ENCN_0296.jpg? 1386038117 
Lámina 5.12

Programa1_Mercado Dels Encants

\section{MERCADO DELS ENCANTS}
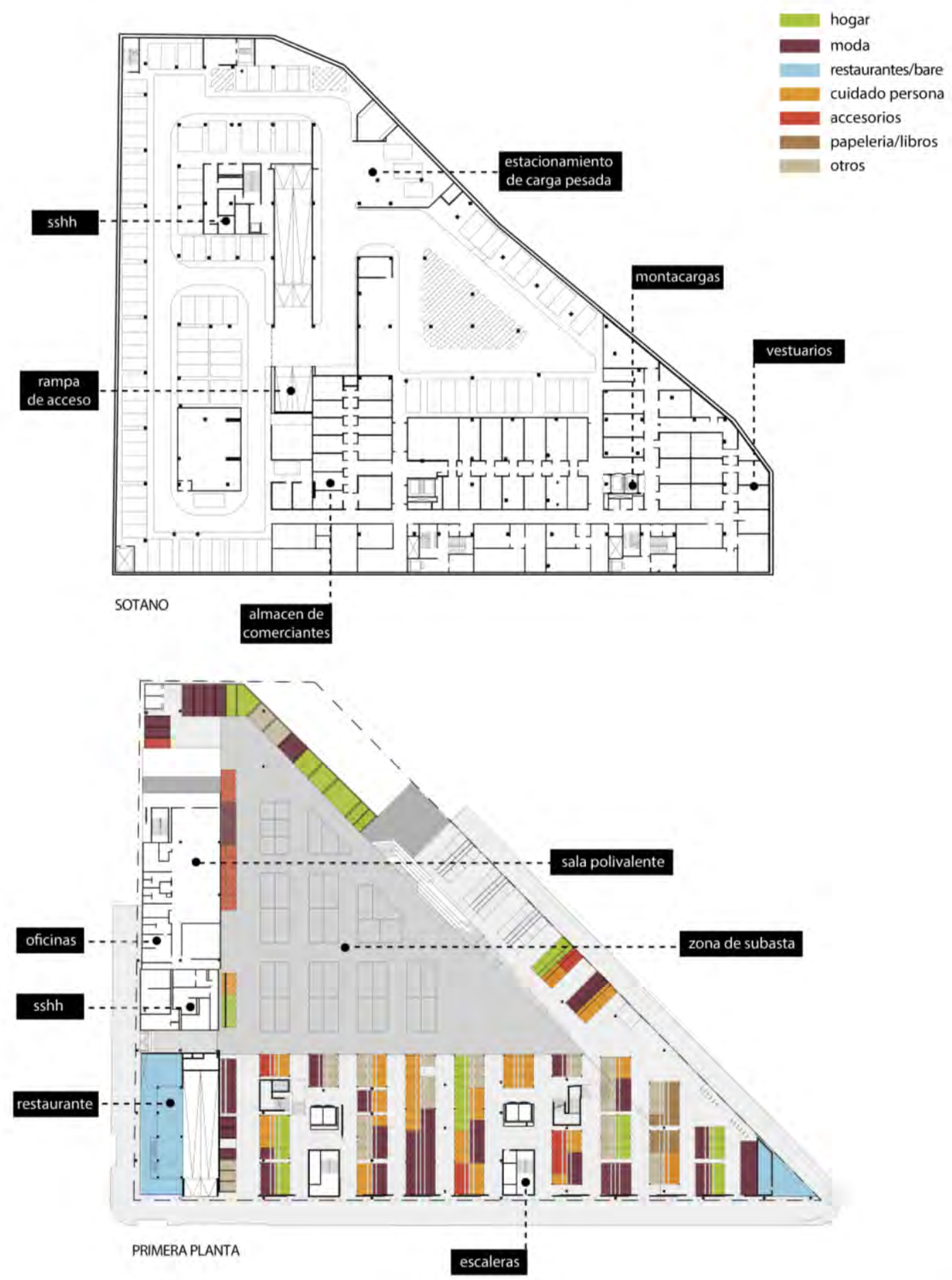

PROGRAMA

Gráfico elaborado por los autores. 
Lámina 5.13

Programa2_Mercado Dels Encants

\section{MERCADO DELS ENCANTS}
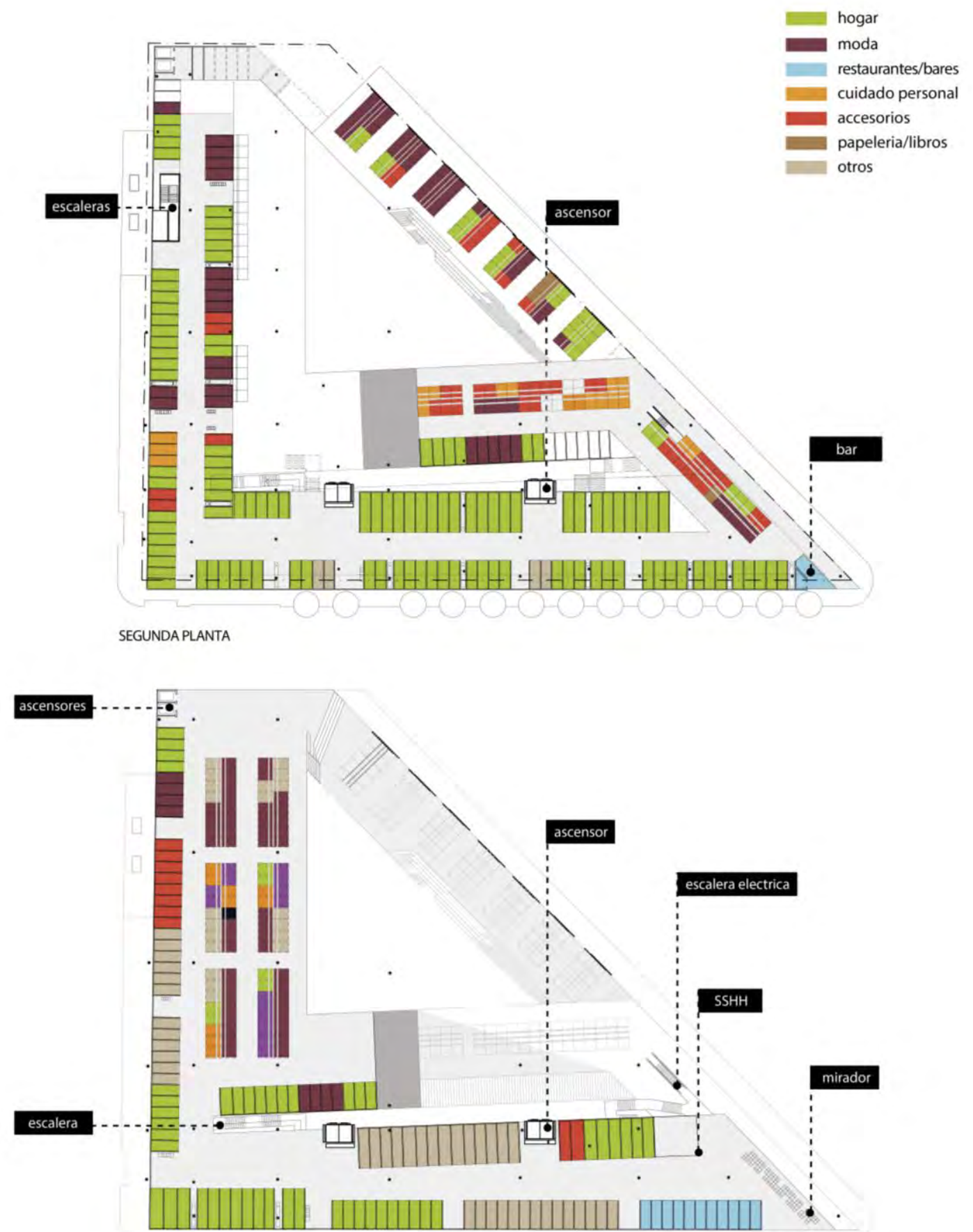

TERCERA PLANTA

\section{PROGRAMA}

Gráfico elaborado por los autores. 
Lámina 5.14

Programa3_Mercado Dels Encants

\section{MERCADO DELS ENCANTS}

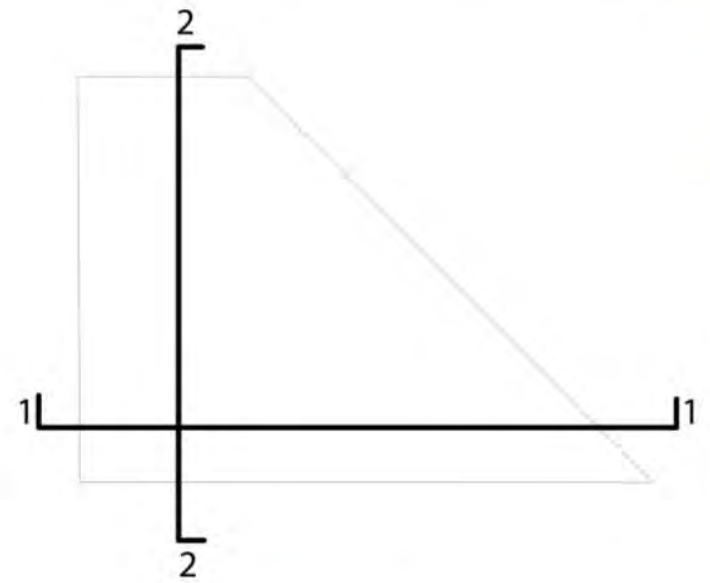

Logar

moda

restaurantes/bares

cuidado personal

accesorios

papeleria/libros

otros 1
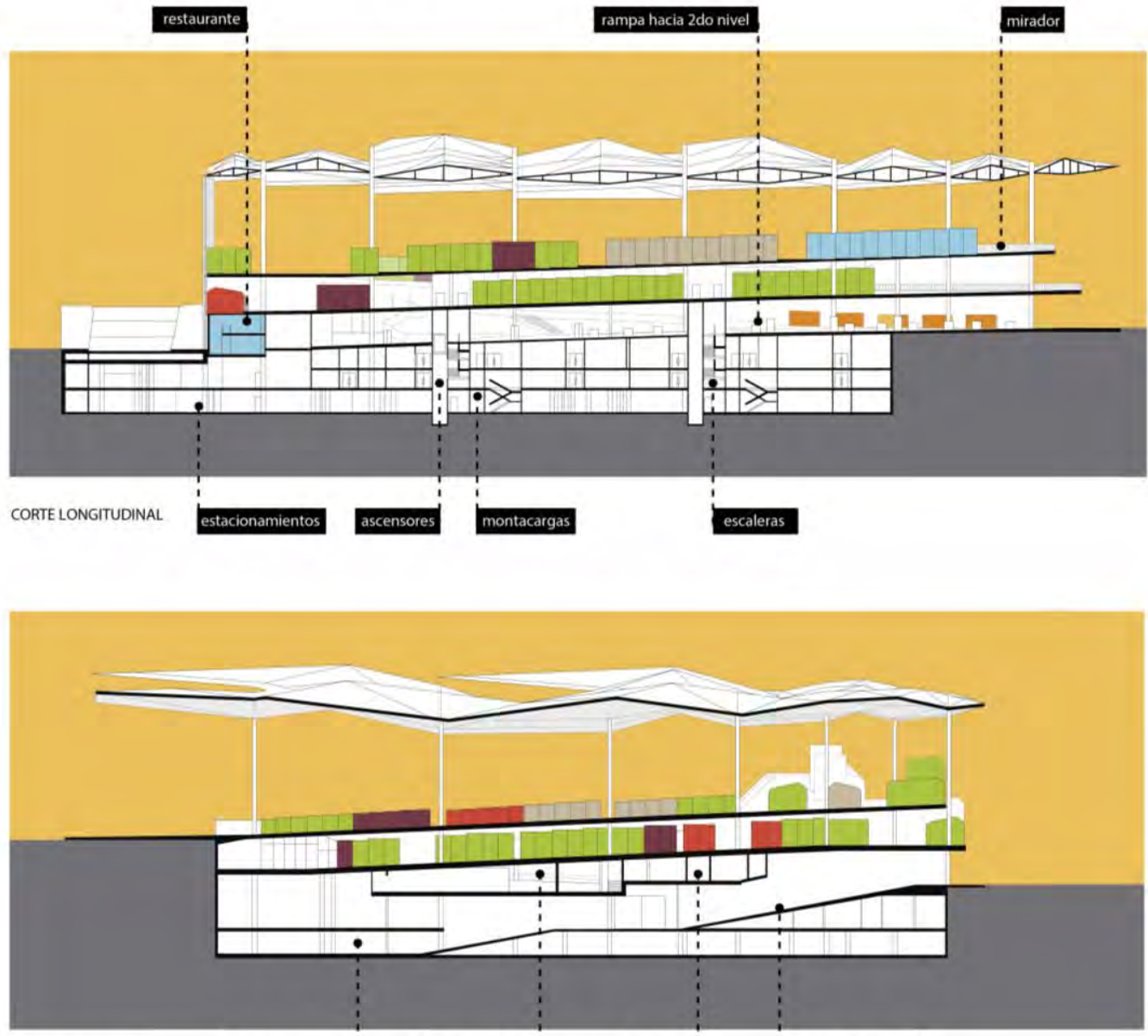

CORTE TRANSVERSAL

estacionamientos sala polivalente

oficinas rampa vehicular

PROGRAMA

Gráfico elaborado por los autores. 
Lámina 5.15

Cuadro de áreas_Mercado Dels Encants

\section{MERCADO DELS ENCANTS}
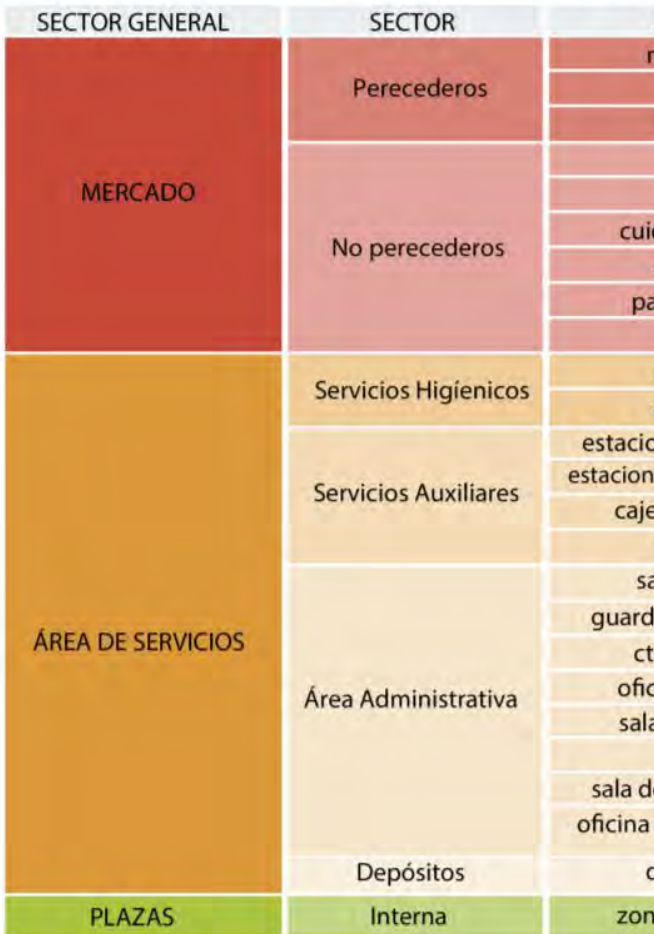

AMBIENTE

restaurantes

bares

cafetines

\begin{tabular}{|c|}
\hline hogar \\
\hline moda
\end{tabular}

moda

cuidado personal

accesorios

papeleria/libros

otros

sshh damas

Servicios Higienicos

sshh varones

estacionmto. de clientes

estacionmto. del mercado

cajeros automáticos

vestuarios

sala polivalente

guardianía y seguridad

cto.de limpieza

oficinas de gestion

sala de reuniones

$$
\text { sshh }
$$

sala de capacitaciones

oficina del administrador

CANTIDAD ÁREA

\begin{tabular}{c|c}
\hline 01 & 222.96 \\
\hline
\end{tabular}

\begin{tabular}{|c|c|}
\hline 01 & 56.26 \\
\hline 02 & 113.60 \\
\hline
\end{tabular}

\begin{tabular}{|l|l|}
\hline 209 & 2286.48 \\
\hline
\end{tabular}

\begin{tabular}{|l|c|}
\hline 209 & 2286.48 \\
\hline 185 & 2005.4 \\
\hline
\end{tabular}

\begin{tabular}{l|l}
79 & 827.92 \\
\hline
\end{tabular}

\begin{tabular}{|l|l|}
\hline 77 & 834.68 \\
\hline
\end{tabular}

\begin{tabular}{|l|l|}
\hline 13 & 136.24 \\
\hline
\end{tabular}

\begin{tabular}{|l|l|}
\hline 103 & 44.25 \\
\hline
\end{tabular}

\begin{tabular}{l|l}
\hline 04 & 44.25 \\
\hline
\end{tabular}

\begin{tabular}{l|l}
06 & 44.25
\end{tabular}

\begin{tabular}{l|l}
174 & 4003.27 \\
\hline
\end{tabular}

\begin{tabular}{l|l}
24 & 186.13
\end{tabular}

\begin{tabular}{l|l}
01 & 16.68 \\
\hline
\end{tabular}

\begin{tabular}{l|l}
03 & 16.68 \\
\hline
\end{tabular}

\begin{tabular}{|l|l|}
01 & 185.31 \\
\hline
\end{tabular}

$04 \quad 19.76$

02
02

\begin{tabular}{l|l}
04 & 40.25 \\
\hline
\end{tabular}

\begin{tabular}{ll}
01 & 43.40 \\
\hline
\end{tabular}

\begin{tabular}{l|l}
02 & 11.51
\end{tabular}

\begin{tabular}{ll}
01 & 27.36 \\
\hline
\end{tabular}

$01 \quad 17.13$

$30 \quad 1466.46$

zona de subasta

666

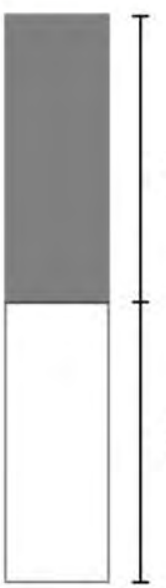

$49 \%$

Depósitos

Interna

PUESTOS DEL MERCADO

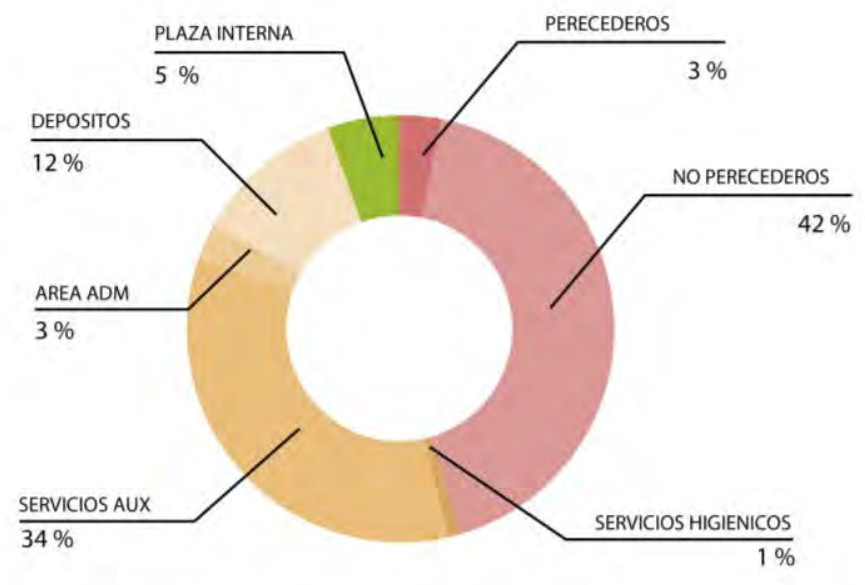

PERECEDEROS $6 \%$

NO PERECEDEROS $93.98 \%$

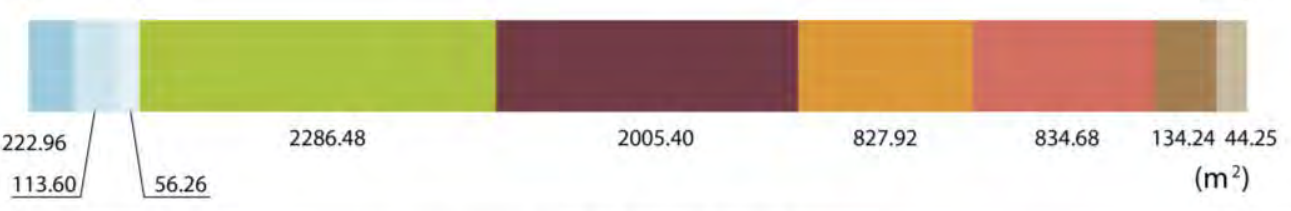

\section{CUADRO DE ÁREAS}

Gráfico elaborado por los autores. 


\section{Tecnología}

La morfología de la cubierta es compleja, debido a que los planos que la definen no son paralelos. Está construida por una serie de pares de pirámides acopladas por sus bases (Ver Figura 5.24). La estructura de cada módulo esta soportada por cuatro pilares con diámetros de 508 y $610 \mathrm{~mm}$ con alturas de hasta $24 \mathrm{~m}$, organizado por seis vigas principales, cuatro que delimitan su perímetro con morfología más rectangular, y dos diagonales. Se le añaden vigas en celosía para reducir el peso de la estructura cuando el canto es mayor a 500mm. Por otro lado, las mayorías de las uniones de las piezas se realizaron de forma atornilladas, con la finalidad de resolver nudos de hasta doce perfiles concéntricos (Costales Calvo, 2014, p. 7).

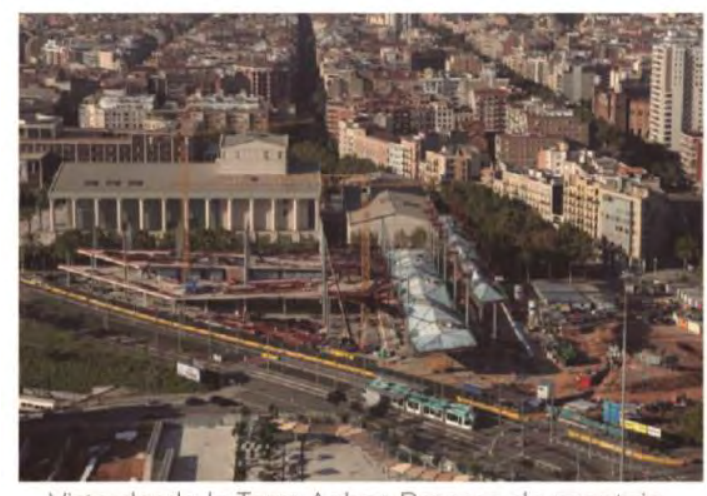

Vista desde la Torre Agbar. Proceso de montaje

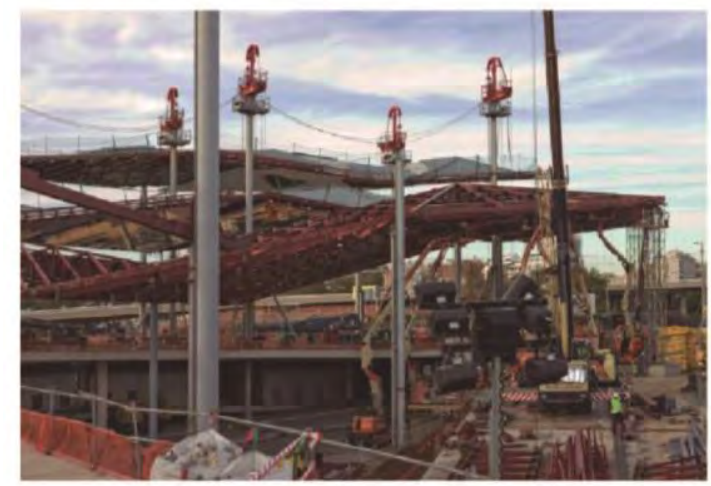

Proceso del izado

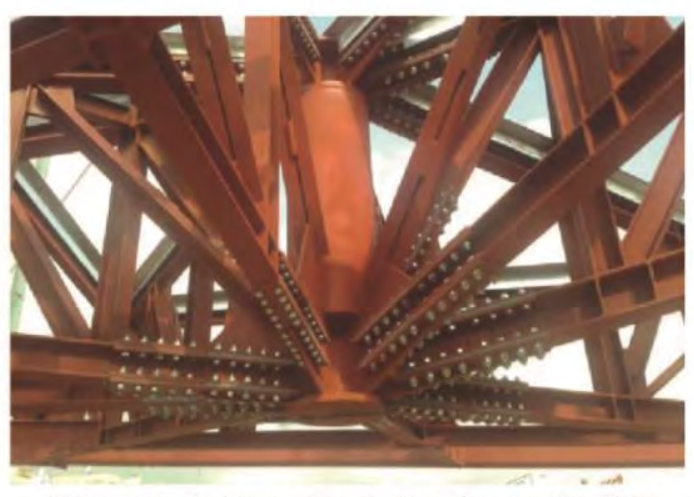

Vista uno de los nudos de la cubierta metálica

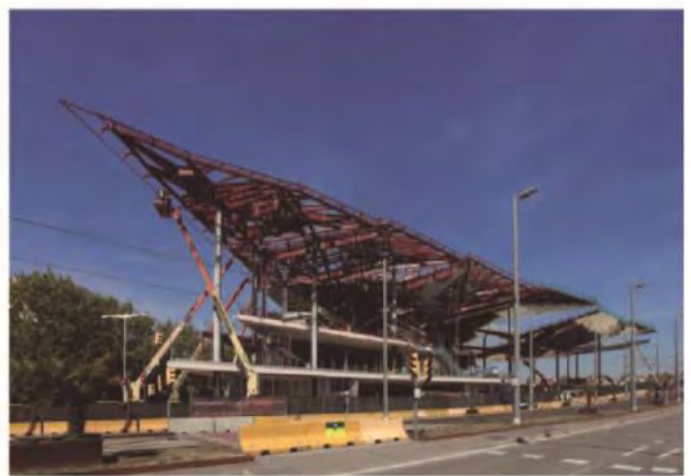

Estructura metalica a punto de ser completada

Figura 5.24 Mercado Dels Encants_Cubierta

Fuente: Ignacio Costales

En: https://upcommons.upc.edu/bitstream/handle/2117/86003/Encants+Barcelona.pdf 
La cubierta cubre un área de $8500 \mathrm{~m}^{2}$ del terreno del mercado (Ver Figura 5.25) está hecha de acero inoxidable, recubierto por aluminio y zinc. El revestimiento inferior de la cubierta, usa un falso techo de paneles "Honeycomb" Ippon de color amarillo, y para la parte superior, se utiliza una chapa de aluminio de la casa Kalzip (ver lámina 5.16). Para diseño de la cubierta, se utilizó un software basado en la Dinámica Computacional de Fluidos, que analiza la acción del viento sobre el edificio y generan hipótesis que ayudan con el diseño, es así como cada pieza de la cubierta funciona similar a la de un ala de avión que logra desviar el viento (Costales Calvo, 2014, p. 8).

La cubierta es el principal elemento arquitectónico que le brinda personalidad al edificio del mercado y lo representa como icono de la ciudad de Barcelona. Acompañado del espejo de la cubierta bajo el concepto de querer reflejar la gran dinámica generada por la actividad comercial, integrando al mercado con el entorno que rodea, a pesar de que esta se encuentre a 25m separada del edificio (Ver Figura 5.26).

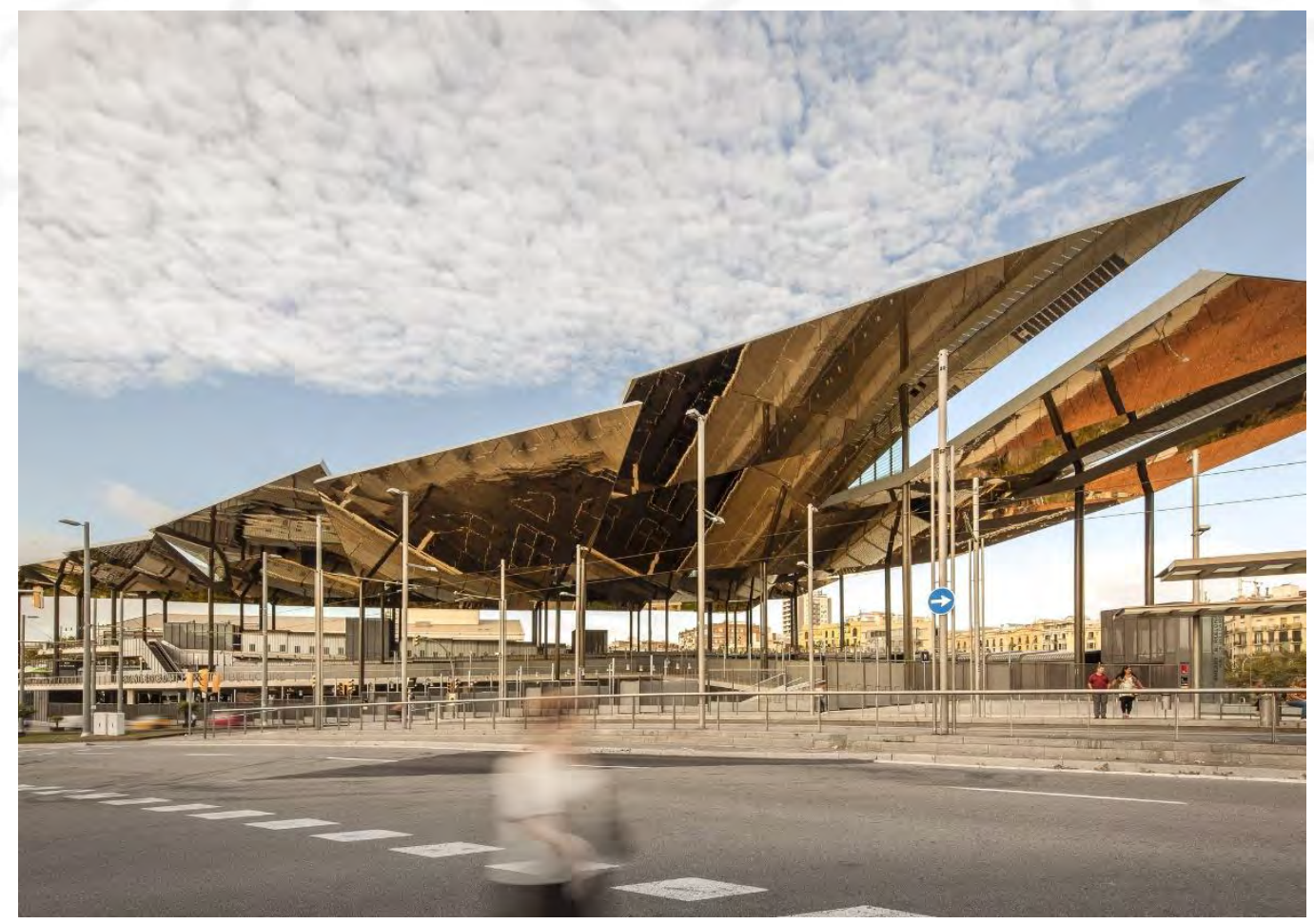

Figura 5.25 Mercado Dels Encants_Recubrimiento Fuente: Rafael Vargas

En:https://images.adsttc.com/media/images/529d/4470/e8e4/4e01/2000/0055/large_jpg/ENCN_9333.jpg ?1386038336 
Lámina 5.16

Aporte tecnológico_ Mercado Dels Encants

\section{MERCADO DELS ENCANTS}

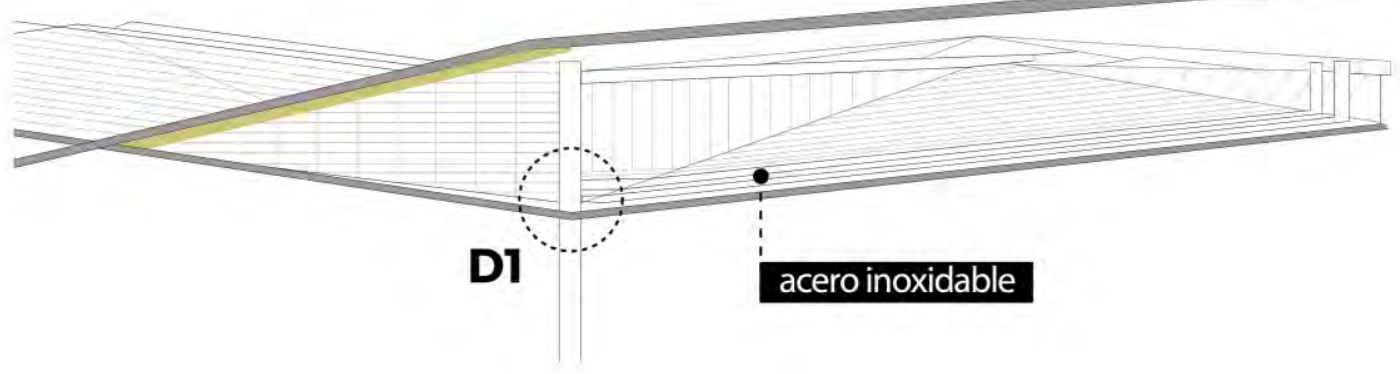

\section{cubierta}

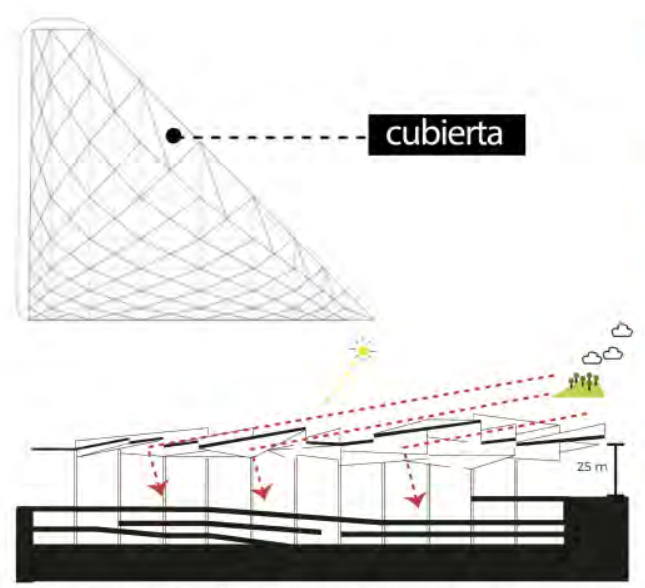

Compuesta por multiples planos quebrados a diferentes niveles y con diferentes anchos

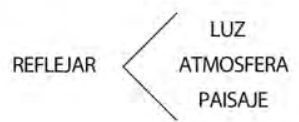

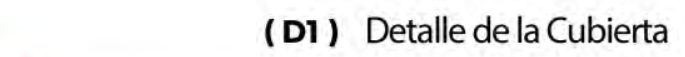

(7)

(6)
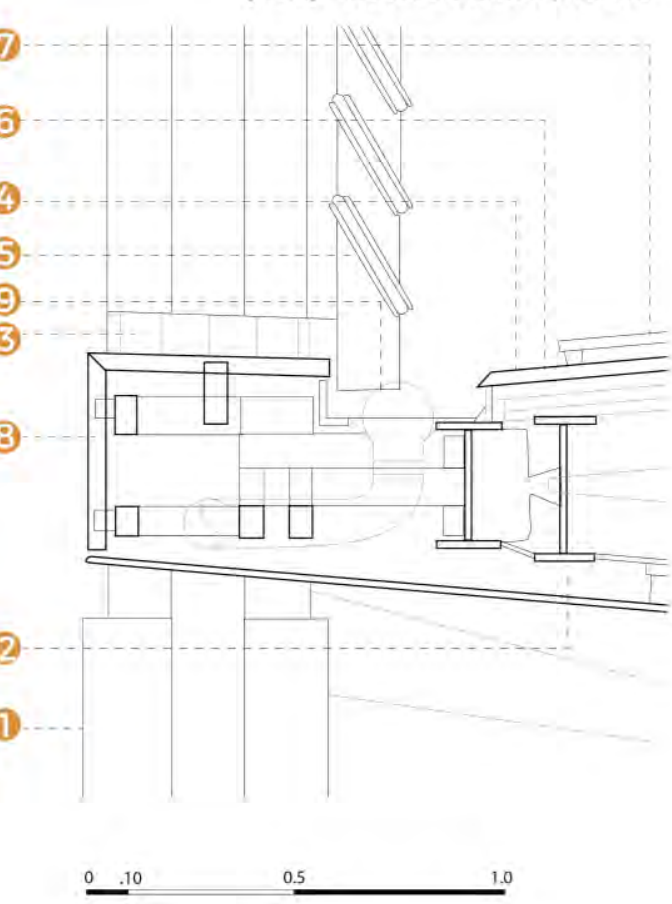
(1) Pila de placas de acero
(2) Vigas de acero laminado
(3) Soporte de acero
(4) Sistema de cobertura

(5) Tubo de acero

(8) Bandejas plegadas de zinc

(6) Aislamiento rigido

(9) Anclas ajustable de aluminio

(7) Bandeja de acero galvanizado

\section{APORTE TECNOLÓGICO}

Gráfico elaborado por los autores. 
Figura 5.26

Mercado Dels Encants_Fachada

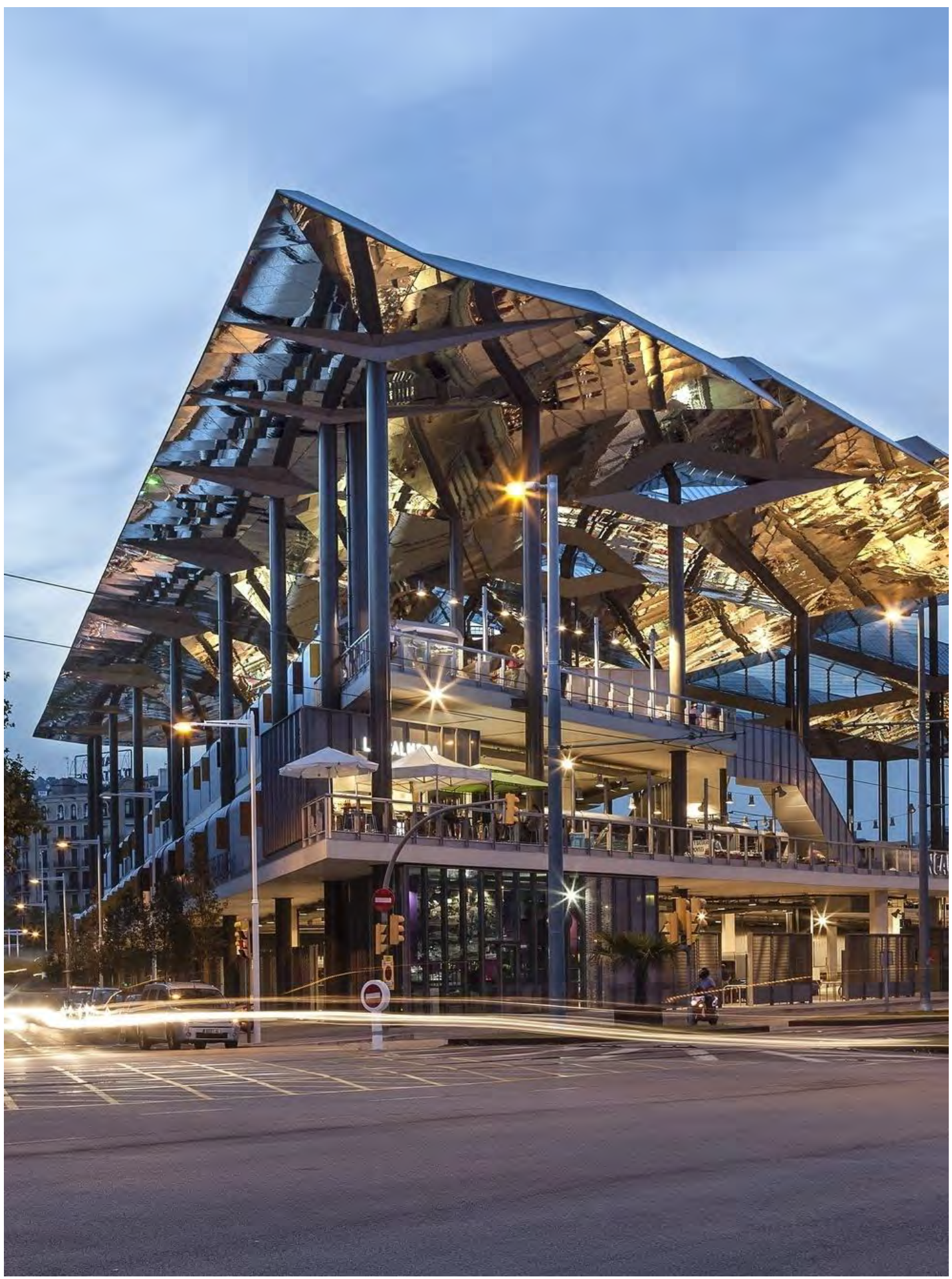

Fuente: Rafael Vargas

En:https://images.adsttc.com/media/images/529d/442c/e8e4/4eca/5b00/0052/large_jpg/ENCN_9058.jpg? 1386038267 


\subsubsection{Mercado Central de Lima}

En el siglo XIX, Lima se caracterizaba por contar con pequeñas plazas de abasto, pues la idea del "Mercado" aún no era conocida ni utilizada y se organizaban por medio de las ramadas, que funcionaban en los atrios de las iglesias o plazas públicas. Una de las plazas públicas más utilizadas para el mercado informal era la Plaza Mayor, en donde el caos, el desorden, la bulla y la basura estaban presente a diario, por eso las autoridades municipales los trasladaban hacia la Plaza de la Inquisición.

Los lugares que funcionaban como mercados, eran sinónimos de caos, no existía el más mínimo control de la autoridad municipal sobre los mismo, esto ocasionaba al gobierno de la ciudad, un enorme desorden, convirtiéndose en foco perenne de insalubridad y de posibles infecciones. (Coello Rodríguez, 2014, p. 369)

Ante este problema se iniciaron las gestiones para que Lima pueda tener su primer mercado moderno, que cumpla con los estándares de higiene y salubridad, y de organizar la actividad comercial. Entonces en 1850 se ocupó el terreno del antiguo Convento de la Concepción que estaba ocupado por monjas, pero dejando mucho terreno abandonado generando un mal aspecto a la ciudad.

Para elaborar el mercado, primero se convocó a licitación, el cual José Dañino, quien ofreció realizar el mercado por 209000 pesos, salió ganador. El Mercado se inaugura en 1852, con el nombre de Mercado Central, durante el segundo gobierno del General Castilla, pero los pobladores lo denominaban Mercado de la Concepción (Ver Figura 5.27) por el antiguo convento, y por decreto supremo del 29 de noviembre de 1859 el mercado pasó a manos de la Municipalidad de Lima.

El mercado ocupaba un área de $13000 \mathrm{~m} 2$, además la fachada y la organización espacial del mercado en aquella época estaba conformada de la siguiente manera:

Los muros de su recinto exterior formaban las fachadas de 66 puertas de tiendas y un almacén en cada esquina o sea cuatro (...) en el interior había 60 tiendas y 2 corrales. 70 columnas sirven para formar en los cuatro lados interiores de la plaza, portales de $5 \mathrm{y}$ medias varas de ancho, las ramadas del centro están sostenidas por 176 columnas. La entrada al local era por 11 puertas estando la principal hacia la actual Calle Paz Soldán. Al interior, el mercado, estaba separado por cuarteles, que obedecían a los tipos de productos que se vendían. (Coello Rodríguez, 2014, p. 370) 


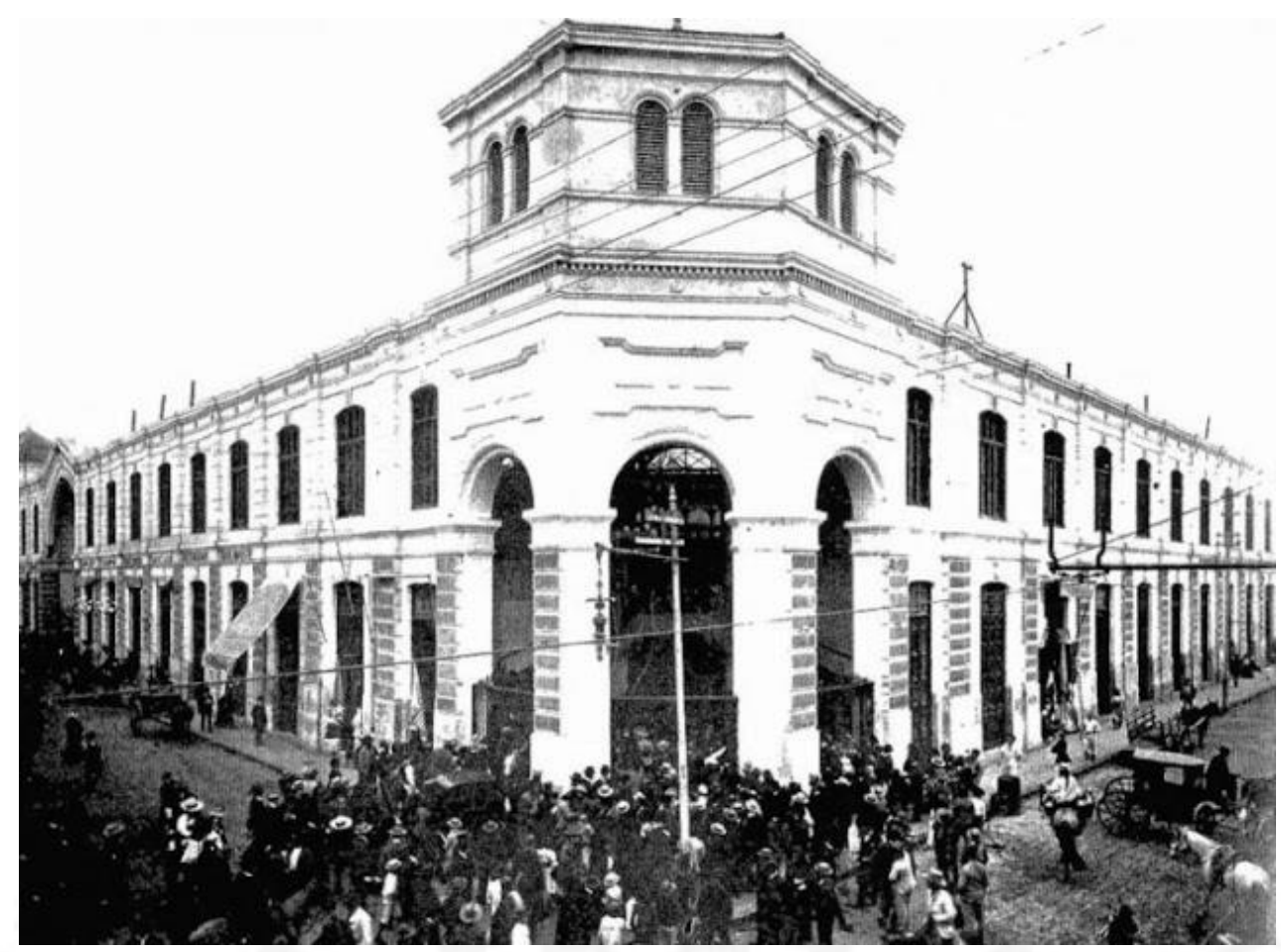

Figura 5.27 Mercado de la Concepción Fuente: Lima La Única

En: https://limalaunica.blogspot.pe/2012/07/el-antiguo-mercado-de-la-concepcion.html

A penas se habilitó el funcionamiento del mercado, este fue invadido por una gran cantidad de ambulantes en su interior como en el exterior, convirtiéndolo intransitable, de mal aspecto, insalubre y con malos olores. Con el paso del tiempo el Mercado Central siguió soportando estos problemas, pero a esto se le sumó la dejadez del Municipio de Lima, y el comienzo de la inseguridad ciudadana, presentando continuos asaltos y trifulcas hacia los compradores como visitantes (Coello Rodríguez, 2014, p. 374).

Los problemas llegarán a su tope en el siglo XX, cuando el Mercado de la Concepción en 1964 desaparecerá debido a un incendio, que hasta ahora no se sabe su fue un accidente o fue provocado, pero a raíz de esto el Alcalde Luis Bedoya ve la oportunidad de realizar un nuevo mercado que será bautizado como Mercado Central Mariscal Ramón Castilla, haciendo honor a su artífice original. 
Lámina 5.17

Datos Generales_Mercado Central

\section{MERCADO CENTRAL}

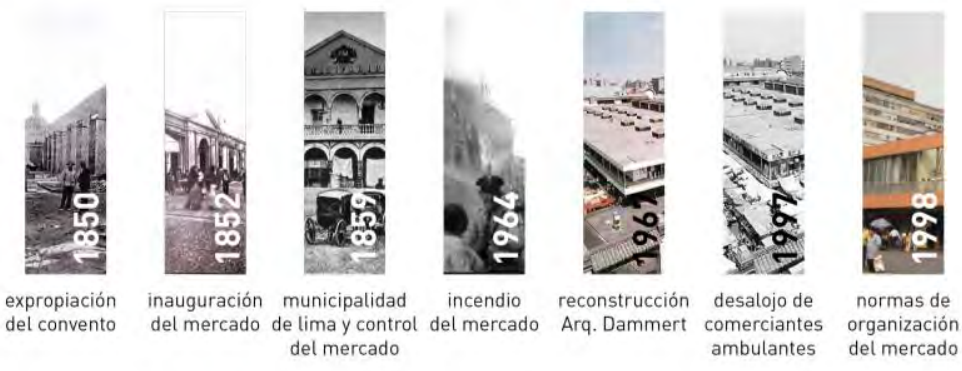

La toma de partido del mercado era realizar un gran contenedor para los puestos de venta en tres niveles y combinarlo con un edificio residencial.

Esto se logra al dividir el interior del mercado en medios niveles comunicados por un nùcleo de rampas y la vivienda suspendida sobre el mercado estructurada por dos núcleos de circulación vertical.

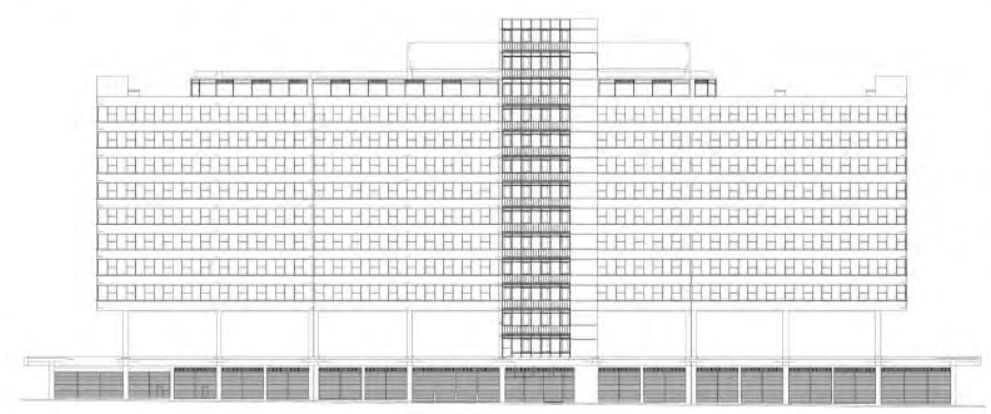

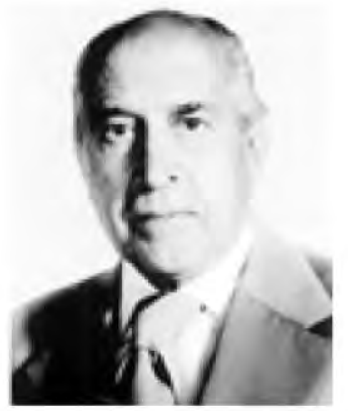

Alfredo Dammert Muelle nació el 23 de Octubre de 1906 en Lima, Perú. Estudió arquitectura en la Universidad Aachen de Alemania en 1923 al 1928, por lo que fue formado con los principios de la escuela de la Bauhaus y de Walter Adolph Gropius.

En su retorno al país fue profesor en la Facultad de Ingeniería de la Universidad Católica de 1935 a 1944. formó parte de la comisión de arquitectos del Municipio de San Isidro de 1940 a 1944, y en 1964 fue nombrado como el primer decano del Colegio de Arquitectos del Perú.

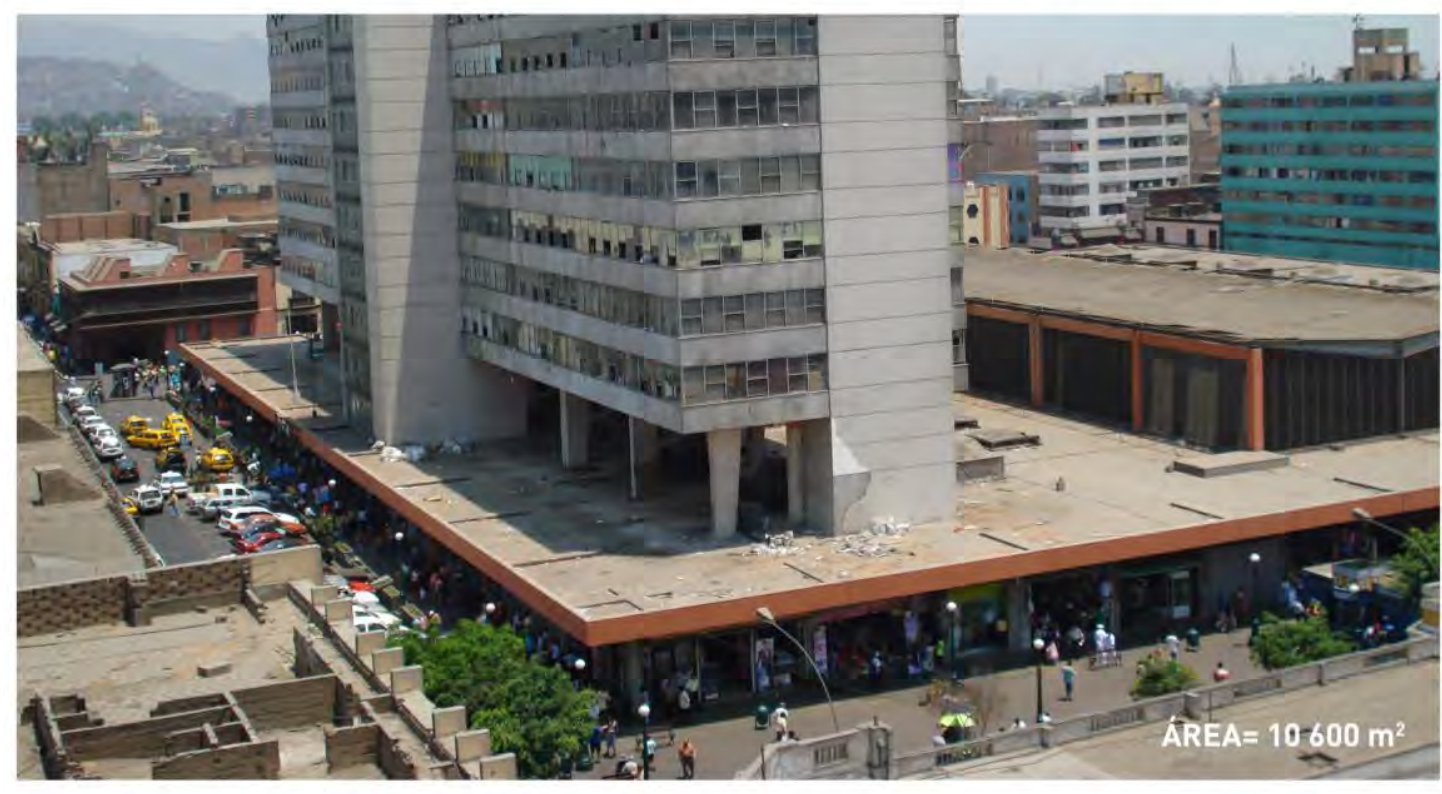

\section{DATOS GENERALES}

Gráfico elaborado por los autores. 


\section{Relación con el entorno}

El Mercado Central ocupa toda una manzana urbana del distrito de Cercado de Lima, y está delimitado por los jirones Huallaga, Ayacucho, Andahuaylas y Ucayali, de uso residencial y comercial. Se puede optar por diferentes modalidades para llegar, ya sea por trasporte público como por buses de empresas privadas, vehículos particulares, y a nivel peatonal desde la Av. Abancay (Ver Figura 5.28).

Por otro lado, cerca al mercado se encuentra la calle peatonal conocida como “Calle Capón”, la cual surge junto con la construcción del mercado en el año 1852, debido a que este barrio fue ocupado por los inmigrantes chinos que arribaron al país como apoyo en la mano de obra, y con el pasar de los años se instalaron permanentemente en dicha calle (Ver Lámina 5.18).

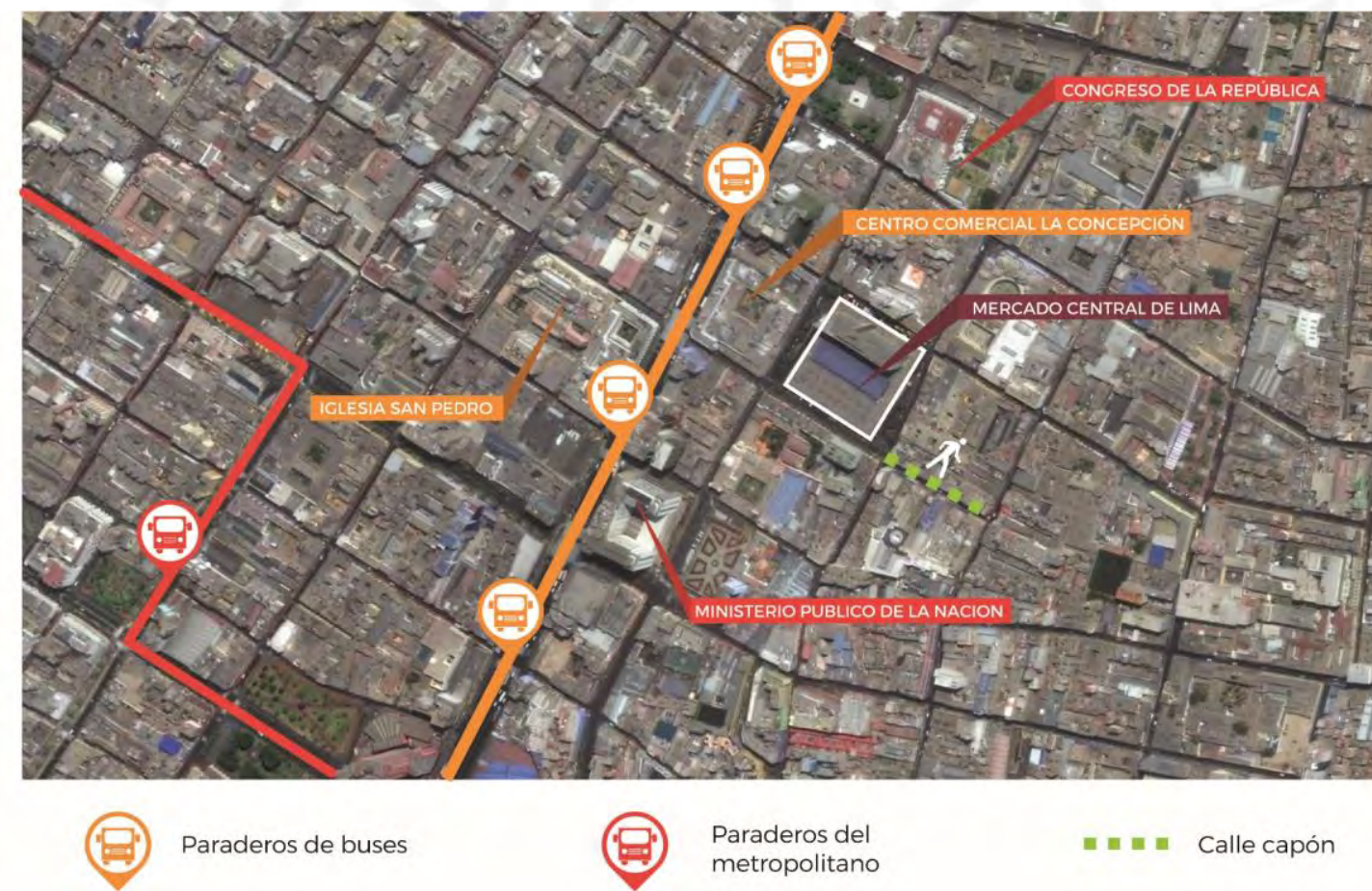

Figura 5.28 Relación con el Mercado Central

Gráfico elaborado por los autores. 
El mercado se encuentra rodeado de viviendas de baja densidad y con comercio en su primer nivel, por lo que la altura del mercado es de un solo piso en la mitad de la manzana urbana, mientras que en otro es de dos pisos, manteniendo la escala barrial de esta zona del distrito.

Y ante la necesidad del edificio residencial y a su gran altura, se requirió que se retire de los perímetros del mercado, para establecer una diferencia en los usos, por más que compartan estructura, y evitar que se utilicen todos los aires del terreno y dañe la trama urbana (Ver Figura 5.29).

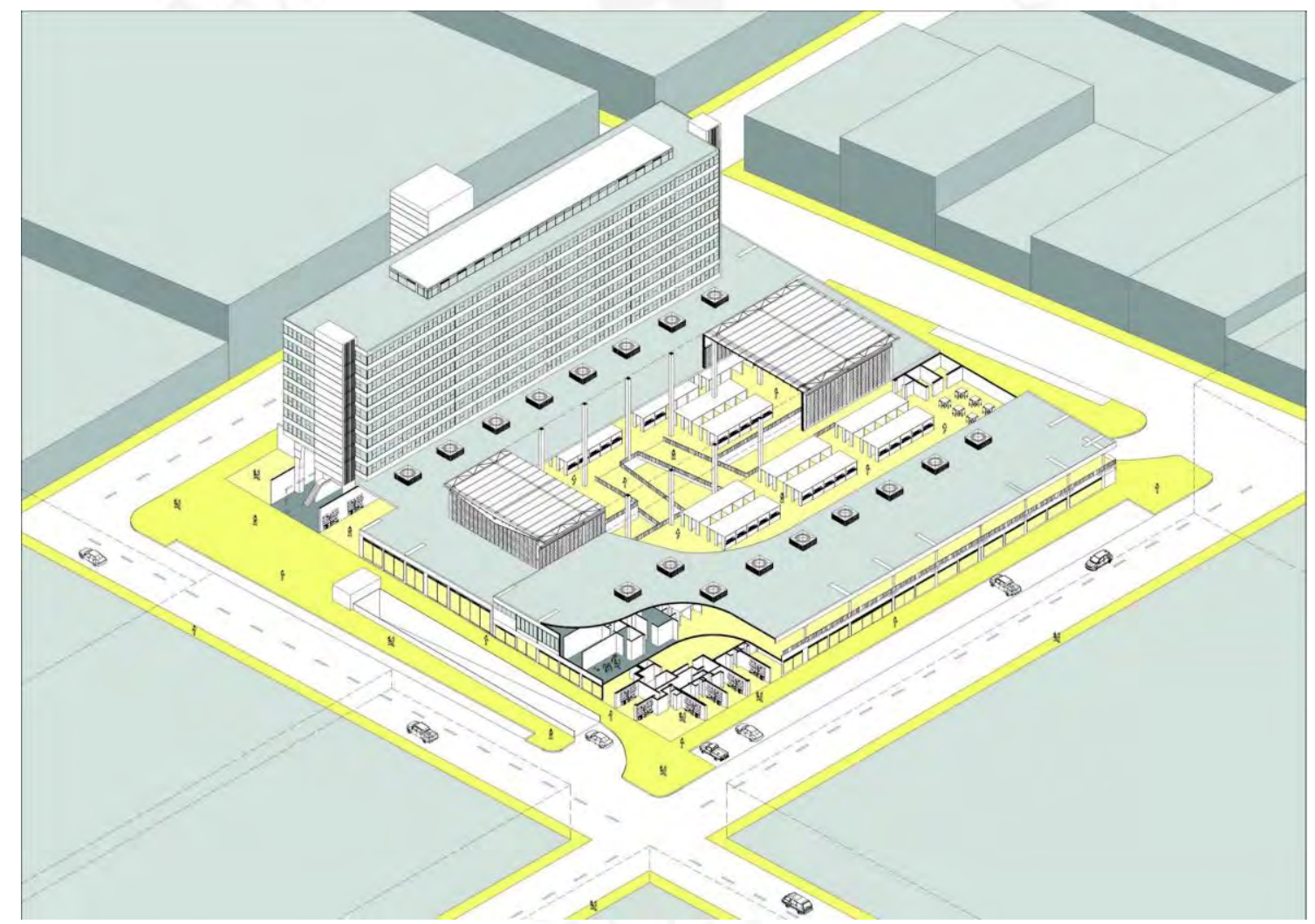

Figura 5.29 Relación con el entorno_ Mercado Central

Fuente: Nómena Arquitectura 
Lámina 5.18

Localización Mercado Central

\section{MERCADO CENTRAL}

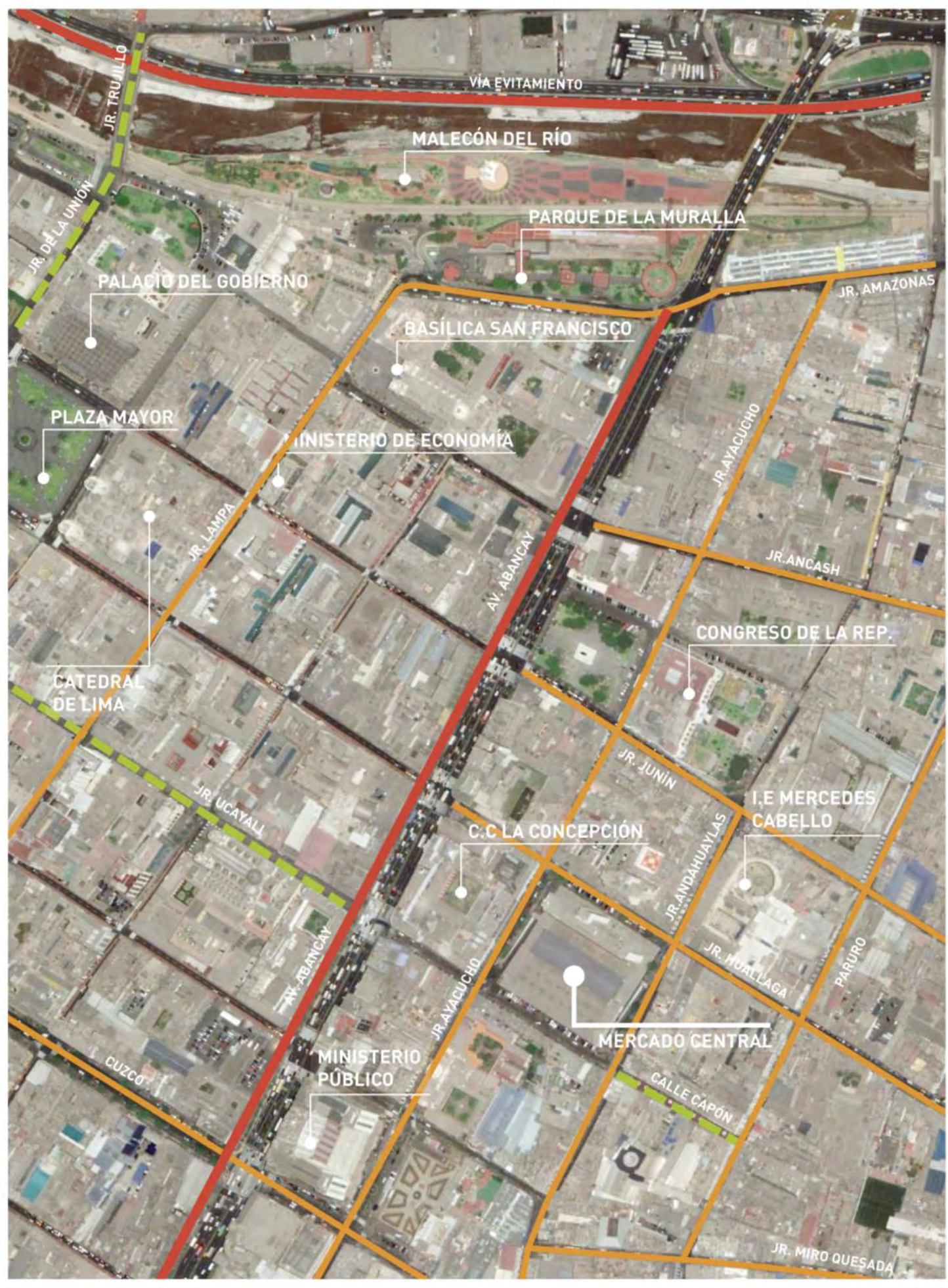

LOCALIZACIÓN

Gráfico elaborado por los autores. 
Lámina 5.19

Relación con el entorno_Mercado Central

\section{MERCADO CENTRAL}

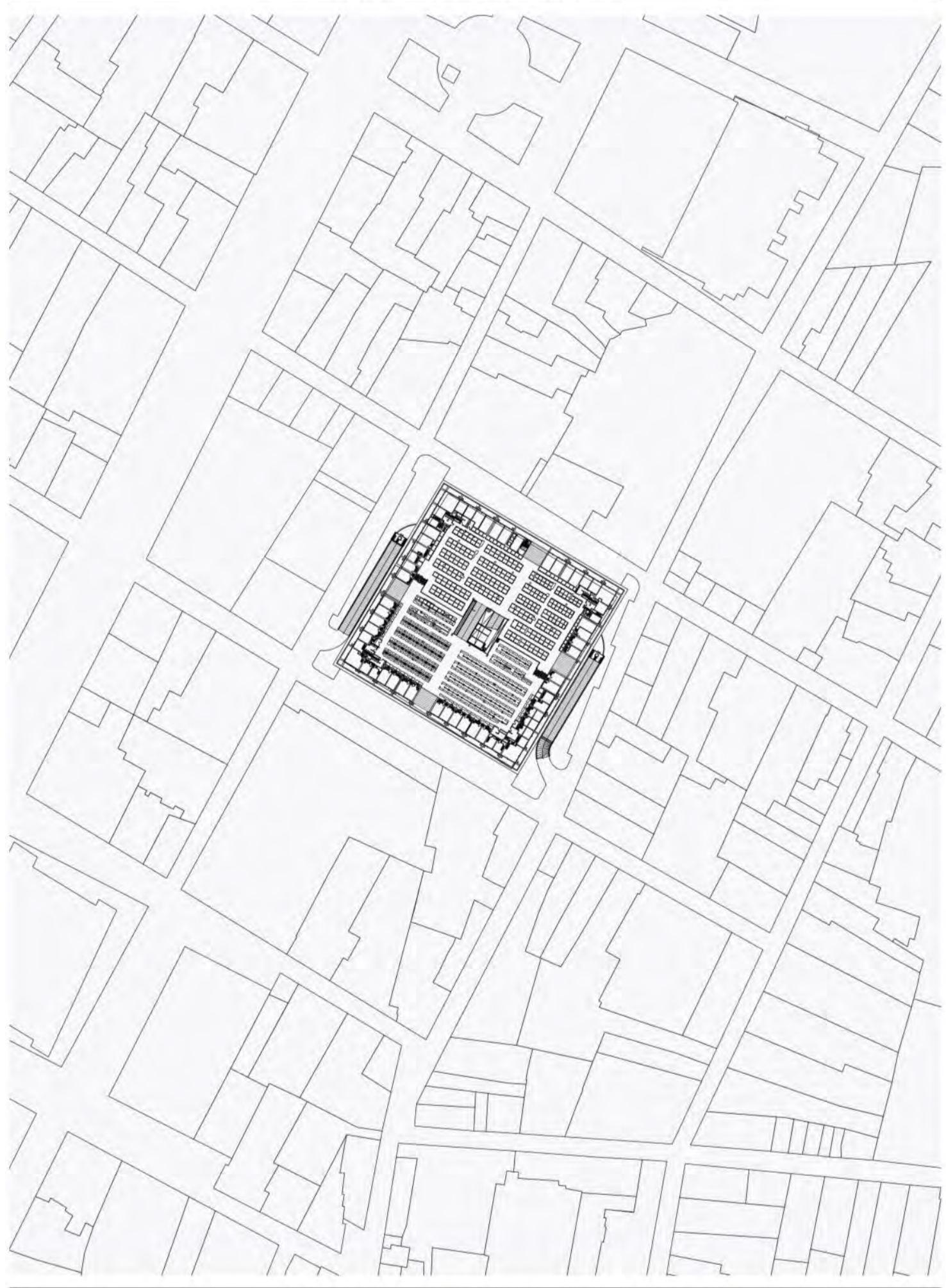

RELACIÓN CON EL ENTORNO

Gráfico elaborado por los autores. 


\section{Flujos y accesos}

La fachada del Mercado central está conformada por pequeños comercios que rodean en su mayoría los cuatro lados del mercado, pero no son puestos destinados a los productos perecederos, sino que son al rubro textil. Gracias a estos puestos ubicados al perímetro del mercado hay una gran cantidad de flujo de personas que no solo transita, sino que se detienen a observar o adquirir el producto. Al flujo denso peatonal le sumamos el gran flujo vehicular, que está presente tanto de día como de noche, esto se debe a que las personas que visitan el mercado cruzan las calles por donde pueden y no solo por las líneas peatonales (Ver Figura 5.30).

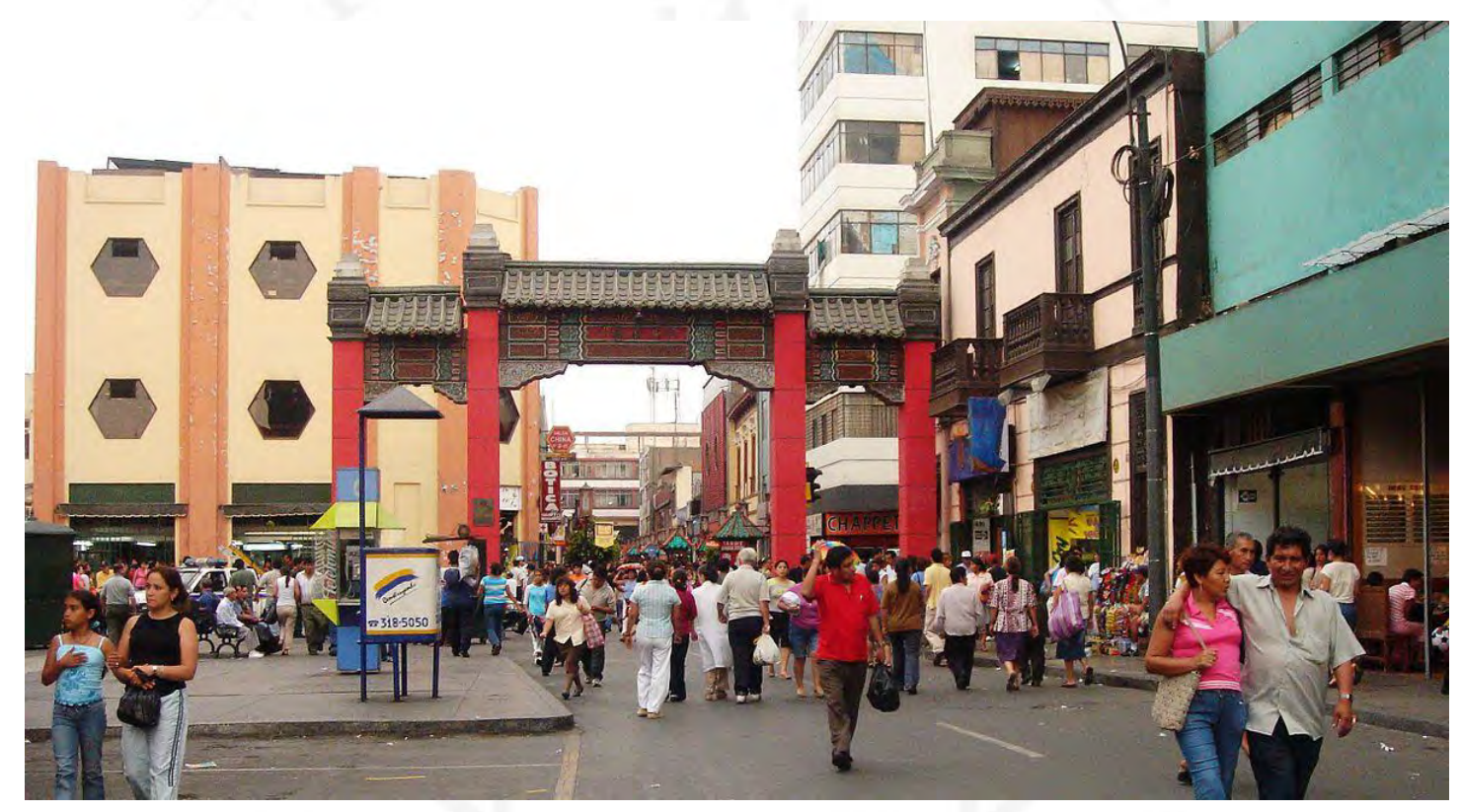

Figura 5.30 Mercado Central_Flujo peatonal

Fuente: Miguel Ángel Chong

En: https://es.wikipedia.org/wiki/Barrio_chino_de_Lima\#/media/File:Chinatown,_Lima20060002.JPG

El mercado posee 4 accesos a desnivel, a través de rampas, una por cada calle con un ancho de $9.50 \mathrm{~m}$ y una longitud de $8.60 \mathrm{~m}$, además cuenta con un sótano destinado para el uso de vehículos privados, vehículos de carga, y depósitos, con dos accesos uno en el Jirón Andahuaylas y otro por el Jirón Ayacucho (Ver Lámina 5.20). 
Lámina 5.20

Flujos y accesos_Mercado Central

\section{MERCADO CENTRAL}
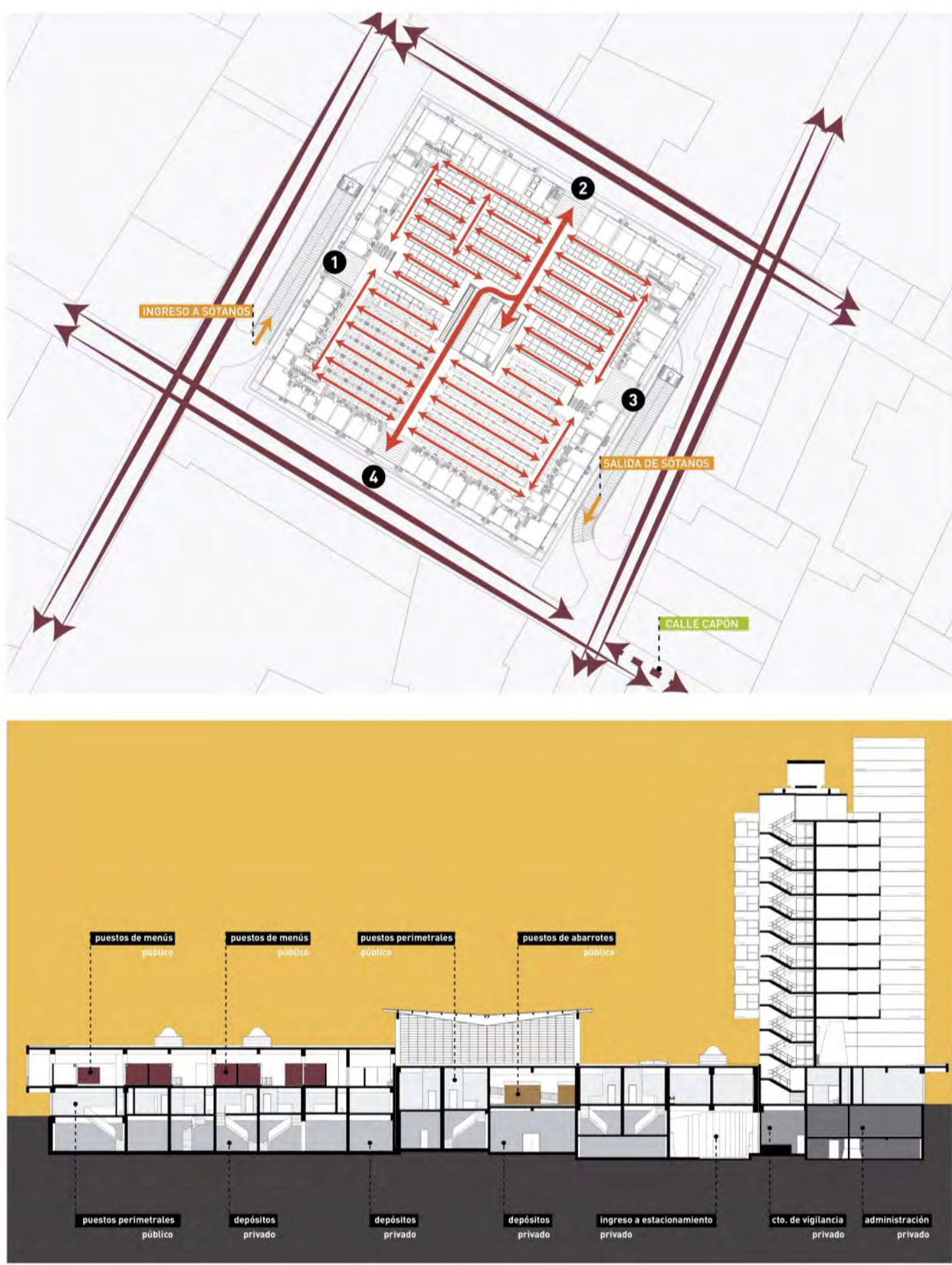

FLUJOS Y NIVEL DE PRIVACIDAD

Gráfico elaborado por los autores. 


\section{Programa}

El Mercado Central está compuesto por 3 niveles, de los cuales el sótano está destinado para el uso exclusivo de estacionamientos para la zona de carga y descarga de los productos de los comerciantes que tienen sus depósitos al lado de esta zona de abastecimiento y que se comunican directamente con los puestos en el nivel superior (Ver Lámina 5.21). En el primer nivel se encuentran todos los puestos de venta en la parte central y está rodeado por otros puestos de comercio no destinados a los productos perecederos, estos normalmente son de ropa, costura, artefactos y electrodomésticos, entre otros.

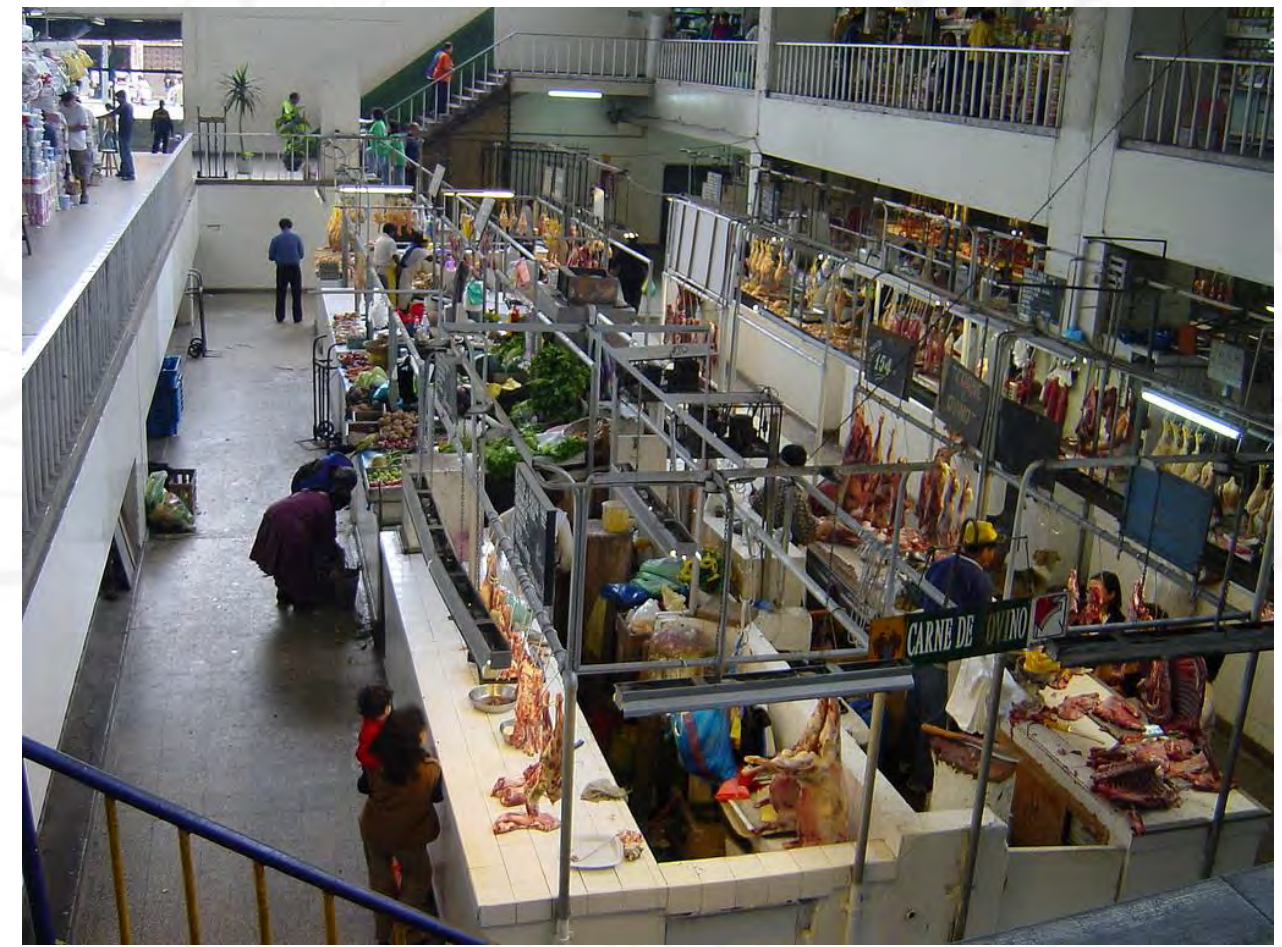

Figura 5.31 Mercado Central_Puestos de carnes

Fuente: Robert Cutts

En: https://www.flickr.com/photos/panr/3173211275

La gran rampa central es la que comunica tanto el primer piso como el segundo, lo que permite un flujo más rápido y directo (Ver Figura 5.32). En el segundo nivel, también se encuentran otros tipos de comercio, pero un poco más relacionado a los alimentos como especias y aderezos, además posee un sector de puestos de restaurante que se llenan en las mañanas alrededor de las 8:00 am y a las 12:00 del mediodía. 


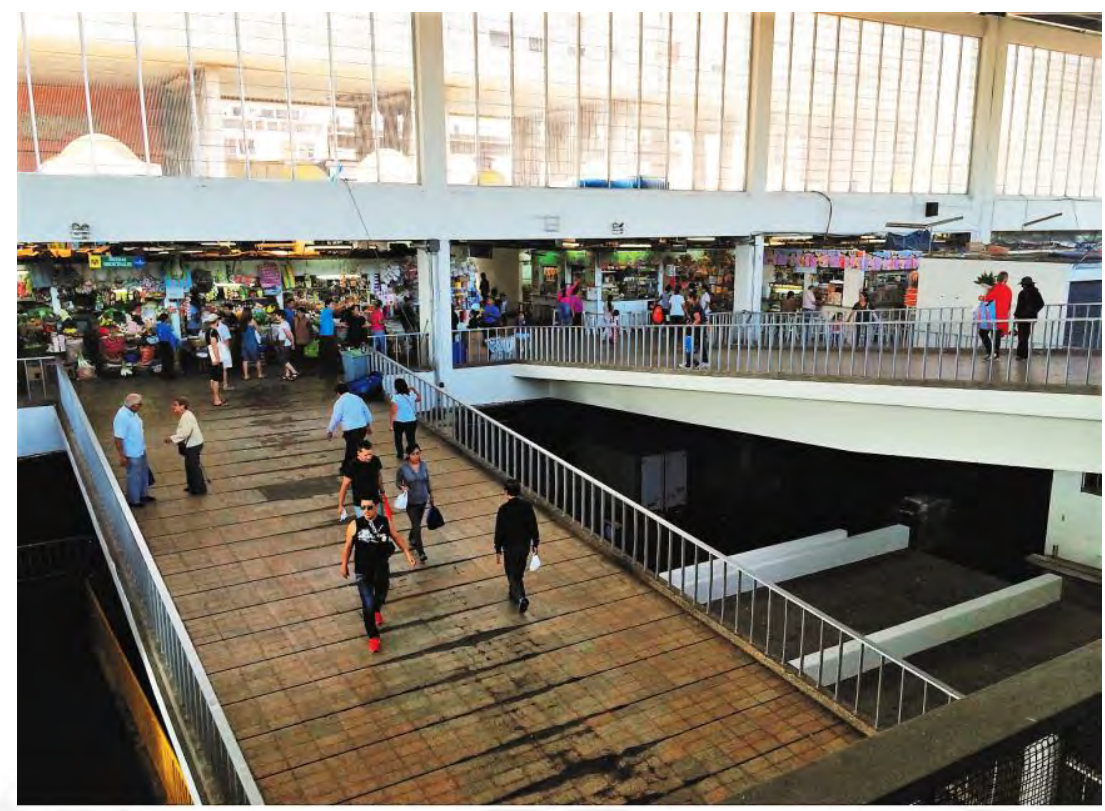

Figura 5.32 Mercado Central_Núcleo central Fotografía realizada por los autores.

La organización de este mercado es lineal y se da en altura (Ver Figura 5.33), generando diferentes niveles de privacidad, y a su vez un mejor nivel de eficiencia al poseer depósitos que se comunican directamente con los puestos, esto evita que los comerciantes sobrecarguen su espacio con los productos, exhiban lo necesario y si le hace falta se abastece inmediatamente.

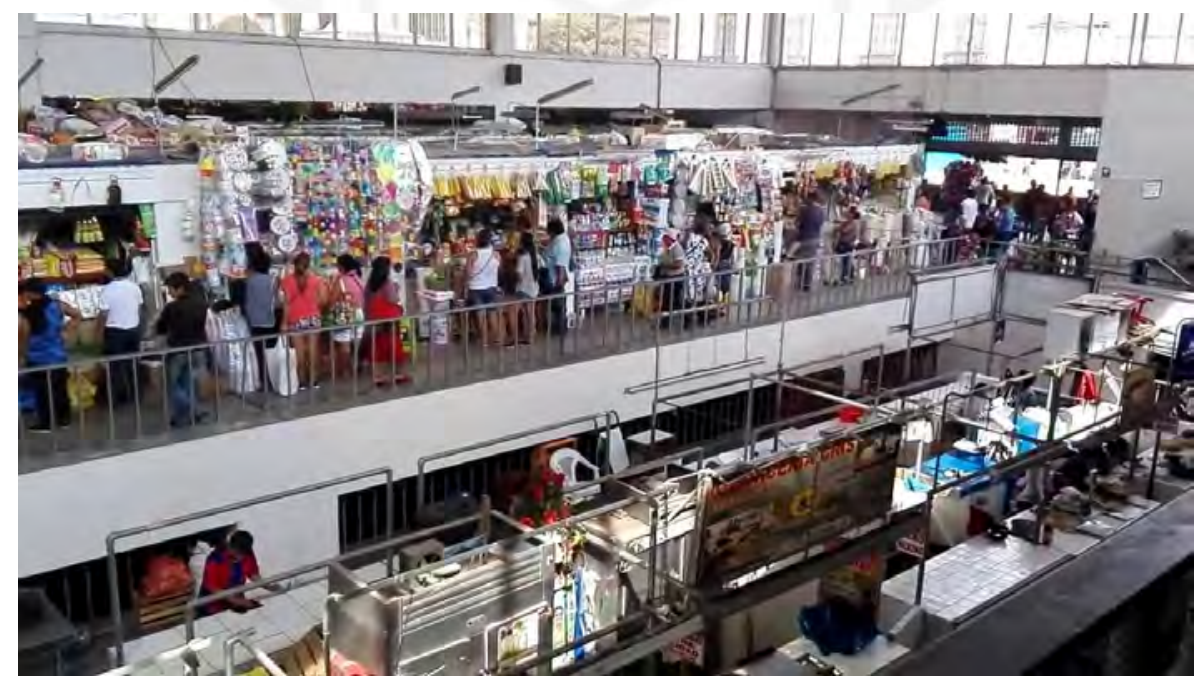

Figura 5.33 Mercado Central_Organización lineal

Fotografía realizada por los autores. 
Lámina 5.21

Programa_Mercado Central

\section{MERCADO CENTRAL}
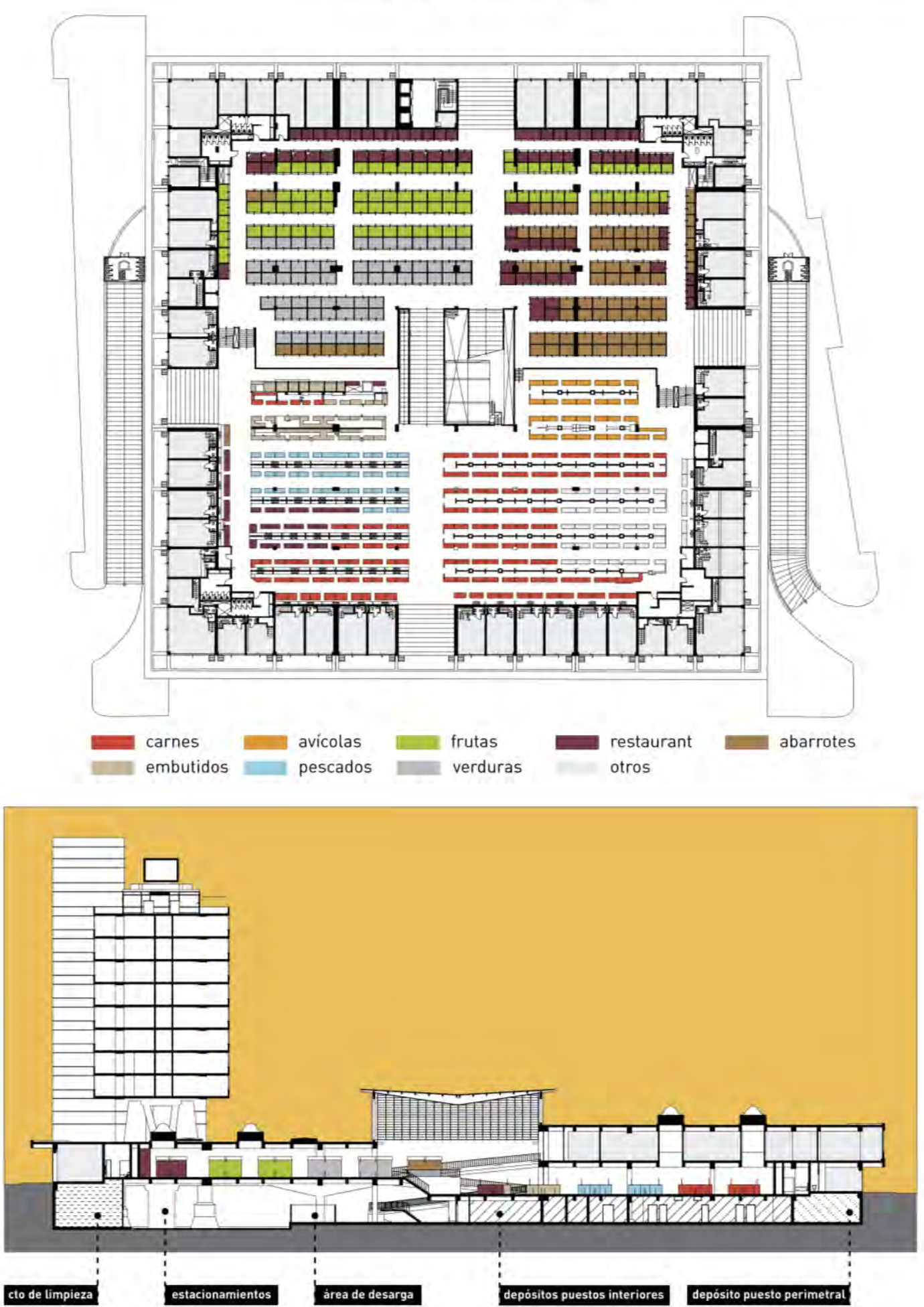

PROGRAMA

Gráfico elaborado por los autores. 
Lámina 5.22

Cuadro de áreas_Mercado Central

MERCADO CENTRAL

\begin{tabular}{|c|c|c|c|c|}
\hline SECTOR GENERAL & SECTOR & AMBIENTE & CANTIDAD & ÁREA \\
\hline \multirow{10}{*}{ MAIN MARKET } & \multirow{8}{*}{ Perecederos } & restaurantes & 70 & 441.25 \\
\hline & & carnes & 140 & 687.8 \\
\hline & & avicolas & 30 & 156.6 \\
\hline & & frutas & 85 & 348.45 \\
\hline & & abarrotes & 83 & 341.61 \\
\hline & & embutidos & 57 & 277.7 \\
\hline & & pescados & 40 & 175 \\
\hline & & verduras & 64 & 334.05 \\
\hline & \multirow{2}{*}{ No Perecederos } & interior & 270 & 3128.63 \\
\hline & & puestos perimetrales & 56 & \\
\hline \multirow{17}{*}{ ÁREA DE SERVICIOS } & \multirow{2}{*}{ Servicios Higienicos } & sshh varones & 5 & 192.8 \\
\hline & & sshh damas & 5 & 121.4 \\
\hline & \multirow{5}{*}{ Servicios Auxiliares } & área de residuos & & 50 \\
\hline & & área de abastecimiento & & 850 \\
\hline & & pesaje & & 35 \\
\hline & & área de lavado & & 50 \\
\hline & & estacionamiento de clientes & & 2100 \\
\hline & \multirow{8}{*}{ Área Administrativa } & guardianía y seguridad & & 58.5 \\
\hline & & cto.de limpieza & & 96.05 \\
\hline & & oficina de gestion & & 61.25 \\
\hline & & sala de reuniones & & 40 \\
\hline & & comedor & & 37 \\
\hline & & sshh & & 15 \\
\hline & & cocineta & & 8.5 \\
\hline & & oficina del administrador & & 20 \\
\hline & \multirow{2}{*}{ Depósitos } & Depósitos de secos & 155 & 5048.88 \\
\hline & & Depósitos de fríos & 3 & 1007 \\
\hline
\end{tabular}

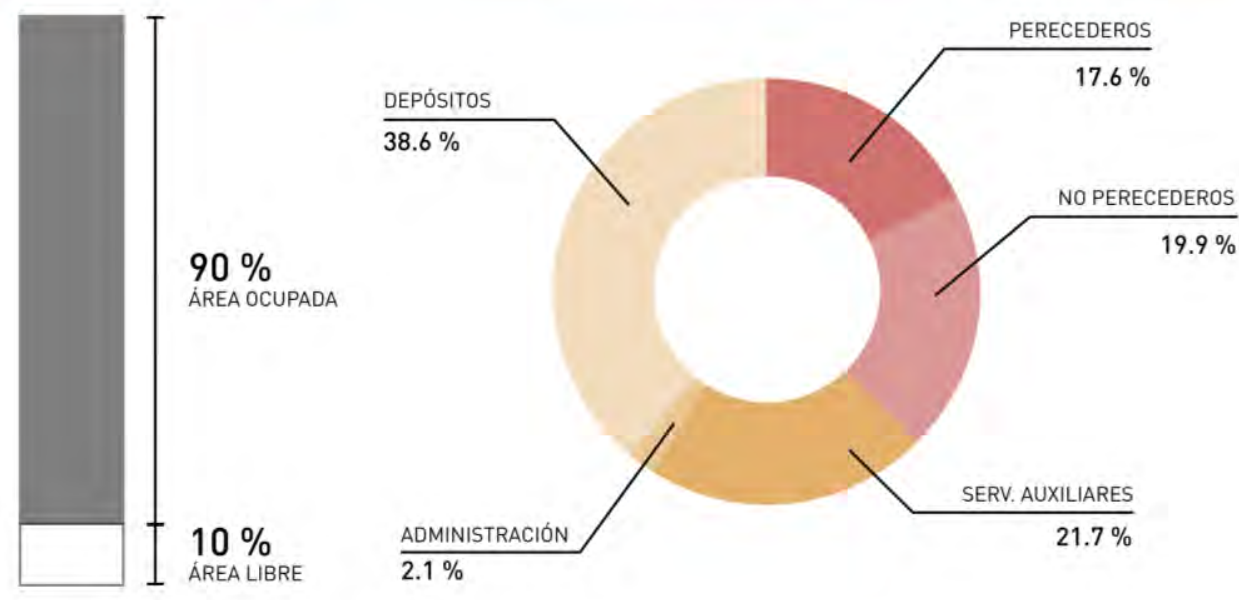

NO PERECEDEROS $\mathbf{5 3 . 1 0 \%}$

vS. PERECEDEROS $46.90 \%$

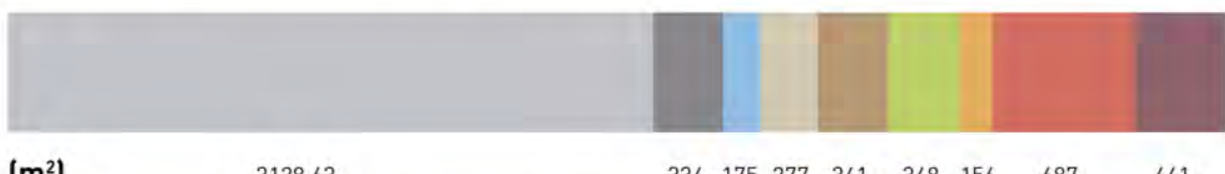

CUADRO DE ÁREAS

Gráfico elaborado por los autores. 


\section{Aporte tecnológico}

En la parte central del mercado existe un techo metálico a $15.70 \mathrm{~m}$ del nivel $+/-0.00 \mathrm{~m}$, realizado en la época del modernismo peruano, el cual está conformado por tijerales de acero de alma llena y con sección variable, además tiene una serie de viguetas que ayudan a sostener las planchas metálicas que protegen el interior del mercado, a este sistema se le denomina Nave industrial (Ver Figura 5.34), el cual permite tener grandes luces, su elaboración es más sencilla y rápida por lo que la mayoría de sus elementos son prefabricados, es decir, se elabora la estructura previamente en planta, y luego se ensamblan en obra (Ver Lámina 5.23).

Figura 5.34

Mercado Central_Nave industrial

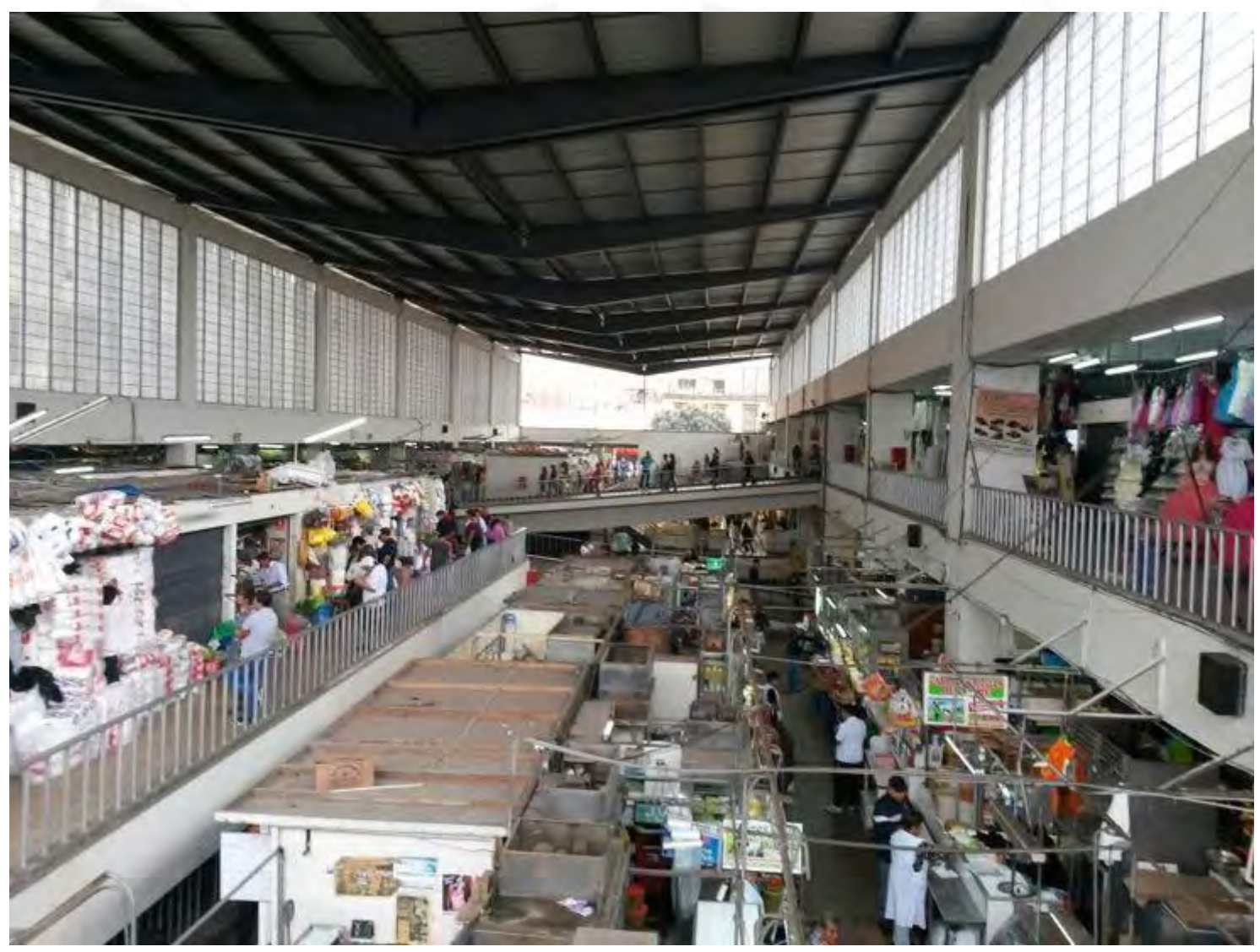

Fotografia realizada por los autores. 
Lámina 5.23

Aporte tecnológico_Mercado Central

\section{MERCADO CENTRAL}

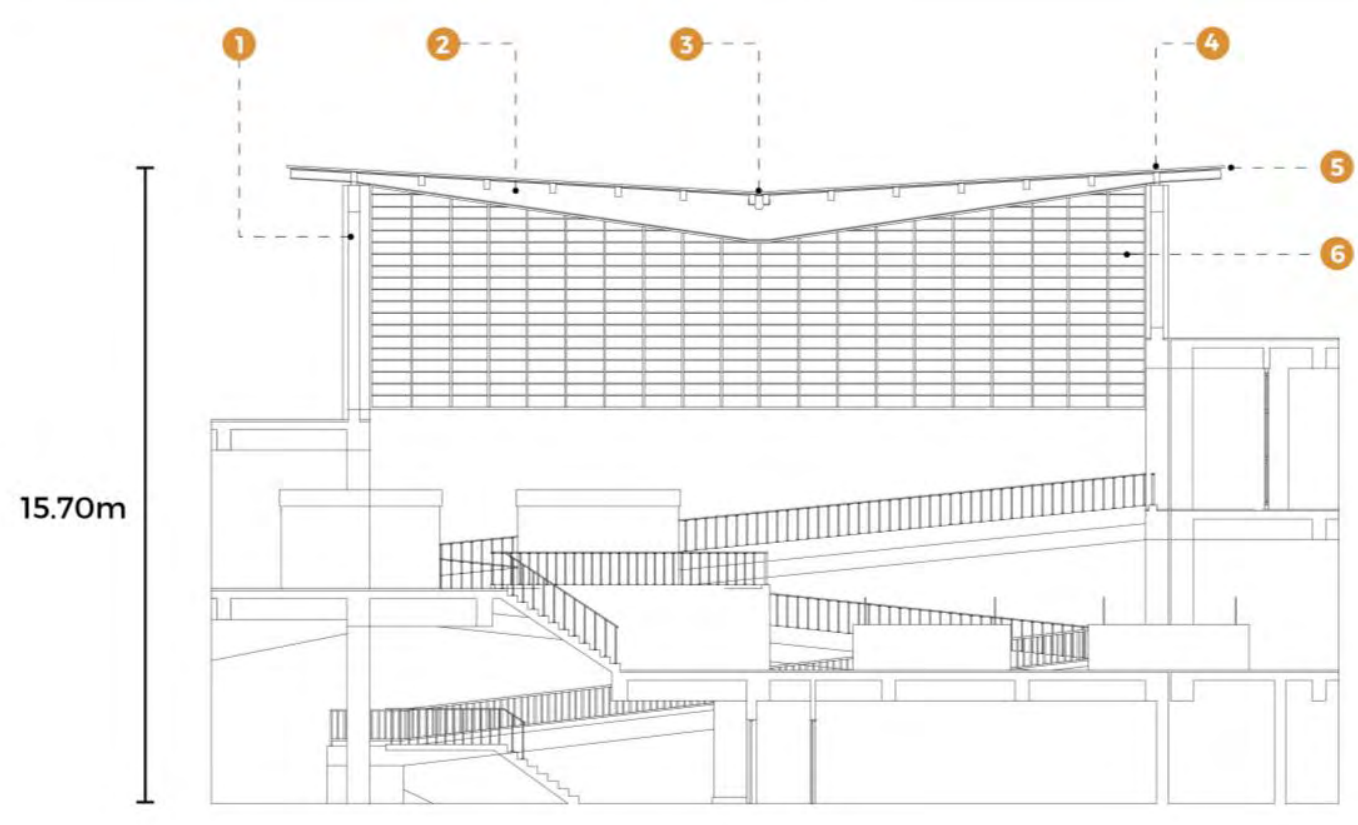

DETALLE COBERTURA
(1) Tubo de acerc
(3) Panel de madera
(5) Panel de madera
(2) Platina de acero $E=8$
(4) Perfil en $T E=8$
6 Perfil en $T E=8$

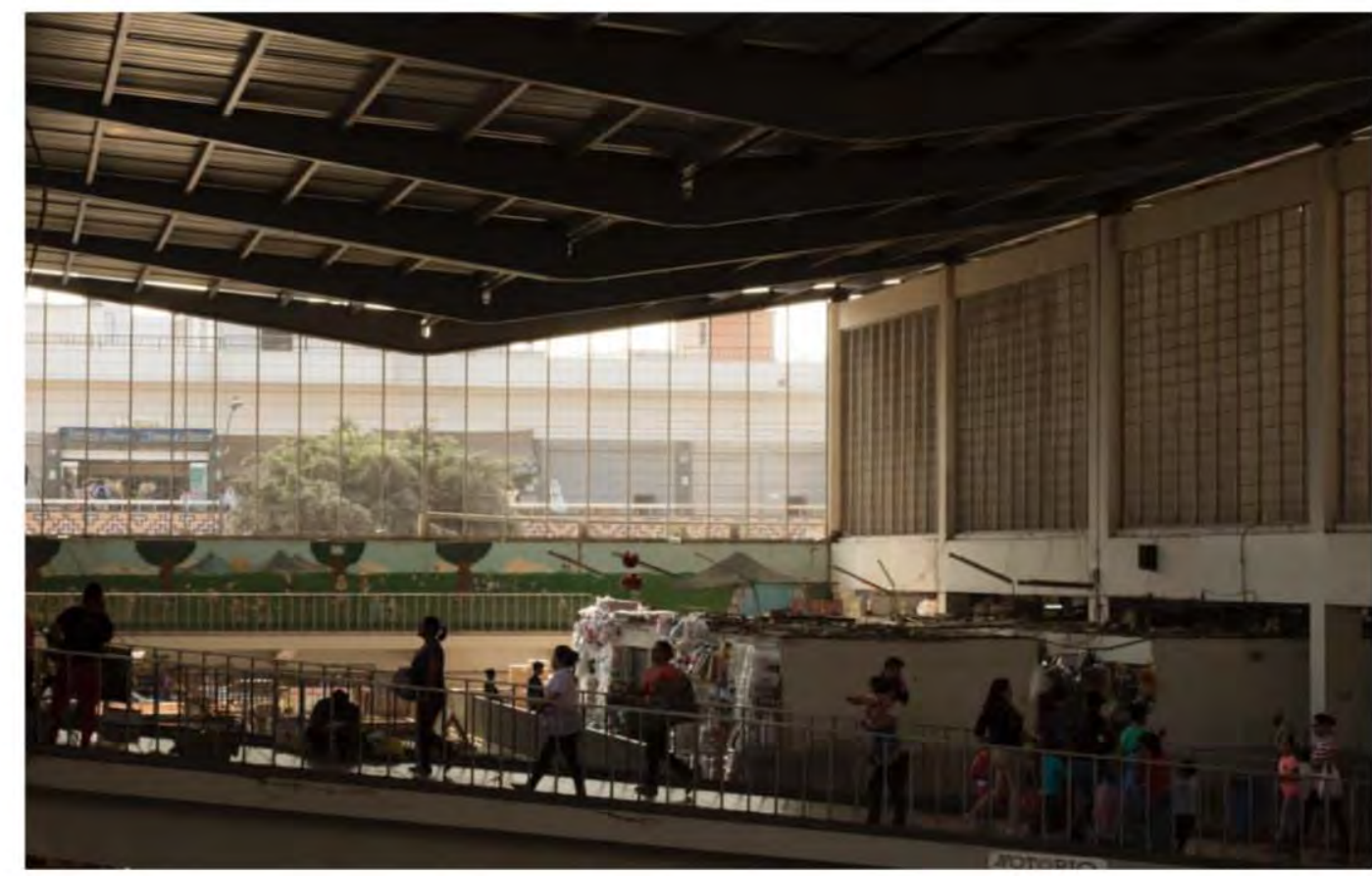

\section{APORTE TECNOLÓGICO}

Gráfico elaborado por los autores. 


\subsection{Estudio de casos proyectuales}

\subsubsection{Mercado Tirso de Molina}

El proyecto del Mercado Tirso de Molina nace en consecuencia a la construcción de la nueva vía Costera Norte, lo que provocó la necesidad de disminuir el impacto de esta vía con el barrio La Chimba y la estación Mapocho.

El mercado siempre mantuvo su ubicación actual desde que se comenzó a generar el comercio entorno a los vagones del tranvía en 1955, donde la actividad inicialmente era ambulante, la cual comenzó a aumentar considerablemente, gracias a ser el paradero final del transporte público, lo que a mediados de los 70's provocó que la Municipalidad de Recoleta junte a los comerciantes dispersos en un solo mercado provisorio, construyendo una cobertura metálica que delimite su espacio, hasta reubicarlos definitivamente, pero que nunca ocurrió (Bonnef, 2015, párr.3).

Por lo que en 1998 el Ministerio de Obras Públicas se encargó de darle una ubicación definitiva al mercado tras una resolución de la Comisión Regional de Medio Ambiente, que dictamina la creación de 3 edificios comerciales, dotado de servicios, baños públicos, salas de reunión, tratamiento de residuos, entre otros, en un área de 9000 $\mathrm{m}^{2}$ cuya inversión final fue de $\$ 5891$ millones (Gobierno de Chile, 2015, p. 3).

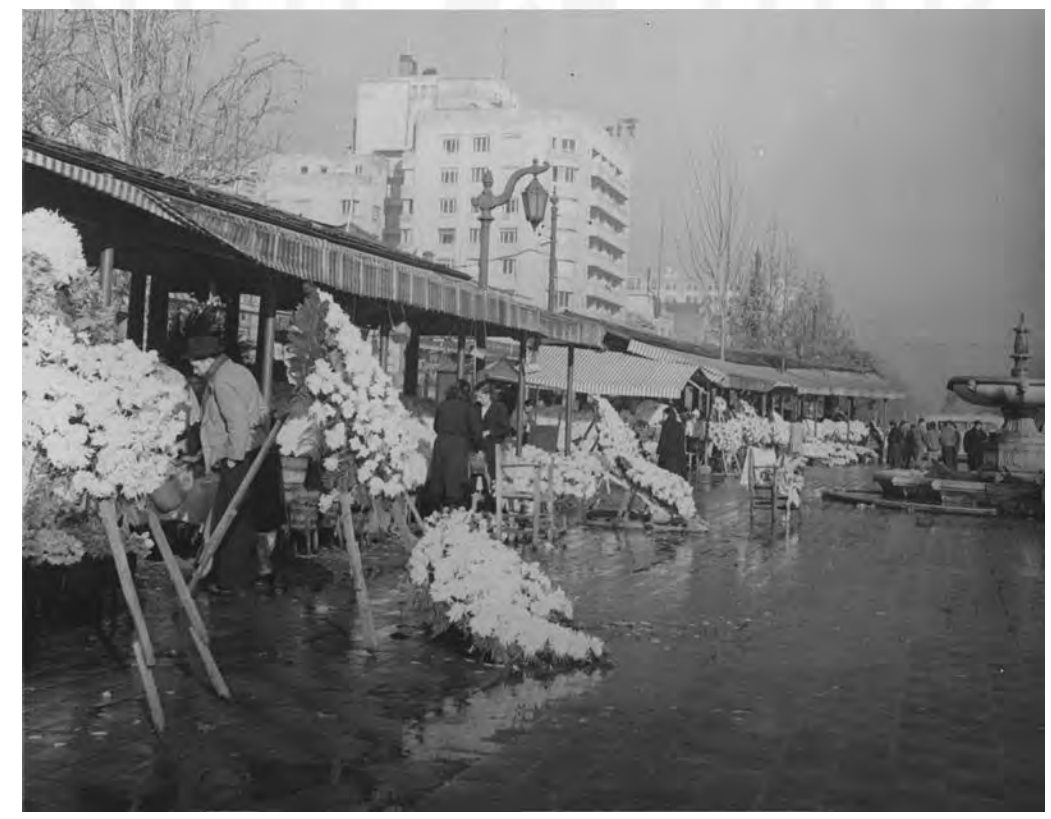

Figura 5.35 Mercado Tirso de Molina_ 1948

Fuente: Comportamientos Aparentes

En: https://comportamientosaparentes.wordpress.com/ 
La obra se inició en el 2010 a cargo de la constructora Salfa, bajo el diseño de Iglesis Prat Arquitectos, y el Ministerio de Obras Públicas como unidad técnica responsable. El Mercado Tirso de Molina cuenta con 352 puestos comerciales en dos niveles, además de una remodelación de $15000 \mathrm{~m}^{2}$ de espacios públicos y estacionamientos, arborización e iluminación (Gobierno de Chile, 2015, p. 3).

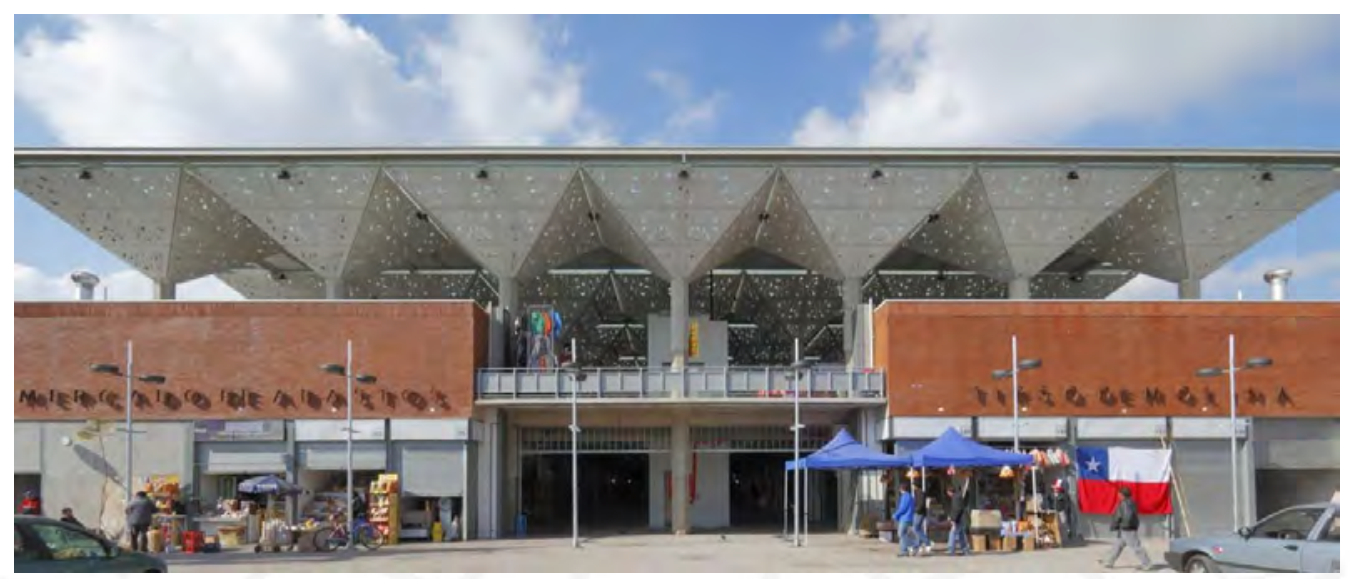

Figura 5.36 Mercado Tirso de Molina_2018

Fuente: Prat Arquitectos

En: https://pratarquitectors.cl/

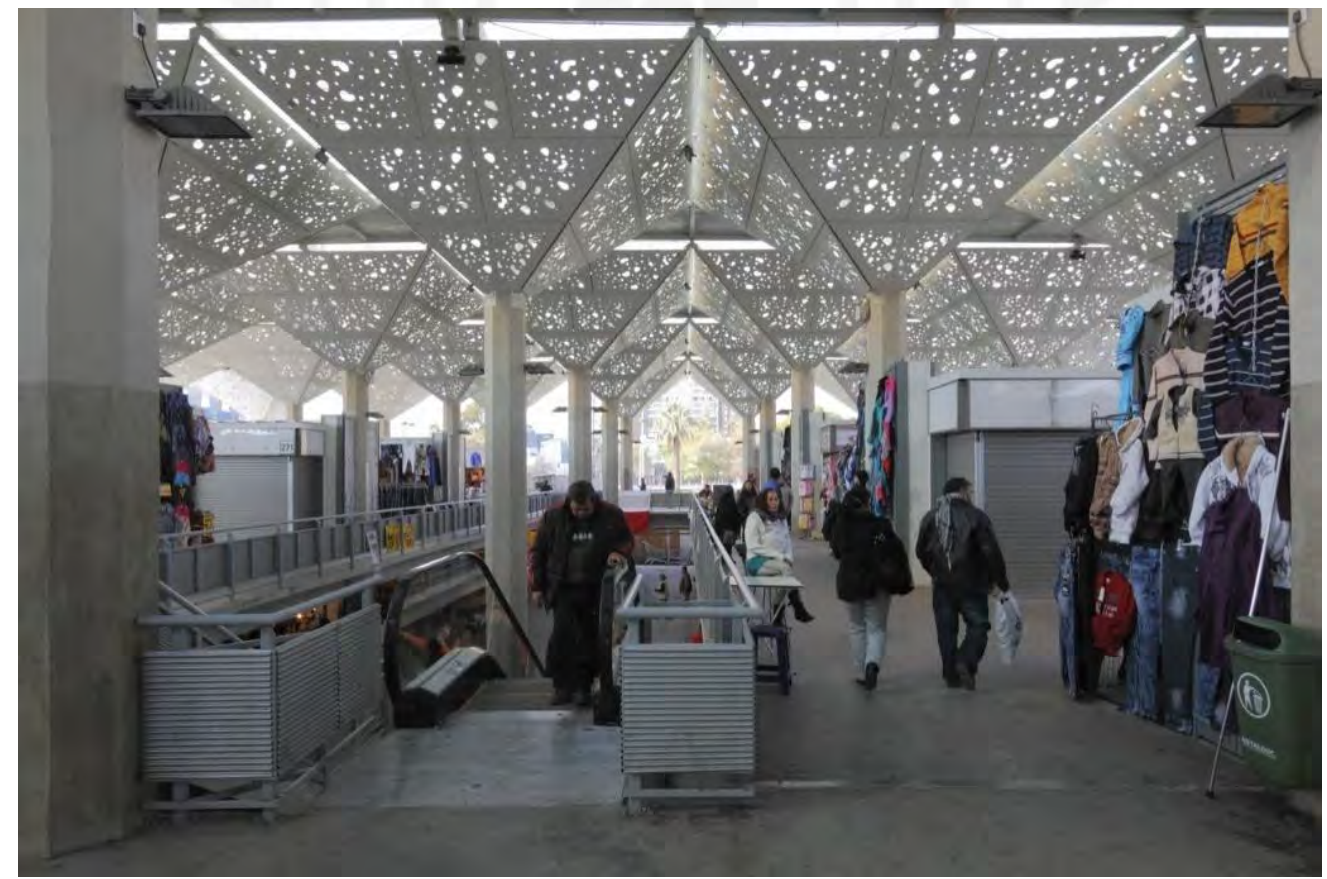

Figura 5.37 Mercado Tirso de Molina_Interior Fuente: Prat Arquitectos

En: https://pratarquitectors.cl/ 


\section{Concepto}

El mercado buscó mantener la identidad y el carácter del peatón mediante un diseño permeable a los sentidos que permita observar las actividades que se generan en el interio del mercado, resolviendo el impacto de los vehículos ante la nueva autopista Costera Norte, además de rescatar la condición de borde de río, reinterpretando las arboledas y tajamares particulares del sector (Gobierno de Chile, 2015, pág. 3).

En una entrevista a Jorge Iglesis realizada por D+A Magazine comenta: "El Mercado Tirso de Molina se trata de emplazar felizmente la obra en su entorno, o sea, poder entender hasta qué punto se puede recoger las tipologías del lugar y hasta qué punto debes realizar nuevas propuestas" (Junge, 2014, párr.14).

Es por eso que el proyecto adopta las fachadas continuas, uso de la albañilería en su horizontalidad y los ochavados en las esquinas que son considerados como un punto de significativo encuentro e interacción social entre los ciudadanos. Además, se tuvo que analizar el mercado y los flujos de los consumidores, porque los comerciantes al dialogar con el estudio de arquitectos Iglesis Prat, comentaron que querían que sus compradores circulen en el interior para poder atraerlo y detenerlo hacia el puesto de venta (Ver Figura 5.38 y Figura 5.39).

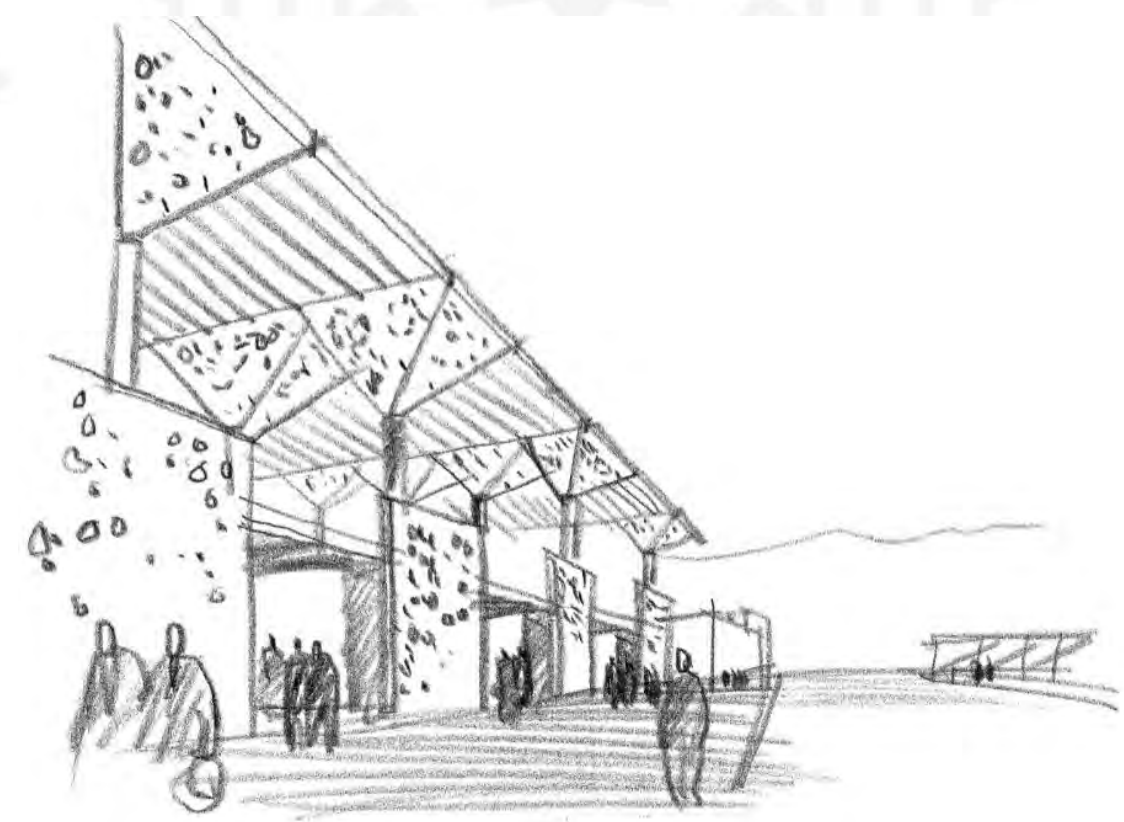

Figura 5.38 Mercado Tirso de Molina_Permeabilidad

Fuente: Prat Arquitectos

En: https://pratarquitectors.cl/ 


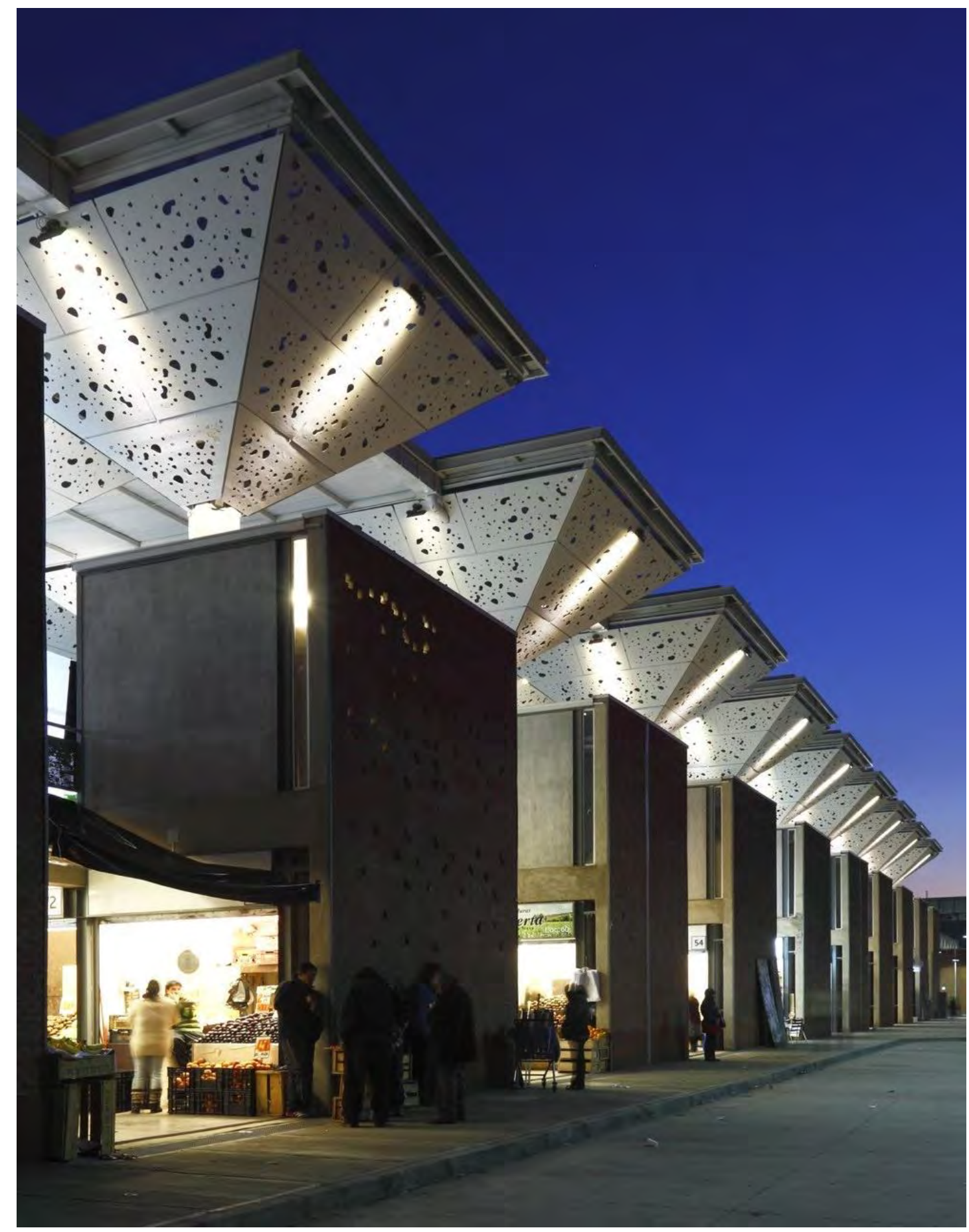

Figura 5.39 Actividad comercial vista desde el exterior Fuente: Prat Arquitectos

En: https://pratarquitectors.cl/ 


\section{Cubierta}

La cubierta se trabajó en base a un sistema modular, en el cual las pérgolas poseen un módulo de $6 \mathrm{~m}$ x $6 \mathrm{~m}$ realizado en acero y que descansan en altos pilares que luego son repetidos, definiendo una planta libre y flexible para la ubicación de los puestos comerciales y la libertad de recorrido en el interior (Rossi \& Aschner, 2015, p. 200).

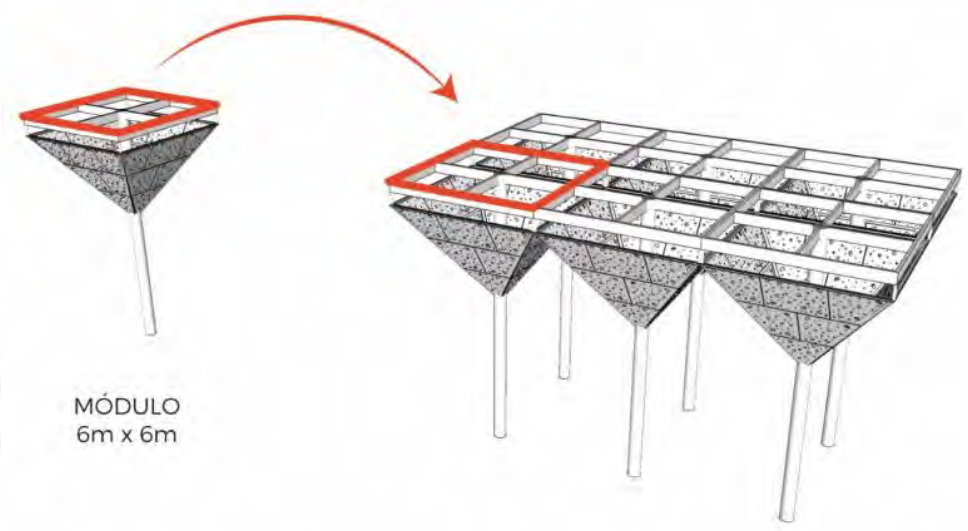

Figura 5.40 Mercado Tirso de Molina_Módulo Gráfico elaborado por los autores.

Cada módulo está conformado por una estructura piramidal invertida que simula una iluminación similar a la del follaje de los árboles, reinterpretando las arboledas por su condición de borde de río (Rossi \& Aschner, 2015, p. 200). Además, al juntarse todos estos módulos produce un juego de sombras e iluminación únicas en su interior que se ven reflejadas en las paredes y en el suelo de múltiples formas a lo largo del día, permitiendo mantener el mercado al "aire libre".

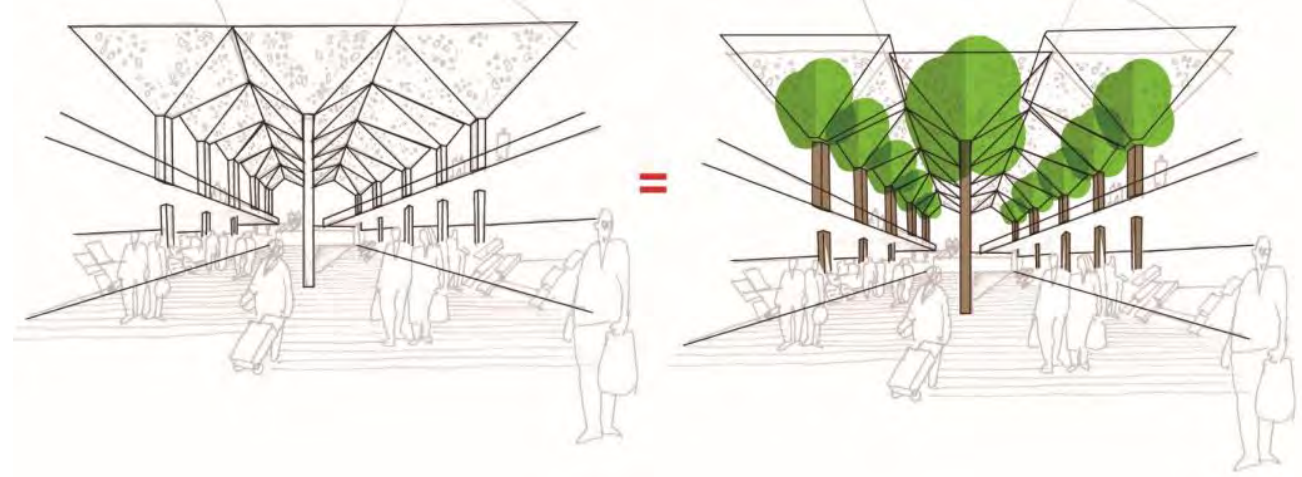

Figura 5.41Reinterpretación del follaje de los árboles

Gráfico elaborado por los autores. 


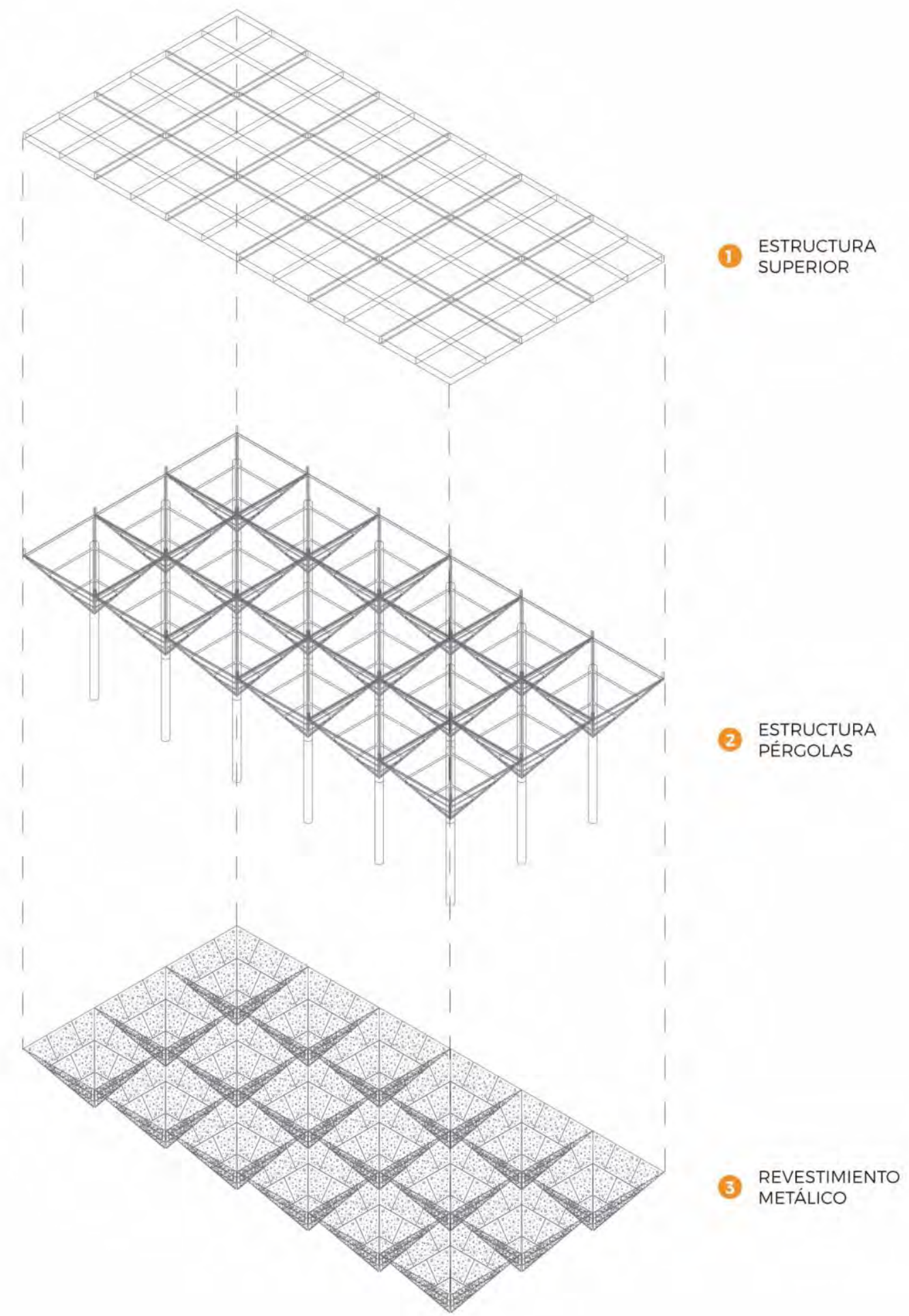

Figura 5.42 Isometría explotada de la cobertura

Gráfico elaborado por los autores. 


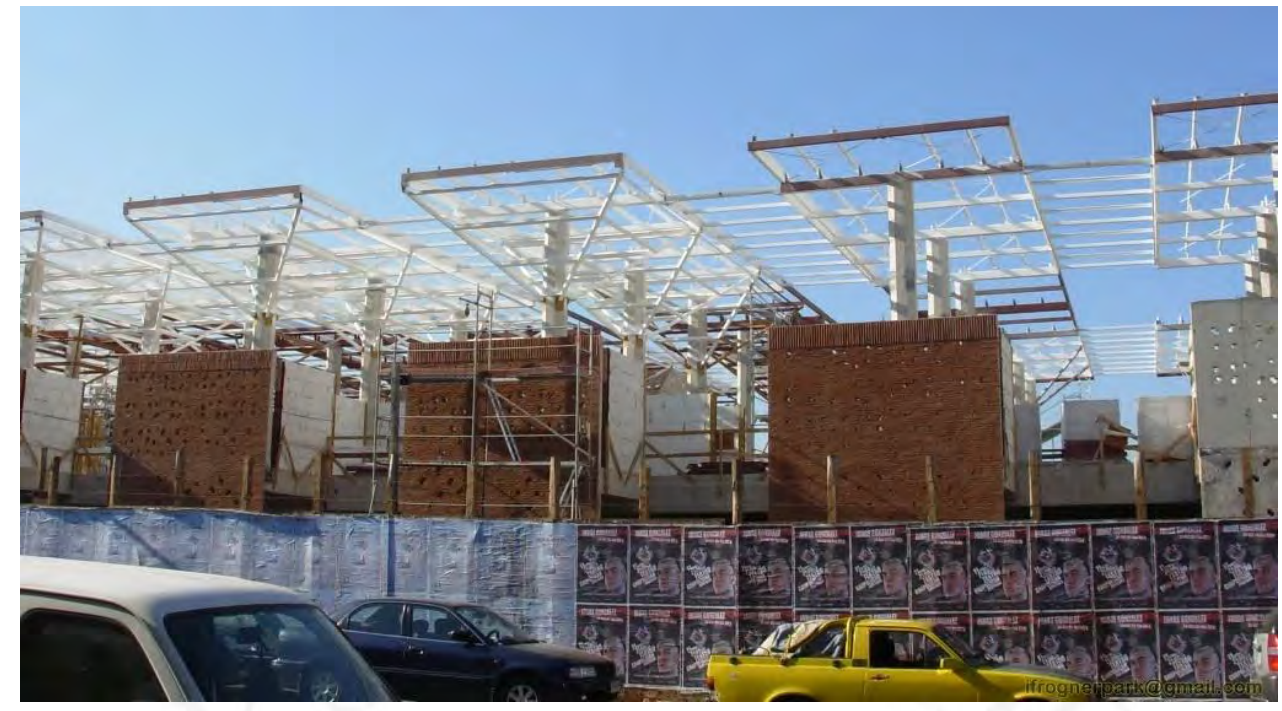

Figura 5.43 Construcción de pérgolas

Fuente: $\mathrm{D}+\mathrm{A}$

En:http://www.disenoarquitectura.cl/pergola-de-las-flores-y-mercado-tirso-de-molina-de-iglesis-pratarqtos/

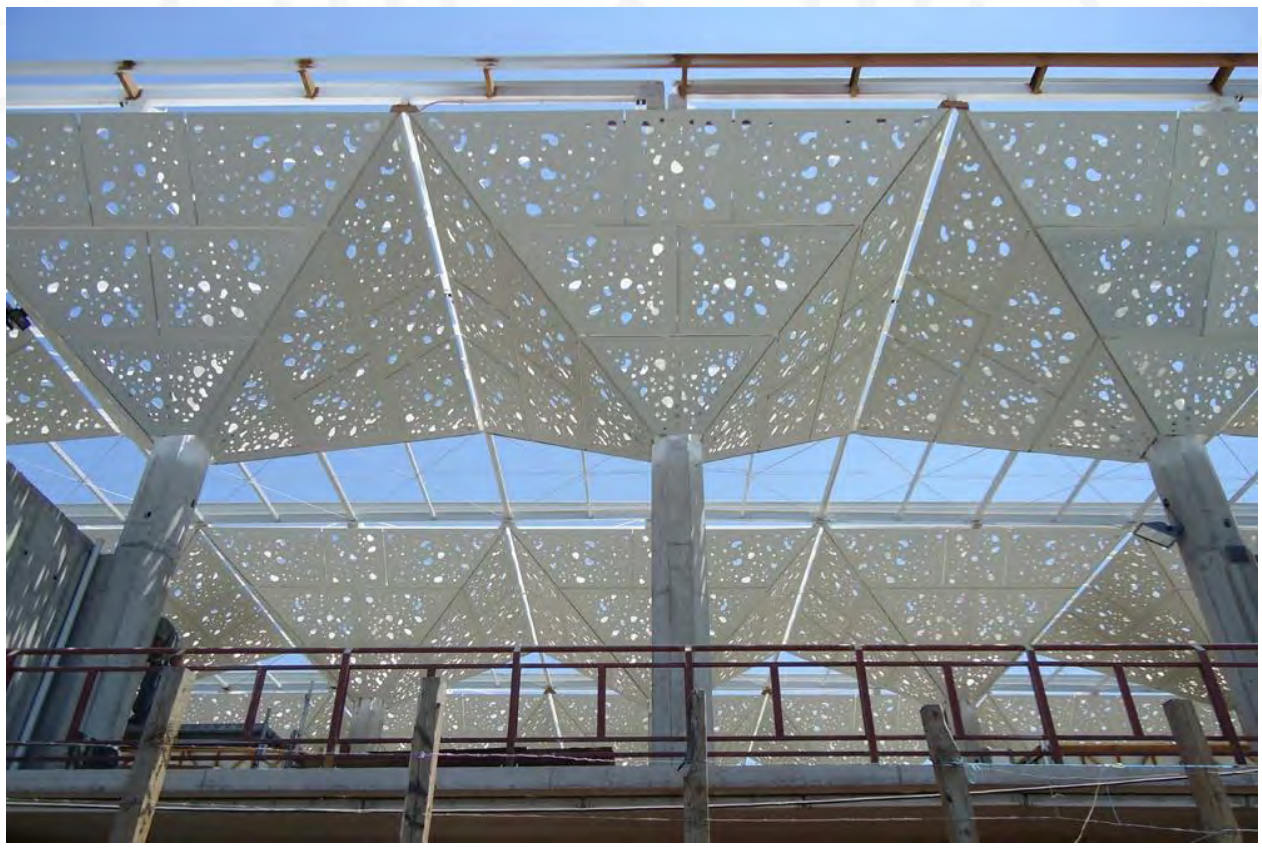

Figura 5.44 Revestimiento metálico de las pérgolas

Fuente: D+A

En:http://www.disenoarquitectura.cl/pergola-de-las-flores-y-mercado-tirso-de-molina-de-iglesis-pratarqtos/ 


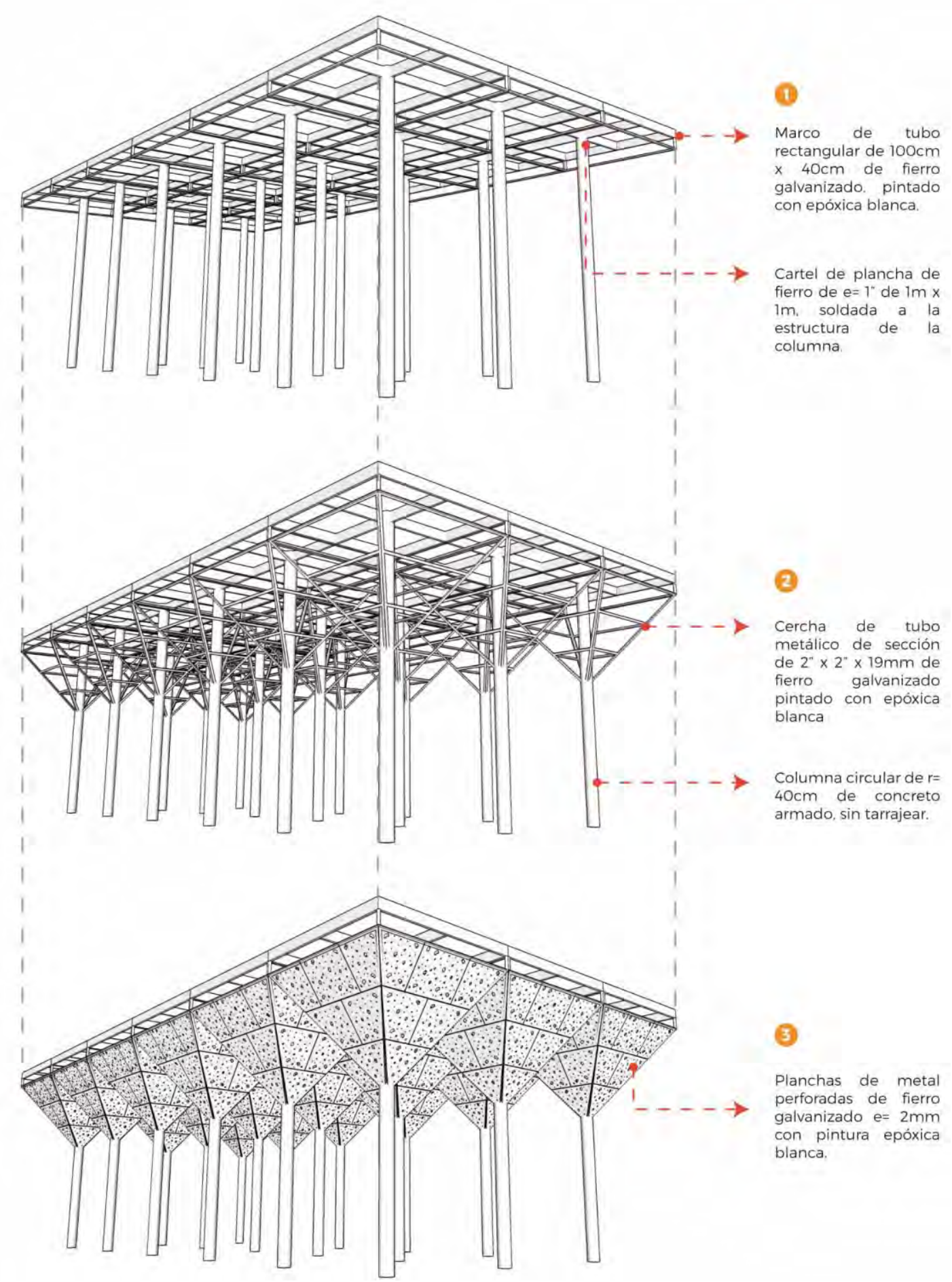

Figura 5.45 Materialidad de las pérgolas

Gráfico elaborado por los autores. 


\subsubsection{Mercado La Barceloneta}

El mercado nació en 1884 en el barrio de la Barceloneta, distrito de Ciutat Vella cercano al principal puerto marítimo de la ciudad de Barcelona, motivo por el cual tiene un carácter pesquero. El actual edificio es resultado de la remodelación realizada en el 2007 por MiAS Arquitectes integrado por los arquitectos Josep Miás, Silvia Brandi, Adriana Porta, María Chiara Ziliani, Andreu Canut y Carles Bou.

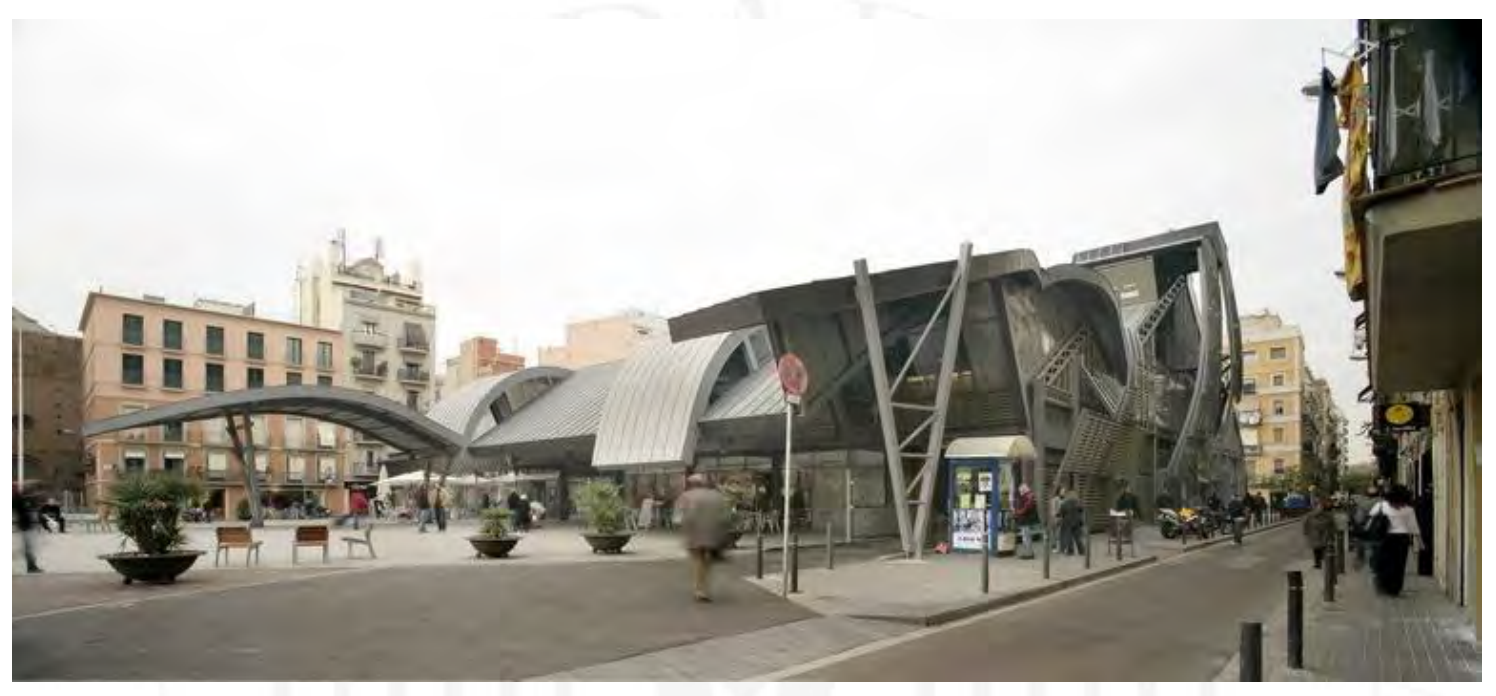

Figura 5.46 Mercado La Barceloneta Fuente: Adriá Goula En: https://images.adsttc.com/media/images/512a/c6f8/b3fc/4b11/a700/a141/large_jpg/13074730481307112657-28a-n7x1606-07.jpg?1414266388

El estudio MiAS Arquitectes (2011), comenta que:

El Mercado siempre ha sido un elemento de cohesión social del barrio, un referente, a veces casi secreto y solamente visible para sus habitantes. Esta condición (...) debía de ser una condición del proyecto, de manera que el edificio y su entorno realmente deviniesen punto de referencia claro de esta pequeña parte de la ciudad de Barcelona. (MiAS Architects, 2011, párr. 4)

Por lo tanto, el proyecto de remodelación preservó gran parte de la cobertura de hierro que poseía el mercado desde su creación, manteniendo la memoria colectiva de los ciudadanos con el mercado. Al mismo tiempo se añadieron nuevas figuras metálicas en la cobertura a partir de un collage de peces realizado por el artista español César Manrique 
(Ver Figura 5.47) y que forman nuevos espacios dentro y fuera del mercado, pero estas no generan una carga estructural a la antigua cobertura, sino que flota sobre ella y se extiende hacia el espacio público del mercado (Ver Figura 5.48).

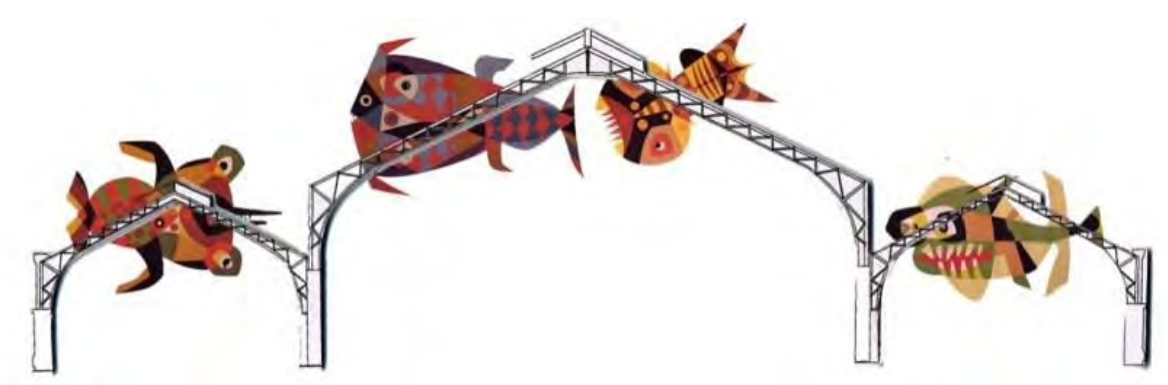

Figura 5.47 Esquema conceptual del Mercado La Barceloneta Fuente: MiAS Arquitectes

En: https://images.adsttc.com/media/images/512a/c729/b3fc/4b11/a700/a14a/large_jpg/13074730601307113154-estruc-copy3-1000x282.jpg?1414266412

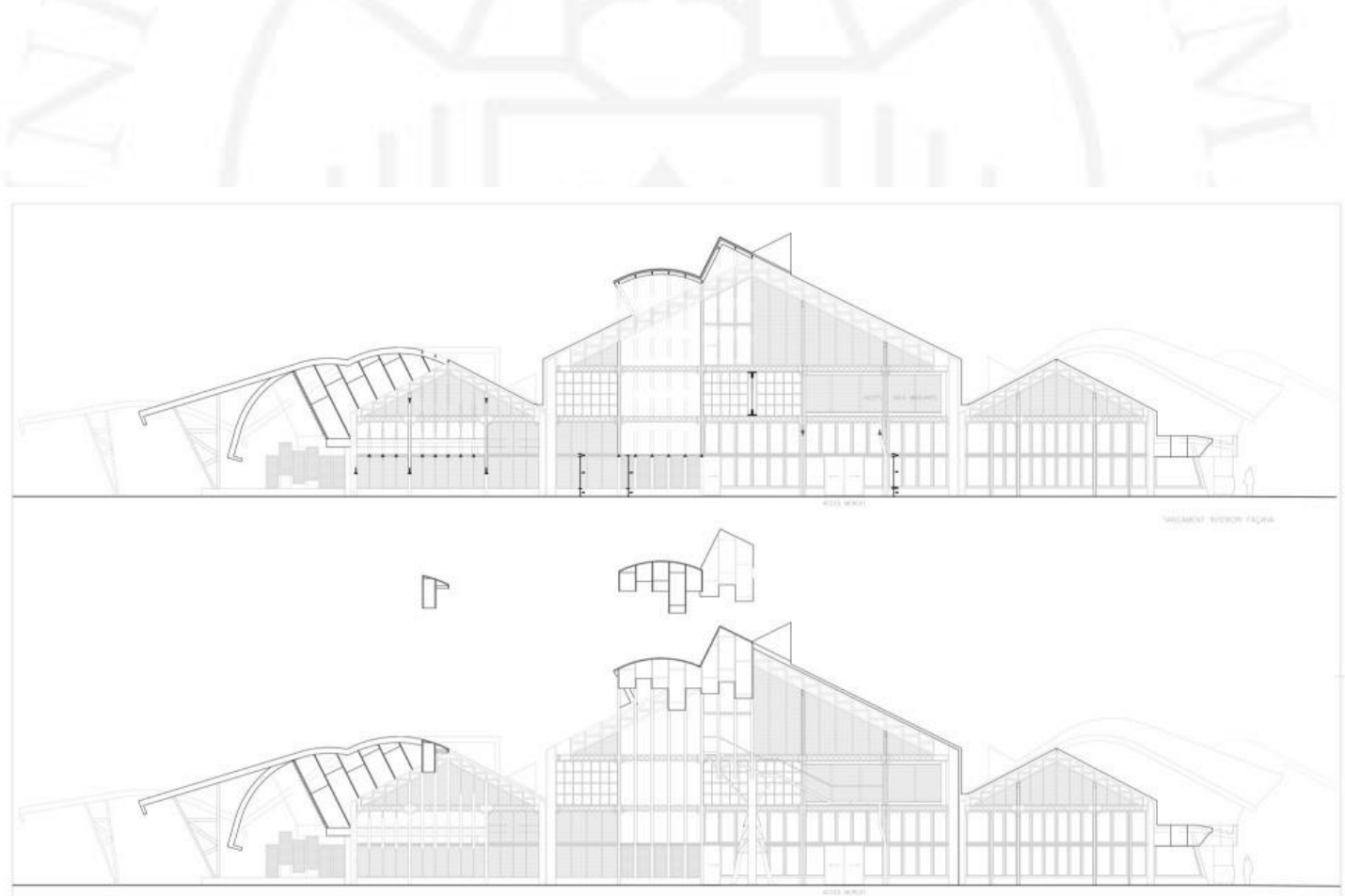

Figura 5.48 Sección longitudinal_ Mercado La Barceloneta Fuente: MiAS Arquitectes En: https://images.adsttc.com/media/images/512a/c70e/b3fc/4b11/a700/a145/large jpg/13074730551307113137-0001og-1000x706.jpg?1414266400 
La remodelación del mercado también se destaca por el diseño del espacio público de la Plaza de La Font y del Poeta Boscá, siendo uno de los mayores espacios abiertos del barrio y donde se desarrolla la actividad cívica incrementando la importancia del equipamiento comercial.

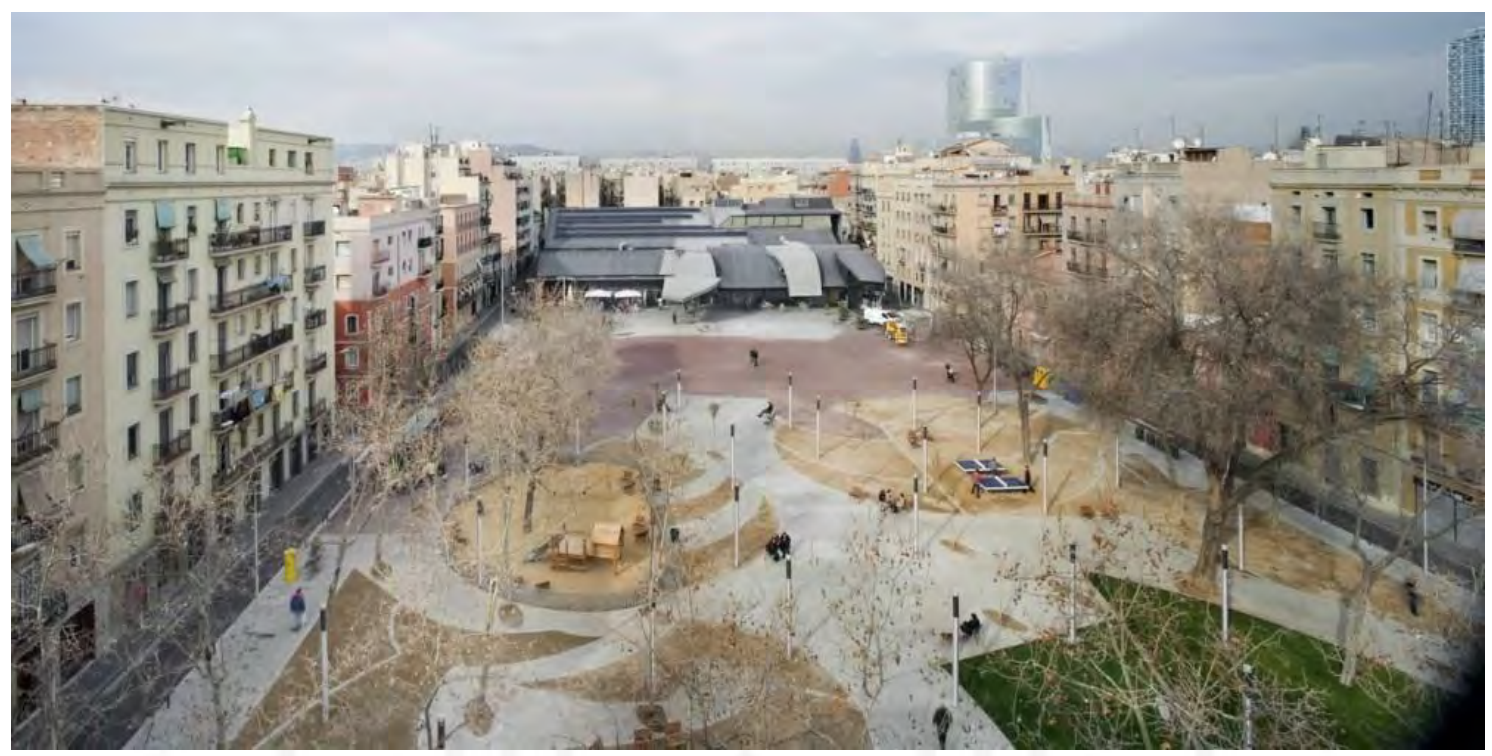

Figura 5.49 Espacio público del Mercado La Barceloneta Fuente: Adriá Goula

En: https://images.adsttc.com/media/images/512a/c6c7/b3fc/4b11/a700/a137/large_jpg/13074730371307112625-n7x1787-88-1000x500.jpg?1414266371

Según Martínez (2014), la división de las áreas de la plaza se debe a 3 variables:

- Primero a su historia, debido a que se mantienen las ubicaciones de los accesos y salidas orientadas hacia las calles que rodean la plaza, creando un área de circulación peatonal dinámica y de amplitud comercial.

- Segundo, se debe al color del material y diseño visual del pavimento que termina en un uso y funciones diferentes, marcando zonas de juegos, circulación, estancia y contemplación, fortaleciendo la interacción social.

- Y tercero, por el carácter densidad de las vías que dan a la plaza y el mercado, generando áreas de juego para niños y áreas de descanso con vegetación en las calles menos transitadas, o como boulevares generados hacia las calles con mayor actividad comercial. 


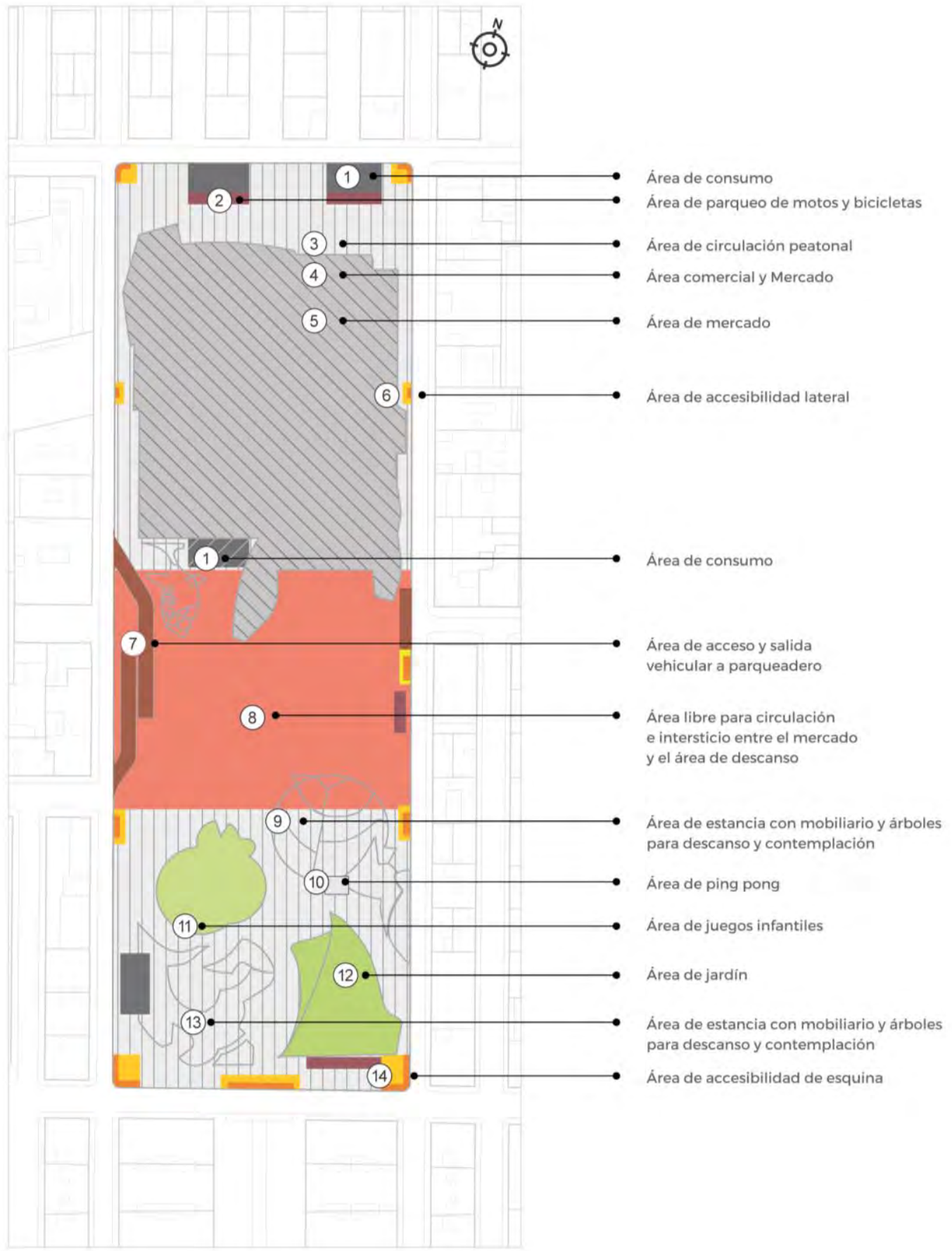

Figura 5.50 División de áreas de la plaza

Gráfico elaborado por los autores, según Martínez Palacios (2014).

En las distintas zonas de la Plaza de la Font y del Poeta Boscá se utilizan varios tipos de pavimentos que se diferencian por el color, el material, acabado, según la función que tenga el espacio. Esta diferencia de los pavimentos comunica a las personas alrededor del mercado y la plaza que ofrece más usos aparte de la actividad comercial. Este intercambio de forma y color genera una composición formal, funcional y de color que 
nace del arte de la abstracción de formas marinas de César Manrique (Martínez Palacios, 2014, p. 24). Los materiales presentes en los pavimentos alrededor del mercado son los bordillos de granito, panots y asfalto para la calzada; mientras que en las plazas se utiliza asfalto, losetas de granito y concreto estampado de 60 x 40cm (Noguera, 2011, p. 56).

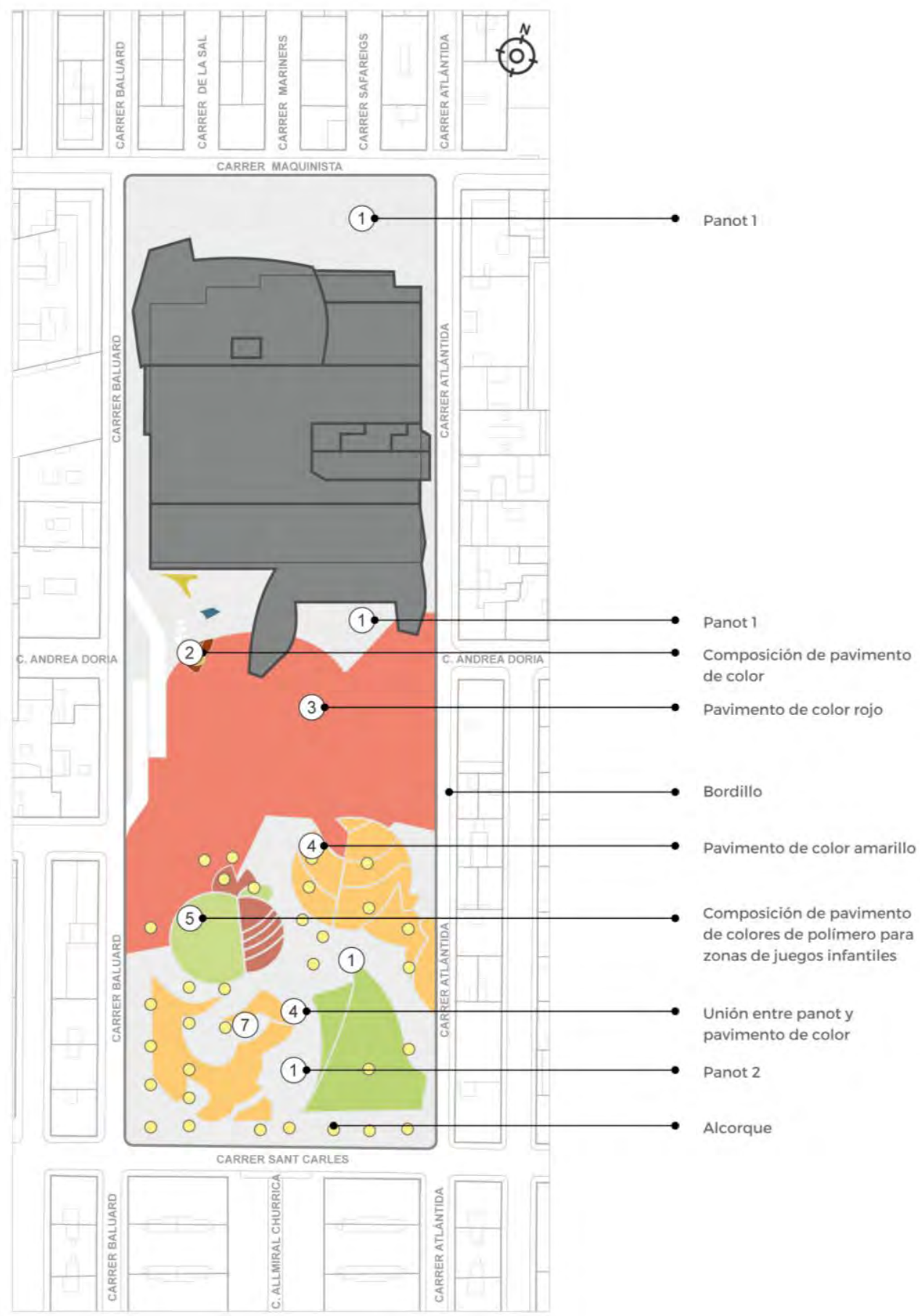

Figura 5.51 Pavimentos del espacio público del Mercado La Barceloneta

Gráfico elaborado por los autores, según Martínez Palacios (2014). 


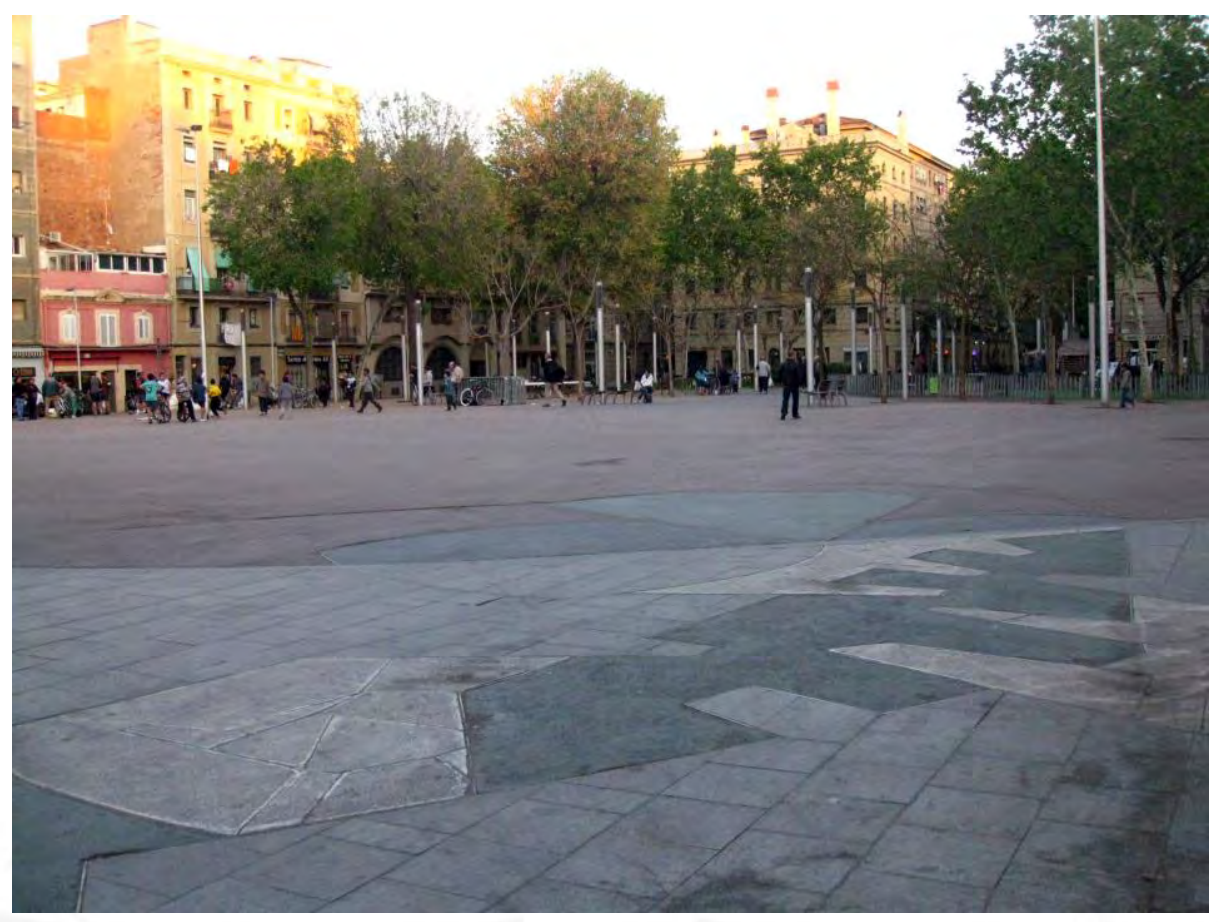

Figura 5.52 Pavimento de la Plaza de La Font Fuente: Enfo

En:https://commons.wikimedia.org/wiki/File:49_Paviment_del_peix,_de_Josep_Mi\%C3\%A0s,_pl._Poet a_Bosc $\%$ C3\%A0.jpg

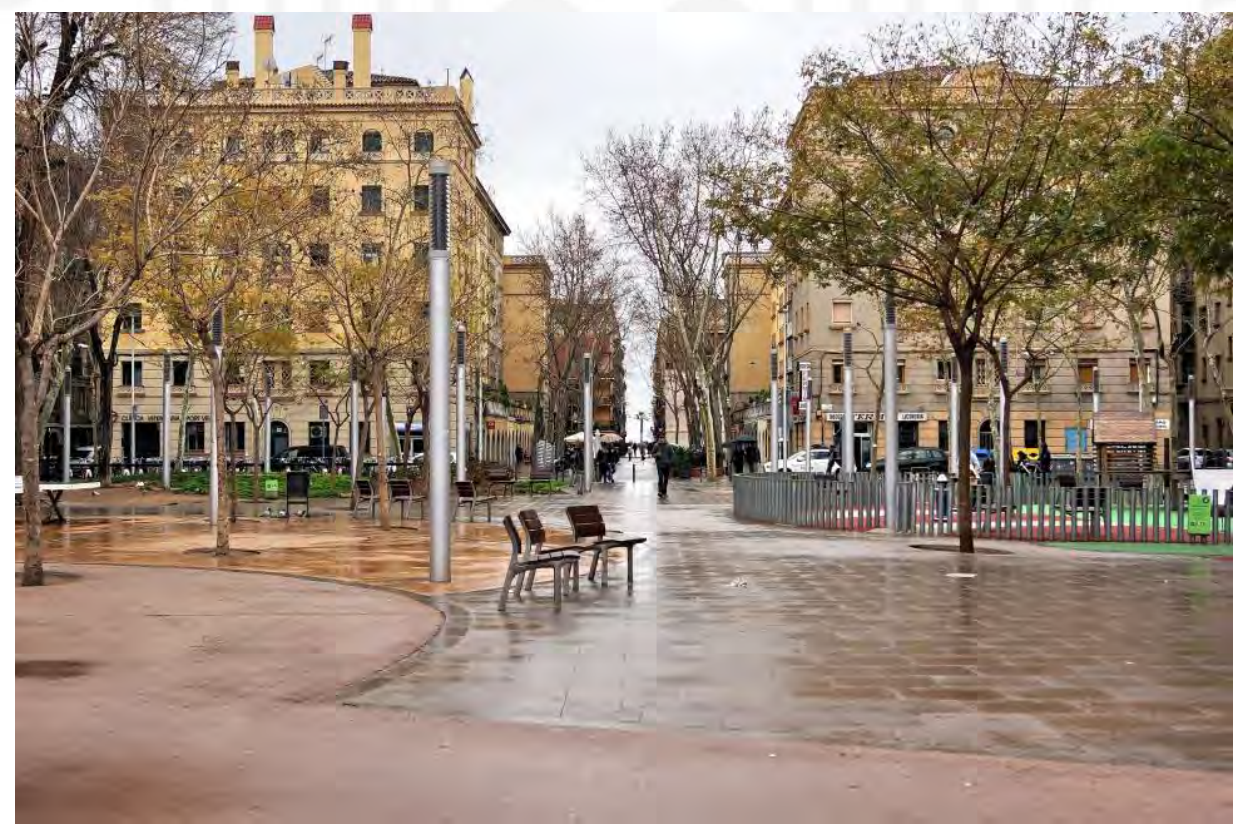

Figura 5.53 Pavimento de la Plaza del Poeta Boscá

Fuente: Yuri Rapoport

En: https://h5.googleusercontent.com/p/AF1QipOSit5YA6L9JX8CbK7of_i-

3OJe5NwDa7PgQteo=h1440 
La mayor parte de la vegetación se encuentra en la Plaza del Poeta Boscá y son de vital importancia debido a que permiten marcar recorridos, crear un ambiente confortable con sombra, diferenciar áreas, comunicar direcciones, y generar aspectos de privacidad dentro del espacio público (Martínez Palacios, 2014, p. 30). Los tipos de árboles que se identificaron fueron: Almez, Jacarandas, Acacia negra, Plátano de sombra y Margallo (Ver Figura 5.54).

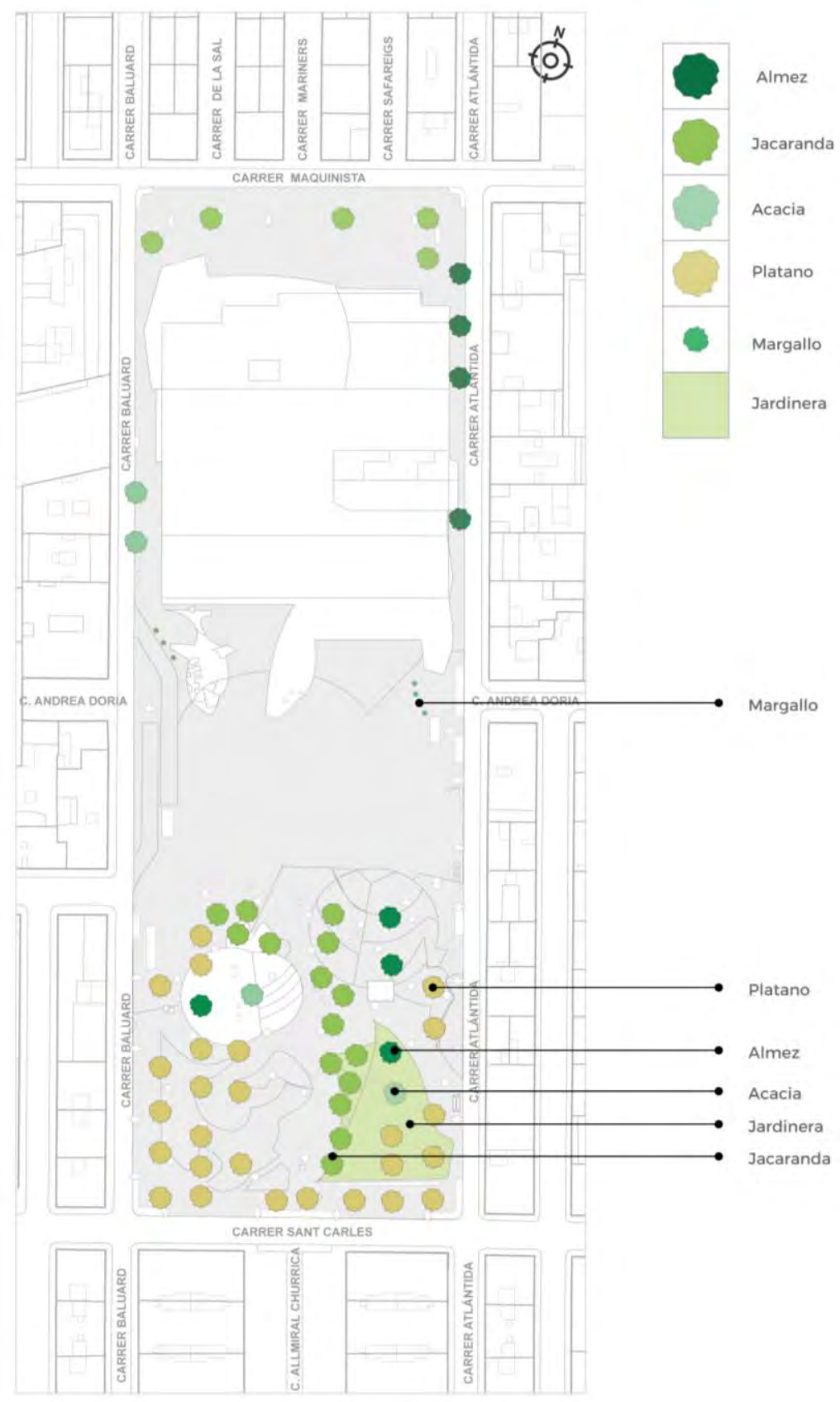

Figura 5.54 Identificación y ubicación de la vegetación_Plaza del Poeta Boscá Gráfico elaborado por los autores, según Martínez Palacios (2014). 
El espacio público del mercado también está dotado de mobiliario urbano y son identificables porque son elementos de uso cotidiano por toda la ciudad de Barcelona. Los materiales utilizados mayormente son de acero fundido y de madera curada, proporcionando una gran resistencia al uso y la intemperie, haciendo que sean objetos de bajo mantenimiento (Martínez Palacios, 2014, p. 26).

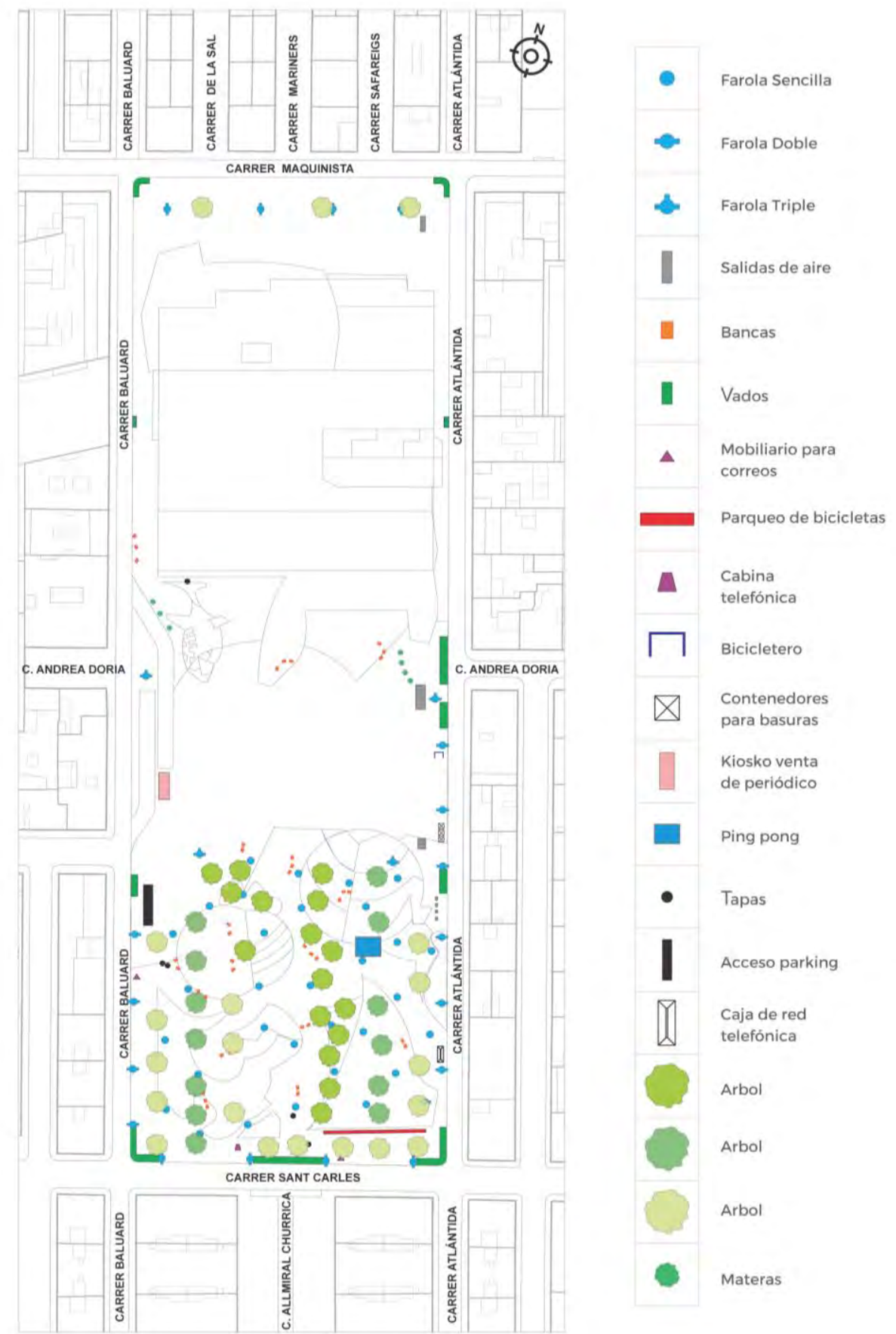

Figura 5.55 Mobiliario urbano del espacio público del Mercado La Barceloneta Gráfico elaborado por los autores, según Martínez Palacios (2014). 

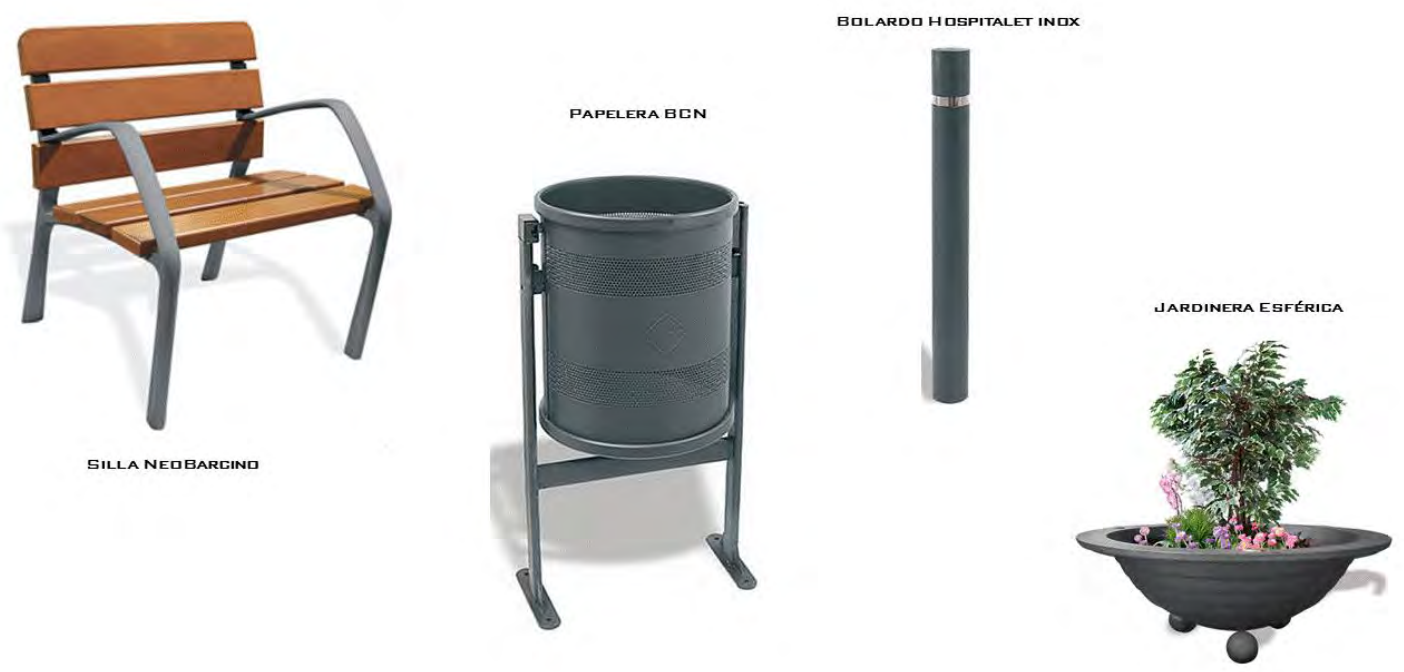

Figura 5.56 Tipo de mobiliario urbano en el espacio público del Mercado La Barceloneta Fuente: Samuel Padilla

En: http://samuel.padillano.com/wp-content/uploads/2016/03/Diapositiva37.gif

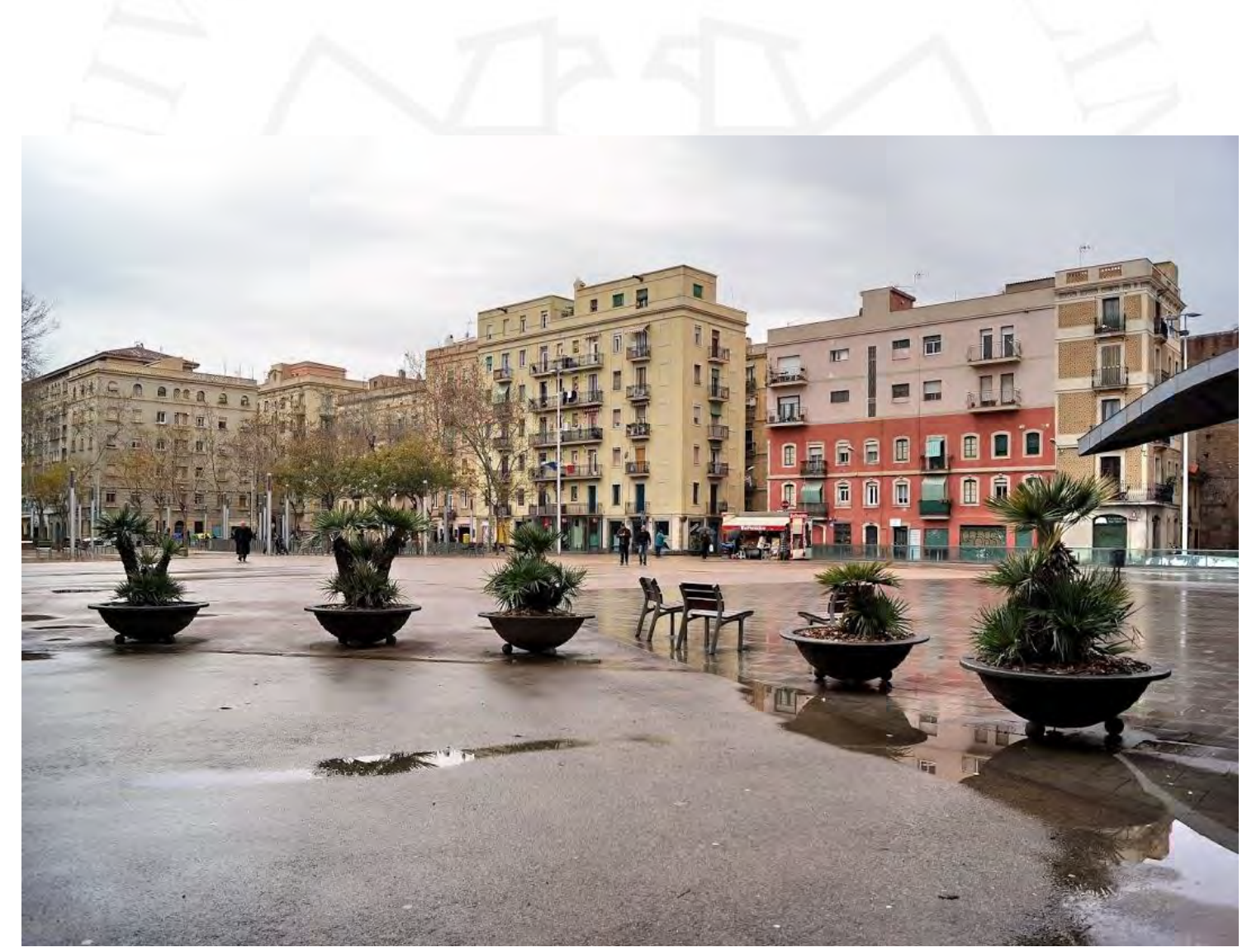

Figura 5.57 Mobiliario de la Plaza de La Font

Fuente: Yuri Rapoport

En:https://lh5.googleusercontent.com/p/AF1QipMf4Uir_jpnSe2u52gi3R_lpnAsAFXiC1EHjXMG=h144 0 


\subsubsection{Los pasajes como espacios semi-públicos}

Dentro de la trama urbana de Lima y del distrito de Jesús María están presentes las viviendas callejones y las quintas que poseen un pasaje previo y en muchos casos remata en un patio interno en los que se daba la interacción social entre las familias y se realizaban diversas actividades colectivas para el bien de la comunidad. Además, el pasaje y la plaza son considerados espacios semi-públicos al no poseer un acceso restringido y por permitir el ingreso gradual de los vecinos hacia las viviendas, generando un intermedio entre lo público y privado.

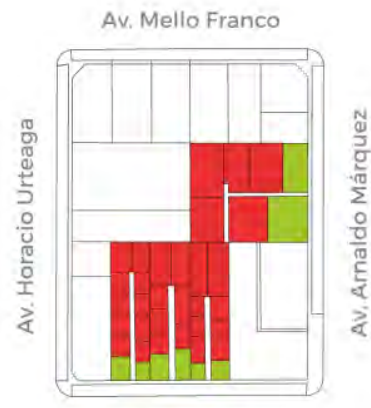

Jr. Luzuriaga

Leyenda:

viviendas exteriores

- viviendas interiores

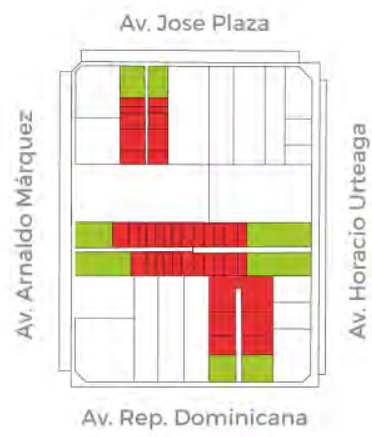

Av. Rep. Dominicana

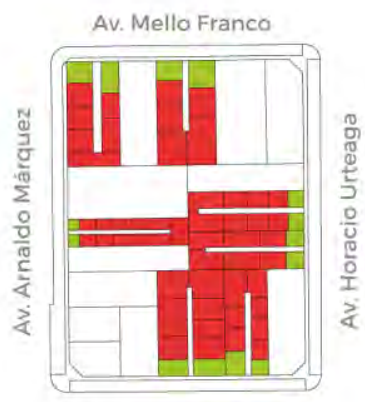

Av. Húsares de Junín

Figura 5.58 Quintas y callejones en Jesús María

Gráfico elaborado por los autores.

Las viviendas callejones son una tipología constituida por un conjunto de pequeñas unidades organizadas alrededor de un pasaje central sin techo con servicios comunes. Este tipo de vivienda surge dentro de la trama urbana de Lima durante la época colonial, en las que albergaban a pobres, religiosos de bajo status y caballeros en desgracia; y que posteriormente después de la caída de la muralla y la mudanza de la clase social alta fuera del centro, fue ocupada por indios dedicados al comercio o a la artesanía (Castillo, Huamaní, \& Vilchez, 2009, p. 2). 

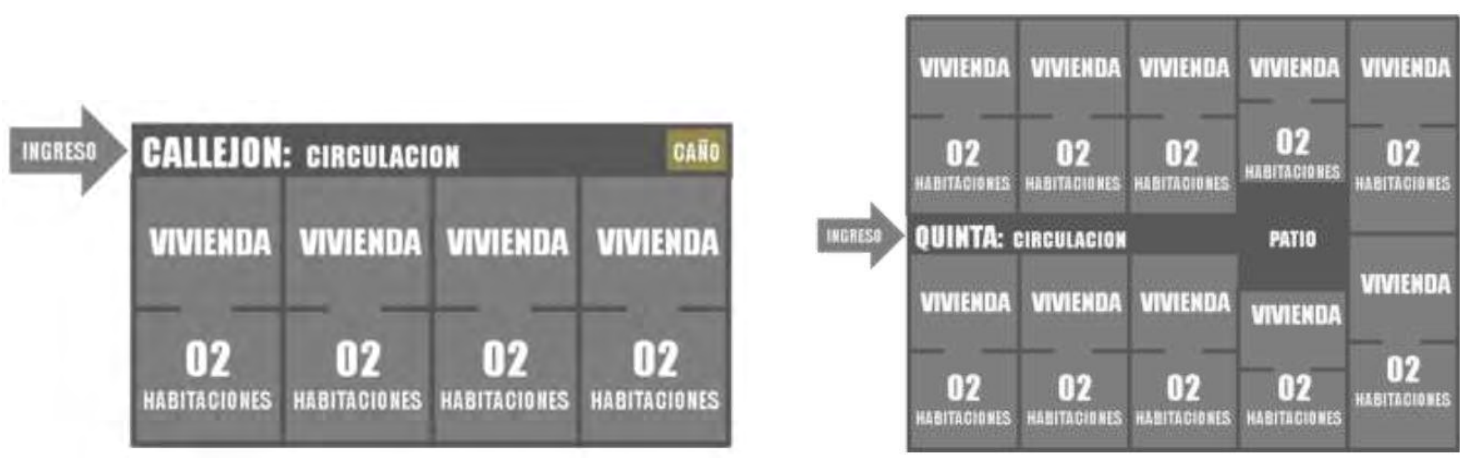

Figura 5.59 Distribución de la vivienda callejón Fuente: Cesar Salazar (2013).

Del mismo modo que los callejones aparecieron las quintas que poseen una dimensión mayor del pasaje y se le proporcionó un patio interno, además de incrementar las dimensiones de las viviendas internas y dotarlos de servicios higiénicos privados. Pero también tienen similitudes ya que parten de una fachada sin ventanas y con una sola puerta que colinda a la calle, la que permite el ingreso hacia las viviendas por un corredor central que puede ser de forma lineal, en "T", o de forma irregular como un laberinto, y que remataban en una plaza interna. Es en estos corredores y espacios abiertos en donde se generaban diversas expresiones culturales colectivas, debido a la cercanía de los vecinos, que con el tiempo se creaban fuertes lazos sociales y compromisos afectivos compartiendo actividades laborales como tiempos de diversión.

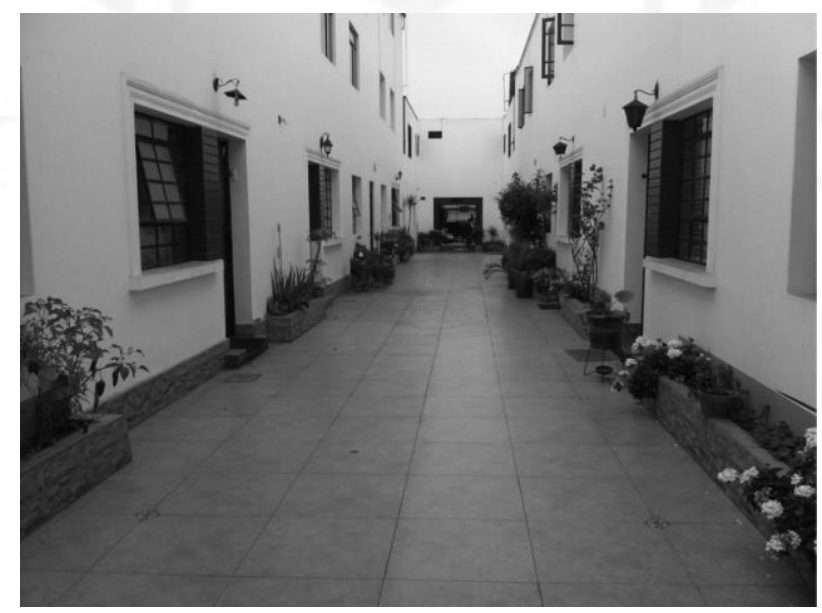

Figura 5.60 Vivienda tipo quinta_1

Fuente: A donde vivir

En: https://www.adondevivir.com/propiedades/en-venta-linda-casita-en-interior-de-quinta-51273079.html 


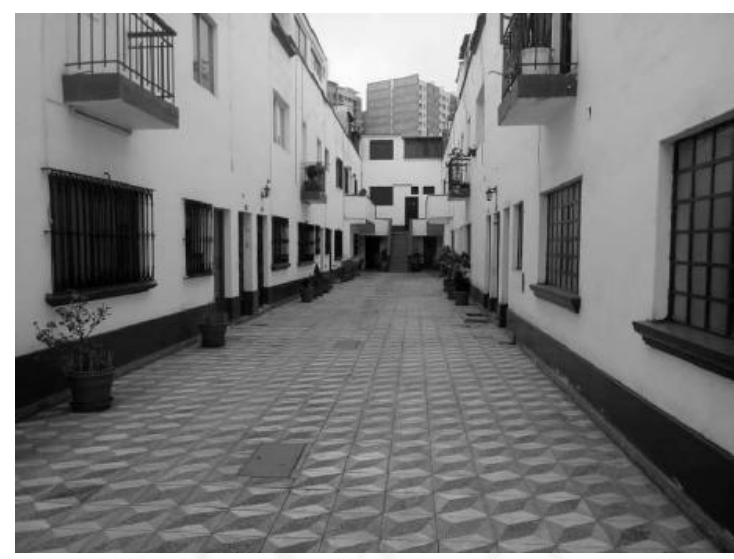

Figura 5.61 Vivienda tipo quinta_2

Fuente: Info Casas

En: infocasas.com.pe

La tipología de viviendas callejones y las quintas se extendieron considerablemente por la ciudad de Lima para fines del siglo XX, donde la mayoría de la población popular vivía en ellos, ocupando hasta una manzana entera con dos salidas a diferentes calles. El callejón y el solar eran considerados como espacios públicos semi privados, un lugar de encuentro compartido que invitaba al diálogo, a la comunicación (Del Águila, 1995, p. 563).

Actualmente, los pasajes presentes en las viviendas siguen siendo espacios de socialización entre los vecinos, y se puede notar su presencia y variaciones en el distrito de Jesús María (ver figura 5.62). Los lotes rellenos de color rojo son los que predominan en el distrito siendo estas viviendas callejones lineales de 2 a 3 niveles de altura, seguido de los lotes rellenos de color morado que el pasaje tiene forma de $\mathrm{L}$ o $\mathrm{T}$ abarcando más espacio dentro de una manzana urbana y generando otro nivel de provacidad mientras más se aleja a la calle, asi también estan los lotes rellenos de color naranja que son callejones angostos que ingresan por una calle y salen por el otro lado de la manzana, mientras que los lotes rellenos de color marrón son aquellas que tienen un pasaje más amplio pero que es más parecido a un laberinto, finalmente estan las quintas rellenas de color magenta que tienen una lectura clara con un pasaje lineal y rematan en un patio interno. 

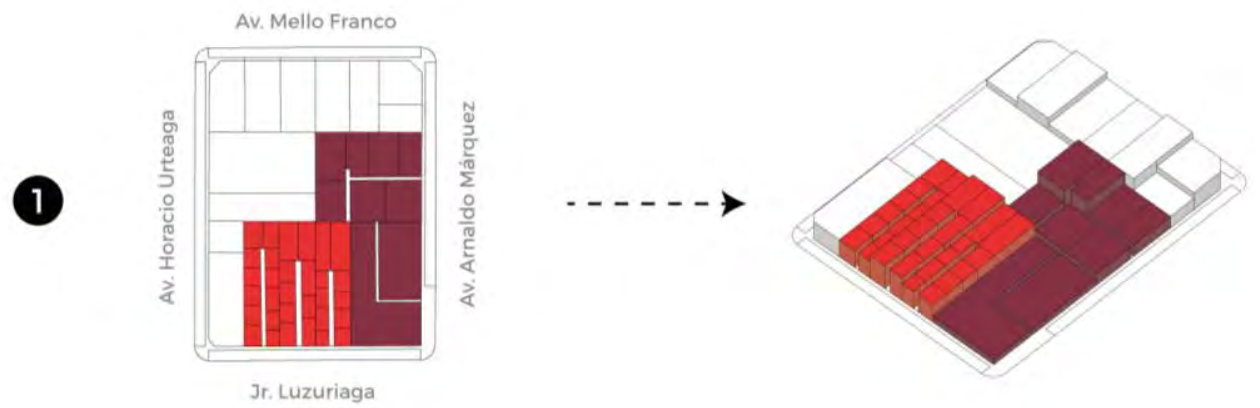

2
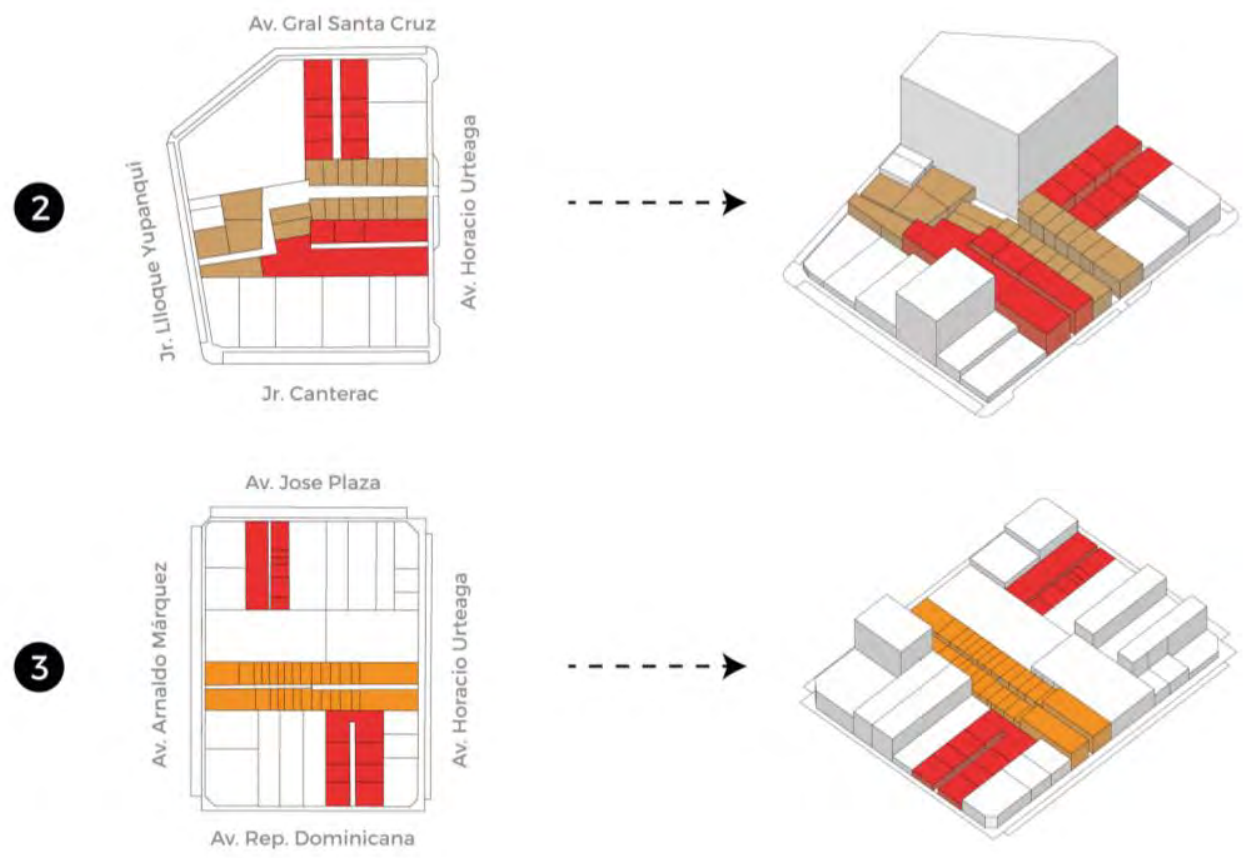

(4)
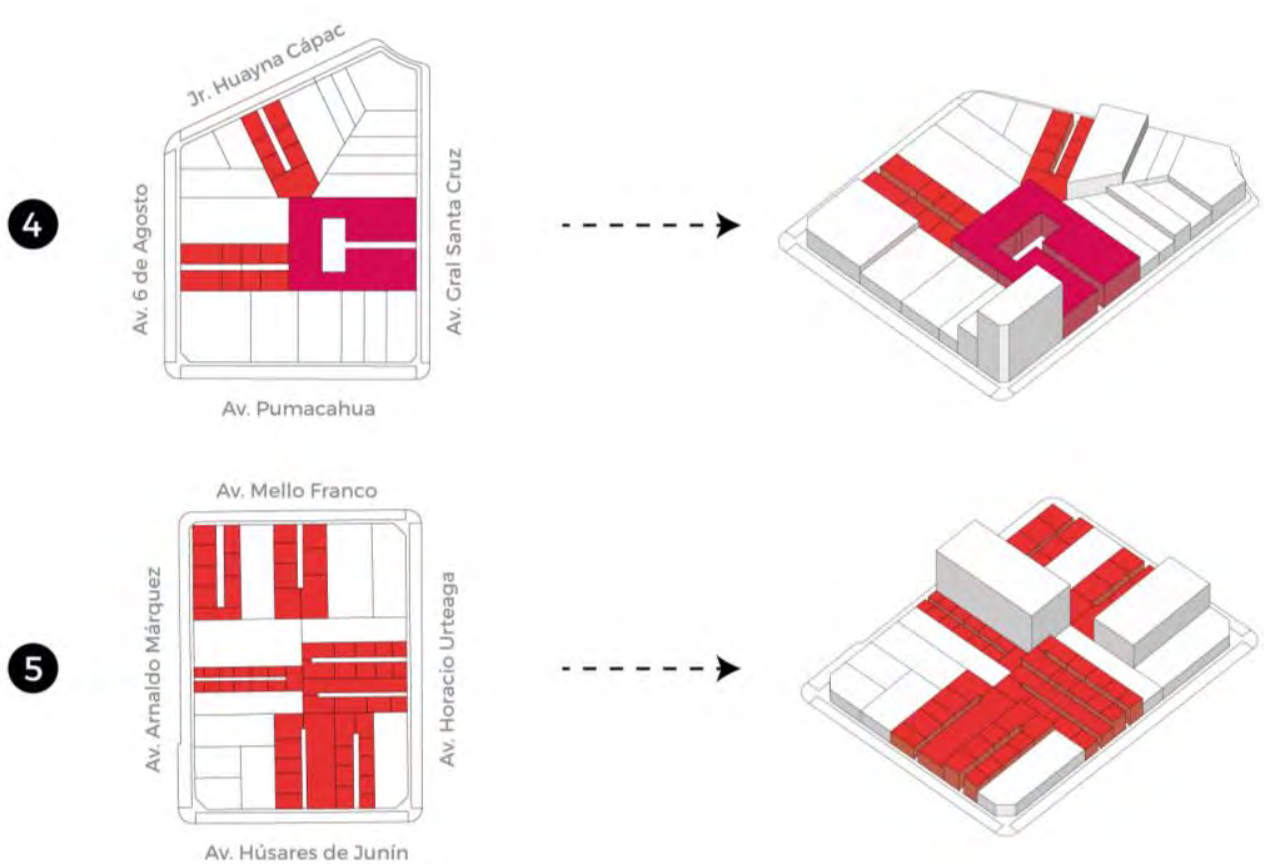

Figura 5.62 Tipos de pasajes en la trama urbana de Jesús María Gráfico realizado por los autores. 


\subsection{Conclusiones parciales}

En cuanto a los referentes análogos analizados muestran un emplazamiento distinto en cada uno de ellos debido al contexto en el que se encuentran, desde una zona con edificaciones de la época medieval con calles angostas, otro que sufrió muchos traslados durante su historia, y uno que se encuentra dentro del centro histórico de la ciudad. En cada uno de ellos, el mercado responde a su entorno y presenta una organización espacial distinta según sus necesidades. En el caso de los mercados remodelados en España como el Santa Caterina y el Dels Encants presentan plazas dentro del terreno del mercado especialmente en la zona de los ingresos o salidas, brindando espacio de ocio a la ciudad, por lo que la propuesta del Mercado San José también tendrá plazas internas que permitan fortalecer las interacciones sociales y al mismo tiempo generar espacios de ocio para los habitantes.

La cantidad de ingresos al mercado determina su grado de accesibilidad y la relación con su entorno, en los casos del Mercado Santa Caterina y el Mercado Central poseen 4 ingresos amplios, uno en cada fachada, mientras que en el Mercado Dels Encants tiene 11 ingresos en total, distribuidos perimetralmente generando un intercambio de flujos constante con el exterior y evitando las barreras arquitectónicas como muros ciegos. Actualmente el Mercado San José posee 6 ingresos, pero también tiene $164 \mathrm{ml}$ de muros ciegos, impidiendo que se relacione con su entorno, por lo que la propuesta del mercado suprimirá las barreras arquitectónicas y generará una mayor cantidad de ingresos para que se pueda relacionar con la Plaza San José, el pasaje Punta Pacochas y la Av. República Dominicana.

$\mathrm{Al}$ analizar las áreas de cada paquete programático, se muestra en general que en los tres mercados el área de servicio posee igual o mayor porcentaje que el área de ventas, debido a que en esta se encuentran los estacionamientos para los clientes, área de abastecimiento del mercado, depósitos, áreas de residuos, entre otros. Y se ubican en los sótanos de cada proyecto, ya que es una actividad que no se debe mostrar al público, evitando una mala imagen, y que se genere tráfico alrededor, debido a la duración y a todo el largo proceso que conlleva el abastecimiento del mercado. 
También se pudo observar que la zona de los puestos de venta o también llamado el main market, se diferencian en tamaño y distribución al programa complementario, debido a que estos no necesariamente están destinados a la venta de productos perecederos. Estos programas complementarios se designan dependiendo de lo que requiere el entorno en que se ubica el mercado, y es una particularidad de los mercados remodelados en España debido a que esto incrementa su afluencia y alarga su actividad en cuanto a las horas de atención, y al mismo tiempo satisface las demandas del consumidor local y extranjero. En el Mercado Santa Caterina, los programas complementarios fueron una zona arqueológica, unidades de vivienda, una zona de productos envasados y un bar/restaurante; mientras que en el Mercado Dels Encants generó una zona de subastas y el Street food que es un conjunto de puestos de comida con un patio con mobiliario que atienden hasta altas horas de la noche. Debido a esto, la propuesta del Mercado San José tendrá programa complementario, dependiendo de lo que necesite el distrito de Jesús María y relacionado al futuro Boulevard Gastronómico, pero estará separado de la actividad de los puestos destinados a la venta de productos perecederos.

En cuanto a los puestos de venta estos tienen una zonificación más clara dentro de los mercados remodelados, debido a que están unidos por rubro o giro, generando que los clientes puedan identificar rápidamente donde se encuentran los productos que desean comprar. Además, la mejor organización de los puestos de venta, es decir la configuración interna del mercado que pudimos observar en los casos análogos fue el del Mercado Santa Caterina, debido a que responde a la trama urbana de la zona en el que se encuentra el mercado, e imita los desplazamientos que realizan los habitantes diariamente. Por lo que la configuración interna del Mercado San José responderá a los desplazamientos realizados por los habitantes del distrito, y también se re zonificarán los puestos de venta para una lectura más clara de la organización del mercado y que los productos que se ofrezcan se complementen, generando una actividad comercial más funcional y amigable para los clientes. 
La cantidad de puestos por rubro depende de la identidad de cada mercado, por ejemplo, los rubros que predominan en el Mercado Santa Caterina son la venta de pescados y los menús relacionados con mariscos, debido a que se encuentra cerca del puerto marítimo de la ciudad; mientras que en el Mercado Dels Encants predominan los puestos para el hogar y las antigüedades porque tiene la identidad de ser lo que antiguamente se denominaba como mercado de pulgas. Por tales motivos, la propuesta del mercado debe fortalecer su identidad con los puestos de menús, generando un mayor porcentaje y área para este rubro, además de equiparlo internamente para que el comerciante realice los platos de manera óptima e higiénica, además de pensar en una zona para que los clientes puedan sentarse a comer.

En cuanto a la cobertura, este debe estar ligada a la estructura principal con la finalidad de generar grandes luces en el interior, y que en consecuencia permita que el flujo sea más libre, flexible y sin obstáculos. Además, la cobertura también permite el manejo de la iluminación y ventilación al interior del mercado, y muchas veces su diseño se configura como un hito en la ciudad. Por ejemplo, en el Mercado Del Encants la cubierta esta sostenida por pilares permitiendo una circulación fluida en su interior, y su morfología compleja con el revestimiento metálico le otorga una personalidad única al establecimiento posicionándola como ícono de la ciudad. En el Mercado Santa Caterina, la cobertura tiene la función de ser la quinta fachada del proyecto, debido a que los edificios a su alrededor tienen visual directa hacia el techo del mercado. Y en el caso del Mercado Tirso de Molina es en base de un módulo de estructura metálica que se repite para controlar la iluminación. Entonces, la propuesta debe generar una cobertura que posea pocos apoyos y no impida con la circulación del mercado, a su vez debe protegerlo del asoleamiento y permitir una correcta circulación de los vientos, además de que esta cobertura deba posicionar al mercado como un hito de la ciudad ya sea por su forma y su materialidad.

La remodelación del Mercado La Barceloneta es uno de los pocos mercados que posee un espacio público aledaño en donde se desarrolla la actividad cívica, incrementando su valor como equipamiento comercial. Para el diseño de la plaza se usaron 3 variables que pueden ser aplicadas al proyecto como: el mantener la ubicación 
de los accesos orientadas hacia las calles, colores de los materiales y diseño visual del pavimento que delimita usos y funciones diferentes, y por último el uso de la vegetación en mayor o menor cantidad dependiendo del uso y a cuan cerca de la calle se encuentra.

Una de las variantes que se encontraron en el distrito son las quintas, por lo que se decidió analizar la dinámica y su funcionamiento. Los pasajes de las quintas son espacio semi-públicos debido a que no hay un acceso restringido y permite un ingreso gradual de los vecinos y los visitantes. Es en estos pasajes donde se generan interacciones sociales y donde se genera ciudadanía, y que muchas de estas quintas terminando el pasaje rematan en un patio, por lo que la idea de pasaje como filtro y eje para que remate hacia un espacio abierto puede ser reinterpretada y adoptada al proyecto.

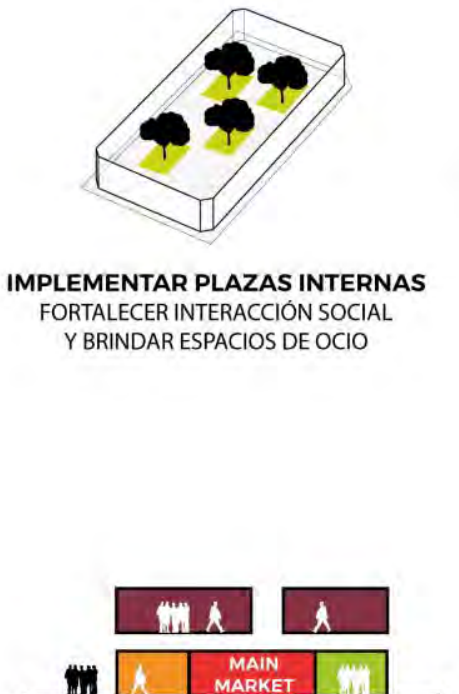

PROGRAMA COMPLEMENTARIO IMPLEMENTAR USOS MIXTOS Y SEPARAR EL PROGRAMA DEL MAIN MARKET

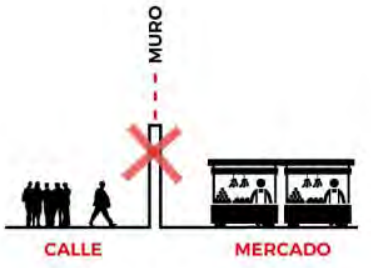

SUPRIMIR BARRERAS ARQ. MAYOR ACCESIBILIDADY RELACIÓN CON EL ENTORNO

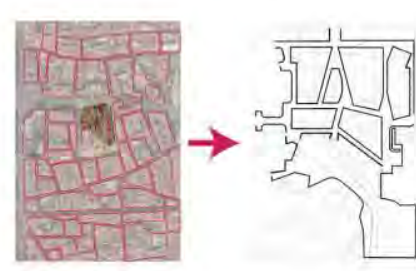

DESPLAZAMIENTOS HABITUALES

CIRCULACIÓN INTERNA IGUAL A LA TRAMA URBANA

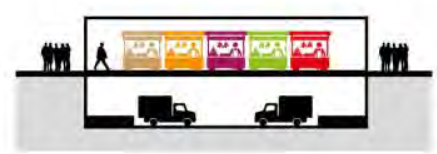

ABASTECIMIENTO EN SÓTANO SEPARAR ÁREA DE SERVICIOS DEL MAIN MARKET

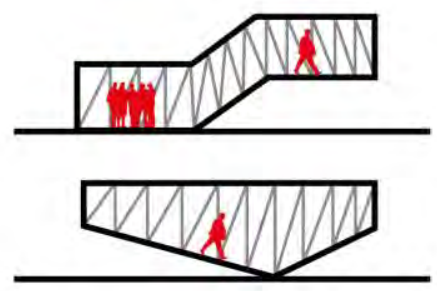

VARIACIÓN ESPACIAL USO DE LAS CARACTERÍSTICAS DE LAS CERCHAS METÁLICAS

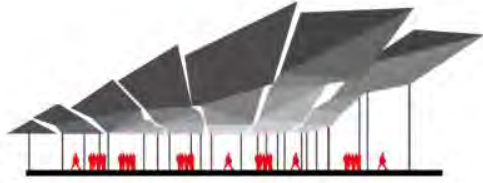

COBERTURA COMO HITO CONTROLAR ILUMINACIÓN, VENTILACIÓN Y DESPERTAR AFECTOS Y EMOCIONES EN LOS HABITANTES.

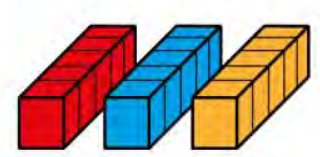

RE-ZONIFICACIÓN RE ORGANIZAR TODOS LOS PUESTOS DE VENTA SEGÚN SU RUBRO Y RUBRO QUE LO COMPLEMENTE.

Figura 5.63 Lógicas_Marco Operativo

Gráfico elaborado por los autores. 

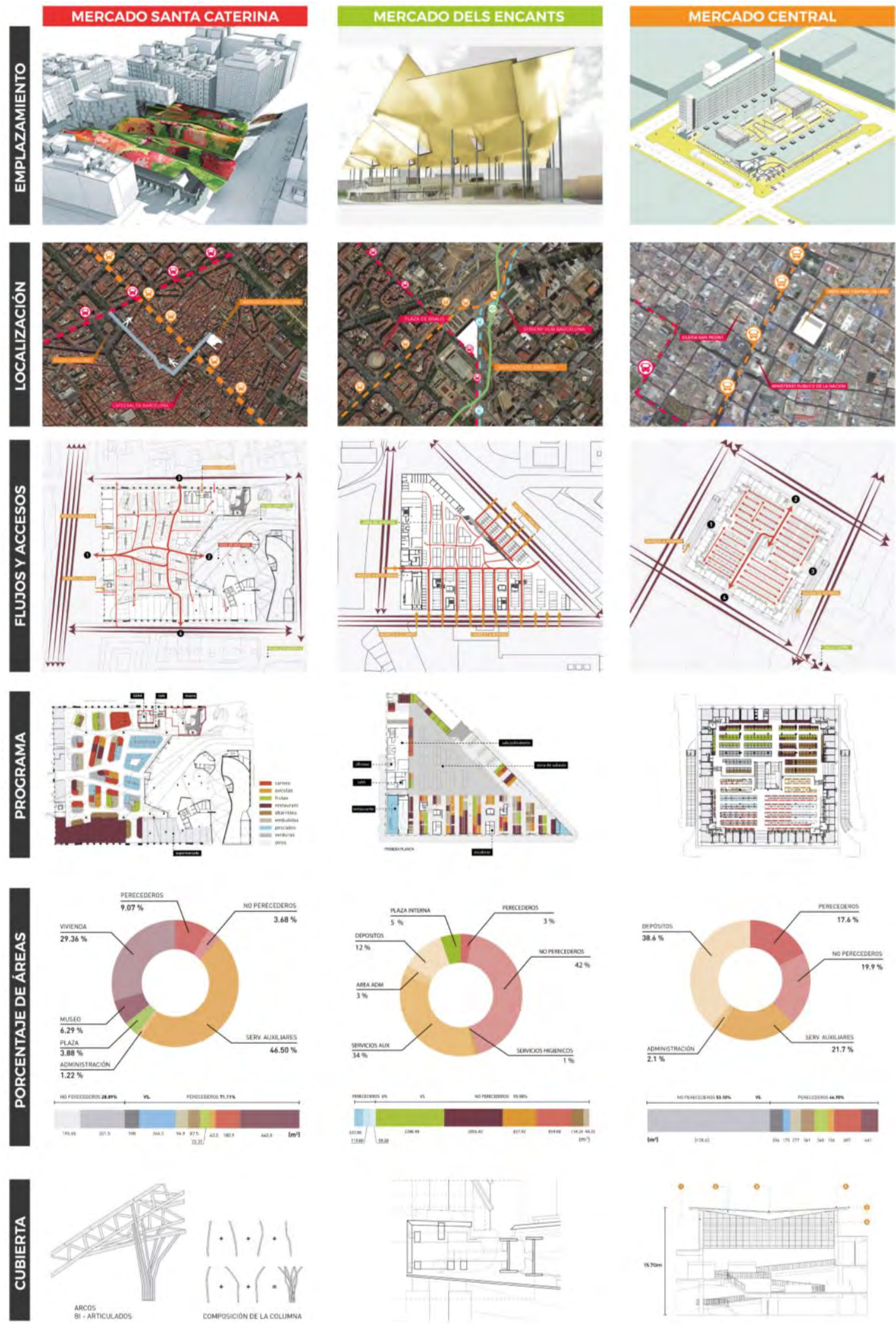

Figura 5.64 Comparación de casos análogos

Gráfico elaborado por los autores. 


\section{CAPÍTULO VI: Marco contextual}

\subsection{Redes de equipamiento y radio de influencia}

Para entender el nivel de abastecimiento de Lima es necesario analizar la cantidad de mercados de abasto y su distribución dentro de la ciudad. En el último censo de mercados de abasto realizado por el Instituto Nacional de Estadística e Informática, muestra el crecimiento de estos equipamientos en un $138.1 \%$ durante los últimos 20 años en el país, es decir, de 1097 mercados registrados en 1996 pasó a 2612 en el 2016, debido al crecimiento de la economía y de la población. Además, la ciudad de Lima concentra el 47,2\% (1 232) del total de mercados en el país, debido al tamaño de su economía regional y al aporte que tiene en el PBI del país (Instituto Nacional de Estadística e Informática, 2017, p. 11).

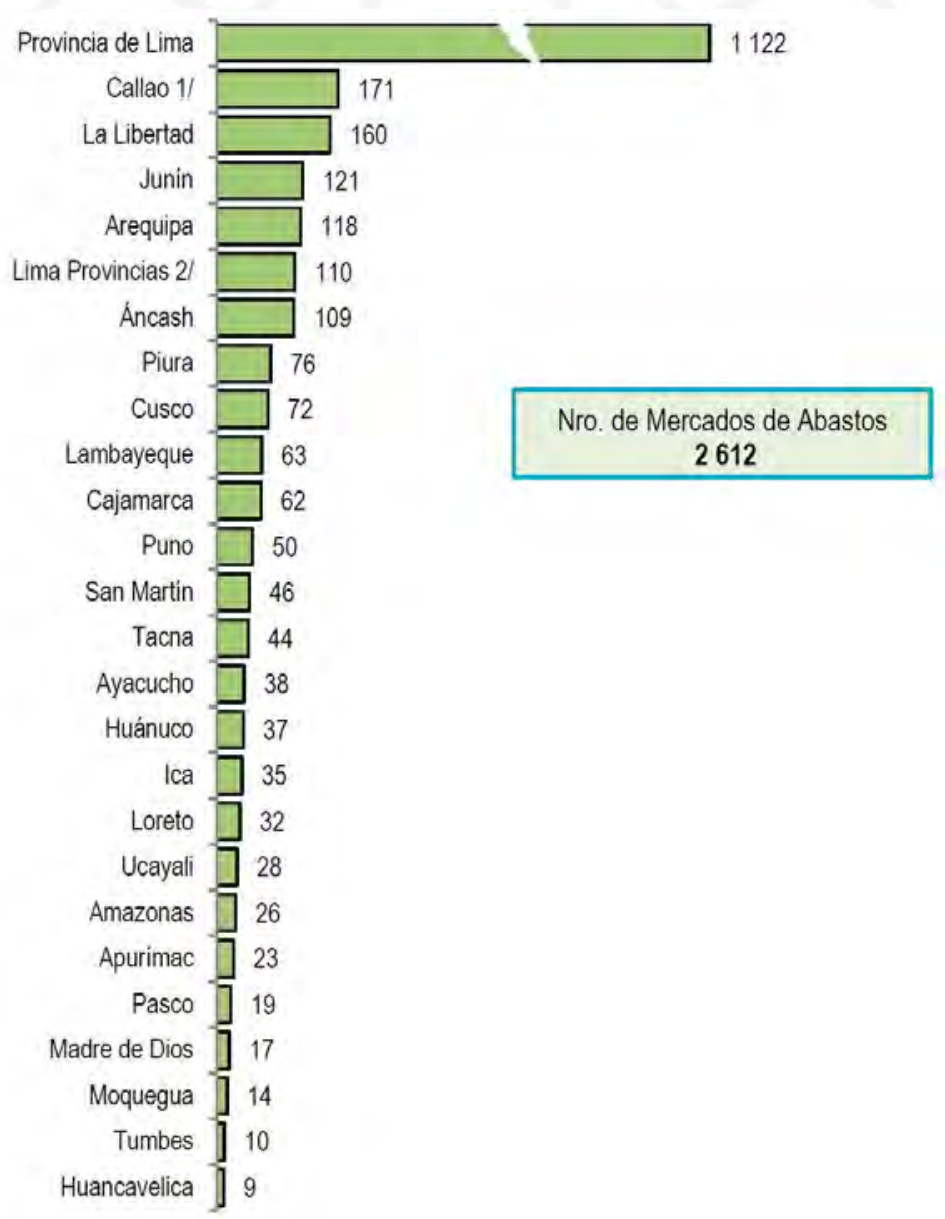

Figura 6.1 Mercados registrados según departamento

Fuente: INEI, 2017 
Pero los mercados de Lima no se encuentran correctamente distribuidos, ya que tan solo cinco distritos concentran el $40 \%$ del total de estos equipamientos, estos distritos son Callao, Comas, San Juan de Lurigancho, San Martín de Porres y Ate, los cuales poseen más de 100 mercados cada uno. Mientras que, en los distritos como La Punta, San Isidro, Miraflores, Barranco, La Molina, Magdalena, y Jesús María poseen menos de 11 mercados cada uno, concentrando tan solo el 4\% del total de mercados que hay en Lima (Consultora CCR, 2014, p. 5).

Esta irregularidad del servicio de mercados en la ciudad, de algún modo explica ciertos comportamientos del asentamiento poblacional, ya que los distritos que poseen mayor cantidad de mercados son los que tienen una población mayor debido a las migraciones, y los distritos que carecen de este se debe a la expansión del canal moderno (Consultora CCR, 2014, p. 5).

Si bien parece que la distribución de estos mercados fuera parte de un plan que se ejecutó rigurosamente, no es así, sino que fue un proceso paulatino por efecto propio de las economías de oferta y demanda. Lo resaltante es que más del $80 \%$ de los mercados son gestionados por cooperativas y asociaciones de comerciantes, $\mathrm{y}$ han sido capaces de asentarse, crecer y consolidarse como parte fundamental de la vida cotidiana de la ciudad. Pero al carecer de asesoría profesional y al poco apoyo de las municipalidades, existe una constante amenaza debido a la falta de salubridad y a su infraestructura inadecuada que funciona al margen de la normativa del país, presentando que 3/4 partes de los centros de abasto son informales o no están registrados (Leung, 2016, p. 44).

Además, existen varios vacíos en Lima que no disponen de mercados tradicionales, de los cuales muchos se deben a los tipos de actividades propuestos por planes urbanos (Ver Figura 6.2) como el Aeropuerto Jorge Chávez, el puerto marítimo, zonas agrarias, zonas recreativas y antiguos polos industriales. Y otros vacíos se deben a que los mercados se concentran en las principales arterias urbanas, a la demanda de los distritos con alta densidad poblacional, o a la distancia del mercado a las viviendas en relieves de mucha pendiente condicionando al poblador a visitar a los más cercanos (Leung, 2016, p. 48). 
Así también, existe un vacío en la parte sur del distrito de Lima Cercado, centro histórico de la ciudad, que no presentan mercados, pero sí poseen gran cantidad de edificaciones residenciales de densidad media y alta, edificaciones de usos mixtos, y alto flujo vial, por lo que decidimos profundizar más sobre esta zona para obtener los motivos de la ausencia de mercados.

Y al contrastar la red de mercados de Lima con el mapa de ingreso per cápita por hogar, pudimos notar una similitud del déficit de mercados con las familias que poseen un nivel adquisitivo medio y alto (Ver Figura 6.3 y Figura 6.4). La relación de la población con mayor nivel adquisitivo con la cantidad de mercados por $\mathrm{Km}^{2}$, nos hace pensar en cómo se abastecen estas familias con tan poca cantidad de mercados, por lo que se contrastó su distribución con la de los supermercados, y efectivamente se demuestra la relación del vacío con el formato de autoservicio (Ver Figura 6.5).

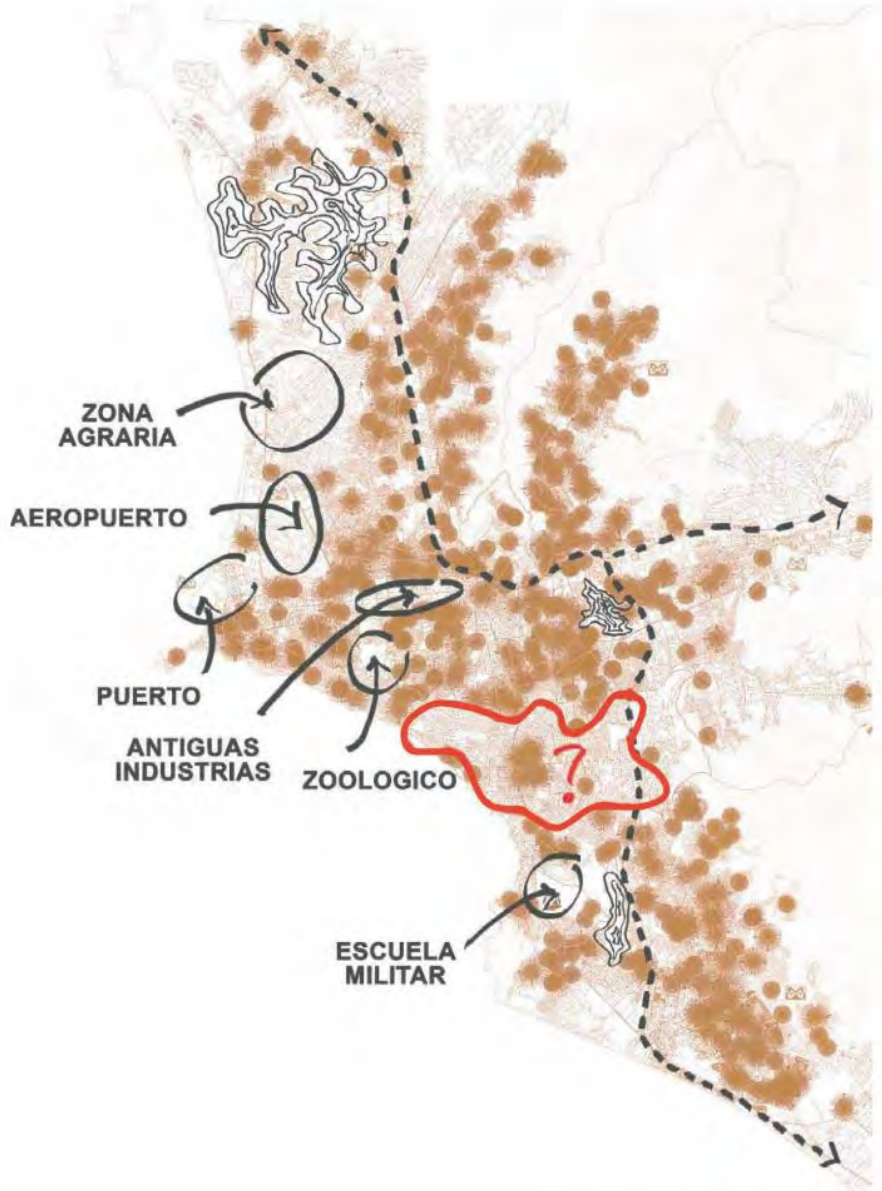

Figura 6.2 Red de mercados de Lima

Fuente: Jauyin Leung, 2016 


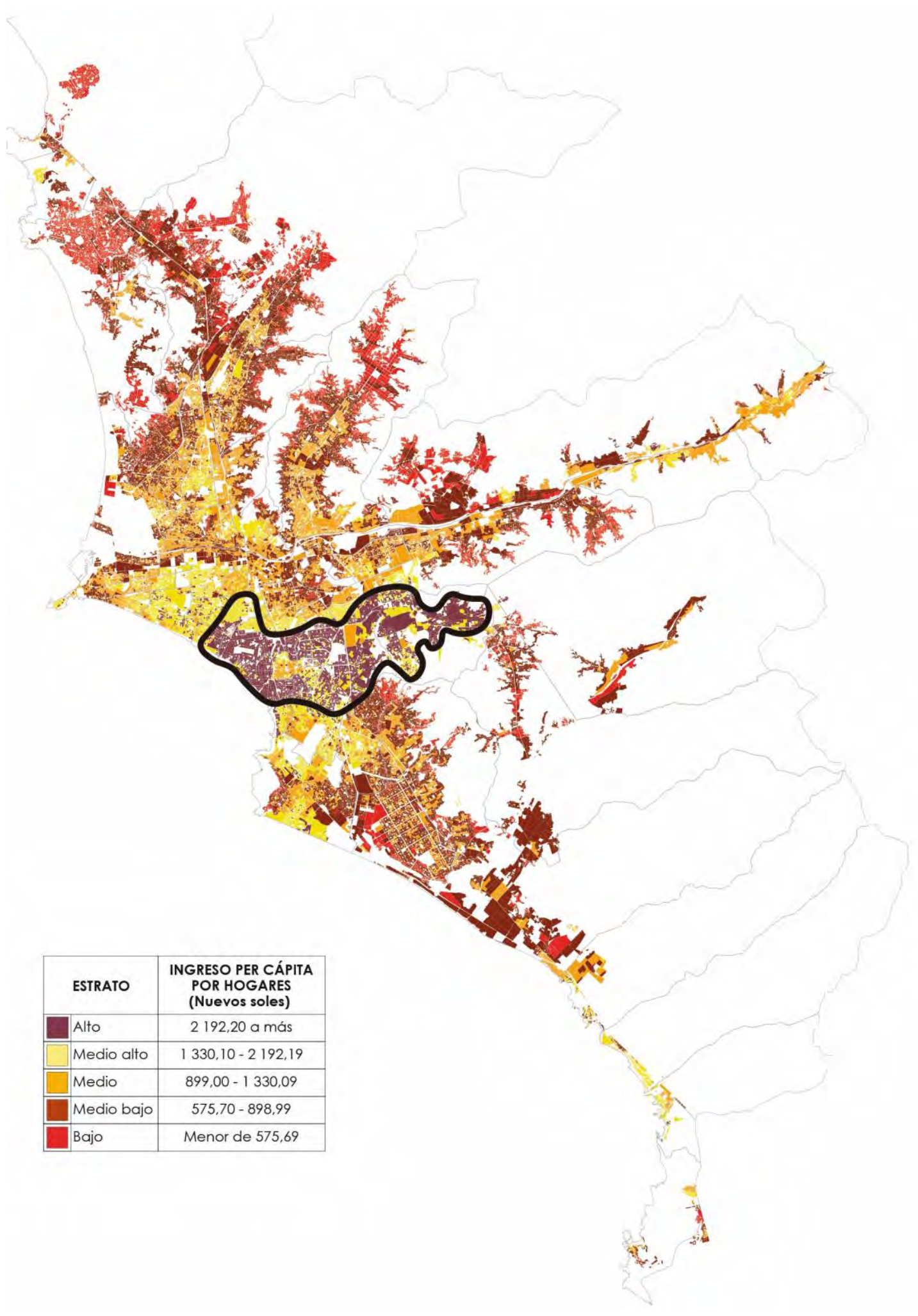

Figura 6.3 Ingreso per cápita del hogar - Lima 2016

Gráfico realizado por los autores, según mapa de ingreso per cápita del hogar del INEI, 2016. 


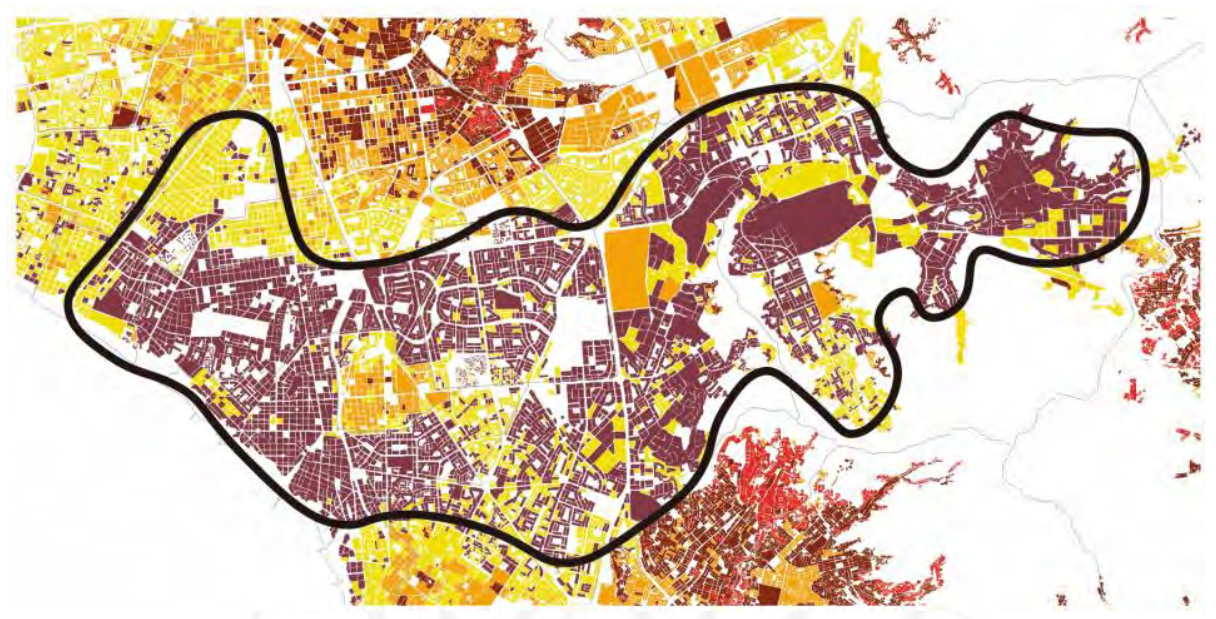

Figura 6.4 Vacío de mercados vs ingreso per cápita

Gráfico realizado por los autores, según mapa de ingreso per cápita del hogar del INEI, 2016.

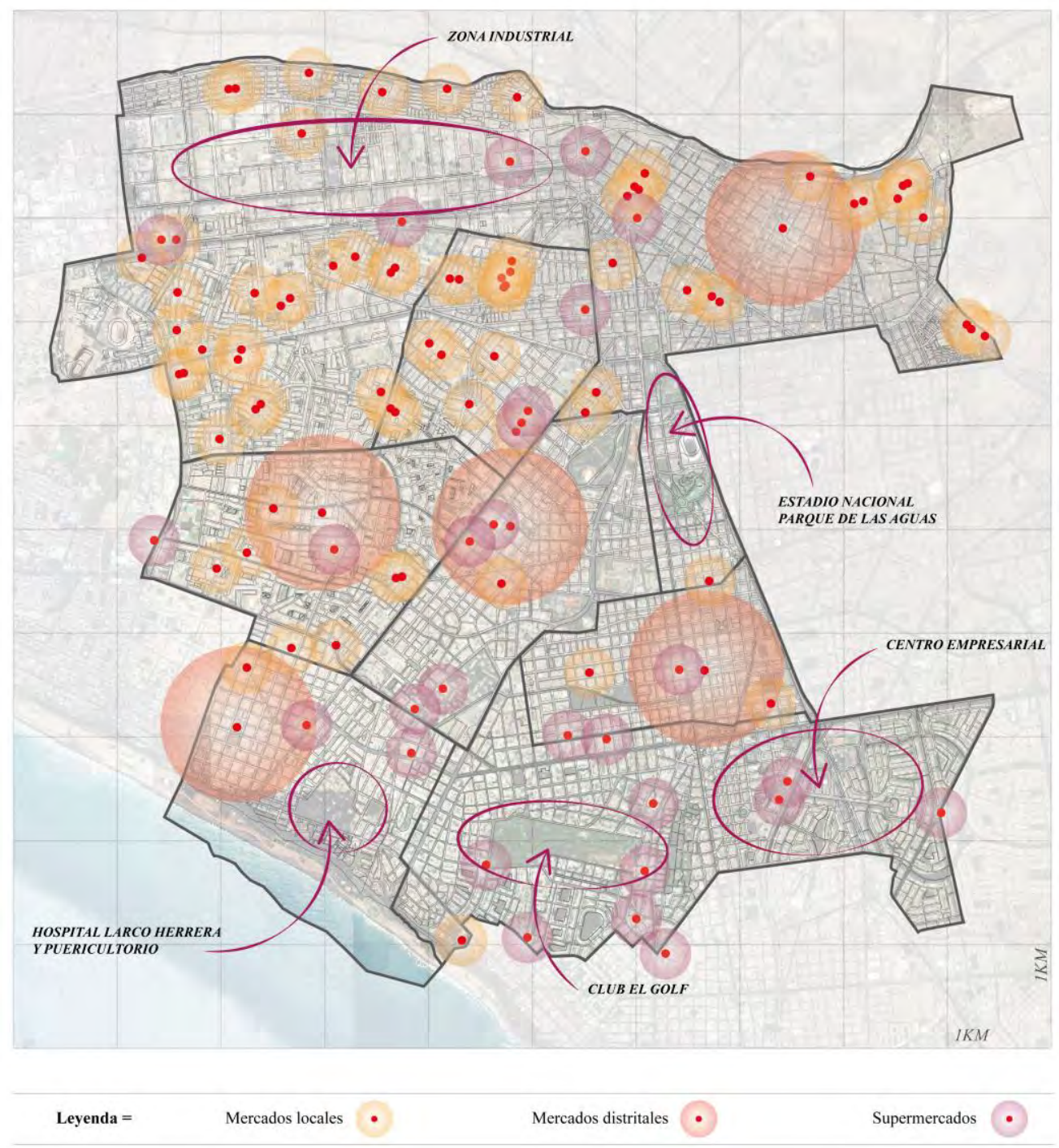

Figura 6.5 Mercados vs Supermercados

Gráfico elaborado por los autores. 
Si bien el mercado tradicional sigue siendo el formato comercial de preferencia de los peruanos, su crecimiento del número de establecimientos ha sido mucho menor que el de los supermercados, los cuales aumentaron un 529,4\% del 2007 al 2016, mientras que los mercados tradicionales un 62,7\% de 1990 al 2016, reflejando que la aceptación a estos formatos de autoservicio continúa en aumento, debido a que cumplen con las demandas y exigencias del consumidor actual, obteniendo como consecuencia la desaparición o reemplazo de los mercados de abasto como lo sucedido con el Mercado Central de Barranco, que actualmente es un Supermercado Metro (Rodríguez, 2014; Leung, 2016).

Diana Baquero (2011) establece que la desaparición de los mercados tradicionales en Bogotá se debe directamente a los nuevos formatos comerciales:

Las plazas de mercado decayeron por el descuido administrativo y la generación de un nuevo modelo de abastecimiento más atractivo para la población donde la confluencia de servicio, la accesibilidad en el transporte masivo y la novedad de los nuevos nodos comerciales atrajeron a la nueva población y se desplazó el concepto de la plaza de mercado de un lugar para el encuentro social y con valor histórico a un espacio donde predomina el deterioro espacial y de uso exclusivo para las personas de bajos recursos económicos. (p. 15)

Beatriz Filgueiras (2006) también cuenta sobre la repercusión en los mercados ante la llegada de los nuevos formatos comerciales:

Esos procesos hicieron que en algunas partes, los mercados paulatinamente desaparecieran por completo, como por ejemplo, en las principales ciudades brasileñas. En las grandes ciudades de Brasil donde todavía existen, son mantenidos como vestigios de otros tiempos (y de otra ciudad), sufren intensos procesos de transformación y son disputados por y/o integrados a proyectos de conservación del patrimonio histórico-cultural y de incentivo al turismo. (p. 74) 
Como se pudo ver anteriormente, existen vacíos de mercados en ciertas partes de la ciudad, pero para entender mejor su distribución es necesario analizar el nivel de abastecimiento de cada distrito político, debido a que cada municipalidad distrital es responsable de los mercados pertenecientes a su territorio, a diferencia de Barcelona que su gestión es regulada por una sola entidad.

Para el presente estudio se clasificará el abastecimiento de la zona central de Lima (Ver Figura 6.6), debido a que presenta una disminución considerable en la existencia de mercados de abasto, y también porque esta zona de la ciudad tiene mucho más tiempo de consolidación porque conformaron la Lima colonial y post colonial (Leung, 2016, p. 58).

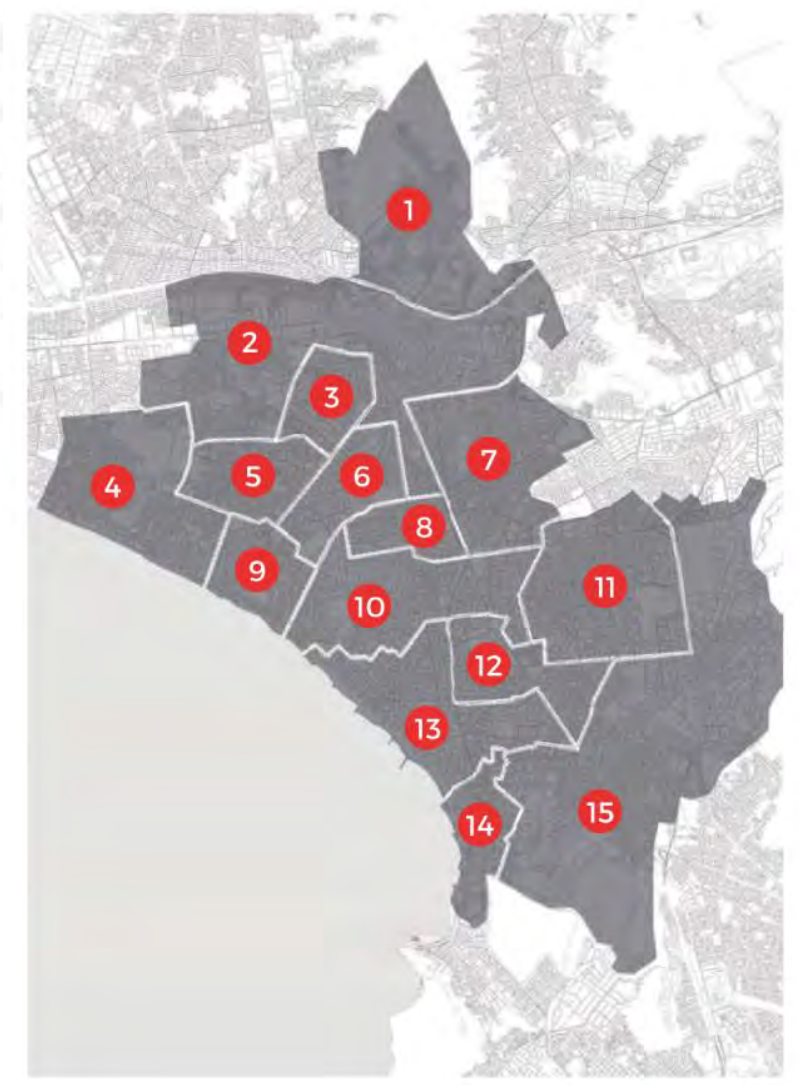


Utilizando los radios de influencia para mercados de abasto designado en el PLAM 2035 (Ver Figura 6.7), realizando un mapeo de los mercados tradicionales en cada distrito, y revisando el índice poblacional de cada uno, podremos clasificar los distritos de la zona central de Lima en: distritos abastecidos, des- abastecidos, y sobre- abastecidos por mercados tradicionales (Ver Figura 6.8).

\begin{tabular}{|c|c|c|}
\hline EQUIPAMIENTO & UBICACIONN Y ACCESIIILIDAD & $\begin{array}{l}\text { POBLACION } \\
\text { ATENDIDA }\end{array}$ \\
\hline $\begin{array}{l}\text { MERCADO LOCAL } \\
\text { (Escala Local) }\end{array}$ & $\begin{array}{l}\text { Su ubicación debe promover acceso de modos sostenibles (ver el Sistema de } \\
\text { Movilidad), con énfasis en acceso peatonal y a través de ciclovias, con recorridos } \\
\text { caminables, directos y en un entorno seguro y adecuado. } \\
\text { La dotación de las Mercados Municipales debe tener en cuenta un radio de } \\
\text { cobertura ideal de entre } 500-1,500 \text { metros, aproximadamente } 15-20 \text { minutos } \\
\text { caminando. }\end{array}$ & $\begin{array}{l}1 \text { por cada } 10,000 \\
\text { habitantes }\end{array}$ \\
\hline
\end{tabular}

Figura 6.7 Población atendida por mercado

Fuente: Instituto Metropolitano de Planificación, 2014

Los distritos abastecidos por mercados tradicionales son aquellos que tienen una distribución regular de sus mercados dentro de su territorio, por lo que los distritos de Pueblo Libre, San Miguel, Breña y Lince, cumplen con las condiciones. Realizando una comparación de estos distritos se puede notar que ninguno sobrepasa el índice de 1 mercado cada 10000 habitantes, lo que demuestra una correcta cantidad de establecimientos. Además, poseen una gran cantidad de habitantes por $\mathrm{Km}^{2}$, debido a su centralidad dentro de la ciudad, y por ser distritos planificados, es por eso que sus perímetros son geométricamente regulares. Muchos de estos, también son de estrato socioeconómico medio y los usos de suelo que predominan son el residencial y comercial.

Los distritos des-abastecidos por mercados tradicionales son los que no poseen una buena cantidad de mercados y los que sí poseen no se encuentran correctamente distribuidos en el territorio. Muchos de los distritos que se encuentran dentro de esta clasificación cedieron espacio a los formatos comerciales de autoservicio, especialmente los distritos con mayor poder adquisitivo como Jesús María, San Borja, Miraflores, Barranco y San Isidro. 
DISTRITOS ABASTECIDOS
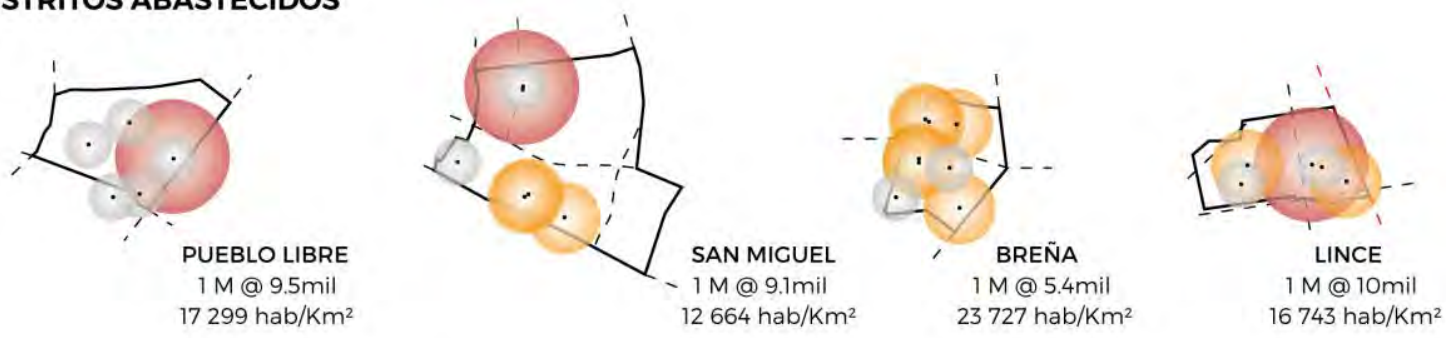

DISTRITOS DES ABASTECIDOS
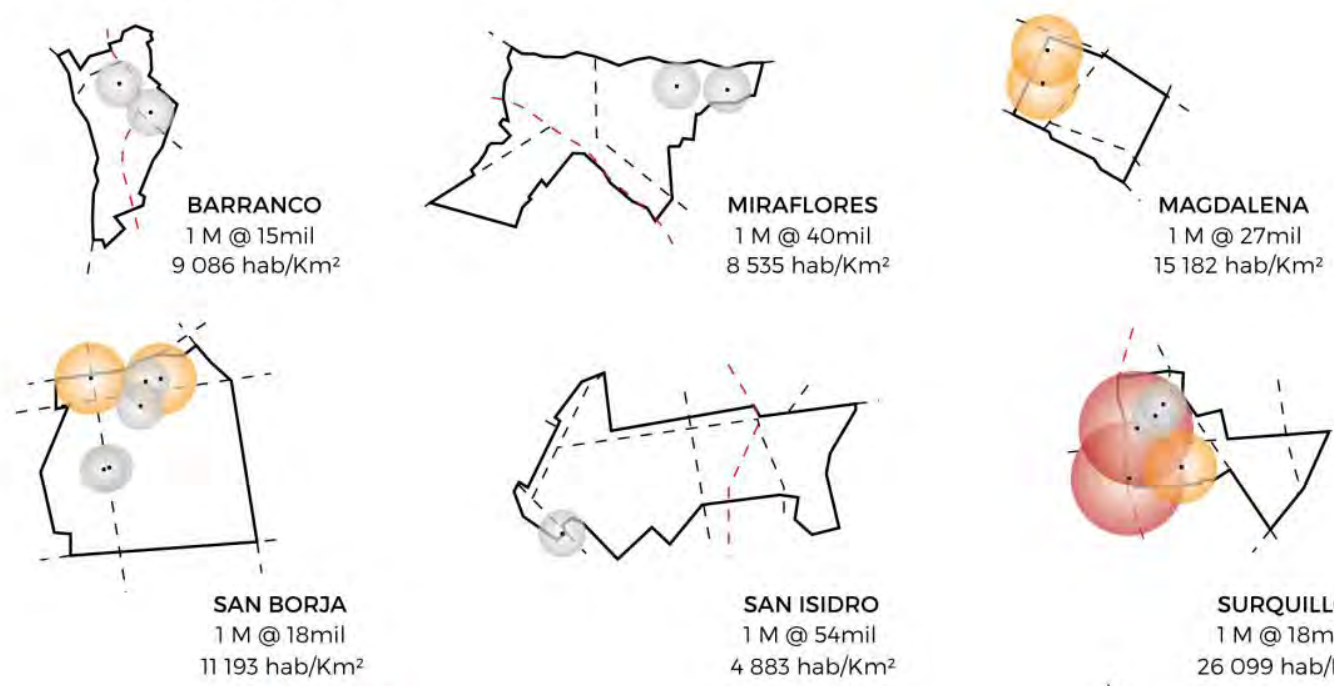

SURQUILLO

$1 \mathrm{M}$ @ 18mil $26099 \mathrm{hab} / \mathrm{Km}^{2}$
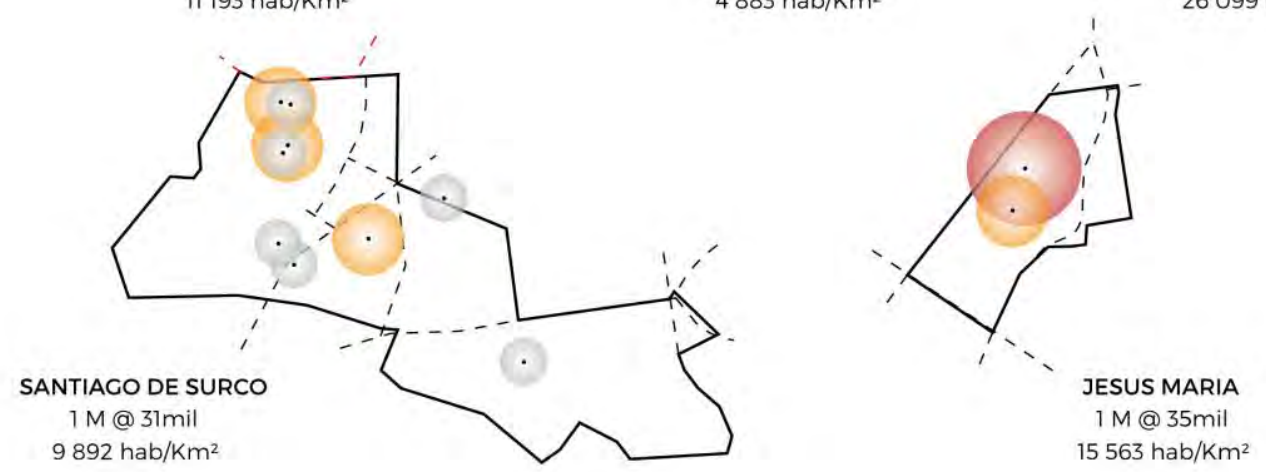

\section{DISTRITOS SOBRE ABASTECIDOS}
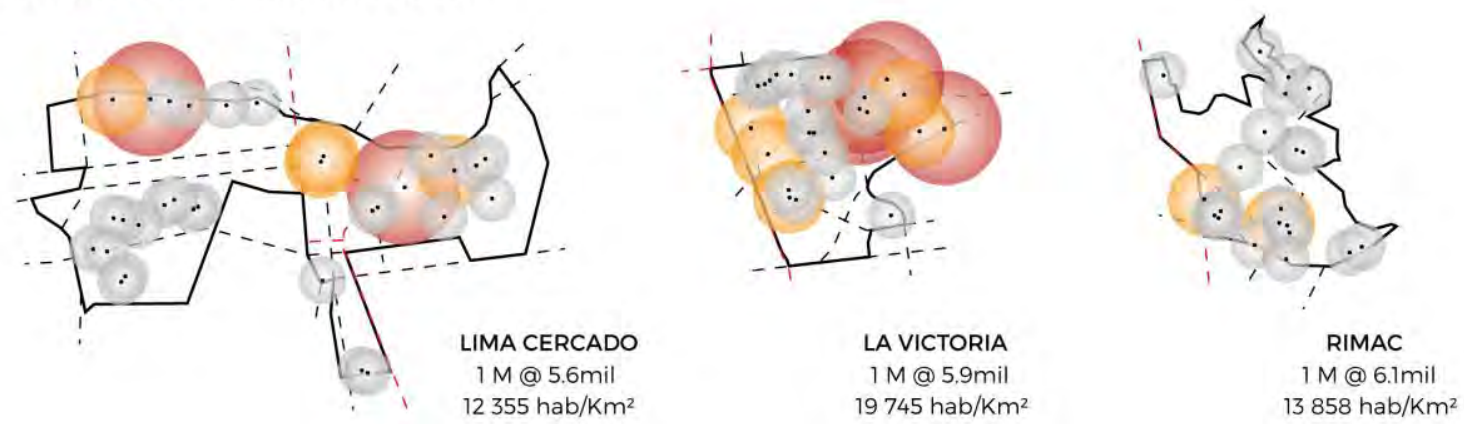

Figura 6.8 Clasificación de abastecimiento de distritos de Lima Centro

Gráfico elaborado por los autores. 
Los distritos de Magdalena, Surquillo y Santiago de Surco son casos especiales, ya que poseen mercados en un solo lado del distrito, mientras que el otro se encuentra desabastecida, debido a su proximidad con los distritos de NSE alto y por efectos de gentrificación. Además, Miraflores, San Isidro y Jesús María son los distritos que menor cantidad de mercados poseen, pero sólo el Mercado San José de Jesús María es el que tiene un radio de influencia de escala distrital y tiene una ubicación céntrica por lo que su presencia en el distrito en cuanto a niveles de abastecimiento es muy importante, no como el Mercado Municipal de San Isidro y los dos mercados de Miraflores que tienen poca presencia y se encuentran aislados territorialmente.

$Y$ en cuanto a los distritos sobre-abastecidos son aquellos que poseen un excedente en la cantidad de mercados en su territorio como Lima Cercado, La Victoria y el Rímac. Estos distritos conformaron la Lima colonial y post-colonial, ubicadas cercanas a las murallas que luego de su derrumbe comenzaron las expansiones sin planificación, lo que por años presentó un crecimiento desordenado, impulsado por el fenómeno migratorio, originando la creación de nuevos mercados por necesidad de abastecimiento, pero principalmente como oportunidad de negocio independiente. Otro de los motivos es por su centralidad espacial y actividad económica, pues se debe transitar por sus vías para cruzar la ciudad. Estos distritos mayormente son de densidad media y la población tiene un nivel adquisitivo bajo, y como usos de suelo predomina los edificios residenciales, así como los de actividad comercial, solo el centro histórico alberga instituciones gubernamentales.

Identificados los niveles de abastecimiento de cada distrito, se puedo notar que hay ciertos mercados que tienen un mayor radio de influencia que otros, por lo que se analizarán los motivos, catalogarán y agruparán de acuerdo a su emplazamiento en la trama urbana, para determinar sus características y las dinámicas que generan en su entorno. Los tipos de mercados se catalogarán de la siguiente manera: Mercados en medianeras, mercados en esquina, mercados pool, mercados patio, mercados plaza y mercados centrales. 
a. Los mercados que se ubican en medianeras son aquellos que se emplazaron en una parcela de la manzana urbana, es la tipología que más predomina en la zona central de Lima (Ver Figura 6.9) y en la mayoría de casos son mercados que surgieron sin planificación, por eso poseen problemas espaciales y carecen de dotaciones comunes que impiden su correcto funcionamiento, ya que se encuentran contenidos impidiendo su crecimiento, por eso su radio de influencia es de tan solo $0.5 \mathrm{~km}$. En muchos de ellos, los trabajos de abastecimiento del mercado se realizan fuera del establecimiento, produciendo congestión vehicular, suciedad, y desorden en la vía pública.

Estos mercados también pueden tener variaciones como la accesibilidad, pudiendo contar con uno o dos ingresos como el Mercado Chacra Colorada de Breña; o como la irregularidad de la parcela que permite que el mercado ocupe los vacíos existentes en la manzana urbana como el Mercado Moderno de Jesús María que es la unión de dos parcelas y un vacío (Ver Figura 6.10). Las ventajas de estos mercados es que pueden originar una dinámica donde antes no existía, abasteciendo a barrios pequeños que carecían de mercados y ofreciendo una oportunidad de empleo para los comerciantes.

b. Los mercados ubicados en esquinas son los que ocupan parcelas ubicadas en las esquinas de las manzanas urbanas, en la mayoría de casos se encuentran al lado de una vía muy transitada. Se distinguen por tener doble frente y más de un acceso, son de tamaño más regular y de mayor dimensión, lo que los hace más atractivos y con mayor presencia dentro del barrio donde se ubican (Ver Figura 6.10).

c. En cuanto a los mercados patio, son un caso muy peculiar dentro de la zona central de Lima, debido a que son mercados que se encuentran dentro de otro edificio, o lo que originalmente vendría a ser su patio. Estos establecimientos suelen ser de grandes dimensiones, muchas veces ocupan media manzana urbana, pero al darse la actividad comercial en el interior y compartir otro uso, su acceso es restringido. Por ejemplo, en el Mercado Modelo de Magdalena la actividad comercial sucede en el patio interior, y los edificios perimetrales presenta comercio en la planta baja y el 
resto son de uso residencial. Esta tipología puede ser tomada como un modelo de utilizar los mercados con usos mixtos que complementen la actividad del mercado y convertirse en catalizadores urbanos por su colectividad a través de hábitos cotidianos (Ver Figura 6.11).

d. Los mercados plaza son los que ocupan una manzana entera dentro de la trama urbana de la ciudad, su uso es exclusivamente la alimentación perecedera y tienen múltiples ingresos lo que facilita el ingreso y la salida del establecimiento. Estos mercados son de forma regular, debido a que su ubicación es intencional y planificada, son autónomos al no compartir área con otras construcciones, pero que tienen la facilidad de adaptarse a posibles remodelaciones y ofrecer nuevos servicios a los vecinos (Ver Figura 6.11).

e. Los mercados centrales perfectamente pueden estar dentro de las dos anteriores, pero se destacan por la gran dinámica que han generado en los distritos en los que se ubican, esto se debe a que originalmente fueron planificados, convirtiéndose en puntos de centralidad, al consolidarse y generar una memoria con los habitantes. Todos los mercados dentro de esta clasificación han provocado mucha actividad comercial entorno al mercado, y además poseen un alto flujo peatonal y vehicular, por lo que sus radios de influencia llegan a $1.5 \mathrm{Km}$ por ser referentes urbanos (Ver Figura 6.12).

f. Los mercados pool se destacan por estar articulados con otros equipamientos, es decir que la actividad del mercado no es la única, sino que su dinámica se fortalece por la presencia de otros edificios ya sean residenciales, religiosos, educativos, deportivos, salud y recreacionales. Un ejemplo es el Mercado Santa Rosa que forma parte del Conjunto Habitacional Palomino, dotado de edificios educativos, religiosos y deportivos aledaños al mercado, dando soporte y abastecimiento a todos los habitantes del conjunto y sus alrededores (Ver Figura 6.12). 


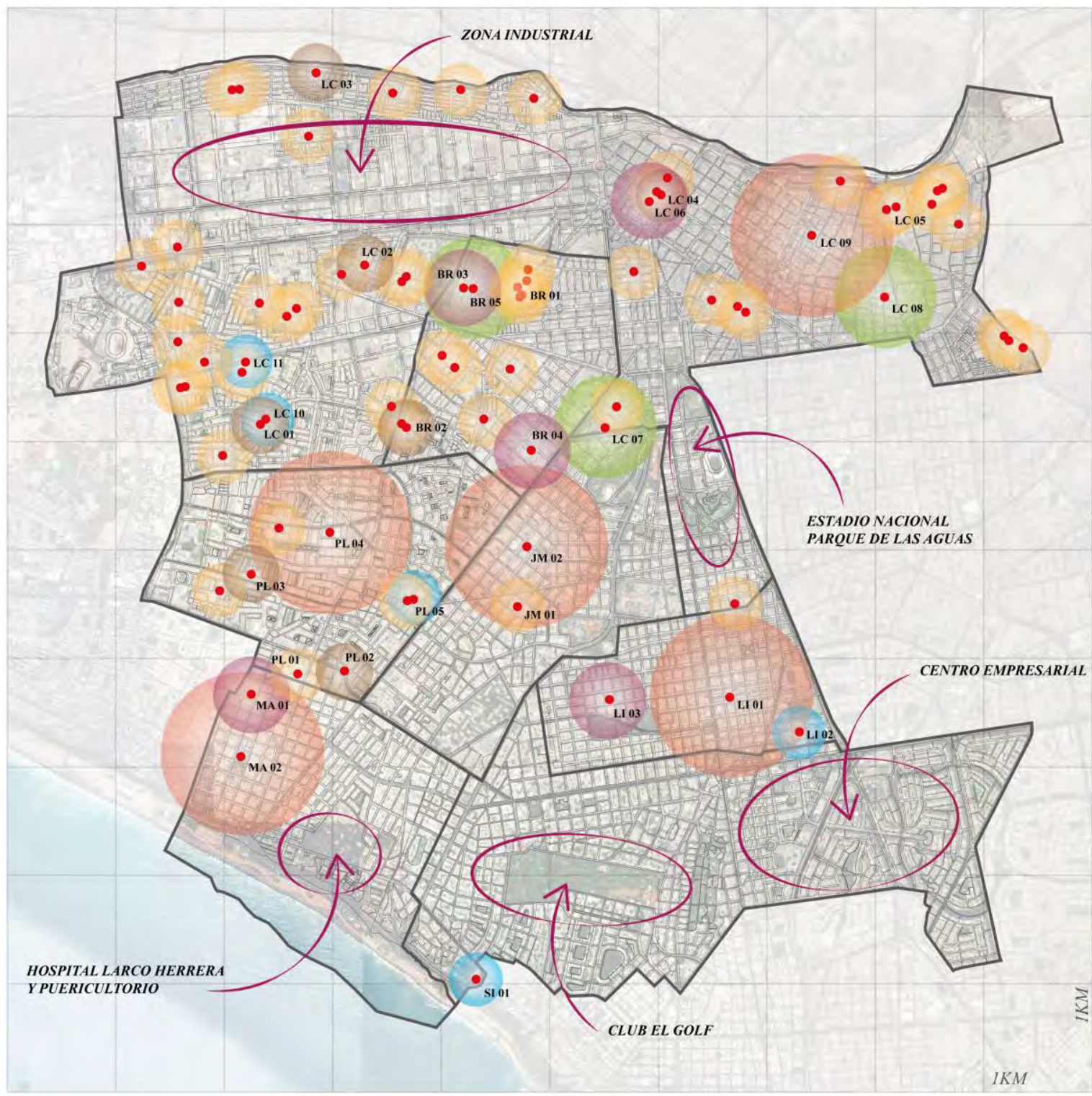

\section{Leyenda}

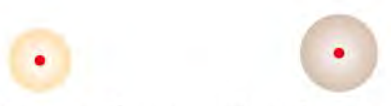

Mercados en medianera Mercados en esquina

$0.5 \mathrm{Km}$

$0.6 \mathrm{Km}$

Mercados Pool

$0.6 \mathrm{Km}$
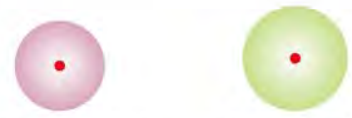

Mercados Patio

Mercados Plaza

$1.0 \mathrm{Km}$

Mercados Centrales

$0.8 \mathrm{Km}$

$1.5 \mathrm{Km}$

BR 01 $=$ Chacra Colorada

BR 02 = Nosiglia

JM 01 $=$ Moderno

LC $01=1$ de Mayo

LC $02=$ Condominio

LC $\mathbf{0 3}=$ La Merced

LC 04 $=$ La Aurora
LC $05=$ Mercedarias

PL 01 $=$ Amazonas

PL 02 $=$ La Marina

PL 03 $=$ Pachacutec

BR 03 $=\mathrm{N}^{\circ} 2$ de Manoa

BR 04 $=N^{\circ} 3$ de Breña

LC 06 $=$ Moderno
MA 01 $=$ Modelo de Magdalena

BR 05 $=$ Productores $\mathrm{N}^{\circ} 5$

LC $\mathbf{0 7}=28$ de Julio

LC 08 $=$ Buenos Aires

JM 02= San José

LC 09= Central de Lima

LI 01= Lobatón

MA 02 $=$ Municipal de Magdalena PL 04= Bolívar

LC 10 $=1$ ro de Junio

LC 11 = Santa Rosa

LI $02=\mathrm{N}^{\circ} 3$ de Lince

PL 05 = Parada de Bellido

SI 01 = Municipal de San Isidro LI $\mathbf{0 3}=\mathrm{N}^{\circ} 2$ de Risso

Figura 6.9 Tipos de mercados y radios de influencia

Gráfico elaborado por los autores. 


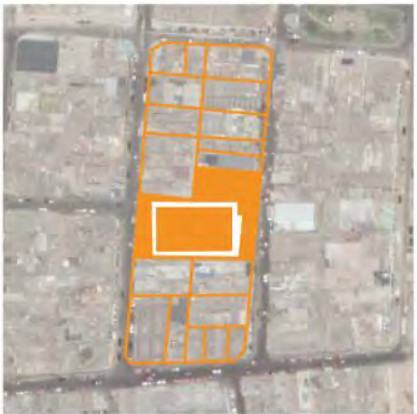

BR 01: Chacra Colorada 1939 | 240 puestos | $2528 \mathrm{~m}^{2}$

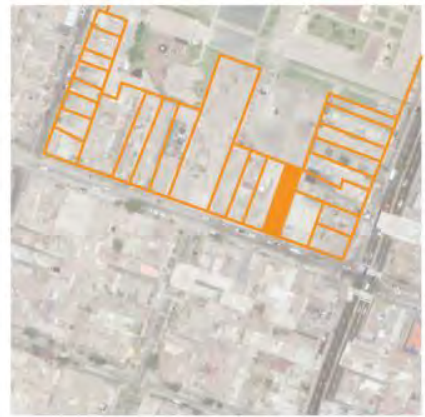

\section{PL 01: Amazonas}

1963 | 51 puestos | $702 \mathrm{~m}^{2}$

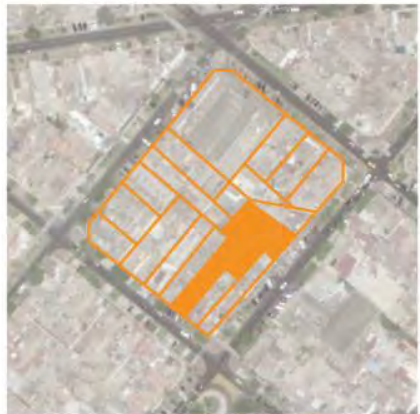

JM 01: Moderno

1966 | 100 puestos | $950 \mathrm{~m}^{2}$

\section{MERCADOS EN ESQUINA}

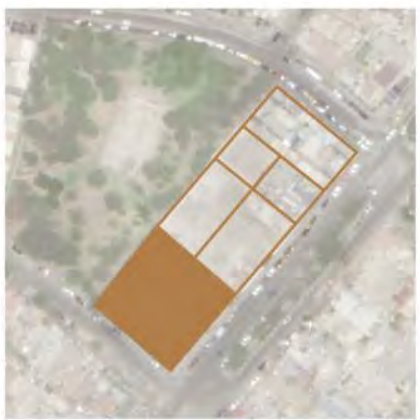

LC 01: 1ro de Mayo

$1991 \mid 74$ puestos $\mid 1500 \mathrm{~m}^{2}$

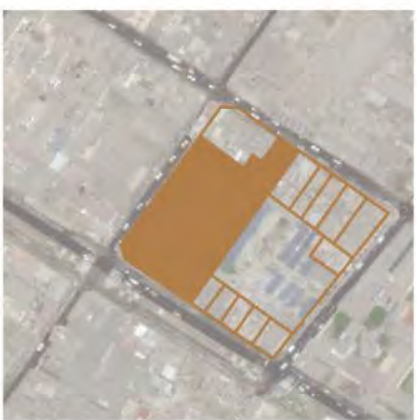

LC 04: La Aurora

1969 | 150 puestos | $3550 \mathrm{~m}^{2}$

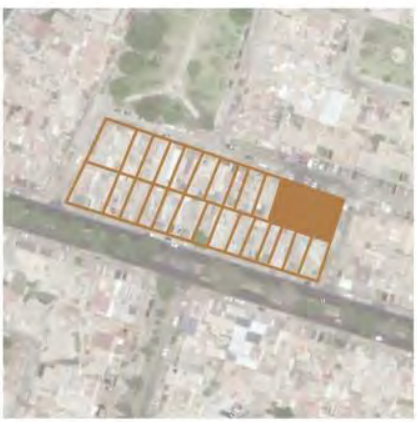

PL 03: Pachacutec

1970 | 38 puestos $\mid 260 \mathrm{~m}^{2}$

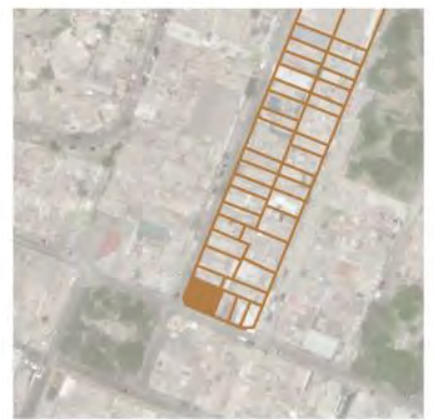

\section{LC 02: Condominio} 1965 | 20 puestos | $170 \mathrm{~m}^{2}$

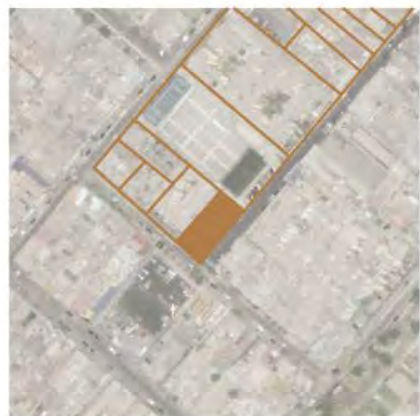

BR 02: Nosiglia

$1960 \mid 55$ puestos $\mid 600 \mathrm{~m}^{2}$

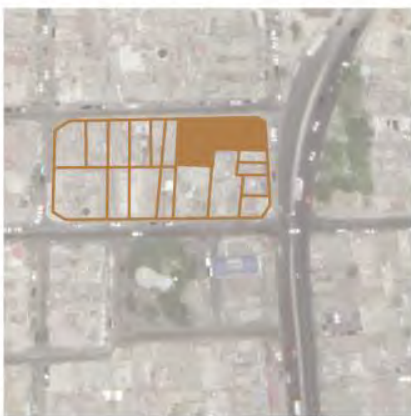

LC 03: La Merced

$1950 \mid 68$ puestos $\mid 674 \mathrm{~m}^{2}$

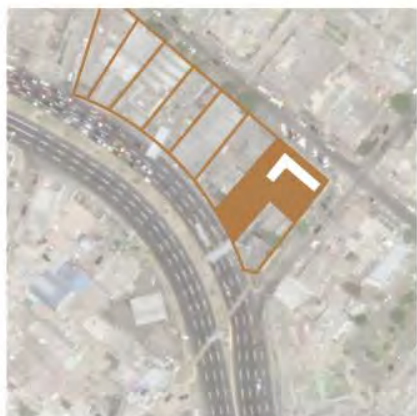

PL 02: La Marina

$1972 \mid 76$ puestos $\mid 785 \mathrm{~m}^{2}$

Figura 6.10 Mercados en medianera y en esquina

Gráfico elaborado por los autores. 


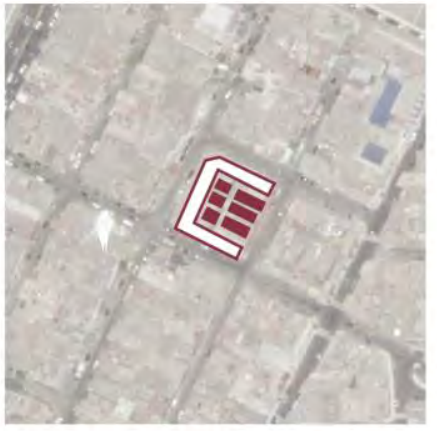

BR 03: N² de Manoa 1950 | 60 puestos $\mid 1725 \mathrm{~m}^{2}$

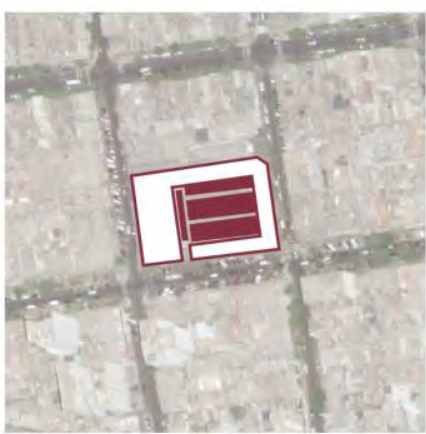

LI 03: N`2 de Risso

1965 | 211 puestos | $3590 \mathrm{~m}^{2}$

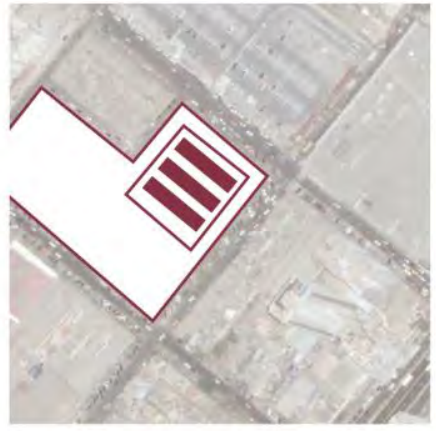

BR 04: $N^{\circ} 3$ de Breña 1953 | 530 puestos | $4800 \mathrm{~m}^{2}$

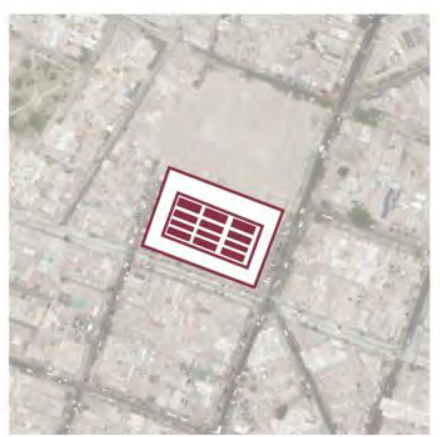

MA 01: Modelo de Magdalena 1965 | 280 puestos | $6266 \mathrm{~m}^{2}$

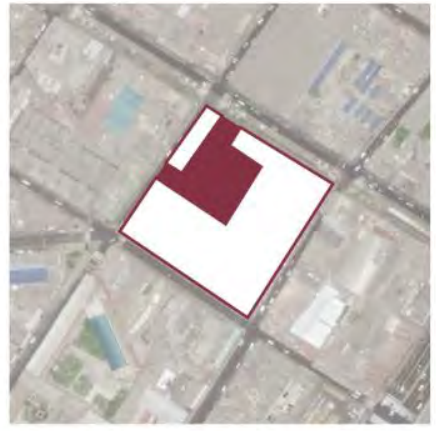

LC 06: Moderno

1971 | 284 puestos | 1776 m² $^{2}$

\section{MERCADOS PLAZA}

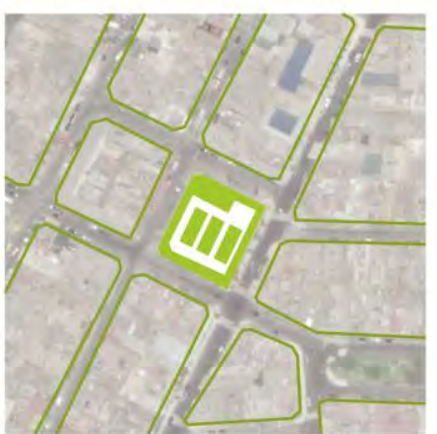

BR 05: Productores $\mathrm{N}^{\circ} 5$ 1975 | 60 puestos | $1200 \mathrm{~m}^{2}$

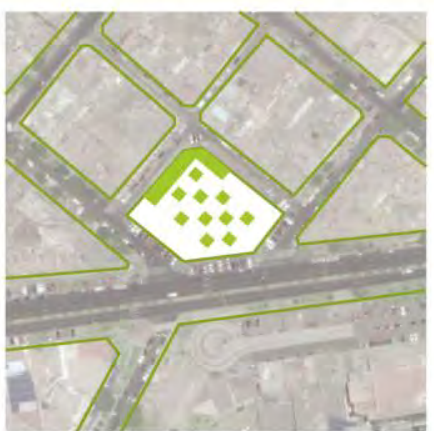

LC 07: 28 de Julio

1927 | 105 puestos | $2800 \mathrm{~m}^{2}$

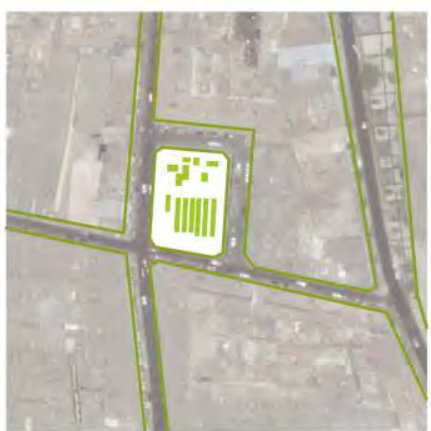

LC 08: Buenos Aires

1941 | 243 puestos | $1830 \mathrm{~m}^{2}$

Figura 6.11 Mercados patio y mercados plaza

Gráfico elaborado por los autores. 


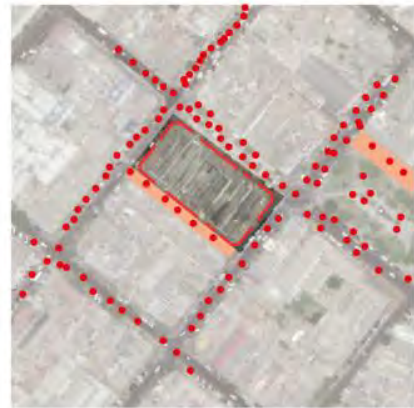

JM 02: San José

1943 | 226 puestos $\mid 4068 \mathrm{~m}^{2}$

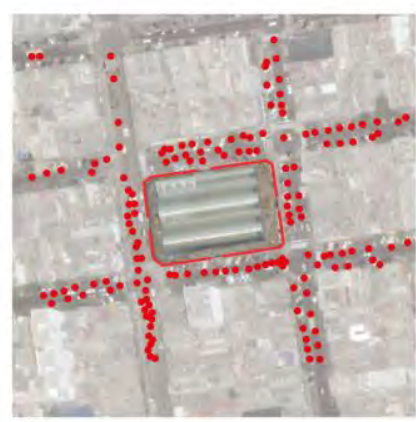

LI 01: Lobatón

1929 | 201 puestos $\mid 3478 \mathrm{~m}^{2}$

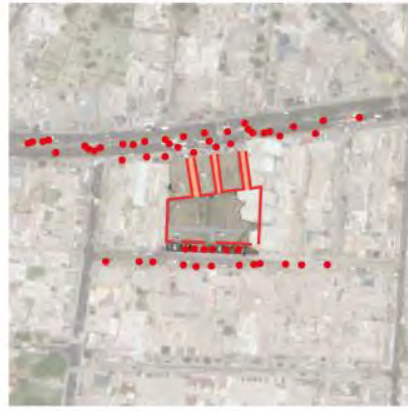

\section{PL 04: Bolívar}

1975 | 230 puestos | $2580 \mathrm{~m}^{2}$

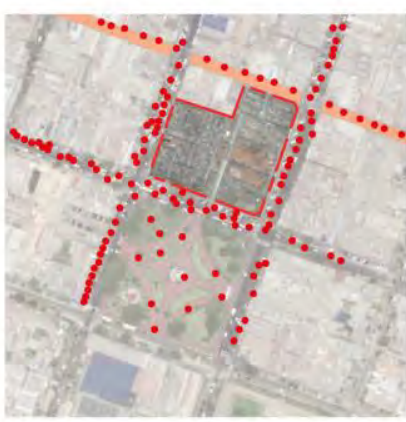

MA 02: Municipal de Magdalena 1936 | 709 puestos | $8371 \mathrm{~m}^{2}$

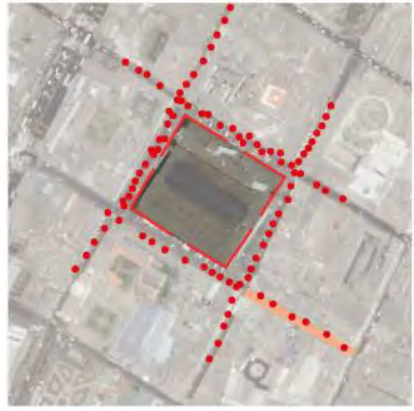

LC 09: Central de Lima

1967 | 936 puestos | $10443 \mathrm{~m}^{2}$

\section{MERCADOS POOL}

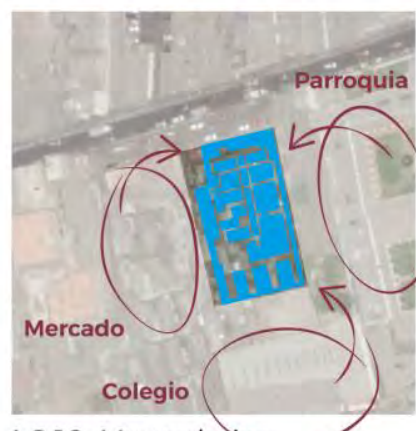

LC 10: Mercedarias

1965 | 130 puestos | $2900 \mathrm{~m}^{2}$

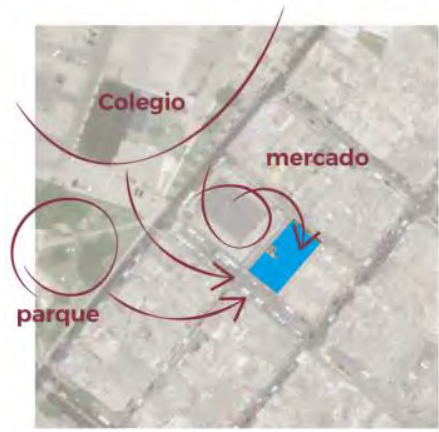

PL 05: Parada de Bellido $1962 \mid 75$ puestos $\mid 700 \mathrm{~m}^{2}$

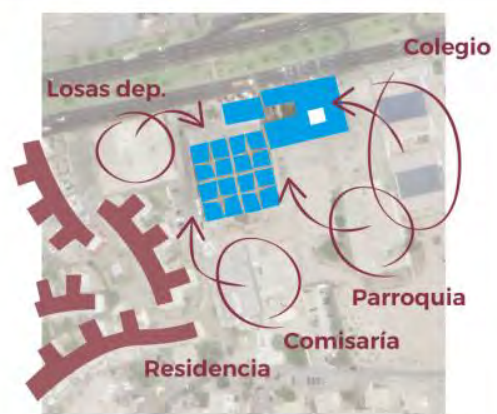

LC 11: Santa Rosa

$1970 \mid 80$ puestos $\mid 1400 \mathrm{~m}^{2}$

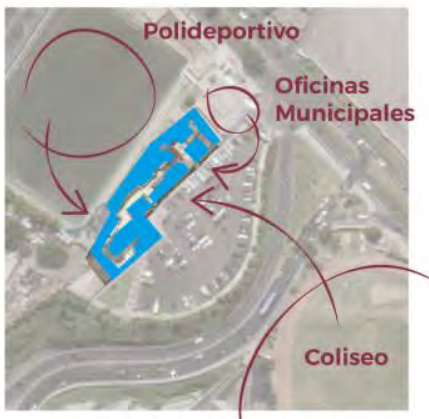

SI 01: Municipal de San Isidro 1969 | 90 puestos $\mid 870 \mathrm{~m}^{2}$

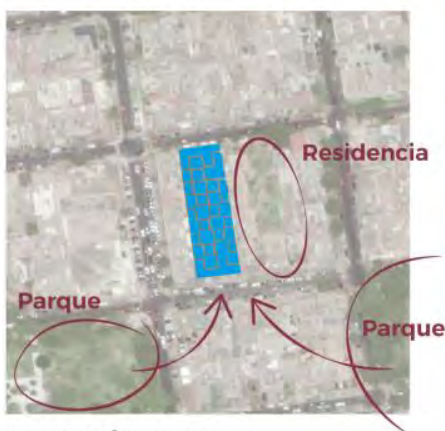

LI 03: N³ de Lince

$1954 \mid 150$ puestos $\mid 2000 \mathrm{~m}^{2}$

Figura 6.12 Mercados centrales y mercados pool

Gráfico elaborado por los autores. 


\subsection{Análisis del lugar}

Para la elección del mercado en donde se realizará el proyecto generamos tres criterios que servirán para filtrar el distrito y el mercado (Ver Figura 6.13). Dentro de todos los distritos pertenecientes a la zona central de Lima, y que se clasificaron anteriormente según su nivel de abastecimiento, escogeremos aquellos que se encuentren en un nivel más crítico de acuerdo a su índice de población atendida, seleccionando los distritos de San Isidro, Miraflores, Jesús María, Surco y Magdalena (Ver Tabla 6.1).

Tabla 6.1

Distritos con mayor índice de des-abastecimiento

\begin{tabular}{|c|c|}
\hline \multicolumn{2}{|c|}{ MERCADO VS. POBLACIÓN ATENDIDA } \\
\hline DISTRITO & ÍNDICE \\
\hline SAN ISIDRO & 1 MERCADO I 54 MIL HABITANTES \\
\hline MIRAFLORES & 1 MERCADO I 40 MIL HABITANTES \\
\hline JESÚS MARÍA & 1 MERCADO I 35 MIL HABITANTES \\
\hline SURCO & 1 MERCADO I 31 MIL HABITANTES \\
\hline MAGDALENA & 1 MERCADO \& 27 MIL HABITANTES \\
\hline
\end{tabular}

Tabla realizada por los autores.

Dentro de estos distritos, los que tienen mayor potencial para que el mercado se convierta en un producto turístico son Miraflores, Magdalena, y Jesús María, debido a sus atractivos monumentales, culturales, y gastronómicos, además de tener un alto grado de accesibilidad tanto peatonal como vehicularmente.

Pero no todos estos distritos poseen una tipología de mercado en la que un proyecto genere gran un impacto en el lugar donde se ubiquen, ya sea por su emplazamiento dentro de la trama urbana, perjudicando su grado de accesibilidad, o porque se encuentran aislados en los límites del distrito, por lo que la clasificación de la tipología de mercados realizado anteriormente (Ver Figura 6.12), nos ayudará a descartar aquellos mercados que no cumplan con las condiciones que buscamos, escogiendo a los grandes mercados centrales los cuales tienen la ventaja de tener mucha dinámica en su entorno, poseen bastante área ocupada, son puntos de centralidad debido a su consolidación en la trama urbana y a su localización. Por tales motivos se descartan los distritos de San Isidro, Miraflores y Santiago de Surco, al no tener mercados de abasto de tipología de mercados centrales (Ver Figura 6.14). 

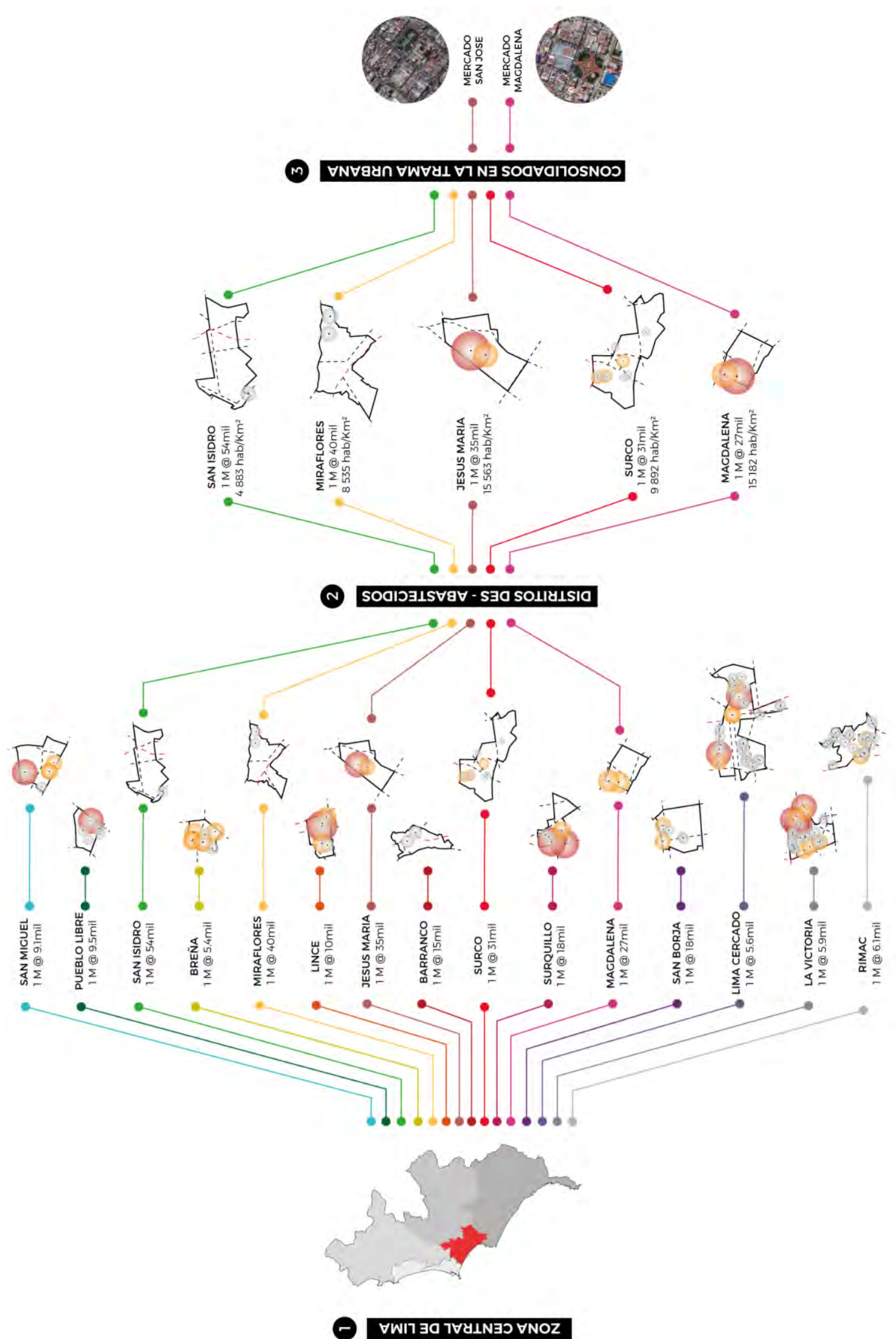

Figura 6.13 Filtro para la selección del mercado Gráfico elaborado por los autores. 


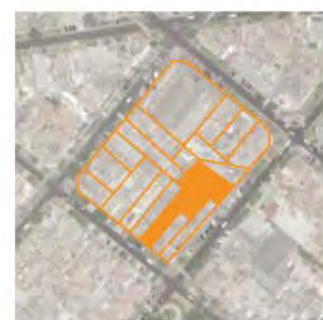

JM 01: Moderno

1966 | 100 puestos | $950 \mathrm{~m}^{2}$

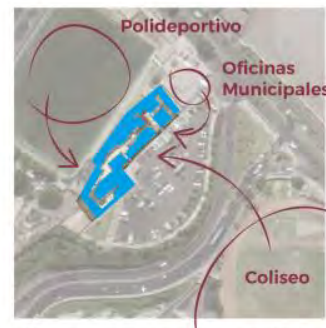

SI 01: Municipal de San Isidro 1969 | 90 puestos $\mid 870 \mathrm{~m}^{2}$

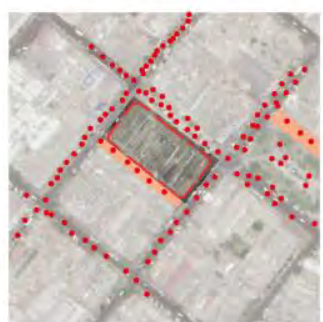

JM 02: San José

$1943 \mid 226$ puestos $\mid 4068 \mathrm{~m}^{2}$

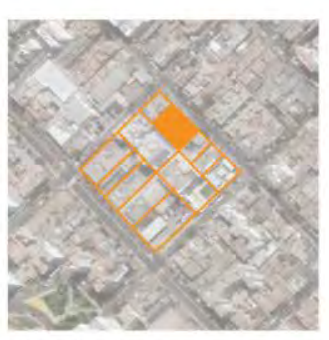

MI 01: La Unión

1976 | 60 puestos $\mid 750 \mathrm{~m}^{2}$

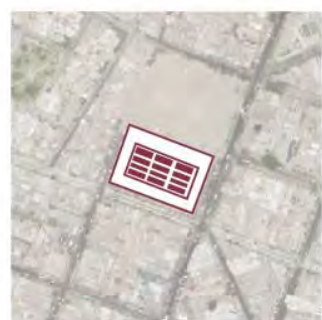

MA 01: Modelo

$1965 \mid 280$ puestos | $6266 \mathrm{~m}^{2}$

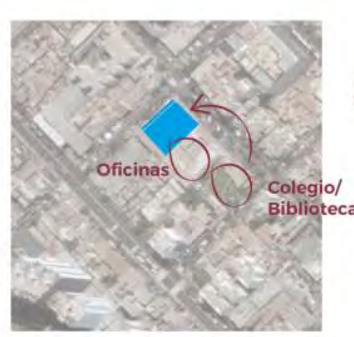

MI 02: Santa Cruz

1967 | 110 puestos $\mid 900 \mathrm{~m}^{2}$

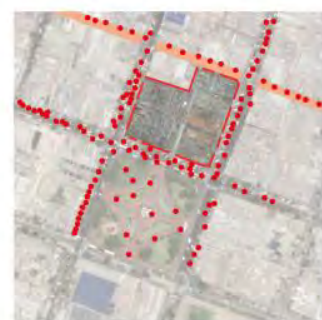

MA 02: Magdalena

1936 | 709 puestos $\mid 8371 \mathrm{~m}^{2}$

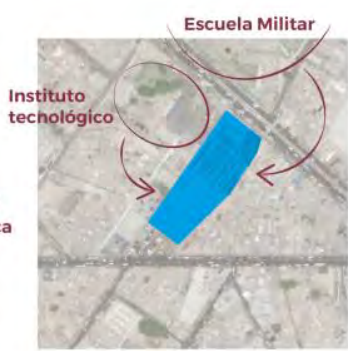

SS 01: N ${ }^{\circ} 2$ de Surco 1971 | 450 puestos | $4900 \mathrm{~m}^{2}$

Figura 6.14 Escala de los mercados filtrados Gráfico elaborado por los autores.

Después de establecer estos criterios tuvimos como resultado el Mercado Magdalena y el Mercado San José de Jesús María. La situación de estos mercados es muy similar, por ejemplo, los dos mercados tienen problemas como el ser la zona más insegura dentro de sus distritos, la mala condición de la edificación, ausencia de dotaciones comunes, la falta de higiene y salubridad, entre otros.

Pero también poseen oportunidades similares como el de contar con servicios básicos, ser accesibles, estar integrados dentro de un damero comercial, contar con una plaza y equipamientos cercanos que son atractivos turísticos, por lo que se realizará un cuadro para la selección de un terreno adecuado que nos permita comparar las ventajas y desventajas de cada uno (Ver Tabla 6.2). 
Tabla 6.2

Cuadro comparativo de terrenos

\begin{tabular}{|c|c|c|c|c|c|}
\hline & & MERCADO SAN JOSE & & MERCADO MAGDALENA & \\
\hline \multirow{3}{*}{$\frac{\bar{c}}{\frac{o}{\tilde{z}}}$} & \multirow{3}{*}{$\begin{array}{l}\text { INTEGRACIÓN A } \\
\text { PLANES URBANOS }\end{array}$} & \multirow{3}{*}{$\begin{array}{l}\text { Integrado al Plan del Boulevard } \\
\text { Gastronómico de la Av. Cuba }\end{array}$} & 1 & \multirow{3}{*}{ No integrado a planes urbanos } & 1 \\
\hline & & & 2 & & 2 \\
\hline & & & 3 & & 3 \\
\hline \multirow{3}{*}{ 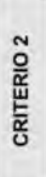 } & \multirow{3}{*}{$\begin{array}{l}\text { PROPIETARIOS DEL } \\
\text { TERRENO }\end{array}$} & \multirow{3}{*}{$\begin{array}{l}\text { Propiedad de la Asociación de } \\
\text { Comerciantes del mercado }\end{array}$} & 1 & \multirow{3}{*}{ Propiedad en litigio } & 1 \\
\hline & & & 2 & & 2 \\
\hline & & & 3 & & 3 \\
\hline \multirow{3}{*}{ 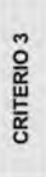 } & \multirow{3}{*}{$\begin{array}{l}\text { ATRACTIVOS } \\
\text { MONUMENTALES, } \\
\text { CULTURALES Y } \\
\text { GASTRONÓMICOS }\end{array}$} & \multirow{3}{*}{$\begin{array}{l}\text { Iglesia San José / Plaza San José / } \\
\text { Múltiples restaurantes }\end{array}$} & 1 & \multirow{3}{*}{$\begin{array}{l}\text { Plaza Túpac Amaru / Iglesia } \\
\text { Sagrado Corazón }\end{array}$} & 1 \\
\hline & & & 2 & & 2 \\
\hline & & & 3 & & 3 \\
\hline \multirow{3}{*}{ 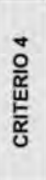 } & \multirow{3}{*}{ MORFOLOGIAA } & \multirow{3}{*}{$\begin{array}{l}\text { Terreno plano / Forma ortogonal y } \\
\text { simétrica / Área: } 4200 \mathrm{~m} 2\end{array}$} & 1 & \multirow{3}{*}{$\begin{array}{l}\text { Terreno plano / Forma ortogonal y } \\
\text { simétrica / Área: } 22815 \mathrm{~m} 2\end{array}$} & 1 \\
\hline & & & 2 & & 2 \\
\hline & & & 3 & & 3 \\
\hline \multirow{3}{*}{ 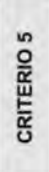 } & \multirow{3}{*}{ PERCEPCIÓN } & \multirow{3}{*}{$\begin{array}{l}\text { Zona comercial y residencial con } \\
\text { viviendas de estilo chalet, visuales } \\
\text { hacia la plaza y la iglesia San Jose, } \\
\text { pero con contaminación visual por la } \\
\text { cantidad de vehículos estacionados. }\end{array}$} & 1 & \multirow{3}{*}{$\begin{array}{l}\text { Alta dinámica comercial muy } \\
\text { variada, calles peatonales, y } \\
\text { visuales hacia la Plaza Túpac } \\
\text { Amaru. }\end{array}$} & 1 \\
\hline & & & 2 & & 2 \\
\hline & & & 3 & & 3 \\
\hline \multirow{3}{*}{ 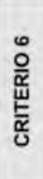 } & \multirow{3}{*}{$\begin{array}{l}\text { ACCESIBILIDAD AL } \\
\text { TERRENO }\end{array}$} & \multirow{3}{*}{$\begin{array}{l}\text { Entre dos avenidas principales } \\
\text { (Av.Brasil y Salaverry) }\end{array}$} & 1 & \multirow{3}{*}{ Av. Brasil } & 1 \\
\hline & & & 2 & & 2 \\
\hline & & & 3 & & 3 \\
\hline \multirow{3}{*}{ 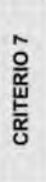 } & \multirow{3}{*}{$\begin{array}{l}\text { CARÁCTER DEL } \\
\text { MERCADO }\end{array}$} & \multirow{3}{*}{ Puestos de comida (cevicherias) } & 1 & \multirow{3}{*}{ Sin carácter definido } & 1 \\
\hline & & & 2 & & 2 \\
\hline & & & 3 & & 3 \\
\hline \multirow{3}{*}{ 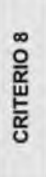 } & \multirow{3}{*}{$\begin{array}{l}\text { CONDICIÓN DE LA } \\
\text { EDIFICACIÓN }\end{array}$} & \multirow{3}{*}{$\begin{array}{l}\text { Cobertura por sectores y de material } \\
\text { ligero, instalaciones expuestas y } \\
\text { circulación interna angosta }\end{array}$} & 1 & \multirow{3}{*}{$\begin{array}{l}\text { Cobertura por sectores y de material } \\
\text { ligero, instalaciones expuestas y } \\
\text { circulación interna angosta }\end{array}$} & 1 \\
\hline & & & 2 & & 2 \\
\hline & & & 3 & & 3 \\
\hline 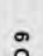 & & Cuenta con red de agua, luz y & 1 & Cuenta con red de agua, luz y & 1 \\
\hline 总 & $\begin{array}{l}\text { INFRAESTRUCTURA Y } \\
\text { SERVICIOS }\end{array}$ & $\begin{array}{l}\text { desague / pisos de mayólica / sin } \\
\text { área de abastecimiento y }\end{array}$ & 2 & $\begin{array}{l}\text { desague / pisos de cemento pulido / } \\
\text { sin área de abastecimiento y }\end{array}$ & 2 \\
\hline & & recoleccion de residuos & 3 & & 3 \\
\hline & & TOTAL & 24 & & 15 \\
\hline
\end{tabular}

Tabla elaborada por los autores. 
Después de revisar los resultados de cada criterio en la tabla comparativa, si bien ambos son posibles, el Mercado San José tiene más oportunidades que el Mercado de Magdalena. Una de ellas es el primer criterio, porque el Mercado San José se encuentra integrado al Plan de Desarrollo Económico del distrito de Jesús María que propone realizar un Boulevard Gastronómico en la Av. Cuba integrando al mercado y la Plaza San José, mientras que el Mercado de Magdalena no está integrado a un plan urbano elaborado por el distrito o de parte de alguna institución a fin.

El segundo criterio también fue determinante, debido a que el Mercado San José tiene la ventaja de ser privado y que le pertenece a la Asociación de Comerciantes del mercado, pero el terreno en donde se ubica el Mercado de Magdalena se encuentra en litigio, lo que dificulta con la posibilidad de un acuerdo ante una propuesta arquitectónica.

Además, la percepción (criterio 5) y los atractivos (criterio 3) que posee el distrito de Jesús María son factores determinantes al momento de pensar al mercado como producto turístico, ya que va a complementar la actividad que se genere entorno a este. Si bien el mercado está ubicado en el damero comercial, a su alrededor también se encuentran viviendas de estilo chalet de la época post-colonial que se han mantenido con los años junto con la Plaza y la Iglesia San José, que han estado presentes desde la formación del distrito, además de contar con numerosos restaurantes en la Av. Cuba y la llegada de la actividad hotelera al distrito (Ver Figura 6.15).

Así también, la accesibilidad al distrito de Jesús María fue importante para la elección del mercado, debido a que se encuentra entre dos avenidas principales que comunican el centro histórico con los balnearios, ya sea por transporte público o privado. La planificación que tuvo Jesús María en su trama urbana generó que el mercado sea céntrico en su localización y bien comunicado por diferentes redes viales, atrayendo gran flujo de personas (Ver Figura 6.16). 


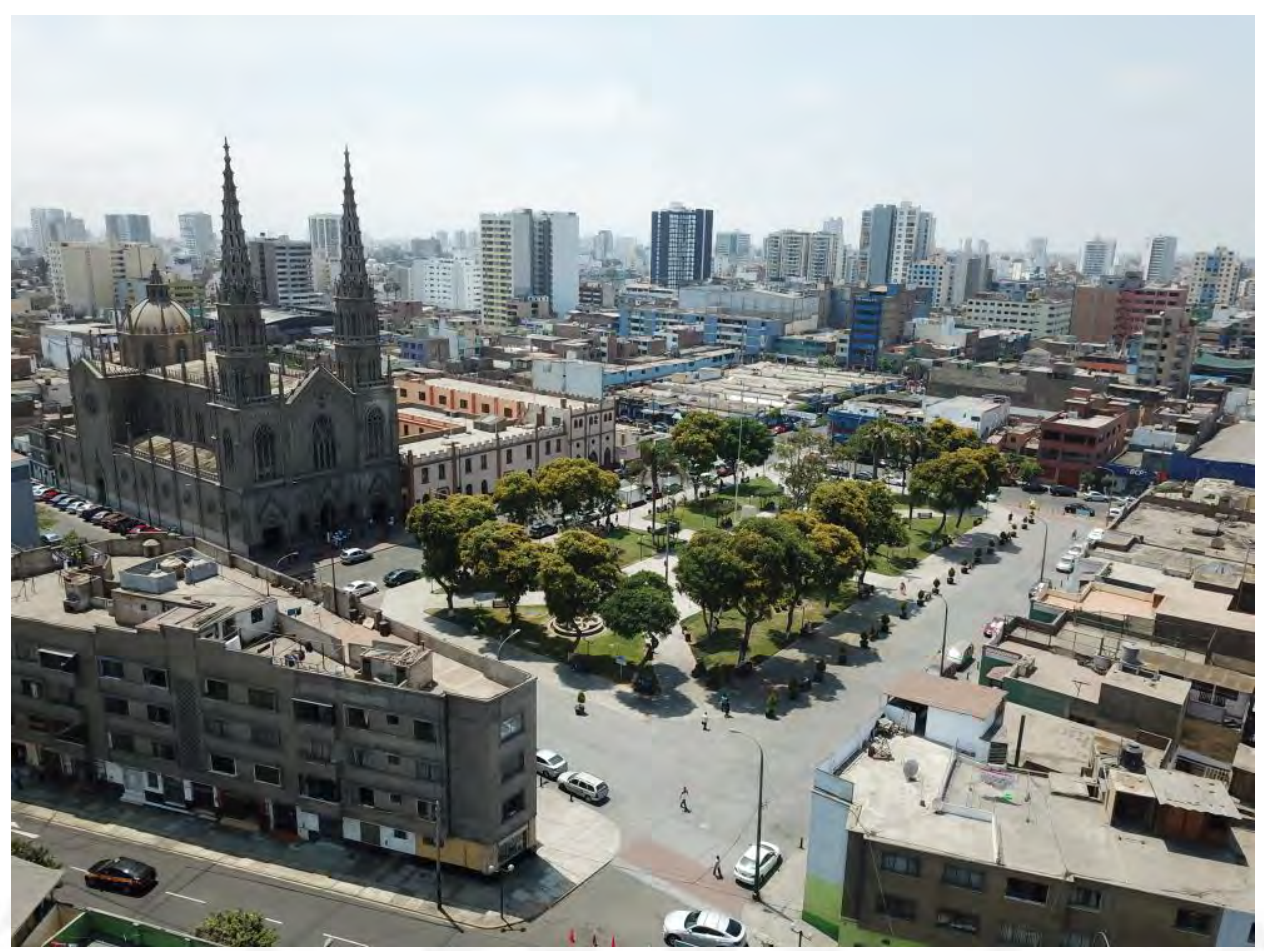

Figura 6.15 Percepción del lugar

Fotografía realizada por los autores.

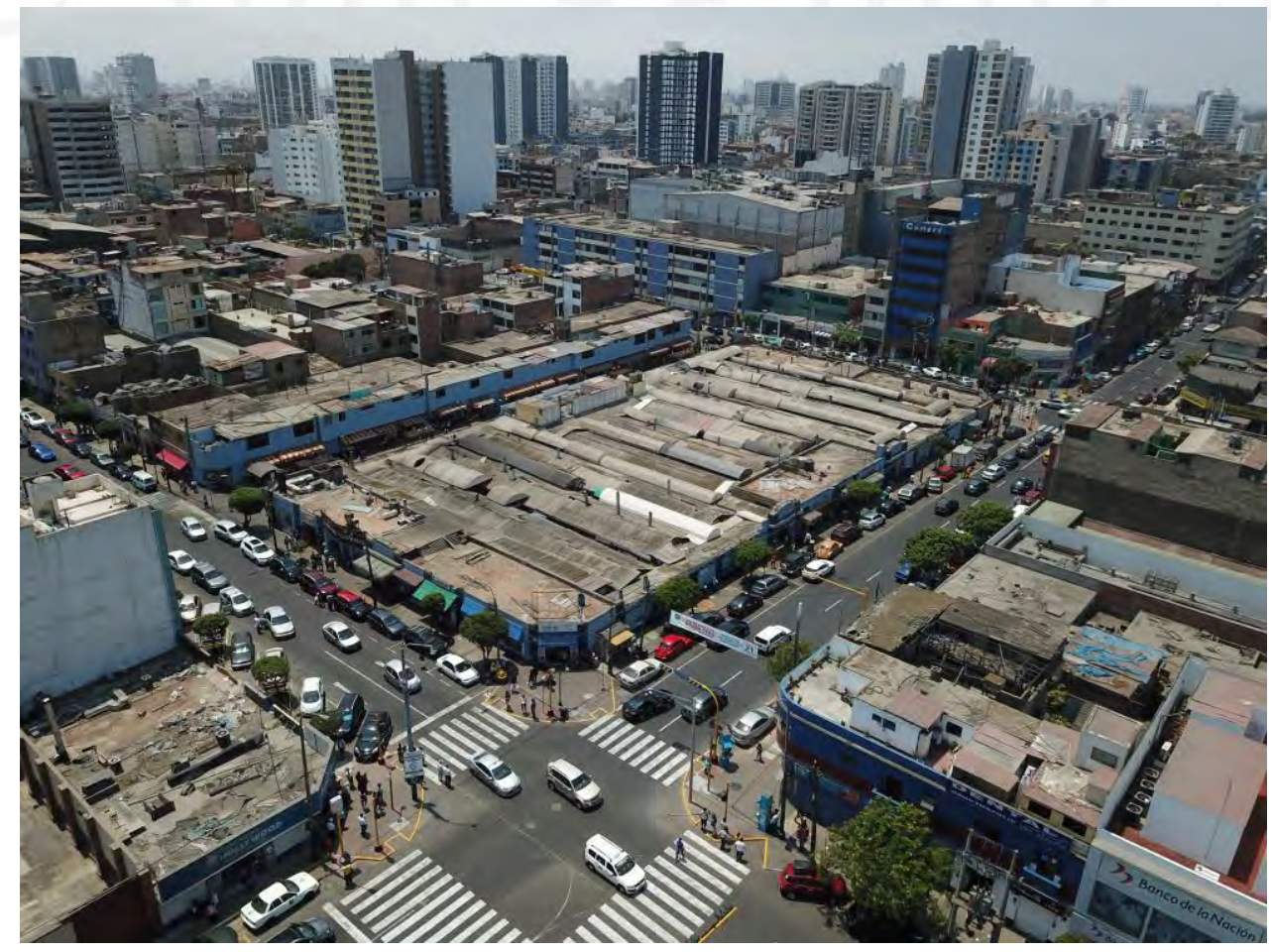

Figura 6.16 Vista semi-aérea del Mercado San José

Fotografía realizada por los autores. 


\subsection{Variables del lugar}

Una vez escogido el mercado en el que se realizará la propuesta analizaremos variables que se irán descomponiendo en diversos sistemas, profundizando en los aspectos más importantes para el proyecto y que se sintetizarán en una propuesta que responda al lugar.

Para el respectivo análisis se han considerado los siguientes puntos:

- Lámina 6.1_Perfil del usuario

- Lámina 6.2_ Tipología de quintas

- Lámina 6.3_Funcionamiento del mercado

- Lámina 6.4_Condiciones medio ambientales

- Lámina 6.5_Sistema de áreas libres

- Lámina 6.6_Hitos, Sendas, Barrios, Bordes y Nodos

- Lámina 6.7_Lugares de interés

- Lámina 6.8_ Alturas

- Lámina 6.9_Usos de suelo

- Lámina 6.10_ Tipo de comercio

- Lámina 6.11_ Tipo de servicio

- Lámina 6.12_Oferta de restaurantes

- Lámina 6.13_Zonificación

- Lámina 6.14_Parámetros

- Lámina 6.15_Percepción

- Lámina 6.16_Levantamiento fotográfico

- Lámina 6.17_Potencialidades y limitaciones 


\section{POBLACIÓN}

RANCO DE ANÁLISIS $=1 \mathrm{~km}$

SUPERFICIE $=3 \mathrm{~km} 2$

habitantes

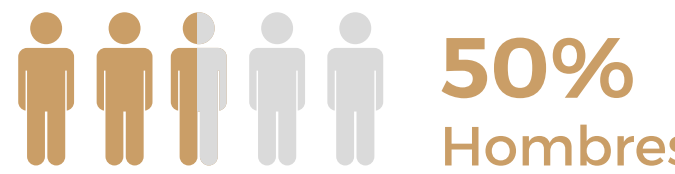

17675 hogares

\section{iiin $50 \%$ \\ Mujeres}

\section{RANGO ETARIO}

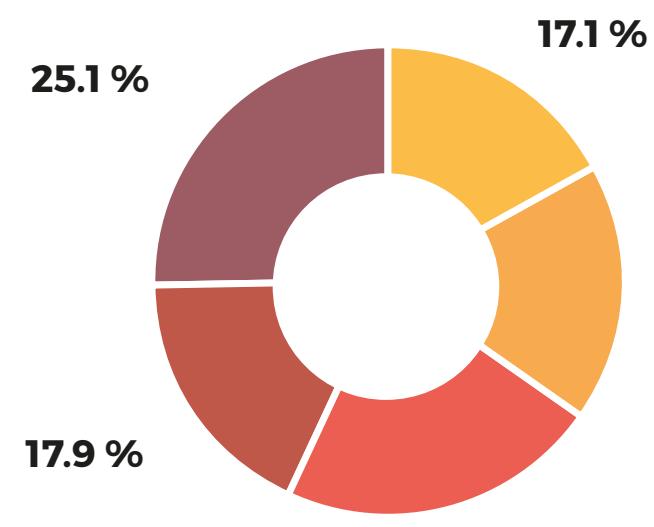

$17.1 \%$

$22 \%$

\section{ESTADO CIVIL}

$10.3 \%$

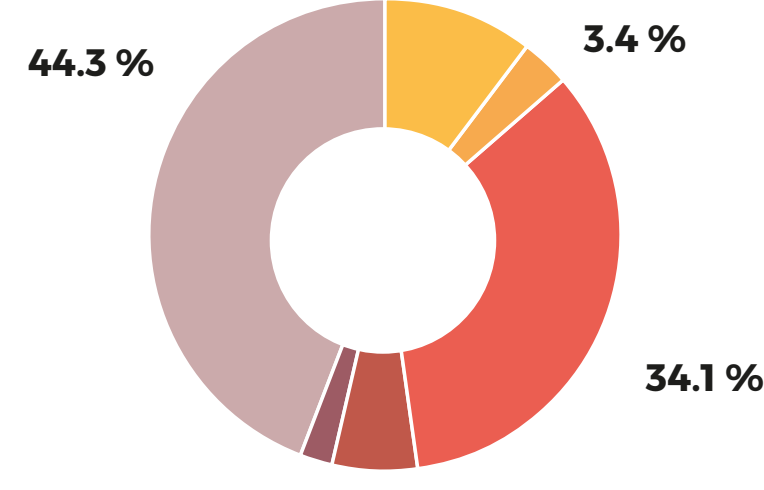

$2 \%$

$5.9 \%$

Convivientes $=5600$

Separados $=1835$

Casados = 18427

- Viudos =3185

Divorciados $=1129$

Solteros $=23730$

\section{NIVEL DE ESTUDIOS}

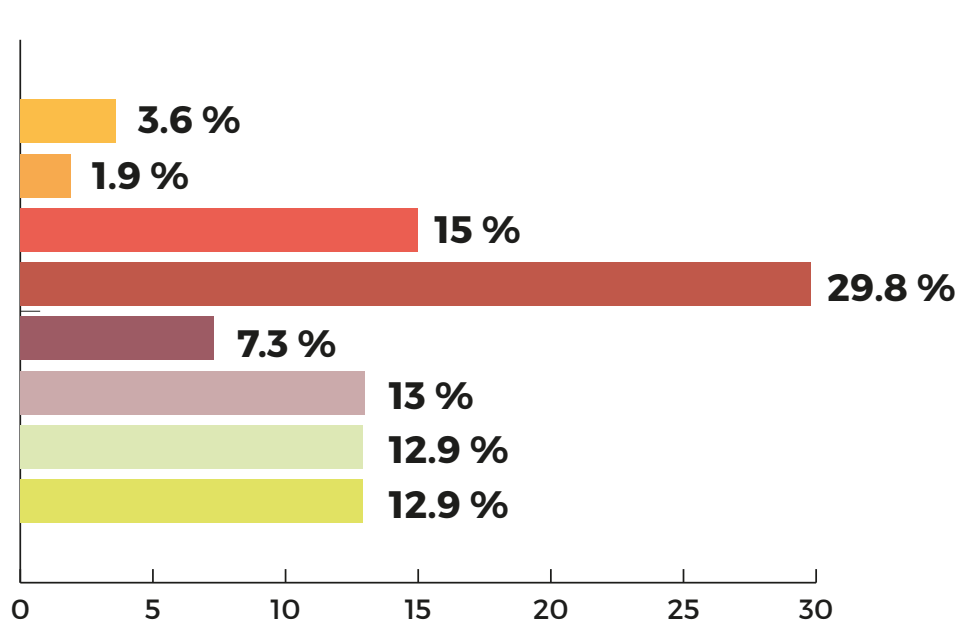

Sin educación $\quad=1878$

Inicial

$=997$

- Primaria

$=7745$

$=17310$

Superior incompleta $\quad=3811$

Superior completa $\quad=6800$

Universitaria incompleta $=6750$

Universitaria completa $=6750$

\section{NIVEL SOCIO-ECONÓMICO}

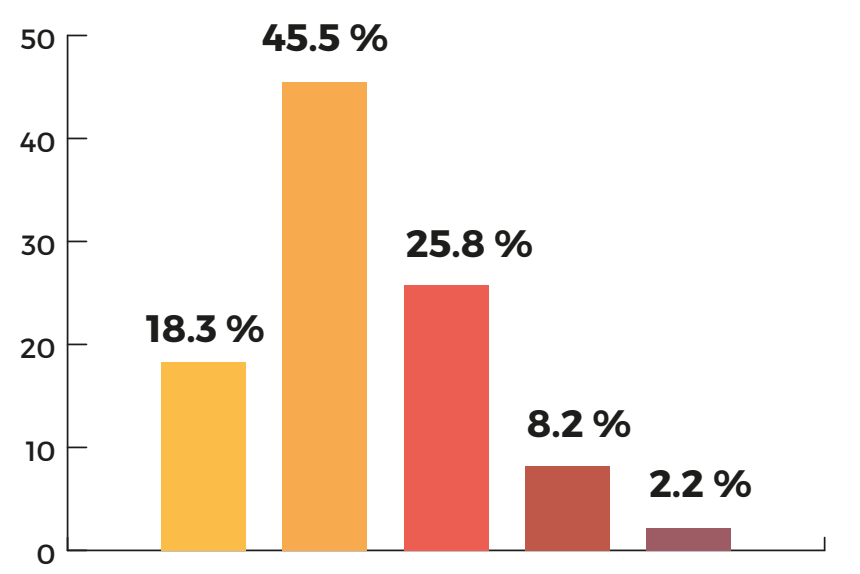

\section{OCUPACIÓN}

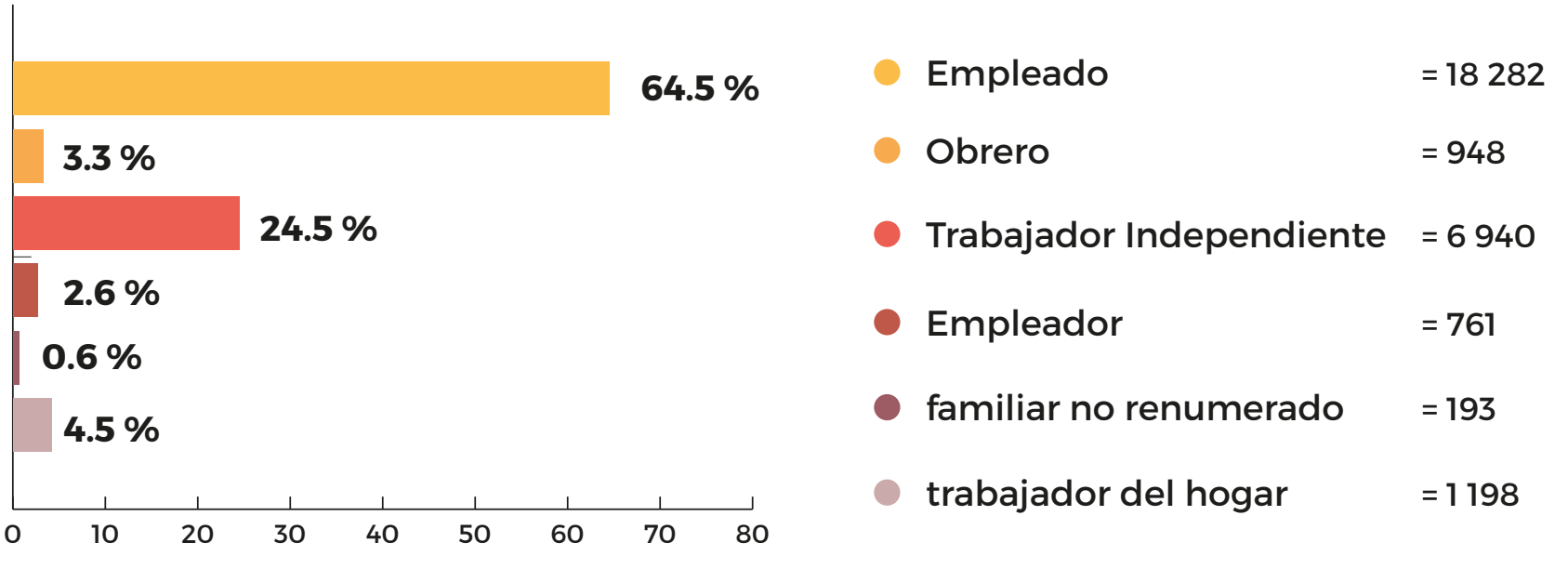



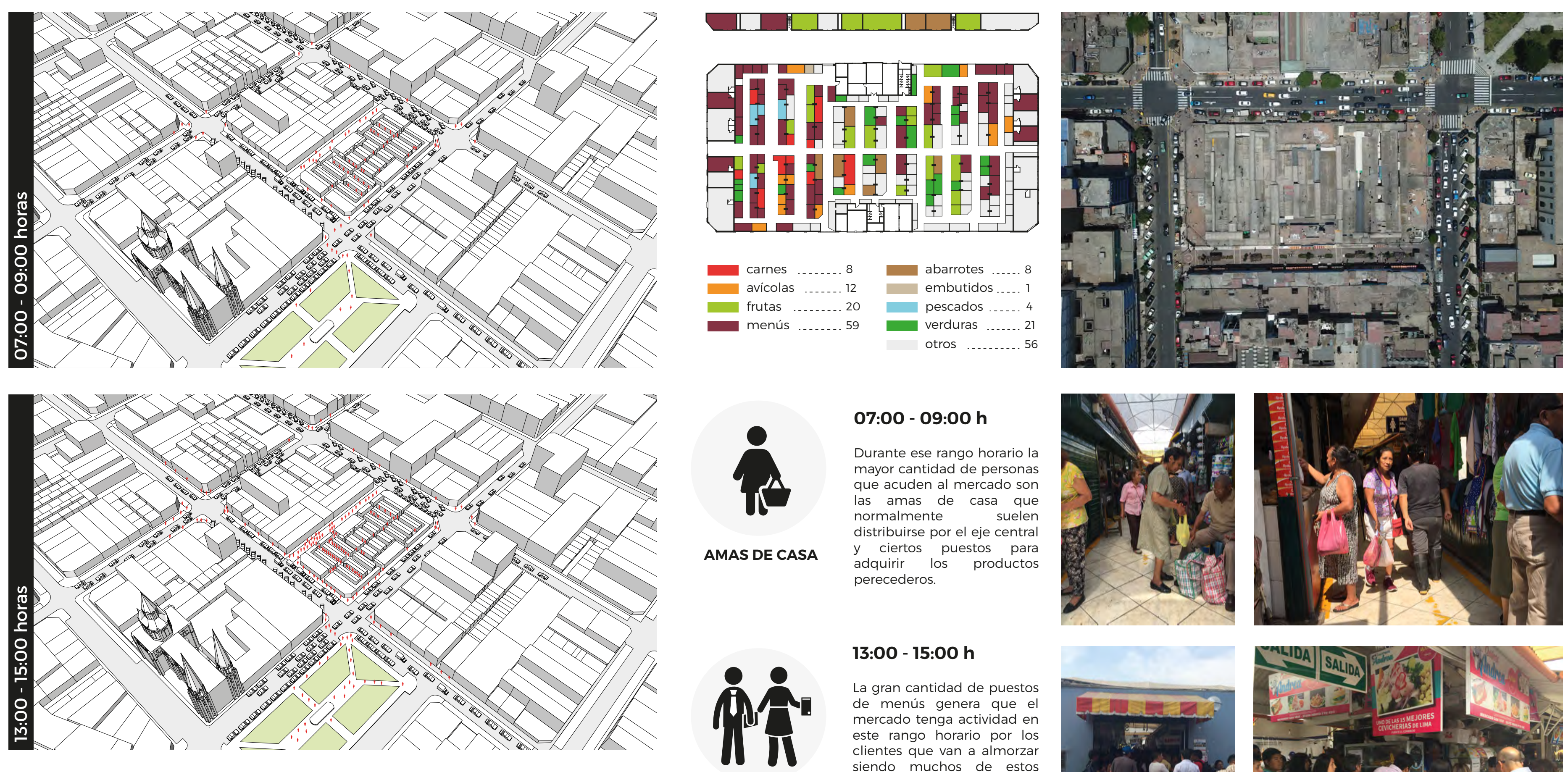

\section{3:00 - 15:00 h}

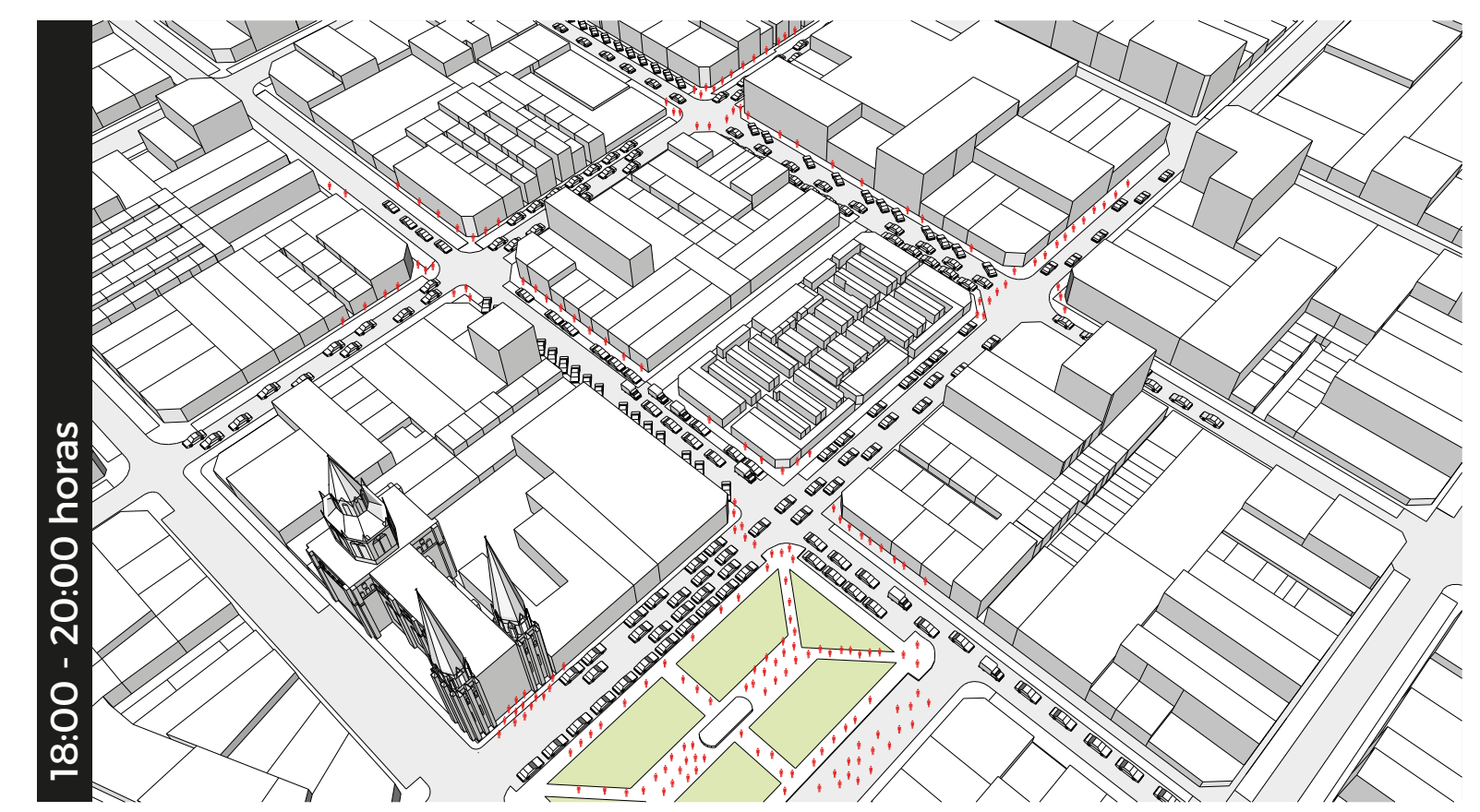

TRABAJADORES YESTUDIANTES

La gran cantidad de puestos 作 menus genera que este rango horario por los clientes que van a almorzar
siendo muchos de estos personas que laboran. Acumulándose en el Pasaje Punta Pacochas esperando
su turno y deteniéndose para comer.
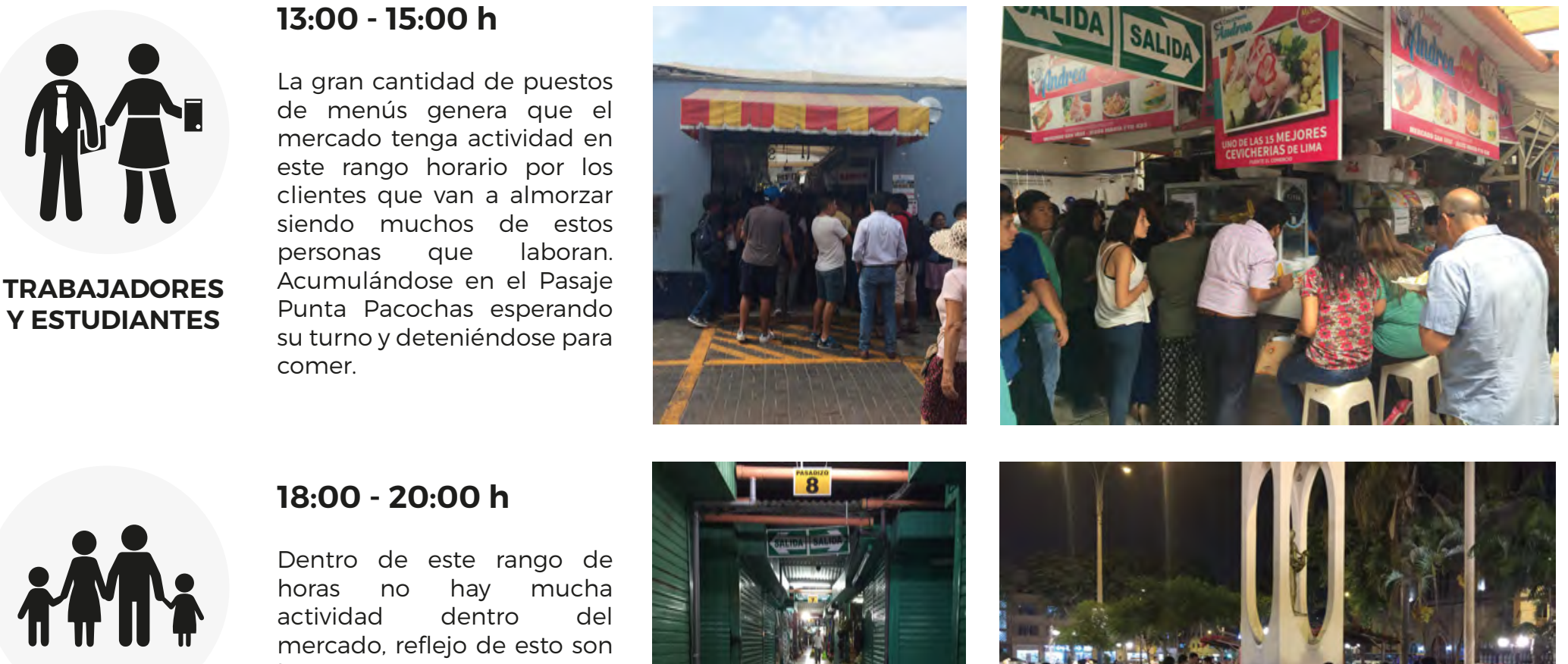

18:00 - 20:00 h

Dentro de este rango de

horas no hay mucha mercado, reflejo de esto son los numerosos puestos aún esta presente alrededor FAMILIAS del mercado, especialmente en la Plaza San José y en los locales de alrededor.
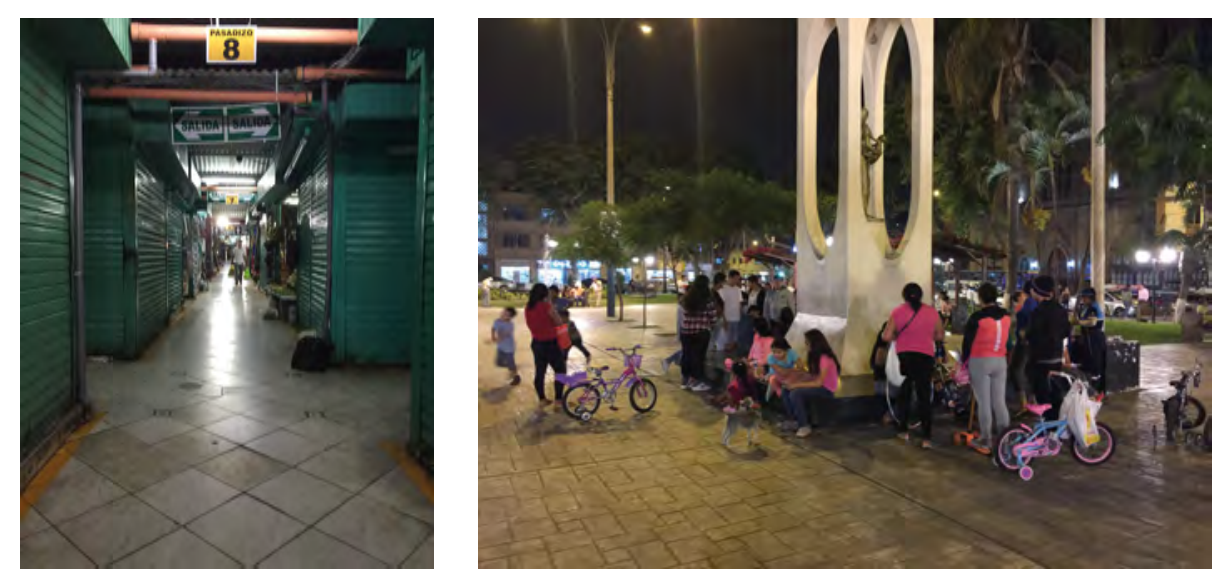


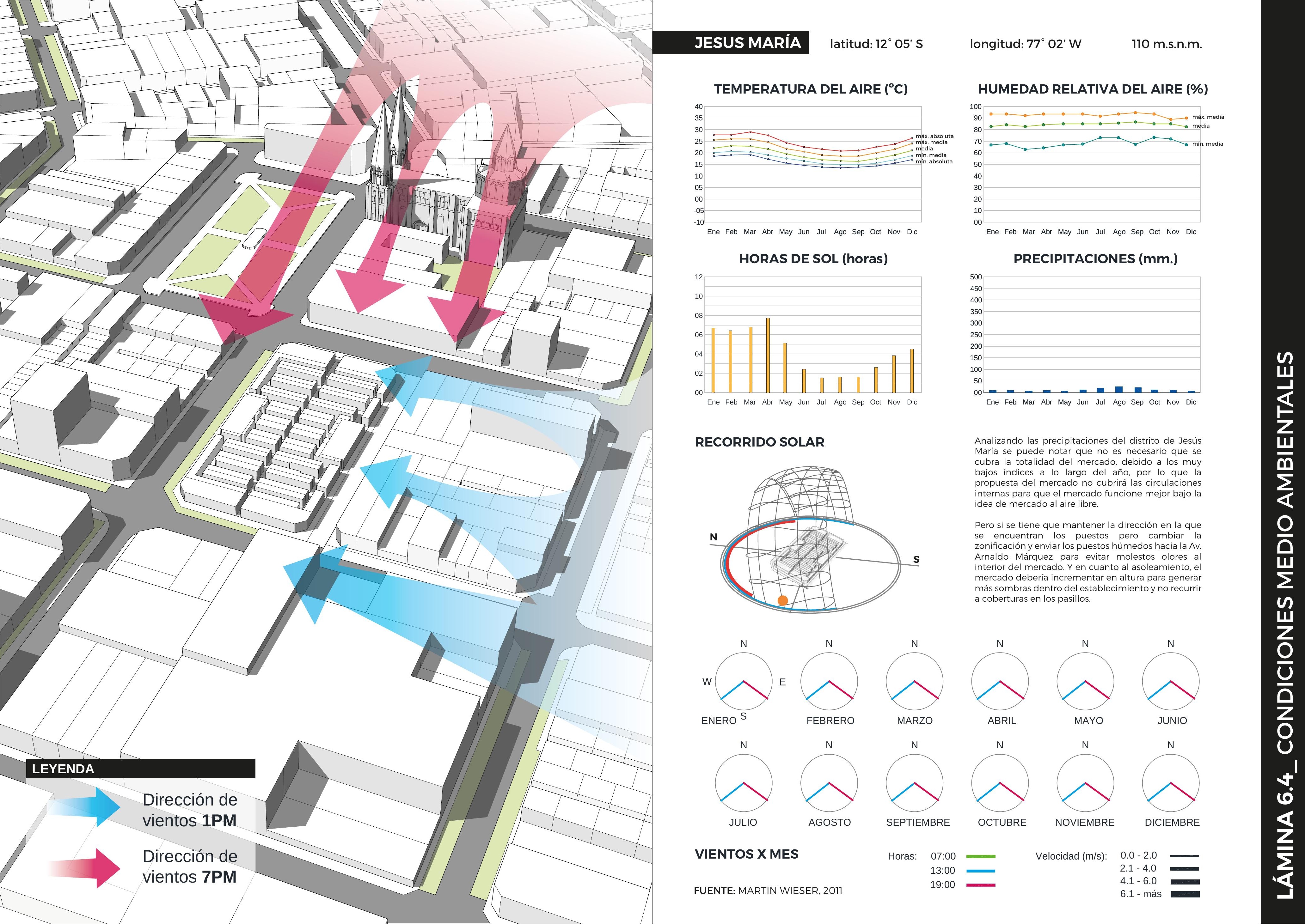




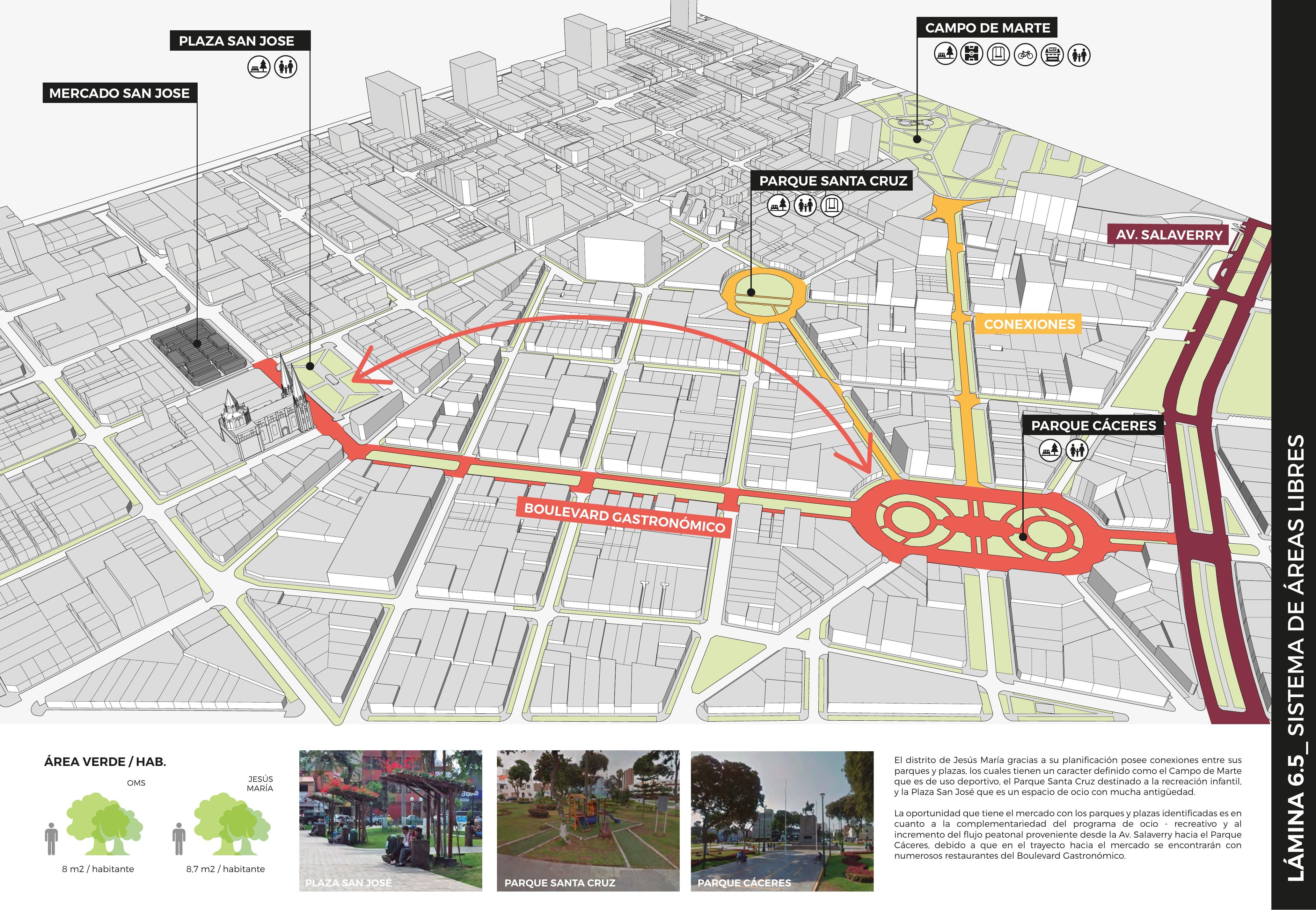




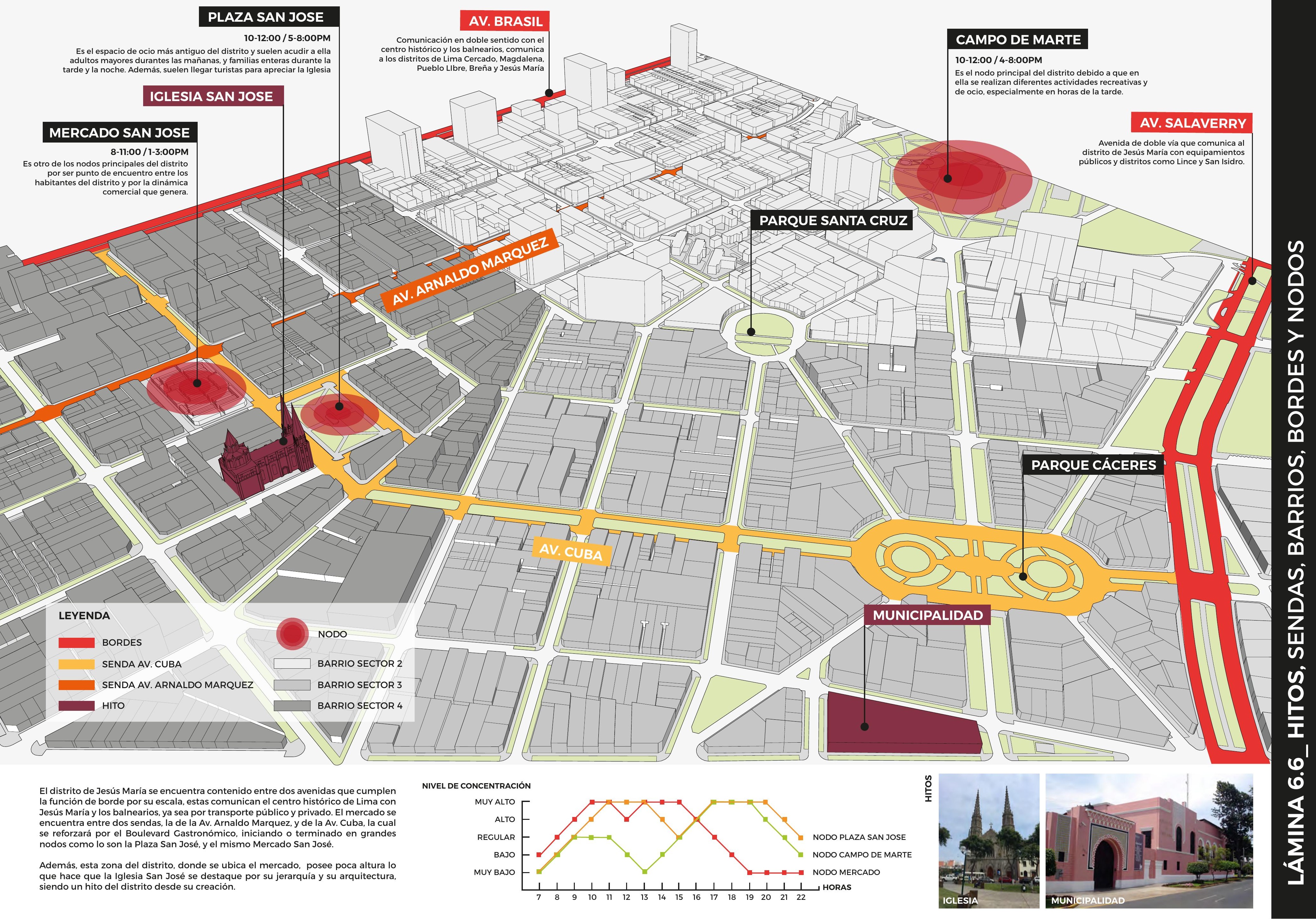



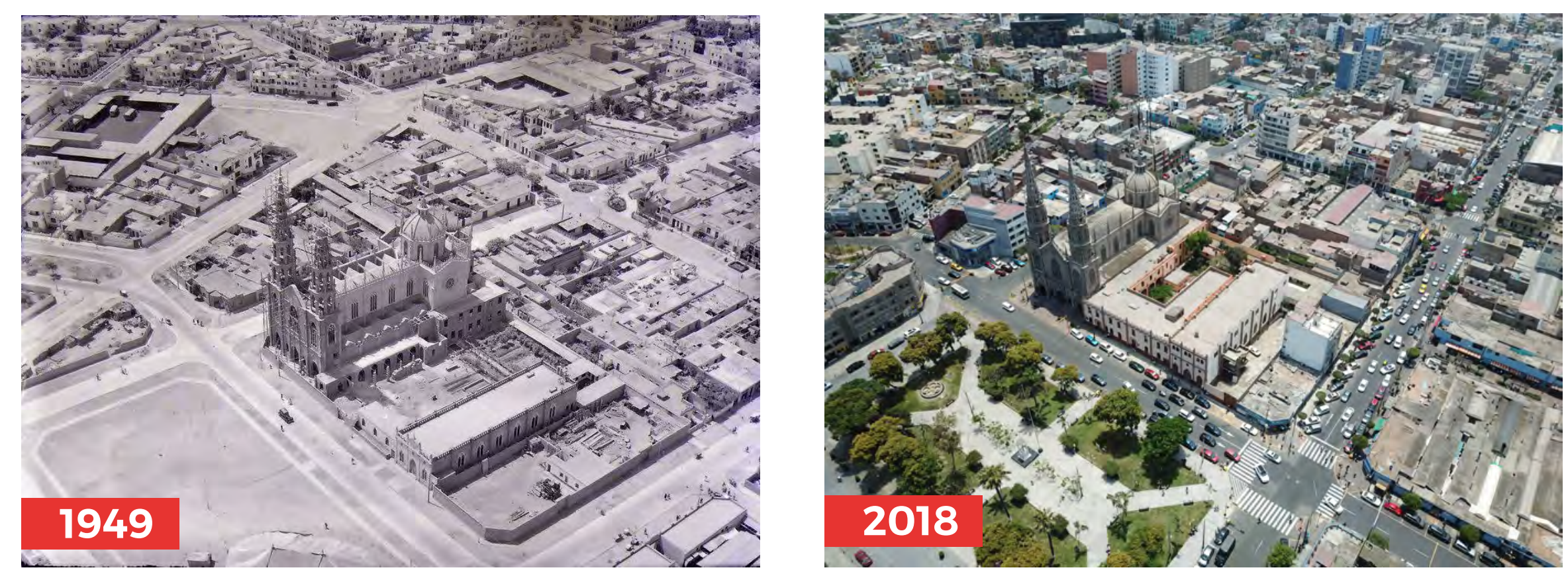

La Plaza, la Iglesia y el Mercado

El Mercado San José se encuentra dentro del sector más importante e historico del distrito, debido a sus edificaciones religiosas y espacios de ocio que estuvieron presente desde que se comenzó a formar el distrito de Jesús María.

La primera edificación en emplazarse dentro de este sector fue la Parroquia San Jose en 1945, perteneciente a Los Padres Carmelitas, la cua ción de la Iglesia San José.
Paralelamente a la construcción de la Iglesia se realizaba el mercado, que se ubicó en terrenos lotizados pertenecientes a Carlos Orézzoli; además de la plaza, que se pavimento y dotó de áreas verdes, creando un espacio de reacreación para los habitantes.

La llegada del mercado originó cambios en la morfología de la manzana urbana en la que se ubico, creando el Pasaje Punta Pacochas que ayudó a que el mercado sea accesible perimetralmente, y que su actividad se separe de las viviendas.

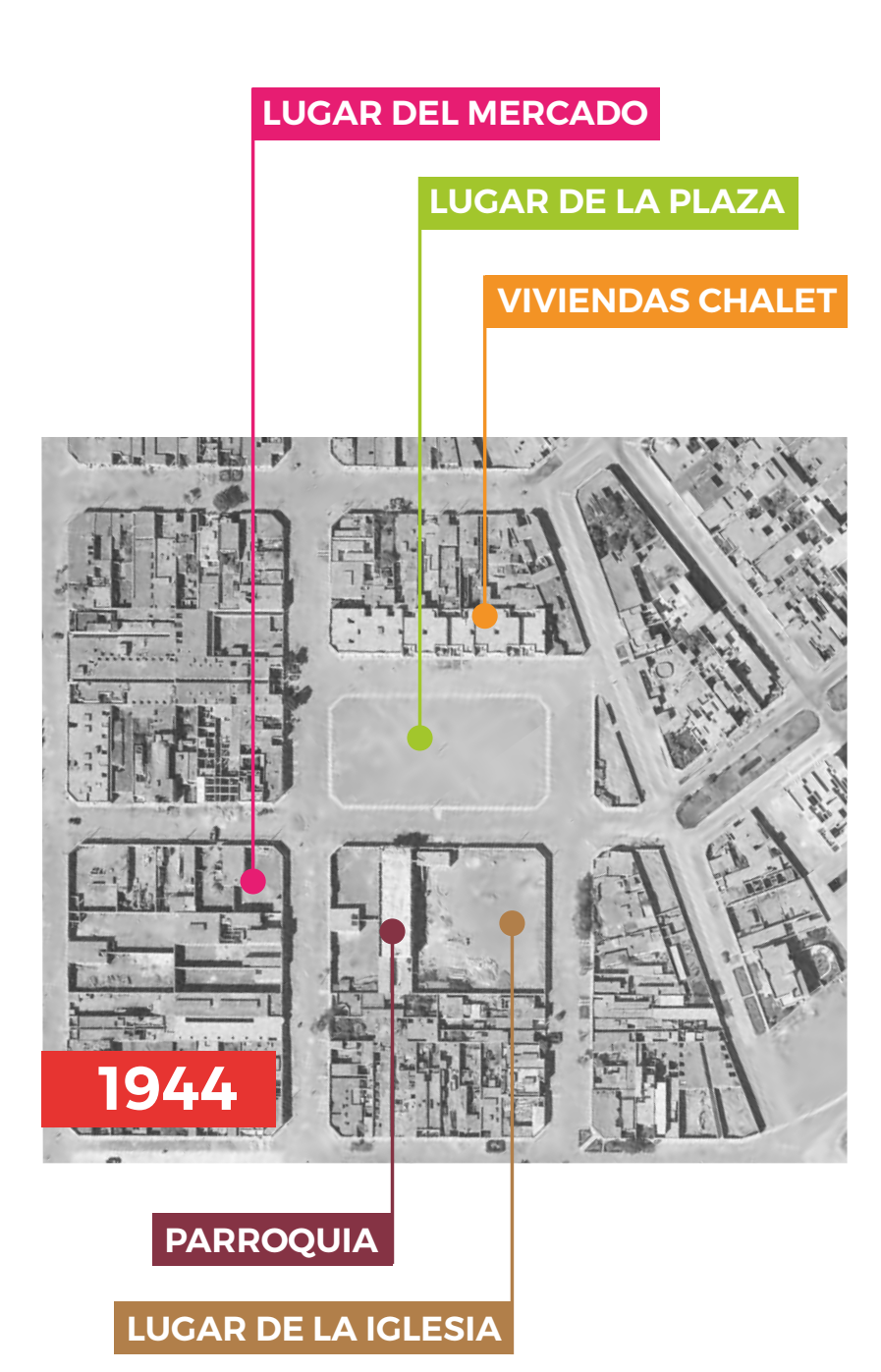

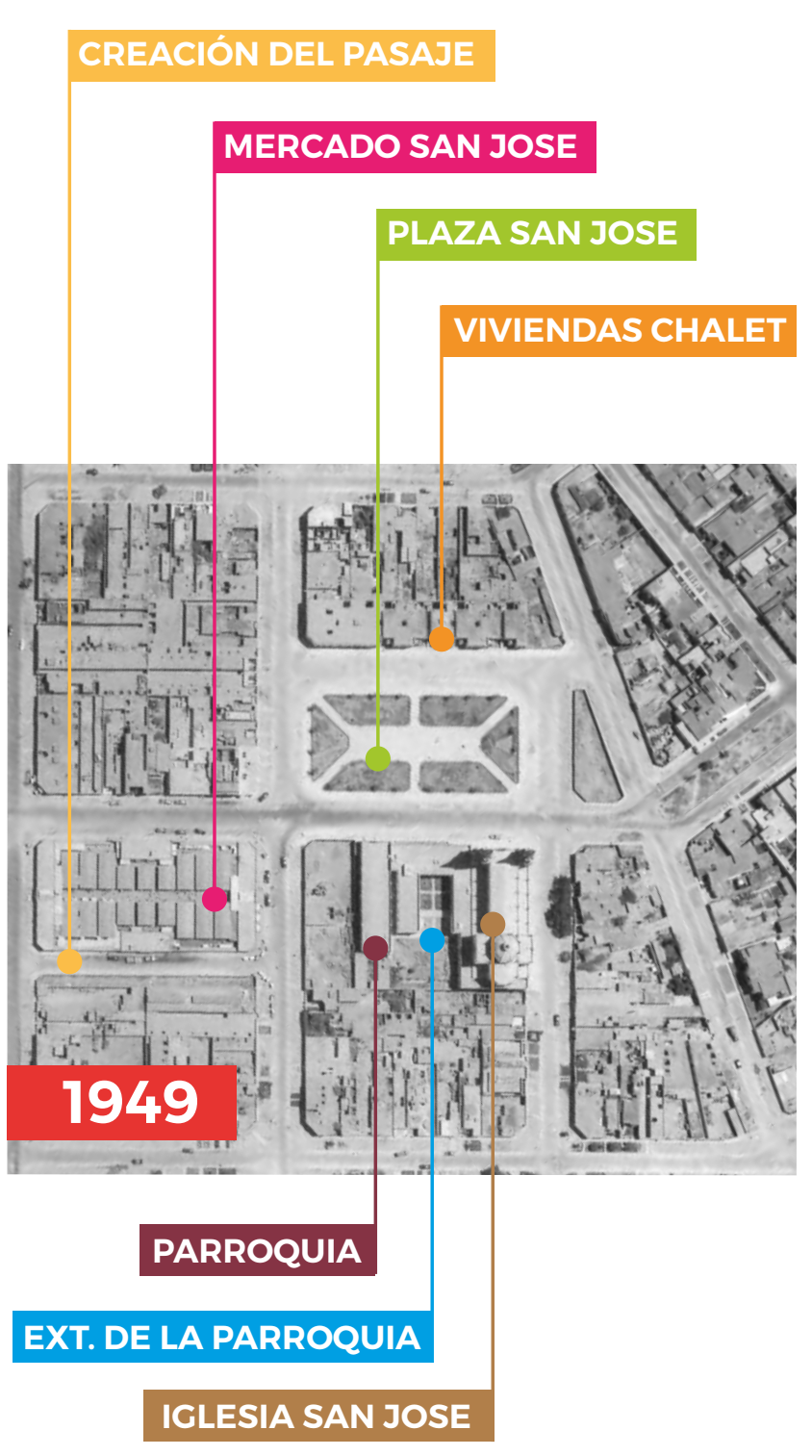

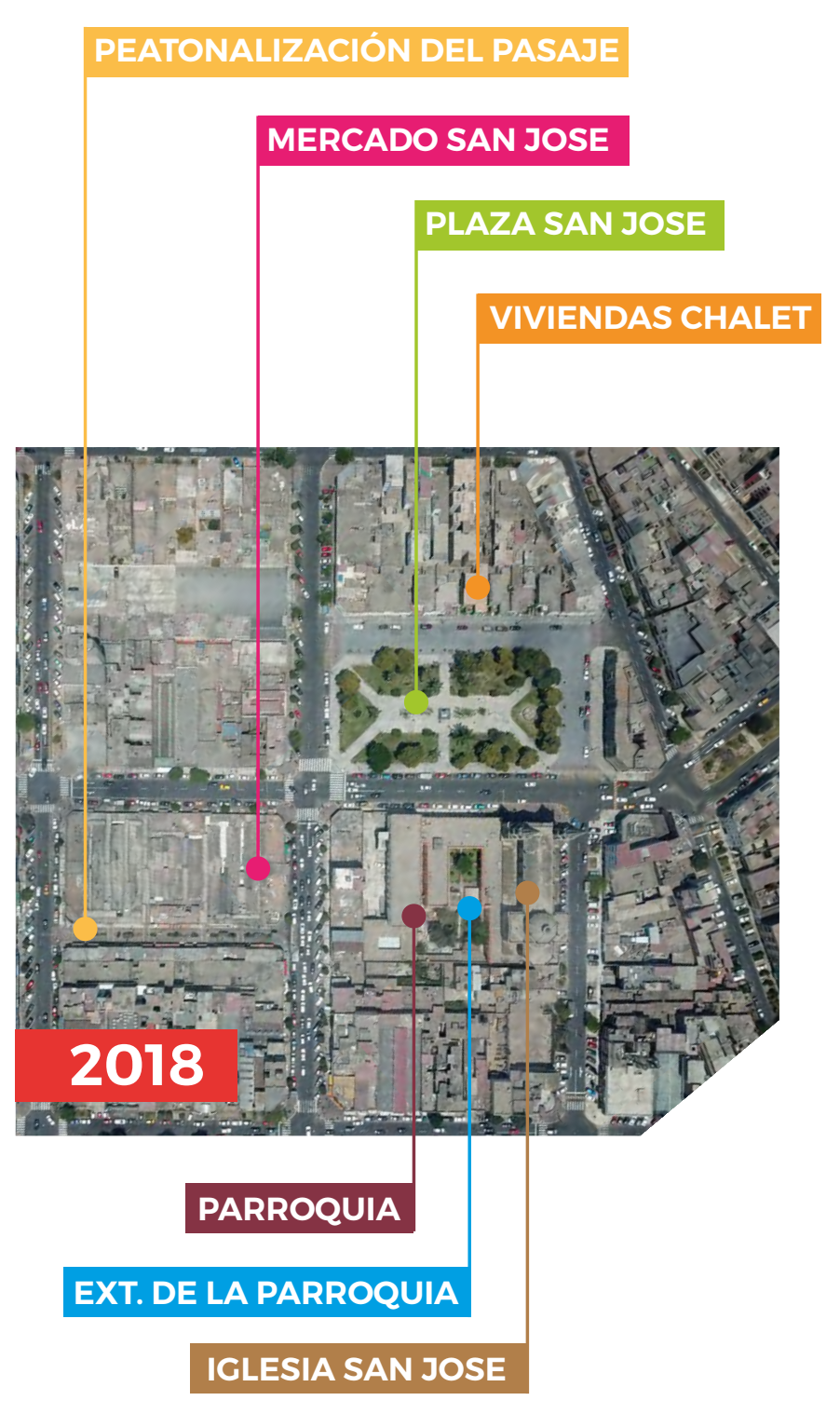




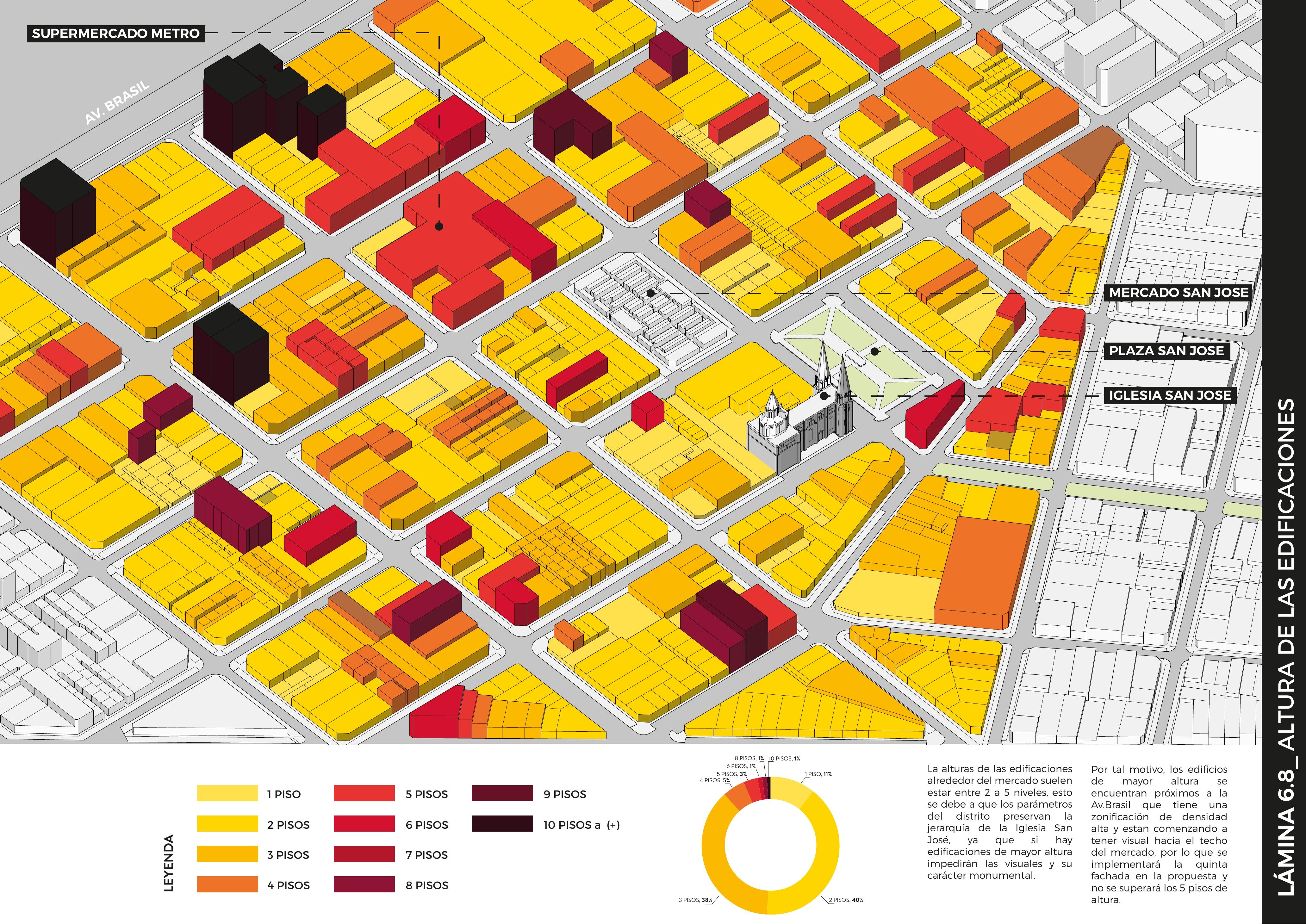




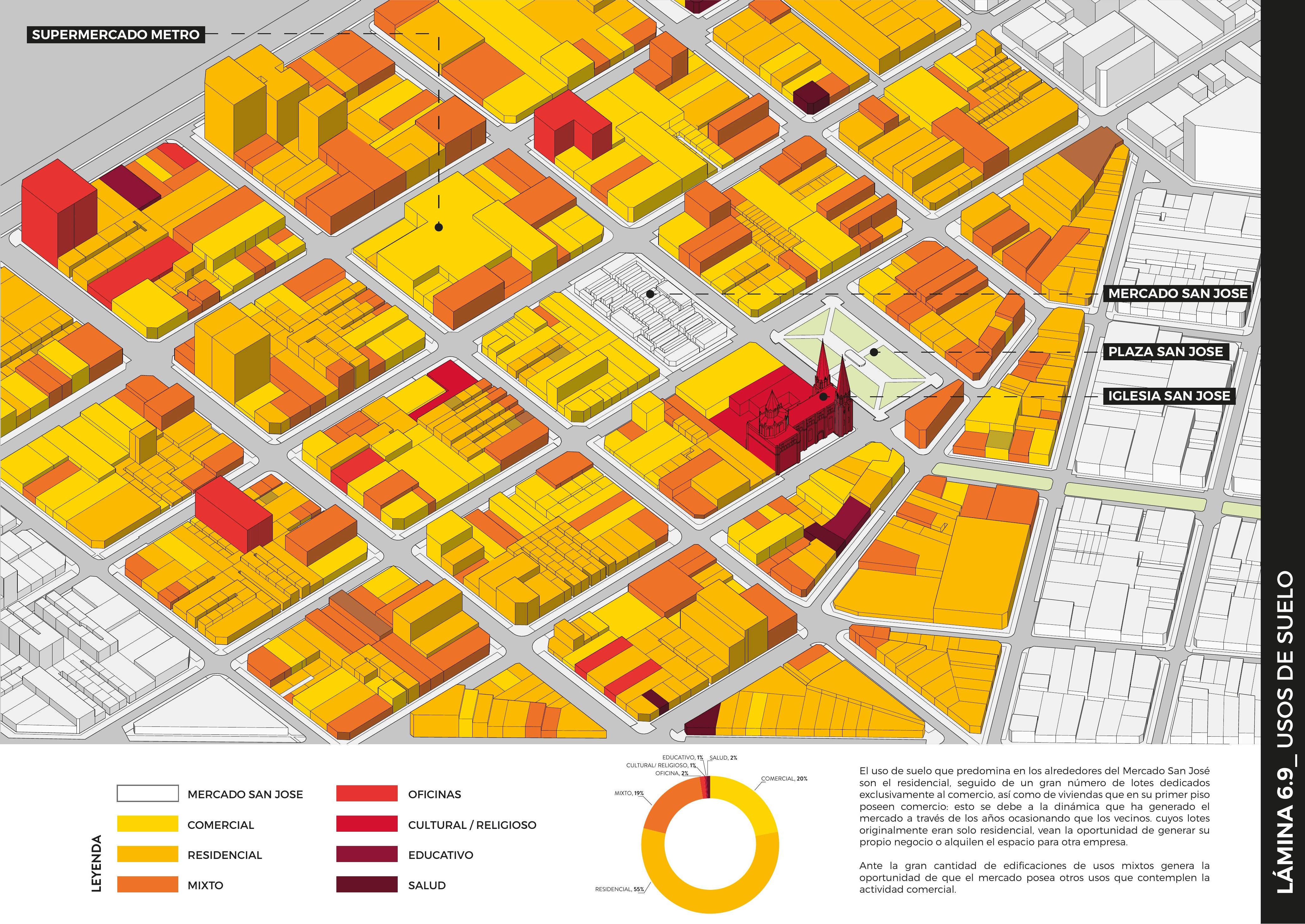




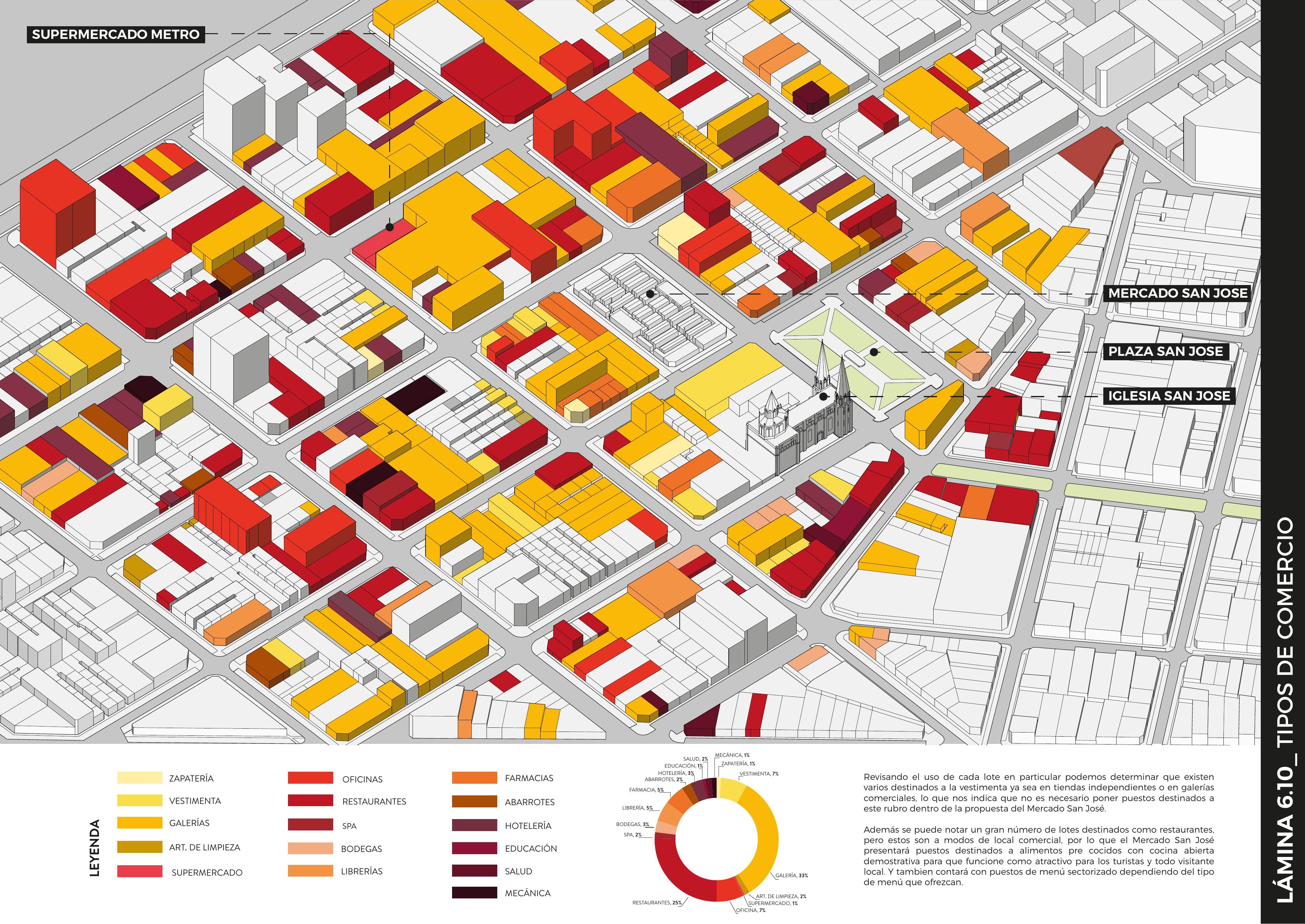




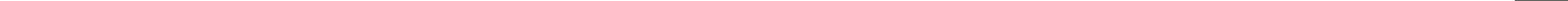




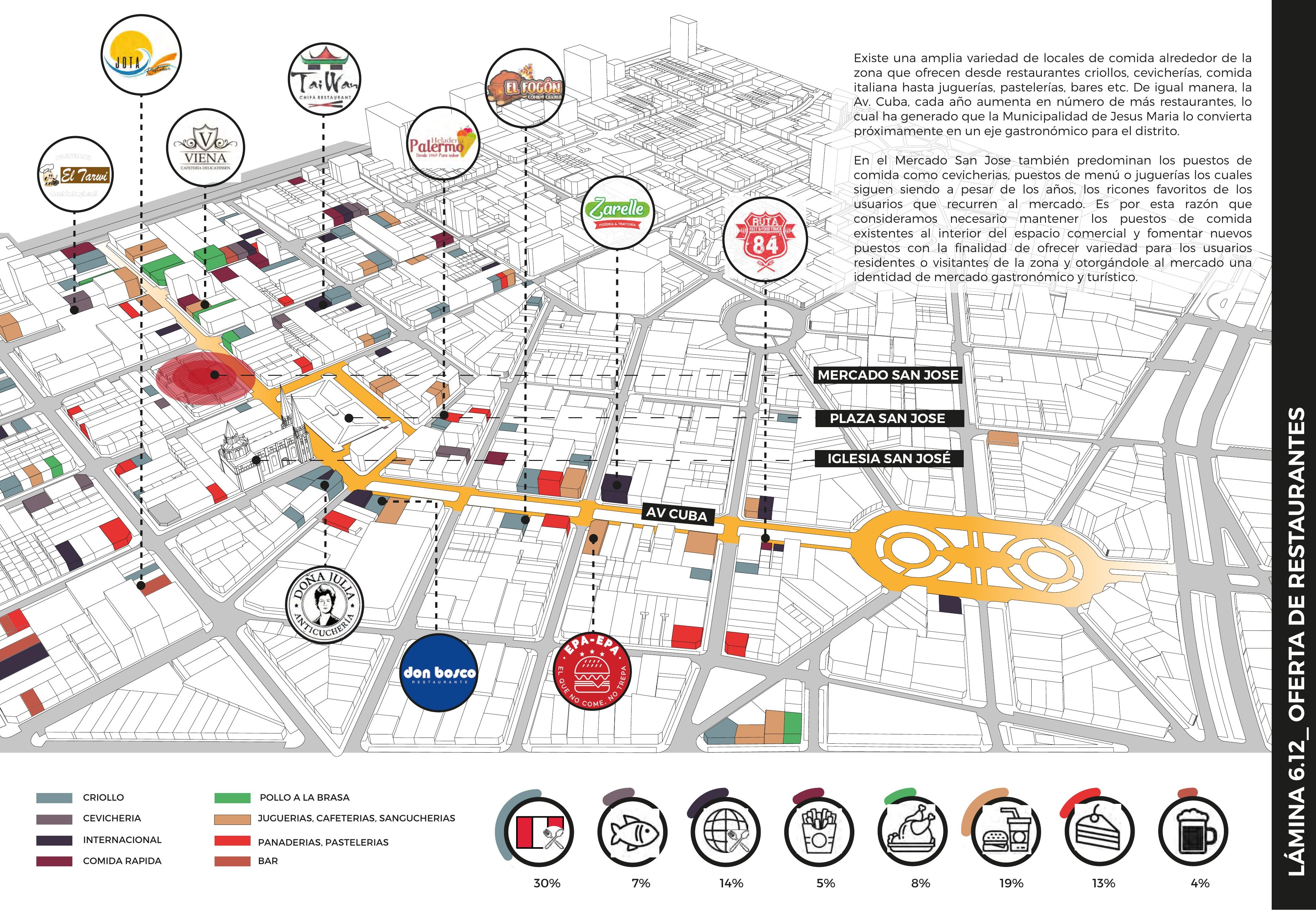


PLANO DE ZONIFICACION DISTRITO DE JESUS MARIA ZONARESIDENCIALES

RDA (RESIDENCIAL DE DENSIDAD ALTA) RDM (RESIDENCIML DE DENSDDPMTA) ZONA COMERCIALES CM (COMERCIO METROPOLITANO)

CZ (COMERCIO ZONAL)

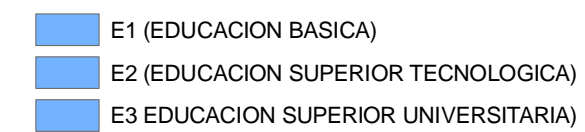
E2 EDUCACION SUPERIOR UNIVERSITARIA)
E3 E4 (EDUCACION SUPERIOR POST GRADO) H3 (HOSPITAL GENERAL) OU (OTROS USOS) Z7] ZRE (ZONA DE REGLAMENTACION ESPECIAL)
ZRP (ZONA DE RECREACION PUBLICA)

E1

RDA RDA RA
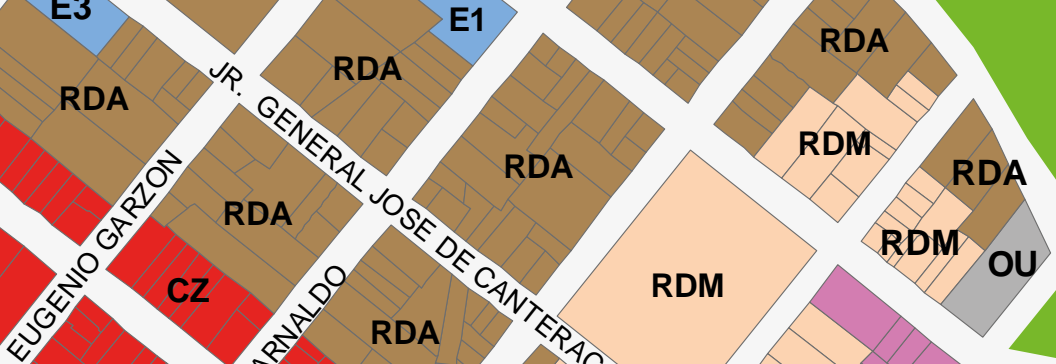

RDM OU RDM OU Rina RDM CV AV. TALARA की

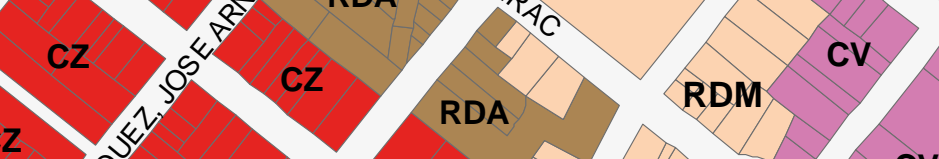

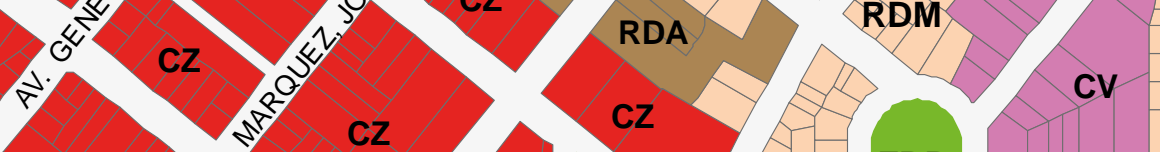
E4

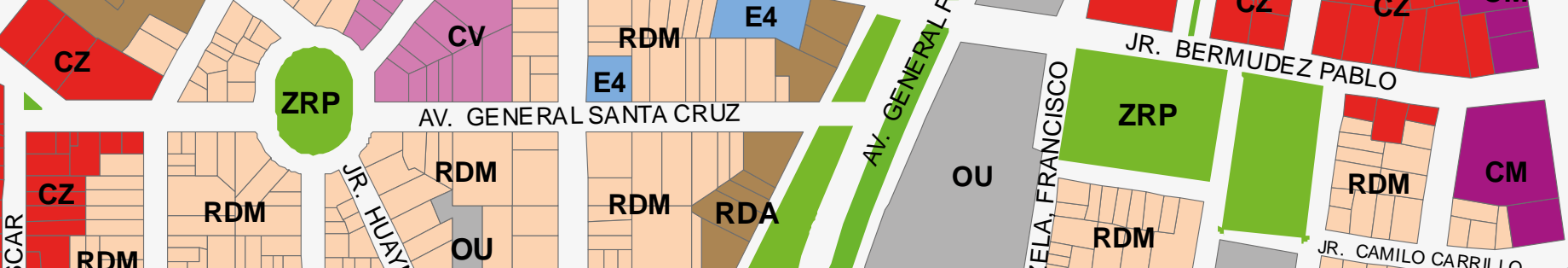

MERCADO SAN JOSE
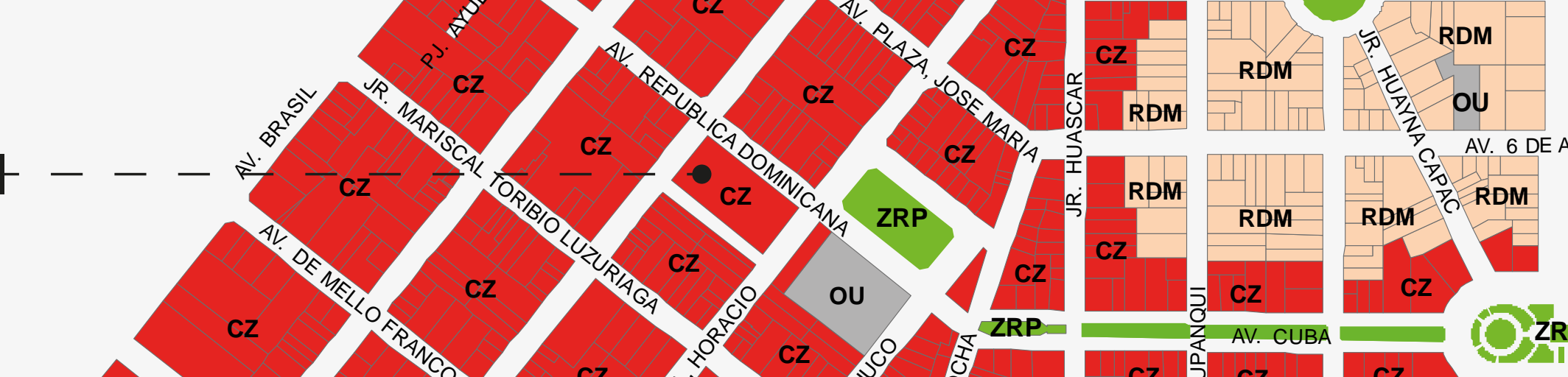

IITSO

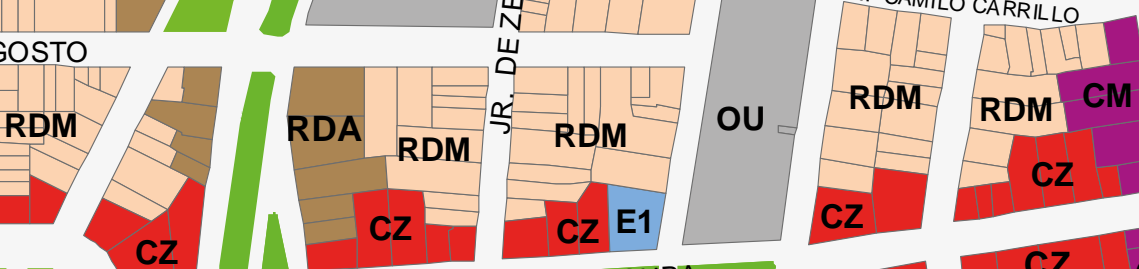

\section{(OZRP:}
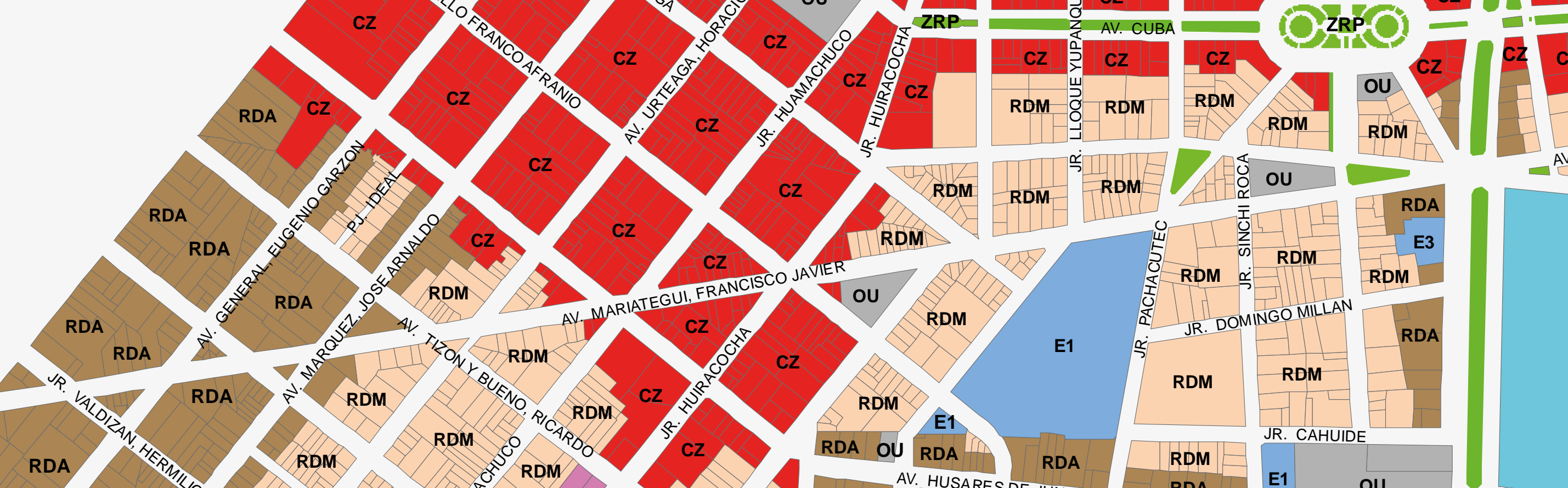

RDA
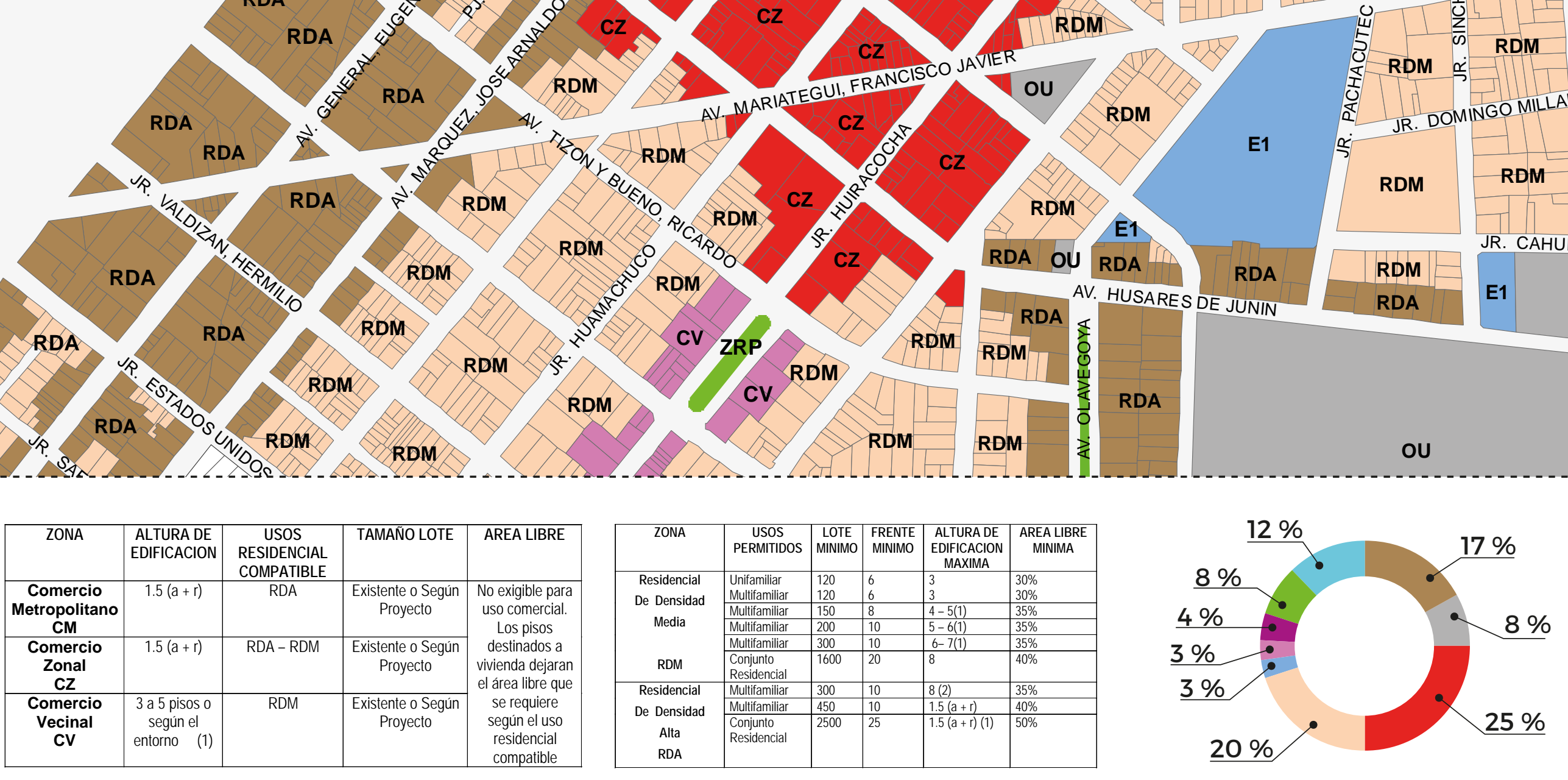

Cran parte de la zonificación del sector del mercado esta destinado al comermercado en su contexto.

Además, se puede observar que la zonificación cercana a la Av. Brasil ha estos lotes actualmente son de Densidad Media, lo que indica un futuro crecimiento demográfico.

También se observa que la zonificación de la Av. Cuba se modificó gracias al vando la llegada de nuevas marcas y franquicias. 
CERTIFICADO DE PARAMETROS URBANISTICOS Y EDIFICATORIOS

$$
\text { N³7-2019-MDJM/GDU/SOPPU }
$$

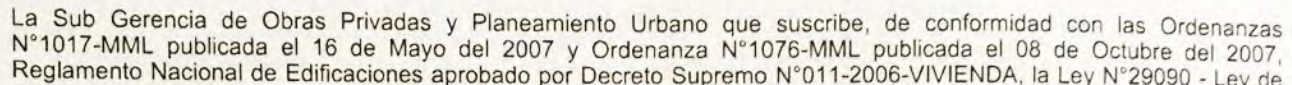

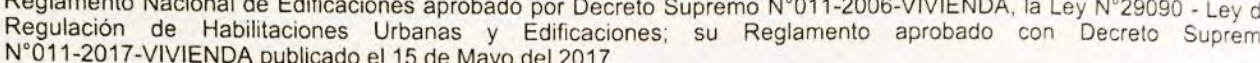
INFORMACION DEL CONTRIBUYENTE:

Expediente :
Solicitante:

$\begin{array}{ll}\text { Solicitante: } & \text { JOSE RONALD PANDURO MESIAS } \\ \text { Ubicacion del inmueble: } & \text { AV. REPUBLICA DOMINICANA N } 356-364 / \text { AV. JOSE ARNALDO MARQUEZ N } \\ & \text { Jo }\end{array}$

CERTIFICA:

JESUS MARIA (Datos consignados por el solicitante)

PARÁMETROS URBANISTICOS Y EDIFICATORIOS

\begin{tabular}{|c|c|}
\hline \multicolumn{2}{|r|}{$\begin{array}{l}\text { INFORMACIÓN TECNICA } \\
\end{array}$} \\
\hline $\begin{array}{l}\text { AREA DE TRATAMIENTO } \\
\text { NORMAIIO }\end{array}$ & "I Área de Mayor Hetereogeneidad de Función \\
\hline ZONIFICACIÓN & 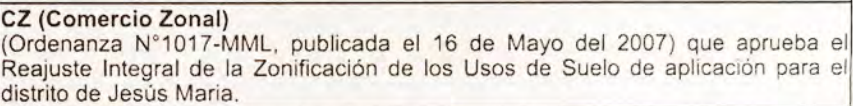 \\
\hline ALINEAMIENTO DE FACHADA & 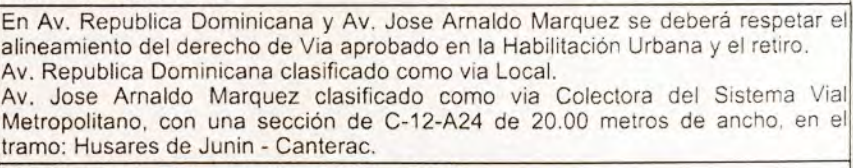 \\
\hline $\begin{array}{l}\text { USOS PERMIIBLLES Y } \\
\text { COMPATIBLES }\end{array}$ & 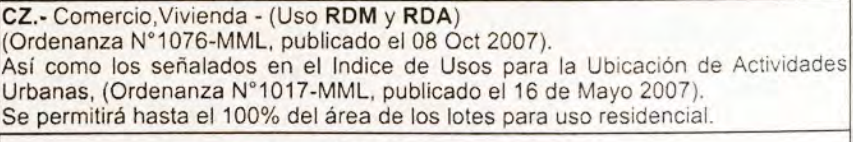 \\
\hline RETROS & $\begin{array}{l}\text { Av. Republica Dominicana con } 5.00 \mathrm{ml} \\
\text { Av. Jose Arnaldo Marquez con } 5.00 \mathrm{ml}\end{array}$ \\
\hline
\end{tabular}

CUADRO DE USO COMERCIO ZONAL - CZ

\begin{tabular}{|c|c|c|c|c|c|}
\hline \multicolumn{5}{|c|}{ CUADRO DE USO COMERCIO ZONAL - CZ } & \\
\hline $\begin{array}{l}\text { ALTURA DE } \\
\text { EDIFICACIOON }\end{array}$ & $\begin{array}{c}\text { USOS } \\
\text { PERMITIDOS }\end{array}$ & \begin{tabular}{|c|} 
TAMAÑO DE \\
LOTE
\end{tabular} & AREA LIBRE MINIMA & $\begin{array}{l}\text { ESTACIONAMIENTO } \\
\text { MINIMO }(3)\end{array}$ & \\
\hline $1.5(\mathrm{a}+\mathrm{r})$ & $\begin{array}{l}\text { Residencial de } \\
\text { Densidad Alta- } \\
\text { RDA. } \\
\text { Residenciald } \\
\text { Densidad } \\
\text { Media-RDM. }\end{array}$ & $\begin{array}{l}\text { Existente o según } \\
\text { Proyecto }\end{array}$ & $\begin{array}{l}\text { No exigible para Uso } \\
\text { Comercial. } \\
\text { Los pisos destinados a } \\
\text { Vivivendad adjaran el àrea } \\
\text { libre que se requiere segun } \\
\text { el luso residencial } \\
\text { compatible. }\end{array}$ & & - \\
\hline
\end{tabular}

$\mathrm{V}^{\circ} \mathrm{B}^{\circ}$

Martin Cundermo

\section{Ordenanza N ${ }^{\circ} 1076$ - MML (2007)}

A.10 Los requerimientos de estacionamiento para los usos no contemplados en las normas anteriores serán los
que se indican en el Cuadro siguiente. La Municipalidad necesarias, las que deberán ser evaluadas y aprobadas por Ordenanza Metropolitana.

\begin{tabular}{|c|c|}
\hline & UN ESTACIONAM \\
\hline $\begin{array}{l}\text { - Supermercados } \\
\text { - Tiendas de Autose }\end{array}$ & $\begin{array}{l}100 \mathrm{~m} 2 \text { de àrea de venta } \\
1000 \mathrm{~m} 2 \text { de arrea de venta }\end{array}$ \\
\hline $\begin{array}{l}\text { - Mercados } \\
\text { - }\end{array}$ & 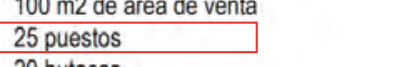 \\
\hline $\begin{array}{l}\text { - Cines, teatros y locales de } \\
\text { Espectáculos }\end{array}$ & 20 butacas \\
\hline $\begin{array}{l}\text { - Locales Culturales, Clubes } \mathrm{e} \\
\text { Instituciones y Yiminiares }\end{array}$ & $75 \mathrm{~m} 2$ de área tech. \\
\hline - Locales de Culto & $30 \mathrm{~m} 2$ de área de culto \\
\hline
\end{tabular}

Ordenanza N 1017 - MML (2007)

RDB RDM RDA VT CV $\begin{array}{llllll} & \mathrm{CZ} & \mathrm{CM} & 11 & 12 & 13\end{array}$

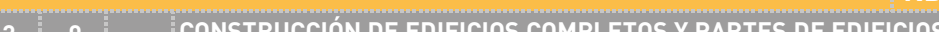

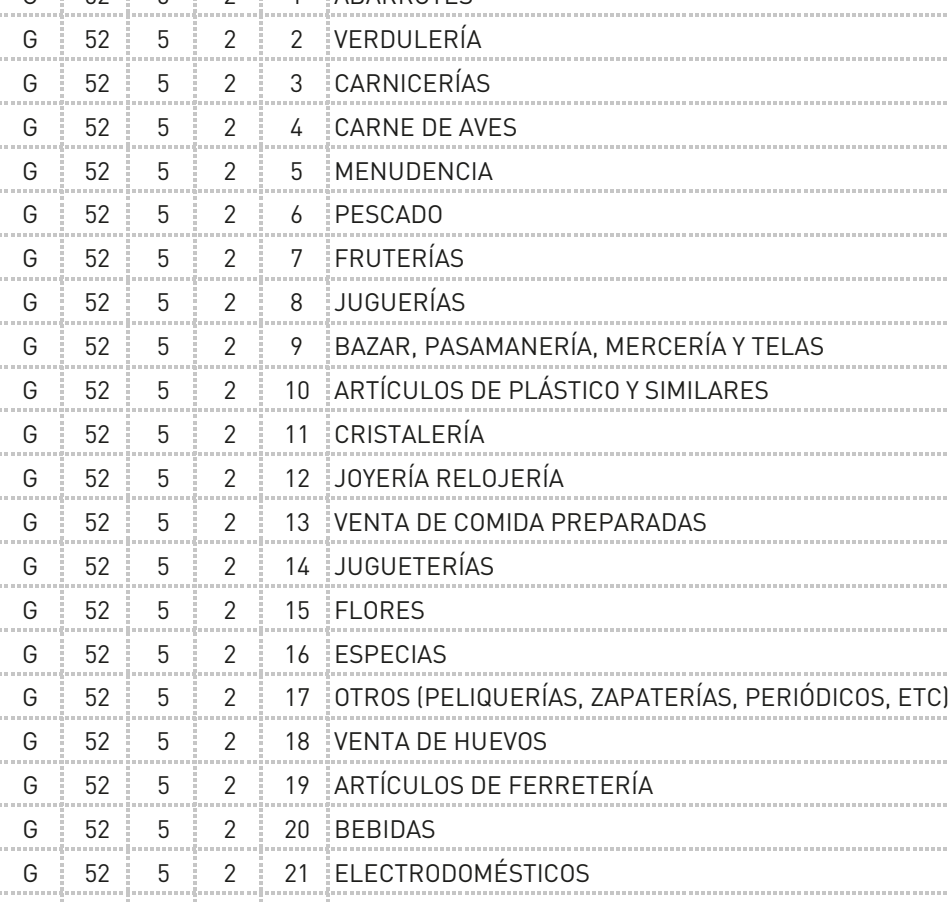



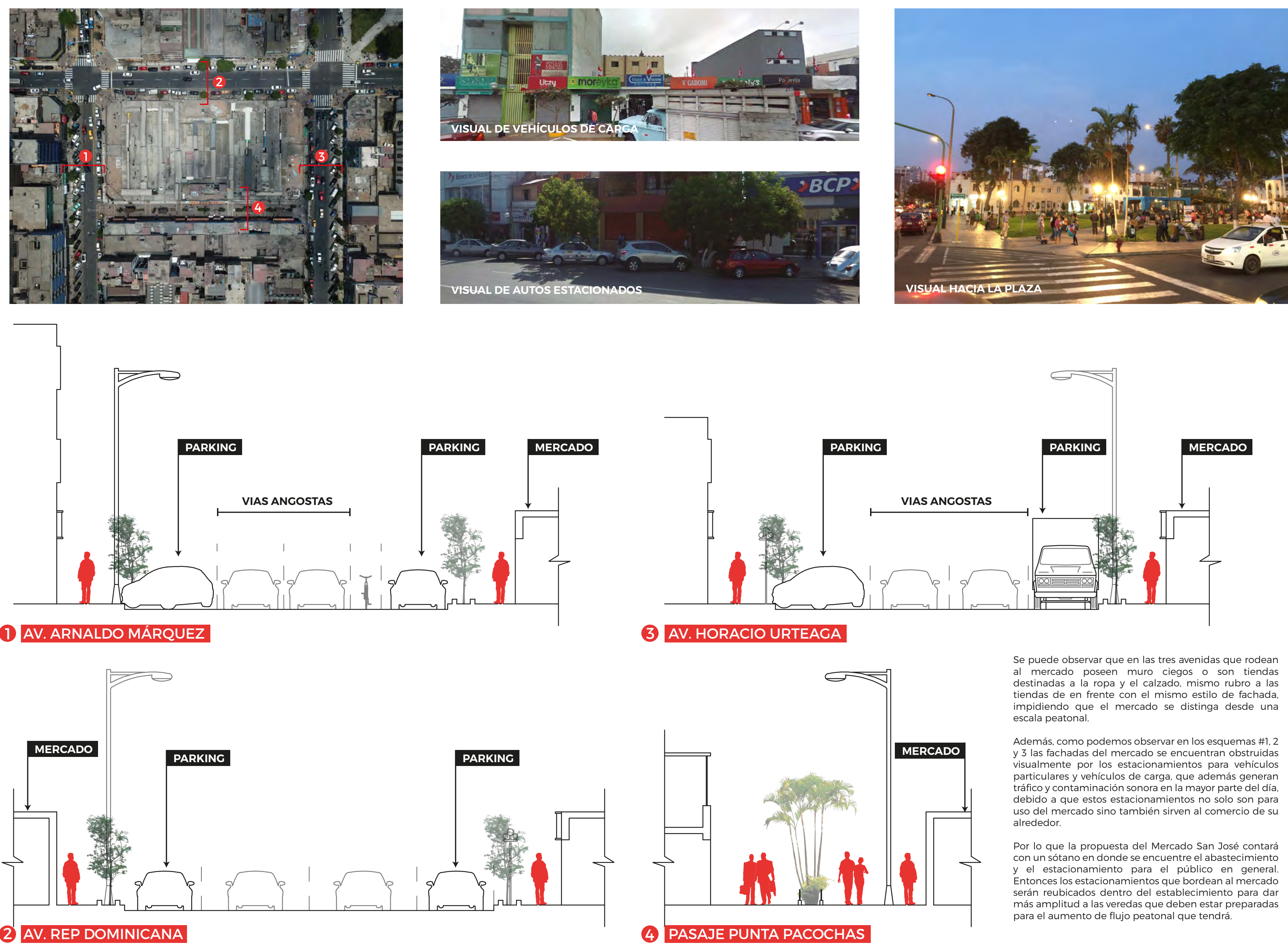

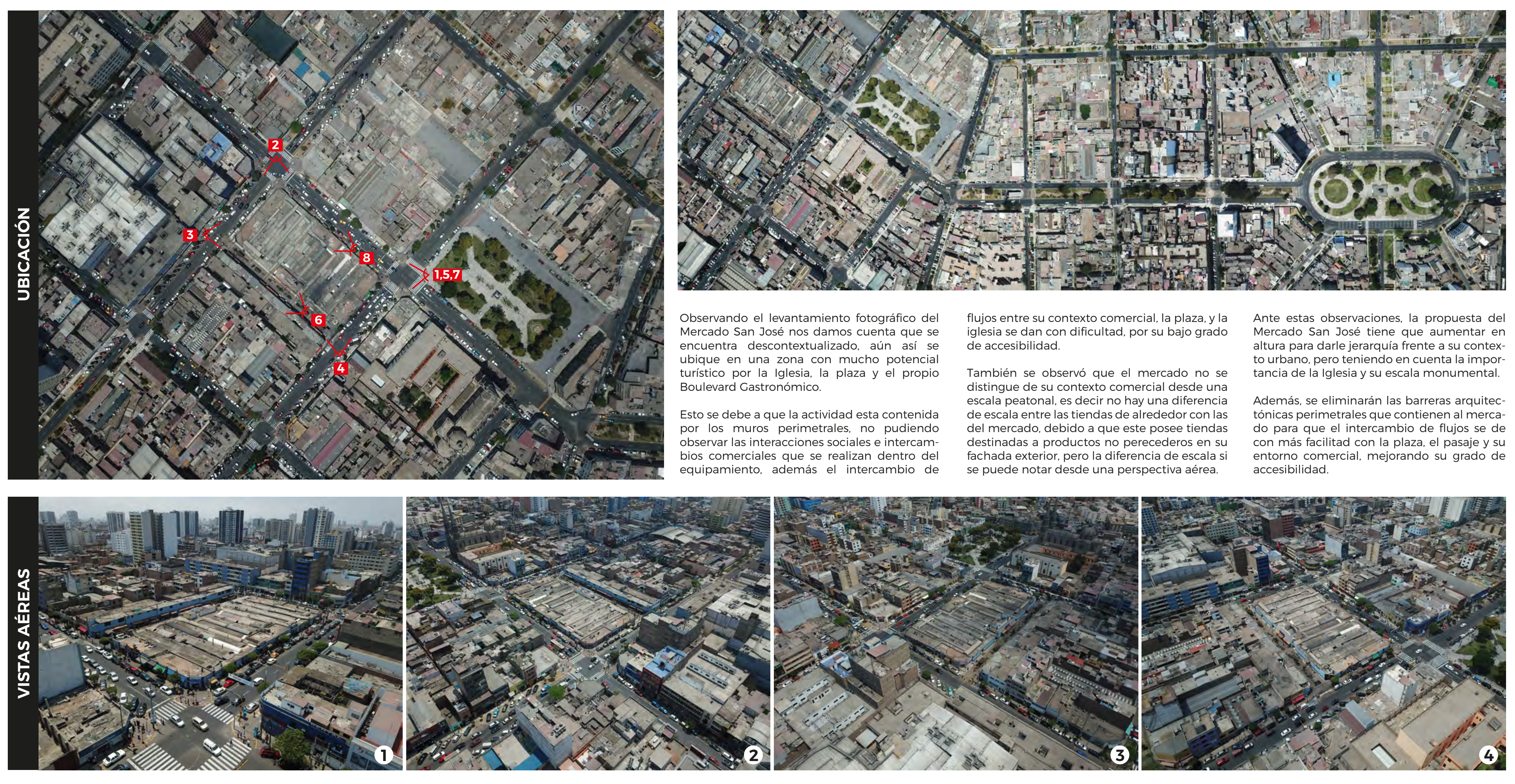

Observando el levantamiento fotográfico de encuentra descontextualizado, aún así se
ubique en una zona con mucho potencial turístico por la Iglesia, la plaza y el propio

Esto se debe a que la actividad esta contenida observar las interaccion es sociales e in tercam equipamiento, además el intercambio de
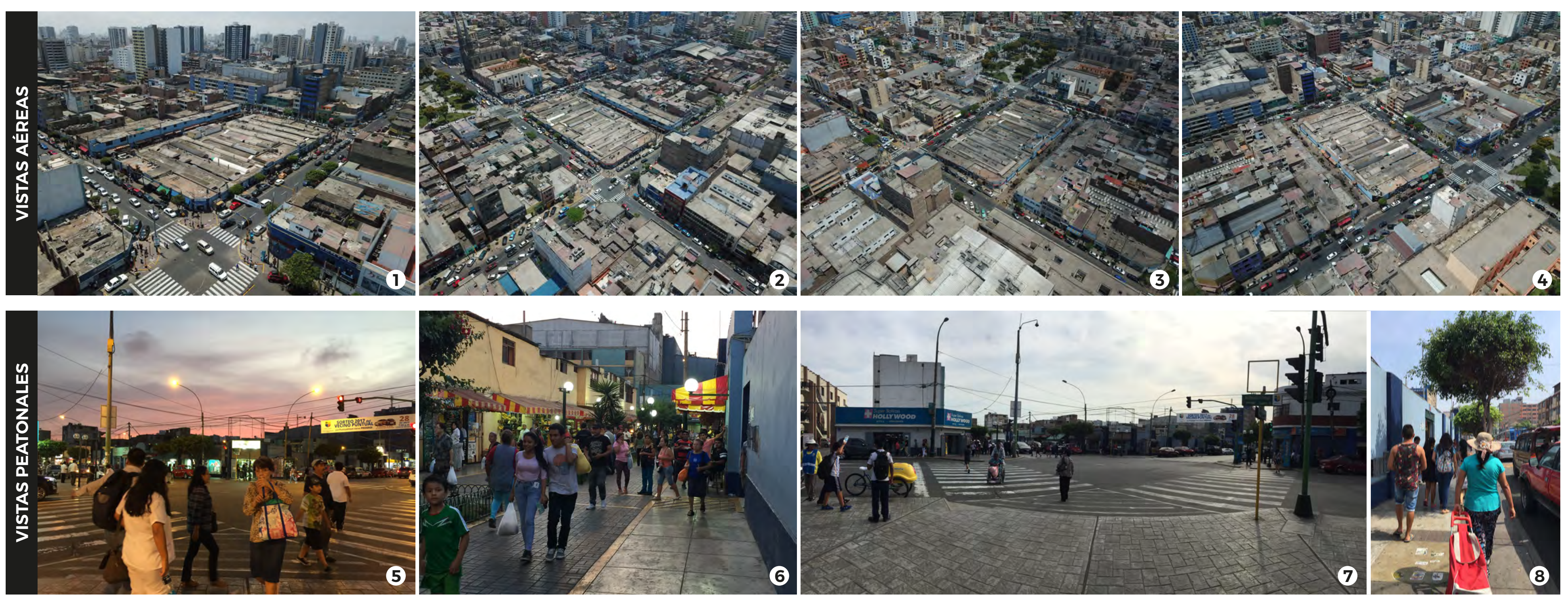

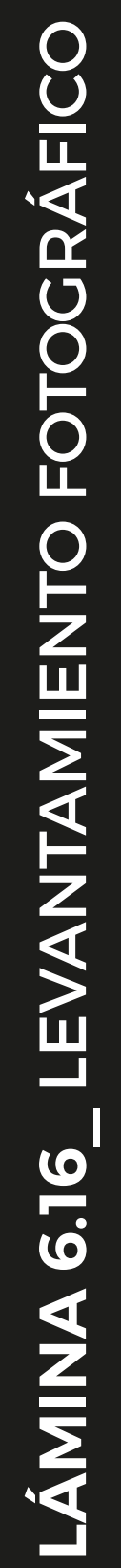



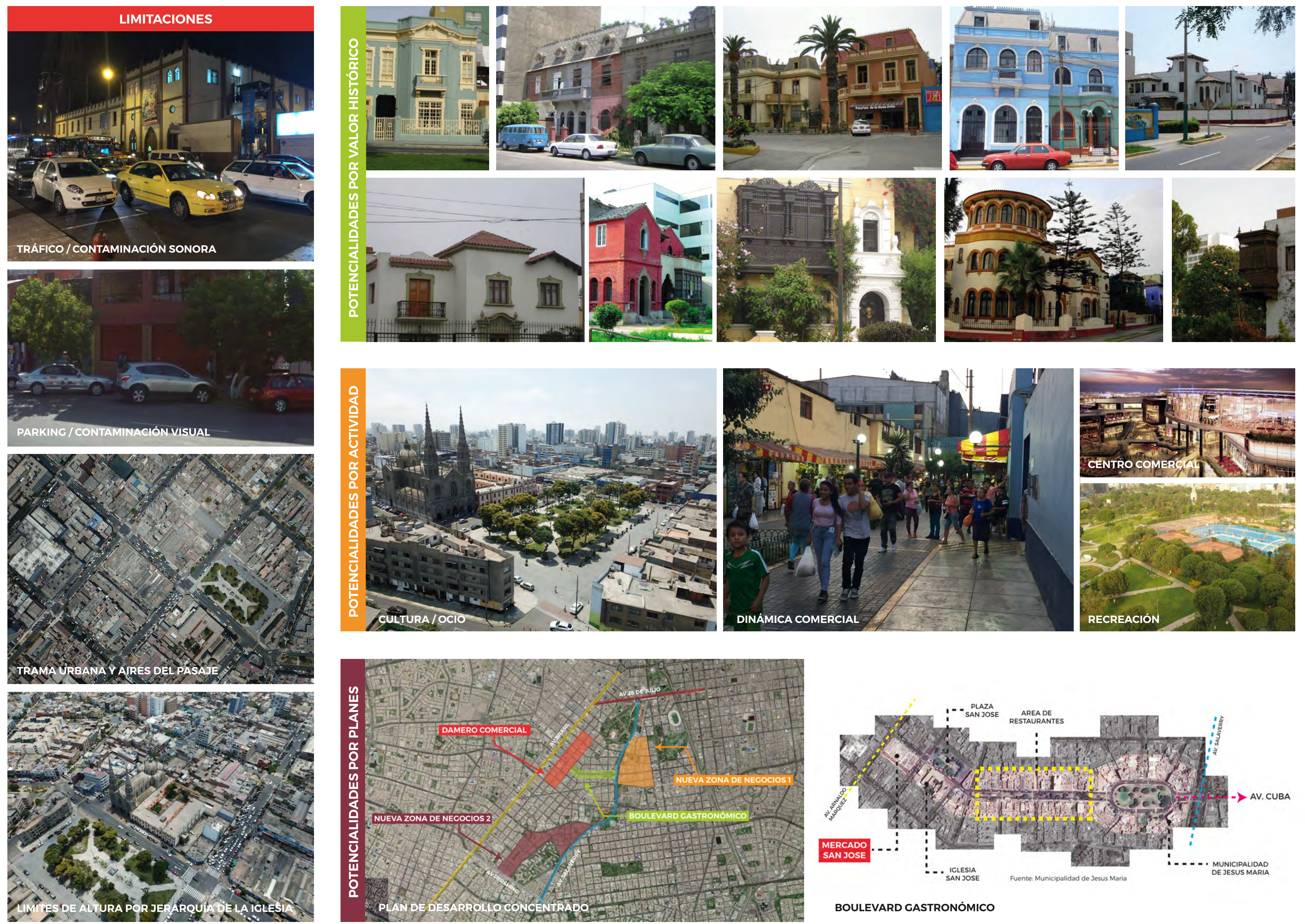

BOULEVARD GASTRONÓMICO

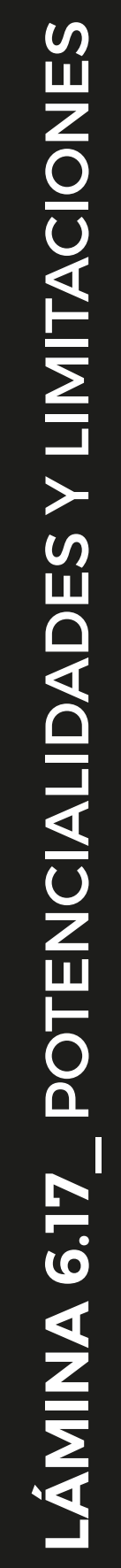




\subsection{Conclusiones parciales}

El distrito de Jesús María tiene un alto déficit de infraestructura de mercados de abasto, presentando tan solo dos, y el único mercado de tipo central que poseen no se encuentra en condiciones de cumplir con la actividad comercial y social en su interior, viéndose relegado frente a los formatos comerciales de autoservicio que si cumplen con las exigencias de los consumidores sofisticados y progresistas presentes en el distrito. Por tales motivos la propuesta del mercado mejorará la calidad de vida de los habitantes, al hacer que el mercado funcione bajo el concepto de espacio público, aumentando su grado de accesibilidad y un correcto emplazamiento.

Para el emplazamiento del mercado es importante saber los desplazamientos habituales que realizan los habitantes dentro de la trama urbana del distrito, notando que dentro de ella existe una gran cantidad de viviendas en forma de quinta, haciendo que los vecinos realicen desplazamientos lineales para llegar a su vivienda. Esta forma de desplazamiento también está presente en la morfología del mercado, debido a la existencia del pasaje Punta Pacochas que permite que los clientes puedan atravesar el mercado. Por lo que la propuesta del Mercado San José adoptará este tipo de desplazamientos en la configuración interna de los puestos de venta, generando circulaciones lineales que comuniquen la calle, con el mercado y el pasaje.

$\mathrm{Al}$ analizar las condiciones ambientales del distrito, no justifica que el mercado posea una cobertura debido a las muy bajas precipitaciones a lo largo del año, pero si proteger en cierto grado el asoleamiento, especialmente en épocas de verano. Debido a esto, la propuesta del mercado no será totalmente techada, sino que se pensara como un mercado al aire libre, pero el incremento de la altura de la edificación ayudará a que los puestos de venta y las circulaciones se protejan del asoleamiento, haciendo la función de aleros. 
Gracias al análisis del sistema de áreas libres como al sistema de cuerpos edificados, el Mercado tiene que tener como ingreso principal en dirección a la Plaza San José, debido a este es un punto de respiro del mercado frente a su contexto urbano que tiene un perfil de densidad baja que tiene la posibilidad de crecer y tapar el mercado perimetralmente, pero la existencia de la plaza posibilita una visual casi completa del mercado y un intercambio de flujos constante con este, de igual manera de la que funciona la plaza con la Iglesia San José.

Además, el Mercado San José tiene que tener una propuesta en cuanto a la cobertura de los puestos de venta, debido al incremento del desarrollo inmobiliario de la Av. Brasil con perfil de densidad alta que están comenzando a tener visual directa hacia el mercado, la plaza y la iglesia, por lo que se realizará una quinta fachada para que el mercado sea contemplado desde una perspectiva diferente.

El distrito de Jesús María presenta una gran cantidad de locales de comida que pertenecen a la zona del damero comercial del distrito, ofreciendo una amplia variedad de tipos de comida desde comida criolla, cevicherías, pollerías, comida internacional, juguerías, pastelerías, bares, etc. Por otro lado, la Av. Cuba, una de las principales avenidas del distrito y que abre paso al sector del damero comercial, cada año crece en relación a restaurantes, lo cual ha conseguido por parte de la municipalidad en convertir esta avenida en un eje gastronómico principal del distrito de Jesús María. Asimismo, en el propio Mercado San José, los puestos predominantes son los de venta de comida los cuales se han mantenido alrededor de los años por su alta demanda de comensales residentes y visitantes que los prefiere.

Por lo tanto, es necesario mantener los puestos de comida existentes al interior del mercado y a su vez generar nuevos puestos que oferten una variedad de comida diferente a la existente con la finalidad de poder otorgarle una identidad gastronómica al Mercado San José, intensificar su oferta para los usuarios que acudan al él y que a la vez pueda funcionar como una continuación de la Av. Cuba como eje gastronómico del distrito de Jesús María. 
En el primer piso en la fachada principal del mercado, se incluirán puestos de comida los cuales cambiarán de acuerdo a su uso durante el día como: juguerías, venta de menú, sanwicherías, anticuchos, etc. De igual manera, en el pasaje Punta Pacochas, estarán ubicados los puestos de menú existentes del mercado, los cuales se reubicarán a lo largo del pasaje con la finalidad de poder hacer uso de su espacio. Por otro lado, el segundo nivel del mercado, también contendrán puestos de comida; sin embargo, estos variarán en cuanto a su oferta, como heladerías, postrarías, bares, etc. Finalmente, se plantea generar un boulevard gastronómico en el mismo nivel que exhiba los platos típicos de las diferentes regiones del Perú, supliendo algunos restaurantes que ya ofrecen esta variedad en la zona y completándola al interior del mercado.

Finalmente, después de analizar el comportamiento de los clientes dentro del mercado a lo largo del día, indica que la mayor afluencia de personas es a partir de las 13:00 a 15:00 horas acumulándose en los puestos de menús, a tal punto que llegan a ocupar el pasaje Punta Pacochas, por lo que la propuesta del mercado generará espacios de ocio en su interior y espacios en donde las personas puedan comer, ya sea en los mismos puestos de venta o un patio de comidas. 


\section{CAPÍTULO VII: Conclusiones finales}

A continuación, se verán los principales aspectos estudiados de la investigación que repercutirán en las tomas de decisiones y su implementación como estrategias proyectuales, además se adjunta una lámina de diagrama de lógicas que resumen las estrategias a utilizarse, según lo revisado en cada capítulo.

\section{Marco Histórico:}

Al analizar la evolución de los mercados a nivel internacional como a nivel local, se concluye que la relación del intercambio comercial y el espacio público se puede encontrar desde el origen de las ciudades. Esta dualidad que fue perdiendo por los cambios tipológicos generados por cambios sociales, culturales, políticos y avances tecnológicos, afectando la locación de los mercados y su grado de accesibilidad con su entorno.

En los procesos tipológicos redactados, se observa que las tipologías que mejor funcionaron a lo largo de la historia son la Estoa (s.V a.C) y la Plaza del Mercado (s. XI), debido a su alto grado de accesibilidad, a su ubicación en las vías principales, al no poseer barreras arquitectónicas que impidan su relación con el exterior, y no había restricción horaria; características que deben ser consideradas a la hora de proyectar un mercado de abasto.

En el Perú también estuvo presente todo el proceso tipológico de los mercados por la influencia de los españoles en la época colonial, pero impusieron una tipología de mercado de acuerdo a su experiencia en Europa, mas no en cómo se realizaba la actividad comercial de las comunidades andinas, donde el Catu era un lugar de treque sin un ánimo lucrativo con el objetivo de crear alianzas con otras sociedades y conseguir productos para alimentarse, por lo que se debe reforzar la idea del mercado como lugar de interacción social. 
Al realizarse un estudio demográfico de la ciudad de Lima a través de los años, vs. los años de operación de los mercados, podemos afirmar que se encuentran directamente relacionados y que su ubicación en el territorio se debe a la necesidad de abastecimiento de la población. Al investigar la historia y la evolución del Mercado San José se observa que nace bajo la necesidad de la población de abastecerse de productos, además analizando la trama urbana desde el inicio de las operaciones del mercado hasta el día de hoy, se puede notar la importancia del Pasaje Punta Pacochas y la linealidad de la configuración del mercado, por lo que se debe respetar la memoria generada en los habitantes.

\section{Marco Operativo:}

Actualmente, los mercados ya no son solo un equipamiento comercial, sino que también son considerados productos turísticos, ofreciendo nuevas experiencias a los turistas como a los clientes locales. Para que un mercado pueda funcionar hoy en día debe generar su propia identidad dentro del contexto urbano en donde se encuentra ubicado, por lo que, en los casos analizados, el mercado rompe con el límite que lo define, por medio de una arquitectura permeable que permite desdibujar las barreras arquitectónicas que evitan que la actividad comercial se muestre desde el exterior.

Si bien cada mercado analizado se ubica en un contexto distinto, se puede observar que presentan plazas como programa complementario, y se suelen ubicar en los ingresos o salidas, brindando espacio de ocio a la ciudad, como también fortalece la idea de evitar límites y barreras arquitectónicas al realizar plazas in-out y a su vez incrementan las interacciones sociales al ser un punto de encuentro para los clientes.

Estos mercados también tienen un alto grado de accesibilidad, debido a que intercambian flujos constantemente con el exterior, gracias a la cantidad de ingresos que poseen y porque el área de ventas se encuentra a nivel con la calle, si el mercado posee más niveles de venta, como es en los casos analizados, se tiene que mostrar la actividad desde el exterior para que genere curiosidad en los clientes incentivándolos a subir, e implementar el uso de rampas o escaleras eléctricas, para evitar un mayor esfuerzo al cambiar de nivel. 
En cuanto al programa arquitectónico de los mercados, estos no siempre son destinados solo a la venta de productos perecederos, sino que, dependiendo de lo que requiere el entorno en donde se ubican se designa un programa que lo complemente, permitiendo un incremento en la cantidad de clientes y la actividad horaria, al mismo tiempo satisface otras necesidades (según el programa complementario) en un mismo lugar comercial.

La distribución de los puestos de venta, es consecuente a la trama urbana de la localidad en el que se encuentran y reinterpreta los desplazamientos habituales de los habitantes para adoptarlos en la circulación del mercado, relacionado el mercado con su contexto. Además, los puestos de venta de los mercados analizados poseen una zonificación más clara, debido a que están agrupados por rubro o giro, permitiendo que los clientes puedan dirigirse rápidamente hacia donde se encuentra el producto que requieren.

También podemos inferir que la cantidad de puestos por rubro, depende de la identidad de cada mercado generado por su propio contexto y su demanda comercial, por ejemplo, en el Mercado Santa Caterina, son la venta de pescados y productos marítimos, debido a su cercanía al puerto de la ciudad, mientras que el Mercado Dels Encants predominan productos para el hogar y antigüedades por ser antiguamente un mercado de pulgas.

Y en cuanto a la cobertura del mercado, se concluye que esta debe estar ligada a la estructura principal para lograr luces más amplias que permitan un tránsito más fluido, flexible y sin obstáculos. También, la cobertura actualmente es considerada una fachada más del proyecto, ya que debido al contexto en el que se ubica, los edificios aledaños pueden tener visual hacia el establecimiento, como también el diseño de la cobertura y su materialidad pueden configurarlo como un hito en la ciudad, al otorgarle una personalidad única. 


\section{Marco Teórico:}

$\mathrm{Al}$ analizar los referentes del marco operativo queda demostrado que el espacio público está contemplado en los proyectos analizados. Estos espacios son representados como plazas o toman la apariencia de calles en la configuración interna con sus amplios pasillos (como es el caso del Mercado Dels Encants). Sin embargo, esta condición de espacio público no se repite para todos los casos. En el Perú, la mayoría de mercados son vistos solo como lugares para la compra y venta de bienes y servicios. Sumado a ello, muchas ciudades peruanas están experimentando conflictos de privatización, proponiendo el desarrollo de plataformas comerciales ocasionado en paralelo el abandono de los mercados tradicionales y crisis de identidad. Por lo tanto, es importante enfrentar estas problemáticas y demostrar a través del proyecto las cualidades que los mercados como espacios públicos ofrecen, tales como: ser un lugar que promueve las necesidades psicológicas manifestadas al momento de hacer las compras, ser un espacio de reunión pública y ser un escenario para la construcción y desenvolvimiento de relaciones sociales. Asimismo, los mercados presentan diversas fisonomías en función al grado de turistificación que pueda darse en ellos. En este sentido, una nueva tipología de mercados nace, promocionando las ciudades y representando las prácticas de consumo, hábitos alimenticios y costumbres de cada lugar.

No obstante, para devolverle al mercado su condición de espacio público y como nuevo referente turístico, debemos tener presente el tratamiento del límite como límite difuso para el diseño del mercado. Por lo tanto, se deberá contar con una arquitectura permeable que garantice la accesibilidad a todos los usuarios, una envolvente ligera en donde la estructura en conjunto con la transición de la materialidad y la transparencia, propicien esa fina capa de separación del límite hacia el exterior y logre exhibir las actividades desarrolladas al interior del mercado, aparentando ser parte del espacio público de la ciudad, a pesar de ser un espacio contenido, permitiéndole al usuario verse participe de lo público. De esta manera, se compartiría un sentimiento de lo común y se comenzaría a crear identidad en la ciudad. Asimismo, insertar plazas en los ingresos del proyecto, ayudaría desdibujar el límite del mercado generando una mejor relación con su entorno. 
De esta manera, se reactivarán los espacios en desuso que se presentan actualmente alrededor del mercado, se reducirían los índices de criminalidad como consecuencia de las actividades en el espacio, se atraerían nuevos visitantes con un nuevo programa y diseño de la envolvente y se mejoraría la calidad de vida de la zona. En el caso del mercado San José, esto repercutiría de manera positiva ya, generando nuevos espacios para recreación y mejoraría de la calidad de la zona, pero, sobre todo brindaría identidad y sentido de pertenencia de los pobladores hacia el mercado.

\section{Marco Contextual}

Al realizar el análisis de la trama urbana del distrito se notó que existe un gran número de viviendas que pertenecientes a la tipología de quintas, haciendo habitual que los habitantes realicen desplazamientos lineales que rematan en un espacio de encuentro. Este tipo de desplazamientos también está presente en la morfología del mercado, pero se encuentra contenida no pudiendo rematar en espacios de encuentro o con el mismo pasaje Punta Pacochas. Por este motivo se realizarán espacios públicos en los puntos de encuentro del mercado para que cada pasaje remate en un área pública y así comunicar, la calle, el mercado y el pasaje.

Además, el mercado al no poseer una jerarquía frente a su contexto, ni contar con ingresos principales, el proyecto debería generar una fachada en dirección hacia el Parque San José porque posibilita una visual casi completa del establecimiento lo que permitiría un intercambio de flujos constante con él.

Finalmente, en cuanto a la oferta comercial, se implementará puestos de productos perecederos, puestos de servicios, y un nivel para oficinas, generando que el mercado tenga una venta especializada, más completa y con un rango horario de funcionamiento más amplio. Los servicios que predominará en el proyecto serán los menús y la venta de alimentos pre- cocidos, manteniendo la identidad gastronómica que posee, y fortalecerlo pensando en el plan urbano del boulevard gastronómico propuesto por la Municipalidad de Jesús María. 


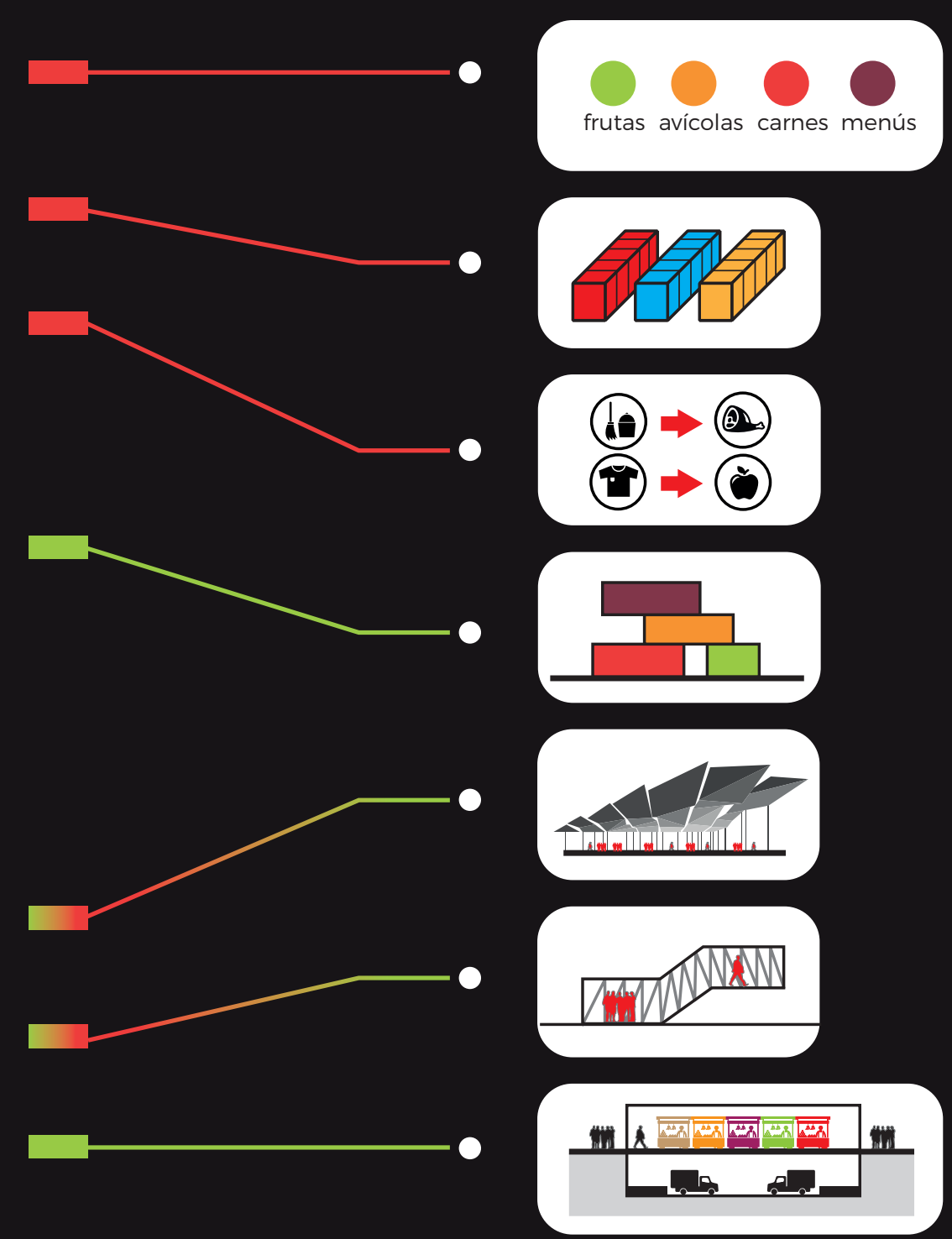

DEFINICIONES DE MERCADO :

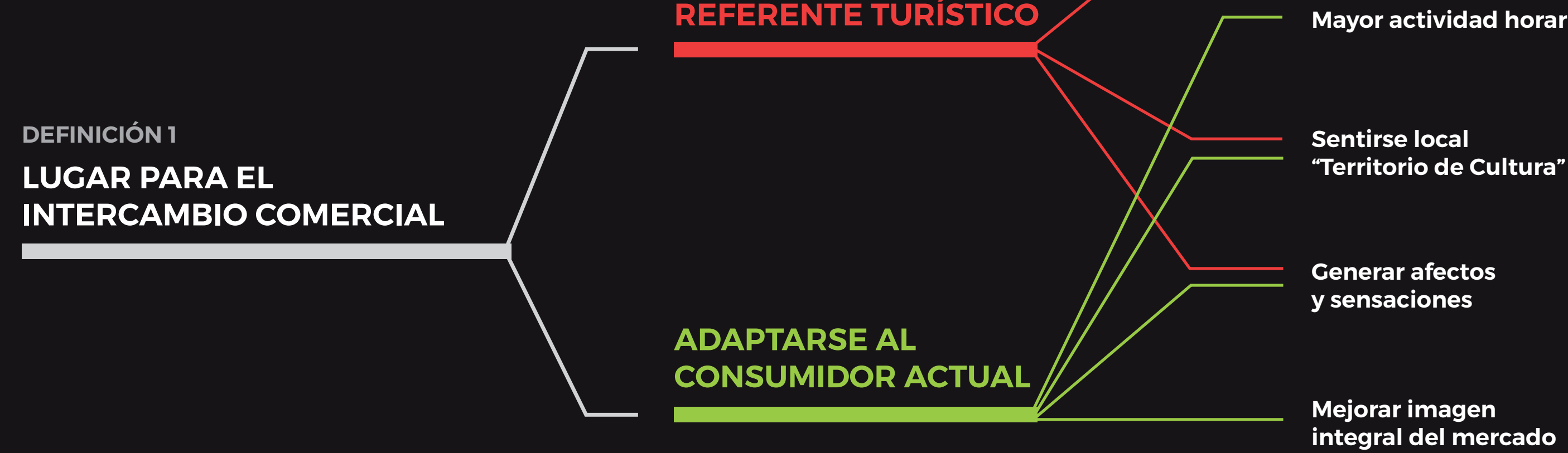

integral del mercado

Crear espacios de atractivos

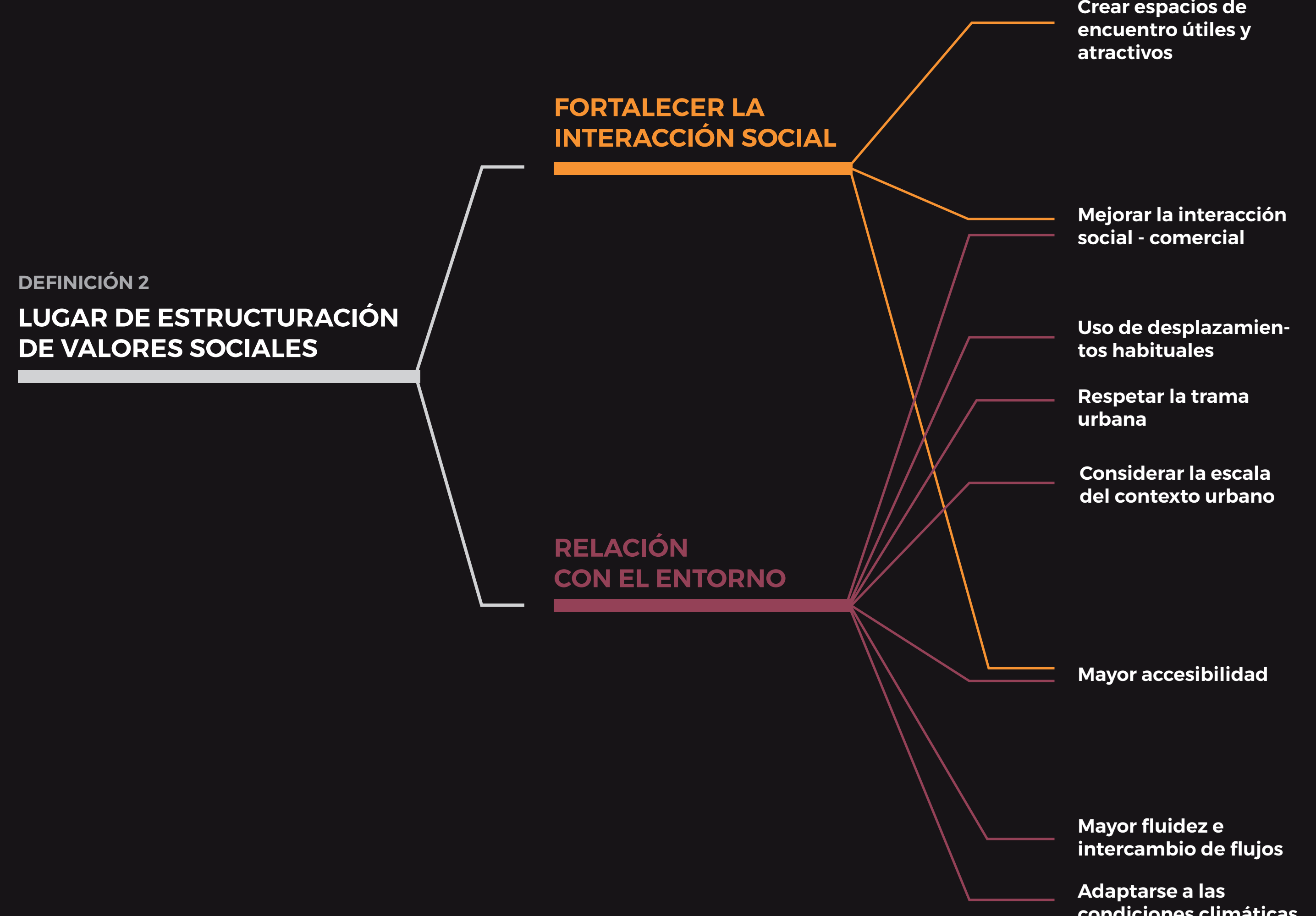

ón de los puestos

Cambios de rubro

Re - dimensionamiento

- puestos y pasajes

- Implementar usos mixtos

Implementar espacio para

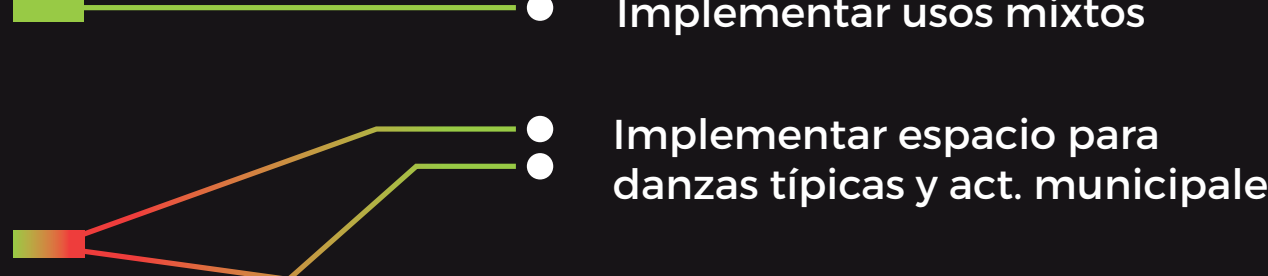

Utilizar vegetación local

- Cobertura como Hito

- Espacialidad cambiante

visible al público

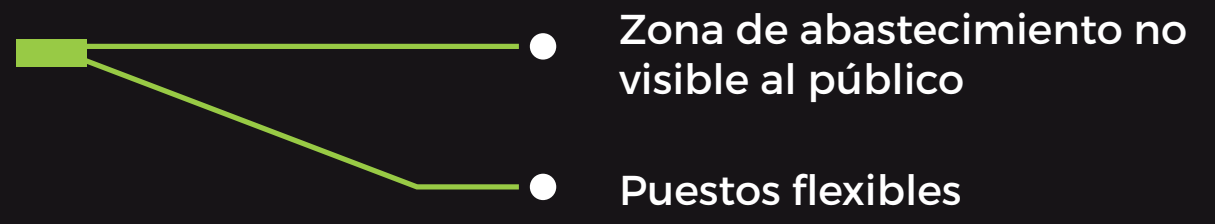

Uso de vegetación en los

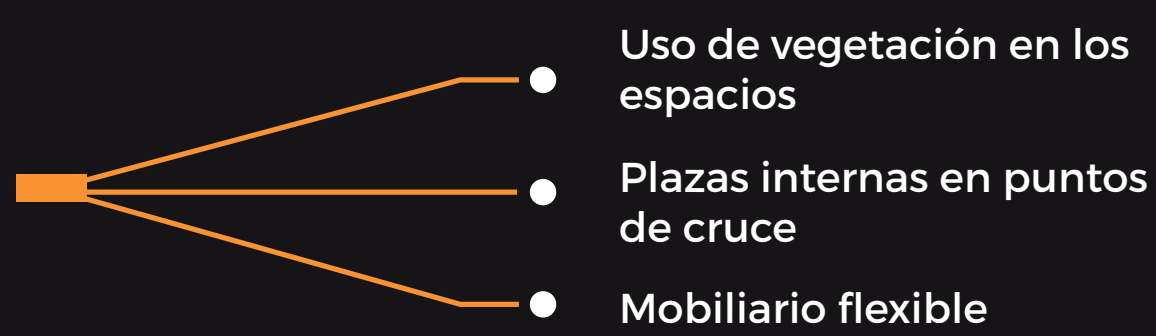

- Mobiliario flexible

- Plazas In- Out

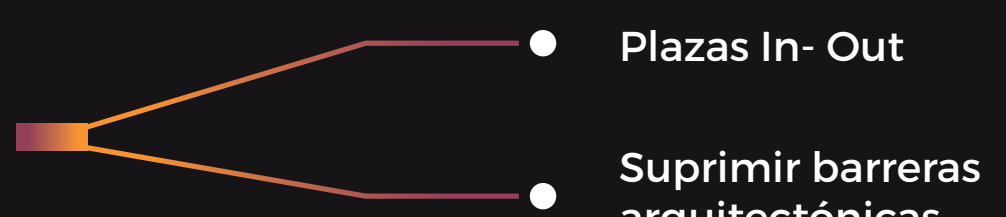

Suprimir barreras

- Usar la linealiedad de

las quintas

- No variar las dimensiones

Tener en cuenta la jerarquía
de la iglesia (MÁX. 5 PISOS)

Implementar 5ta Fachad

- Incrementar $\mathrm{N}^{\circ}$ de ingresos

- Disolver límites horizontales

Eliminar estacionamientos para vehículos privados y de
carga alrededor del mercado

Pocos apoyos estructurales

- Protección contra e asoleamiento

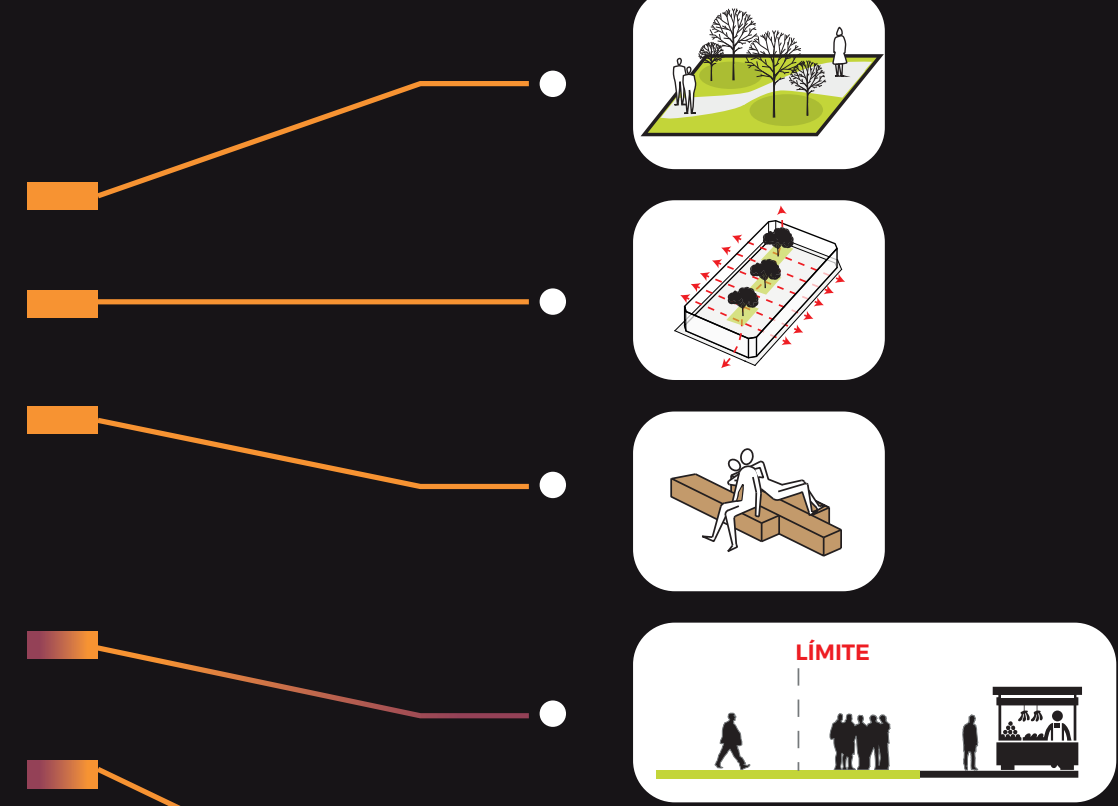

- mat a
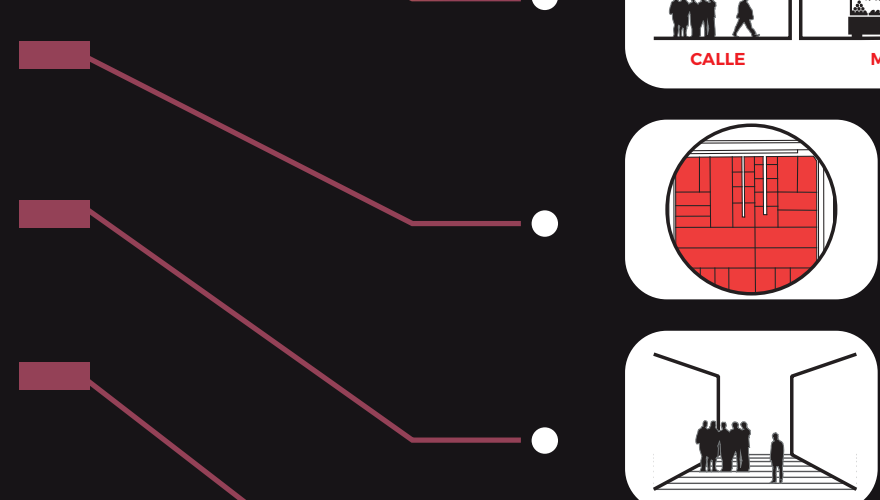

-

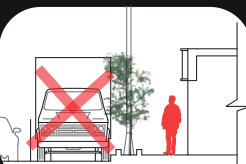

岛 


\section{CAPÍTULO VIII: Proyecto}

\subsection{Proyecto}

El proyecto tiene como propósito mejorar la calidad física del lugar para devolverle al mercado su condición como espacio de reunión pública; fortaleciendo la interacción social de la comunidad y su relación con su entorno. Asimismo, se propone una nueva identidad para el mercado, que se adapte a los cambios del consumidor actual y ser un nuevo referente turístico que oferte la diversidad de oportunidades de consumo desde su interior.

Para el diseño del nuevo mercado, se toman las teorías analizadas previamente del espacio público, el límite difuso del orden de Toyo Ito y el turismo local. Estas teorías ayudaran a condicionar las variables del diseño de la estructura, las plazas internas, el envolvente, la fachada, los puestos de venta y flujos del mercado. A continuación, se presentarán las estrategias que se usarán para la propuesta del proyecto, las cuales se irán describiendo desde el primer hasta el último nivel del mercado.

\subsubsection{Toma de partido}

El concepto del Mercado San José propone la idea de mercado como espacio público en donde el criterio es la fluidez espacial y su capacidad de relacionarse con el entorno. El proyecto se entenderá como la extensión de la Plaza San José por medio de un eje central con plazas intermedias, el cual partirá desde la calle hacia el interior del mercado, logrando fusionar la actividad comercial con el espacio público existente. Al mismo tiempo, se reinterpreta la trama urbana y los desplazamientos habituales de las personas en el distrito generado por la tipología de quintas, para proponer la configuración interna de los puestos de venta, además de disolver el límite existente del mercado con la calle. Finalmente, a través de una fina envolvente, de materialidad translucida y de ligera estructura, se pretenderá desdibujar los límites del edificio, con la finalidad de exhibir las interacciones sociales vividas al interior del mercado y semejar que este sigue siendo parte de lo público. 


\subsubsection{Estrategias proyectuales}

\section{Del Terreno}

El terreno se ubica en el damero comercial del distrito de Jesús María, rodeado por avenidas en tres de sus frentes, y en una de ellas por un pasaje. Por su frente más largo de 89.95 metros, orientado hacia el noreste, pasa la Av. República Dominicana, prolongación de la Av. Cuba, que permite la conexión del distrito con la zona financiera de San isidro por el cruce de dos grandes avenidas como la Av. Salaverry y la Av. Arequipa. Hacia el sureste, cuenta con un frente de 61.02 metros de largo por el cual pasa la Av. Horacio Urteaga. Por el sur, con 89.95 metros, colinda con el pasaje Punta Pacochas, calle peatonal que divide al proyecto del mercado en dos partes. Finalmente, por el noroeste, con 61.02 metros de largo, pasa la Av. Arnaldo Márquez. Por lo tanto, el proyecto está conformado por 5 frentes, 3 que miran hacia avenidas principales y dos de ellos hacia el pasaje. Asimismo, es importante resaltar la cercanía que tiene el terreno del mercado con respecto a dos hitos importantes del distrito tales como: la plaza y la iglesia San José.

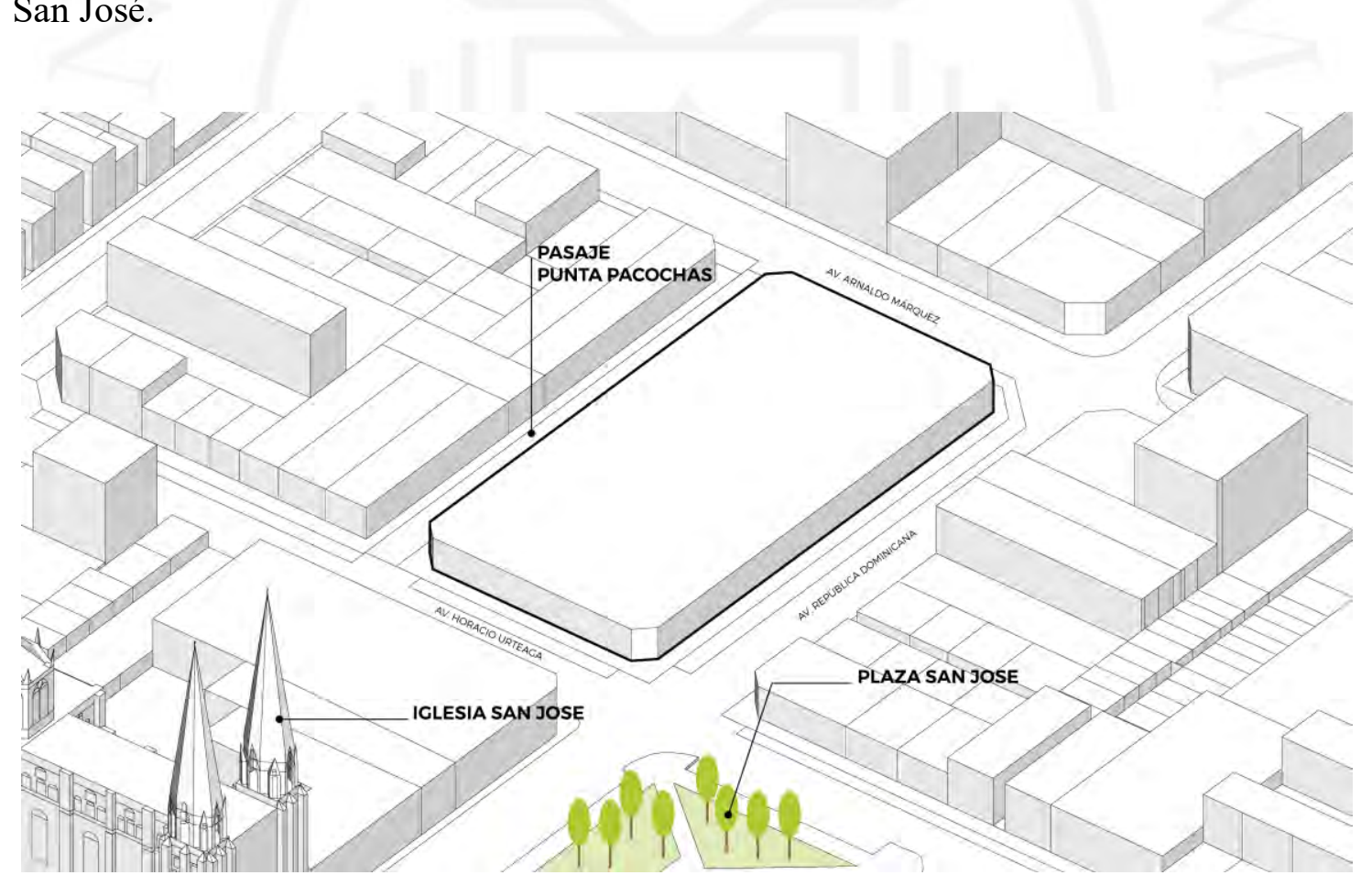

Figura 8.1 Ubicación del terreno

Gráfico elaborado por los autores. 
Actualmente el mercado solo cuenta con un solo nivel, el cual no se comunica con su entorno inmediato y no posee una jerarquía en comparación con los edificios aledaños generando que el mercado no se observe inmediatamente. Por tales motivos, se incrementará en altura el equipamiento, y el frente del ochavado será más amplio con la finalidad de lograr una visual directa con la plaza, generar un espacio previo al ingreso y descongestionar el flujo peatonal.

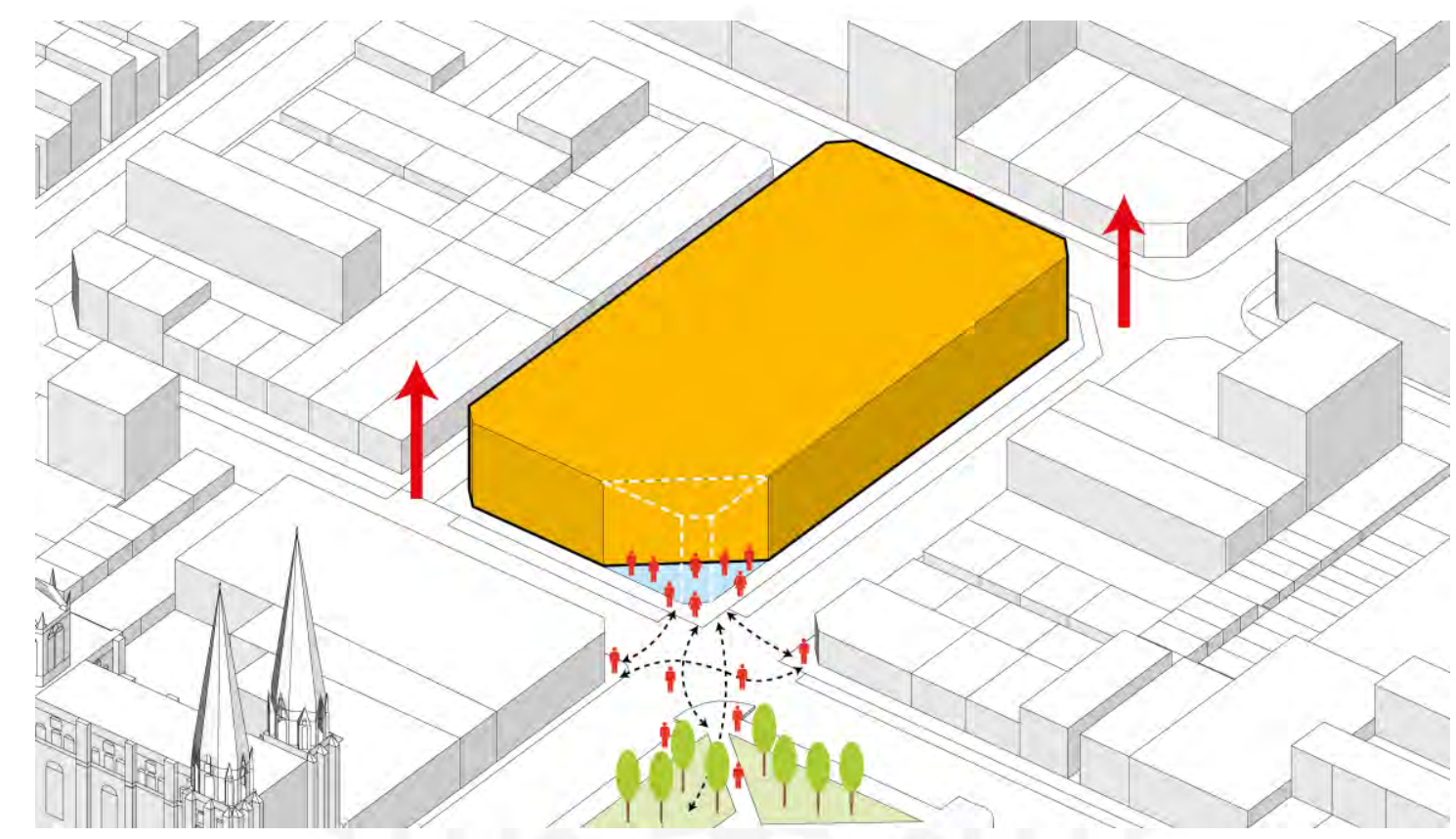

Figura 8.2 Estrategias_Jerarquía frente al contexto urbano

Gráfico elaborado por los autores.

\section{Organización interna}

El terreno se encuentra rodeado de puestos de venta ajenos al programa del mercado que impiden una relación directa del mercado con su entorno. Además, muchos de estos puestos, con la finalidad de ganar más área de venta, han ido ocupando parte de los pasajes del mercado, obstaculizando el tránsito y actuando como una barrera que impide al usuario desplazarse con libertad dentro del establecimiento. Asimismo, el programa administrativo y el área de servicios del mercado como depósitos, servicios higiénicos, etc. ubicados en la fachada colindante a la Av. Rep. Dominicana y en la fachada con frente al pasaje Punta Pacochas, ocultan la actividad comercial desde la calle. 
Por lo tanto, siguiendo con nuestra teoría del límite difuso propuesta por Toyo Ito, establece que los límites de la edificación deben de romper los márgenes entre el interior y el exterior, de manera que se tenga un entorno más dinámico y no estático, con ganas de ser vivido. Entonces, se reubicaría los puestos de venta ajenos al programa del mercado, así como también su área administrativa y de servicios (todos señalados en color amarillo) para ser reemplazados por puestos de venta y tener un borde más activo, exhibiendo la actividad del mercado y reforzando su relación con su entorno.

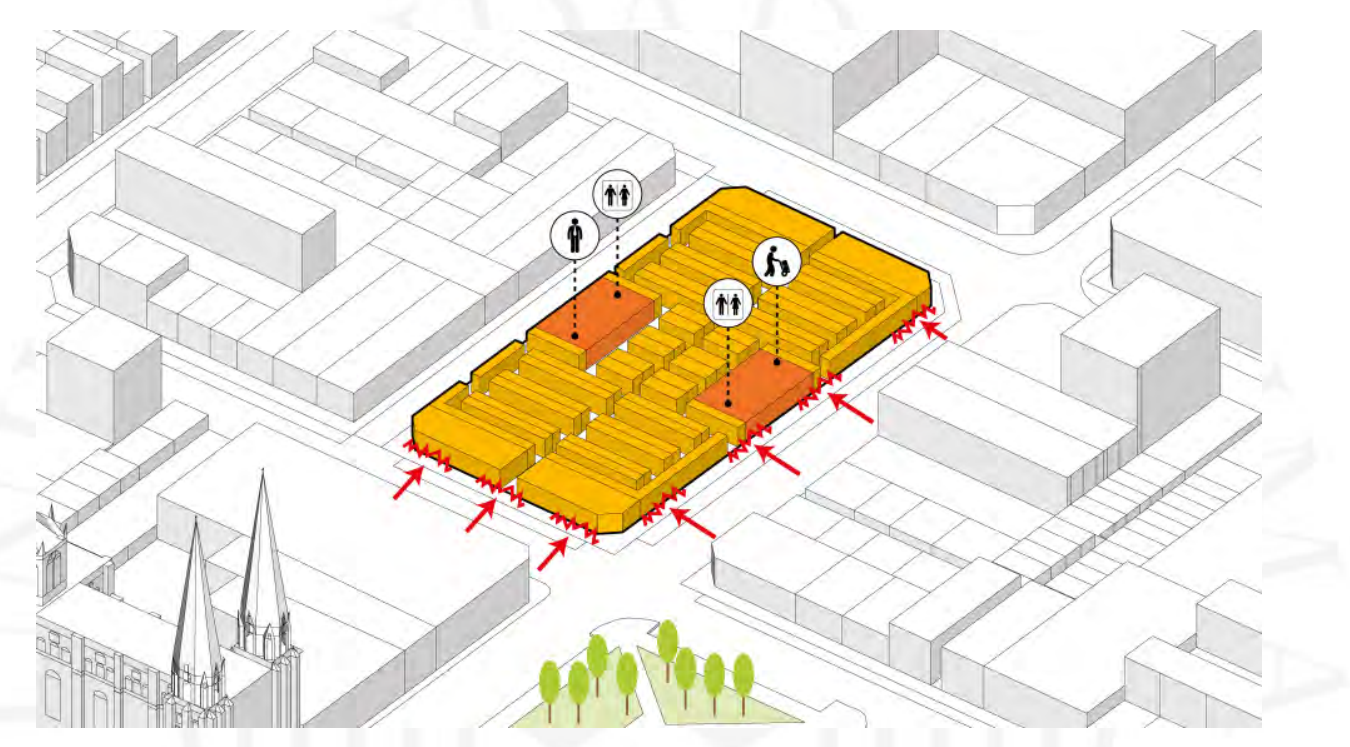

Figura 8.3 Estrategias_Suprimir barreras peatonales Gráfico elaborado por los autores.

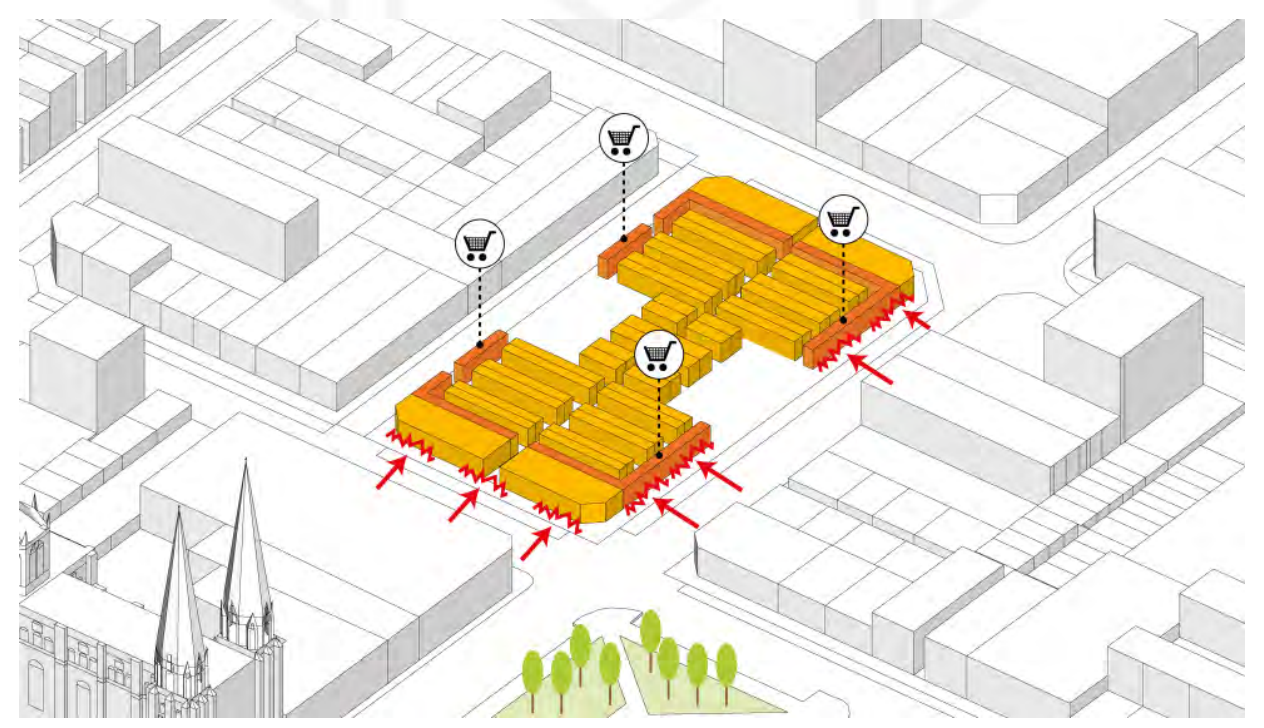

Figura 8.4 Estrategias_Re dimensión de puestos externos

Gráfico elaborado por los autores. 
Asimismo, se logrará tener un acceso directo desde la calle hacia los puestos de venta logrando un espacio comercial más permeable. En este sentido, el mercado contará con diez pabellones situados de manera perpendicular a la Av. Rep. Dominicana. Ocho de ellos, ubicados en la parte central del mercado, estarán destinados a la venta de productos perecederos como: carnes, pescados, frutas, verduras, abarrotes, entre otros; mientras que los dos pabellones restantes, ubicados en las fachadas laterales del terreno, contarán con los servicios y programa complementario para el mercado como: servicios higiénicos, guardería, tópico, lactario, etc.

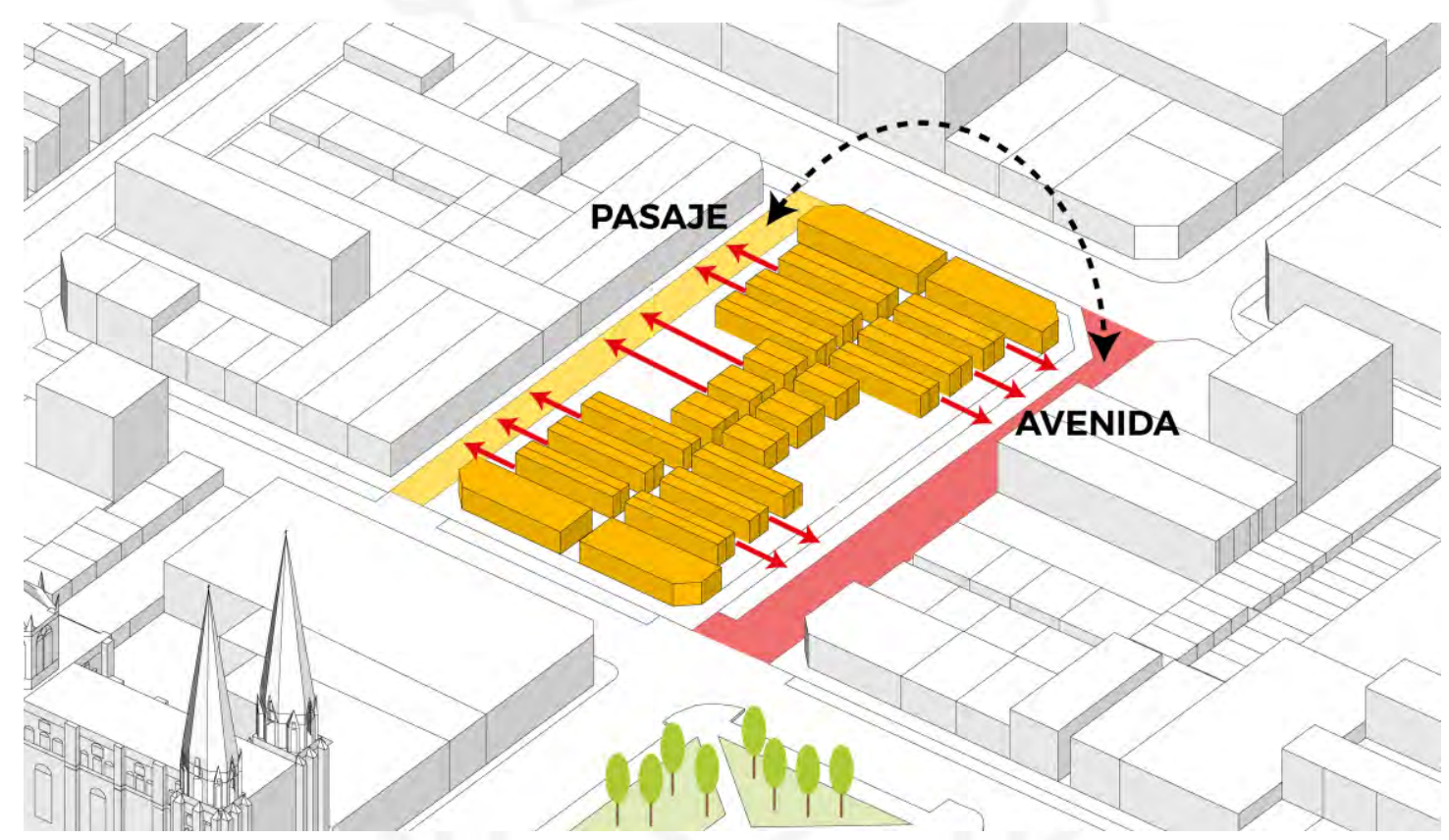

Figura 8.5 Estrategias_Relación pasaje-avenida

Por otro lado, se tomará en cuenta la linealidad de las quintas predominantes en la trama urbana para el recorrido hacia los puestos de venta, de tal manera que el poblador familiarice la nueva configuración del mercado con el uso de sus desplazamientos habituales de la zona.

\section{De la plaza al mercado}

Para aprovechar la cercanía que se tiene de la plaza San José al proyecto, se diseñara un eje en diagonal que atraviese todo el primer nivel del mercado. Este eje funcionaria como una extensión de la plaza y se convertiría en el principal del proyecto. Asimismo, se mejoraría la apertura del mercado, permitiéndole a las personas ingresar al proyecto desde 
la plaza y recorrerlo desde principio a fin, sin sentir la obligación de entrar solo para realizar las compras. La forma sinuosa del eje central, rompería con la ortogonalidad de los puestos de venta, logrando un recorrido más fluido dentro del proyecto.

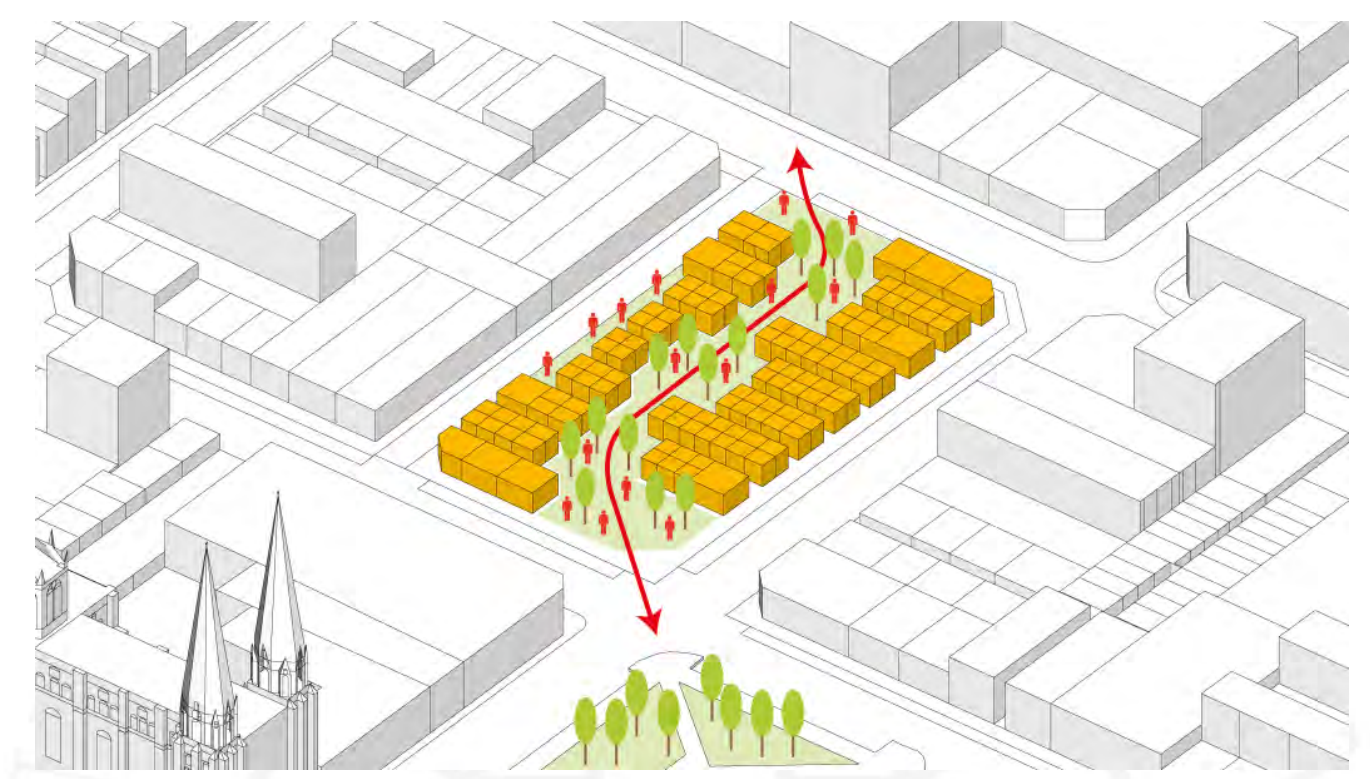

Figura 8.6 Estrategias_Re dirección de flujo peatonal

Gráfico elaborado por los autores.

\section{Plazas internas}

El proyecto contara con tres plazas internas, que surgirán del eje central, las cuales funcionaran como puntos de encuentro al interior del proyecto; dándole al usuario un panorama más amplio de la organización e interacción del mercado, logrando la fluidez espacial deseada, y reforzando la idea de mercado como espacio público.

Luego, se plantea liberar de puestos dos extremos del mercado (al inicio y final del eje central) los cuales se sustituirían con plazas semi-públicas, de tal manera que se consiga mostrar la interacción social-comercial que se lleva acabo al interior del mercado y permita al usuario sentirse fuera del proyecto estando aun dentro de él. 


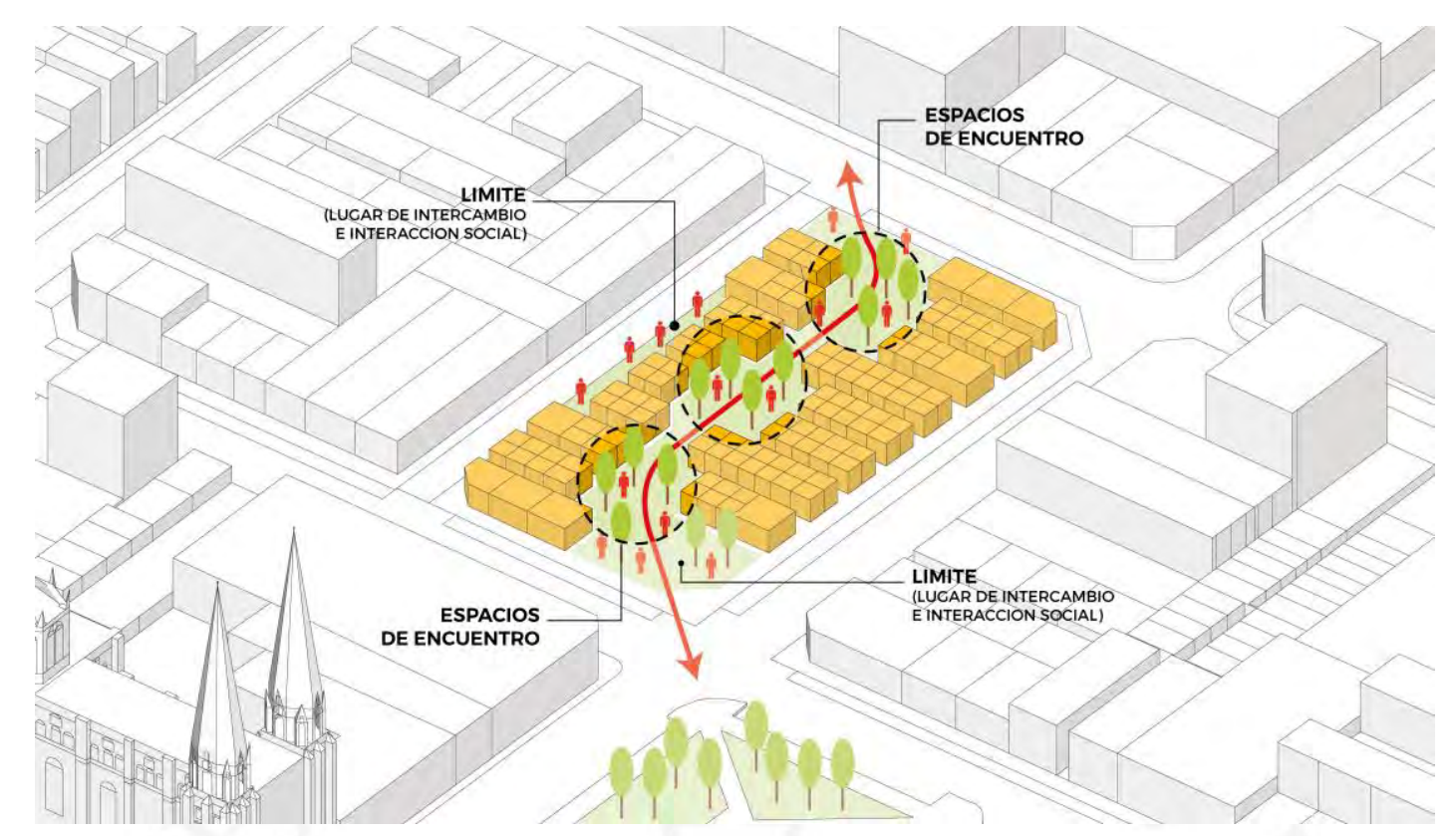

Figura 8.7 Estrategias_Límite como espacio de encuentro e interacción social Gráfico elaborado por los autores.

De este modo, el límite funcionaria como un espacio de encuentro, en donde la liberación del plano vertical evita el concepto de barrera y acepta su condición de limite como espacio de relación. Por otro lado, para reforzar la idea del eje central del mercado, se peatonalizará el cruce de las avenidas Rep. Dominicana y Horacio Urteaga de manera que el usuario pueda transitar con mayor facilidad hacia el mercado y se sienta la calle como parte del proyecto.

\section{Diferenciación de accesos}

El proyecto del nuevo mercado contara con un sótano con dos ingresos diferenciados: uno para el abastecimiento del mercado (carga y descarga de productos) por la Av. Horacio Urteaga y otro para los estacionamientos del público en general por la Av. Arnaldo Márquez. Estos ingresos se darán por los extremos del lote del mercado que se encuentra separado por el pasaje Punta Pacochas, que cuenta actualmente con puestos de venta en el primer nivel y depósitos de algunos comerciantes en el segundo nivel. Esta decisión se tomó con la finalidad de no restarle puestos de venta al terreno más grande del mercado y poder mantener la relación del mercado con el pasaje sin que este sea interrumpido. 


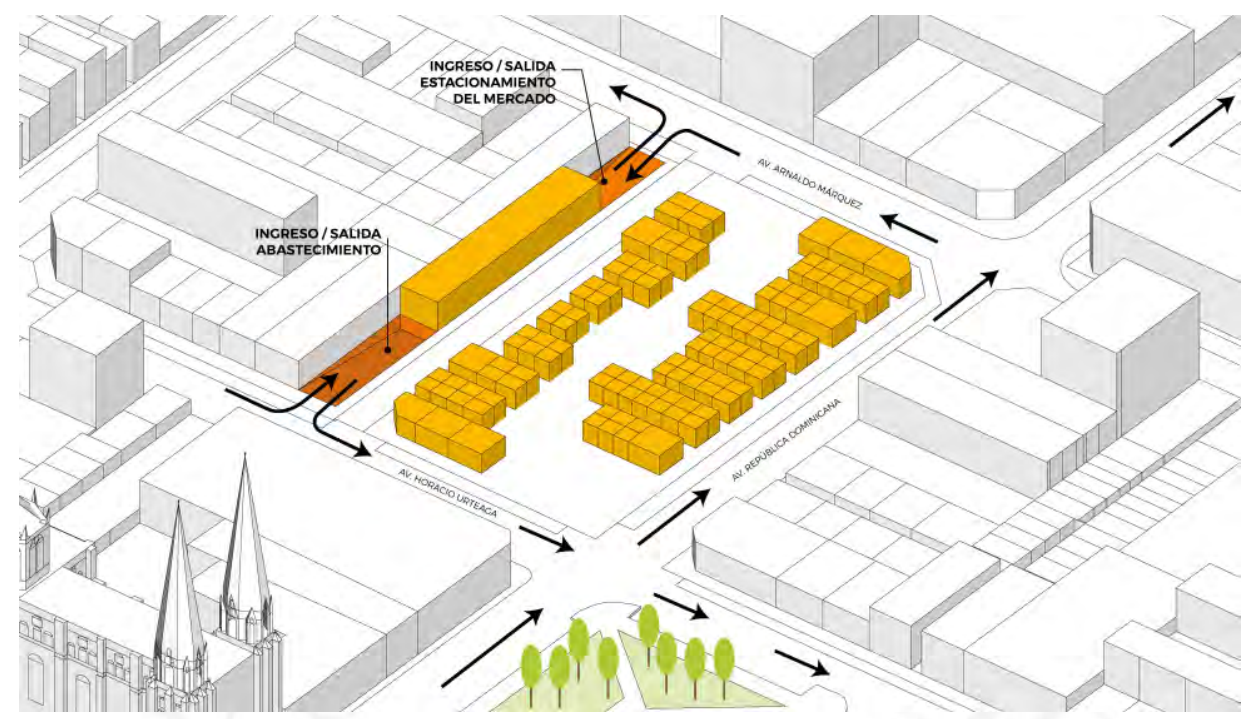

Figura 8.8 Estrategias_Diferenciación de accesos al sótano

Gráfico elaborado por los autores.

\section{Núcleos de escaleras}

El mercado contará con un segundo nivel al cual se podrá acceder por escaleras eléctricas, en los ingresos principales del mercado y en la plaza central. Además, se dispondrán de escaleras y graderías metálicas en la misma plaza con la finalidad de poder sentarse y observar los eventos que se lleven a cabo en dicho espacio, o simplemente sentarse a comer y disfrutar del día. En este sentido, el grado de permanencia de la actividad opcional de "sentarse" lograría hacer del mercado un lugar más habitable.

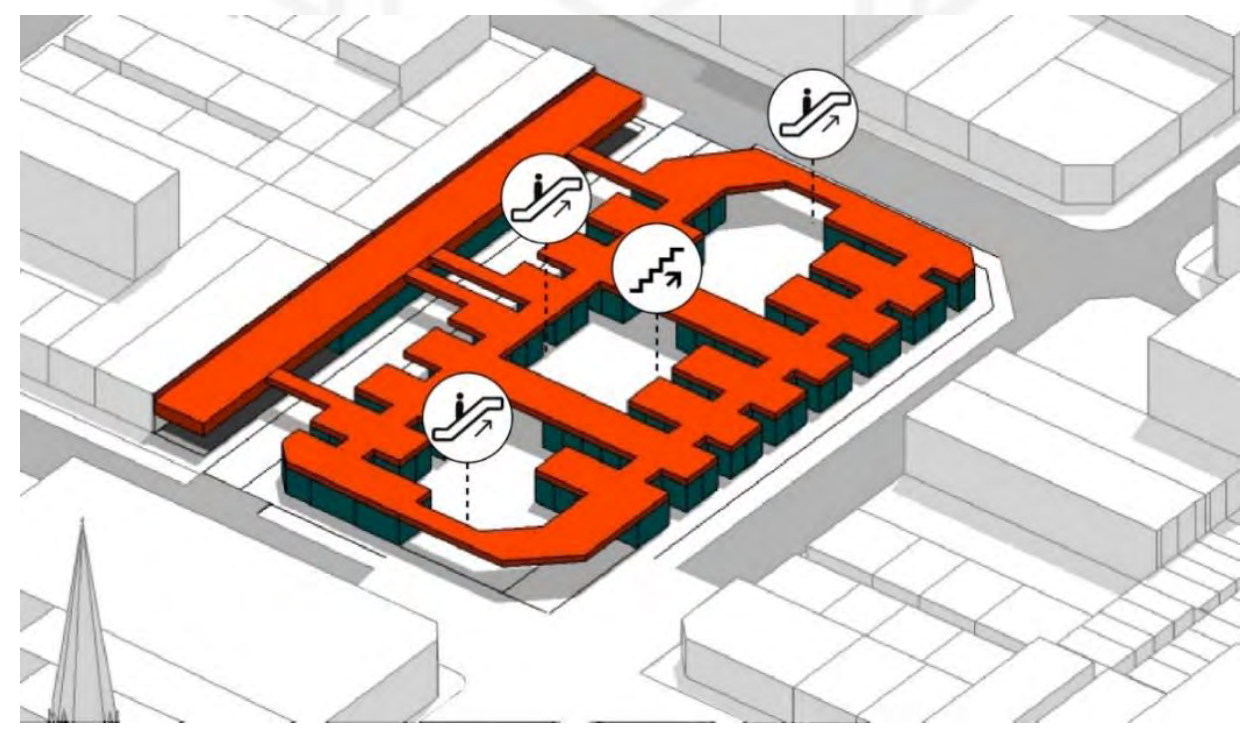

Figura 8.9 Estrategias_Accesibilidad al 2do nivel y graderías

Gráfico elaborado por los autores. 


\section{Puentes en el segundo nivel}

El proyecto contara con un segundo nivel con módulos que oferten servicios complementarios al mercado como: impresiones, zapatería, cerrajería, librería, etc. Sin embargo, este nivel físicamente se encontraría dividido, por el eje central que abarca todo el primer piso del mercado. Es por ello que se crearán dos puentes centrales como extensión de los techos de los pabellones que unirán la zona frontal y posterior del edificio. De igual manera, cuatro puentes secundarios conectaran el lote del mercado actualmente dividido por el pasaje Punta Pacochas con la finalidad de comprender el nuevo proyecto del mercado como uno solo. Asimismo, el segundo piso del lote alejado, dispondrá de puestos de menús y área para mesas en toda su longitud, otorgando de carácter gastronómico, la nueva zona del pasaje Punta Pacochas. Por otro lado, se techarán los ingresos principales al proyecto, con la finalidad de enmarcar el espacio de plazas públicas en el primer nivel y delimitar los ingresos principales al proyecto.

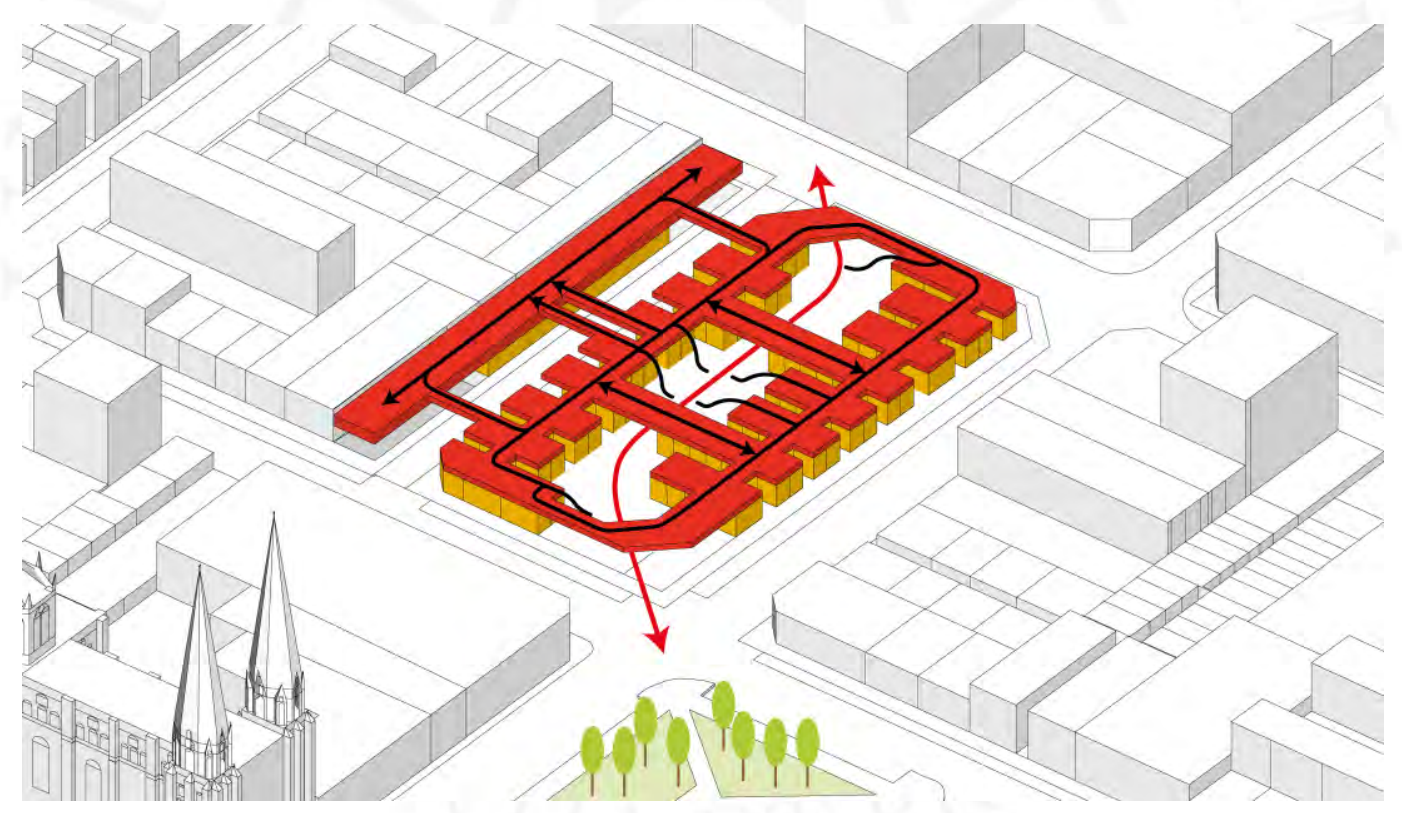

Figura 8.10 Estrategias_Extensión de techos para conectar zonas

Gráfico elaborado por los autores. 


\section{Programa adicional}

El proyecto contará con un tercer nivel de oficinas como programa adicional, el cual se desarrollará en forma de anillo, bordeando el lote principal del mercado. Esta estrategia nace a partir de mantener una lectura del mercado al aire libre, al no cubrir por completo los puestos inferiores con el nuevo programa añadido.

Por otro lado, se establecerán 4 núcleos circulación para acceder a este último nivel del proyecto, estos nacerán desde el sótano y se ubicarán dos, en la fachada con frente a la Av. Rep. Dominicana y dos, en la fachada con frente al pasaje Punta Pacochas. Los núcleos contaran con un ascensor y una escalera de emergencia en cada uno de ellos.

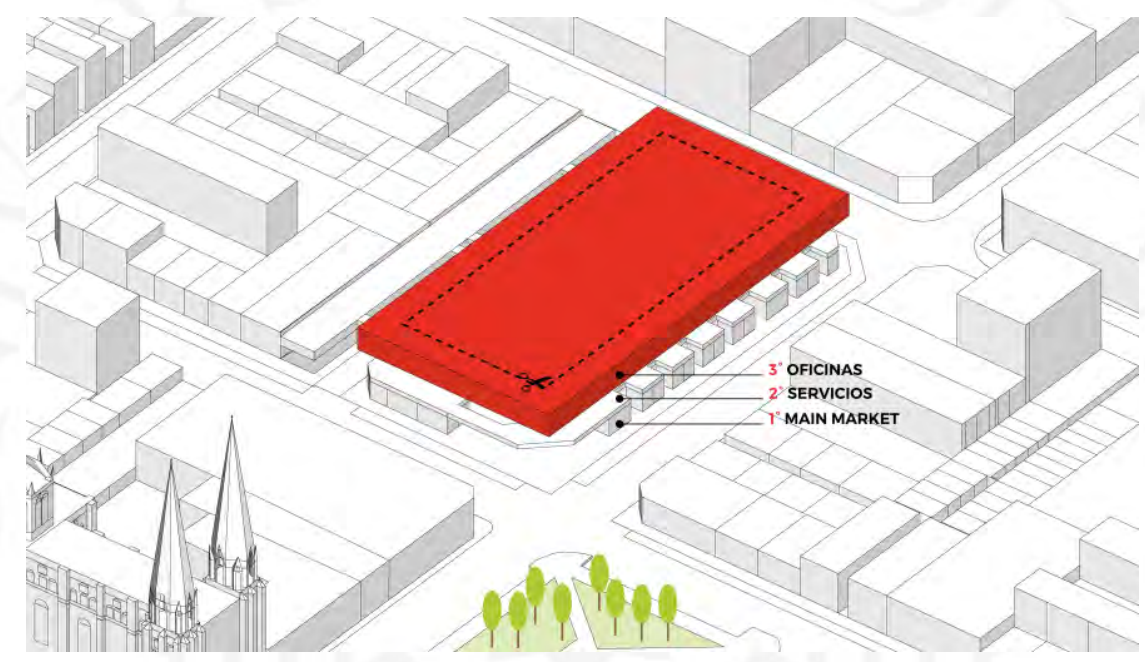

Figura 8.11 Estrategias_Separación de usos por nivel Gráfico elaborado por los autores.

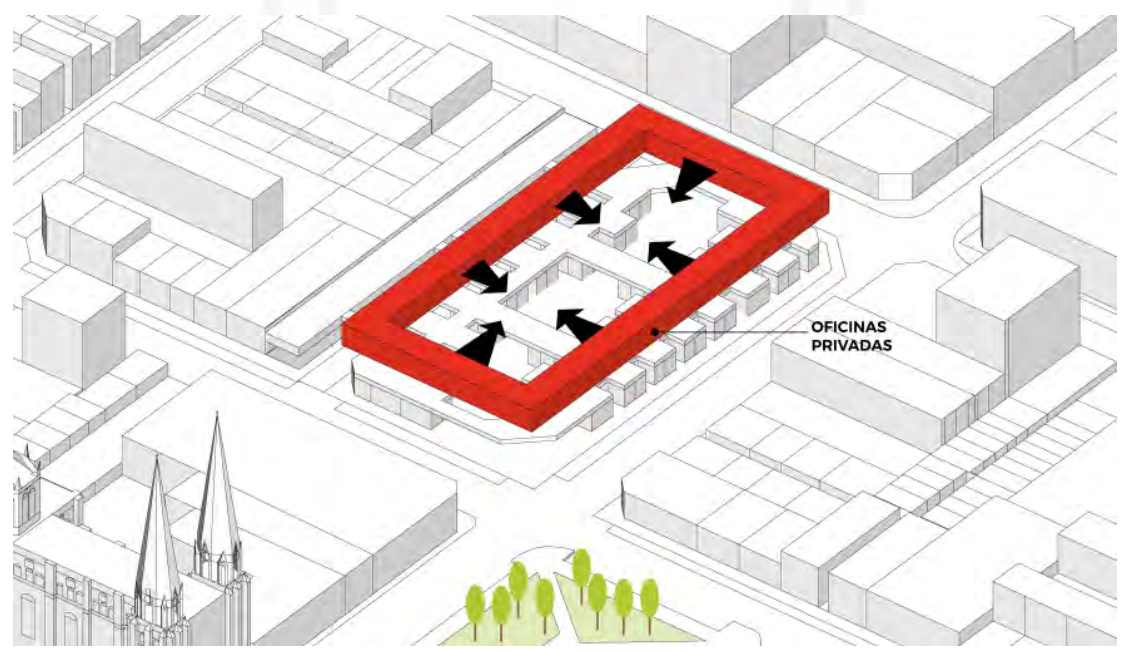

Figura 8.12 Estrategias_Anillo de oficinas y mercado al aire libre.

Gráfico elaborado por los autores. 


\section{Envolvente}

Para el envolvente del mercado, se trazarán los pasajes y configuraciones de los puestos de venta reflejados hacia el exterior. Una vez establecidas las secciones, se dejarán las plazas y pasajes del mercado libres de cobertura, para una mejor iluminación y ventilación; y contribuir con la idea de mercado al aire libre.

Luego, el envolvente caerá y se convertirá en la fachada del edificio, de manera que se logre entender la cobertura y la fachada como una unidad. El uso del metal como material de la cobertura, brindará ligereza al proyecto y permitirá un menor número de apoyos en la estructura; dejando que la cobertura se lea como un elemento flotante, que se posa sobre el proyecto.

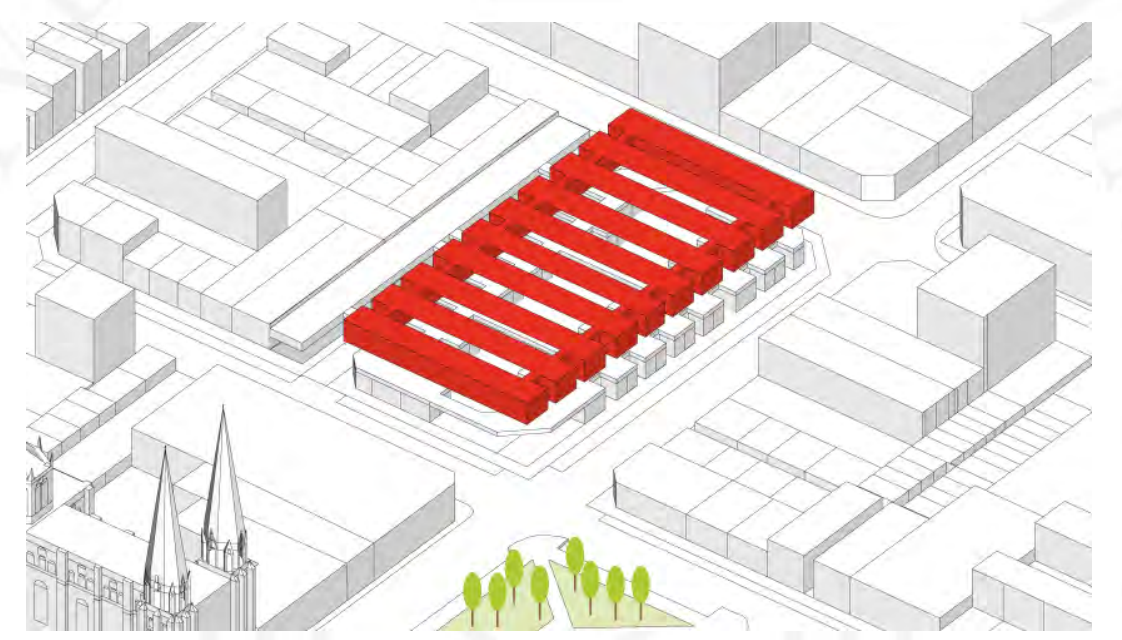

Figura 8.13 Estrategias__ Marcar configuración lineal en fachada y cobertura Gráfico elaborado por los autores.

Pero al momento de realizar la cubierta, nos percatamos que los niveles del mercado y su espacialidad no eran consecuentes con la forma del techo, los estratos del mercado estaban diferenciados y divididos, el cual no era el objetivo. Entonces, analizando los proyectos y bocetos de Constant surgió la idea de unificar estos estratos haciendo que los techos formen espacios, como ser el techo de los puestos de venta y generar espacios públicos intermedios. 


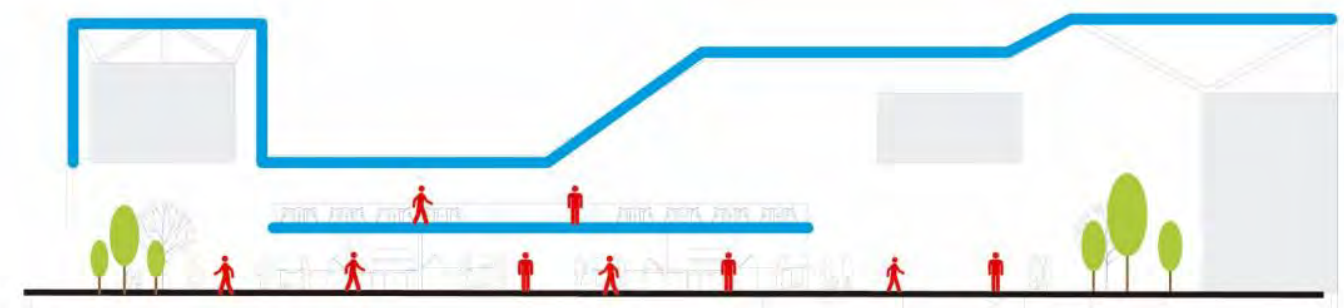

ESTRATOS DIFERENCIADOS

Figura 8.14 Estrategias_Estratos diferenciados

Gráfico elaborado por los autores.

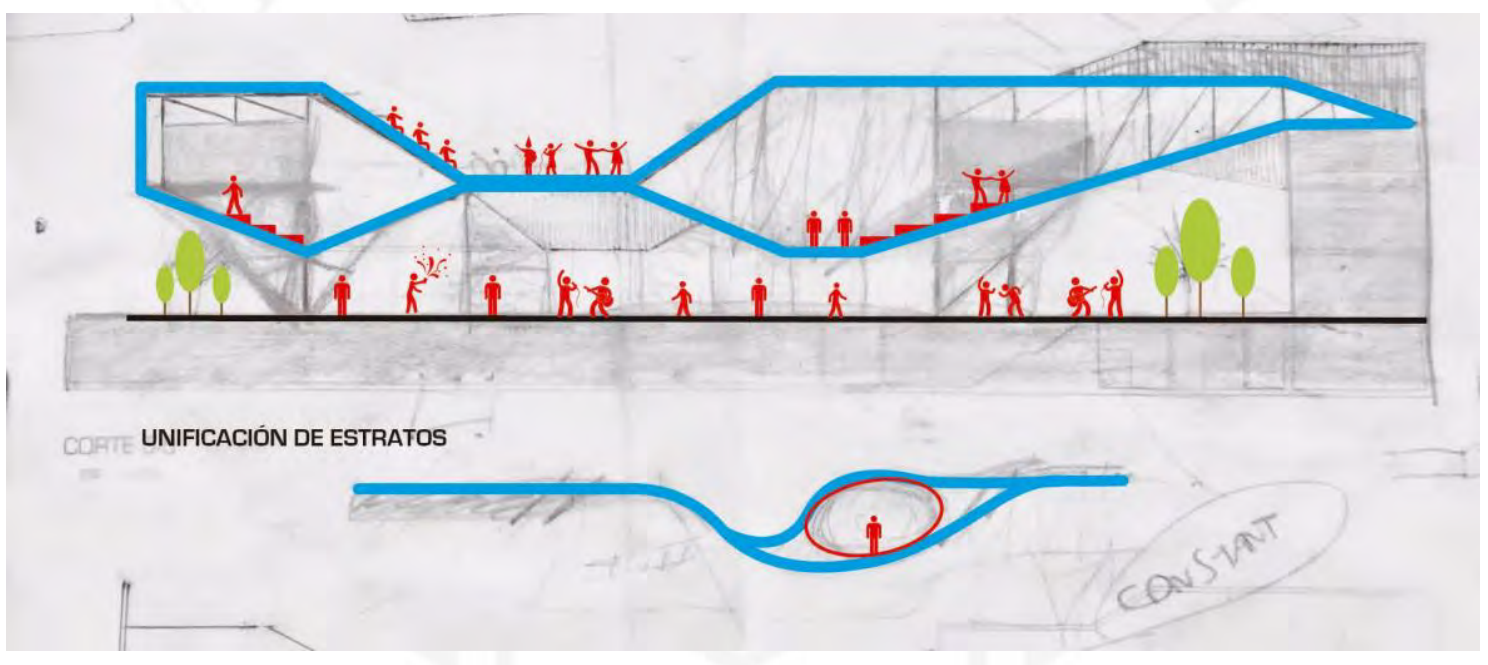

Figura 8.15 Estrategias_Unificación de estratos

Gráfico elaborado por los autores. 


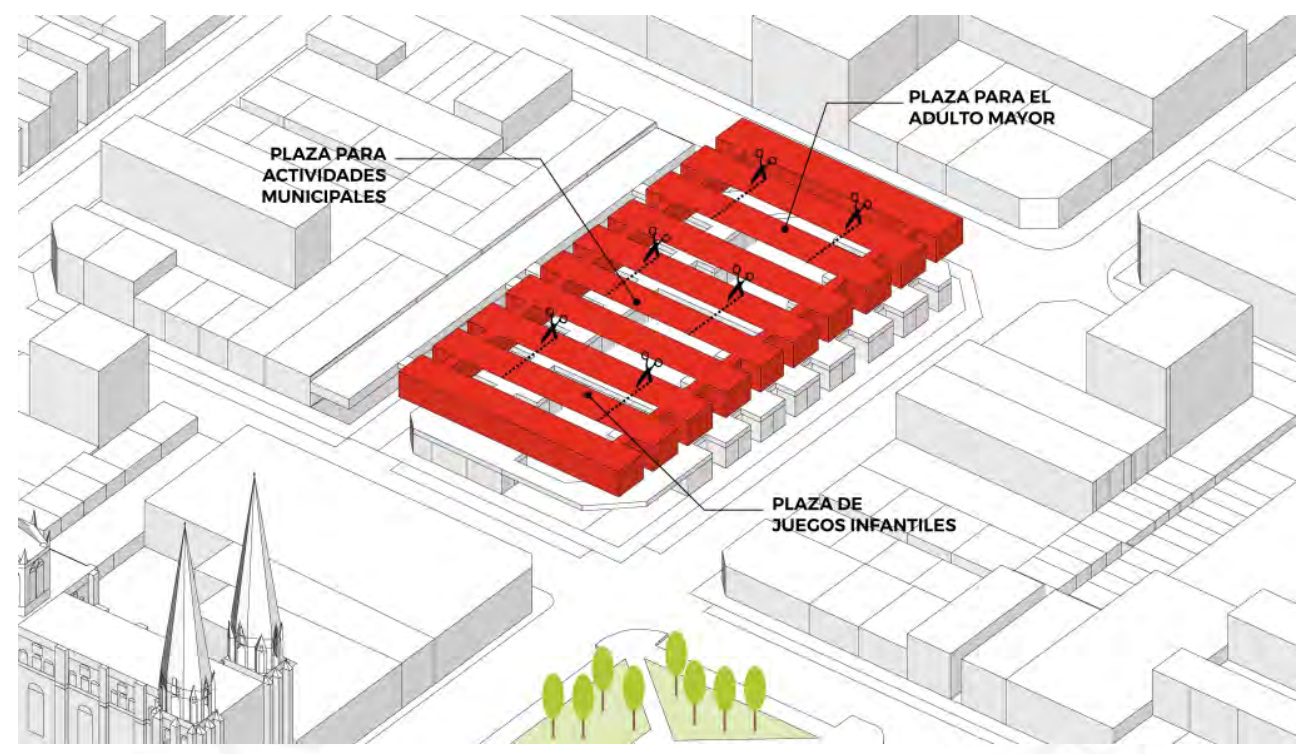

Figura 8.16 Estrategias_Aberturas en plazas internas

Gráfico elaborado por los autores.

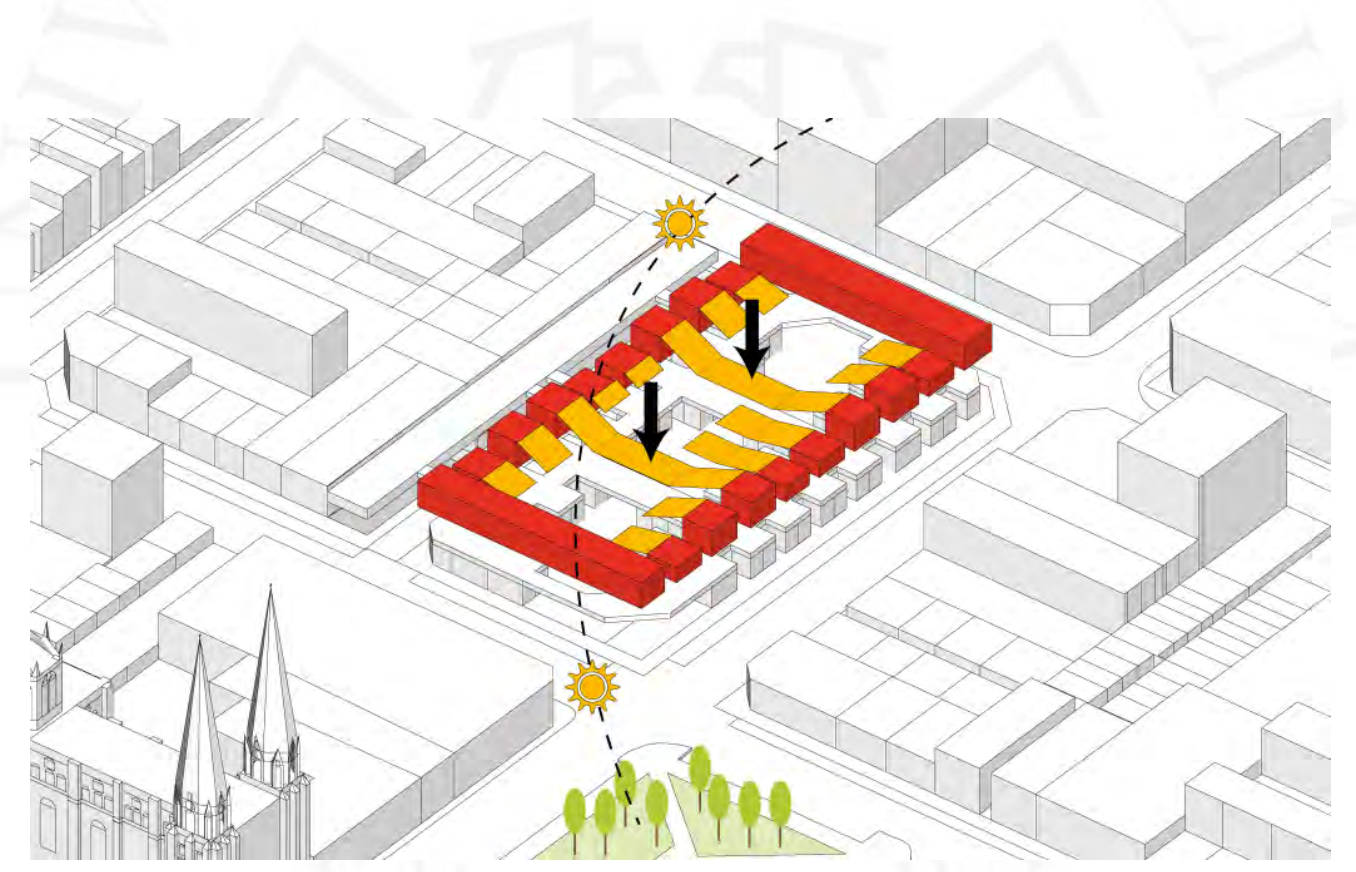

Figura 8.17 Estrategias_Desfases según el asoleamiento y espacialidad

Gráfico elaborado por los autores. 


\subsubsection{Programa arquitectónico}

\section{Demanda de oficinas en Jesús María}

Según Gonzáles-Prada (2018), Gerente General de Urbania, el distrito de Jesús María tiene cada vez más presencia en cuanto al implemento de oficinas comerciales, actualmente cuenta con 31 oficinas a la venta y 80 en alquiler, manejando precio promedio de venta de 1647 dólares por m2 y 13.1 dólares por m2 (p. 1).

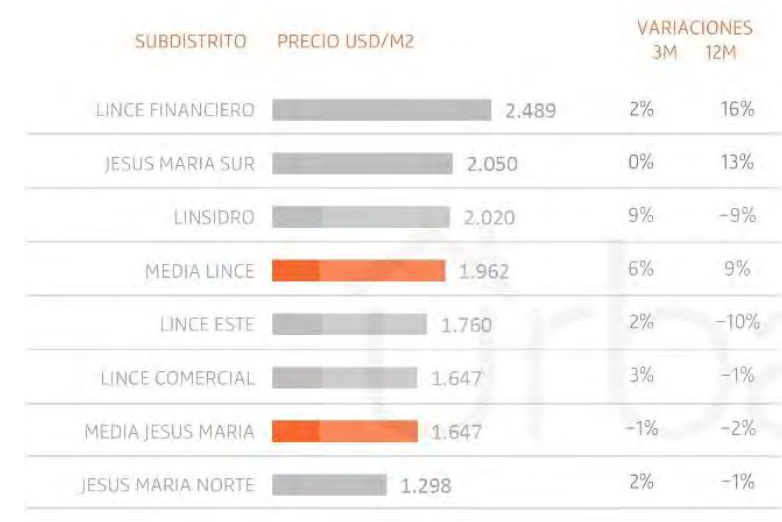

Figura 8.18 Precios de Jesús María y Lince Fuente: (Urbania, 2019).

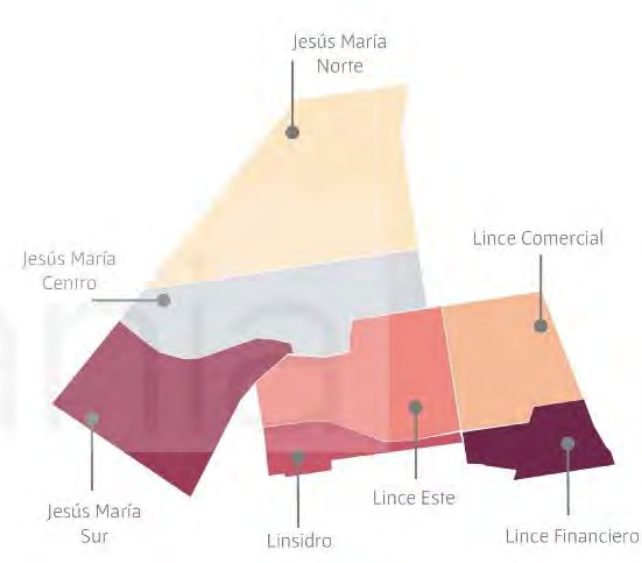

Una de las causas del incremento de la demanda de oficinas es por su ubicación, debido a que se encuentra cercano a los distritos de San Isidro, Magdalena y Miraflores, importantes para la actividad financiera, pero el mercado se ha saturado tanto que casi no hay espacio disponible para que las compañías ingresen a este sector de Lima, optando por los distritos aledaños que presentan un menor valor de mercado con las mismas facilidades de acceso, ya que cuentan con avenidas principales como Salaverry y Brasil, y por su cercanía a hitos urbanos de gran utilidad para diferentes gestiones de negocios como la ONPE, el INEI, la SUNARP, y el SENAMHI (V \& V Grupo inmobiliario, 2018, párr. 7).

Según George Limache, jefe de investigación de Binswanger, dice que la demanda existente en Jesús María y Lince proviene de estudios de abogados, contadores, médicos y agencias de publicidad, las cuales no requieren ubicarse en el centro financiero. 
Inclusive muchas viviendas se han adecuado para ser utilizadas como oficinas, alquilándolas como tal a un precio menor al valor del mercado, porque no posee todas las facilidades e implementos que un proyecto de oficinas (Ver Figura 8.19).

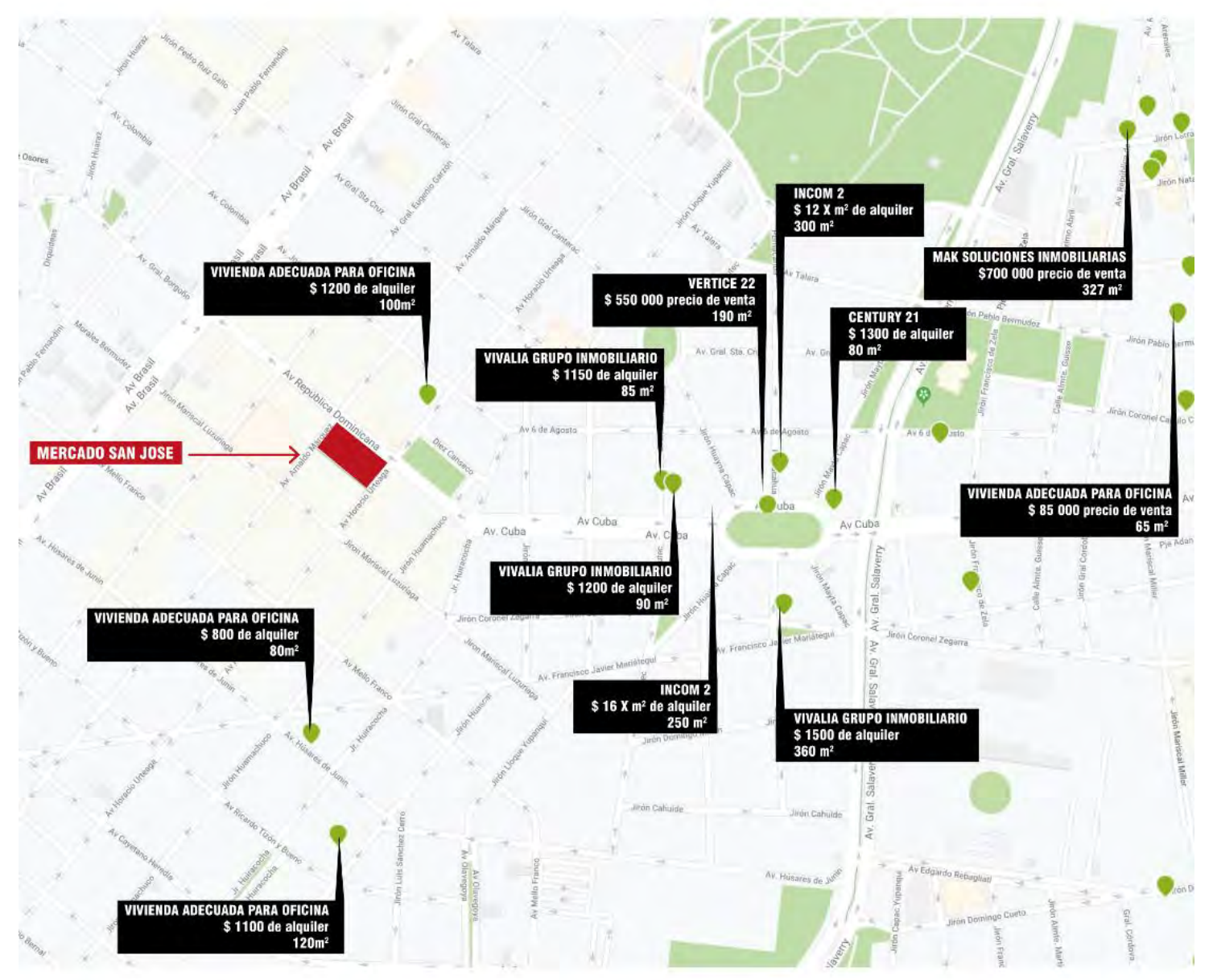

Figura 8.19 Análisis de demanda y precios de oficinas

Gráfico elaborado por los autores.

El distrito de Jesús María presenta un precio promedio de 13,1 dólares por m2 (Ver Figura 8.20), superando la media de 12,3 dólares por $\mathrm{m} 2$ de la ciudad, y solo se encuentra por debajo del centro financiero y sus distritos aledaños, sin embargo, es el distrito con mayor rentabilidad de alquiler de oficinas con un $9,5 \%$ anual, lo que se considera un estimado de 10 años de alquiler para recuperar la inversión, mientras que en distritos como San Borja se requieren 16,7 años (Urbania, 2019, p. 30). 


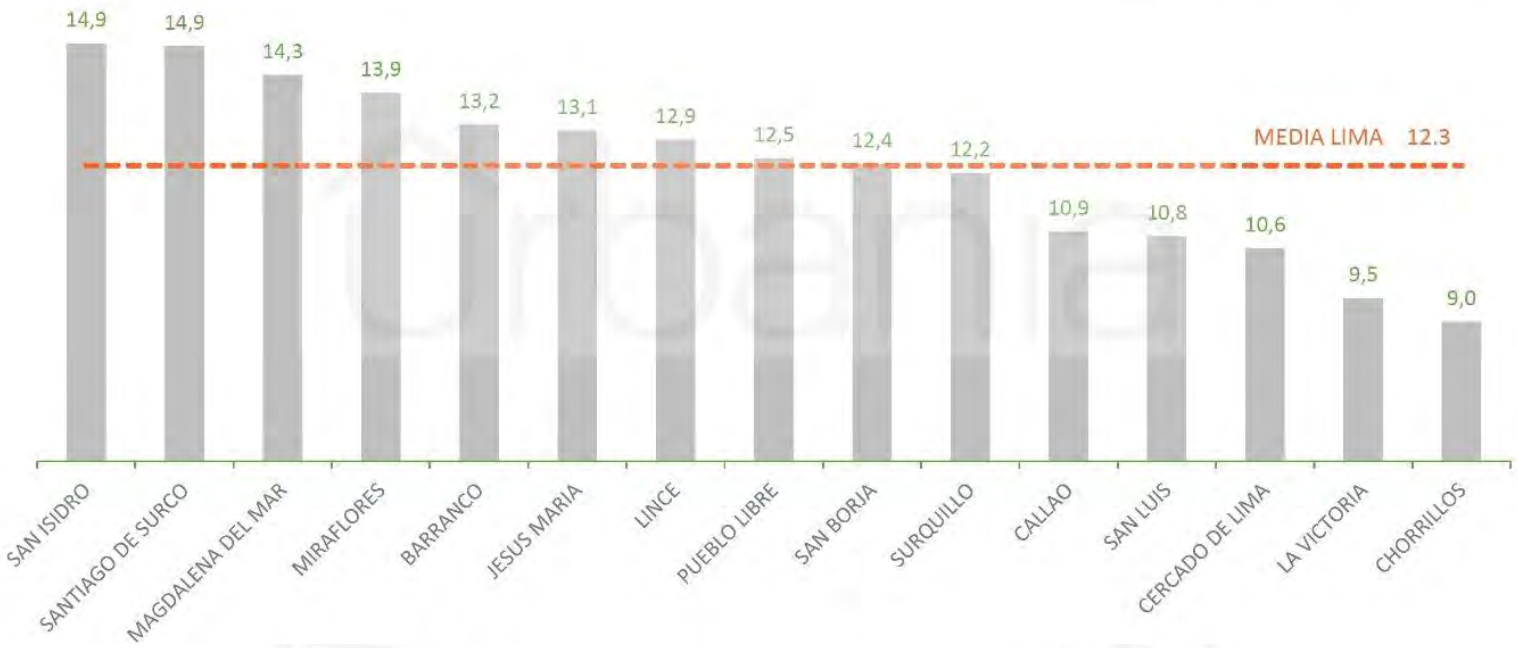

Figura 8.20 Precio en USD / $\mathrm{m} 2$ por mes de alquiler de oficinas

Fuente: (Urbania, 2019).
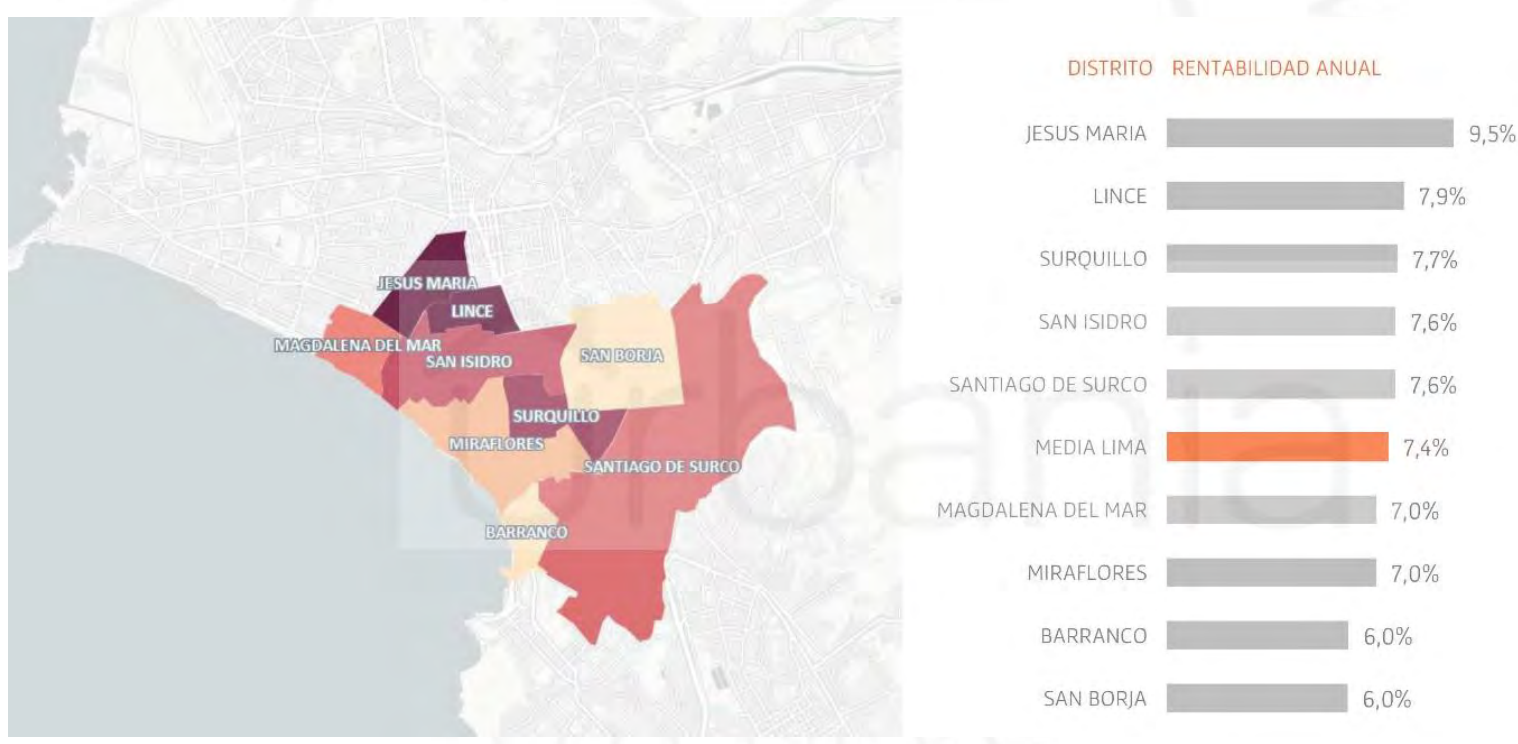

Figura 8.21 Rentabilidad anual por alquiler de oficinas

Fuente: (Urbania, 2019). 


\section{Puestos de comida}

El distrito de Jesús María presenta una gran cantidad de locales de comida que pertenecen a la zona del damero comercial del distrito, ofreciendo una amplia variedad de tipos de comida desde comida criolla, cevicherías, pollerías, comida internacional, juguerías, pastelerías, bares, etc. Por otro lado, la Av. Cuba, una de las principales avenidas del distrito y que abre paso al sector del damero comercial, cada año crece en relación a restaurantes, lo cual ha conseguido por parte de la municipalidad en convertir esta avenida en un Eje gastronómico principal del distrito de Jesús María. Asimismo, en el propio mercado San José, los puestos predominantes son los de venta de comida los cuales se han mantenido alrededor de los años por su alta demanda de comensales residentes y visitantes que los prefiere.

Por lo tanto, se puede concluir que si bien tanto el damero comercial como en el mercado predominan los locales de venta de comida, es necesario mantener los puestos de comida existentes al interior del mercado y a su vez generar nuevos puestos que oferten una variedad de comida diferente a la existente con la finalidad de poder otorgarle una identidad gastronómica al mercado San José, intensificar su oferta para los usuarios que acudan al él y que a la vez pueda funcionar como una continuación de la Av. Cuba como futuro eje gastronómico del distrito de Jesús María.

En el primer piso en la fachada principal del mercado, se incluirán puestos de comida los cuales cambiarán de acuerdo a su uso durante el día como: juguerías, venta de menú, sangucherías, anticuchos, etc. De igual manera, en el pasaje Punta Pacochas, estarán ubicados los puestos de menú existentes del mercado, los cuales se reubicarán a lo largo del pasaje con la finalidad de poder hacer uso de su espacio. En el segundo nivel del mercado, también contendrán puestos de comida; sin embargo, estos serán de alimentos pre cocidos o comida al paso, como heladerías, postrarías, bares, etc. Finalmente, se plantea generar un boulevard gastronómico en el mismo nivel que exhiba los platos típicos de las diferentes regiones del Perú, supliendo algunos restaurantes que ya ofrecen esta variedad en la zona y completándola al interior del mercado, estos puestos sí contarán con campana extractora. 


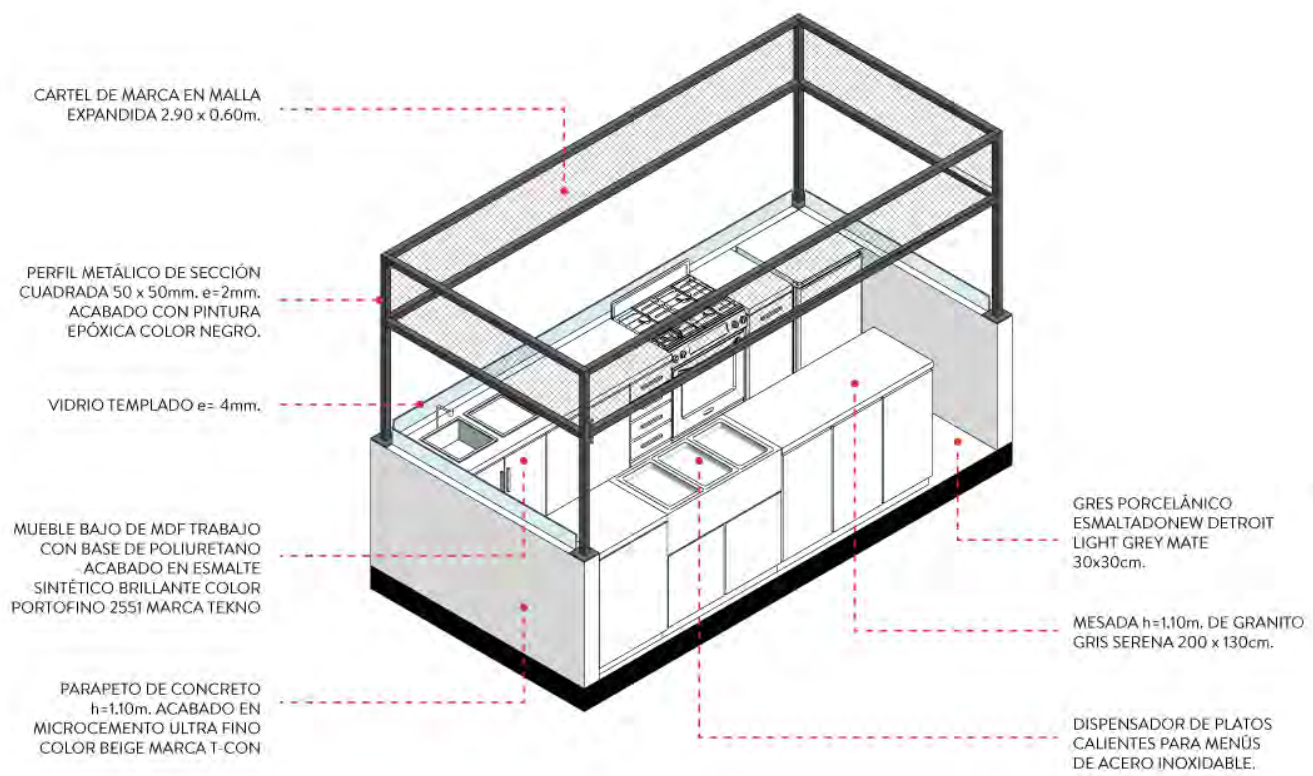

Figura 8.22 Puesto de comidas pre cocidas Gráfico realizado por los autores.

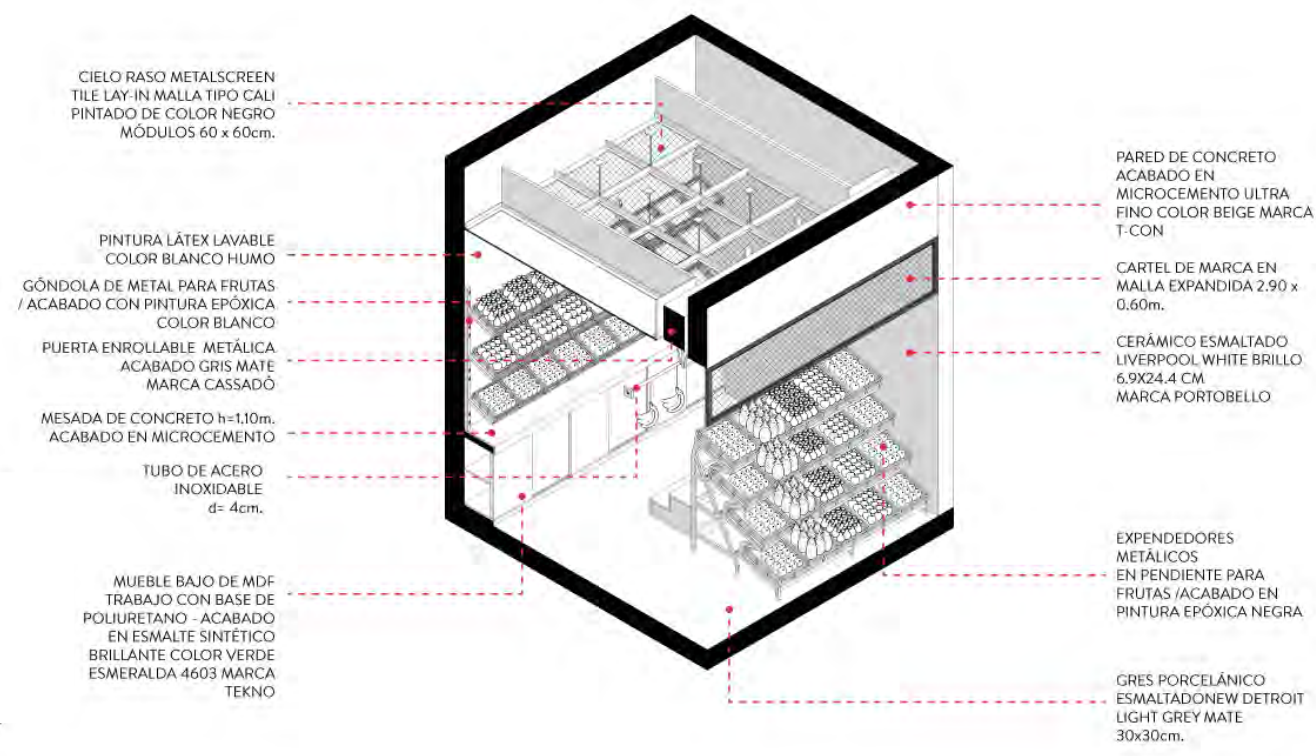

Figura 8.23 Puesto de frutas

Gráfico realizado por los autores. 


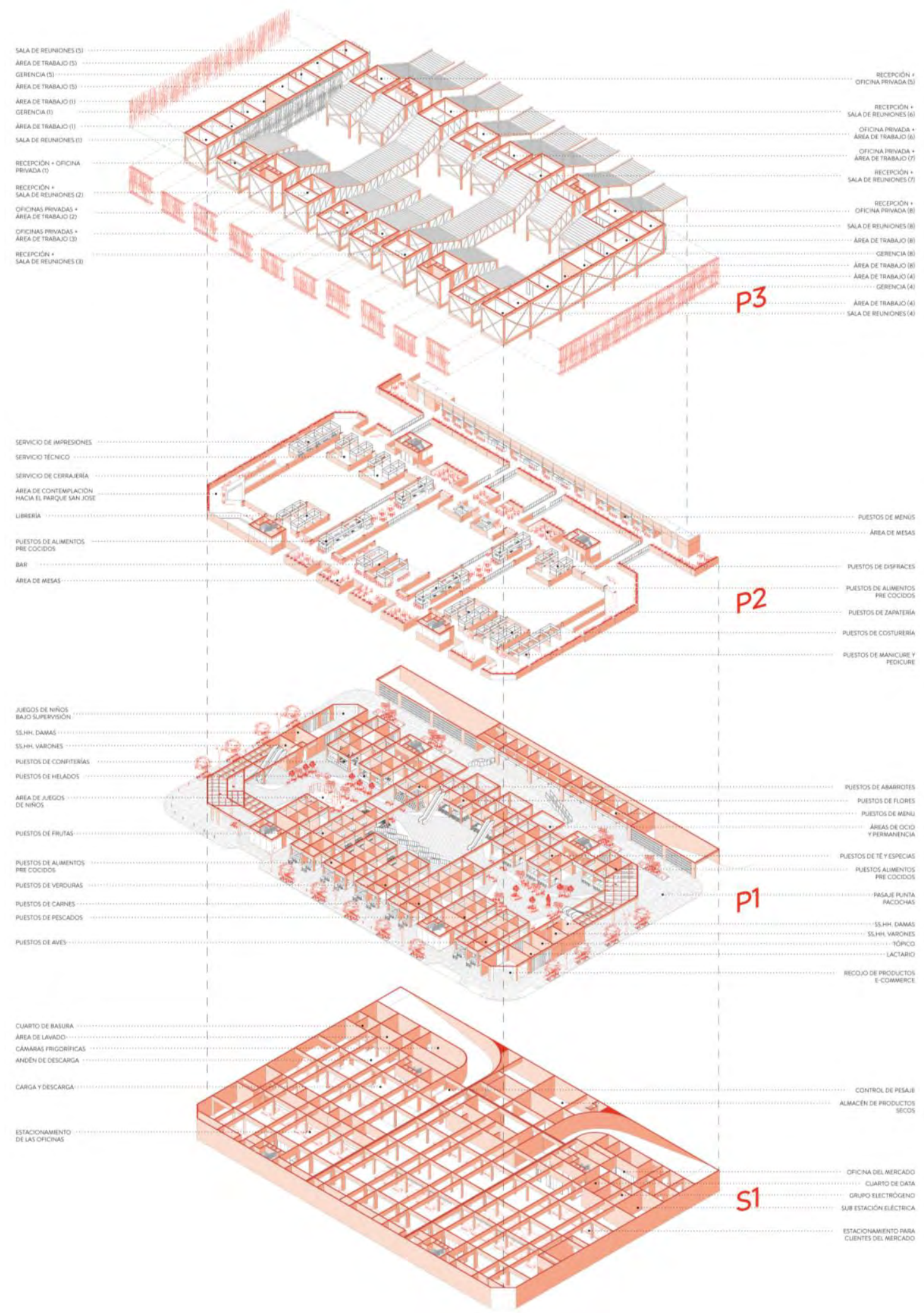

Figura 8.24 Axonometría por niveles del mercado

Gráfico realizado por los autores. 
Tabla 8.1

Programa del Mercado San José

\begin{tabular}{|c|c|c|c|c|c|c|}
\hline \multicolumn{7}{|c|}{ PROGRAMA_MERCADO SAN JOSE } \\
\hline \multicolumn{2}{|c|}{ Área del predio } & \multicolumn{5}{|c|}{$5476.33 \mathrm{~m} 2$} \\
\hline & & $\begin{array}{l}\text { Área de } \\
\text { uso (m2) }\end{array}$ & Capacidad & $\begin{array}{c}\text { Indicador } \\
\text { (m2/persona) }\end{array}$ & $\begin{array}{c}\text { Horario de } \\
\text { funcionamiento }\end{array}$ & $\begin{array}{c}\text { Días de } \\
\text { funcionamiento }\end{array}$ \\
\hline \multicolumn{7}{|c|}{ Área de Cisternas / NPT -7.50m } \\
\hline 1 & Cuarto de bombas & 76.2 & & & & \\
\hline 2 & Cisterna del mercado & 136.9 & & & & \\
\hline 3 & Cisterna de las oficinas & 75.86 & & & & \\
\hline 4 & Cisterna contra incendio & 135 & & & & \\
\hline 5 & Pit del Ascensor & 3.7 & & & & \\
\hline 6 & Montantes & 3.6 & & 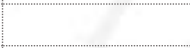 & & \\
\hline 7 & Circulación vertical & 11.95 & & & & \\
\hline 8 & Circulación & 17.7 & & & & \\
\hline \multicolumn{7}{|c|}{ Abastecimiento / NPT $-5.00 \mathrm{~m}$} \\
\hline \multirow[t]{5}{*}{1} & Cámaras frigoríficas & & & & & \\
\hline & Antecámara de frigoríficos & 13 & 6 & 2.17 & $L-M-V$ & $5-8 h$ \\
\hline & Cámara de carnes & 57.5 & 15 & 3.83 & $L-M-V$ & $5-8 h$ \\
\hline & Cámara de avícolas & 27.9 & 8 & 3.49 & $L-M-V$ & $5-8 h$ \\
\hline & Cámara de pescados y mariscos & 55.45 & 15 & 3.70 & $L-M-V$ & $5-8 h$ \\
\hline \multirow[t]{5}{*}{2} & Almacen de productos secos & & & & & \\
\hline & Almacen de los menús & 44 & 4 & 11.00 & $M-J-S$ & $5-8 h$ \\
\hline & Almacenes generales & 306.28 & 8 & 38.29 & $M-J-S$ & $5-8 h$ \\
\hline & Montacargas & 9.5 & 4 & 2.38 & $L-S$ & $5-8 h$ \\
\hline & Circulación & 174 & & & & \\
\hline \multirow[t]{9}{*}{3} & Área de carga y descarga & & & & & \\
\hline & Oficina de control & 14 & 2 & 7.00 & $L-S$ & $5-8 h$ \\
\hline & Área de pesaje & 42.75 & & & $L-S$ & $5-8 h$ \\
\hline & Andén de descarga & 137.3 & 4 & 34.33 & $L-S$ & $5-8 h$ \\
\hline & Estacionamiento para furgonetas & 117 & & & $L-S$ & $5-8 h$ \\
\hline & Patio de maniobras & 270.2 & 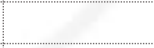 & & & \\
\hline & Lavado de productos & 20.6 & 4 & 5.15 & $L-S$ & $5-8 h$ \\
\hline & Depósito de remolques & 18.5 & 2 & 9.25 & $L-S$ & $5-8 h$ \\
\hline & Depósito de limpieza & 15.6 & 2 & 7.80 & $L-S$ & $5-8 h$ \\
\hline \multirow[t]{4}{*}{4} & Área técnica & & & & & \\
\hline & Cuarto de tableros & 10.5 & 1 & 10.50 & & \\
\hline & Grupo electrógeno & 19.37 & 2 & 9.69 & & \\
\hline & Cuarto de extracción de monóxido & 35.8 & 2 & 17.90 & & \\
\hline \multirow[t]{6}{*}{5} & Área de residuos & & & & & \\
\hline & Antecámara del cto. De basura & 11.8 & 2 & 5.90 & $L-D$ & $19-21 \mathrm{~h}$ \\
\hline & Cuarto de basura & 28 & 2 & 14.00 & $L-D$ & $19-21 \mathrm{~h}$ \\
\hline & Depósito de desechos orgánicos & 18 & 2 & 9.00 & $L-D$ & $19-21 \mathrm{~h}$ \\
\hline & Depósito de desechos inorgánicos & 18.7 & 2 & 9.35 & $L-D$ & $19-21 \mathrm{~h}$ \\
\hline & Cuarto séptico & 8.25 & 1 & 8.25 & $L-D$ & $19-21 \mathrm{~h}$ \\
\hline \multicolumn{7}{|c|}{ Área para el personal del mercado / NPT $-5.00 \mathrm{~m}$} \\
\hline \multirow[t]{7}{*}{1} & Área técnica & & & & & \\
\hline & Sub estación eléctrica & 44 & 2 & 22.00 & & \\
\hline & Grupo electrógeno & 25.88 & 2 & 12.94 & & \\
\hline & Cuarto de data & 13.1 & 2 & 6.55 & & \\
\hline & Cuarto séptico & 7.76 & 1 & 7.76 & & \\
\hline & Cuarto de tableros & 15.4 & 1 & 15.40 & & \\
\hline & Cuarto de extracción de monóxido & 42.7 & 2 & 21.35 & & \\
\hline
\end{tabular}




\begin{tabular}{|c|c|c|c|c|c|c|}
\hline \multirow{2}{*}{$A$} & \multicolumn{6}{|l|}{ Administración del mercado } \\
\hline & Estar del personal & 38.8 & 4 & 9.70 & $L-D$ & $5-21 h$ \\
\hline & Sala de juntas & 23.6 & 10 & 2.36 & $L-D$ & $8-21 h$ \\
\hline & Oficina privada del administrador & 12.3 & 3 & 4.10 & $L-D$ & $8-21 h$ \\
\hline & Oficina privada del contador & 12.3 & 3 & 4.10 & $L-D$ & $8-21 h$ \\
\hline & Área de archivos & 14.28 & 2 & 7.14 & $L-D$ & $5-21 h$ \\
\hline & Central de vigilancia y atención al cliente & 28 & 6 & 4.67 & $L-D$ & $8-21 h$ \\
\hline & Circulación & 20 & & & & \\
\hline \multirow[t]{4}{*}{3} & Servicios para el personal & & & & & \\
\hline & SSHH para damas & 36 & 8 & 4.50 & $L-D$ & $5-21 \mathrm{~h}$ \\
\hline & SSHH para varones & 36 & 8 & 4.50 & $L-D$ & $5-21 h$ \\
\hline & Lockers para el personal & 57.3 & 15 & 3.82 & $L-D$ & $5-21 h$ \\
\hline \multirow[t]{3}{*}{4} & Depósitos & & & & & \\
\hline & Depósito de limpieza & 10.8 & 2 & & & \\
\hline & Depósito & 37.2 & 2 & & & \\
\hline
\end{tabular}

\section{Estacionamientos / NPT $-5.00 \mathrm{~m}$}

1 Estacionamiento del mercado Estacionamiento de vehículos para clientes Estacionamiento de bicicletas para clientes Módulo de pago

Hall de ascensores hacia el mercado Circulación

\begin{tabular}{|c|c|c|c|c|}
\hline & & & & \\
\hline 344 & & & $L-D$ & $8-21 \mathrm{~h}$ \\
\hline 10.45 & & & $\mathrm{~L}-\mathrm{D}$ & $8-21 \mathrm{~h}$ \\
\hline 13.85 & 2 & 6.93 & $\mathrm{~L}-\mathrm{D}$ & $8-21 \mathrm{~h}$ \\
\hline 38 & 18 & 2.11 & $\mathrm{~L}-\mathrm{D}$ & $8-21 \mathrm{~h}$ \\
\hline 631 & & & & \\
\hline 545 & & & & \\
\hline 49 & 20 & 2.45 & $\mathrm{~L}-\mathrm{V}$ & $8-20 \mathrm{~h}$ \\
\hline 24 & 4 & 6.00 & $\mathrm{~L}-\mathrm{V}$ & $8-20 \mathrm{~h}$ \\
\hline 108 & & & $\mathrm{~L}-\mathrm{V}$ & $8-20 \mathrm{~h}$ \\
\hline 21.35 & 2 & 10.68 & $\mathrm{~L}-\mathrm{V}$ & $8-20 \mathrm{~h}$ \\
\hline 862 & & & & \\
\hline 60 & & & & \\
\hline 14.4 & & & & \\
\hline 14.8 & & & & \\
\hline
\end{tabular}

2 Estacionamiento de las oficinas Estacionamiento para las oficinas Hall de ascensores hacia las oficinas Módulos de vigilancia

Depósitos de las oficinas Servicios higiénicos

3 Circulaciones

Circulación vertical

Montantes

Ascensores

14.8

\section{Nivel del mercado / N. $0.00 \mathrm{~m}$}

\begin{tabular}{|c|c|c|c|c|c|c|}
\hline \multirow{2}{*}{1} & \multicolumn{6}{|l|}{ Puestos del mercado } \\
\hline & Frutas & 179 & 36 & 4.97 & $L-D$ & $8-21 h$ \\
\hline & Verduras & 160 & 32 & 5.00 & $L-D$ & $8-21 h$ \\
\hline & Carnes & 122 & 24 & 5.08 & $L-D$ & $8-21 h$ \\
\hline & Pescados & 56 & 12 & 4.67 & $L-D$ & $8-21 h$ \\
\hline & Avícolas & 80 & 16 & 5.00 & $L-D$ & $8-21 h$ \\
\hline & Confiterías & 68 & 12 & 5.67 & $L-D$ & $8-21 h$ \\
\hline & Heladerías & 43 & 8 & 5.38 & $L-D$ & $8-21 h$ \\
\hline & Abarrotes & 68 & 12 & 5.67 & $L-D$ & $8-21 h$ \\
\hline & Flores & 66 & 12 & 5.50 & $L-D$ & $8-21 h$ \\
\hline & Té y especias & 137 & 24 & 5.71 & $L-D$ & $8-21 h$ \\
\hline & Puestos externos & 175 & 56 & 3.13 & $L-D$ & $8-23 h$ \\
\hline & Menús & 292 & 56 & 5.21 & $L-D$ & $8-21 h$ \\
\hline \multirow[t]{6}{*}{2} & Servicios para el cliente & & & & & \\
\hline & Juegos para niños & 75 & 19 & 3.95 & $L-D$ & $8-21 h$ \\
\hline & Tópico y lactario & 36.75 & 8 & 4.59 & $L-D$ & $8-21 h$ \\
\hline & Recojo de productos e-commerce & 38.3 & 20 & 1.92 & $L-D$ & $8-21 h$ \\
\hline & SSHH para clientes varones & 47.7 & 8 & 5.96 & $L-D$ & $8-21 h$ \\
\hline & SSHH para clientes damas & 44.15 & 8 & 5.52 & $L-D$ & $8-21 h$ \\
\hline \multirow[t]{4}{*}{3} & Espacio público & & & & & \\
\hline & Ingreso principal & 213 & 70 & 3.04 & $L-D$ & $8-21 h$ \\
\hline & Área de juegos de niños & 168 & 55 & 3.05 & $L-D$ & $8-21 h$ \\
\hline & Área de actividades municipales & 175 & 55 & 3.18 & $L-D$ & $8-21 \mathrm{~h}$ \\
\hline
\end{tabular}




\begin{tabular}{|c|c|c|c|c|c|c|}
\hline & Área para el adulto mayor & 170 & 50 & 3.40 & $L-D$ & $8-21 h$ \\
\hline & Ingreso secundario & 133.4 & 40 & 3.34 & $L-D$ & $8-21 h$ \\
\hline & Pasaje Punta Pacochas & 766.3 & 100 & 7.66 & $L-D$ & $8-21 h$ \\
\hline 4 & Circulaciones & 1268.8 & & & & \\
\hline & Circulación vertical & 60 & & & & \\
\hline & Montantes & 14.4 & & & & \\
\hline & Hall de ascensores & 84 & & & & \\
\hline & Ascensores & 14.8 & & & & \\
\hline \multicolumn{7}{|c|}{ Nivel de servicios / NPT +3.85m } \\
\hline \multirow[t]{12}{*}{1} & Puestos del 2do piso & & & & & \\
\hline & Impresiones (5) & 34.9 & 10 & 3.49 & $L-D$ & $8-21 h$ \\
\hline & Servicio técnico (4) & 18 & 4 & 4.50 & $L-D$ & $8-21 h$ \\
\hline & Cerrajerías (4) & 18 & 4 & 4.50 & $L-D$ & $8-21 h$ \\
\hline & Comida pre cocida (22) & 107.1 & 22 & 4.87 & $L-D$ & $8-21 h$ \\
\hline & Disfraces (4) & 18 & 4 & 4.50 & $L-D$ & $8-21 h$ \\
\hline & Pedicure (4) & 34.9 & 16 & 2.18 & $L-D$ & $8-21 h$ \\
\hline & Costurería (6) & 18 & 6 & 3.00 & $L-D$ & $8-21 h$ \\
\hline & Zapatería (6) & 18 & 6 & 3.00 & $L-D$ & $8-21 h$ \\
\hline & Librería (6) & 18 & 6 & 3.00 & $L-D$ & $8-21 h$ \\
\hline & Bar (6) & 34.25 & 8 & 4.28 & $L-D$ & $8-21 h$ \\
\hline & Menús (19) & 161.5 & 30 & 5.38 & $L-D$ & $8-21 h$ \\
\hline \multirow[t]{9}{*}{2} & Servicios para el cliente & & & & & \\
\hline & Área de mesas & 418 & 215 & 1.94 & $L-D$ & $8-21 h$ \\
\hline & SSHH para clientes varones (2) & 18 & 8 & 2.25 & $L-D$ & $8-21 h$ \\
\hline & SSHH para clientes damas (2) & 18 & 8 & 2.25 & $L-D$ & $8-21 h$ \\
\hline & Área de cajeros automáticos & 15 & 12 & 1.25 & $L-D$ & $8-21 h$ \\
\hline & Área de cambistas & 50 & 16 & 3.13 & $L-D$ & $8-18 h$ \\
\hline & Juegos para niños & 31.2 & 8 & 3.90 & $L-D$ & $8-21 h$ \\
\hline & Mirador & 113.8 & 20 & 5.69 & $L-D$ & $8-21 h$ \\
\hline & Espacios de ocio & 156.25 & 50 & 3.13 & $L-D$ & $8-21 h$ \\
\hline 3 & Circulaciones & 1237 & & & & \\
\hline \multirow{2}{*}{2} & Circulación vertical & 60 & & & & \\
\hline & Montantes & 14.4 & & & & \\
\hline & Ascensores & 14.8 & & & & \\
\hline \multicolumn{7}{|c|}{ Oficinas / NPT +9.00m } \\
\hline \multirow[t]{4}{*}{1} & Hall de las oficinas & & & & & \\
\hline & Hall & 84 & 16 & 5.25 & $L-V$ & $8-20 h$ \\
\hline & Área de no trabajo & 41 & 8 & 5.13 & $L-V$ & $8-20 h$ \\
\hline & Llegada del ascensor & 9.85 & 4 & 2.46 & $L-V$ & $8-20 h$ \\
\hline \multirow[t]{8}{*}{2} & Oficinas de $140 \mathrm{~m} 2(4)$ & & & & & \\
\hline & Recepción y sala de espera & 87.8 & 5 & 17.56 & $L-V$ & $8-20 h$ \\
\hline & Sala de reuniones & 89 & 8 & 11.13 & $L-V$ & $8-20 h$ \\
\hline & Área de trabajo & 192 & 8 & 24.00 & $L-V$ & $8-20 h$ \\
\hline & Oficina privada 1 & 48 & 3 & 16.00 & $L-V$ & $8-20 h$ \\
\hline & Oficina privada 2 & 48 & 3 & 16.00 & $L-V$ & $8-20 h$ \\
\hline & Servicios higiénicos & 21.92 & 2 & 10.96 & $L-V$ & $8-20 h$ \\
\hline & Gerencia & 70 & 3 & 23.33 & $L-V$ & $8-20 h$ \\
\hline \multirow[t]{9}{*}{3} & Oficinas de $245 \mathrm{~m} 2(4)$ & & & & & \\
\hline & Recepción y sala de espera & 89 & 5 & 17.80 & $L-V$ & $8-20 h$ \\
\hline & Oficina privada 1 & 89 & 3 & 29.67 & $L-V$ & $8-20 h$ \\
\hline & Kitchenette & 28.8 & 3 & 9.60 & $L-V$ & $8-20 h$ \\
\hline & Sala de reuniones & 87.2 & 8 & 10.90 & $L-V$ & $8-20 h$ \\
\hline & Oficina privada 2 & 72.6 & 3 & 24.20 & $L-V$ & $8-20 h$ \\
\hline & Servicios higiénicos & 29.4 & 2 & 14.70 & $L-V$ & $8-20 h$ \\
\hline & Área de trabajo 1 & 204 & 8 & 25.50 & $L-V$ & $8-20 h$ \\
\hline & Área de trabajo 2 & 150 & 8 & 18.75 & $L-V$ & $8-20 h$ \\
\hline
\end{tabular}




\begin{tabular}{|c|c|c|c|c|c|c|}
\hline & Gerencia & 88 & 3 & 29.33 & $L-V$ & $8-20 h$ \\
\hline & Circulación & 150.12 & & & & \\
\hline \multirow[t]{4}{*}{4} & Circulaciones & & & & & \\
\hline & Circulación vertical & 60 & & & & \\
\hline & Montantes & 14.4 & & & & \\
\hline & Ascensores & 14.8 & & & & \\
\hline
\end{tabular}

Tabla elaborada por los autores.

\subsubsection{Espacio público}

Para el diseño del espacio público del mercado se utilizaron los siguientes lineamientos de diseño: pisos de concreto estampado, mobiliario flexible con bancas de madera, vegetación interior y exterior con plantas y árboles aromáticas y decorativas.

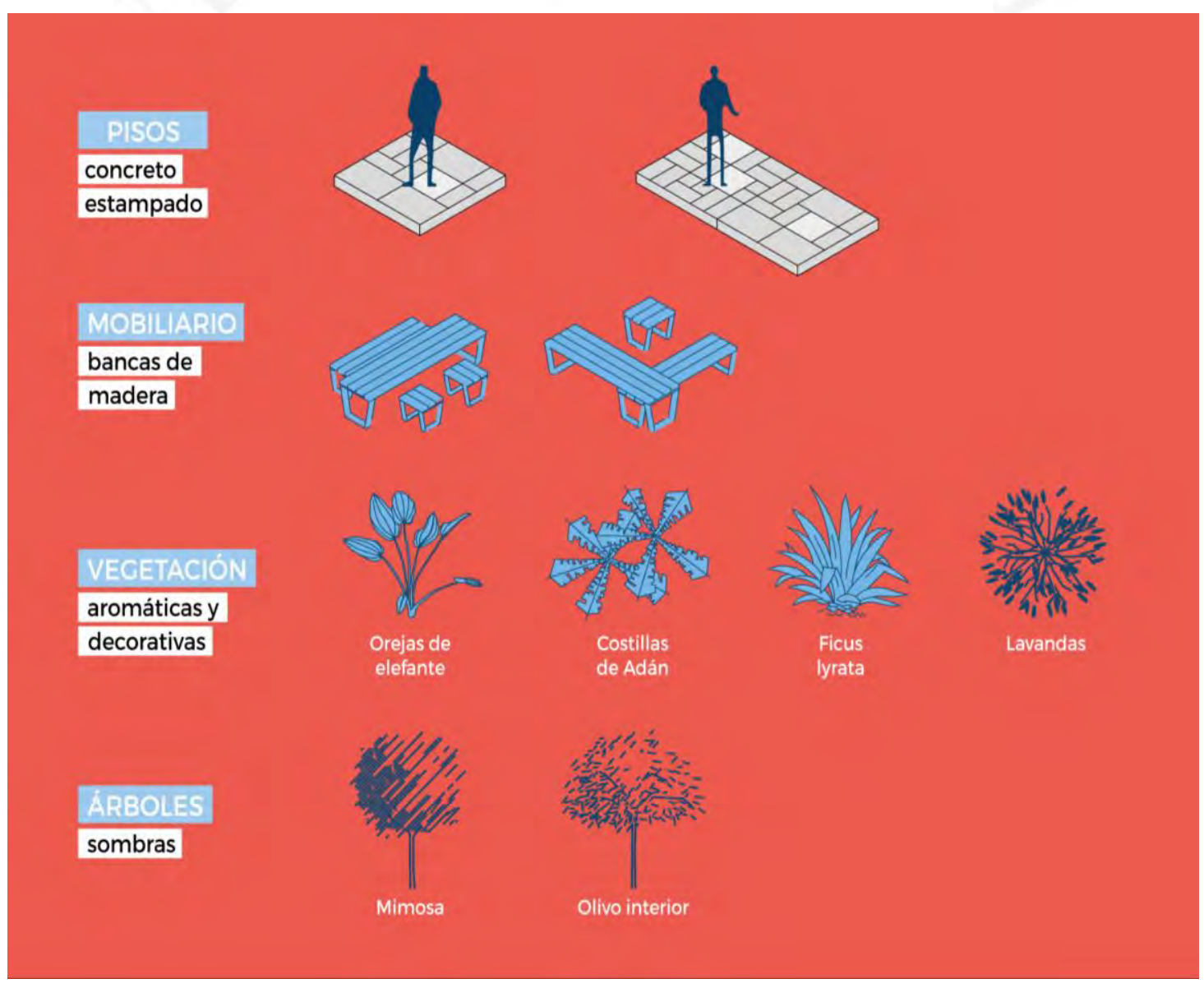

Figura 8.25 Lineamientos de diseño del espacio público

Gráfico realizado por los autores. 
En cuanto al piso del mercado se establecieron 2 tipos de módulo de 1.80 x 1.80m, que internamente tienen diferentes tamaños pero que mantienen una proporción para un diseño más versátil, y se puedan combinar entre sí (Ver Figura 8.26). La variación de las dimensiones del piso responderá según el flujo peatonal de las personas alrededor del mercado para no generar un cambio brusco entre el mercado y la calle, a fin de difuminar el límite del lote.

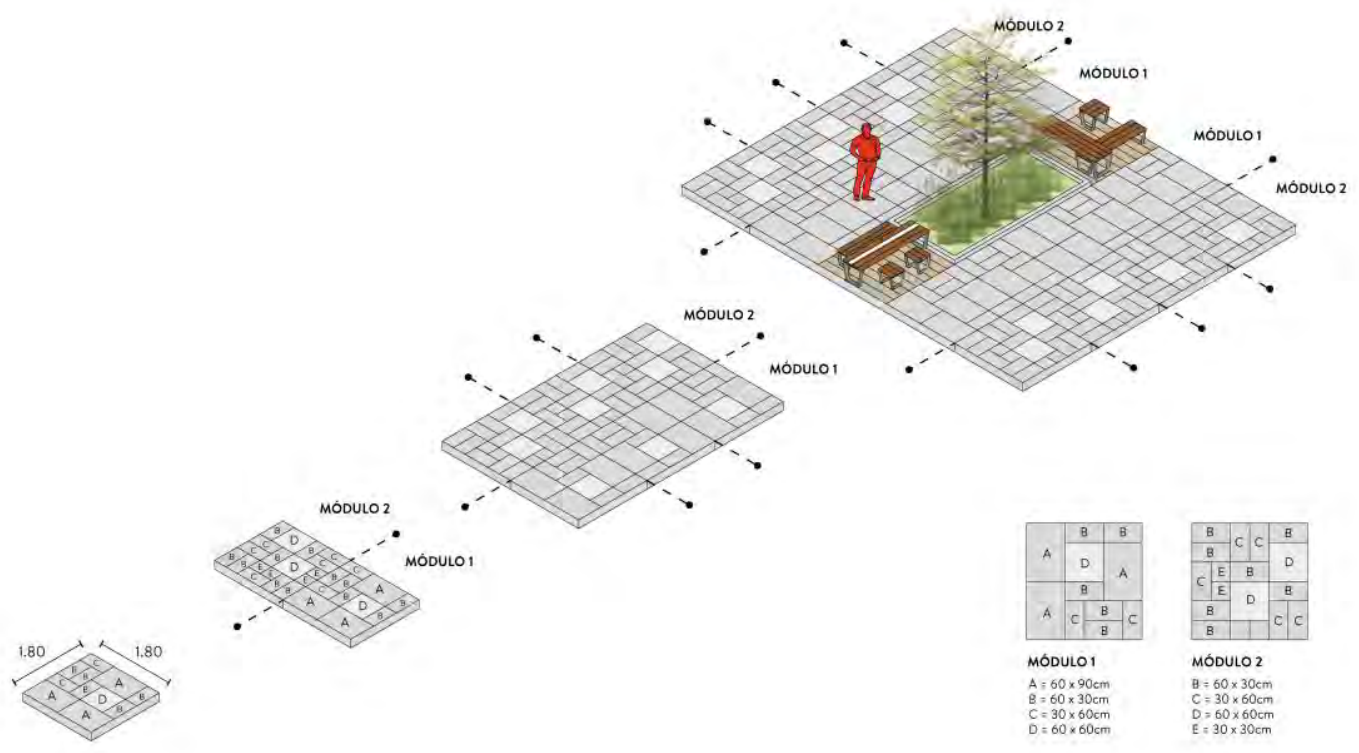

Figura 8.26 Diseño de pavimento

Gráfico elaborado por los autores.

Dentro del mercado se realizaron 3 plazas internas cada uno destinado para diferente usuario. La plaza de los juegos de niños (ver Figura 8.27) se encuentra próximo a los puestos de confiterías y las heladerías y su área esta diferenciada del piso de la circulación principal del mercado por el caucho rojo como pavimento, además está equipado con columpios, saltarines y caballitos para el entretenimiento de los niños, mientras los padres de familia realizan sus compras.

Siguiendo por la circulación interna del mercado los peatones se encontrarán con la Plaza Central (ver Figura 8.28) destinada a actividades municipales y eventos realizados por los miembros del mercado, es por tal motivo que no tiene un diseño de 
mobiliario en particular, pero las escaleras poseen graderías techadas para que las personas puedan observar el espectáculo.

Finalmente, está la Plaza del Adulto Mayor (ver Figura 8.29) que se encuentra aledaño a los puestos de té y especias, esta plaza se encuentra equipada con la virgen del mercado la cual fue reubicada, así también como bancas realizadas en concreto y madera, con una jardineras y árboles para proporcionar espacios con sombras.

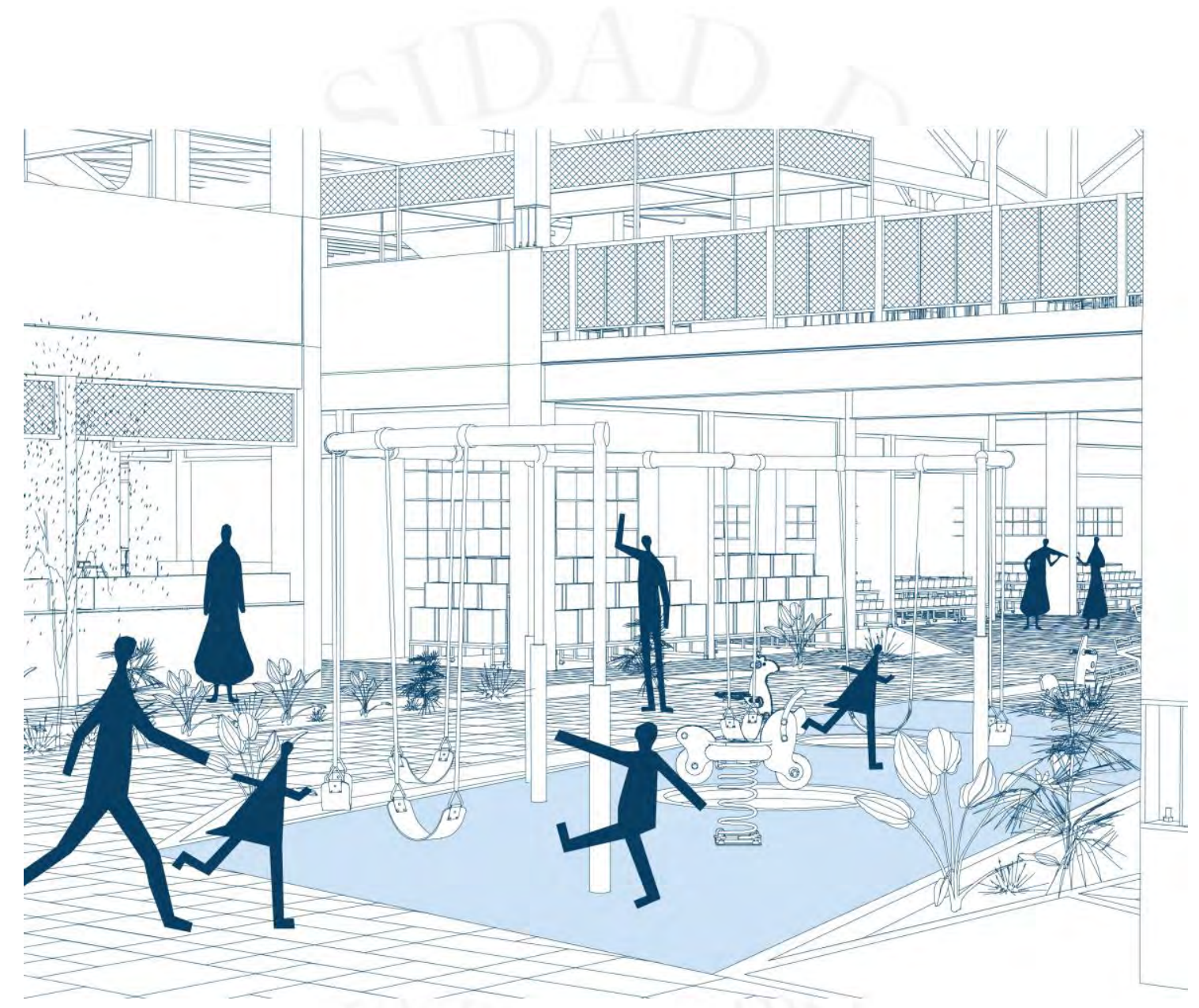

Figura 8.27 Plaza de juegos de niños

Gráfico realizado por los autores. 


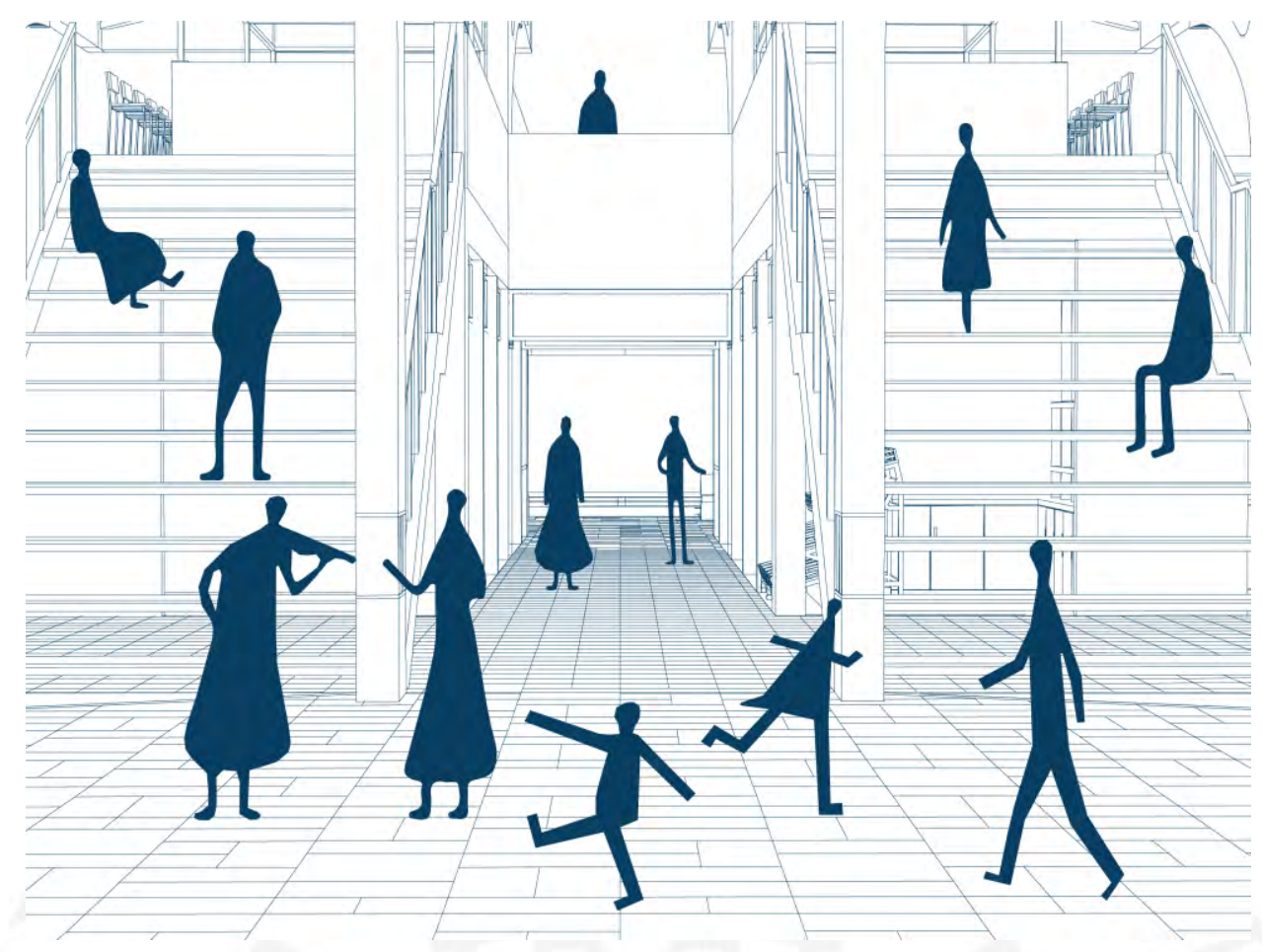

Figura 8.28 Plaza central de actividades municipales Gráfico realizado por los autores.

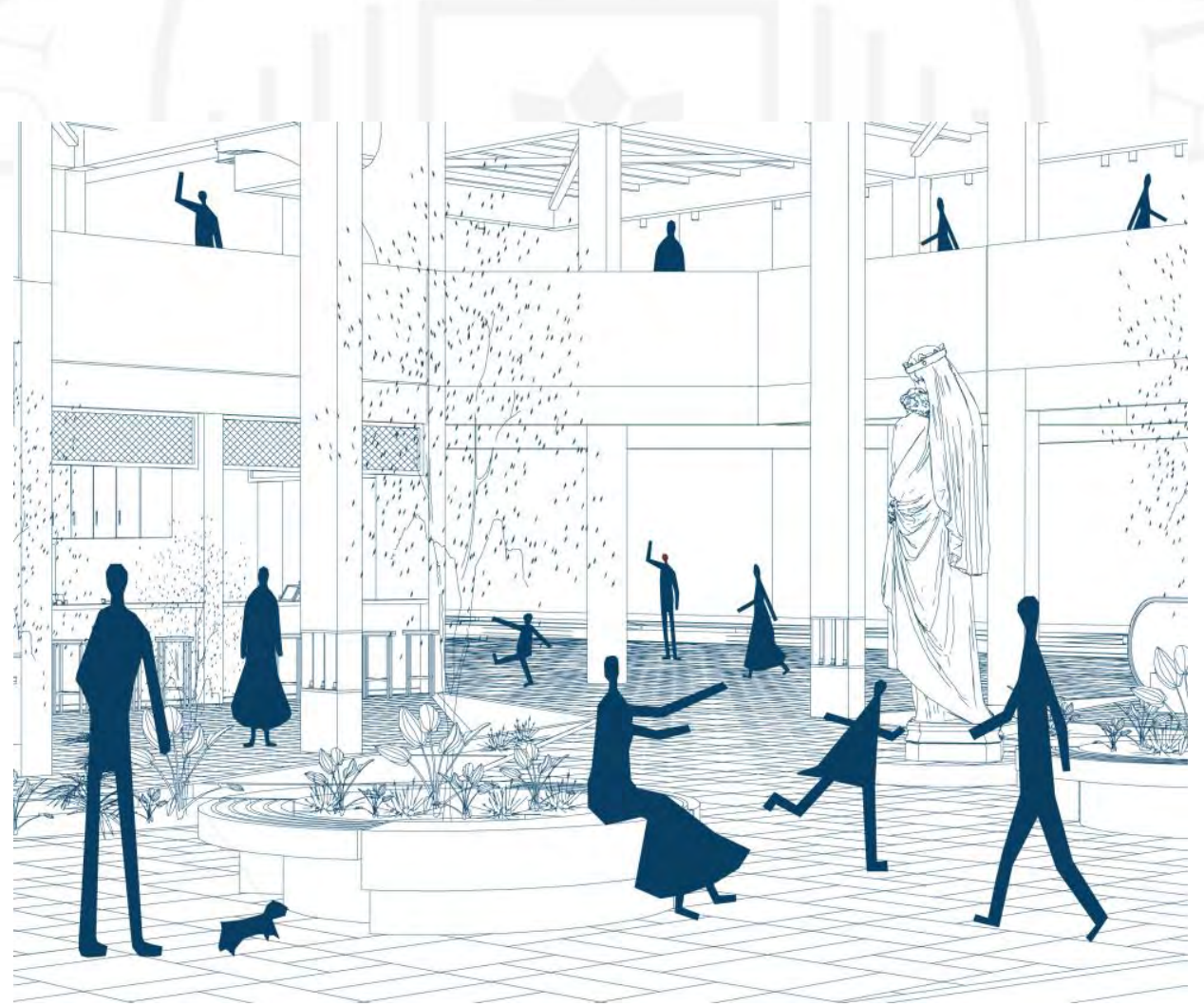

Figura 8.29 Plaza del adulto mayor

Gráfico realizado por los autores. 
La propuesta del Pasaje Punta Pacochas (ver Figura 8.30) cuenta con puestos de menú que atienden hacia este, pero las personas no son atendidas interrumpiendo en la circulación de los peatones, sino que estos puestos tienen un retiro interno que permite la cómoda atención de los clientes además de la colocación de mesas y asientos. El pasaje también cuenta con mobiliario ligero realizado con madera y estructura metálica para que las personas puedan acomodarlo libremente dependiendo de la dinámica que se quiera realizar. Además, el Pasaje Punta Pacochas cuenta con 2 escaleras que dirigen el flujo hacia el área de menús del segundo nivel del mercado y los puestos de servicios. Finalmente, la cobertura del mercado realiza la función de sol y sombra y al mismo tiempo es estructura principal de los pabellones metálicos suspendidos de las oficinas.

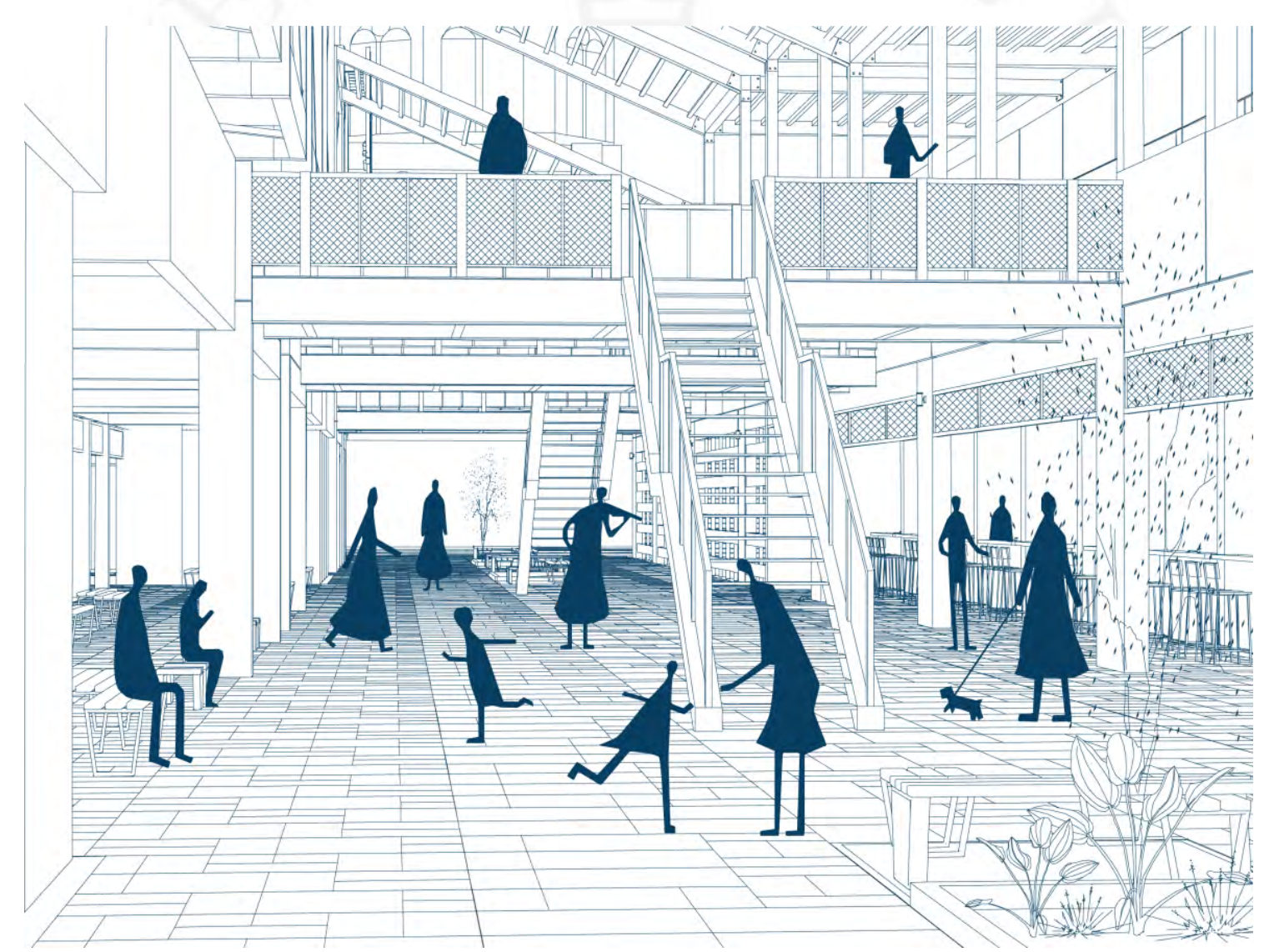

Figura 8.30 Propuesta del pasaje Punta Pacochas Gráfico realizado por los autores. 


\subsection{Especialidades}

\subsubsection{Memoria descriptiva de estructuras}

Para el desarrollo del Mercado San José, se trabajaron dos sistemas estructurales diferentes. Cada uno corresponde a la espacialidad requerida para su correcto funcionamiento, es así como el sótano del mercado en donde se encuentran los estacionamientos y el área de abastecimiento son realizados en base al sistema aporticado de concreto, este sistema prevalece en el primer nivel en donde se encuentran los puestos del mercado y los espacios públicos - recreativos que lo complementan.

Es a partir del segundo nivel donde sucede un cambio en el sistema estructural, trabajando con estructura metálica permitiendo luces más amplias y menor cantidad de columnas. Este sistema estructural, ayuda a que el mercado no tenga muros perimetrales y se pueda observar la actividad comercial del segundo nivel desde los diferentes niveles del mercado y desde el exterior, a su vez genera la impresión de volúmenes suspendidos en el tercer nivel donde se ubican las oficinas, además, la estructura metálica es cambiante y ayuda a formar el techo de los puestos de venta. 


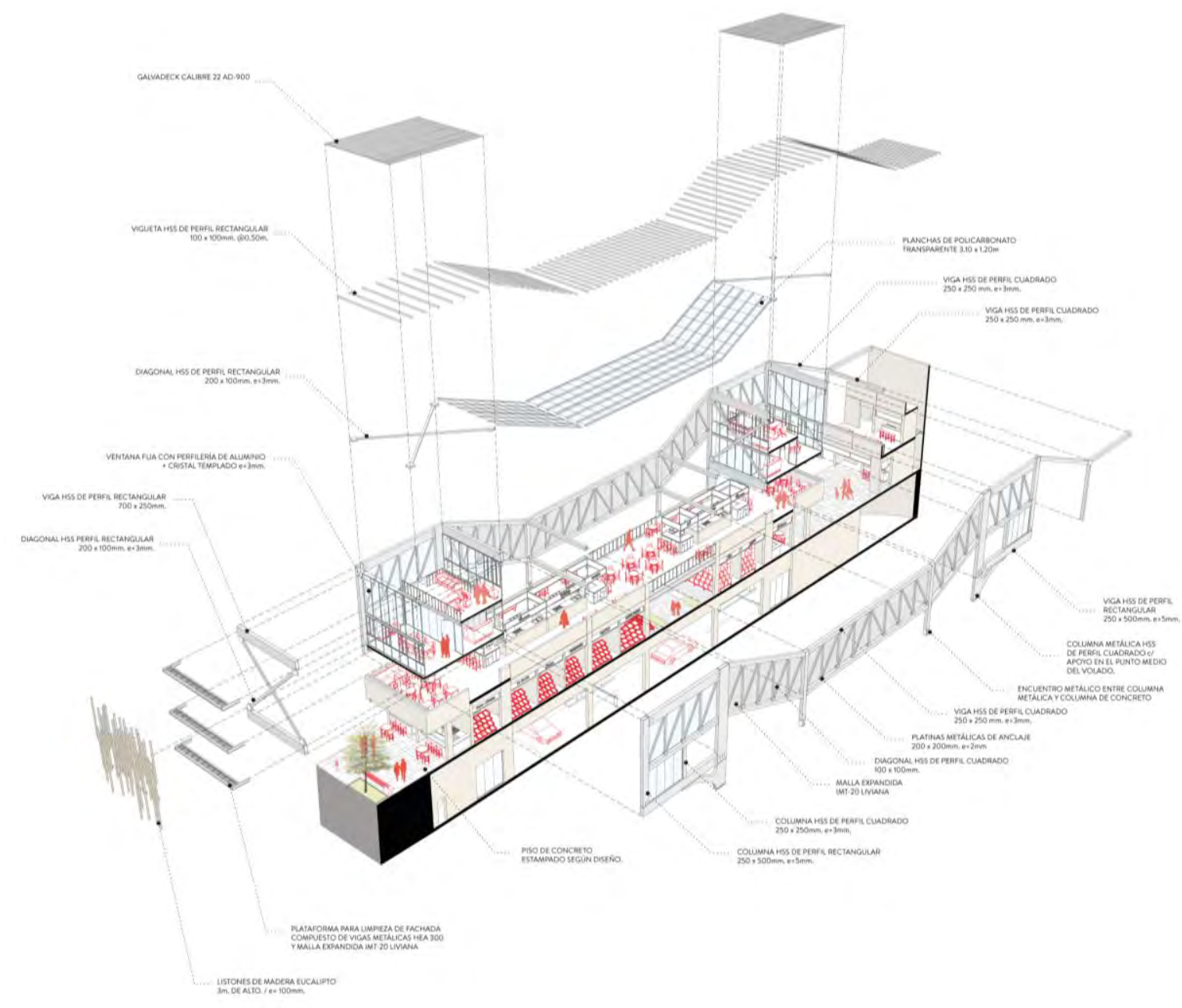

Figura 8.31 Axonometría de un pabellón del mercado Gráfico realizado por los autores. 


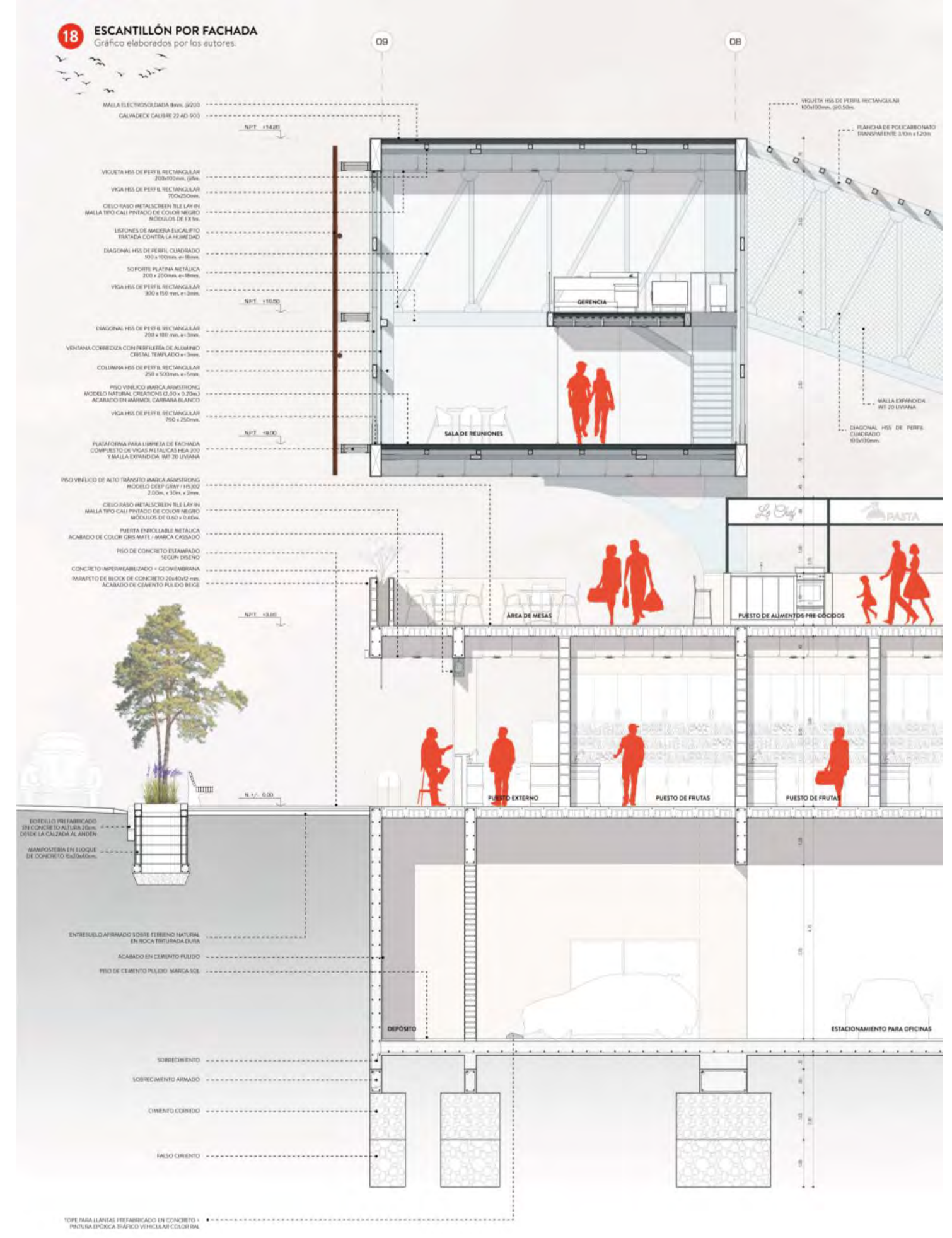

Figura 8.32 Escantillón por fachada del mercado

Gráfico realizado por los autores. 


\subsubsection{Memoria descriptiva de instalaciones eléctricas}

El mercado cuenta con una acometida pública que ingresa hacia la sub estación eléctrica que lo vuelve en energía estable para el uso de los diferentes ambientes y puestos que conforman el proyecto del Mercado San José. La sub estación eléctrica se encuentra en el sótano y tiene un ingreso desde el mercado y otro desde el exterior para su mantenimiento y trabajos realizados por la empresa encargada, sin tener la necesidad de que entren al establecimiento y los perjudique si es que el mercado se encuentra cerrado.

Una vez que la energía pasa por la sub estación eléctrica, esta se puede controlar desde el tablero eléctrico y se distribuyen hacia los tableros de distribución por los ductos ubicados en cada hall de ascensores. Si el mercado en algún momento se queda sin energía por causas externas, posee 2 grupos electrógenos uno al sector derecho y otro al lado izquierdo del mercado, cada uno con su rejilla de ventilación.

Una vez que la energía eléctrica llega al primer y segundo nivel, esta es dividida para 4 sectores cada uno con su tablero para uso de áreas comunes, otro para uso de los puestos del mercado, seguido de un tablero para las luces de emergencia, y tableros de fuerza para uso de los ascensores y escaleras mecánicas. Del tablero para uso de los puestos del mercado, nace la red hacia cada puesto de venta que cuenta con un sub tablero, un medidor y un punto de luz, que independiza su consumo eléctrico.

De igual manera que las redes de luz, la misma lógica se maneja con las redes de tomacorrientes, que, del tablero de uso de los puestos, va hacia el sub tablero de cada puesto para suministrar hacia los puntos de tomacorrientes, uno doble con toma a tierra y otros dos doble a prueba de agua con toma a tierra.

Finalmente, las áreas públicas tanto internas como externas, tendrán puntos de tomacorriente doble a prueba de agua con toma a tierra en las bancas, mesas, y jardineras para uso de los clientes. 


\subsubsection{Memoria descriptiva de instalaciones sanitarias}

El proyecto del mercado posee 4 diferentes niveles a los que se tiene que abastecer de agua, por lo que es necesario tener un cuarto de bombas que impulse los fluidos con una presión constante. Este cuarto de bombas se encuentra debajo del área de los estacionamientos del mercado, donde también están ubicados las cisternas, los cuales irradiarán mediante tuberías troncales y montantes hacia todos los extremos del mercado.

El núcleo está conformado por una cisterna de agua potable para el uso del mercado, una cisterna para el uso de las oficinas, y una última cisterna de agua contra incendios, además del cuarto de bombas y los ductos que contienen las montantes que distribuyen el fluido en cada nivel. El abastecimiento del agua se da directamente desde la red pública hacia la cisterna, pasando a través de un medidor correspondiente para el uso general del mercado.

En el área del mercado del primer y segundo nivel, cada pasillo tiene una troncal principal que distribuye el agua hacia cada puesto de venta que posea aparatos sanitarios, no sin antes pasar por un medidor y por una llave de paso. Esta distribución de la red, nos permite que cada puesto de venta sea independiente y asuma sus gastos por el uso del agua que utiliza.

Finalmente, en el área de las oficinas el uso del agua es mucho menor, debido a la poca cantidad de aparatos sanitarios, esto solo se encuentran ubicados en los baños de cada oficina y en los kitchenette. La red de distribución de agua proviene desde el sótano y las montantes pasan por los ductos de agua indicadas cercana al hall de ascensores y a la escalera de evacuación. 


\subsection{Viabilidad}

A continuación, se estudiará la viabilidad del proyecto en el que evaluarán diferentes variables para justificar su construcción. Primero se realizará un presupuesto de obra calculando los ingreso y egresos, siendo el primer indicador para saber su rentabilidad. Una vez determinado el monto de la construcción del proyecto, podremos determinar la forma en la que podría ser financiada la construcción, y en cuanto tiempo se obtendría la recuperación de la inversión a través de un flujo de caja, calculando el valor anual neto (VAN) y la tasa interna de retorno (TIR). Sin embargo, esto no es lo único que ayuda a determinar su viabilidad, debido a que existen elementos adicionales que se deben considerar, como el valor social del proyecto y los beneficios que traería consigo para los habitantes del distrito de Jesús María y para la ciudad de Lima.

El terreno del mercado actualmente le pertenece a la Asociación de Mercaderes del Mercado San José y se encuentra dividido por el pasaje Punta Pacochas cuyo dueño es la Municipalidad de Jesús María. En la propuesta de diseño del mercado consideramos utilizar los aires del pasaje para comunicar los flujos del mercado con la zona de menús mediante puentes, y también se utilizará el sub suelo del pasaje para estacionamientos de uso público y para la carga y descarga de los productos que abastecerán al mercado.

El uso del pasaje es posible mediante el Derecho de Usufructo (H. Elguera, comunicación personal, 1 de febrero de 2019), el cual es derecho real y temporal sobre un bien ajeno tal como lo establece el artículo 1030 del Código Civil Peruano. Esto quiere decir que existe una potestad de construir sobre un terreno ajeno y la potestad de hacerse dueño de lo que se edifica en el sobresuelo y/o subsuelo de un terreno sin que se pierda la titularidad del propietario inicial (Fernández Salas, 2012, p. 241).

Por lo tanto, el Usufructuario se debe encargar de preservar, recuperar o retardar la pérdida de las condiciones estructurales y funcionales del pasaje Punta Pacochas, así también como el mantenimiento rutinario, el mantenimiento periódico y el mantenimiento de emergencia, a cambio de las construcciones necesarias para el desarrollo y la puesta en operación del Mercado San José y un intercambio económico anual, bajo un contrato de 30 años de duración. 


\subsubsection{Presupuesto}

Para verificar la viabilidad del proyecto es necesario realizar un presupuesto financiero, para determinar qué tipo de financiamiento se debe utilizar. Primero se realizó un cuadro de ingresos en donde se detalla los ítems que serán vendidos y alquilados. Y después se realizó el cuadro de egresos en base a ratios por metro cuadrado designados a través de un estudio de proyectos de mercados de abasto cuyos valores varían según del sistema estructural. Cabe resaltar que los montos que manejan ratios incluyen costo de diseño, construcción e instalación (ver Tabla 8.2).

En cuanto a la sección de arquitectura se realizó un metrado del proyecto y se multiplicó por el precio unitario de los materiales según los proyectos presentes en la revista Costos. Mientras que en la sección de equipos (ascensores, escaleras mecánicas, montacargas, grupo electrógeno, etc.) se manejaron montos reales consultados a proveedores.

También se considera como parte de los egresos el gasto por derecho de usufructo por el uso de los aires del Pasaje Punta Pacochas con un monto de S/. 374400.00 anuales pagados a la Municipalidad de Jesús María. Además, consideramos el gasto por el mantenimiento del mercado una vez iniciada sus operaciones con un monto global de S/. 200000.00 anuales.

Tabla 8.2

Ingresos y egresos del proyecto

\begin{tabular}{|c|c|c|c|c|c|}
\hline DESCRIPCION & UNIDAD & METRADO & PU & & CIAL \\
\hline \multicolumn{6}{|l|}{ VENTAS } \\
\hline M2. VENDIBLES DE OFICINAS X VALOR DE VENTA POR M2. & S./m2 & $1,540.00$ & $5,940.00$ & S/ & $9,147,600.00$ \\
\hline VENTA DE ESTACIONAMIENTOS PARA LAS OFICINAS & Unid. & 39.00 & $39,600.00$ & $\mathrm{~S} /$ & $1,544,400.00$ \\
\hline DEPÓSITOS PARA LAS OFICINAS & S./m2 & 108.00 & $4,950.00$ & S/ & $534,600.00$ \\
\hline VENTA TOTAL & & & INGRESO POR VENTAS & $\mathrm{S} /$ & $11,226,600.00$ \\
\hline
\end{tabular}

\begin{tabular}{|c|c|c|c|c|}
\hline \multicolumn{5}{|l|}{ ALQUILER (5 AÑOS) } \\
\hline \# PUESTOS DE VENTA X VALOR DE ALQUILER & 208.00 & $3,000.00$ & S/ & $37,440,000.00$ \\
\hline INGRESO POR ESTACIONAMIENTOS DE USO PÚBLICO & 25.00 & $5,400.00$ & S/ & $675,000.00$ \\
\hline ALQUILER TOTAL & & INGRESO POR ALQUILER & S/ & $38,115,000.00$ \\
\hline
\end{tabular}




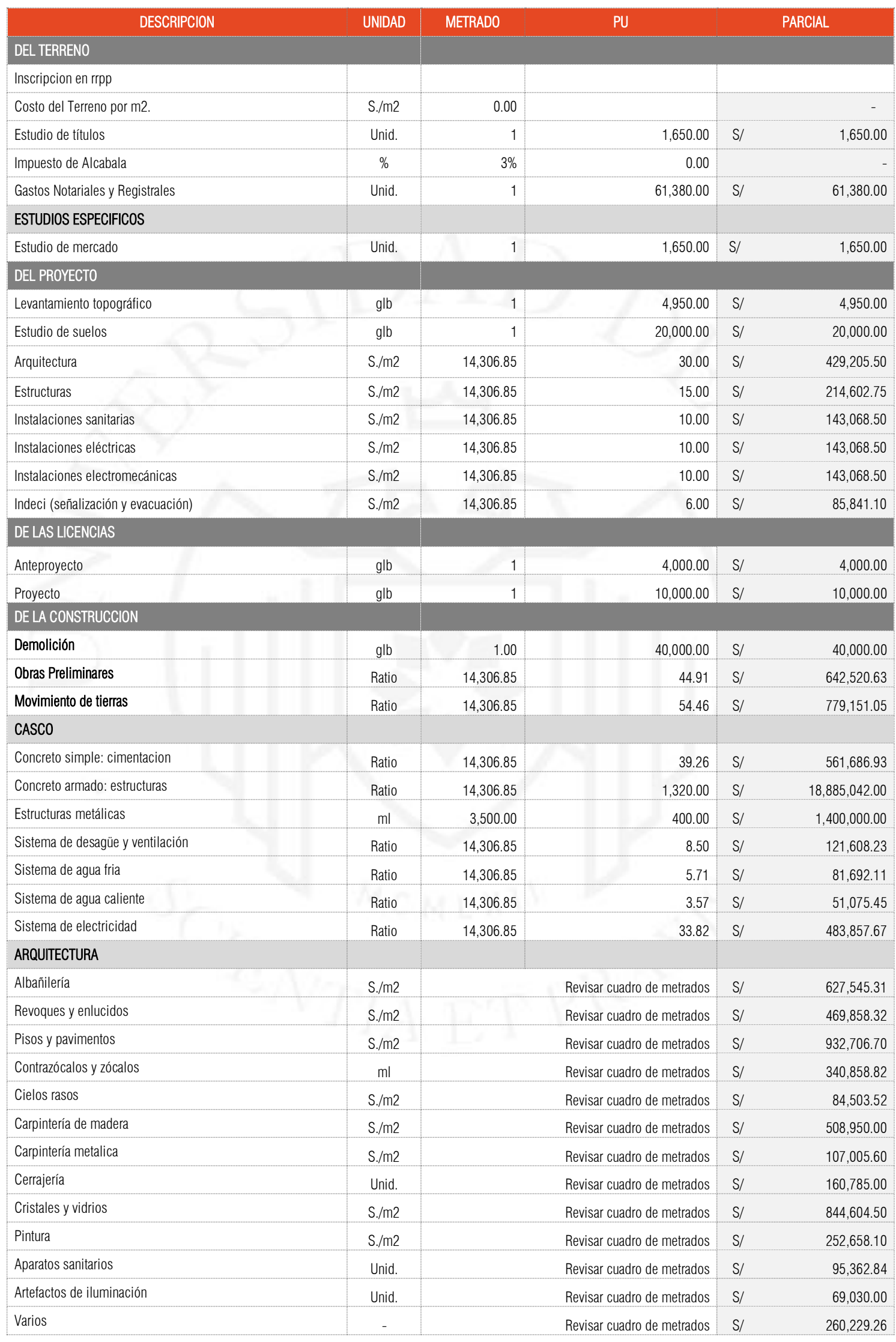




\begin{tabular}{|c|c|c|c|c|c|}
\hline \multicolumn{6}{|l|}{ EQUPOS } \\
\hline Ascensor & Unid. & 4.00 & $115,500.00$ & S/ & $462,000.00$ \\
\hline Sistema de agua contra incendios & Ratio & $14,306.85$ & 12.00 & S/ & $171,682.20$ \\
\hline Grupo electrógeno & Unid. & 2.00 & $30,000.00$ & S/ & $60,000.00$ \\
\hline Sistema de comunicaciones & Ratio & $14,306.85$ & 6.00 & S/ & $85,841.10$ \\
\hline Sistema de detección y alarmas & Ratio & $14,306.85$ & 10.00 & S/ & $143,068.50$ \\
\hline Sistema de extracción de monóxido & Ratio & $14,306.85$ & 1.55 & S/ & $22,175.62$ \\
\hline Mobiliario especial y counter & Unid. & 1.00 & $10,000.00$ & S/ & $10,000.00$ \\
\hline Escaleras mecánicas & Unid. & 4.00 & $150,000.00$ & S/ & $600,000.00$ \\
\hline Montacargas & Unid. & 2.00 & $82,500.00$ & S/ & $165,000.00$ \\
\hline Suministro e instalación de cámaras frigoríficas & Unid & 3.00 & $22,500.00$ & S/ & $67,500.00$ \\
\hline Gastos generales y utilidades para contratista & $\%$ & $30 \%$ & $23,955,931.53$ & S/ & $7,186,779.46$ \\
\hline \multicolumn{6}{|l|}{ SERVICIOS PUBLICOS } \\
\hline Suministro de agua y desagüe & glb & 1.00 & $10,000.00$ & S/ & $10,000.00$ \\
\hline Suministro de energía eléctrica & glb & 1.00 & $40,000.00$ & S/ & $40,000.00$ \\
\hline Instalaciones de gas & glb & 1.00 & $62,000.00$ & S/ & $62,000.00$ \\
\hline Instalación de teléfono/cable/internet & $g l b$ & 1.00 & $40,000.00$ & $\mathrm{~S} /$ & $40,000.00$ \\
\hline \multicolumn{6}{|l|}{ LEGAL } \\
\hline Inscripcion de nuevas propiedades & Unid. & 290 & 300.00 & S/ & $87,000.00$ \\
\hline Conformidad de obra & Unid. & 290 & 100.00 & S/ & $29,000.00$ \\
\hline Inscripción de declaratoria de fábrica & Unid. & 290 & 200.00 & S/ & $58,000.00$ \\
\hline Certificado de numeración & Unid. & 290 & 60.00 & S/ & $17,400.00$ \\
\hline Independización & Unid. & 290 & 100.00 & S/ & $29,000.00$ \\
\hline Registro de marcas & $\mathrm{glb}$ & 1 & $100,000.00$ & S/ & $100,000.00$ \\
\hline \multicolumn{6}{|l|}{ DE LA GERENCIA DE PROYECTO } \\
\hline $\begin{array}{l}\text { Porcentaje del gasto administrado (según complejidad y/0 } \\
\text { tamaño) }\end{array}$ & $\%$ & $10.0 \%$ & $12,000,000.00$ & S/ & $1,200,000.00$ \\
\hline \multicolumn{6}{|l|}{ GASTOS DE PROMOCION Y VENTA } \\
\hline Venta-corretaje (rango entre $2 \%$ a 4\%) según tamaño & $\%$ & $3 \%$ & $11,226,600.00$ & S/ & $336,798.00$ \\
\hline Publicidad, promocion, caseta (1 a $2 \%$ de las ventas) & $\%$ & $1 \%$ & $11,226,600.00$ & S/ & $112,266.00$ \\
\hline \multicolumn{6}{|l|}{ GASTOS POR DERECHO DE USUFRUCTO (5 AÑOS) } \\
\hline Comisión por alquiler de puestos & $\%$ & $1 \%$ & $37,440,000.00$ & S/ & $1,872,000.00$ \\
\hline INVERSION TOTAL & & & SUMA TOTAL DE GASTOS & S/ & $42,030,727.76$ \\
\hline
\end{tabular}

Fuente: Tabla elaborada por los autores.

\subsubsection{Formas de inversión del proyecto}

Para justificar la inversión que requiere la construcción del Mercado San José con sus espacios públicos internos y sus oficinas en el último nivel, se deben analizar algunos factores para calcular la recuperación de la inversión, como los ingresos por alquiler anual, la venta de las oficinas, y los ingresos por el uso de estacionamiento de las personas que no compran dentro del mercado, hasta los beneficios sociales, culturales y económicos generados a partir de su implementación. 
El sistema de financiamiento será a partir de un crédito hipotecario por parte de una entidad bancaria el cual brindará el $60 \%$ de la inversión a una tasa del 12\% anual, y los miembros de la Asociación de Comerciantes del Mercado San José asumirán el 40\% restante y se harán cargo de la construcción. Es importante resaltar que mientras el mercado deje de operar por la construcción, se brindará un pago mensual a los 13 miembros de la Asociación de Comerciantes según su ingreso mensual promedio actual.

Para calcular la rentabilidad del proyecto se utilizó el valor anual neto (VAN) y la tasa interna de retorno (TIR), a partir de la sumatoria de los egresos e ingresos del proyecto derivados al flujo de caja anual durante 2 años de construcción y 8 años de operación del mercado. A continuación, presentamos el cuadro final de la velocidad del retorno de inversión en años (ver Tabla 8.3), y como se puede notar a partir del octavo año el mercado obtiene ganancias sin la reducción del capital por el préstamo bancario y los ingresos empiezan a ser de manera constante.

Tabla 8.3

VAN y TIR del proyecto

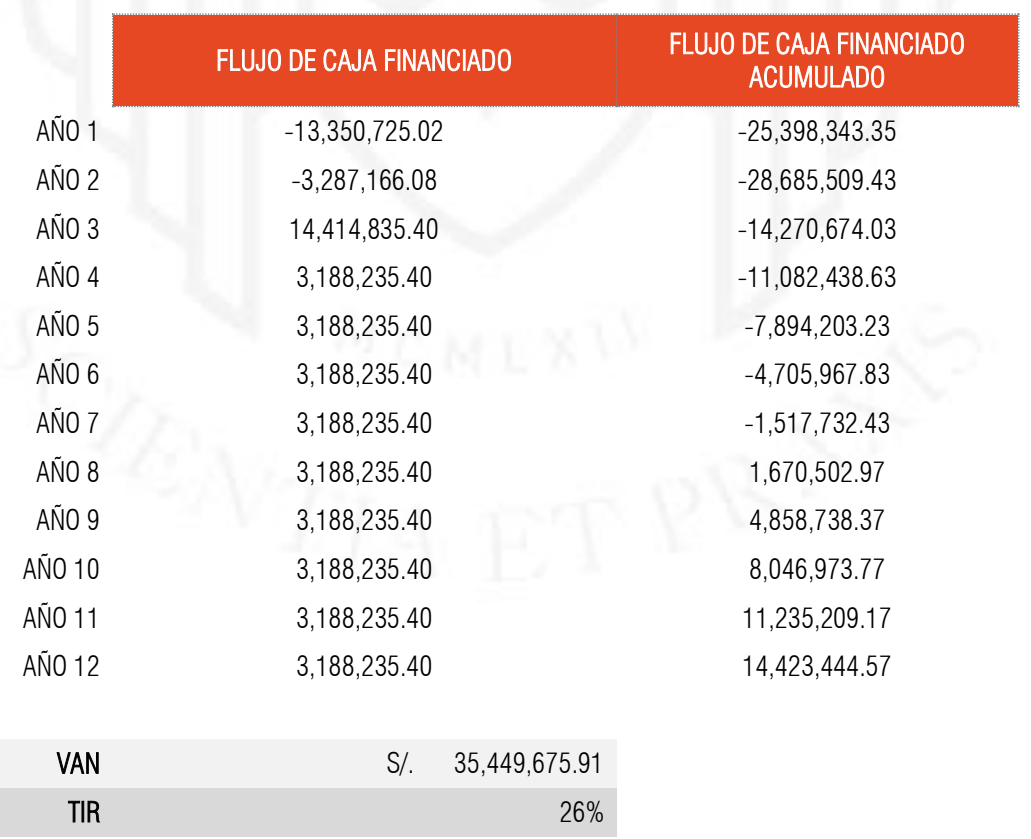

Tabla elaborada por los autores. 
Además, se adjunta el Flujo de Caja (ver Tabla 8.4) del proyecto del mercado en el cual se puede apreciar la distribución de los egresos de forma anual. Los 2 primeros años es la etapa de construcción que un $60 \%$ será financiada por un crédito hipotecario y el 40\% restante será aporte de la Asociación de Mercaderes del Mercado San José.

Dentro del primer año, como fase preliminar se consideran gastos por estudio de títulos, gastos notariales y registrales, estudio de mercado. Así también como el levantamiento topográfico, estudios de suela, y la realización de los planos de arquitectura, estructuras y especialidades.

Una vez obtenida las licencias de anteproyecto como la de proyecto se puede empezar con la etapa de construcción la cual esta valorizada en S/. 36, 774,778.91. Finalizada la construcción empiezan los gastos por suministro de agua y desagüe, energía eléctrica, instalaciones de gas, teléfono, cable e internet; seguido de la fase legal por conformidad de obra, declaratoria de fábrica, certificado de numeración, independización y registro de marcas.

El mercado inicia sus operaciones en el año 3, y se consideran los ingresos anuales por el alquiler de los puestos de venta, ingresos por uso de los estacionamientos públicos, y por venta de las oficinas con sus estacionamientos y depósitos, ventas que serán promocionadas por lo tanto se consideran dichos egresos dentro del flujo de caja. También son considerados los gastos por derecho de usufructo, gastos por mantenimiento, y el pago por el préstamo realizado por el banco con un interés del $10 \%$ anual. 
Tabla 8.4

Flujo de caja del Mercado San José

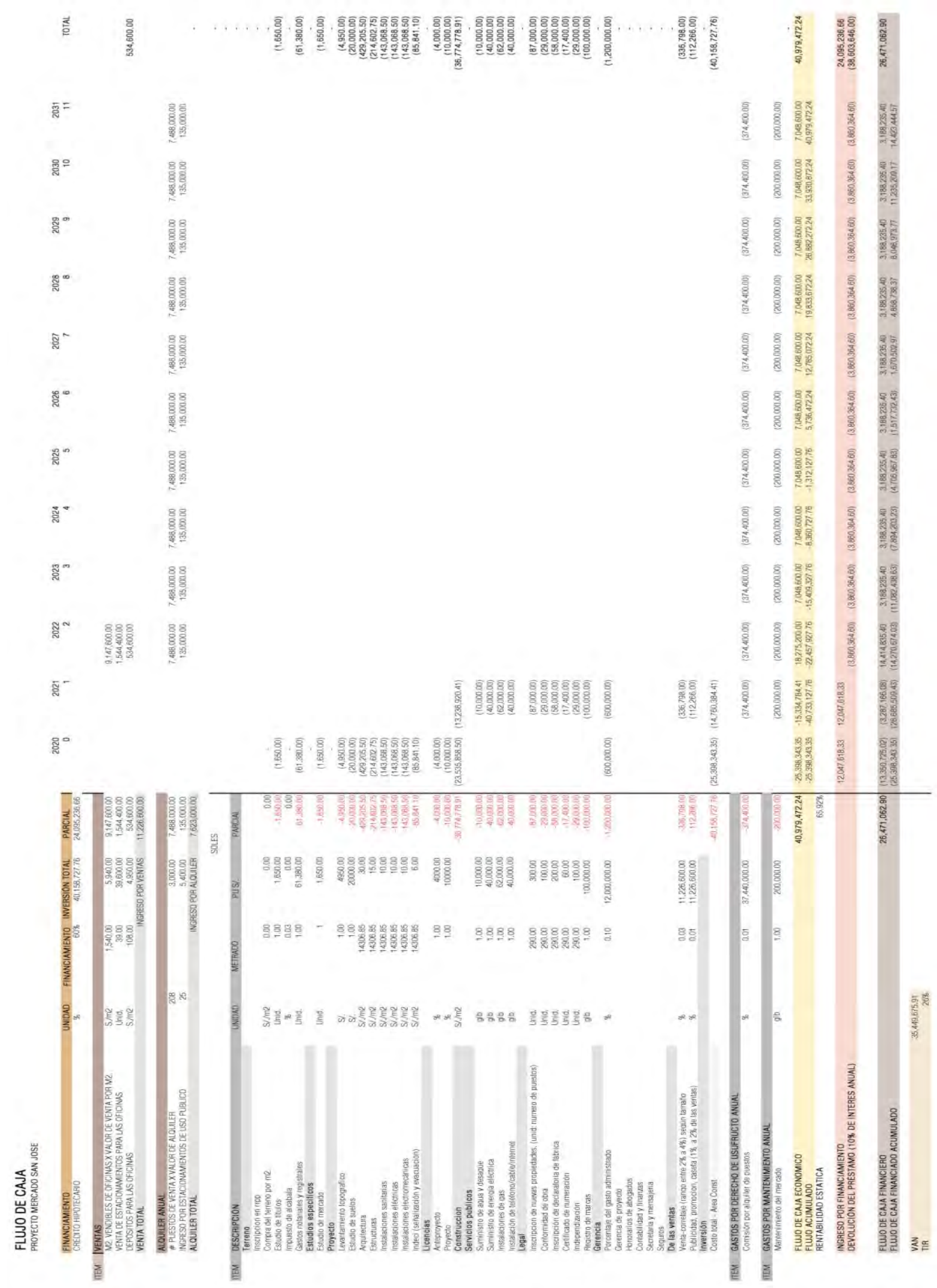




\subsubsection{Beneficio social}

\subsubsection{Ahorro en gastos familiares por alimentos}

Actualmente los gastos en alimentación de las familias peruanas representan un $34,7 \%$ de la canasta familiar (ver Figura 8.33) por encima de gastos como el de transporte, salud y gastos por vestimenta. Esto quiere decir que el mayor gasto que tienen las familias peruanas, es en alimentación, con un costo promedio mensual de S/. 1312 si es un hogar de 4 miembros y S/. 328 si es solo una persona independiente (ver Figura 8.34).

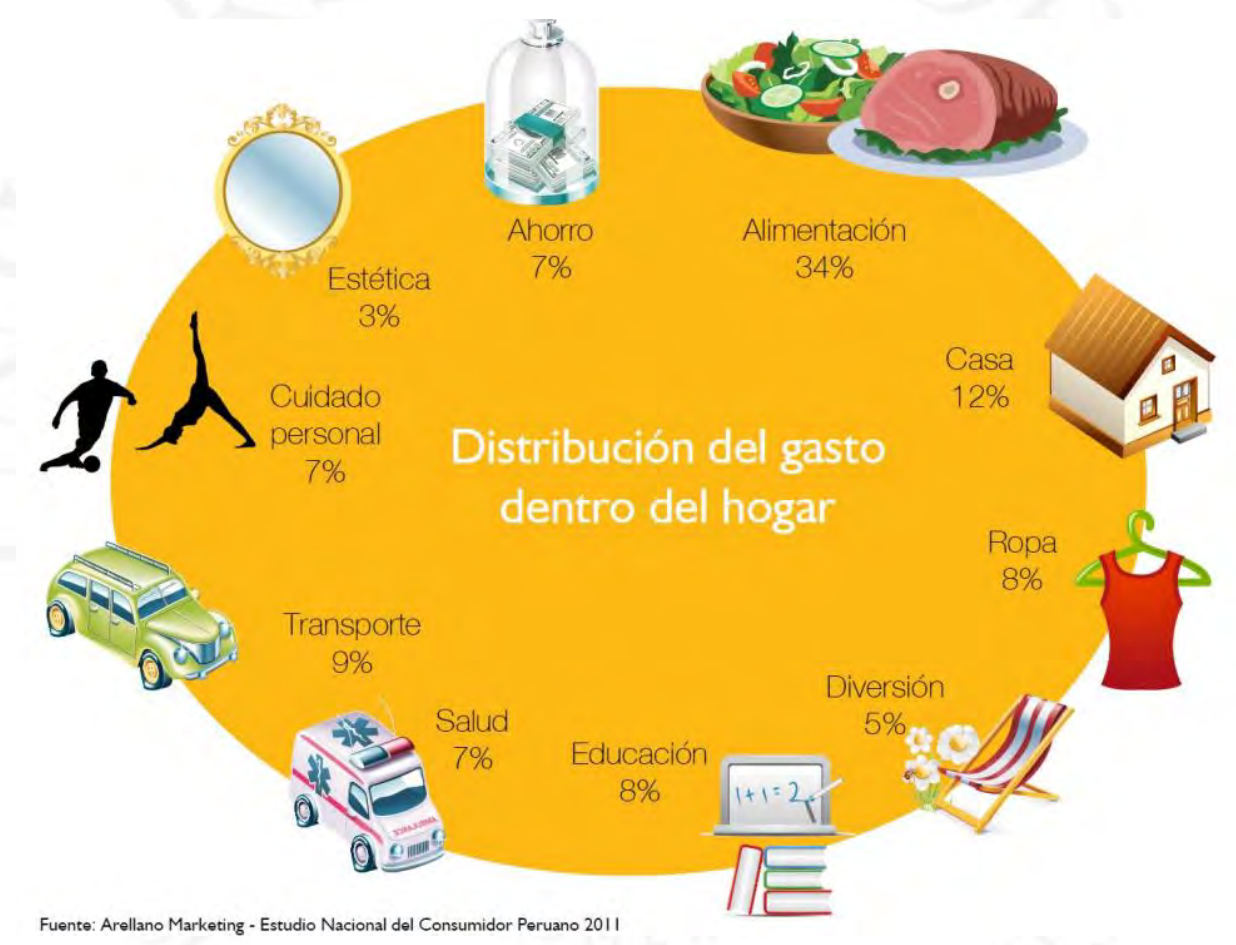

Figura 8.33 Distribución del gasto dentro del hogar

Fuente: Arellano Marketing, 2011 


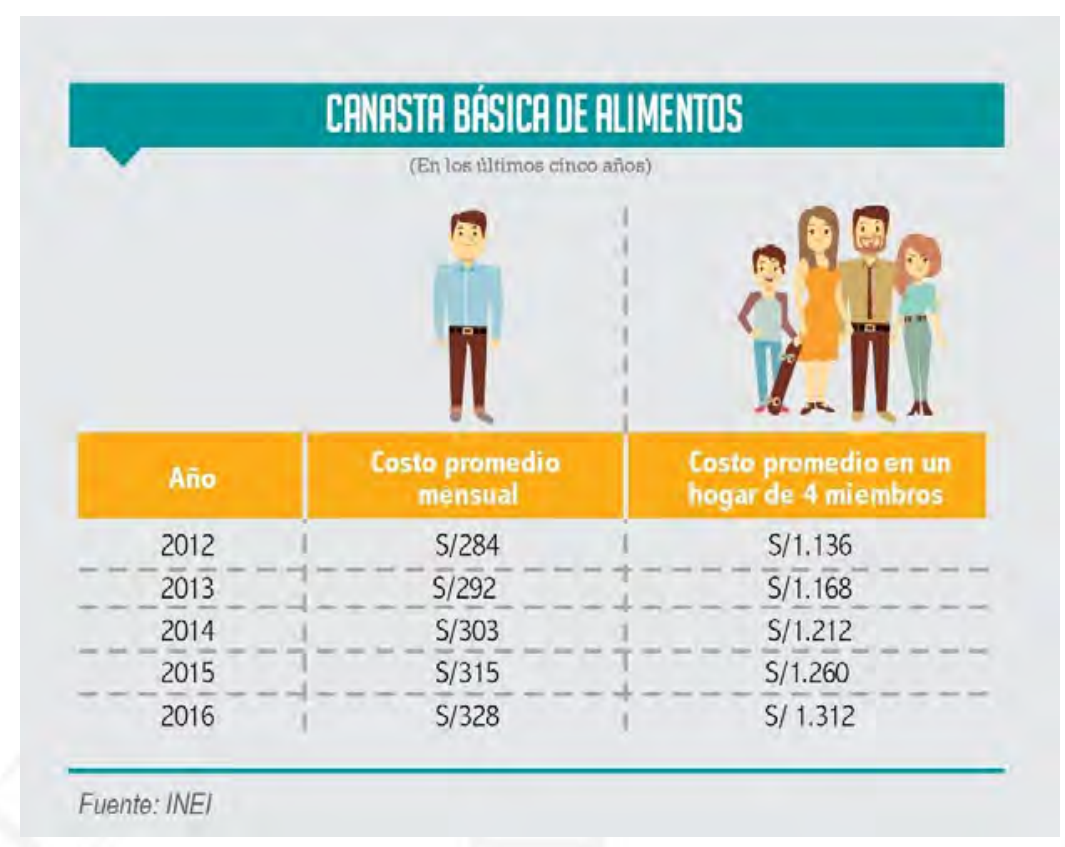

Figura 8.34 Costo promedio mensual por alimentos

Fuente: INEI, 2012

La canasta familiar en el Perú está compuesta por 532 productos que incluyen carnes, lácteos, legumbres, huevos, cereales, grasas, frutas, verduras, entre otros, pero la diferencia de precios radica en los formatos comerciales en las que las familias van a adquirir sus productos, a continuación, presentamos un cuadro comparativo de precios entre los diferentes formatos comerciales vs. un mercado de abasto (ver tabla 8.5) concluyendo que muchos de los precios ofrecidos por el mercado de abasto son inferiores y más frescos que los productos ofrecidos por los supermercados, ahorrando hasta un $\mathrm{S} /$. 35.59 , multiplicando este dato por la población atendida en un radio de influencia de 0.5 $\mathrm{Km}^{2}$ según el software de inteligencia territorial, Mi Entorno, al año se podría ahorra $\mathrm{S} /$. 18129261.28 (ver tabla 8.6). 
Tabla 8.5

Comparación de precios_Autoservicios vs Mercado

\begin{tabular}{|c|c|c|c|c|c|c|c|c|}
\hline PRODUCTOS & \multicolumn{2}{|c|}{ METRO } & \multicolumn{2}{|c|}{ PLAZA VEA } & \multicolumn{2}{|c|}{ WONG } & \multicolumn{2}{|c|}{ MERCADO } \\
\hline ARROZ (Kg) & S/ & 3.40 & S/ & 3.99 & S/ & 4.40 & S/ & 2.60 \\
\hline AZUCAR BLANCA (5Kg) & S/ & 15.50 & S/ & 16.50 & S/ & 17.50 & S/ & 11.90 \\
\hline LECHE (6 latas) & S/ & 17.49 & S/ & 17.99 & S/ & 19.20 & S/ & 18.00 \\
\hline ACEITE & S/ & 5.99 & S/ & 6.99 & S/ & 7.20 & S/ & 5.00 \\
\hline FIDEOS (bolsa de $1 / 2 \mathrm{Kg}$ ) & S/ & 2.30 & S/ & 2.79 & S/ & 3.10 & S/ & 2.10 \\
\hline POLLO & S/ & 7.20 & S/ & 7.69 & S/ & 7.99 & S/ & 6.00 \\
\hline CARNE (BISTEC Kg) & S/ & 25.00 & S/ & 28.59 & S/ & 30.50 & S/ & 14.00 \\
\hline PAPA ROSADA (Kg) & S/ & 3.99 & S/ & 4.69 & S/ & 4.79 & S/ & 1.80 \\
\hline TOMATES (Kg) & S/ & 3.49 & S/ & 3.99 & S/ & 4.49 & S/ & 2.50 \\
\hline LIMÓN (Kg) & S/ & 2.09 & S/ & 2.99 & S/ & 3.49 & S/ & 1.80 \\
\hline LENTEJAS (bolsa de $1 / 2 \mathrm{Kg}$ ) & S/ & 3.85 & S/ & 3.80 & S/ & 4.49 & S/ & 3.00 \\
\hline SHAMPOO (frasco de $400 \mathrm{ml}$ ) & S/ & 16.50 & $\mathrm{~S} /$ & 15.50 & S/ & 16.50 & S/ & 14.00 \\
\hline JABÓN DE TOCADOR (3 unidades 900g) & S/ & 7.20 & S/ & 7.20 & S/ & 7.99 & S/ & 5.00 \\
\hline PASTA DENTAL (2 cajas de $75 \mathrm{ml}$ ) & S/ & 12.90 & S/ & 12.90 & S/ & 13.55 & S/ & 7.00 \\
\hline FILETE DE TRUCHA (500 g) & S/ & 22.50 & S/ & 19.90 & S/ & 24.90 & S/ & 20.00 \\
\hline MANZANA DELICIA (Kg) & S/ & 3.89 & S/ & 3.69 & $\mathrm{~S} /$ & 4.59 & S/ & 3.00 \\
\hline TOTAL & s/ & 153.29 & S/ & 159.20 & & 174.68 & S/ & 17.70 \\
\hline VARIACIÓN & $-5 /$ & 35.59 & -5 & 41.50 & & 56.98 & s/ & - \\
\hline
\end{tabular}

Fuente: Tabla elaborada por los autores.

Tabla 8.6

Beneficio por ahorro en gasto de alimentos

\begin{tabular}{|r|r|rr|r|}
\hline \multicolumn{4}{|c|}{ AHORRO ECONÓMICO POR ADQUISICIÓN DE PRODUCTOS ALIMENTICIOS } \\
\hline $\begin{array}{c}\text { USUARIOS ATENDIDOS A } \\
\text { LA SEMANA (promedio) }\end{array}$ & $\begin{array}{c}\text { S/. AHORRADOS POR } \\
\text { PERSONA A LA SEMANA }\end{array}$ & $\begin{array}{c}\text { AHORRO ECONÓMICO } \\
\text { TOTAL SEMANAL }\end{array}$ & AHORRO ECONÓMICO AL AÑo \\
\hline $9,796.00$ & S/ $/ 35.59$ & S/ $348,639.64$ & S/ & $18,129,261.28$ \\
\hline
\end{tabular}

Fuente: Tabla elaborada por los autores.

\subsubsection{Atractivo cultural y turístico}

Hoy en día los mercados son considerados como vitrinas socioculturales que exhiben la cultura de un país, desde la aglomeración de productos frescos y platos típicos que se exponen de manera visual hacia los turistas, brindando una gama de texturas, colores y aromas únicos. Además, se reflejan las distinciones culturales de los mismos comerciantes que provienen de diferentes partes del Perú. 
Es así como los mercados se convierten en productos turísticos, atrayendo a turistas que buscan sentirse local y escapar de la homogeneidad, es precisamente por esa búsqueda lo que incita a los turistas a visitar los mercados, con la finalidad de conocer y aprender la idiosincrasia del lugar como los hábitos alimenticios, gustos, costumbres, y la manera de ofertar (García, 2017, p.169). Es por tales motivos que los turistas suelen gastar un promedio de $\$ 95$ diarios en su estadía en el Perú, de los cuales $\$ 35$ son utilizados para la alimentación (PROMPERÚ, 2017, p.22). Los ingresos totales del mercado por turismo al año serían de S/. 6006000.00 (ver tabla 8.7), pero no solo ellos se beneficiarían, sino también las galerías comerciales, restaurantes, la iglesia, la plaza San José, y la revalorización del valor por $\mathrm{m} 2$ de las viviendas aledañas.

Tabla 8.7

Beneficio por turismo

\begin{tabular}{|c|c|c|c|c|c|c|}
\hline \multicolumn{7}{|c|}{ INGRESOS POR GENERACIÓN DE TURISMO } \\
\hline $\begin{array}{l}\text { TURISTAS ATENDIDOS A } \\
\text { LA SEMANA (promedio) }\end{array}$ & $\begin{array}{l}\text { GAS } \\
\text { TURIS }\end{array}$ & $\begin{array}{l}10 \text { DE UN } \\
\text { ENTACIÓN }\end{array}$ & ING & $\begin{array}{l}\text { MANAL POR } \\
\text { ISMO }\end{array}$ & $\begin{array}{r}\text { ING } \\
T\end{array}$ & $\begin{array}{l}\text { TOTAL POR } \\
\text { MO AL AÑO }\end{array}$ \\
\hline $1,000.00$ & $\mathrm{~S} /$ & 115.50 & S/ & $115,500.00$ & S/ & $6,006,000.00$ \\
\hline
\end{tabular}

Fuente: Tabla elaborada por los autores.

\subsubsection{Generación de empleo}

El mercado por sí solo crea empleos directos necesarios para que funcione diariamente, como el personal de vigilancia, atención al cliente, la administración del mercado, las personas que atienden tanto en el tópico del mercado, como en el área de recojo de productos e-commerce, y especialmente los comerciantes y sus ayudantes, entre otros. Un total de 231 personas que laboran directamente en el mercado, multiplicado por un sueldo promedio de S/. 1 500, genera un ingreso anual de S/. 4158000.00 (ver tabla 8.8).

Tabla 8.8

Beneficio por generación de empleo

\begin{tabular}{|r|lr|lr|}
\hline \multicolumn{3}{|c|}{ GENERACIÓN DE EMPLEO } \\
\hline EMPLEOS DIRECTOS & \multicolumn{2}{|l|}{ SUELDO PROMEDIO } & \multicolumn{2}{|l|}{ INGRESOS ANUALES } \\
\hline 231.00 & S/ & $1,500.00$ & S/ & $4,158,000.00$ \\
\hline
\end{tabular}

Fuente: Tabla elaborada por los autores. 


\subsubsection{Generación de espacio público}

Otro beneficio social del mercado, pero no medible, es la generación de colectividad y ciudadanía a través del espacio público. El ser humano desde que nace es un ser social, que se desarrolla con el pasar de los años a través de la interacción con otras personas, mediante el proceso de socialización donde las personas adquieren hábitos y valores que ayudan a que formen su identidad (Yubero, 2005, p. 819).

Y el mercado de abasto como campo semántico posee dos dimensiones, primero es un lugar donde se realiza el intercambio comercial, y segundo, es un espacio de carácter público que cumple la función de estructuración de las relaciones sociales en un espacio urbano, pero este último se ha dejado de lado con el pasar de los años, y solo se lo ha reconocido como un equipamiento comercial (Robles, 2008, 2014). Cuando un espacio público está ausente en la ciudad, no se encuentra integrado socialmente, ni articulado física y simbólicamente, y la tolerancia como valor ciudadano se ven superados por la segregación y la exclusión (Borja, 2011, p. 39).

Es por tales motivos que el concepto del Mercado San José radica en un proyecto de recuperación del espacio público - comercial, para que las personas satisfagan sus necesidades psicológicas de contacto, de conocimiento, y de estímulo, a través de las interacciones sociales, formando una vida cotidiana colectiva y con valores.

\subsubsection{Ahorro económico total por beneficio social}

Se realizó un cuadro final con la sumatoria de los beneficios sociales que podría generar el proyecto del mercado (ver tabla 8.9). Estos beneficios serán a partir del tercer año, es decir una vez culminado la construcción, y nos ayudarán a justificar la utilización de los aires del pasaje Punta Pacochas ante la Municipalidad de Jesús María por todos los beneficios que trae el proyecto al distrito. 
Tabla 8.9

Ahorro por beneficio social

\begin{tabular}{|l|r|r|r|}
\hline \multicolumn{3}{|c|}{ AHORRO ECONÓMICO POR BENEFICIO SOCIAL } \\
\hline $\begin{array}{l}\text { AHORRO POR ADQUISICIÓN DE PRODUCTOS } \\
\text { ALIMENTICIOS }\end{array}$ & S/ & $18,129,261.28$ & ANUAL \\
\hline INGRESOS POR GENERACIÓN DE TURISMO & $\mathrm{S} /$ & $6,006,000.00$ & ANUAL \\
\hline GENERACIÓN DE EMPLEO & $\mathrm{S} /$ & $4,158,000.00$ & ANUAL \\
\hline
\end{tabular}

Fuente: Tabla elaborada por los autores.

\subsection{Vistas del proyecto}

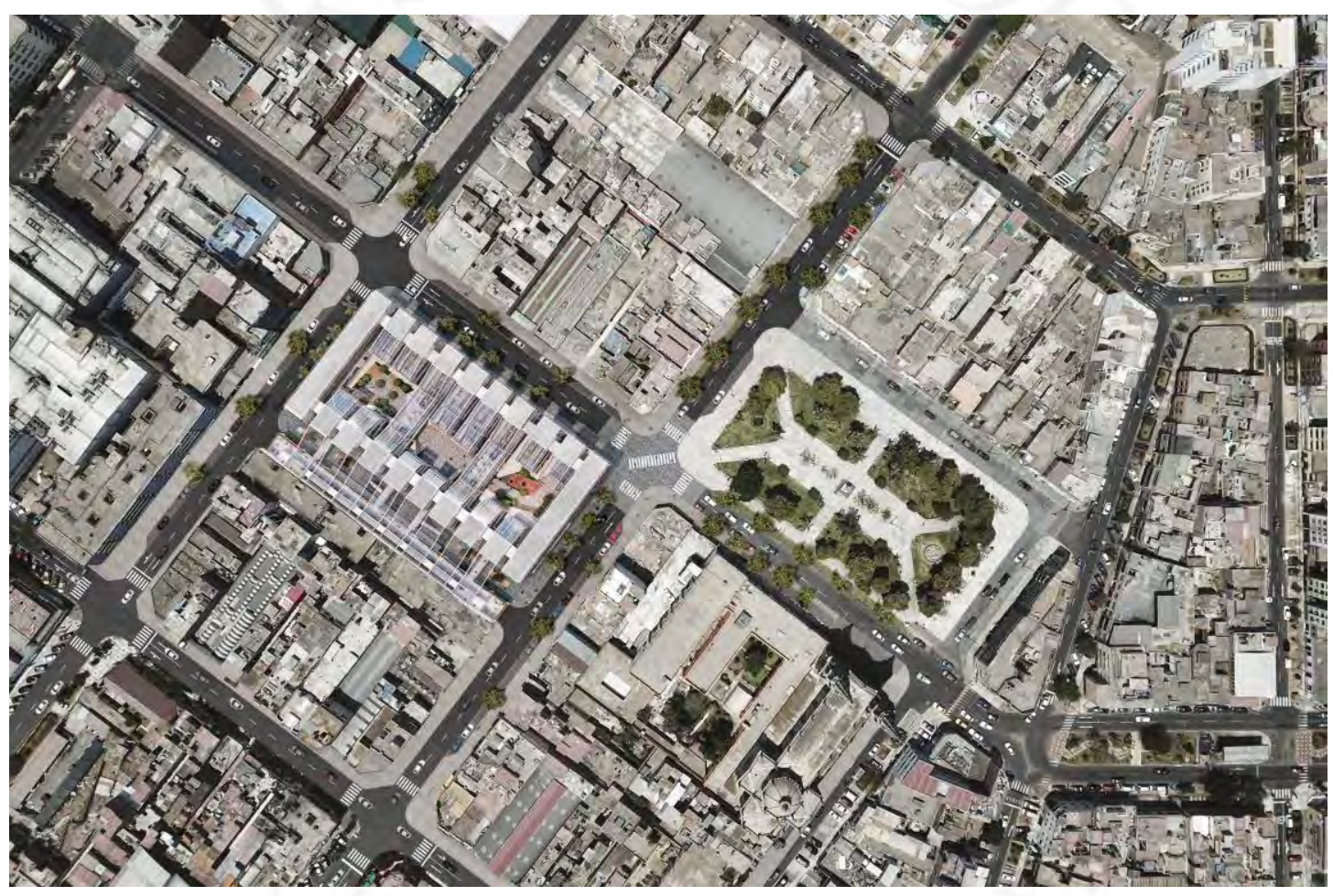

Figura 8.35 Vista aérea del proyecto

Gráfico elaborado por los autores. 


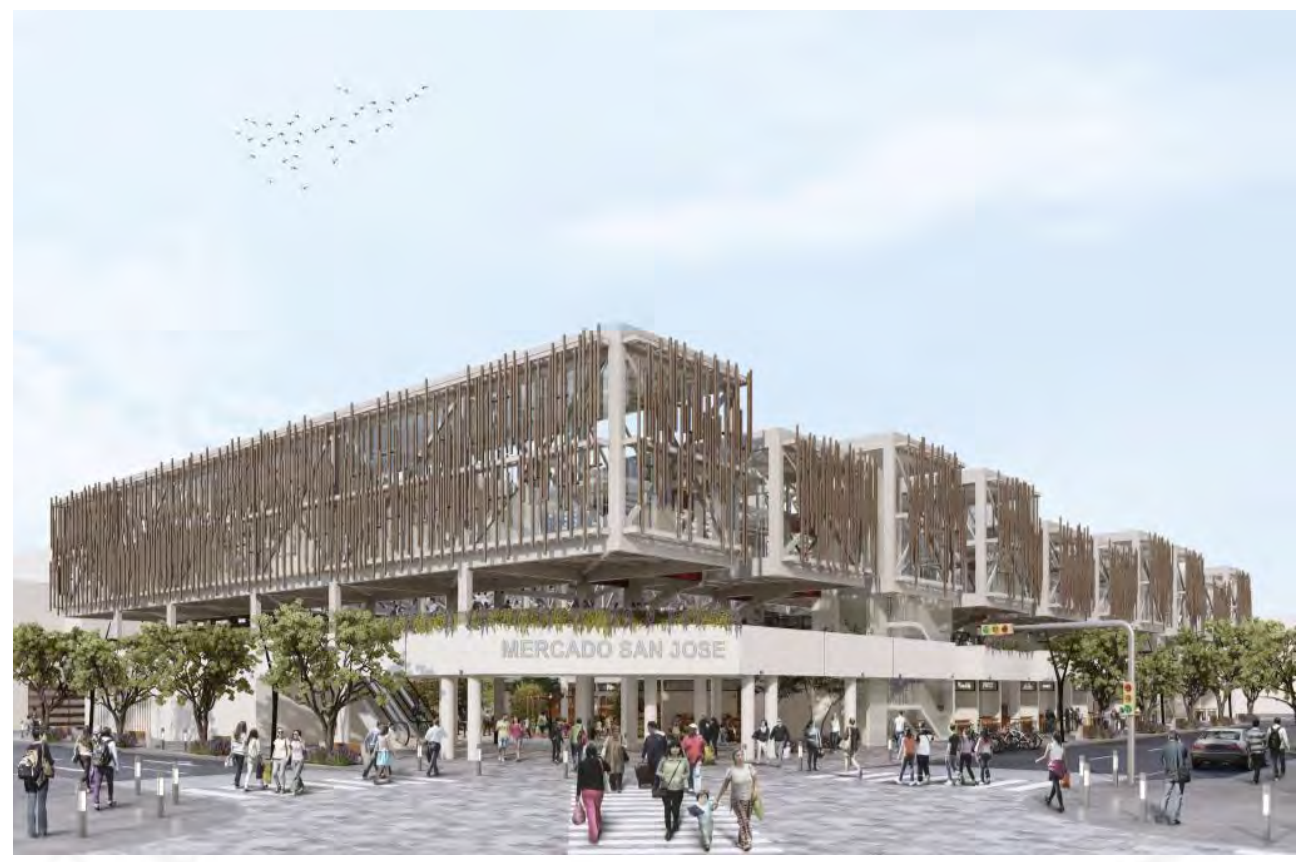

Figura 8.36 Vista exterior del proyecto

Vista elaborada por los autores.

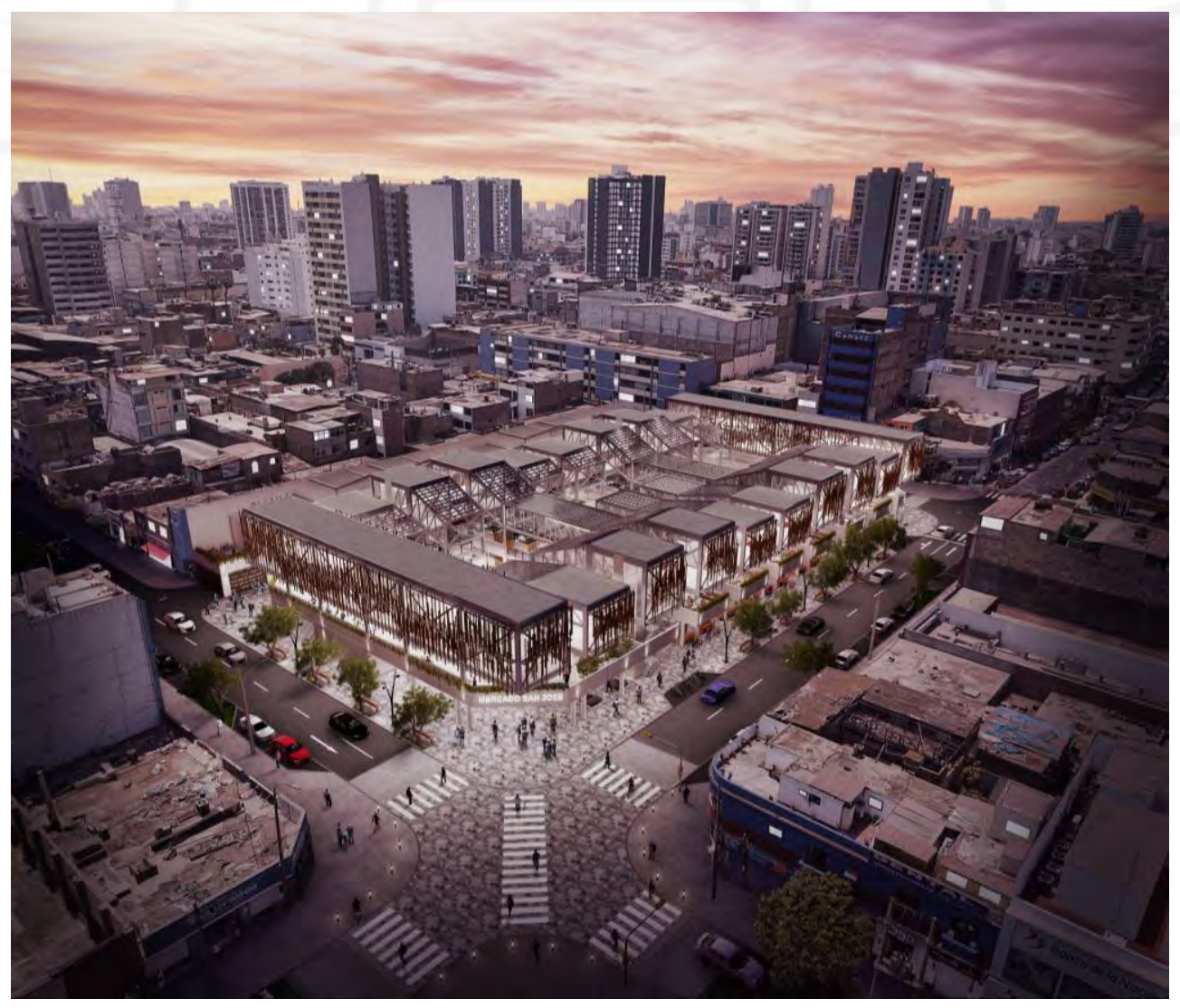

Figura 8.37 Vista exterior nocturna del proyecto

Vista elaborada por los autores. 


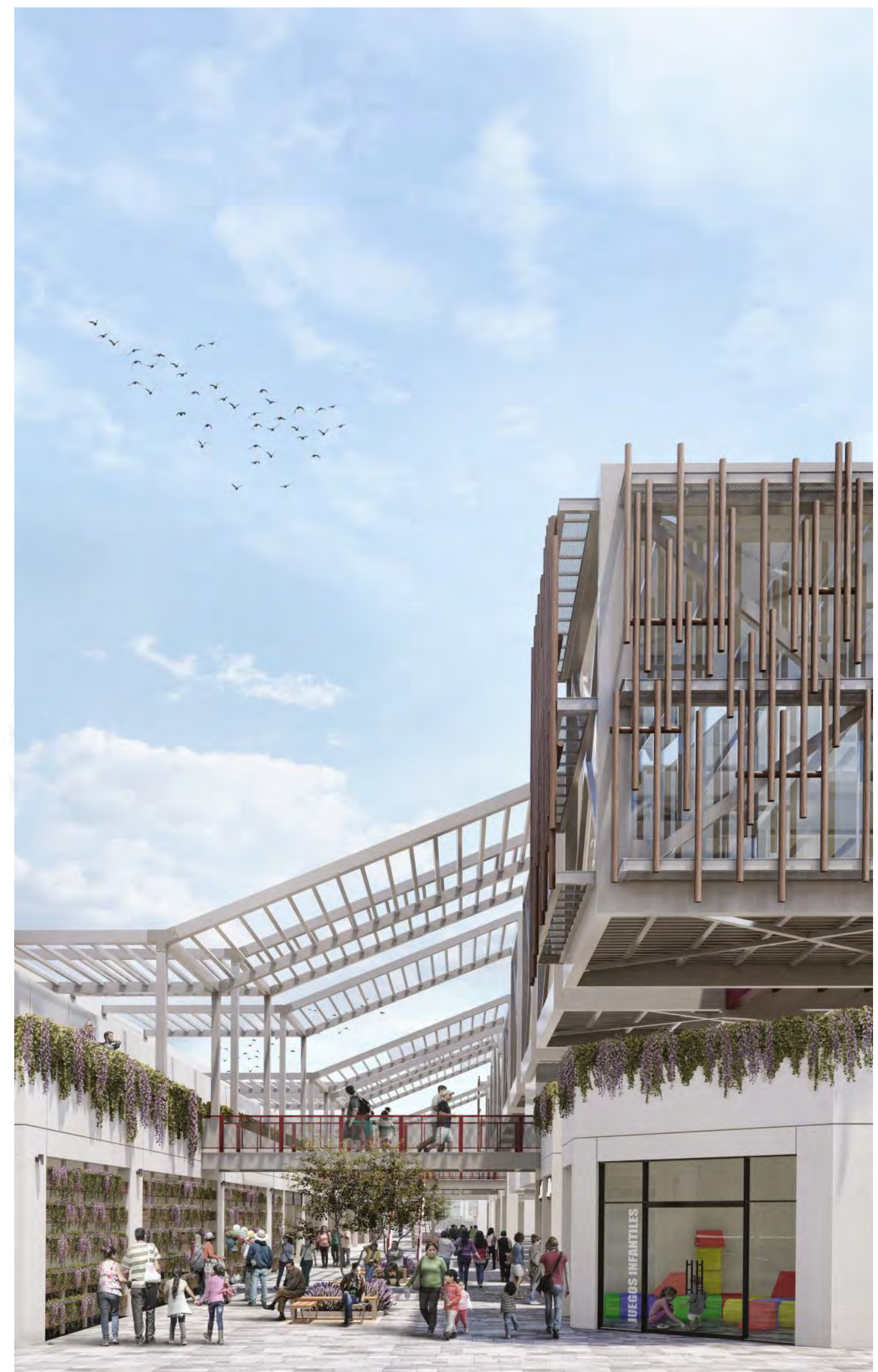

Figura 8.38 Vista hacia el pasaje Punta Pacochas

Vista realizada por los autores. 


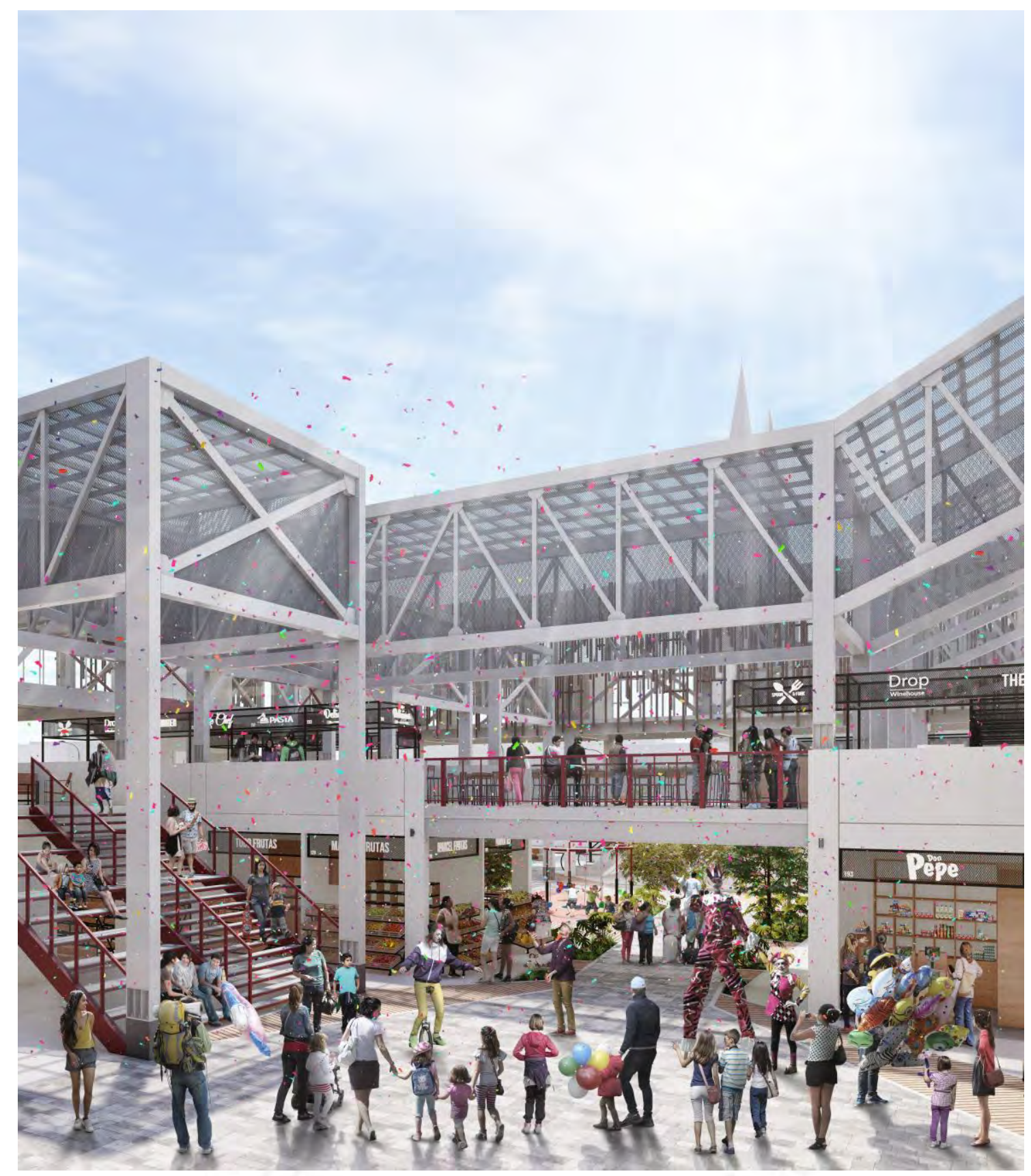

Figura 8.39 Vista interior del proyecto

Vista elaborada por los autores. 


\section{REFERENCIAS}

Acevedo, A., \& Llona, M. (2016). Cátalogo Arquitectura Movimiento Moderno del Perú. Obtenido de http://cammp.ulima.edu.pe/\#1

Acosta, L. L. (2018). Espacios públicos no tan públicos. Revista de Ciencia Política, Año 9, primer semestre, $N^{o} 16,75-109$.

Aime, M. (2002). La casa di nessuno. I mercati in Africa occidentale (Primera ed.). Turín: Bollati Borlinghieri.

Alonso, R., Estrada, M., \& Sartorius, A. (2007). Los Mercados Minoristas como Motor para el Desarrollo Económico, Social y Cultural de una Ciudad. Nueva York: Unidad de Diseño del BID.

Apega. (2013). El Boom Gastronómico Peruano al 2013. Lima: Oxfam.

Apega. (15 de Setiembre de 2016). Mistura 2016: Conoce las cifras que dejó la feria. Obtenido de Mistura: http://mistura.pe/mistura-2016-conoce-las-cifras-que-dejo-la-feria/

Aranguren, L. M. (2009). Entrevista personal.

ArcelorMittal Europe. (2013). Puestos de venta resistentes a la corrosión fabricados con acero de ArcelorMittal: Mercat dels Encants Vells en Barcelona. Recuperado el 16 de Setiembre de 2018, de Caso práctico: Mercat dels Encants Vells: http://constructalia.arcelormittal.com/es/casos_practicos/espana/mercat_dels_encants_v ells_barcelona

Arellano Marketing. (21 de Junio de 2017). Estudio Nacional del Consumidor Peruano. Obtenido de Arellano: https://www.arellano.pe/estilos-de-vida/

Ayuntamiento de Madrid. (2003). Ordenanzza de Comercio Minorista de la Alimentación. Madrid.

Ayuntamiento de Madrid. (2010). Ordenanda de Mercados de Distrito. Madrid.

Baquero, D. (2011). Las palzas de mercado como catalizadores urbanos. Tesis de maestría, Universidad Nacional de Colombia, Bogotá.

Bently, I. B., Alcock, A., Murrain, P., McGlynn, S. M., \& Smith, G. (1985). Responsive environments. A manual for designers. Oxford: Elsevier. 
BiS Arquitectos. (09 de Junio de 2017). Centro Cultural El Tranque / BiS Arquitectos. Obtenido de ArchDaily Perú: https://www.archdaily.pe/pe/873310/centro-cultural-el-tranque-bisarquitectos

Bonnef, M. (16 de Agosto de 2015). Mercado de Abasto Tirso de Molina / Pérgola de las Flores. Recuperado el 21 de Mayo de 2017, de Comportamientos Aparentes: https://comportamientosaparentes.wordpress.com/2015/08/16/mercado-de-abasto-tirsode-molina-pergola-de-las-flores/

Borja, J. (2000). Espacio publico, ciudad y ciudadania. Barcelona.

Borja, J. (2012). Revolución urbana y derechos ciudadanos: Claves para interpretar las contradicciones de la ciudad actual. Barcelona.

Bramwell B, R. L. (1996). Tourism Marketing Images of Industrial Cities. Annals of Tourism Research, 23(1), 201-221.

Cabrera Neyra, M. (1979). Estudio de los Mercados Minoristas Tradicionales en los distritos de Pueblo Libre, San Miguel, Magdalena, Jesús María y Lince. Tesis de título, Pontificia Universidad Católica del Perú, Agronomía. Recuperado el 2017 de Abril de 20

Carmona, M., Magalhães, C. d., \& Hammond, L. (2008). Public Space. The managment of dimension. New York: Routledge.

Casares Ripol, J. (Mayo-Junio de 2003). Los mercados municipales y el futuro de las ciudades. Distribucion y Consumo, 34-37.

Castillo, J., Huamaní, L., \& Vilchez, G. (2009). Con un pie adentro y otro afuera: Los callejones en el Rímac. Pontificia Universidad Católica del Perú, Lima.

Centeno, P. V. (2006). El Espacio Publico. La movilidad y la revaloracion de la ciudad. Cuadernos arquitectura y ciudad (número 3), 1-75.

Coello Rodríguez, A. (2014). Unas notas sobre el antiguo Mercado de la Concepción, hoy Mercado Central de Lima. Arqueología y Sociedad(28), 367-378.

Coleman, P. (2014). Shopping Environments: Evolution, Planning and Design. Oxford: Architectural Press.

Consultora CCR. (2014). ¿Qué lleva hoy, Caserita? Lima.

Corbusier, L. (1977). Hacia una nueva arquitectura. Barcelona: Poseidon. 
Costales Calvo, I. (18 de Diciembre de 2014). Encants Barcelona: nueva plaza comercial y aparcamiento en Barcelona. (A. d. d'Estructures, Ed.) Quaderns d'Estructures(51), 5-11. Obtenido de https://upcommons.upc.edu/handle/2117/86003

Crespi, M., \& Domínguez, M. (Abril de 2016). Los mercados de abastos y las ciudades turisticas. Pasos. Revista de turismo y patrimonio cultural, Vol. $14 N^{\circ} 2 .$, 401-416.

Crousse, V. (2011). configuración del paisaje, espacio público y arte público en el perú. Barcelona.

De Padua, A., Dutra, I., Teixeira, J., Machado, B., \& Tijoux, M. (2012). Metamorfoseando los mercados centrales: El turismo gastronómico como estrategia en el Mercado Central de Santiago y el Mercado Municipal de Sao Paulo. Estudios y perspectivas en turismo, 12, 88-107.

De Soto, H. (1986). El Otro Sendero, La Revolución Informal. Lima: El Barranco.

De Terán, F. (1997). La Ciudad Hispanoamericana. El Sueño de un orden. Madrid: Centro de Estudios Históricos de Obras Públicas y Urbanismo.

Del Águila, A. (1995). Callejones y mansiones o la reconstrucción de los espacios públicos en Lima (1895-1919). Estudios Sociológicos XIII(39), 545-571.

Diez De Castro, E., Landa Bercebal, F., \& Navarro García, A. (2006). Merchandising: Teoría y práctica. Madrid: Piramide.

El comercio. (18 de Mayo de 2011). Jesús María: reabren mercado de San José tras llegar a un acuerdo. $\quad$ Cl Omercio. Obtenido de http://archivo.elcomercio.pe/amp/sociedad/lima/jesus-maria-reabren-mercado-san-joseacuerdo-comerciantes-noticia-759560

Elguera Chumpitazi, H. (2017). El impacto de la imagen visual en el comportamiento de compra por impulso: un modelo comercial. CIC: 3er boletín del Centro de Investigación de la Creatividad UCAL, 1, 17-28.

Ergun, B. (2010). Evolution of shopping malls: recent trends and the question for regeneration. Cancaya: Universidad de Cancaya.

Espil, E. G. (2003). Hacer ciudad. La construccion de la metropolis.

Fernández Salas, J. (2012). El Derecho de Superficie. Themis - Revista de Derecho(62), 237- 253.

Filgueiras, B. (2006). Do mercado popular ao espaço de vitalidade: o Mercado Central de Belo. Tesis de Maestría, Universida de Federal do Rio de Janeiro, Planificación Urbana y Regional, Rio de Janeiro. Obtenido de 
http://webcache.googleusercontent.com/search?q=cache:9cQAOercNuAJ:www.urbano. org.

Forqués, N. (21 de Fabrero de 2006). La flexibilidad en la arquitectura. Obtenido de Mito: Revista Cultural: http://revistamito.com/la-flexibilidad-en-la-arquitectura/

Fuentes Carrasco, M. (2005). Aproximación a la Nueva Babilonia de Constant. Boetica: Estudios de Arte, Geografia e Historia(27), 41-60.

Galofaro, L. (2004). El arte como aproximacion al paisaje contemporaneo. Barcelona: Gustavo Gili.

Gámez, F. C. (Abril- Setiembre de 2014). Fronteras difusas. Arquitectura, ciudad arte y paisaje. Sinapsis Social. Revista cientifica de sostenibilidad, 1(1).

García Calderón, L. (s.f.). El Mercado de barrio hace ciudad. Recuperado el 23 de Abril de 2017, de www.urbano.org.pe/.../El\%20Mercado\%20de\%20barrio\%20hace\%20ciudad

García Martínez, I. (2013). El límite difuso: Tectónica del límite en Toyo Ito 1971-2001. Madrid: Universidad Politécnica de Madrid.

García, B. (2017). Los mercados de abastos y su comercialización como producto de turismo de expreciencias: El caso de Madrid. Cuadernos de turismo(39), 167-189.

Garcia, J. H. (2012). Turismo, marca de ciudad y barrios populares. Turismo y sociedad, 13, 8597.

Garrido, J. L. (2011). Perfil del consumidor y tendencias del mercado. Universidad de Piura, Escuela de Dirección, Lima.

Gausa, M., Guallart, V., Muller, W., Soriano, F., Porras, F., \& Morales, J. (2001). Diccionario Metapolis de Arquitectura Avanzada. Actar.

Gehl, J. (1971). La humanizacion del espacio público. Barcelona: Reverté.

Gehl, J. (2006). La humanizacion del espacio público. Barcelona: Reverté S.A.

Gehl, J., \& Gemzøe, L. (2000). New City Spaces. Copenhagen: The Danish.

Gestión. (30 de Julio de 2013). Mercado San José de Jesús María sería centro comercial. Gestión, pág. parrafo 12. Obtenido de https://gestion.pe/impresa/mercado-san-jose-jesus-mariaseria-centro-comercial-44295

Gobierno de Chile. (2015). Construcción Plaza de Abastos y Pérgolas de las Flores. Ministerio de Obras Públicas, Dirección de Arquitectura, Santiago. Obtenido de 
http://www.disenoarquitectura.cl/pergola-de-las-flores-y-mercado-tirso-de-molina-deiglesis-prat-arqtos/

Gomes Teixeira, A. K., de Azevedo Barbosa, M. d., \& Gomes de Souza, A. ( 2013). El sistema de oferta de restaurantes de alta gastronomia. Una perspectiva sensorial de las experiencias de consumo. (C. d. Turísticos, Ed.) Estudios y Perspectivas en Turismo, 22(2), 336-356.

Gómez Wilkinson, J. (2016). La historia y los orígenes de los Encants Barcelona. Recuperado el 12 de enero de 2019, de Encants Barcelona: http://encantsben.com/es/Historia

Gomis, A. (1992). Historia de la ciencia y de la técnica. Madrid: Akal S.A.

Gonçalves Silveira, F. E., \& Barretto, M. (2010). Tuismo de Transformacion. Ecoturismo en reservas de la biosfera dentro del marco de la economía de la experiencia. Estudios y Perspectivas en Turismo, 19, 315 -329.

Gonzáles-Prada, E. (04 de Mayo de 2018). Oficinas: Jesús María y Lince más rentables. Binswanger Perú. Obtenido de https://binswanger.com.pe/oficinas--jesus-maria-y-lincemas-rentables

Grupo El Comercio. (31 de Julio de 2014). Cinco distritos concentran el $40 \%$ del total de mercados de abastos en Lima. (E. C. S.A., Ed.) Gestión. Recuperado el 28 de Julio de 2018, de https://gestion.pe/economia/empresas/cinco-distritos-concentran-40-totalmercados-abastos-lima-66976

GrupoRPP. (18 de Mayo de 2011). Capital . Obtenido de Tu opinion importa : http://www.capital.com.pe/actualidad/cierran-mercado-san-jose-de-jesus-maria-noticia366539

Guardia Bassols, M. (25 de Agosto de 2007). Los mercados públicos en la ciudad contemporánea: El caso de Barcelona.

Gutiérrez, R. (1997). La Cludad Hispanoamericana. El Sueño de un Orden. Madrid: Ministerio de Fomento.

Harvey, D. (1996). From Space to Place and Back Again: Justice, Nature and the Geography of Difference. Oxford: Blackwell.

Hernández, J. M. (2004). Historia de las formas urbanas medievales. Sevilla: GG.

Herzog, J. (2002). La Naturaleza del Artificio: Una conversación con Jacques Herzog. El Croquis(109/110), 16-31.

Herzog, J. (2006). Ornamento, Estructura, Espacio. Croquis(129-130), 22-39. 
Herzog, J., \& De Meuron, P. (2002). Herzog \& De Meuron:Natural History. (P. Ursprung, Ed.) Montréal: Lars Muller Publishers.

Huamán, G. (2015). Complejo de abastos en el distrito de Lince. Tesis de grado, Universidad San Martín de Porres, Facultad de Ingeniería y Arquitectura, Lima.

Ibaceta, C. G. (2015). ACCIONES Y ELEMENTOS PRIMITIVOS DE LA ARQUITECTURA ORIGINARIA. Chile.

INEI. (2008). Censo Nacional Economico 2008. ESTABLECIMIENTOS CENSADOS POR ACTIVIDAD ECONÓMICA, SEGÚN ÁMBITO POLÍTICO ADMINISTRATIVO, 2008, INEI, Lima, Lima. Obtenido de http://censos.inei.gob.pe/cenec2008/tabulados/\#

INEI. (13 de Junio de 2017). Al año 2016 a nivel nacional existen 2 mil 612 mercados de abastos.

Obtenido de Instituto Nacional de Estadística e Informática: https://www.inei.gob.pe/prensa/noticias/al-ano-2016-a-nivel-nacional-existen-2-mil612-mercados-de-abastos-9794/

Instituto Metropolitano de Planificación. (2014). Plam Lima y Callao 2035 (Vol. Memoria de Ordenamiento ). Lima: Instituto Metropolitano de Planificación.

Instituto Nacional de Defensa Civil. (2018). Acerca de INDECI. Recuperado el 04 de Agosto de 2018, de Instituto Nacional de Defensa Civil: https://www.indeci.gob.pe/contenido.php?item=MQ==

Instituto Nacional de Estadística e Informática. (2016). Encuesta Nacional de Hogares . Lima.

Instituto Nacional de Estadística e Informática. (2017). Censo Nacional de Mercados de Abastos. Lima.

Instituto Nacional de Estadística e Informática. (2017). Provincia de Lima: Compedio Estadístico 2017. Lima.

Iñiguez, D. (31 de Diciembre de 2015). El espacio público en Les Halles de París a través de los siglos. Obtenido de Medium Corporation: https://medium.com/@Daniel_ij/el-espaciop\%C3\%BAblico-en-les-halles-en-par\%C3\%ADs-una-convicci\%C3\%B3n-a-pesar-delos-siglos-ec3991403b74

Ito, T. (2000). Escritos. Murcia: Colegio Oficial de Aparejadores y Arquitectos Técnicos.

Jacobs, J. (2011). Muerte y vida de las grandes ciudades . Madrid: Capitán Swing .

Joffre, G. R. (2004). El Guión de la Cirugía Urbana: Lima 1850-1940. Universidad Nacional Mayor de San Marcos, Ciencias Sociales, Lima. 
Junge, J. (20 de Junio de 2014). Pérgola de las Flores y Mercado Tirso de Molina. (D. I. Carter, Editor) Recuperado el 21 de Mayo de 2017, de D+A Diseño y Arquitectura: http://www.disenoarquitectura.cl/pergola-de-las-flores-y-mercado-tirso-de-molina/

Junta de Andalucía. (2006). Plan de Modernización de los Mercados Municipales de Andalucía. Kadmos.

Kahatt, S. (2014). Cinco siglos de orden y caos. Breve recuento de crecimiento y transformación socio-espacial. Rita: Revista Indexada de Textos Académicos(2), 38-43.

Kidder Smith, G. E. (1990). Looking at Architecture. Nueva York: Harry N Abrams Inc.

Kipnis, J. (1997). La Astucia de la Cosmética: Una reflexión personal sobre la arquitectura de Herzog \& de Meuron. El Croquis(84), 22-28.

La Rosa, M. (2014). Las Transformaciones de los espacios públicos ocurridas dentro de los contextos del neoliberalismo y la inseguridad ciudadanda: Caso del distrito de Jesús María. Tesis de título, Pontificia Universidad Católica del Perú, Geografía y Medio Ambiente, Lima.

Leung, J. (2016). Abastecer o ser abastecido: La influencia de los mercados tradicionales sobre el tejido urbano de Lima. Tesis de maestría, DUOT, Urbanismo.

López Fontanals, M. (1 de Octubre de 2014). Rotterdam inaugura el markthal, el primer mercado cubierto de holanda. Obtenido de EFE News Service: http://fresno.ulima.edu.pe/ss_bd00102.nsf/RecursoReferido?OpenForm\&id=PROQUE ST-41716\&url=/docview/1566590364?accountid=45277

Ludeña, W. (2006). Lima y la globalización, Una expansión urbana difusa. Identidades: Reflexión,Arte y Cultura $N^{o} 100$.

Lynch, K. (1984). La imagen de la ciudad. Barcelona: Gustavo Gili.

Mantey, D., \& Kepkowicz, A. (2018). Types of Public Spaces: The Polish Contribution to the Discussion. Taylor \& Francis Group, LLC.

Mark, L. (3 de Octubre de 2014). MVRDV completa la sala del mercado de Rotterdam. Obtenido de The Architects Journal: http://fresno.ulima.edu.pe/ss_bd00102.nsf/RecursoReferido?OpenForm\&id=PROQUE ST-41716\&url=/docview/1571609683?accountid $=45277$

Martinez Ballester, M., \& García Vicente, J. (2009). Historia del supermercado. Universidad de Alicante. Alicante: Close City - Wordpress. Recuperado el 05 de 11 de 2017, de https://closecity.files.wordpress.com/2009/11/historia4.pdf 
Martínez Palacios, E. (2014). El diseño del suelo: Plaza del Poeta Boscá y la PLaza de La Font. Universitat de Barcelona, Barcelona.

Medina Luque, F. X. (2013). Mercados y espacio público:transformación y renegociación de nuevas demandas urbanas. Analisis comparativo de casos (Barcelona, Budapest y Buenos Aires). Universidad Oberta de Catalunya, Barcelona.

Medina, X. (2014). Mercados y espacio público: transformación y renegociación de nuevas demandas urbanas. Zainak(36), 183-200.

Medina, X., \& Álvarez, M. (2007). El lugar por donde pasa la vida... los mercados y las demandas urbanas contemporáneas: Barcelona y Buenos Aires. Revista d'Etnologia de Catalunya, 183-201.

Meignen, F. (2010). Procesos graduales de ocupación del mercado en el espacio público. Tesis de título, Universidad Simón Bolívar, Caracas.

Mercasa. (2012). Mercado de San Pedro en Cuzco. Salamanca.

MiAS Architects. (2011). Barceloneta Market and Square. Obtenido de MiAS Architects: http://www.miasarquitectes.com/portfolio/barceloneta-market/

Miles, P. (18 de Setiembre de 2015). ¿Será el markthal de Rotterdam equivalente al guggenheim de bilbao? Obtenido de FT.Com: http://fresno.ulima.edu.pe/ss_bd00102.nsf/RecursoReferido?OpenForm\&id=PROQUE ST-41716\&url=/docview/1722783971?accountid $=45277$

Ministerio de Comercio Exterior y Turismo. (8 de Agosto de 2016). Iglesia San José. Obtenido de Ficha de recopilación de datos para informacion del inventario de recursos turísticos: https://www.mincetur.gob.pe/turismo/directorios-manuales/inventario-de-recursosturisticos/

Ministerio de la Producción. (2017). Normativa de Mercados de Abastos. Lima.

Ministerio de la Producción. (2018). Acerca del Ministerio. Recuperado el 04 de Agosto de 2018, de Ministerio de la Producción: https://www.produce.gob.pe/index.php/ministerio/acerca-de

Ministerio de Salud . (2003). Reglamento Sanitario de Funcionamiento de Mercados de Abasto. Lima.

Ministerio de Salud. (2018). ¿Qué hacemos? Recuperado el 04 de Agosto de 2018, de Ministerio de Salud: https://www.gob.pe/739-ministerio-de-salud-que-hacemos

Miquel, S. (2008). Distribución comercial (6ta ed.). España: ESIC. 
Miralles, E. (2006). EMBT MIRALLES-TAGLIABUE. Universidad de Navarra, Escuela Técnica Superior de Arquitectura. Navarra: T6 ediciones .

Montaner, J. M. (2008). Sistemas arquitectonicos contemporaneos. Barcelona: Gustavo Gili.

Moussavi, F., \& Cubo, M. (2008). La Función del Ornamento. Barcelona: Actar.

Munari, B. (1983). Diseño y comunicación visual. Barcelona: Gustavo Gili.

Municipalidad de Jesús María. (2013). Plan de Desarrollo Económico Local de Jesús María 2013-2025. Lima.

Municipalidad de Jesús María. (2016). Plan de Desarrollo Concentrado Distrital 2015-2021 de Jesús María. Lima.

Municipalidad de Lima. (2013). Guía para la competitividad de mercados de abasto. Lima: Impresión Arte Perú E.I.R.L.

Municipalidad de San Borja. (2003). Unidad de Educación, Cultura y Turismo. Obtenido de http://www.munisanborja.gob.pe/cultura/

Muñoz, O., Reano, J., \& Reyes, C. (2007). Mercado San José de Jesús María. Pontificia Universidad Católica del Perú, Especialidad de Antropología, Lima.

MVRDV. (2003). Redefiniendo las herramientas de la radicalidad. Madrid: El Croquis.

Negro, S. (2009). La plaza mayor de Lima. En VV.AA., La plaza mayor de Las Palmas de (pág. 357). Las Palmas de Gran Canaria.

Neufert, E. (2016). Educación investigación. En E. Neufert, Arte de proyectar en arquitectura.

Nieuwenhuys, C. (2009). La Nueva Babilonia. Barcelona: Gustavo Gili.

Noguera, J. (2011). MODELO BARCELONA: Diseño urbano y espacio público: La peatonalización alrededor de los mercados municipales del siglo XIX. Tesis de maestría, Universidad de Barcelona, Barcelona.

Norberg Schulz, C. (2005). Los principios de la arquitectura moderna: sobre la nueva tradición del siglo XX. Barcelona : Reverté.

Norwich, J. (1984). The World Atlas of Architecture. Londres: Mitchell Beazley.

O'NEIL, D. (30 de Septiembre de 2005). Project for public spaces. Recuperado el 23 de Diciembre de 2018, de Diez cualidades para hacer mercados publicos exitosos: https://www.pps.org/article/tencharacteristics-2 
Orrego, J. L. (01 de Febrero de 2010). El distrito de Jesús María. Recuperado el 08 de Julio de 20118, de Pontificia Universidad Católica del Perú: http://blog.pucp.edu.pe/blog/juanluisorrego/2010/02/01/el-distrito-de-jesus-maria/

Pixel Publishing. (11 de Mayo de 2005). Cubiertas Inclinadas. Constructiva(5), 58-61.

Plazola, A. (2001). Enciclopedia de Arquitectura (Vol. 7). México D.F: Plazola Editores.

Polanyi, K., Arensberg, C., \& Pearson, H. (s.f.). The and Market in the Early Empires. Glencoe, Illinois: The free press.

Portabella, J. (2006). Salutació. Barcelona.

Project for Public Spaces. (28 de Febrero de 2010). Project for Public Spaces. Recuperado el 23 de Diciembre de 2018, de Los beneficios transformadores de los mercados públicos: https://www.pps.org/article/the-benefits-of-public-markets

PROMPERÚ. (2017). Perfil del Turista Extranjero 2016. Lima: Comisión de Promoción del Perú.

Pulido-Fernández, J. I.-F., \& Navarro Hermoso, Ú. (2014). Identificacion de items para medir las experiencias. Cultur. Revista de cultura y turismo(1).

Real Academia Española. (07 de 01 de 2019). Real Academia Española. Obtenido de http://dle.rae.es/?id=De2S7ue

Reaño, J., Reyes, C., \& Muñoz, V. (2007). Mercado "San José" de Jesús María. Monografía, Pontificia Universidad Católica del Perú, Antropología económica, Lima.

Regal, A. (1967). Castilla Constructor: Las obras de ingeniería de Castilla. Lima: Banco de Crédito del Perú.

Regalado, O., Fuentes, C., Aguirre, G., García, N., Román, M., \& Vallejo, R. (2009). Factores críticos de éxito en los centros comerciales. Lima: Editorial Cordillera S. A. C.

Reglamento Nacional de Edificaciones. (2016). Reglamento Nacional de Edificaciones. Lima: Fondo Editorial ICG.

Rieunier, S., \& Daucé, B. (2002). Marketing sensorial en puntos de venta. Investigación y Aplicaciones en Marketing, 17(n 4), 46-65.

Rivarola Cores, A. (2015). Nuevo Mercado para el distrito de Magdalena del Mar. Tesis, Universidad Peruana de Ciencias Aplicadas, Lima.

Robles, J. I. (2008). Mercados, vidas y barrios: mercados municipales en espacios metropolitanos. Comercio urbano en espacios metropolitanos, 19-31. 
Robles, J. I. (2014). Mercados municipales y tecnologías digitales: Entre el e-comercio y nuevas formas de convivialidad. Anthropologica(33), 137-161.

Rodríguez, S. (2014). La transformación de los mercados municipales de Madrid: Análisis legislativo, comercial y económico de los mercados de abastos madrileños. Universidad Politécnica de Madrid, Departamento de Urbanística y Ordenación del Territorio, Madrid.

Rogers Stirk Harbour + Partners. (06 de Setiembre de 2018). The Leadenhall Building. Obtenido de https://www.rsh-p.com/projects/the-leadenhall-building/

Rojas, L. A. (2011). Mercados y mercaderes: Hacia una antropologia de las prácticas económicas. Lima.

Rosales Meana, D. I. (2013). La música y los límites del mundo. Un estudio desde Eugenio Trías y Agustín de Hipona. Anales del Seminario de Historia de la Filosofía, 30(1), 27-47.

Rosas, L. (18 de Mayo de 2011). Cierran mercado San José de Jesús María por incumplir normas de seguridad. Andina Agencia Peruana de Noticias. Obtenido de https://andina.pe/agencia/noticia.aspx?id=359064

Rossi, C., \& Aschner, J. P. (2015). Pérgolas de las Flores y Mercado Tirso de Molina. (U. d. Andes, Ed.) DEARQ(17), 200-216.

Rubert de Ventós, M. (2014). La Ciudad no es una hoja en blanco. Barcelona: Laboratori dÚrbanisme.

Rubert, M. (06 de 02 de 2004). El mejor mercado es una plaza. El Periódico de Catalunya. $\begin{array}{lllllll}\text { Recuperado el } & 10 \text { de } & 05 \text { de }\end{array}$ http://mariarubertarquitecta.blogspot.pe/p/articles.html

Ruiz, N. (2013). En los limites de la arquitectura. Espacio, sistema y disciplina. Tesis doctoral, Universidad Politécnica de Cataluña, Departamento de Expresión Gráfica Arquitectónica, Barcelona.

Sebastian, A. R. (2014). Análisis de la transformación de los mercados de Abastos Madrileños. Universidad Politécnica de Madrid, Madrid.

Siena, D. D. (30 de Marzo de 2011). Espacio público como lugar de construcción de ciudadanía. Obtenido de http://urbanohumano.org/blog/2011/03/30/espacio-publico-como-lugar-deconstruccion-de-ciudadania/

Simone, R. L. (2009). Arquitectura como producto cultural de consumo. Produccion arquitectonica en el post-capitalismo y su relacion con construccion de identidad. Chile. 
Solnick, J., Kannenberg, C., Eckerman, D., \& Waller, M. (1980). An Experimental Analysis of Impulsivity and Impulse Control in Humans. Learning and Motivation(11), 61-77.

Soriano, W. E. (2005). Las lenguas nativas del altiplano peruano-boliviano en el siglo XVI. Lima

Takano, G., \& Tokeshi, J. (2007). Espacio público en la ciudad popular: reflexiones y experiencias desde el Sur. Lima: Desco.

Taylor, J. (2001). Authenticity and sincerity in tourism. Annals of Tourism Research, 7-26.

The Leadenhall Building Development Company. (06 de Setiembre de 2018). The Building's spaces. Obtenido de The Leadenhall Building : https://www.theleadenhallbuilding.com/architecture/spaces/

Tonnelat, S. (2010). The Sociology of Urban Public Spaces. París: Atlantis Press.

Torres, F. (2009). Forman red de 33 mercados que modernizarán locales. El Comercio. Recuperado el 23 de Abril de 2017, de http://elcomercio.pe/lima/300464/noticia-formanred-33-

Trigoso López, M. (31 de 07 de 2014). Gestión: Diario de economía y negocios de Perú. Recuperado el 20 de 05 de 2017, de http://gestion.pe/empresas/cinco-distritosconcentran-40-total-mercados-lima-2104364

Universidad Nacional de Ingeniería. (1994). Inventario del patrimonio monumental inmueble de la ciudad de Lima. Lima.

Urbania. (2019). Oficinas en Lima_ Reporte de mercado. Estudio de mercado, Grupo El Comercio, Lima. Obtenido de https://urbania.pe/indice_m2/oficinas/\#1504733372940b0955479-0d6c

V \& V Grupo inmobiliario. (22 de Octubre de 2018). El nuevo centro empresarial de Lima está en Jesús María. Obtenido de VyV Grupo Inmobiliario: https:/vyv.pe/venta-de-oficinaslima/nuevo-centro-empresarial-lima-esta-jesus-maria-compra-una-oficina-ahora/

Valero, D. (2011). Reorganización de la plaza tres gracias (Caracas-Venezuela). Revista Geográfica de América Central, 2, 1-15.

Van Eyck, A. (1962). Architectural Design 12 (Vol. XXXII).

Verdu. (2001). La sociedad americana: ¿sociedad del futuro?

Wigley, M. (1998). Constant's New Babylon: The Hyper-architecture of Desire. Rotterdam: Witte de With CfCA. 
World Travel Adwards. (10 de Diciembre de 2017). World's Leading Culinary Destination 2017. Recuperado el 28 de Julio de 2018, de World Travel Adwards: https://www.worldtravelawards.com/award-worlds-leading-culinary-destination-2017

Wright, F. L. (1971). The natural house. Londres.

Yubero, S. (2005). Socialización y Aprendizaje social. En D. Páez, I. Fernández, S. Ubillos, \& E. Zubieta, Psicología social, cultura y educación (págs. 819-844). Madrid: Pearson. 


\section{BIBLIOGRAFÍA}

Acevedo, A., \& Llona, M. (2016). Cátalogo Arquitectura Movimiento Moderno del Perú. Obtenido de http://cammp.ulima.edu.pe/\#1

Acosta, L. L. (2018). Espacios públicos no tan públicos. Revista de Ciencia Política, Año 9, primer semestre, $N^{o} 16,75-109$.

Aime, M. (2002). La casa di nessuno. Imercati in Africa occidentale (Primera ed.). Turín: Bollati Borlinghieri.

Alonso, R., Estrada, M., \& Sartorius, A. (2007). Los Mercados Minoristas como Motor para el Desarrollo Económico, Social y Cultural de una Ciudad. Nueva York: Unidad de Diseño del BID.

Apega. (2013). El Boom Gastronómico Peruano al 2013. Lima: Oxfam.

Apega. (15 de Setiembre de 2016). Mistura 2016: Conoce las cifras que dejó la feria. Obtenido de Mistura: http://mistura.pe/mistura-2016-conoce-las-cifras-que-dejo-la-feria/

Aranguren, L. M. (2009). Entrevista personal.

ArcelorMittal Europe. (2013). Puestos de venta resistentes a la corrosión fabricados con acero de ArcelorMittal: Mercat dels Encants Vells en Barcelona. Recuperado el 16 de Setiembre de 2018, de Caso práctico: Mercat dels Encants Vells: http://constructalia.arcelormittal.com/es/casos_practicos/espana/mercat_dels_encants_v ells_barcelona

Arellano Marketing. (21 de Junio de 2017). Estudio Nacional del Consumidor Peruano. Obtenido de Arellano: https://www.arellano.pe/estilos-de-vida/

Ayuntamiento de Madrid. (2003). Ordenanzza de Comercio Minorista de la Alimentación. Madrid.

Ayuntamiento de Madrid. (2010). Ordenanda de Mercados de Distrito. Madrid.

Baquero, D. (2011). Las palzas de mercado como catalizadores urbanos. Tesis de maestría, Universidad Nacional de Colombia, Bogotá.

Bently, I. B., Alcock, A., Murrain, P., McGlynn, S. M., \& Smith, G. (1985). Responsive environments. A manual for designers. Oxford: Elsevier. 
BiS Arquitectos. (09 de Junio de 2017). Centro Cultural El Tranque / BiS Arquitectos. Obtenido de ArchDaily Perú: https://www.archdaily.pe/pe/873310/centro-cultural-el-tranque-bisarquitectos

Bonnef, M. (16 de Agosto de 2015). Mercado de Abasto Tirso de Molina / Pérgola de las Flores. Recuperado el 21 de Mayo de 2017, de Comportamientos Aparentes: https://comportamientosaparentes.wordpress.com/2015/08/16/mercado-de-abasto-tirsode-molina-pergola-de-las-flores/

Borja, J. (2000). Espacio publico, ciudad y ciudadania. Barcelona.

Borja, J. (2012). Revolución urbana y derechos ciudadanos: Claves para interpretar las contradicciones de la ciudad actual. Barcelona.

Bramwell B, R. L. (1996). Tourism Marketing Images of Industrial Cities. Annals of Tourism Research, 23(1), 201-221.

CABE Space. (2004b). The Value of Public Space, How High Quality Parks and Public Spaces Create Economic, Social and Environmental Value. London: CABE.

Cabrera Neyra, M. (1979). Estudio de los Mercados Minoristas Tradicionales en los distritos de Pueblo Libre, San Miguel, Magdalena, Jesús María y Lince. Tesis de título, Pontificia Universidad Católica del Perú, Agronomía. Recuperado el 2017 de Abril de 20

Carmona, M., Heath, T., Oc, T y S. Tiesdell. (2003). Public Places, Urban Spaces: The Dimensions of Urban Design. Oxford: Architectural Press.

Carmona, M., Magalhães, C. d., \& Hammond, L. (2008). Public Space. The managment of dimension. New York: Routledge.

Casares Ripol, J. (Mayo-Junio de 2003). Los mercados municipales y el futuro de las ciudades. Distribucion y Consumo, 34-37.

Castillo, J., Huamaní, L., \& Vilchez, G. (2009). Con un pie adentro y otro afuera: Los callejones en el Rímac. Pontificia Universidad Católica del Perú, Lima.

Centeno, P. V. (2006). El Espacio Publico. La movilidad y la revaloracion de la ciudad. Cuadernos arquitectura y ciudad (número 3), 1-75.

Coello Rodríguez, A. (2014). Unas notas sobre el antiguo Mercado de la Concepción, hoy Mercado Central de Lima. Arqueología y Sociedad(28), 367-378.

Coleman, P. (2014). Shopping Environments: Evolution, Planning and Design. Oxford: Architectural Press.

Consultora CCR. (2014). ¿Qué lleva hoy, Caserita? Lima. 
Corbusier, L. (1977). Hacia una nueva arquitectura. Barcelona: Poseidon.

Costales Calvo, I. (18 de Diciembre de 2014). Encants Barcelona: nueva plaza comercial y aparcamiento en Barcelona. (A. d. d'Estructures, Ed.) Quaderns d'Estructures(51), 5-11. Obtenido de https://upcommons.upc.edu/handle/2117/86003

Crespi, M., \& Domínguez, M. (Abril de 2016). Los mercados de abastos y las ciudades turisticas. Pasos. Revista de turismo y patrimonio cultural, Vol. $14 N^{\circ} 2 .$, 401-416.

Crousse, V. (2011). configuración del paisaje, espacio público y arte público en el perú. Barcelona.

De Padua, A., Dutra, I., Teixeira, J., Machado, B., \& Tijoux, M. (2012). Metamorfoseando los mercados centrales: El turismo gastronómico como estrategia en el Mercado Central de Santiago y el Mercado Municipal de Sao Paulo. Estudios y perspectivas en turismo, 12, 88-107.

De Soto, H. (1986). El Otro Sendero, La Revolución Informal. Lima: El Barranco.

De Terán, F. (1997). La Ciudad Hispanoamericana. El Sueño de un orden. Madrid: Centro de Estudios Históricos de Obras Públicas y Urbanismo.

Del Águila, A. (1995). Callejones y mansiones o la reconstrucción de los espacios públicos en Lima (1895-1919). Estudios Sociológicos XIII(39), 545-571.

Diez De Castro, E., Landa Bercebal, F., \& Navarro García, A. (2006). Merchandising: Teoría y práctica. Madrid: Piramide.

El comercio. (18 de Mayo de 2011). Jesús María: reabren mercado de San José tras llegar a un acuerdo. $\quad$ Comercio. Obtenido de http://archivo.elcomercio.pe/amp/sociedad/lima/jesus-maria-reabren-mercado-san-joseacuerdo-comerciantes-noticia-759560

Elguera Chumpitazi, H. (2017). El impacto de la imagen visual en el comportamiento de compra por impulso: un modelo comercial. CIC: 3er boletín del Centro de Investigación de la Creatividad UCAL, 1, 17-28.

Ergun, B. (2010). Evolution of shopping malls: recent trends and the question for regeneration. Cancaya: Universidad de Cancaya.

Espil, E. G. (2003). Hacer ciudad. La construccion de la metropolis.

Fernández Salas, J. (2012). El Derecho de Superficie. Themis - Revista de Derecho(62), 237- 253. 
Filgueiras, B. (2006). Do mercado popular ao espaço de vitalidade: o Mercado Central de Belo. Tesis de Maestría, Universida de Federal do Rio de Janeiro, Planificación Urbana y Regional, Rio de Janeiro. Obtenido de http://webcache.googleusercontent.com/search?q=cache:9cQAOercNuAJ:www.urbano. org.

Forqués, N. (21 de Fabrero de 2006). La flexibilidad en la arquitectura. Obtenido de Mito: Revista Cultural: http://revistamito.com/la-flexibilidad-en-la-arquitectura/

Fuentes Carrasco, M. (2005). Aproximación a la Nueva Babilonia de Constant. Boetica: Estudios de Arte, Geografia e Historia(27), 41-60.

Galofaro, L. (2004). El arte como aproximacion al paisaje contemporaneo. Barcelona: Gustavo Gili.

Gámez, F. C. (Abril- Setiembre de 2014). Fronteras difusas. Arquitectura, ciudad arte y paisaje. Sinapsis Social. Revista cientifica de sostenibilidad, 1(1).

García Calderón, L. (s.f.). El Mercado de barrio hace ciudad. Recuperado el 23 de Abril de 2017, de www.urbano.org.pe/.../El\%20Mercado\%20de\%20barrio\%20hace\%20ciudad

García Martínez, I. (2013). El límite difuso: Tectónica del límite en Toyo Ito 1971-2001. Madrid: Universidad Politécnica de Madrid.

García, B. (2017). Los mercados de abastos y su comercialización como producto de turismo de expreciencias: El caso de Madrid. Cuadernos de turismo(39), 167-189.

Garcia, J. H. (2012). Turismo, marca de ciudad y barrios populares. Turismo y sociedad, 13, 8597.

Garrido, J. L. (2011). Perfil del consumidor y tendencias del mercado. Universidad de Piura, Escuela de Dirección, Lima.

Gausa, M., Guallart, V., Muller, W., Soriano, F., Porras, F., \& Morales, J. (2001). Diccionario Metapolis de Arquitectura Avanzada. Actar.

Gehl, J. (1971). La humanizacion del espacio público. Barcelona: Reverté.

Gehl, J. (2006). La humanizacion del espacio público. Barcelona: Reverté S.A.

Gehl, J., \& Gemzøe, L. (2000). New City Spaces. Copenhagen: The Danish.

Gehl, J. \& Svarre, B. (2000). How to study public life. Washington DC: Island Press 
Gestión. (30 de Julio de 2013). Mercado San José de Jesús María sería centro comercial. Gestión, pág. parrafo 12. Obtenido de https://gestion.pe/impresa/mercado-san-jose-jesus-mariaseria-centro-comercial-44295

Gobierno de Chile. (2015). Construcción Plaza de Abastos y Pérgolas de las Flores. Ministerio de Obras Públicas, Dirección de Arquitectura, Santiago. Obtenido de http://www.disenoarquitectura.cl/pergola-de-las-flores-y-mercado-tirso-de-molina-deiglesis-prat-arqtos/

Gomes Teixeira, A. K., de Azevedo Barbosa, M. d., \& Gomes de Souza, A. ( 2013). El sistema de oferta de restaurantes de alta gastronomia. Una perspectiva sensorial de las experiencias de consumo. (C. d. Turísticos, Ed.) Estudios y Perspectivas en Turismo, 22(2), 336-356.

Gómez Wilkinson, J. (2016). La historia y los orígenes de los Encants Barcelona. Recuperado el 12 de enero de 2019, de Encants Barcelona: http://encantsbcn.com/es/Historia

Gomis, A. (1992). Historia de la ciencia y de la técnica. Madrid: Akal S.A.

Gonçalves Silveira, F. E., \& Barretto, M. (2010). Tuismo de Transformacion. Ecoturismo en reservas de la biosfera dentro del marco de la economía de la experiencia. Estudios y Perspectivas en Turismo, 19, 315 -329.

Gonzáles-Prada, E. (04 de Mayo de 2018). Oficinas: Jesús María y Lince más rentables. Binswanger Perú. Obtenido de https://binswanger.com.pe/oficinas--jesus-maria-y-lincemas-rentables

Grupo El Comercio. (31 de Julio de 2014). Cinco distritos concentran el 40\% del total de mercados de abastos en Lima. (E. C. S.A., Ed.) Gestión. Recuperado el 28 de Julio de 2018, de https://gestion.pe/economia/empresas/cinco-distritos-concentran-40-totalmercados-abastos-lima-66976

GrupoRPP. (18 de Mayo de 2011). Capital . Obtenido de Tu opinion importa : http://www.capital.com.pe/actualidad/cierran-mercado-san-jose-de-jesus-maria-noticia366539

Guardia Bassols, M. (25 de Agosto de 2007). Los mercados públicos en la ciudad contemporánea: El caso de Barcelona.

Gutiérrez, R. (1997). La Cludad Hispanoamericana. El Sueño de un Orden. Madrid: Ministerio de Fomento. 
Hammond, L. (2002). The New Urban Public Space. University of London: MPhil Thesis.

Harvey, D. (1996). From Space to Place and Back Again: Justice, Nature and the Geography of Difference. Oxford: Blackwell.

Hernández, J. M. (2004). Historia de las formas urbanas medievales. Sevilla: GG.

Herzog, J. (2002). La Naturaleza del Artificio: Una conversación con Jacques Herzog. El Croquis(109/110), 16-31.

Herzog, J. (2006). Ornamento, Estructura, Espacio. Croquis(129-130), 22-39.

Herzog, J., \& De Meuron, P. (2002). Herzog \& De Meuron:Natural History. (P. Ursprung, Ed.) Montréal: Lars Muller Publishers.

Huamán, G. (2015). Complejo de abastos en el distrito de Lince. Tesis de grado, Universidad San Martín de Porres, Facultad de Ingeniería y Arquitectura, Lima.

Ibaceta, C. G. (2015). ACCIONES Y ELEMENTOS PRIMITIVOS DE LA ARQUITECTURA ORIGINARIA. Chile.

INEI. (2008). Censo Nacional Economico 2008. ESTABLECIMIENTOS CENSADOS POR ACTIVIDAD ECONÓMICA, SEGÚN ÁMBITO POLÍTICO ADMINISTRATIVO, 2008, INEI, Lima, Lima. Obtenido de http://censos.inei.gob.pe/cenec2008/tabulados/\#

INEI. (13 de Junio de 2017). Al año 2016 a nivel nacional existen 2 mil 612 mercados de abastos. Obtenido de Instituto Nacional de Estadística e Informática: https://www.inei.gob.pe/prensa/noticias/al-ano-2016-a-nivel-nacional-existen-2-mil612-mercados-de-abastos-9794/

Instituto Metropolitano de Planificación. (2014). Plam Lima y Callao 2035 (Vol. Memoria de Ordenamiento ). Lima: Instituto Metropolitano de Planificación.

Instituto Nacional de Defensa Civil. (2018). Acerca de INDECI. Recuperado el 04 de Agosto de 2018, de Instituto Nacional de Defensa Civil: https://www.indeci.gob.pe/contenido.php?item=MQ==

Instituto Nacional de Estadística e Informática. (2016). Encuesta Nacional de Hogares . Lima. Instituto Nacional de Estadística e Informática. (2017). Censo Nacional de Mercados de Abastos. Lima.

Instituto Nacional de Estadística e Informática. (2017). Provincia de Lima: Compedio Estadístico 2017. Lima. 
Iñiguez, D. (31 de Diciembre de 2015). El espacio público en Les Halles de París a través de los siglos. Obtenido de Medium Corporation: https://medium.com/@Daniel_ij/el-espaciop $\%$ C3\%BAblico-en-les-halles-en-par\%C3\%ADs-una-convicci\%C3\%B3n-a-pesar-delos-siglos-ec3991403b74

Ito, T. (2000). Escritos. Murcia: Colegio Oficial de Aparejadores y Arquitectos Técnicos.

Jacobs, J. (2011). Muerte y vida de las grandes ciudades . Madrid: Capitán Swing .

Joffre, G. R. (2004). El Guión de la Cirugía Urbana: Lima 1850-1940. Universidad Nacional Mayor de San Marcos, Ciencias Sociales, Lima.

Junge, J. (20 de Junio de 2014). Pérgola de las Flores y Mercado Tirso de Molina. (D. I. Carter, Editor) Recuperado el 21 de Mayo de 2017, de D+A Diseño y Arquitectura: http://www.disenoarquitectura.cl/pergola-de-las-flores-y-mercado-tirso-de-molina/

Junta de Andalucía. (2006). Plan de Modernización de los Mercados Municipales de Andalucía. Kadmos.

Kahatt, S. (2014). Cinco siglos de orden y caos. Breve recuento de crecimiento y transformación socio-espacial. Rita: Revista Indexada de Textos Académicos(2), 38-43.

Kärrholm, M. (2012). Retailising Space. Architecture, Retail and the Territorialisation of Public Space. England: Ashgate Publishing Limited.

Kidder Smith, G. E. (1990). Looking at Architecture. Nueva York: Harry N Abrams Inc.

Kipnis, J. (1997). La Astucia de la Cosmética: Una reflexión personal sobre la arquitectura de Herzog \& de Meuron. El Croquis(84), 22-28.

La Rosa, M. (2014). Las Transformaciones de los espacios públicos ocurridas dentro de los contextos del neoliberalismo y la inseguridad ciudadanda: Caso del distrito de Jesús María. Tesis de título, Pontificia Universidad Católica del Perú, Geografía y Medio Ambiente, Lima.

Leung, J. (2016). Abastecer o ser abastecido: La influencia de los mercados tradicionales sobre el tejido urbano de Lima. Tesis de maestría, DUOT, Urbanismo.

Levene, R. Y Marquez, F. (1995). Toyo Ito 1986-1995. Madrid: El Croquis.

López Fontanals, M. (1 de Octubre de 2014). Rotterdam inaugura el markthal, el primer mercado cubierto de holanda. Obtenido de EFE News Service: http://fresno.ulima.edu.pe/ss_bd00102.nsf/RecursoReferido?OpenForm\&id=PROQUE ST-41716\&url=/docview/1566590364?accountid $=45277$ 
Ludeña, W. (2006). Lima y la globalización, Una expansión urbana difusa. Identidades: Reflexión,Arte y Cultura $N^{o} 100$.

Lynch, K. (1984). La imagen de la ciudad. Barcelona: Gustavo Gili.

Mantey, D., \& Kepkowicz, A. (2018). Types of Public Spaces: The Polish Contribution to the Discussion. Taylor \& Francis Group, LLC.

Mark, L. (3 de Octubre de 2014). MVRDV completa la sala del mercado de Rotterdam. Obtenido de The Architects Journal: http://fresno.ulima.edu.pe/ss_bd00102.nsf/RecursoReferido?OpenForm\&id=PROQUE ST-41716\&url=/docview/1571609683?accountid $=45277$

Martinez Ballester, M., \& García Vicente, J. (2009). Historia del supermercado. Universidad de Alicante. Alicante: Close City - Wordpress. Recuperado el 05 de 11 de 2017, de https://closecity.files.wordpress.com/2009/11/historia4.pdf

Martínez Palacios, E. (2014). El diseño del suelo: Plaza del Poeta Boscá y la PLaza de La Font. Universitat de Barcelona, Barcelona.

Medina Luque, F. X. (2013). Mercados y espacio público:transformación y renegociación de nuevas demandas urbanas. Analisis comparativo de casos (Barcelona, Budapest y Buenos Aires). Universidad Oberta de Catalunya, Barcelona.

Medina, X. (2014). Mercados y espacio público: transformación y renegociación de nuevas demandas urbanas. Zainak(36), 183-200.

Medina, X., \& Álvarez, M. (2007). El lugar por donde pasa la vida... los mercados y las demandas urbanas contemporáneas: Barcelona y Buenos Aires. Revista d'Etnologia de Catalunya, 183-201.

Meignen, F. (2010). Procesos graduales de ocupación del mercado en el espacio público. Tesis de título, Universidad Simón Bolívar, Caracas.

Mercasa. (2012). Mercado de San Pedro en Cuzco. Salamanca.

MiAS Architects. (2011). Barceloneta Market and Square. Obtenido de MiAS Architects: http://www.miasarquitectes.com/portfolio/barceloneta-market/

Miles, P. (18 de Setiembre de 2015). ¿Será el markthal de Rotterdam equivalente al guggenheim de bilbao? Obtenido de FT.Com: http://fresno.ulima.edu.pe/ss_bd00102.nsf/RecursoReferido?OpenForm\&id=PROQUE ST-41716\&url=/docview/1722783971?accountid $=45277$ 
Ministerio de Comercio Exterior y Turismo. (8 de Agosto de 2016). Iglesia San José. Obtenido de Ficha de recopilación de datos para informacion del inventario de recursos turísticos: https://www.mincetur.gob.pe/turismo/directorios-manuales/inventario-de-recursosturisticos/

Ministerio de la Producción. (2017). Normativa de Mercados de Abastos. Lima.

Ministerio de la Producción. (2018). Acerca del Ministerio. Recuperado el 04 de Agosto de 2018, de Ministerio de la Producción: https://www.produce.gob.pe/index.php/ministerio/acerca-de

Ministerio de Salud . (2003). Reglamento Sanitario de Funcionamiento de Mercados de Abasto. Lima.

Ministerio de Salud. (2018). ¿Qué hacemos? Recuperado el 04 de Agosto de 2018, de Ministerio de Salud: https://www.gob.pe/739-ministerio-de-salud-que-hacemos

Miquel, S. (2008). Distribución comercial (6ta ed.). España: ESIC.

Miralles, E. (2006). EMBT MIRALLES-TAGLIABUE. Universidad de Navarra, Escuela Técnica Superior de Arquitectura. Navarra: T6 ediciones .

Montaner, J. M. (2008). Sistemas arquitectonicos contemporaneos. Barcelona: Gustavo Gili.

Moussavi, F., \& Cubo, M. (2008). La Función del Ornamento. Barcelona: Actar.

Munari, B. (1983). Diseño y comunicación visual. Barcelona: Gustavo Gili.

Municipalidad de Jesús María. (2013). Plan de Desarrollo Económico Local de Jesús María 2013-2025. Lima.

Municipalidad de Jesús María. (2016). Plan de Desarrollo Concentrado Distrital 2015-2021 de Jesús María. Lima.

Municipalidad de Lima. (2013). Guía para la competitividad de mercados de abasto. Lima: Impresión Arte Perú E.I.R.L.

Municipalidad de San Borja. (2003). Unidad de Educación, Cultura y Turismo. Obtenido de http://www.munisanborja.gob.pe/cultura/

Muñoz, O., Reano, J., \& Reyes, C. (2007). Mercado San José de Jesús María. Pontificia Universidad Católica del Perú, Especialidad de Antropología, Lima.

MVRDV. (2003). Redefiniendo las herramientas de la radicalidad. Madrid: El Croquis.

Negro, S. (2009). La plaza mayor de Lima. En VV.AA., La plaza mayor de Las Palmas de (pág. 357). Las Palmas de Gran Canaria. 
Neufert, E. (2016). Educación investigación. En E. Neufert, Arte de proyectar en arquitectura.

Nieuwenhuys, C. (2009). La Nueva Babilonia. Barcelona: Gustavo Gili.

Noguera, J. (2011). MODELO BARCELONA: Diseño urbano y espacio público: La peatonalización alrededor de los mercados municipales del siglo XIX. Tesis de maestría, Universidad de Barcelona, Barcelona.

Norberg Schulz, C. (2005). Los principios de la arquitectura moderna: sobre la nueva tradición del siglo $X X$. Barcelona : Reverté.

Norwich, J. (1984). The World Atlas of Architecture. Londres: Mitchell Beazley.

Nute, K. (1993). Frank Lloyd Wright y Japan. The role of traditional Japanese art and architecture in the work of Frank Lloyd Wright. London: Chapman y Hall.

O'NEIL, D. (30 de Septiembre de 2005). Project for public spaces. Recuperado el 23 de Diciembre de 2018, de Diez cualidades para hacer mercados publicos exitosos: https://www.pps.org/article/tencharacteristics-2

Orrego, J. L. (01 de Febrero de 2010). El distrito de Jesús María. Recuperado el 08 de Julio de 20118, de Pontificia Universidad Católica del Perú: http://blog.pucp.edu.pe/blog/juanluisorrego/2010/02/01/el-distrito-de-jesus-maria/

Pixel Publishing. (11 de Mayo de 2005). Cubiertas Inclinadas. Constructiva(5), 58-61.

Plazola, A. (2001). Enciclopedia de Arquitectura (Vol. 7). México D.F: Plazola Editores.

Polanyi, K., Arensberg, C., \& Pearson, H. (s.f.). The and Market in the Early Empires. Glencoe, Illinois: The free press.

Portabella, J. (2006). Salutació. Barcelona.

Project for Public Spaces. (28 de Febrero de 2010). Project for Public Spaces. Recuperado el 23 de Diciembre de 2018, de Los beneficios transformadores de los mercados públicos : https://www.pps.org/article/the-benefits-of-public-markets

PROMPERÚ. (2017). Perfil del Turista Extranjero 2016. Lima: Comisión de Promoción del Perú.

Pulido-Fernández, J. I.-F., \& Navarro Hermoso, Ú. (2014). Identificacion de items para medir las experiencias. Cultur. Revista de cultura y turismo(1).

Real Academia Española. (07 de 01 de 2019). Real Academia Española. Obtenido de http://dle.rae.es/?id=De2S7ue 
Reaño, J., Reyes, C., \& Muñoz, V. (2007). Mercado "San José" de Jesús María. Monografía, Pontificia Universidad Católica del Perú, Antropología económica, Lima.

Regal, A. (1967). Castilla Constructor: Las obras de ingeniería de Castilla. Lima: Banco de Crédito del Perú.

Regalado, O., Fuentes, C., Aguirre, G., García, N., Román, M., \& Vallejo, R. (2009). Factores críticos de éxito en los centros comerciales. Lima: Editorial Cordillera S. A. C.

Reglamento Nacional de Edificaciones. (2016). Reglamento Nacional de Edificaciones. Lima: Fondo Editorial ICG.

Rieunier, S., \& Daucé, B. (2002). Marketing sensorial en puntos de venta. Investigación y Aplicaciones en Marketing, 17( $\mathrm{n}^{\circ}$ 4), 46-65.

Rivarola Cores, A. (2015). Nuevo Mercado para el distrito de Magdalena del Mar. Tesis, Universidad Peruana de Ciencias Aplicadas, Lima.

Robles, J. I. (2008). Mercados, vidas y barrios: mercados municipales en espacios metropolitanos. Comercio urbano en espacios metropolitanos, 19-31.

Robles, J. I. (2014). Mercados municipales y tecnologías digitales: Entre el e-comercio y nuevas formas de convivialidad. Anthropologica(33), 137-161.

Rodríguez, S. (2014). La transformación de los mercados municipales de Madrid: Análisis legislativo, comercial y económico de los mercados de abastos madrileños. Universidad Politécnica de Madrid, Departamento de Urbanística y Ordenación del Territorio, Madrid.

Rogers Stirk Harbour + Partners. (06 de Setiembre de 2018). The Leadenhall Building. Obtenido de https://www.rsh-p.com/projects/the-leadenhall-building/

Rojas, L. A. (2011). Mercados y mercaderes: Hacia una antropologia de las prácticas económicas. Lima.

Rosales Meana, D. I. (2013). La música y los límites del mundo. Un estudio desde Eugenio Trías y Agustín de Hipona. Anales del Seminario de Historia de la Filosofia, 30(1), 27-47.

Rosas, L. (18 de Mayo de 2011). Cierran mercado San José de Jesús María por incumplir normas de seguridad. Andina Agencia Peruana de Noticias. Obtenido de https://andina.pe/agencia/noticia.aspx?id=359064

Rossi, C., \& Aschner, J. P. (2015). Pérgolas de las Flores y Mercado Tirso de Molina. (U. d. Andes, Ed.) DEARQ(17), 200-216. 
Rubert de Ventós, M. (2014). La Ciudad no es una hoja en blanco. Barcelona: Laboratori dÚrbanisme.

Rubert, M. (06 de 02 de 2004). El mejor mercado es una plaza. El Periódico de Catalunya. $\begin{array}{lllllll}\text { Recuperado } & \text { el } & 10 & \text { de } & 05 & \text { de }\end{array}$ $\mathrm{http}: / /$ mariarubertarquitecta.blogspot.pe/p/articles.html

Ruiz, N. (2013). En los límites de la arquitectura. Espacio, sistema y disciplina. Tesis doctoral, Universidad Politécnica de Cataluña, Departamento de Expresión Gráfica Arquitectónica, Barcelona.

Sebastian, A. R. (2014). Análisis de la transformación de los mercados de Abastos Madrileños. Universidad Politécnica de Madrid, Madrid.

Siena, D. D. (30 de Marzo de 2011). Espacio público como lugar de construcción de ciudadanía. Obtenido de http://urbanohumano.org/blog/2011/03/30/espacio-publico-como-lugar-deconstruccion-de-ciudadania/

Simone, R. L. (2009). Arquitectura como producto cultural de consumo. Produccion arquitectonica en el post-capitalismo y su relacion con construccion de identidad. Chile.

Solnick, J., Kannenberg, C., Eckerman, D., \& Waller, M. (1980). An Experimental Analysis of Impulsivity and Impulse Control in Humans. Learning and Motivation(11), 61-77.

Soler, M. (2004). Del Ágora griega al Foro Romano. In Alimentos ¿Qué hay detrás de la etiqueta?. Barcelona: Viena.

Soriano, W. E. (2005). Las lenguas nativas del altiplano peruano-boliviano en el siglo XVI. Lima.

Takano, G., \& Tokeshi, J. (2007). Espacio público en la ciudad popular: reflexiones y experiencias desde el Sur. Lima: Desco.

Tangires, H. (2008). Public Markets. Mexico: W.W. Norton \& Company.

Taylor, J. (2001). Authenticity and sincerity in tourism. Annals of Tourism Research, 7-26.

The Leadenhall Building Development Company. (06 de Setiembre de 2018). The Building's spaces. Obtenido de The Leadenhall Building : https://www.theleadenhallbuilding.com/architecture/spaces/

Tonnelat, S. (2010). The Sociology of Urban Public Spaces. París: Atlantis Press.

Torres, F. (2009). Forman red de 33 mercados que modernizarán locales. El Comercio. Recuperado el 23 de Abril de 2017, de http://elcomercio.pe/lima/300464/noticia-formanred-33- 
Trigoso López, M. (31 de 07 de 2014). Gestión: Diario de economía y negocios de Perú. Recuperado el 20 de 05 de 2017, de http://gestion.pe/empresas/cinco-distritosconcentran-40-total-mercados-lima-2104364

Universidad Nacional de Ingeniería. (1994). Inventario del patrimonio monumental inmueble de la ciudad de Lima. Lima.

Urbania. (2019). Oficinas en Lima_ Reporte de mercado. Estudio de mercado, Grupo El Comercio, Lima. Obtenido de https://urbania.pe/indice_m2/oficinas/\#1504733372940b0955479-0d6c

V \& V Grupo inmobiliario. (22 de Octubre de 2018). El nuevo centro empresarial de Lima está en Jesús María. Obtenido de VyV Grupo Inmobiliario: https://vyv.pe/venta-de-oficinaslima/nuevo-centro-empresarial-lima-esta-jesus-maria-compra-una-oficina-ahora/

Valero, D. (2011). Reorganización de la plaza tres gracias (Caracas-Venezuela). Revista Geográfica de América Central, 2, 1-15.

Van Eyck, A. (1962). Architectural Design 12 (Vol. XXXII).

Verdu. (2001). La sociedad americana: ¿sociedad del futuro?

Wigley, M. (1998). Constant's New Babylon: The Hyper-architecture of Desire. Rotterdam: Witte de With CfCA.

World Travel Adwards. (10 de Diciembre de 2017). World's Leading Culinary Destination 2017. Recuperado el 28 de Julio de 2018, de World Travel Adwards: https://www.worldtravelawards.com/award-worlds-leading-culinary-destination-2017

Wright, F. L. (1971). The natural house. Londres.

Yaranga, Y. (2015). La comunicación para el desarrollo desde los mercados populares: estudio de caso del mercado "Santa Rosa" de Chorrillos. Pontificia Universidad Católica del Perú.

Yubero, S. (2005). Socialización y Aprendizaje social. En D. Páez, I. Fernández, S. Ubillos, \& E. Zubieta, Psicología social, cultura y educación (págs. 819-844). Madrid: Pearson.

Zavala, M. (2013). Intervenciones contemporáneas en los mercados municipales representativos de Cataluña y Valencia, construidos a finales del siglo XIX y principios del XX. Universitat Politécnica de Catalunya (UPC). 
